University of Nebraska - Lincoln

DigitalCommons@University of Nebraska - Lincoln

\title{
The Fabric of Gifts: Culture and Politics of Giving and Exchange in Archaic Greece
}

\author{
Beate Wagner-Hasel \\ Leibniz University of Hannover, wagner-hasel@hist.uni-hannover.de
}

Follow this and additional works at: https://digitalcommons.unl.edu/zeabook

Part of the Ancient History, Greek and Roman through Late Antiquity Commons, Classical Archaeology and Art History Commons, Classical Literature and Philology Commons, Fiber, Textile, and Weaving Arts Commons, and the Museum Studies Commons

\section{Recommended Citation}

Wagner-Hasel, Beate, "The Fabric of Gifts: Culture and Politics of Giving and Exchange in Archaic Greece" (2020). Zea E-Books Collection. 92.

https://digitalcommons.unl.edu/zeabook/92

This Book is brought to you for free and open access by the Zea E-Books at DigitalCommons@University of Nebraska - Lincoln. It has been accepted for inclusion in Zea E-Books Collection by an authorized administrator of DigitalCommons@University of Nebraska - Lincoln. 


\section{Beate Wagner-Hasel}

\section{The Fabric of Gifts}

Culture and Politics of Giving and Exchange in Archaic Greece

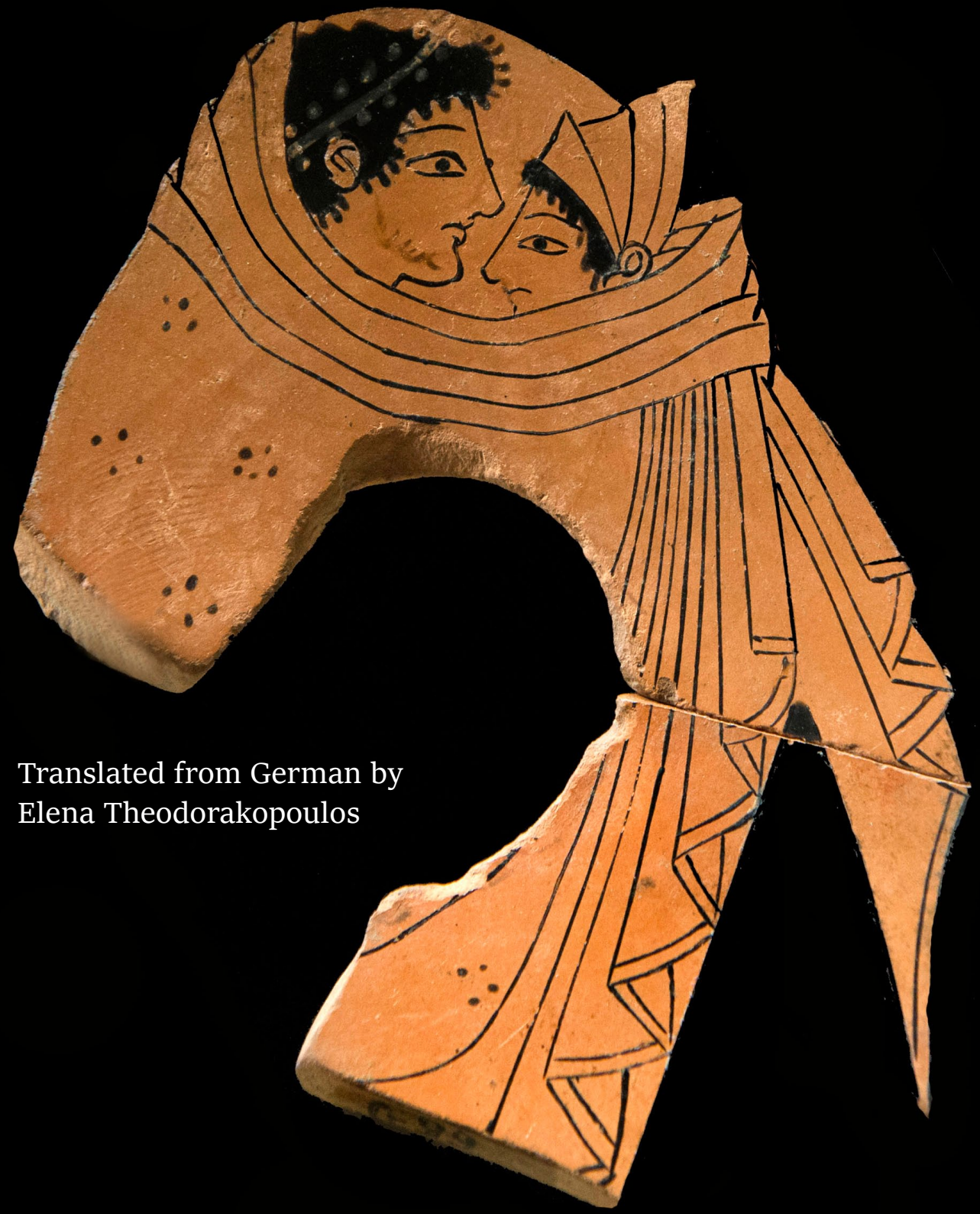


When the Greek leader Agamemnon took for himself the woman awarded to Achilles as his spoils of battle, the warrior's resulting anger and outrage nearly cost his side the war. Beyond the woman herself was what she symbolised - a matter of esteem rather than material value. In Archaic Greece the practices of gift giving existed alongside an economy of market relations. The value of gifts and the meanings of exchange in ancient societies are fundamental to the debates of 19th-century economists, to Marcel Mauss's famous Essai sur le don (1923-4), and to the definition of experiential value by modern philosopher Yanis Varoufakis.

In this book Beate Wagner-Hasel analyses the sensory content and the social context of many examples of Greeks bearing gifts: to guests, at sacrificial rituals and at funerals, to brides and to heroes. The fabric of these gifts unfolds a panorama of social networks and models of rulership embedded in a world of pastoral and textile economy. Among the gifted objects that represent this world, textiles offer the clearest representation of social cohesion - the key value ascribed to the gift by the earliest theorists of gift-giving.

Beate Wagner-Hasel was Professor of Ancient History at the Leibniz University of Hannover 2001-2018, specializing in economic history and gender studies. She is the author of Antike Welten (2017), Alter in der Antike (2012), Die Arbeit des Gelehrten (2011), and Der Stoff der Gaben (2000), and co-editor (with Marie-Louise Nosch) of Gaben, Waren und Tribute (2019).

The Fabrics of Gifts is a revised edition of her study of gifts in Early Greece (Der Stoff der Gaben, 2000).

Zea Books

Lincoln, Nebraska

ISBN: 978-1-60962-173-5

doi 10.32873/unl.dc.zea.1102

\section{Nebraska




\section{Beate Wagner-Hasel}

\section{The Fabric of Gifts}

Culture and Politics of Giving and

Exchange in Archaic Greece

Translated from German by Elena Theodorakopoulos

\section{Revised edition of Der Stoff der Gaben: Kultur und Politik des}

Schenkens und Tauschens im archaischen Griechenland

(Frankfurt \& New York: Campus 2000)

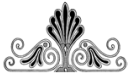

Zea Books

Lincoln, Nebraska

2020 


\section{Copyright (C) 2020 Beate Wagner-Hasel}

ISBN: 978-1-60962-173-5

doi 10.32873/unl.dc.zea.1102

Composed in Sitka, New Athena, and Lithos types.

Zea Books are published by the University of Nebraska-Lincoln Libraries.

Electronic (pdf) edition available online at https://digitalcommons.unl.edu/zeabook/

Print edition available from

http://www.lulu.com/spotlight/unllib

UNL does not discriminate based upon any protected status.

Please go to https://www.unl.edu/equity/notice-nondiscrimination

\section{Nebraska \\ Lincoln}




\section{CONTENTS}

List of Illustrations . . . . . . . . . . . . . . . . . . . . . 5

Preface and Acknowledgements . . . . . . . . . . . . . . . . . . . . 7

Introduction . . . . . . . . . . . . . . . . . . . . . . . . . . . . 9

1. The Circulation of Goods and the Theory of Gifts: A Debate on

Economy and Morality . . . . . . . . . . . . . . . . . . . . . . 19

1.1. Prehistory of the gift: Discourses of law and economics on gifts and exchange . . . . . . . . . . . . . . . . . . . . . . . . 19

1.1.1. The gift in the debates of the Historical School of political economy . . . . . . . . . . . . . . . . . 20

1.1.2. The legal-historical debate: From reciprocity to free surrender . . 26

1.1.3. The sociological debate: The contribution of Marcel Mauss . . . . 35

1.2. Critique of modernity and the idealisation of the gift. . . . . . . . . 39

1.3. Return ticket to the South Sea Islands: On the use of ethnological comparisons and a critique of reciprocity . . . . . . . . . . . . . 53

1.4. Gift-exchange in the Greek world: The debate over the formation of state and polis . . . . . . . . . . . . . . . . . . . . . . . 59

1.5. Methodological reflections: The sensory world of signs and the imagery of Homeric epic . . . . . . . . . . . . . . . . . . . . 76

2. Guest-Gifts and Relationships in Homer: Xeinia and Phila Dōra . . . . . . 80

2.1. Xeinion and dōtinē: The hospitality of the herdsmen Eumaeus and Polyphemus . . . . . . . . . . . . . . . . . . 83

2.2. Exchanging arms: Glaucus and Diomedes . . . . . . . . . . . . 96

2.3. Goblets and textiles: Xeinion as keimēlion and the ritual of guest-friendship . . . . . . . . . . . . . . . . . . . . . . 112

2.3.1. Mementoes and tributes: Tripods, goblets, mixing bowls, and cloth. . . . . . . . . . . . . . . . . . . . . . . 113

2.3.2. The ritual of guest-friendship: Bathing, libation, and dressing . 122

2.3.3. The terms of hospitality: Xeinizein, komizein, phileein . . . . 127

2.4. Woven textiles, sacrifice, and the formation of bonds: Philotēs. . . . 133

3. Structures of Reciprocity and the Production of Signs: Charis and the Charites . . . . . . . . . . . . . . . . . . . . . . . . . . 144

3.1. The warrior's service and the gods' favour . . . . . . . . . . . . 146

3.2. Women's thanks and the weaving of amphipoloi and Charites . . . . 155

3.3. Visualizing status: Charis in appearance and speech . . . . . . . . 169 
4. Timē and Geras: Gifts of Honour and Structures of Power . . . . . . 185

4.1. Homeric kingship . . . . . . . . . . . . . . . . . . . . . . 185

4.2. The visibility and socioeconomic value of honour: Fighting for Agamemnon's timē and the geras of Achilles . . . . . . . . . 192

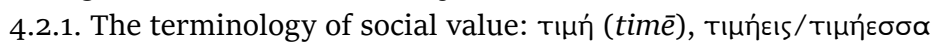
(timēeis/timēessa), tínıоs (timios), and ö́тıоs (atimos) . . . . 193

4.2.2. The economic meaning of honour: Dōtinai, themistes, temenos . . . . . . . . . . . . . . . . . . . . . . . 200

4.2.3. Rulership and social control: Aidōs . . . . . . . . . . . . 209

4.2.4. Honouring the basileus and the basileia . . . . . . . . . . . .215

4.2.5. Themistes and the sceptre . . . . . . . . . . . . . . . . 219

4.2.6. The distribution of time and the character of Homeric kingship . . . . . . . . . . . . . . . . . . . . . . . 222

4.3. Penelope's trick and the geras of Odysseus: Weaving as a symbol of power . . . . . . . . . . . . . . . . . . . . . . 232

4.4. The geras of the dead and the process of renewal in the death ritual . . . . . . . . . . . . . . . . . . . . 246

5. The Benefits of Travel and Supraregional Exchange in the Archaic Age . 266

5.1. Paying debts of cattle and exchanging pasture lands:

Prēxis, chreios, and amoibē . . . . . . . . . . . . . . . . . . 270

5.2. Kerdos and ōnos hodaiōn: Pastoral yields and profits from kidnapping . . . . . . . . . . . . . . . . . . . . . . . . 280

5.2.1. Kerdos, kerdea, kerdios, kerdaleos . . . . . . . . . . . . . 280

5.2.2. Ōnos and apoina. . . . . . . . . . . . . . . . . . . . 290

5.3. The quest for the means of living (biotos) and other necessary goods: Alum, purple, linen, and metals . . . . . . . . . . . . . 295

5.4. Transhumance, supraregional exchange, and the emergence of extra-urban sanctuaries . . . . . . . . . . . . . . . . . . . 311

5.4.1. The golden tripod of the Seven Sages . . . . . . . . . . . 311

5.4.2. Transhumance and exchange . . . . . . . . . . . . . . 315

5.4.3. Sanctuaries at the periphery . . . . . . . . . . . . 320

6. Conclusion: The Sensory World of Gifts: Weaving, Signs, and

Communication . . . . . . . . . . . . . . . . . . . . 328

Bibliography . . . . . . . . . . . . . . . . . . . . . . 347

Index . . . . . . . . . . . . . . . . . . . . . . . . . . . . . . 412 


\section{ILLUSTRATIONS}

Figure 1a: The joint coverlet. Red-figure kylix. Paris. Louvre G 99.

Photo: Egisto Sani, https://www.flickr.com/photos/69716881@

$\mathrm{No} 2 / 9195936448$. . . . . . . . . . . . . . . . . . . . . 140

Figure 1b: Couple sitting on a klinē and wrapped in a common mantle.

Attic red-figure kylix of the Marlay painter, ca 430 BCE.

Vienna, Kunsthistorisches Museum 131. After Koch-Harnack

1989: 137, Fig. 7. . . . . . . . . . . . . . . . . . . . . . . 140

Figure 2: Wool working at Athens. Attic black-figure lekythos of the

Amasis painter. 540 BCE. New York, The Metropolitan Museum

of Art, Fletcher Fund 1931, 31.11.10

https://www.metmuseum.org/en/art/collection/search/253348. . . . 158

Figure 3: The warp-weighted loom. Harlizius-Klück 2004: 103, Fig. 11, cf. also Barber 1991: 270, Fig. 12.3 with modifications. . . . . . . . 164

Figure 4: Warp-weighted loom with figured weave.

Ellen Harlizius-Klück 2016: 70, Fig. 5.2. . . . . . . . . . . . . . 165

Figure 5: Prothesis. Geometric Attic mixing bowl, ca 750 BCE.

Paris, Louvre A 517. After Kurtz and Boardman 1971: Fig. 7. . . . . . 166

Figure 6: Indonesian ceremonial cloth. Supplementary weft weave.

Sumatra, Lampung, late nineteenth century CE.

After Kahn-Majlis 1991: Fig. 78. . . . . . . . . . . . . . . . . 167

Figure 7: The mourning Penelope. Red-figure skyphos of the Penelope painter, ca 440 BCE. Chiusi, Museo Nazionale Archaeologico Inv. 1831. After Boardman 1989: Fig. 247 (= J. D. Beazley, Attic Red-figure Vase-paintings 1963: 1300, 2 = A. Furtwängler and K. Reichhold, Griechische Vasenmalerei, 1904-32).. . . . . . .260

Figure 8: Hermes weighing eidola. Attic black-figure lekythos, 5 th century BCE. London, British Museum B 639. https://research.britishmuseum.org/research/collection online/collection object details/collection image gallery.aspx?partid=1\&assetid=1305 6680018 objectid $=459047$. . . . . . . . . . . . . . . . . . . 261 
Figure 9: Arcesilaus weighing silphium or wool. Laconian kylix, ca 56o BCE. Bibliothèque Nationale, Cabinet des Médailles 1899. http://medaillesetantiques.bnf.fr/ark:/12148/c33gbhc8h . . . . . .304

Figure 10: Nine women wrapped in a common cloak. Black-figure kylix, 5th century BCE. Berlin, Antikenmuseum F 3993. After Koch-Harnack 1989: 111, Fig. 1. . . . . . . . . . . . . . .342

Figure 11: A group of women on Sumba wrapped in an Indian cotton textile performing a dance prior to the burial of King Umbu Nai Wolang of Kapunduk. After Kahn-Majlis 1991: Fig. 2. . . . . . . . . . . . . . . . 342 


\section{PREFACE AND ACKNOWLEDGEMENTS}

$\mathrm{T}$ his study, The Fabric of Gifts: Culture and Politics of Giving and Exchange in Archaic Greece, is a revised edition of my book Der Stoff der Gaben: Kultur and Politik des Schenkens und Tauschens im archaischen Griechenland, a book originally developed as a Habilitationschrift in 1995 and published in 2000. Marie-Louise Nosch, the founder of the Centre for Textile Research at the University of Copenhagen, took an interest in my research on textiles as gifts and suggested a translation of my study into English to make it accessible to a wider academic readership. In 2013 a cooperation between the Copenhagen Centre of Textile Research and the Historical Seminar (Historisches Seminar) of the Leibniz Universität Hannover was established, thanks to the generous support from the Alexander von Humboldt-Stiftung and the Anneliese Maier Award. The results of this cooperation were presented at a conference in Hannover in 2016; the papers on Waren, Gaben und Tribute: Stoffkreisläufe und antike Textilökonomie were published in 2019. The interest our cooperation has raised, current interest in economic history, ${ }^{1}$ and recent research in the cultural history of material objects, especially in the historical investigation of sensory experiences, ${ }^{2}$ encouraged me to take up Marie-Louise Nosch's suggestion and work on the English translation.

In recent years, practices of giving in the ancient world have become the subject of many publications and conferences. ${ }^{3}$ Yet little attention is being paid to the symbolism of the materiality of gifts. It is this symbolism that is at the core of my argument. I am also confident that my study The Fabric of Gifts offers some answers to the new debate on the character of archaic aristocracy, in which the circulation of goods forms a key factor for understanding elite competition. ${ }^{4}$ Parts of the first chapter of my book,

1. Drexhage, Konen and Ruffing 2002; Mattingly and Salmon 2001; Eich 2006; Morley 2007; Klinkott et al. 2007; Bresson 2008; Burns 2010; Wagner-Hasel 2011: 315-340; Droß-Krüpe and Nosch 2016.

2. See now Grand-Clément 2011; Hamilakis 2012; Bradley 2015; Squire 2016; Purves 2018; Canevaro 2018.

3. See Algazi, Groebner and Jussen 2003; Satlow 2012; Lyons 2012; Carlà and Gori 2014. 4. See Duplouy 2006; Fisher and van Wees 2015; Domingo Gygax 2016; Meister 2020. 
those dealing with the relationship between gift theory and the critique of modernity, ${ }^{5}$ were published in English in 2003 and 2005. ${ }^{6}$ Some considerations on the exchange of gifts between couples, discussed in the third chapter, can be found in my publications in English on the Charites and colour-weaving ${ }^{7}$ and on the Solonian regulation of the dowry in ancient Athens. ${ }^{8}$ As part of the translation, some footnotes have been revised and some additions made to the bibliography. The final chapter of the original book, that on the role played by Delphi as the centre of a supraregional network of transhumant relationships, has been omitted from this English version. Instead, I have added a new section on Transhumance, supraregional exchange, and central sanctuaries to the fifth chapter, dealing with the terminology of exchange. Translations from the Greek are by Elena Theodorakopoulos unless otherwise acknowledged. Abbreviations follow The Oxford Classical Dictionary.

I thank Elena Theodorakopoulos for her careful translation. Particular thanks are due to Claire Taylor and Liselotte Glage for reading and helpful comments. My warmest thanks go to Marie-Louise Nosch and her generosity in supporting the English publication. I would like to thank, once again, those colleagues and friends who supported the German version of this book with their valuable comments and hints, especially Okko Behrends, Hinnerk Bruhns, Justus Cobet, Hans-Joachim Gehrke, Susanne Gödde, Ruth E. Harder, Elke Hartmann, Hans-Jürgen Hildebrandt, Ludolf Kuchenbuch, Jochen Martin, Astrid Möller, Wilfried Nippel, Évelyne Scheid-Tissinier, Pauline Schmitt Pantel, Michael Stahl, Katharina Waldner, and Anja Wieber. Last but not least I would like to thank Paul Royster and Linnea Fredrickson from the University of Nebraska-Lincoln Libraries for their efficient and kind help with the final editing. The University of Nebraska and the Leibniz University of Hannover are partner universities. This book is therefore a result not only of the cooperation between Copenhagen and Hannover, but also between Europe and the United States.

Hannover, February 2020

5. See now Azoulay 2012, who took up my argument.

6. Wagner-Hasel 2003; 2005.

7. Wagner-Hasel 2002. The ideas I developed there were used by McNeil 2005.

8. Wagner-Hasel 2012. 


\section{INTRODUCTION}

I n Plutarch's Life of Solon, the circulation of the tripod among the Seven Sages is said to have 'contributed still further to their standing and fame' as it was handed around 'with honourable good will' (Plutarch, Sol. 4.1). ${ }^{1}$ Barely a century ago a similar circulation of objects undertaken for the sake of honour could be observed in the South Pacific. The father of modern anthropology, Bronislaw Malinowski, describes the circulation and exchange of prestige goods, called the Kula or Kula ring, in his famous 1922 book Argonauts of the Western Pacific. This title involved reference to ancient practices-not to the tale of the circulation of the golden tripod but to the myth of the first seafarers, the Argonauts, and their search for the Golden Fleece. Shortly afterwards Marcel Mauss would develop crucial elements of his theory of the gift with reference to the Kula. ${ }^{2}$ In his famous Essai sur le don: Forme et raison de l'échange dans les sociétés archaiques, published in 1923/24 in the journal L'Année sociologique, ${ }^{3}$ Mauss undertook to grasp both the social and the ethical dimensions of the exchange of objects observed in the Trobriand Islands and elsewhere in the world. The flow of goods in the Trobriand system of exchange does not imply a transfer of ownership, but it does involve forms of compensation, which means that it cannot legally be defined as a form of goods-exchange or trade, nor is it simple gift-giving. Thus, this new form of exchange was defined as giftexchange, or more simply as reciprocity. ${ }^{4}$

The results from this early ethnographic research, and of the sociological theorisation that built on it, have made a lasting impact on anthropology and on sociology, even if they have been subject to numerous modifications and critical reviews. ${ }^{5}$ Our own disciplines saw the Return of the Argonauts from the South Pacific-to cite the programmatic title of a 1982 study of the

1. For further detail see ch. 5.4.

2. For the influence of Malinowski on Mauss see Firth 1963: 222.

3. Mauss's Essai sur le don was translated into English as The Gift in 1954 by Ian Cunnison, in 1990 by W. D. Halls, and in 2016 by Jane Guyer.

4. The concept of reciprocity ('Gegenseitigkeit') goes back to Richard Thurnwald, who, like Malinowski, conducted his ethnographic research in the South Pacific. For further detail see ch. 1 .

5. For an overview of the anthropological debate see Gregory 1982; Godelier 1996: 19-53. 
influence of economic anthropology on the field of ancient history-around fifty years after Malinowski's and Mauss's first contributions. ${ }^{6}$ Since the beginning of the 1980 s there has been a marked increase in the influence of gift theory in classics and ancient history, ${ }^{7}$ as demonstrated by titles such as Reciprocities in Homer, ${ }^{8}$ The Treasury at Persepolis: Gift-Giving at the City of the Persians, ${ }^{9}$ Gift and Commodity in Archaic Greece, ${ }^{10}$ Gifts to the Gods, ${ }^{11}$ and Reciprocity and Ritual. ${ }^{12}$ Such scholarship is no longer limited only to the analysis of the Homeric world, which was the focus of Moses Finley's 1954 book The World of Odysseus-often thought of as the first work to apply Mauss's research to the analysis of ancient evidence. ${ }^{13}$ These days, the rule of Roman imperial families is as likely to be analysed in terms of gift-exchange ${ }^{14}$ as the practices of early Greek tyrants or the politicians of classical Athens. ${ }^{15}$ Not only Homer and other Greek authors such as Pindar, Aeschylus, Euripides, and Herodotus ${ }^{16}$ but also Roman writers like Seneca or Martial are thought now to bear witness to the widespread ancient practice of establishing networks of obligation and reciprocity through the exchange of gifts. ${ }^{17}$

A large number of early publications were concerned with the debate about the character of ancient rulership and the development of the polis and/or the state in ancient Greece. Here, the focus is primarily on rituals of generosity and on competitive forms of giving, which are interpreted

6. Nippel 1982: 1-39; for a modified reprint see Nippel 1990: 124-51.

7. In France, Louis Gernet, a sometime collaborator of Marcel Mauss, contributed the earlier and more sustained influence of Maussian theory on ancient historians and classicists. See Humphreys 1983: 175-79.

8. Donlan 1982.

9. Cahill 1985.

10. Morris 1986.

11. Linders and Nordquist 1987.

12. Seaford 1994.

13. Cf. e.g. Donlan 1989: 2 and Qviller 1981: 112, who praises the revolutionary character of Finley's discovery. In the first edition of the World of Odysseus, Finley refers only to Malinowski and to Karl Polanyi; it was only in the revised edition, published in 1978, that he named Marcel Mauss. For the discussion of the scientific background of Finley's research, see Shaw and Saller 1981; Nafissi 2005; Scheid-Tissinier 2005.

14. Cf. Flaig 1993: 289-305; Martin 1994: 106; Grüner 2007; Zuiderhoek 2009; Beyeler 2011.

15. Herman 1987; 2006; Satlow 2012; Carlà and Gori 2014; Domingo Gygax 2016; Maehle 2018.

16. Campagner 1988: 77-93; Gould 1991; Seaford 1994; Gill, Postlethwaite and Seaford 1998; Mueller 2001; Lyons 2012.

17. Spisak 1998; Griffin 2003; Grüner 2007: 460; Zuiderhoek 2009; Coffee 2017; Hildebrandt 2019; Wieber 2019. 
as evidence for the lack of institutionalisation in early Greek systems of rulership,$^{18}$ and the creation of bonds through guest-friendship. ${ }^{19}$ Prehistorians are especially interested in the debate around the relationship between trade and goods-exchange and guest-friendship. ${ }^{20}$ Other aspects of religious or social practices of gift-giving such as sacrifice, votive offering, ${ }^{21}$ or the giving of gifts in the contexts of marriage ${ }^{22}$ or pederasty, are increasingly examined. ${ }^{23}$

Theoretical concepts are no longer limited to the influence of Mauss and Malinowski but remain indebted to social and economic anthropology. The work of the Hungarian-American historian and economist Karl Polanyi is of considerable significance here. In the 1940s Polanyi differentiated between forms of exchange such as 'reciprocity', 'distribution', and 'market exchange', developing categories that were further refined and modified by his students and colleagues. ${ }^{24}$ Of these developments, the most significant for classical scholarship were Marshall Sahlins's distinction between generalised, balanced, and negative reciprocity and Paul Bohannan's recognition of the separation between the routes of circulation of subsistence and prestige goods. ${ }^{25}$ The differentiation between short-term and long-term transactional orders made by Maurice Bloch and Milman Parry is now widely accepted. ${ }^{26}$ Notwithstanding some variations in theoretical frameworks, most scholars accept the Maussian notion that gifts create a relationship of obligation between the giver and the receiver. ${ }^{27}$ Originally, these forms of exchange had been thought of as belonging to separate historical eras, but since ethnographic observations suggest the contemporaneous presence of practices of gift-exchange and market exchange, recent scholarship postulates a similar contemporaneity for antiquity. ${ }^{28}$ Therefore, economic

18. See esp. Qviller 1981: 109-155; Donlan 1982: 1-15; 1989: 5-29. Cf. also Stahl 1987: 87, 141; Stein-Hölkeskamp 1989: 50-54 in reference to rituals of demonstrative consumption.

19. Herman 1987; Mitchell 1997; Zuiderhoek 2009; Grüner 2007.

20. Kromer 1982: 21-30; Bradley 1982: 108-22; 1985: 692-704; Coldstream 1983: 201-207; Rowlands, Larsen and Kristiansen 1987; Shortman 1989: 52-65.

21. von Straten 1981: 65-151, 283-311; Linders and Nordquist 1987; Bartoloni, Colonna and Grottanelli 1989-90; Silber 2002; Patera 2012; Brøns 2017.

22. Finley 1955; Scheid 1979; Wagner-Hasel 1988; 2009; 2012; Mueller 2001; Lyons 2003, 2012; McNeil 2005; Wieber 2019.

23. Koch-Harnack 1983; von Reden 1995: 195-216.

24. Polanyi 1957a: 243-270.

25. Sahlins 1974: 185-275 and Bohannan 1955; 1968. Donlan 1982 uses both concepts. 26. Cf. e.g. von Reden 1995; Foxhall 2007: 30; Widzisz 2012.

27. Von Reden 1995; Domingo Gygax 2016: 29; Grüner 2007: 459.

28. Cf. e.g. Morris 1986 who refers to the anthropological research of Gregory 1982. 
concepts, such as game theory and rational choice theory, developed for the interpretation of economic behaviour in modern societies, are now used to interpret ancient practices of reciprocity. ${ }^{29}$

The close links between classical scholarship on gift-exchange and ethnographical theory account also for the delayed reception of the Maussian concept of the gift by ancient historians. It is not surprising that Malinowski chose to refer to an ancient myth in the title of his book. The long history of the reception of classical myth in Europe meant that whenever explorers set out towards the rest of the world, they could take comfortable recourse in projecting their experiences onto the 'closest other'. The projection of the Greek myth of the Argonauts onto the Kulatraders in the Western Pacific may serve to assimilate or familiarise the foreign culture into a Western discourse. Conversely, however, it has an alienating effect too. Through association with the gift-exchange practices of the Trobriands, the Greeks, cultural heroes of the Western world, are moved into the realm of what-not so long ago-was thought of as the 'savage' or 'uncivilised' world. Even Finley refers to the Trobriand islanders as 'primitive' and is keen to emphasise the cultural superiority of the Greeks: 'The Greeks of Homer were not primitive men, like Malinowski's Trobriands; they lived in what is often called, by convention, an archaic society. And the Greeks of the succeeding centuries were remarkably civilised people.' ${ }^{\prime 3}$

The homage paid here by Finley to the belief in the greatness of ancient civilisation may sound anachronistic today, but it is entirely in keeping with the ethos of classical scholarship in Europe in the decades after World War II. ${ }^{31}$ In our now 'inter-connected, polyphonous world', 'in which all demand to be heard by all', as the classical archaeologist Tonio Hölscher put it several years ago in his plea for an alienated view of ancient art, the old Eurocentric position threatens to lock classical scholarship into an ivory tower. ${ }^{32}$ Christian Meier is right when he demands

29. Cf. e.g. Herman 1998; 2006; Low 2007: 43-54; Tracy 2014. For discussions in recent economic theory see Rehbinder 2012.

30. Finley 2002: 5 (NYRB edition).

31. Cf. e.g. Dodds 1973: 26-27, who praises ancient cultures as a source of moral and intellectual values of the western European culture. Alexander Rüstow warned of the dangers of 'unbridled relativism' that would result from any departure from this 'humanist point of view' (1952: 12).

32. Hölscher 1989: 5 . 
that we acknowledge the changed position of Europe in the world and abandon the privileging of ancient and western history in order to redefine the place of antiquity in the history of the world. ${ }^{33}$ As he notes, 'it will become clear that statements about Greek distinctiveness that do not take into account a rounded view of other cultures, will no longer be up to scholarly standards'. ${ }^{34}$

Taking proper account of the reality of our interconnected 'one world' 35 means that communication with disciplines such as anthropology that are able to give us access to knowledge of non-European cultures is a matter of urgency. Indeed, it is quite likely that such interdisciplinary communication has been responsible for the increasing interest of ancient historians in the practices of gift-exchange over the past thirty years. Comparative approaches are, however, no recent discovery. The progressive Enlightenment scholars of the eighteenth century and the adherents to evolutionary theory of late nineteenth-century legal history were already perfectly happy to compare the Greeks to the 'primitive' peoples of America or the South Seas. ${ }^{36}$ And when we look at the history of the debate on gift-giving we will see that many of the positions now represented with reference to Mauss and Finley can be found-illustrated with examples from ancient, medieval, and non-European contexts-in the writings of evolutionist historical and economic historians of the nineteenth century. This is true for the obligatory and obliging character of gifts that Mauss was so keen to emphasise, as much as for the reciprocal nature of premodern gift-giving. Many of these works of legal and economic history have found their way into ancient history quite independently of Mauss. Both Mauss and Finley thus stand at the beginning and at the end of a tradition of studying archaic forms of communication. This tradition has its origins not only in the Historical School's critique of the universal validity of Adam Smith's classical liberal theory but also looks back to the legal historians' debate over the nature of premodern gift-giving. This prehistory, well known to Mauss himself, has fallen into

33. Meier 1989: 22 and 15. See also Settis 2005.

34. Meier 1989: 24.

35. See Wolf 1982: 23.

36. See Moravia [1970] 1989: 137-44. For the practice of comparative research in classical scholarship history see Finley 1975: 102-20; Humphreys 1983: 15-30; Hunter 1981: 144-55; Ampolo 1986: 127-31; Nippel 1988: 300-18; 1990; Settis 2005; Payen and Scheid-Tissinier 2012. 
oblivion as a consequence of the paradigm shift from evolutionism to cultural relativism and structuralism. Essai sur le don stands at the pivot of this change-a context which has been barely considered to date. ${ }^{37}$

I do not wish to diminish Finley's contribution to the study of giftexchange in antiquity. But the claim that it was he who introduced Mauss's theory into classical scholarship has more to do with scholarly heroworship than it does with the facts of the history of scholarship..$^{38}$ The long interval between the publication of The World of Odysseus in 1954 and the beginning of the gift-exchange debate in classical scholarship in the early 1980 s argues against such linear genealogy.

It was no coincidence that the debate began at a time when the creation of the 'one world', which had begun with the explorers of the early modern age, entered a new stage with the industrialisation of Europe. In their attempts to make theoretical sense of this new stage, evolutionist scholars could look to the ethnographical reports of these explorers. The latter had themselves made practical use of the phenomenon idealised in ethnographic research by using gifts to create obligation. During the same period, the new legal definition of donation as an altruistic act that enriches only the receiver was developed in the centres of the old world. ${ }^{39}$ With this, the distance between the reciprocal customs of gift-giving common in peripheral cultures and the new European conceptions of altruistic gift-giving increased. Theorising about the practice of gift-exchange should also be understood as going hand in hand with the process of structural transformation undergone by the western industrialised societies of the nineteenth and twentieth centuries. The idealising tendencies that can be observed, especially in Mauss but also in Malinowski, make sense as an aspect of theoretical reappropriation such as is often prominent in times of crisis. Like many other new concepts that emerge as forms of a critique of modernity, and in which the strangeness and difference of antiquity are underlined, the theory of the gift also contains a kind of reversal of the present. ${ }^{40}$

37. For the forerunners of Malinowski see Köcke 1979: 119-67. Maffi 1979: 33-62 discusses the development after Mauss. See also Geary 2003, who stresses the influence of American anthropologists on Mauss, and Wagner-Hasel (2011: 289-95 and 2014: 51-69) on the influence of the German Historical School of political economy.

38. See n. 13 .

39. See ch. 1.

40. See e.g. the concept of matriarchy as a kind of critique of modernity. Gossman 1987; Wagner-Hasel 1992: 295-373. 
My first chapter pursues the economic and ethical ramifications of the theory of the gift before subsequent chapters turn to the material content and to the interpretation of ancient evidence. My goal is to gain insight into the structures of communication in archaic Greece and to contribute to the history of the formation of the polis through the analysis of the semantics and circulation of gifts. The object of this historical investigation is not a concrete historical place but a body of texts, the Homeric epics. My starting point is the conceptual analysis of a selection of terms used for giving in Homer. ${ }^{41}$ The aim is to examine the messages conveyed by the material and concrete form of gifts. Starting from their material form, conclusions can be drawn about the symbolic and practical meaning these gifts have with respect to the relationships in which they are put to use. These are the types of gifts which have considerable significance for the reconstruction of social structures of communication.

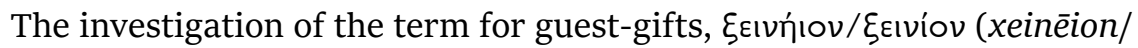
xeinion), in chapter 2 takes into account the whole range of circulating objects and the different relationships into which strangers (xenoi) are temporarily or permanently integrated. The term $x$ ópıs (charis), discussed in chapter 3, gives an insight into the inner workings of such relationships. Charis denotes the material as well as the abstract effects of services or favours, and of gifts; this alignment of the concrete with the abstract imbues the term with the highest symbolic charge. The potential for conflict inherent in the structures of exchange we are considering becomes apparent

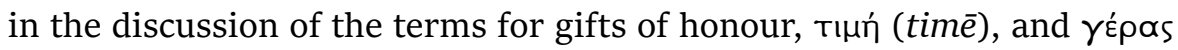
(geras) in chapter 4 . With the analysis of the terminology of trade and ex-

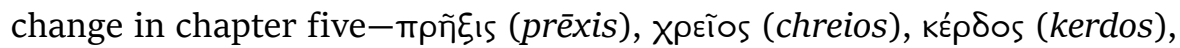
ఓ̃vos (ōnos), and 'ànoıßn (amoibē), usually rendered as 'business', 'debt', 'profit', 'price', and 'exchange'-we return to the question of the function of guest-gifts within reciprocal relationships.

Research into gift-exchange has often disregarded the issue of narrative consistency that is so important for both analytical and unitarian approaches to Homeric epic. ${ }^{42}$ Understanding the circulation of gifts depends to some extent on the logic and consistency of epic narration, especially since the narrative action so often focusses precisely on those occasions when the flow of gifts and counter-gifts becomes susceptible to disturbance or breakdown. So, the Iliad opens with Achilles's anger about the loss of his gift of honour 
(geras), Brisëis, and it depicts the consequences of the dishonoured hero's refusal of service in battle (charis) for Agamemnon. The Odyssey deals with Penelope's refusal to complete her weaving task, which in turn maintains for Odysseus the possibility of attaining gifts of honour. If we do not acknowledge narrative sequence, individual acts of giving may appear functional, even when in the context of the narrative itself they are not. Conversely, the refusal of gifts may appear dysfunctional in isolation, while the narrative context will show the intrinsic logic of such refusal. As an example, one may consider the exchange of arms between Glaucus and Diomedes in Iliad 6 . Scholarship tends to present this as an ideal example of gift-exchange, but I will show further along that the narrative context reveals that this exchange is a reversal of the usual norms of reciprocal giving.

Alongside the question of narrative consistency stands the question of historicity and place. For a long time, archaeological research had pointed to Mycenaean Greece of the second millennium as the historical context for heroic epic. With the oral theory research of the 1930s, dating of the epics has shifted towards the eighth and seventh century as the time when they were fixed as written texts after the spread of the Phoenician alphabet. ${ }^{43}$ This turn reflects both the limited historical depth of oral memory and the role of audiences in the reception of oral poetry. ${ }^{44}$ It suggests also that the poems must have satisfied the interest of those who are said to have commissioned the creation of a written text and organised the recitation of the Homeric poems during the Great Panathenaic festival: the Athenian tyrant Peisistratus and his sons. ${ }^{45}$ Indeed, some scholars think that the epics represent historical realities from as late as the sixth century BCE. ${ }^{4}$ Scholars concerned with Homeric gift-exchange tended rather to backdate the social and historical conditions represented in the epics to the ninth century BCE, claiming that the poems reconstruct a 'pre-state' reality. ${ }^{47}$

43. See Patzek 1992; Latacz 1979; 1989; Raaflaub 1991: 205-56; Ulf 2002; Rengakos and Zimmermann 2011.

44. This is stressed by Svenbro 1976: 16-35; Jensen 1980: 164; Boyd 1995. See also Thomas 1992; Bakker and Kahane 1997.

45. On the sources of the so-called 'Peisistratean Recension' see Merkelbach 1952 and Boyd 1995. In his account of the 'Peisistratean Recension', Boyd concludes that the story of the organisation and editing of the texts of the Iliad and Odyssey must be understood as the product of 'a literate age, even while hoping that we can free ourselves to imagine a world before fixed texts' (1995: 45). Svenbro 1976: 106-7 interprets Hipparchos's and Peisistratus's interest in Homer as an attempt to gain control over the tradition.

46. See Jensen 1980: 167-71; Boyd 1995.

47. This is the case for Finley [1954] 1967 and Donlan 1989. For more detail see ch. 1.4. 
My preferred method, which is to work from the text itself, allows me to reopen the question of the historical era represented in the poems.

Despite the focus on the terminology of giving, this is not strictly a philological study aimed only at establishing the semantic field of individual technical terms. Rather it is intended as a historical study. The analysis of terminology and concepts forms the methodology through which to determine the social symbolism of gifts within early Greek structures of communication. The research context within which I would like to place this investigation is the debate about the formation of regional and supraregional centres that has been invigorated by the works of François de Polignac, La naissance de la cité grecque: Cultes, espace et sociétés VIIIe-VIIe siècles avant J.C. (1984, 1995), and Catherine Morgan, Athletes and Oracles: The Transformation of Olympia und Delphi in the Eight Century B.C. (1990)..$^{8}$ With these studies we see attention paid not merely to the inner workings of individual communities or settlements and to conclusions about the formation of state structures. Rather, the formation of the polis is now seen as a process of spatial integration and of the increased density of spatial communication. This formation can be observed through the placement of temples on the peripheries of poleis and in the establishment of heroic tombs or shrines. ${ }^{49}$ The communicative patterns underlying the distribution of gifts are of considerable significance for an understanding of this process; the epics provide the best literary example of an idealised depiction of such patterns of communication through gifts. Often seen as a repository of cultural knowledge, ${ }^{50}$ the epics have been linked to the spread of hero-cults practised at the heroic tombs and thus to the evolution of the polis..$^{11}$ The supraregional level on which the pattern of gift-exchange appears to operate in the poems suggests, as we shall see, that its sociohistorical context is rooted in the interregional communications of the eighth to sixth centuries. This conclusion is also suggested by the placing of the tripod of the Seven Sages, noted at the beginning of this chapter, in supraregional temples..$^{2}$

Current scholarship on gift-exchange has caused the objects themselves to fade into mere abstractions or symbols of power; a key aim of this study

48. See also Alcock and Osborne 1994; Rowlands, Larsen and Kristiansen 1987: 1-11. 49. See de Polignac 1996; Wagner-Hasel 2002; McInerney 2006: 33-59; Cole 2004.

50. Havelock 1978: 10-12. Thomas 1992: 116 understands the poet as 'administrator' of the cultural heritage. For more detail see ch. 1.5.

51. Cf. e.g. Coldstream 1979: 341-356; Bérard 1982: 89-105; Snodgrass 1982: 107-19; de Polignac 1984: 42-49; Whitley 1988: 173-82; Patzek 1992: 121-43.

52. See ch. 5.4 . 
is to recover the sensory, material content of these objects. My approach has certainly been influenced by the interest in cultural history taken by historians since the $1990{ }^{53}$ However, in this study, cultural interpretation of history focusses not only on mentality and on the imaginary. It is also built on the interest in material objects themselves that in recent years has been gaining much attention. ${ }^{54}$ By analysing the 'sensory content' of gifts, my aim is to illuminate social structures of communication. The title, The Fabric of Gifts (Der Stoff der Gaben), refers to textile gifts that are just as important in the epics as the metal gifts. While metal gifts may be understood to carry more spatial symbolism, textile gifts are more strongly connected to time than to space and to the internal workings of society. What both types of object have in common is their semiotic power, which is as readable as the language that is used to speak about them.

My approach is also linked to an interest in interdisciplinary communication. At its beginning, research into gift-exchange brought together a range of different disciplines so that the theory of the gift is the result of communication between legal history, political economics, and classical scholarship; once it enters firmly into the realms of sociology and economic anthropology, however, this interdisciplinarity came to an end. It was not only classical scholarship that withdrew from interdisciplinary dialogue; 55 sociology and economic anthropology also pursued new paths, putting aside the ancient world as a field of enquiry into the effects of the gift. ${ }^{56}$ The contribution that can now be made by an ancient historical study to the debate on the gift is to recall the roots of that debate, and in particular to recall the critique of modernity which so markedly characterised early discourse on the gift. Thinking about gifts was never only an attempt to approach archaic and forgotten practices. It has always and quite specially been an attempt to understand the relationship between economics and morality-an attempt that may also result in utopian thinking.

53. Cf. Daniel 1993: 69-99; Neidhardt 1986: 10-12; Oexle 1995. For a critique see Kaschuba 1995: 27-46.

54. See Grand-Clément 2011; Wagner-Hasel 2015; Canevaro 2018.

55. In German scholarship, the work of the economic historian Bernhard Laum in the 1920 s on the development of money in the ancient world forms a turning point in appealing to 'Stammesverwandtschaft' and 'Nachbarschaft', with reference to Eduard Meyer's position, as preconditions for comparative methodologies. Laum 1924: 5-6. In anglophone and French scholarship, the comparative approach is and was much more accepted. See Humphreys 1983; Wittenburg 2012.

56. In the meantime, anthropologists and philosophers are also venturing into classical scholarship. See Beidelman 1989; Hénaff 2002. 


\section{CHAPTER 1}

\section{The Circulation of Goods and the Theory of Gifts: A Debate on Economy and Morality}

\subsection{Prehistory of the gift: Discourses of law and economics on gifts and exchange}

The history of the debate on gift-exchange is a history of the relationship between economics and ethics within modern societies. The 'founding fathers' of these theoretical discussions leave no doubt about this connection. In his Argonauts of the Western Pacific (1922) Bronislaw Malinowski described a form of exchange of goods which was meaningless when viewed from the 'perspective of the imperial market-economy of Europe'. In Essai sur le don (1925) Marcel Mauss made use of Malinowski's account to launch an attack on the principles of modern 'rationalism' and 'mercantilism', which were responsible for the increasing value of 'profit and the individual'. He concluded that retaining these principles would harm the 'purpose of the whole, the rhythm of our work and our pleasures, and finally each of us'. ${ }^{2}$ Mauss's message is unambiguously critical of, even hostile to, modernity: he advocates the reunification of economics and morality, of social and economic practice, and the subordination of the individual to the needs of the community. ${ }^{3}$ In contrast to modern marketeconomics, Mauss saw in gift-exchange what he described as a 'system of total prestations' ('le système des prestations totales') in which 'the market is but one element and the circulation of wealth but one part of a wide and enduring contract.' The most significant items exchanged in the Maussian system are 'courtesies, entertainments, ritual, military assistance, women, children, dances and feasts', and these exchanges 'take place under a voluntary guise', although 'they are in essence obligatory, and their sanction is private or open warfare'. The three constitutive elements of this form

1. See Kramer in Malinowski 1979: 557 and 570.

2. Mauss 1990: 76 .

3. See Godelier 1996: 7-12; Berking 1996: 246-55. 
of contract, which is not one between individuals but between groups, are giving ('donner'), receiving ('reçevoir'), and returning ('rendre'). Mauss views the alliance of pairs of phratries in Australian and North American tribes as the best representation of this archaic form of contract. In its most evolved form, it can be found in the agonistic exchange ceremonies ('prestation totale de type agonistique'), known as potlatch, and practised by the Kwakiutl, Tlingit, and Haida on the northwestern coast of America. ${ }^{4}$

With this critique of modernity, Mauss is part of a tradition reaching back through Émile Durkheim (1858-1917) to the Historical School of political economy ('Historische Schule der Nationalökonomie'). In France, any critique of individualism such as the one Mauss undertook implied a critique of the ideals of the French Revolution. ${ }^{5}$ In this, Mauss followed his teacher and uncle, Émile Durkheim, who had argued that the kernel of the development of moral discipline lay in group formation. ${ }^{6}$ Durkheim's belief in the collective, often criticised in sociological research, is also informed by a critique of modernity. ${ }^{7}$ In the preface to the second edition in 1902 of his study De la division du travail social (1893), in which he had laid out the concept of the advance from mechanical to organic solidarity, Durkheim is no less critical than Mauss of the loss of the connection between economics and morality in modern societies. Durkheim suggests here that the dominance of the market over 'military, administrative and religious functions' forms 'a notable source of general demoralization. ${ }^{8}$ As a solution he imagines tying the individual back into the collective sphere through the creation of guilds or similar organisations, which would help to rein in individual egoisms and create feelings of solidarity; for Durkheim this would be synonymous with morality. ${ }^{9}$

\subsubsection{The gift in the debates of the Historical School of political economy}

A key factor in the formation of Durkheim's belief in the collective emerged during his studies under the psychologist Wilhelm Wundt (1832-1920)

4. Mauss 1990: 4 .

5. See Giddens 1976: 710.

6. Cf. Lévy-Bruhl 1948/49: 1-4; Hollier 1972: 55-61; Gane 1992; Cefaï and Mahé 1998: 209-28.

7. Cf. Hofmann 1973: 16-30; Adorno 1984: 7-44; Hauck 1984: 106-9. Hauck criticises the moralism of Durkheim, whereas Giddens (1976: 708-14) underlines the social aspects of Durkheim's concept. See also Borlandi 1998: 27-65.

8. Durkheim 1964: 4 .

9. Durkheim 1964: 26-31. 
and the political economist Gustav von Schmoller (1838-1917) towards the end of the nineteenth century in Germany. Durkheim had drawn his ideas from the Historical School's critique of the neoclassical notion of homo oeconomicus. The Methodenstreit, the dispute between the Historical School of political economy (of which von Schmoller was a leading exponent at the time) and the adherents of neoclassical liberal economic theory around Adam Smith, e.g. Carl Menger (1840-1921), ${ }^{10}$ taking place in the 188 os and 1890 s, was therefore a decisive factor in the development of the theory of gift-exchange.

The Historical School had evolved in the wake of historicism and remained essentially limited to German-speaking areas, and within these circles a strictly ethical conception of the economy dominated. The economy was understood, in a neo-romantic sense, as a socio-organic life process subject to continuous change. ${ }^{11}$ This, in turn, cast doubt upon the universal applicability of modern economic categories. The Historical School's critique was thus directed against the moral implications of the concept of exchange which had become canonical with the emergence of liberal economic theory, and which presented exchange as an act of self-interest aimed at attaining economic advantage. This critique, therefore, developed into a questioning of the universality of such an understanding of exchange. The legal concept of making a gift ('Schenkung') as an altruistic act undertaken for the benefit of another functioned here as a countermodel, a concept of giving associated with a collective economy. Special emphasis was given, however, to the aspect of mutuality ('Wechselseitigkeit') or reciprocity ('Gegenseitigkeit'), so that in the course of time the concept of 'gift-exchange' was established as the accepted designation for this alternative form of interaction. This concept itself was influenced by legal historians, whose reflections on the character of premodern gifting formed the second root of the theory of gift-exchange.

This association between collective economic systems and altruistic forms of human interaction could already be found among exponents of the older Historical School of political economy, such as Adolph Wagner

10. The Austrian economist Carl Menger, using the deductive approach of classical economics, aimed to develop universal principles of economics, while Gustav von Schmoller proceeded with a primarily inductive approach to relativize the economic theorems of neoclassicists. See Winkel 1977: 138-50; Schmölders 1988: 109-121; Starbatty 1989: 97-134; vom Bruch 1988: 219-38. The debate between representatives of formalist and substantive approaches to the economy continued in the 1960s within anthropology. Cf. Röpke 1969: 101-34.

11. Winkel 1977: 82-89. 
(1835-1917). In his book Allgemeine und theoretische Volkswirtschaftslehre (1876) Wagner argued that 'mutual solidarity in granting goods and services' was a typical feature of communal economic systems. ${ }^{12}$ Drawing on this tradition, which was supposed to have made altruism, or rather public spirit, 'an impulse equal in value to that of acquisition', ${ }^{13}$ Gustav von Schmoller distinguished between altruistic domestic economy ('Hauswirtschaft') and egoistic exchange economy ('Tauschwirtschaft'). Schmoller argued that within the former, an individual could be compelled to 'service and assistance', but 'could also receive services and assistance free of charge'. The exchange economy, by contrast, was said to be based on 'the free play of interests with the continual aim at service in return. ${ }^{14}$ In any case simple market and exchange relations were still based, according to Schmoller, 'upon a feeling of a certain solidarity' and 'mutual trust.'. ${ }^{15}$ In his Volkswirtschaftslehre of 1900, Schmoller explained that this change in perspective on perceptions of exchange had arisen through contemporary crises:

The optimistic glorification of the individual's egoistic striving for acquisition and wealth had to give room to a more pessimistic view, when free competition, world-economic crises, and the progress of technology caused the numbers of the poor and the unemployed to rise, inequality of wealth to increase, and the power of the rich to show itself from a less favourable side. Noble humanitarians began to discuss the disadvantages of the new economic order, and in particular of free competition. ${ }^{16}$

Schmoller's younger colleague Karl Bücher (1847-1930) is even more explicit in distancing himself from the notion that exchange was part of the origins of human society. He dismissed this idea as a 'rationalist construct', first in Die Entstehung der Volkswirtschaft (1893) $)^{17}$ and more clearly still in Schenkung, Leihe und Bittarbeit (1918)..$^{18}$ Instead, he assumed for the earliest days of history a form of 'unpaid surrender where goods and services transition from one household to another' ${ }^{19}$ He counted loan

\footnotetext{
12. Wagner 1876: 164 .

13. Schmoller 1900: 33 .

14. Schmoller 1900: 2.

15. Schmoller 1900: 37 .

16. Schmoller 1900: 93 .

17. Bücher 1893: 39 .

18. Bücher 1918: 3 .

19. Bücher 1918: 4 .
} 
('Leihe') and boon-work ('Bittarbeit'), as well as gift-exchange, among such nonpaid forms of giving, and considered taxes, duties, and tributes to have developed from these over time. Bücher considered all these forms of unpaid giving to be altruistic in character, but underlined the necessity of reciprocation, while denying the need for exact equivalence in value that characterised modern exchange. 'In all of these cases, it is not a matter of attaining service in return, but rather of affirming devotion with the purpose of attaining something different, the amount of which, to a certain degree, one was able to determine'. ${ }^{20}$ As an economist with prior training in ancient history, ${ }^{21}$ Bücher especially emphasised reciprocity with respect to borrowing, referring back to Hesiod in support of this. ${ }^{22}$ Other forms of unpaid giving, such as gifts handed over to guests or bridal gifts, also demanded reciprocation according to Bücher, since the acceptance of gifts created obligation: 'To refuse them would be a serious insult to the giver; their acceptance obligates the receiver absolutely, and the giftgiving is only concluded when the gift-giver has declared himself satisfied with the counter-gift. Up until that point the initial gift can be recalled. ${ }^{23}$ All these forms of mutual gift-giving, in Bücher's opinion, benefitted the interests of single households, and belonged to the developmental phase of what he termed a 'closed domestic economy' in his Entstehung der Volkswirtschaft. ${ }^{24}$

Bücher was also concerned with the connections between ethics and economics. Thus, his representation of unpaid forms of exchange concludes as a plea for the consideration of ethics in market-economics:

Boon-work alone has remained unchanged in rural economies. Indeed, it has even become ennobled, since in situations when a family is lacking a bread-winner, neighbours will often undertake urgent field-labour in a form of voluntary mass-labour.

20. Bücher 1918: 4 .

21. See Schefold 1988: 239-68; Wagner-Hasel 2011: 31-37; 2014.

22. Bücher 1918: 12 .

23. Bücher 1918: 6-7. This concept was widely accepted in the economic and social anthropology of these years. Cf. e.g. Post 1895: 681: 'Schenkungen scheinen bei uncivilisierten Völkern stets auf Gegenseitigkeit zu beruhen'. Similar Berolsheimer 1907: 222-27.

24. The second edition of the book was translated into English and French. While at first Bücher had assumed that an exchange of goods at the stage of the closed household economy occurred only in terms of voluntary gifts or theft, he emphasized the reciprocity of giving in the second edition. See the English translation of S. Morley Wickett: Industrial Evolution 1901: 111-12. 
Here we see the kindness of the human heart shine through; we can assume its effectiveness for all three forms of unpaid giving in ancient times to a far greater degree than may appear at first sight to be the case. Ethics is still a force in economic life, and it would be a dire thing for our future if it were to be eclipsed entirely. ${ }^{25}$

At the beginning of the twentieth century, however, critics of homo oeconomicus were not alone in arguing for reciprocity when it came to gift-giving. In his Güterverkehr in der Urgesellschaft (The Circulation of Goods in Primitive Society) from 1909, Felix Somló (1873-1920) defined the primitive form of interaction he called 'gift-exchange' as a 'clearly defined legal transaction completed according to specific rules, which is the original form of our own gift-giving and exchange'. He considered 'giftexchange' ('Geschenktausch') to be similar to gift-giving in so far 'as it is originally a one-sided gift which corresponds to a one-sided acceptance, and as the size of the gift and the actual fact of giving itself, originate from a one-sided decision made by the giver. It also resembles exchange insofar as the act of giving occurs with the expectation of a return gift, and usually strictly obligates the receiver to offer such. The value of the gift and the value of the return gift are governed by strict customs'. ${ }^{26}$ Unlike Bücher, who regarded gift-exchange as complementary to household economies, Somló, in line with neo-classical liberal theory, sees it as guaranteeing the cohesion of economic groups. Such groups consisted, in Somló's view, even at the lowest level, of mutually dependent individuals and smaller economic units. ${ }^{27}$

Richard C. Thurnwald (1869-1954), a follower of Bücher's work, is similarly placed between the neo-classical and the Historical School of political economy. ${ }^{28}$ In a letter to Bücher from Sarajevo on January 21, 1898, Thurnwald introduced himself 'as one of those German political economists [...] to whom you express the wish in your Entstehung der Volkswirtschaft that they observe "those contemporary peoples who are primitive and lacking in culture according to the economic side of their lives".'29 Because of the connotations of altruism and gift-giving,

25. Bücher 1918: 24 .

26. Somló 1909: 156-57.

27. Somló 1909: 177.

28. Köcke 1979: 119-67.

29. Leipzig University Library, Nachlass 181, Karl Bücher. Tr. T. Lambert. 
Thurnwald avoided the term 'gift-exchange', preferring to refer to 'reciprocity' instead, and integrating this term within a theory of sociation, or Gesellung..$^{30}$ Thurnwald considered the practice of exchange to be both universal and very ancient. In this he differed from his teacher Ferdinand Tönnies, who distinguished in the 188 os between Gemeinschaft (community) and Gesellschaft (society); in this sequential model reciprocity is a feature of community, but exchange and contracts between individuals only arise with the development of Gesellschaft or society. ${ }^{31}$ However-and in this Thurnwald followed the ideas of the Historical School of political economy-he did not believe that exchange is invariably aimed at gaining economic advantage, nor that it is always governed by self-interest. Instead he recognised its social uses, especially in early societies. For instance, he considered exchange acts in 'primitive' communities to be acts of compensation between individuals or families, very unlike the rational impersonal transactions of modern-day societies. ${ }^{32}$ In Thurnwald's account, transactions involving gifts and feasting served to knit a tightly woven fabric of friendship and mutual obligations, while reciprocity forged emotional rather than purely economic bonds. ${ }^{33}$ These bonds are horizontal as well as vertical and can be seen in the relationships between generations and genders, among relatives and within male groups, between the living and the dead. Indeed, according to Thurnwald the obligation of reciprocity affects even the most powerful. ${ }^{34}$ When it came to the question of equivalence, he distinguished between gifts that were identical in type and number, and exchanged like for like, and those that were similar in worth, and where the measure of their worth was to be read as deeply embedded in societal norms and values. Thurnwald suggests that money developed from the use of tokens, which served as reminders and symbols to help maintain reciprocal obligations. ${ }^{35}$

Within the traditions of the Historical School, Bronislaw Malinowski (1884-1942), like Thurnwald, assumed the universality of exchange, although in his assessment profit and self-interest were not always under-

30. Thurnwald 1936: 275-97 (this article is a synthesis of former studies on the subject). See Thurnwald 1911: 422, where he writes: 'Jede Gabe heischt ihre Gegengabe' ('Every gift demands a gift in return'). Similar Thurnwald 1912; 1921; 1932.

31. Tönnies [1887] 1991: 10, 24, 35. On the problematic nature of the opposition between Gemeinschaft and Gesellschaft see Oexle 1994: 118-25.

32. Thurnwald 1936: 282.

33. Thurnwald 1936: 283.

34. Thurnwald 1936: 289 .

35. Thurnwald 1936: 284 . 
lying motivations in all exchange transactions. ${ }^{36}$ For this he earned high praise from his mentor James G. Frazer. In the preface to Argonauts of the Western Pacific, Frazer wrote that Malinowski had provided proof that individual striving for profit and cost-benefit analysis had not always determined the traffic of goods everywhere. In Frazer's view, Malinowski instead demonstrated that 'the curious circulation of valuables', which took place 'between the inhabitants of the Trobriand and other islands, while it is accompanied by ordinary trade', was 'by no means itself a purely commercial transaction.' Malinowski rather showed that this circulation of valuables was 'not based on a simple calculation of utility, of profit and loss', but that it satisfied 'emotional and aesthetic needs of a higher order than the mere gratification of animal wants. ${ }^{37}$

\subsubsection{The legal-historical debate: From reciprocity to free surrender}

An alternative to the egoistical model of exchange came through the work of German legal historians concerned with modern legal definitions of gift-giving, and it was they who introduced the term 'gift-exchange' ('Geschenktausch') to the debate. Their reflections were a response to the legal redefinition of gift-giving which had come to a conclusion in the 1890 . On 1 January 1900, the groundbreaking new German Civil Code (Bürgerliches Gesetzbuch = BGB) came into effect, ${ }^{38}$ defining gifting, assuming that both parties are agreed that there will be no compensation, as an 'allocation through which one person enriches another with his property'. The legal definition, therefore, excluded the possibility of a gift given in expectation of receipt of any equivalent (such cases would be defined as barter or purchase). In modern legal thought, gifting is essentially defined as a one-sided donation. Any obligation is on the side of the giver, and the transfer of property does not aim to place any obligation on the receiver of the gift. This one-sidedness, both economic and ethical, distinguishes modern gift-giving from its ancient predecessors.

36. Malinowski [1922] 1999: 85. Malinowski acknowledged Bücher's pioneering work in the area of economic ethnology: 'The best analysis of the problem of the savage economy is to be found in, in spite of its many shortcomings, in K. Bücher's “Industrial Evolution”, English Translation 1901.' But he criticises Bücher's view of primitive trade. For the influence of Bücher on Malinowski see Köcke 1979: 152-59; Firth 1972: 467; 1963: 209-27, where he criticises Malinowki's concept of economy. Cf. also Spittler 2008: 197-217.

37. Frazer in Malinowski [1922] 1999: X.

38. Wesel 1988: 94-97. 
By contrast, the Prussian Allgemeines Landrecht of 1794 had no such unified notion of gift-giving, requiring 140 paragraphs to regulate different kinds of gifting, which could be one-sided or reciprocal, or remunerative, and which also included ethical elements. ${ }^{39}$ The social and ethical implications of gift-giving played a significant role in the debates leading up to the new definition formulated for the Civil Code. There was discussion for instance about whether gifting should presuppose that the giver approaches the transaction voluntarily and with selflessness. There was also debate about the need for regulation when it came to gifts given as part of social interactions, such as at weddings or birthdays. Finally, it was decided that the only gifts deemed relevant in terms of the code were those that affected property. The focus on property is an expression of the sharp dividing line between law and ethics on which lawmakers such as Hugo Burckhard (1854-1912) insisted..$^{\circ}$ Legal handbooks, by contrast, frequently referred to older German law according to which a gift was not binding in the absence of any form of return gift or service. ${ }^{41}$ In his study of German civil law of 1917, Otto Gierke (1841-1921) showed that the new definition of gifting in the German Civil Code of 1900 formed the conclusion of a gradual evolution from a reciprocal to a one-sided definition of gift-giving. ${ }^{2}$

39. See $\S \S 1037-1177$, as well as $\S 893-900$ (ed. Hattenhauer 1970). According to this legal code, making a gift could be one-sided but could equally be of a mutual and paid nature, thus allowing for moral elements in gift-giving as well. Paragraph 1037 defined gift-making as 'contracts through which one person is obligated to surrender to another person the property of an object without requital'. Mutual gifting required two contracts ( $\S 105$ ). The following was written about 'rewarded giving' in $\S 1169$ : 'If a laudable act or an important service completed is repaid, then this is called a rewarded gift'. § 1041 guaranteed the legal claim to services which arose from the obligation to charity: 'Where a special personal obligation exists, even if it is not fundamentally binding, then it is assumed that this has been given without any reservations in the intention of giving'. Relatives, siblings, married couples, poor people, charities for the poor, and foundations are all named here as examples ( §§ 1042-1045). Cf. Gierke 1917: 430-32, n. 73.

40. Burckhard 1899: 130-31; Mauss 1990: 4, n. 4 refers to the publication, but said he was not able to consult it. For a moral argumentation see Meyerfeld 1835. For the evolution of the modern concept of giving see now Sorge 2012.

41. Cf. Kiekebusch 1928: 286. Ogris 1990: 1382 also states that older German law insists that gifts are binding only when counter-gifts have been given, and that to avoid the possibility of a gift being recalled, it was necessary to disguise the gift as a transaction involving either genuine or apparent compensation. Hattenhauer 1992: 13-14 argues that there was no such thing as a gift without the expectation of compensation in older legal cultures that were founded on the principle of do ut des.

42. Gierke 1917: 432 . 
This process of standardising the legal definition of gift-giving and focussing it entirely on the economic dimension of the unpaid transfer of assets also occurred in a similar way in other countries, crystallizing the distance from past European practices as well as from forms of interaction observed in the colonies..$^{43}$ It created an awareness that it was necessary to rethink those forms of human interaction which could neither be classified as market exchange nor as gift-giving in the sense of the German Civil Code. It is thus no coincidence that the concept of gift-exchange appeared for the first time in legal-historical literature of the 188 os and 189os, although descriptions of the phenomena are clearly older. ${ }^{44}$ With this new concept, a third category was created in addition to paid giving (barter, purchase) and unpaid giving ('pure' gifting), a category which combined elements of both forms of giving.

The concept of gift-exchange was first introduced by historians of German law working on premodern forms of gift-giving. The beginning of this research is found in Jacob Grimm's (1785-1863) etymologically oriented study Ueber Schenken und Geben (On Presenting and Giving, 1848).45 Among subsequent studies, Karl von Amira's two-volume study Nordgermanisches Obligationenrecht (The North Germanic Law of Obligations), published between 1882 and 1885 , was of particular importance..$^{46}$ Von Amira (1848-1930) distinguished conceptually between gifts in the OldSwedish/West-Nordic Middle Ages and modern gifts. In the former, there

43. In France the process found its conclusion in the Code Civil. See Siebert 1938: 144-59. On practices of giving in premodern France see Davis 2000. On reciprocal gifting in premodern Italy see Arru 1998.

44. Cf. e.g. Pallas [1776] 1980: 105, who reported that the Kalmuks 'share everything which can be enjoyed and keep nothing for themselves [...] However, this generosity extends primarily to things that can be consumed. They do not gladly give away property and livestock, except in the hope of a gift in return or as a token of appreciation'. I would like to thank Hans-Heinrich Nolte for this reference. At the same time, the generosity of North American Indians was mentioned by Adam Ferguson [1767] 1986: 212. He draws a parallel between the giving practices of the ancient Germans and the North American Indians in his Essay on the History of Civil Society, published in 1767.

45. Grimm [1848] 1865: 173-210.

46. The pioneering character of Amira's work was emphasised by Max Pappenheim 1933: 35-88. Pappenheim posed the same question as Marcel Mauss ten years previously but did not consult Essai sur le don. For the German debate on premodern gift-giving see Gierke 1917: 420, n. 22; Hattenhauer 1992: 13-15. In studies on the Middle Ages the interest in the subject has been growing since the 1990s: see Hannig 1988: 11-37; Clavero 1996; Groebner 2000; Algazi, Groebner and Jussen 2003; Grünbart 2011; Münkler, Sablotny and Standke 2015. 
was no transfer of assets, which represented, for von Amira, 'marks of favour' that invited gratitude and thus were rewarded with counter-gifts: 'Favour for favour! The receiver must pay for the gift [...]. A gift demands a counter-gift [...]. [This is] a legal tenet which has been definitively confirmed [...]. One gives either because one expects a gift in return, or because the gift itself is supposed to demonstrate the giver's gratitude for favours received or promised'. ${ }^{77}$ Von Amira includes land, payment for healing services, and wedding gifts among such gifts, ${ }^{48}$ as well as guest-gifts and market rights or tithes. ${ }^{49}$ In the first volume von Amira defines this form of giving, which is motivated by reciprocity, as 'obligatory business' ('obligatorisches Geschäft'), 'gift-contract' ('Schenkungsvertrag'), and as the 'prototype of the actual contract ('Urbild des Realvertrages')'. ${ }^{\circ 0}$ In the second volume he uses the term 'Gabentausch' ('gift-exchange'), which he views as based on the equivalence ('Gleichwerthigkeit') of gifts. ${ }^{51}$

A few years later the Germanist Richard M. Meyer (1860-1914), in his work Zur Geschichte des Schenkens (On the History of Gift-Giving), made a first attempt at a synthetic analysis of premodern forms of gift-giving; here he claimed that a new understanding of property accounted for the change from reciprocal to one-sided gift-giving..$^{52}$ In premodern times (no further temporal definition is given), Meyer assumes that property was tied to communities and that this prevented its transfer without reciprocation: 'According to natural law all things are communal and any individual's possessions are only owned subject to the obligation of handing them on'.53 He distinguished between different types of giving, such as giving subject to recall, loaning ('Leihe'), giving with the expectation of return, e.g. sacrifice ('Opfer'), and obligatory sharing ('pflichtmäßiges Austeilen'). The latter also includes the largesse of kings and heads of households as well as public services such as the liturgies that wealthy Athenians were obliged to finance. 'All giving in ancient times', Meyer sums up, 'is either subject to recall, or relies on the obligation of one of the parties involved. ${ }^{54} \mathrm{Al}$ though he considered gift-giving and gift-exchange to be the earliest form of trade, he did not assume that gifts were precisely equivalent, but instead

47. Amira 1882: I, 506-8.

48. Amira 1882: I, 509.

49. Amira 1882: II, 611-12.

50. Amira 1882: I, 510, 516, 619.

51. Amira 1882: II, 615 and 620.

52. Meyer 1898: 18-29.

53. Meyer 1898: 27.

54. Meyer 1898: 19. 
that values were freely estimated and that usually a counter-gift's value would be greater than the value of the initial gift. ${ }^{55}$ Meyer did not take an entirely positive view of this development, as his concluding critique of individualism suggests:

Our modern concept of gift-giving is based on the notion of freely disposable property, which does not apply to earlier times (especially not in Germany), and it also presupposes a lack of restrictions in relations between giver and receiver that is not in keeping with the restrictive ethics of earlier eras. Thus, free giving is an achievement of a new worldview and its individualism. This should not therefore be regarded as progress in every respect. ${ }^{56}$

Late nineteenth-century historians of Roman law also demonstrated awareness of ancient obligations of reciprocity, but they did not employ the term 'gift-exchange', nor did they engage in any critique of individualism or individual contracts. The concept of reciprocity, or mutuality, was most prominent in the scholarship of Roman law, although this was initially used in a purely legal sense. There, reciprocity was a concept connected to contract ethics (lawyers, for example, explained the legal efficacy of unpaid surrender in ancient times through the reciprocity of giving). It was only through its reception by political economists that reciprocity became a socio-economically significant concept. According to Hugo Burckhard, who drew on Roman law in order to establish the modern concept of giving, older forms of law had recognised reciprocal gift-giving. He argued that 'will only becomes legal will once a countergift has been given', and that 'only by presenting non-remunerated business in the form of remunerated business would the parties involved become aware that they were no longer dealing with a service that was entirely dependent on the giver's say-so, but rather with a service under the protection of the law. Only now is the giver legally bound to his stated desire and only now does the receiver have a legal guarantee of

55. Meyer 1898: 26.

56. Meyer 1898: 29. Cf. also Gierke [1902] 1962: 113. Gierke tied a change in the concept of giving to a critique of individualism and praise for the ideal of community. In doing so, he relied on Fichte, Wundt, and the Historical Legal School ('Historische Rechtsschule') as well as on folk psychology ('Völkerpsychologie'). On Gierke's ideas on community see Oexle 1988: 193-217. In his Völkerpsychologie (vol. 8/1: 138-40) Wilhelm Wundt defines gifting and exchange as the earliest forms of communication. Presumably Wundt took up the ideas of Karl Bücher, his colleague at the university of Leipzig. See Wagner-Hasel 2011: 154-56. 
retaining the gift. ${ }^{57}$ According to Burckhard, this practice of presenting unremunerated gifts in the form of remunerated giving was also valid in Islamic law, in the launegild business of the Langobards, and in the giwa of the Northern Germans, as well as in the manicipatio nummo uno donationis causa of Roman law. ${ }^{58}$

The work of the constitutional law scholar Lothar von Dargun (18531983), Egoismus und Altruismus in der Nationalökonomie (1885), forms a significant intervention in the Methodenstreit between legal historians and political economists. ${ }^{59}$ Von Dargun drew on the position of the Historical Legal School ('Historische Rechtsschule'), represented by Rudolf von Jhering (1818-1892), whose study Der Zweck im Recht (Law as a Means to an End, 1887) he considered to be essential for the 'doctrine of mutualism' ('Lehre vom Mutualismus'). He distinguished between acts driven by economic self-interest within the framework of the free flow of goods, and altruistic acts which were especially relevant within the framework of 'collective economies', in associations, families, and, above all, in states. He defined state taxation as a 'grand system of giving of gifts by the individual to the community and of gifts by the community to the individual as well as to smaller communities,' a system in which the opposition between egoism and altruism was transcended by a third form: mutualism. ${ }^{60} \mathrm{He}$ explained this through the concept of society or partnership ('Societät') which was developed by von Jhering as a fusion of self-interested acts of exchange and acts of giving based on altruism and self-denial:

In the contract of exchange, the will desires its own interest at the expense of the other person's (egoism); in gift the will desires the other's interest at the expense of its own (self-denial); in association it desires its own interest in the other's by furthering its

57. Burckhard 1899: 39; 1891.

58. Burckhard 1899: 39-42. On reciprocal, remunerative giving in Roman law, see also Pernice 1882: 37 (donatio reciproca) and Kaser 1971: 399 (§ 265: Die Schenkung). For the social implications of gifts in Roman law see Michel 1962: 434-43 and 596-601, who underlines the obligatory character of gifts. Michel differentiates between two systems of generosity. The first, connected to the terms gratis, gratuitus, and gratuito, makes the recipient a debtor, while in the other system (e.g. donationis causa, fideicommis) generosity serves the recipient. For the current discussion of Roman terms of giving see Verboven 2002 and García Morcillo 2014.

59. Lothar von Dargun was professor of the history of constitutional law and German law (Geschichte des Staatsrechts und Deutsches Recht) at the University of Krakow from 1888 to 1893 . He belongs to the forgotten founding fathers of sociology. See Wagner-Hasel 2011: 221.

6o. Von Dargun 1885: 71. 
own interest in the other's and the other's in its own: partnership equalises all opposition between its own interest and the other's person. ${ }^{61}$

Despite the lack of remuneration, von Jhering thought that Roman giving was characterised by 'the familiar principle of egoism', since gifts were made as a means to an end (even if that end was not material in character). He considers this egoism to be subordinated to a higher social interest, since in Rome 'gratuitous services covered the essential needs of society and the state'.62

This emphasis on the 'egoism of the community', or 'communal egoism', can also be found in von Jhering's study of ancient hospitality. Von Jhering rejected the humanist-idealist view of hospitality as anchored in individual ethics that was common in classical scholarship at the time, and insisted instead on the idea that hospitality was instrumentally motivated. ${ }^{63} \mathrm{He}$ pointed to a justified selfish interest in the development of hospitality, not on the part of individuals but on the part of communities, and thus developed the idea that the germ or seed of international law, which itself made trade and commerce possible, can be found in ancient hospitality ${ }^{64}$ The integrated approach discernible in von Jhering's interpretation of the institutions of hospitality is also characteristic of Mauss's understanding of giftexchange. Mauss claimed that 'all kinds of institutions are given expression at one and the same time-religious, juridical, and moral, which relate to both politics and the family; likewise economic ones, which suppose special forms of production and consumption, or rather, of performing total services [prestation] and of distribution. This is not to take into account the aesthetic phenomena, to which these facts lead, and the [morphological] contours of the phenomena that these institutions manifest. ${ }^{65}$ Von Jhering wrote in very similar terms about the institution of hospitality which for

61. Von Jhering [1877] 1970: I, 217.

62. Von Jhering [1877] 1970: I, 84 and 83.

63. Thus, von Jhering criticises the idealistic view of hospitality in Leopold Schmidt's Ethik der Griechen (1882: 336). Schmidt characterised the hospitality of the Greeks as one of the 'most charming aspects' of their 'emotional life'. Denis (1856: 420) took the view that ancient hospitality demonstrated the spirit of humanity, selflessness and egalitarianism of the ancient world. Similar Curtius 1892: 212.

64. Von Jhering 1887: 378. On social utilitarianism and von Jhering's opposition to romantic-idealistic notions, which were not entirely absent in the Historical Legal School, see Helfer 1970: 79-88; Zweigert 1970: 240-51; Viehweg 1970: 211-16; Wieacker 1973: 63-92.

65. Mauss 1990: 3 . 
him contained 'the signature of an entire cultural era of humanity [...] a juncture at which law, ethics, religion, trade and culture-all of which have nothing to do with hospitality today-joined together. ${ }^{66}$

Von Jhering also used the concept of 'prestation' ('Prästation') by which he means the obligation to perform (economic) services that 'custom imposes on certain relationships'. The obligation to provide such gifts (e.g. wedding-gifts, tips, hospitality, etc.) is social rather than moral for von Jhering as it is for Mauss. Nonetheless von Jhering's investigation of this issue, pursued in volume 2 of Der Zweck im Recht, does not conclude that the obligation to perform services has any social purpose. ${ }^{67}$ Rather, he explains this obligation by comparison to the obligatory generosity imposed upon wealthy citizens of ancient Rome, who were required to provide unpaid services for the community. For von Jhering the obligation to generosity forms part of an ancient system of favours:

There were times when one got services for nothing which now one can get only for money, and that too not only in cases where there were special personal relations but in general and with no limitation. At this time then, favor actually constituted a factor in the life of commerce and exercised a function therein. Similar conditions are still to be found among uncivilized peoples of today in reference to hospitality; and in regions thinly populated they are found among civilized peoples also. ${ }^{68}$

By contrast with Mauss there is no tone of regret in von Jhering's account of the loss of the practice of generosity in the present. Von Jhering's evaluation of such phenomena started from an evolutionary perspective and was based on a clear belief in progress; thus he views the coincidence of the phenomena in a single institution as irreversible, and a return to the past as undesirable. ${ }^{69}$ Despite his notion of association ('Societät') von

66. Von Jhering 1887: 359.

67. Von Jhering [1883] 1970: II, 220-26. Von Jhering already pointed here to the term 'total prestation' which Mauss went on to explore. According to Firth (1963: 222, n. 1) the concept of 'total prestation' was introduced by W. Robertson Smith and taken up by Bronislaw Malinowski.

68. Von Jhering [1877] 1970: I, 79-82. Von Jhering explicated his notion through the example of Roman practices, distinguishing between unpaid and paid services. He conceived of the former as gratuitous contracts and the latter as business contracts. The reward for services given free of charge (munus), he suggested, consisted in honores or honorarium. Italics in the translation. Translation from the 1913 edition.

69. Von Jhering 1887: 361-63. See also ch. 2.1. 
Jhering viewed the individual, whose lack of connectedness had so irked his Germanist colleagues, as the ultimate winner in this development. ${ }^{\circ}$

This social view of the gift also influenced the views of legal and economic anthropologists, who adopted the concepts of gift-exchange and reciprocal giving at the beginning of the twentieth century, using them to describe acts of exchange within non-European cultures. Here, however, the moral evaluation of such practices was often reversed, with the original gift viewed as motivated by egoism rather than altruism. 'The legal concept of "giving", wrote Wilhelm Gaul (1869-1921) in his study Das Geschenk nach Form und Inhalt im besonderen untersucht an afrikanischen Völkern (1914), 'is clearly only formed long after that of "purchasing". In ancient times it differs from our concept of giving and the free gift, as well as from anything arising from altruistic feelings. In the object-oriented, sensuous thinking of "primitive people", it is impossible to give with the right hand without the left hand knowing. Rather, when one gives with the right hand, one puts the left hand out to receive a gift in return. One-sided giving and one-sided taking are thus alien to the native. ${ }^{71}$ Despite the lack of evidence of altruistic tendencies, Gaul initially excluded the existence of 'calculated thinking' among non-European natives, considering the measurement of value to be a later development. As examples of this reciprocal giving, which he also designated as 'Geschenktausch' ('gift-exchange'), Gaul pointed to the exchange of hospitality gifts between strangers, the services of tribute and the gifts to kings and

70. Whereas von Jhering's evolutionary thinking was branded as social Darwinism in the 1970s (see Wieacker 1973: 63-73), those same elements have been relativized in the contemporary reception by legal historians of Jhering's evolutionary theory. These historians see von Jhering as the main representative of a realist, culturalanthropological final phase of the Historical Legal School, one who, far removed 'from all romantic notions of alienation', regarded the individual 'as the great winner of the social world'. Behrends 1991: 290-310.

71. Gaul 1914: 225. This lack of altruism was also confirmed by Waclaw von Brun 1912: 6o-61. He wrote of the Maori: 'Apart from this hospitality, which has very deep roots in the Maori, their so highly celebrated generosity also had its darker side. They were egoistical to a great degree, and gratitude was for them a completely foreign emotion. Even the well-known student and great friend and admirer of the Maori, Wilhelm Colenso, concedes this fully, reporting that one Maori never does a favour for another or gives anything without having his eye chiefly set upon his own advantage; everyone knew this and everyone responded with something equivalent. We have already seen that a tribute or a reward for work was always offered as a "gift". Other forms of "generosity" were probably also dealt with in a similar fashion. They gave "gifts", but expected, for this, gifts in return. And they gave gladly, for according to the firmly established custom, the return gift must be greater than the original one'. 
chiefs who were obligated to generosity. Unlike the Germanists and the Roman legal historians who had emphasized the contractual character of gifts and the legal efficacy of reciprocal gift-giving, Gaul, in keeping with other anthropologists, emphasized the social purpose of reciprocal giftgiving. ${ }^{72}$ Even if such gifts did ultimately enable trade, Gaul viewed gifts exchanged between strangers as primarily social in function, in that they created ties between people. They were a 'magic formula that binds two people closely together'.73 According to Gaul, duty and trade developed from guest-gifts, at which point the 'original purpose of gift-giving-to enable peaceful relationships with strangers' began to recede. ${ }^{74}$ Gaul assumed that tributes and gifts to chiefs and kings formed the origin of taxation..$^{75}$ Like Meyer, Gaul also attributed this change to the easing of social ties and to the increasing availability of property which could be disposed of without limit. ${ }^{7}$

\subsubsection{The sociological debate: The contribution of Marcel Mauss}

This, by no means exhaustive, survey of the beginnings of the scholarly debate on gift-exchange demonstrates the degree to which the definition of the concept had advanced by the time Mauss formulated his theory of the gift in the 1920s. ${ }^{77}$ This is true of the reciprocal character of premodern giving, which had become accepted among legal historians and legal anthropologists as well as economic historians and economic anthropologists by the beginning of the twentieth century; it is also true of the obligating and binding character of gifts, frequently referred to

72. Cf. e.g. Heinrich Schurtz (1898: 65-66) who stresses the connection between trade and gift-giving while interpreting gifts as tokens of friendship rather than commodities.

73. Gaul 1914: 236.

74. Gaul 1914: 235 .

75. Gaul 1914: 245-46.

76. Gaul 1914: 275: “Was uns bei dem "modernen” Geschenk gleich ins Auge fällt, ist der viel freiere Verkehr zwischen Schenker und Beschenkten, eine "nur lose Beziehung zwischen einem Geschenk und einem etwaigen Gegengeschenk", die begründet ist in dem viel freieren Verkehr der einzelnen untereinander und einer unbegrenzten Verfügung über das Eigentum. Beides ist dem knechtenden Zwang sittlicher wie wirtschaftlicher Anschauungen der älteren Zeiten gleich fremd'.

77. See Geary 2003: 132-35. Here he makes clear which of Mauss's own earlier worksgoing back to 1910-could have been used in his Essai sur le don. These earlier works deal primarily with the potlatch as well as with Polynesian practices. Mauss never engaged in any fieldwork himself. 
by economic anthropologists. While legal scholars emphasized the legal dimension of such ties, economic anthropologists and early sociologists, including Thurnwald,${ }^{78}$ reinforced the view that social relations were produced through gifts. The example of von Jhering has demonstrated that the notion of the gift as a 'total phenomenon' was not completely new either.

Mauss himself was well aware of many of his forerunners. Although he distanced himself rather from Bücher's evolutionary interpretation, he praised the works of Meyer, Somló, and Thurnwald. ${ }^{79}$ Another follower of Bücher's theses from the Durkheim school of thought, François Simiand, was particularly struck by Bücher's suggestion that the gift preceded exchange. ${ }^{80}$ Thus Mauss's Essai sur le don represents a combination of different approaches to the problem, to which Mauss himself then added his own specific accent by subsuming a multiplicity of phenomena related to gift-exchange under the single concept of the gift, and by simultaneously sharpening the political economists' and Germanists' critique of modern individualism and economic liberalism. In defining the gift as a contract consisting of three elements (giving, receiving, and giving in return), Mauss worked within the framework of a legal concept of giving, according to which giving became legally binding through acceptance by the receiver and, in premodern law, through reciprocation. ${ }^{81}$ Mauss was more emphatic than his predecessors, however, in construing premodern giving as a counter-model to modern practice by endowing early forms of giving with moral qualities which had been lost during the course of

78. Cf. also Simmel [1901] 1989: 86 stressing the reciprocity of giving in traditional law and hinting at boon-work as an intermediate form between the subjective forms of transfer of ownership represented by robbery and gift, and the objectivity of exchange.

79. Mauss 1990: 153, n. 3. Durkheim and Mauss were editors of the journal L' Année sociologique, first published in 1896-97, which provides ample evidence of Mauss's close knowledge of German scholarship in economic history and anthropology. Mauss himself reviewed works in the fields of psychology and history of religion, such as Wundt's Völkerpsychologie of 1907-9 (L'Année sociologique 11, 1906-1909, 53-69). Mauss's Alsatian origins favoured the intensive treatment of German-language scholarship in the journal. See the biography of Mauss by Fournier 2006: 9-12, 56-63.

80. François Simiand mainly reviewed works of economic history such as the second edition in 1898 of Bücher's Entstehung der Volkswirtschaft and Bücher's studies on primitive economy: Der wirtschaftliche Urzustand; Die Wirtschaft der Naturvölker, 1897 (L'Année sociologique 2, 1899, 440-48 and 456-57). In these reviews, Simiand emphasized the significance of gift-exchange for Bücher's concept of early household economies.

81. Mauss 1990: 33-43, 47-49. 
its standardisation within modern law. Like the political economists who had critiqued the notion of homo oeconomicus, Mauss based his theory of giving not on contractual law but on the authority of the collective. In interpreting gift-exchange as a collective contract, Mauss rejected the idea of the primacy of contracts between individuals as well as the presumption of an evolution from a distant or prehistoric past lacking in rules and law. ${ }^{82}$ In reaching this conceptual goal Mauss, in fact, reversed the process of standardisation that the modern concept of giving had undergone. He was especially successful in doing this because he tied his model of giving to societies located beyond his own world and experience, and which were at once concrete and utopian, such as the Kula ring, a network of exchange on the Trobriand islands, or the potlatch practised by North American indigenous people. ${ }^{83}$ While Mauss' legally oriented predecessors assumed that the functioning of exchange was owed to reciprocity, albeit a reciprocity interpreted according to modern contract law as a legally binding force, ${ }^{84}$ Mauss himself preferred a religious explanation. He argued that archaic societies had a specific moral contract which bound personal law and property law together. From this identity of person and property, Mauss explained the power of gifts to create social bonds as noted by Gaul, Thurnwald, and others. Here he relied upon the idea of the animated nature of objects, developed by the Maori in New Zealand according to his friend Robert Hertz. ${ }^{85}$ Mauss rejected internal or moral motivations for gift-giving as well as external factors such as trade or the requirements of collective economies; for Mauss the key motivating factor is in the essence or spirit of things. He traced the circulation of gifts back to what the Maori call hau, a spirit inherent in the gift, which compels its

82. Mauss follows the concept formulated by his colleague Georges Davy, who explains in his study La foi jurée: La formation du lien social (1922: 374): 'La reaction solidariste qui est venue plus en plus limiter, aux XIX siècle, les excès de l'individualisme de notre doctrine classique et de notre Code civile s'éclaire d'un jour singulier lorsqu'on la rapporte aux origines de notre institution'.

83. Cf. n. 130.

84. See the argumentation of Burckhard 1899. According to Henry S. Maine's Ancient Law ( ${ }^{15} 1894$ : 348-49) contract law is based on 'complete reciprocity' and is associated with rights and obligations. In his study of Roman hospitality Theodor Mommsen ([1864] 1962: 330) linked permanence with reciprocity when he noted the following for ancient Rome: 'Moreover, the actual guest contract is that which leads to a lasting relationship, as through this real reciprocity is first made possible'. Von Jhering's study of hospitality relied on Mommsen's view of hospitality in antiquity (von Jhering 1887: 370).

85. Mauss 1990: 10-13. 
return. ${ }^{86}$ In this he was content to follow the explanations given by the Maori themselves, who had developed the idea in order to legitimise the share which priests received from the hunter's game. Mauss was criticised by Marshall Sahlins for taking such explanations at face value instead of tracing them back to the social necessity which had led the Maori to construct the concept. ${ }^{87}$ Thus for Mauss, the final authority is magic, while the jurists who preceded him viewed society as held together by the law and its ultimate guarantor, the state. With his metaphysical interpretation of gift-exchange, Mauss indirectly completed the very process of depersonalization and objectivization of human relations which he himself had lamented. According to Mauss, social interaction was originally regulated by the things themselves, inextricably bound to humans. Mauss thus mystified the social context at just that point in history, in the years following the First World War, when traditional forces of integration in Europe were losing their power.

Thus, the additions Mauss made to the theory of gift-exchange, namely his interpretation of the gift as a collective contract and his grounding of the obligation to reciprocate in magic, are also the most problematic aspects of his theory of giving. Mauss summarized findings which, until that point, had been scattered throughout scholarly journals. But he idealized and standardized those findings to such a degree that historical practice became occluded by abstract concepts. Mauss extracted a purely formal sediment from the concrete social practices under discussion. ${ }^{88}$ Emptied of content, this sediment was then condensed into a general theory of the gift, a theory which could be understood as valid beyond time and space and which could stand in opposition to modern practice.

86. Mauss 1990: 16: 'the legal tie, a tie occurring through things is one between souls, because the thing itself possesses a soul [...] the thing given is not inactive. Invested with life, often possessing individuality, it seeks to return to what Hertz called its "place of origin", or to produce, on behalf of the clan and the native soil from which it sprang, and equivalent to replace it'.

87. Sahlins 1984: 157-62. This part of his theory has frequently been criticised by subsequent researchers as a mystification of the gift. Cf. Firth 1963: 222; McCormack 1982: 286-93; McCall 1982: 303-19; Laughlin Jr., 1986: 156-76; Cathercole 1978: 324-40; Godelier 1996: 19-39.

88. See the critique of Leacock 1954: 68 and Vogt 1981: 276-97. Vogt stresses the mystifying and idealistic tendencies in Mauss's theory of gifts and attributes these to the neglect of historical and economic aspects of giving. Cf. also the critical remarks of Müller 1981: 312-14. 


\subsection{The critique of modernity and the idealisation of the gift}

These very different reflections on premodern gift-giving, which ultimately resulted in a notion of the gift as possessing the power to integrate, have one common point of reference: the process of the modernisation of society and its social differentiation, and the development of independent subsystems and spheres of action that were described by Max Weber at the beginning of the century as a process of bureaucratization and rationalization. ${ }^{89}$ With respect to practices of gift-exchange, this process was rolled back and the connection between the different spheres re-discovered as 'other'. This is true not only of the convergence of phenomena in a single institution, as exemplified by von Jhering and Mauss, but also for the theory, upheld by Thurnwald and the Hungarian anthropologist Karl Polanyi, that in ancient societies economics was embedded in sociopolitical life. ${ }^{90}$

In scholarship a reversal of this form of integration took place with the development of the discipline of sociology, founded by just those scholars who insisted on the social and integrating function of gifts, and thus with a new focus on social relationships and interactions. ${ }^{91}$ The founders of classical liberal economics, who, like Adam Smith, had developed their theories during the age of colonialism, had, in any case, not perceived the dissonance between economics and ethics. In fact, thinkers of the eighteenth-century Enlightenment endowed trade with just those moral characteristics attributed to noncommercial forms of exchange in theories of gift-giving. For Adam Smith, trade was the source of the wealth of nations, of the security and liberty of their citizens, and brought about the end of internal and external states of war..$^{92}$ In The Spirit of Laws the French Enlightenment thinker Montesquieu argued that 'the spirit of trade produces in the mind of man a certain sense of exact justice [...]. The total privation of trade, on the contrary, produces robbery, which Aristotle ranks in the number of means of acquiring; yet it is not at all inconsistent with certain moral virtues. Hospitality, for instance, is most

89. Cf. Münch 1984; Luhmann 1988.

90. Thurnwald 1932: 45; Polanyi [1944] 2001: 45-58. Firth 1972: 468, n. 1 refers to Thurnwald.

91. Wolf 1982: 7-23. Cf. also Groh 1988: 132. Dahme 1988: 222-74 shows how early sociologists responded to modernisation.

92. For the moral dimension of the liberal theory of Adam Smith see Macfie [1957] 1985: 131-57; Medick 1973: 206-21; Bürgin 1996: 366-9o. 
rare in trading countries, while it is found in the most admirable perfection among nations of vagabonds. ${ }^{93}$

Thus the idea of a convergence of the spheres of justice, ethics, politics, and economics does not only apply to some kind of imagined prehistory. Instead, such fluid circumstances are characteristic of types of individual power and labour relations that were still in place in the nineteenth century. ${ }^{94}$ Unlike ancient practices of gift-exchange, however, these more recent examples were unsuited to idealisation by critics of modernity. ${ }^{95}$

It is not surprising that studies of past gift-exchange practices were already tinged with nostalgia around the turn of the century and that they then culminated in Mauss's fundamental critique of civilisation. Critiques of modernity go hand in hand with the process of modernisation, but they became especially strident at times of upheaval when new and changed conditions upset traditional patterns of behaviour, as will have been the case during the years following the end of the First World War. Individualism, rationalism, utilitarianism, and materialism all came under attack from a critique of civilisation that ultimately contributed to the demise of evolutionism. ${ }^{96}$ While evolutionists were bent on determining a place on the ladder of civilisation for each of the cultures they were studying, cultural relativists, who were critical of the idea of progress, insisted the practices of any alien culture observed in the field should be judged by its own criteria. The drawback of this process, for which Malinowski's work is key, is that the field of enquiry becomes de-historicised, while the cultures under examination become mere frozen relics of the 'archaic'.

Malinowski's perceptiveness, praised by Frazer in the preface to Argonauts of the South Seas, was the sharpened vision of a politically homeless aristocratic intellectual affected by the collapse of the Austro-Hungarian empire and looking for security through his writing. ${ }^{97}$ It was only a matter

93. The Spirit of Law II, 20, 2, 3-4; translation taken from Thomas Nugent (1752) published by Batoche Books 2001.

94. Cf. Wehler 1987: 221, 589-605, who stresses the embeddedness of work into social life in preindustrial Germany. The connectivity of the economy and social life can be studied in nineteenth-century Basle. See Sarasin 1990 and Wagner-Hasel 1998: 33-63.

95. See Bücher 1918: 29 who knew boon-work from personal experience. According to von Dargun 1885: 46-48, the household-economy of his own time gives an ideal image of altruistic economy.

96. Cf. Sontheimer 1978: 41-62; Kiesel 1989: 497-521; Beßlich 2000.

97. For the social and intellectual background of Malinowski see Urry 1992: 181-82, who underlines the 'aristocratic' attitude of his observations of the world of the Trobriands. Malinowski is characterized by Gellner 1985: 5-7 as an 'ahistorical holist'. His role as founding hero is discussed by Fardon 1990: 569-87 and Stagl 1991: 91-105. Cf. also Spittler 2008: 221-42. 
of a couple of generations, according to Malinowski, before the Trobriand Islanders, whom he had observed between 1915 and 1918 from the distance of a nearby mission station, ${ }^{98}$ would be caught up by the progress of civilisation. ${ }^{99}$ The experience of the loss of his own culture was reflected in Malinowski's vision of the imminent demise of Trobriand culture and thus endowed the practices he examined there with an appearance of originality and authenticity that did not fail to affect his contemporaries.

This explains how Malinowski and Mauss came to be credited with the discovery of gift-exchange, even though the concept had already been largely developed by jurists and economists, as we have seen. Their version of gift-exchange unfettered by utilitarianism and interest in profit appeared to offer the promise of an alternative world that was free from the tension between individual and society, between ethics and economics.

But such alternative worlds always also reflect the real world. Mauss could not have known that his idea of a collective held together by magic would be realised fatally in the form of National Socialism with its programme of a return to an idealised past, stage-managed by magical spectacle. ${ }^{100} \mathrm{He}$ was hurt by later accusations that the Durkheim school's naive belief in the collective had prepared the ground for Fascist ideology. ${ }^{101}$ In a letter responding to an article by Svend Ranulf on the scholarly forerunners of Fascism in 1939, Mauss expressed dismay over the role of magic in the political stagings of the Fascist movement: 'That large, modern societies could be hypnotised [suggestionées] as the Australians are by their dances $[. .$.$] is a thing that basically we had not expected. That return to$ the primitive had not been the object of our reflections. ${ }^{102}$ This statement is not without tragic irony: after the occupation of France the National Socialists' archaizing spectacles would pose an immediate threat to Mauss as a scholar of Jewish descent, while other students of Durkheim, including Maurice Halbwachs, lost their lives in concentration camps. ${ }^{103}$

98. This is underlined by Kramer 1981: 82. See Young 1984: 1-26 on Malinowski's choice of location and on his knowledge of the region.

99. Malinowski [1922] 1999: xvi.

10o. Whether this process of modernisation was intended, or an unintended consequence, is open to debate. For discussion see Barkai 1988: 68-102; Peukert 1989: 81-83; Frei 1993: 363-87.

101. Mauss 1939: 16-34.

102. Citation after Vogt 1981: 290, 296, n. 34. The extent to which French observers perceived the National Socialists' cult of the Führer as ritual celebration can be seen in diary entries by Denis de Rougement 1998: 62 (11th March: a holy ceremony). 103. Cf. König 1972: 636. 
The debate on gift-exchange yields further, more explicit links between National Socialist ideas and the Durkheim school's belief in the collective. ${ }^{104}$ While Durkheim's collective is cooperative and viewed by critics as leaning towards Socialism, ${ }^{105}$ the National Socialist idea of Universalism is markedly more 'statist' in character and developed out of concepts introduced by the Historical School. ${ }^{106}$ This difference is relevant to the work of the classically trained economic historian Bernhard Laum, whose 1924 study Heiliges Geld (Sacred Money) focussed on Greek antiquity and is influenced by the concept of gift-exchange. Laum traces the development of Greek coinage back to sacrificial rituals, viewing the state as the creator of a sacred rule of law and defining money as a creature of this system. ${ }^{107}$ He refers to sacrificial ritual as a 'trade transaction', ${ }^{108}$ in which the sacrificed animal is a remuneration for favour granted by the gods; but he also considers this transaction in terms of an exchange of gifts. ${ }^{109} \mathrm{He}$ also stressed the interconnectedness of economic life with other aspects of life, ${ }^{110}$ whose loss he regretted in a later work. In his study Die geschlossene Wirtschaft (1933) his focus is on the present; here, like Mauss in Essai sur le don, Laum complains about the independence of the economy and demands a return to an 'organic whole' and the rejection of the 'individualist quest for profit'. ${ }^{111} \mathrm{He}$ considers the economic crisis of his time to be part of a process of a 'loss of the soul of economic life' and seeks the solutions to this crisis in the state, idealising the latter as the realisation of the idea of justice. ${ }^{12}$ This critique,

104. It is significant that during the years of National Socialist rule, von Jehring's focus of social utilitarianism on the interests of the individual is viewed as the main flaw in his work. See Wieacker 1942: 55-58.

105. See Chiozzi 1983: 631-54. Cf. Birnbaum 1972: 41-54; Hollier 1972: 55-61. Giddens 1976: 712 situates the Durkheim school between conservatism and socialism. For the influence of Durkheim on social and historical theory see Borlandi 1998: 27-65; Oexle 1994: 128-32.

106. Barkai 1988: 68-102.

107. Laum 1924: 160.

108. Laum 1924: 32. Some of Laum's ideas are taken up by Seaford 2004.

109. Laum 1924: 32: 'Die Gabe oder das Opfer an die Götter ist kein Geschenk in

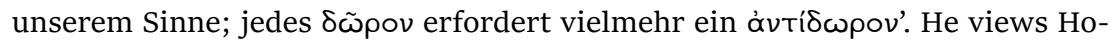
meric exchanges such as the Greeks' purchase of wine at Troy in a similar sense not as trade but as exchange of guest-gifts, based on the assumption that guestfriendship creates the proper conditions for the peaceful acquisition of goods abroad. Laum refers to Bücher's work for his notion of gift-exchange as the origin of trade. Ibid. 13-14.

110. Laum 1924: 161.

111. Laum 1933: 479 and 458.

112. Laum 1933: 15. Besides this Laum notes rationalism, exaggerated specialisation, and unbounded eccentricity as symptoms of the crisis. 
published in 1933 (and repeated more moderately in his 1960 work Schenkende Wirtschaft) is linked to a clear commitment to the National Socialist idea of totality: 'The return to primitiveness and totality, the organic renewal of the people through separation from the outside world, which National Socialism demands, is necessary for the sake of the preservation of life itself. In short: the inner truth of the leading idea of National Socialism rests on the fact that it corresponds to biological necessity. ${ }^{113}$ Although Laum did not repeat this praise after 1945 for obvious reasons, a rejection of individualism remains characteristic of his later work as well. In Schenkende Wirtschaft, where he first engages with Mauss's work, ${ }^{114}$ he borrows the core of Mauss's theory, namely the idea that the obligation to reciprocity originates from the spirit of things: 'Since the giver gives away a piece of his soul with his gift, a magical coercion forces the receiver to reciprocate.'15 Laum's criticism of his own times is primarily directed at what he considered to be the emergence of individualist tendencies that commercialized 'a primal human instinct for giving. ${ }^{116}$ This convergence with National Socialist ideologies at least partly explains why modern scholarship is keen to look elsewhere for the founding fathers of gift-theory.

Unlike Laum and Mauss, Karl Polanyi, a major contributor to economic theories of premodern gift-exchange, ${ }^{117}$ was clearly aware of the ways in which totalising ideologies served to cover up estrangement or alienation, and he warned of the potential dangers emerging from this way of thinking. ${ }^{118}$ Nor was Polanyi sympathetic to the anti-individualism espoused by the totalizers. ${ }^{119}$ His utopian aim is not the unity of individual and community but the reintegration of the economy into society and the subordination

113. Laum 1933: 488.

114. In his earlier study on Sacred Money Laum did not refer to Marcel Mauss. See Wittenburg 1995: 270.

115. Laum 1960: 119.

116. Laum 1960: 460.

117. For Polanyi's position see Zeisel 1968: 172-74; Humphreys 1983: 31-75; Maucourant 2000; 2005.

118. Polanyi 1935; [1947] 1968: 59: 'Behind the fading fabric of competitive capitalism there looms the portent of an industrial civilization, with its paralyzing division of labor, standardization of life, supremacy of mechanism over organism, and organization over spontaneity'.

119. He considered anti-individualism to be the guiding principle of all fascist ideologies, which reify social phenomena, deny the existence of alienation, and propagate the idea of a return to a preconscious social organism (Polanyi 1935). R. M. MacIver's preface to Polanyi (1944) highlights the importance of individual freedom in Polanyi's thinking. In the new edition, of 2001, MacIver's introduction is replaced with a foreword by Joseph E. Stiglitz and an introduction by Fred Block. 
of economic activity to the needs of society. In his work The Great Transformation (1944) he argues that the crises of the twenties and thirties were caused by the increasing independence of a self-regulating market economy, which began with industrialisation and led to economic activity being entirely separate from the fabric of society. His vision of premodern and preindustrial societies takes a view of economics in keeping with previous critics of rampant acquisitiveness. ${ }^{120}$ Unlike classical economic theorists, Polanyi considered ancient economic activity as a form of human cooperation driven by the needs of society. In his view economic activity driven by markets and prices, and oriented towards meeting potentially limitless requirements with a limited supply of means, is characteristic of marketdriven systems typical of industrialised societies. ${ }^{121}$ Polanyi suggested that other forms of exchange, such as reciprocity or redistribution, govern the distribution of goods in societies that lack self-regulating markets. These forms of exchange are linked to social structures, with reciprocity linked to symmetrically organised groups such as family-groups, and redistribution linked to central entities through which the traffic of goods flows. Polanyi agreed with Mauss and Malinowski that an absence of individual profit-seeking is the distinguishing feature of the principle of reciprocity. ${ }^{122}$ Recalling the work of Malinowski, Thurnwald, and Firth, he writes:

The performance of acts of exchange by way of free gifts that are expected to be reciprocated though not necessarily by the same individuals-a procedure minutely articulated and perfectly safeguarded by the establishment of 'dualities' in which groups are linked in mutual obligations-should in itself explain the absence of the notion of gain or even of wealth other than that consisting of objects traditionally enhancing social prestige. ${ }^{123}$

This moderate critique of modernity forms a link between nostalgic interpretations of the gift in the 1920 s and contemporary idealising tendencies that are no longer influenced by the spirit of anti-individualism and nostalgia for a primitive past. Modernisation has long since reached the places and cultures where Malinowski and other anthropologists had

120. See Schmoller 1900: 2 and Dargun 1885: 12. For discussion see Röpke 1984: 101-34.

121. Polanyi [1944] 2001: 45-47; 1957: 243-44. For Polanyi's concept of economy see Humphreys 1983: 39-73.

122. Mauss 2016: 184-85; Malinowski 1999: 175 .

123. Polanyi [1944] 2001: 49. 
made their observations. Economic anthropologists setting out to conduct further studies into gift-exchange after the Second World War did so less to preserve ancient practice than to contribute towards a careful adaptation to modernisation. ${ }^{124}$ Contrary to their expectations, the cultures in question had not abandoned gift-exchange in favour of market economies only but instead developed manifold, mixed forms of exchange. ${ }^{125}$ Thus, today the question is no longer one of a return to an idealised 'whole', symbolised by supposedly primitive cultures, but rather one of looking for the contemporary presence of the gift. The notion of gifts is now complementary to the notion of goods, and gift-exchange viewed as an ethically clad version of the exchange of commodities, not only in developing countries but especially in western industrialised countries. ${ }^{126}$ What Mauss had imagined as the 'total social fact' of the gift has become 'universal fact'.

Mauss's successor to the chair in Sociology at the Collège de France, Claude Lévi-Strauss, led the way towards the universalising of the gift. ${ }^{127}$ In his 1949 work Les structures élémentaires de la parenté (The Elementary Structures of Kinship) Strauss developed the idea that the exchange of women was a universal, original form of reciprocal exchange, while also emphasising the significance of gifts for building social alliance. His concept is akin to the modern myths of origin dismantled by ethnologists since the 1970 . ${ }^{128}$ For Lévi-Strauss gift-exchange is not only an original form of exchange but also a living practice in modern societies. He describes the ritual of dinner invitations and the exchange of Christmas presents as a giant potlatch, which also includes the collective destruction of wealth as seen in the practices of the indigenous people of the North American northwest coast. He views the acquisition of honour, prestige, respect, and power as the essential core of the practice of gift-exchange: 'Goods are not only economic commodities, but vehicles and instruments for realities of another order, such as power, influence, status and emotion; and the skilful game of exchange [...] consists in a complex totality of conscious

124. See the remarks of Dalton 1961: 21: 'Western economic theory has proved a powerful tool for making industrialized market systems grow. But primitive economies are neither industrialized nor market systems. One must start from ethno-economic analysis-with Malinowski, not Ricardo-in order to choose those transformation paths to industrialization which entail only the unavoidable social costs'.

125. Cf. Gregory 1980: 626-52; Bloch and Parry 1989.

126. Elwert 1991: 159-77.

127. Cf. Charle and Teklès 1988: 167-68.

128. Cf. e.g. Weiner 1976. Maurice Godelier, who worked as Lévi-Strauss's assistant, also refers to Weiner in his own study on gifts (L'enigme du don 1996). 
or unconscious manoeuvres in order to gain security and to guard oneself against risks brought about by alliances and rivalries. ${ }^{129}$

Unfortunately, in his search for universal structures, Lévi-Strauss appears to have ignored the fact that the potlatch developed the specific competitive and excessive features he describes only as a consequence of the Kwakiutl tribe's interaction with Europe through the fur trade. ${ }^{130}$ Thus, while it is true that Lévi-Strauss's critique of the idea of the 'spirit of the gift' contributed to the demystification of Mauss's concept of gift-exchange, ${ }^{131}$ he does share Mauss's tendency to universalize and dehistoricize the idea of the gift.

In The Gift Economy (1988) the American sociologist David Cheal is wary of the dangers of nostalgia inherent in Lévi-Strauss's view of 'gift-giving as natural economy'. ${ }^{132}$ In his view the practice of giftexchange represents a system of 'redundant transactions within a moral economy [...] which makes possible the extended reproduction of social relations. ${ }^{133}$ According to Cheal this applies especially to western industrialised societies, within which it is particularly women who, through 'gift-giving', safeguard the reproduction of social relations. ${ }^{134}$

A similar definition of the gift as social bond can be found in a 1991 essay in the Revue de Mauss by Alain Caillé and Jacques Godbout, in which the two sociologists answer the rhetorical question 'Le don existe-t-il (encore)?' with an unequivocal 'yes'. According to them, the gift exists indeed, as a form of primary socialisation taking place within families, neighbourhoods

129. Lévi-Strauss 1967: 54 .

130. More recent research has established that the potlatch forms part of an alternative economy only to a limited extent. In the region of Fort Rupert, where a number of different families of an Indian confederation were competing for influence in the fur trade, the change towards excess and competition was especially pronounced. Here, traditional gift-exchange ceremonies, which served to determine a chieftain and assemble his followers, became especially excessive in the context of competition for fur trade. Success in the ceremonies did also determine greater profit in trade with Western companies, since the followers or entourage gained through the ceremony were also a source of sea otter furs for trading. For a summary of the research see Wolf 1982: 182-92. Cf. also Drucker 1967: 481-93; Codere 1950; Kan 1986: 191-212; Mauzé 1986: 21-63.

131. See Godelier 1996: 27-44.

132. Cheal 1988: 12 .

133. Cheal 1988: 19 .

134. Cheal 1988: 2-9. Cf. also Hyde 1983: 108, who writes: 'to labor with gifts [...] remains a mark of female gender.' Similar Bloch and Boisson 1991: 54-71; Berking 1996: 40 . 
and groups of friends, and accompanied by secondary socialisation in the shape of the market. ${ }^{135}$ In his contribution on the subject of market exchange and gift-exchange, the anthropologist Gerald Berthout proposes a similar model of two forms of social bond, which are complementary and overlapping. ${ }^{136}$ These authors are not concerned to offer a positive evaluation of relations established through gifts, and indeed Caillé and Godbout reject as totalitarian fantasies any attempts to reform modern societies according to archaic structures. ${ }^{137}$ Nonetheless, they warn of the loss of humanity and sociality that might occur if the gift were not taken seriously in the context of market exchange, as Berthoud suggests in reminding us of the 'leçon de sagesse' to be drawn from Mauss. ${ }^{138}$

The difference between such approaches and Mauss's own critique of modernity lies primarily in the location of the archaic. Today's archaic is no longer to be found in the premodern economies of ancient and alien cultures but is instead concealed behind the facade of goods exchange in industrialised western societies. According to the sociologist Georg Elwert, the promise of an economy beyond individualist capitalism that inheres in Mauss's work has been replaced since the 1980 s with talk of a 'patina' of moral economy imposed on relationships based on commodity. As he puts it in an essay of 1991, Gabe, Reziprozität und Warentausch:

Where the generalised reciprocity of informal services governs everyday life in offices and workplaces the interface of interaction between colleagues and within workplace hierarchies is no longer ruled by the contract of salaried employment. Given the dominance of such informal relations, the moral-economic exchange of information, services and presents understood as gifts takes precedence over the formal or contractual working relationships. Informal relations and exchanges cloak the world of work (and it should be

135. Godbout and Caillé 1991: 26. They finish their study with the following remarks: 'La seule hypothèse qu'il soit nécessaire de nous accorder à cette étape est qu'il existe dans la société moderne comme dans la société archaïque ou traditionnelle un mode de circulation des biens qui diffère intrinsèquement du mode analysé par les économistes [...] Qualifions de don toute prestation du bien ou de service effectuée sans garantie de retour, en vue de créer, nourrir et recréer le lien social entre personnes. Nous nous proposons de déterminer la manière dont le don, ainsi caractérisé comme mode de circulation des biens au service du lien social, forme le système social primaire des relations de personne à personne' (32).

136. Berthout 1991: 86 and 12; 1991: 79-96.

137. Godbout and Caillé 1991: 29.

138. Godbout and Caillé 1991: 94. 
noted that they also make working together more pleasant). We recognise generalised reciprocity as a distinctive feature of modern industrialised society, even though it was first spoken about in connection with pre-industrial societies. ${ }^{139}$

Thus gift-exchange continues even today to function as a counter-model to market exchange.

While the gift is viewed as complementary to market exchange and the exchange of goods in western industrialised societies, it seems to some sociologists outside the western world to function as an alternative to the imported economy of industrial centres. In his 1988 article 'Modernity, Identity, and Utopia in Latin America', the Peruvian sociologist Anibal Quijano presents reciprocity as a specifically Latin American form of rationality that unites individualism and solidarity. He suggests 'that in the very center of Latin American cities, the masses of the dominated are building new social practices founded on reciprocity, on an assumption of equality, on collective solidarity, and at the same time on the freedom of individual choice and on a democracy of collectively made decisions, against all external impositions. ${ }^{14^{\circ}}$ Such new social practices based on reciprocity are shaped, according to Quijano, 'outside or against the state and private capital and their respective bureaucracies' as alternatives against the instrumental rationalism of the West. ${ }^{141}$ The opposing forces of individualism and collective thought that had governed the beginnings of the debate on gift-exchange are united in Quijano's reception.

The idealising gaze eventually reached classical scholarship too. Since Bücher, the concept of gift-exchange had been debated from the perspectives of political economy and legal history without any links to the critiques of modernity we see in other fields. ${ }^{142}$ It should be noted, however,

139. Elwert 1991: 163; 1985: 509-13.

140. Quijano 1993: 154 .

141. Quijano 1993: 155. Quijano's argument is based on the critique of reason by Horkheimer and Adorno. In Minima Moralia (1951) Adorno himself objected to the universalising of the principle of gift-exchange and of the transformation of gifts into goods. In his view gift-giving presents itself as unalienated action par excellence: 'Every undistorted relationship, perhaps indeed the conciliation that is part of organic life itself, is a gift' (quoted from the English translation by E. F. N. Jephcott, first published 1974. Verso edition 2005: 43).

142. Besides Laum 1924 see especially Bolkestein 1939: 156-58. According to him, social life in ancient Greece was based on the principle of reciprocity and gifts were given in hope of receiving a counter-gift. Bolkestein's view is based on Bücher and Mauss (see p. 165 and 220-22). Köstler 1950: 23 stands in the tradition of 
that among economic historians the concept of gift-exchange was predominantly used by representatives of a 'primitivist' position who assumed that ancient and modern economies were not comparable. ${ }^{143}$ Within this 'primitivist' tradition the work of ancient historian Moses I. Finley stands out, as he is credited with first bringing Mauss's findings to bear on illuminating ancient evidence. ${ }^{144}$ Finley insisted on the difference between ancient and modern economies (and implicitly criticised modernity) when he argues in The World of Odysseus (1954) that Homeric exchange, by contrast to modern market trading, was not led by the pursuit of profit. ${ }^{145}$ Significantly, Finley refers to the observations of Malinowski who had considered lack of profit-seeking as a distinctive feature of primitive economy. ${ }^{146}$

Only recently have such reflections become consolidated to form a counterpoint to modernity. These debates are governed by the opposition between altruism and egoism that had long been recognised by economists. In a 1990 work, Ma’at: Gerechtigkeit und Unsterblichkeit im Alten Ägypten, the Egyptologist Jan Assmann refers to the theories of Durkheim, Mauss,

Bücher and Laum when he argues that in early Greece transactions were usually organised as gift-giving and exchange was developed in later times. 'Schenkung auf Gegenschenkung' was considered as the original form of exchange also by Bruck 1926: 61 . For the use of the theory of gift-giving by legal scholars see Maffi 1979: 33-62.

143. This is true of Bolkestein whose work Economic Life in Greece's Golden Age (1958) belongs to the primitivists' school of thought that refused to employ modern categories to analyse ancient economies. Karl Bücher is foundational to this too, although Eduard Meyer's polemical rejection of Bücher's theses meant that his views were slow to gain attention among German scholars. On the Bücher-Meyer controversy and its reception see Will 1954b: 7-22; Austin and Vidal-Naquet [1972] 1977, ch. 1; Andreau and Etienne 1984: 55-83; Andreau 1995; Schneider 1990: 417-45; Wagner-Hasel 2011: 198-214; 2014: 51-69.

144. See ch. 1.4 .

145. Finley [1954] 1967: 66: 'Behind the market lies the profit motive, and if there was one thing that was taboo in Homeric exchanges it was gain in the exchange. Whether in trade or in any other mutual relationship, the abiding principle was equality and mutual benefit'. For a similar view today see e.g. Seaford 2004: 23: 'Precise equivalence of value and enforceable immediacy of return have no place in the exchange of gifts'.

146. Finley 1967: 61-62: 'An exchange mechanism was then the only alternative [to violence], and the basic one was gift-exchange. This was no Greek invention. On the contrary, it is the basic organizing mechanism among many primitive peoples, as in the Trobriand Islands, where "most if not all economic acts are found to belong to some chain of reciprocal gifts and counter-gifts."' Here Finley cites Malinowski, Crime and Custom in Savage Society, New York 1952: 40. 
and Marshall Sahlins in his discussion of the concept of 'Ma'at' as a principle of integration through which community, justice, and reciprocity are established between a pharaoh and his people. Assmann sees in 'Ma'at' the realisation of the central virtues connected with solidarity and social justice, namely altruism and the protection of the weak, which are 'disempowered in contemporary economic ideology'. Egyptian 'Ma'at', as a form of vertical solidarity, shows, according to Assmann, that the Egyptians had already constructed 'an alternative [...] to economic liberalism.' ${ }^{147}$

The classicist and scholar of religion Walter Burkert views 'giving' as a universal and timeless behavioural pattern, a survival strategy rehearsed in religious practices. According to Burkert early Greek economic life was especially dominated by gift-exchange, and like others he also emphasises the gulf between ancient and modern economies: 'Modern economy is definitely different, with strategies that aim at immediate profit and ruthless exploitation, ending of course in diminishing return. ${ }^{148}$

A conference at the University of Exeter in 1993 on the subject of ancient reciprocity saw participants debating whether gift-giving was motivated by altruism or utilitarianism. ${ }^{149}$ The debate at the time focussed primarily on the interpretation of the Attic liturgy system, ${ }^{150}$ which Richard Meyer had already studied from the point of view of gift-exchange in 1898. ${ }^{151}$ But the conflict between altruistic and utilitarian views of the gift has become increasingly relevant to the interpretation of sacrifice. In the mid-twentieth century, Laum had tended towards a utilitarian position in interpreting sacrifice as a means of requital in the reciprocal traffic between men and gods. ${ }^{152}$ More recently, the opposite view has tended to dominate. Thus Christiano Grottanelli, referring back to theories of Gerardus van der Leuuw, ${ }^{153}$ understands sacrifice as the repayment of a

147. Assmann 1990: 278. Assmann primarily refers to Marcel Mauss to whom he attributes the achievement of having demonstrated, through the example of the potlatch, the communicative significance of exchange (68).

148. Burkert 1987: 50; 1984: 26. Here Burkert argues that the universal act of giving originates in the distribution of meat after the hunt.

149. Gill, Postlethwaite and Seaford 1998.

150. Whereas Gabriel Herman $(1998 ; 2006)$ interprets the liturgies as altruistic services, Paul Millett (1998) stresses the idea of reciprocity. See now Liddell 2007 and Christ 2012 (who follow the debate opened by Bolkestein 1939 and Hands 1968) and Domingo Gygax 2016 for the connection of reciprocity and euergetism.

151. See n. 54 .

152. Laum 1924: 20.

153. van der Leeuw 1920-21: 241-53. 
debt and the fulfilment of moral obligation towards the gods. ${ }^{154}$ Sitta von Reden's work on ancient Greek gift-exchange focusses on its metaphysical dimensions. She understands the gift-exchange and market exchange practices described in poetic and historical texts as providing insight into Greek world views and into competing, negative and positive, models of the polis and its order. ${ }^{155}$

Contemporary research into gift-exchange is not short of voices warning against its idealisation, and it is unpersuaded of the moral qualities ascribed to this form of giving by the scholars cited here. Objections are made especially by ethnologists, while the idealising tendencies are mostly found in sociological literature. Thus Maurice Bloch and Jonathan Parry argue in Money and Morality (1989) against the imagined high moral value associated with gift-giving and characterise this as the inversion of the values of economic rationalism and utilitarianism into their opposite. ${ }^{156}$ The sociologist Pierre Bourdieu had highlighted the interested nature of giving, and introduced the notion of 'symbolic capital' in his examination of the Kabyle people in the 1970s. He proposed that the rituals of giving he observed were a matter of continuously transforming economic capital into symbolic capital, and thereby concealing naked self-interest. ${ }^{157}$

The more recent idealisations of the gift as a more altruistic, morally more laudable form of transaction, have their origin, once again, in discontent with modernity, and in a loss of trust in traditional paradigms and strategies. Caillé and Godbout for instance claim that the impetus for their reflections on the presence of the gift came from the failure of Marxist, utilitarian, and structuralist interpretative paradigms, which led them to

154. Grottanelli 1989-1990: 45-54. See also Bodei Giglioni 1989-1990: 55-64, who follows a similar idea regarding the position of Aristotle and Theophrastus. For a discussion of the reciprocal character of sacrifice in the epics see Hitch 2009: 93-140.

155. Von Reden 1995: 18.

156. Bloch and Parry 1989: 9. Sitta von Reden 1995: 7 and 171-75 made use of this critique for her metaphysical interpretation of coinage. See also Kurke 1999.

157. Bourdieu [1972] 1977: 171. See also Appadurai 1986: 12 who follows Bourdieu. The classicist Marcel Widzisz (2012) has recently made use of Pierre Bourdieu to analyse Homeric gift-giving from this perspective. Cf. also van Wees 1992: 230, who stresses the utilitarian motivations underlying Homeric gift-giving in xeinosrelationships and the profit-orientation of the heroes in nearly every context. His 1998 summary of anthropological research begins with a quote from Thomas Hobbes (Léviathan 1651: 1.15) saying that no one gives something or anything without expecting to benefit from it (Van Wees 1998: 13). 
search for a new key to solving the world's problems. ${ }^{158}$ For Maurice Godelier, reasons for recalling the practice of gift-giving are found in the crisis of the Western welfare state, systemic unemployment, and an increasingly threadbare social safety net (tissu social). The gift can fill the gap, and assume a mediating function between state and market or between impersonal law and cold calculation. ${ }^{159}$ The German sociologist Helmut Berking is convinced that the dominance of utilitarian profit-seeking has allowed society's moral consensus to evaporate. In the practice of gift-exchange he sees, therefore, the potential for social integration. ${ }^{160}$ In an essay published in 1990, in a commemorative volume for Karl Polanyi, the economist Björn Hettne argues for a revival of the principle of reciprocity, after the failure of neoliberalism to cope with global recession, structural unemployment, and crises in political trust. In his opinion, reciprocal practices are still alive in the informal economic sector of Western industrial societies and also in those of developing countries. ${ }^{161}$

In the 1920 s early idealisations of the gift were led, as we have seen, by a disenchantment with modernity, which ultimately transformed into nostalgia for a return to total unity between individual and society that characterised fascist ideology. We must therefore ask whether contemporary idealisations of the gift as a primary social practice and counterweight to modern capitalist society are not, themselves, expressions of similar misapprehensions. Within the field of management consultancy, there are discussions concerning the replacement of ethical morality with economic morality and arguments that the moral effects of economic actions should be included in any cost-benefit calculations. ${ }^{162}$ This raises the suspicion that we are now negotiating a further step on the way into modernity. Conversely, fields that until now were not market-dominated are also becoming subject to the laws of the market. In this case, conjuring up the presence of the gift would simply be nothing but a reaction to its absence and to the social disintegration caused by the globalisation of markets. ${ }^{163}$

158. Godbout and Caillé 1991: 11-12. Cf. also Godbout 1992.

159. Godelier 1996: 12.

16o. Berking 1996: 9-12.

161. Hettne 1990: 208-20.

162. Cf. Lay 1991; 1990. For a discussion of the benefits of reciprocal and altruistic behaviour in the field of economy see Grant 2014; Singer 2015; Frevert 2019. For a critique of the integration of social life into the market-economy see Siemons 1993: 66-79; Sandel 2012.

163. See Forrester 1996. 


\subsection{Return ticket to the South Sea Islands: On the use of ethnological comparisons and a critique of reciprocity}

What remains of the theory of the gift? Is this conception of gift-exchange simply the reverse image of modern economy, a counter-model to economic liberalism, a utopia? Certainly not. Discussions at the end of the nineteenth century about the standardization and the reconception of giving clearly indicate that the development of the theory of the gift was, in fact, accompanied by changes in the practices of giving, changes that required conceptual formulation. Yet it has become just as clear that these premodern practices cannot be subsumed under a single concept of giving. The British social historian Edward P. Thompson, who developed the concept of a 'moral economy', has noted correctly that there can be no 'constant "act of giving" with constant features, which may be isolated from particular social contexts', since the structure of giving always emerges within the historical peculiarity of the ensemble of social relations 'and not in a particular ritual or form isolated from these'. ${ }^{164}$

Recent anthropological and sociological work has built on the work of Mauss and Malinowski and resulted in more differentiated interpretations of the concept of the gift. They are most frequently indebted to Polanyi's system of categorisation. For example, his students Paul and Laura Bohannan distinguished between different spheres of circulation for subsistence goods and prestige goods. ${ }^{165}$ More famous is Marshall Sahlins's differentiation between generalised, balanced, and negative types of reciprocity. ${ }^{166}$ The organising principle underlying his typology is social distance, with altruism and egoism or self-interest forming the two opposing poles. According to Sahlins, generalised reciprocity refers to transactions that take place within neighbourly or family networks and refers primarily to giving without (immediately) taking. Balanced reciprocity subsumes trade and gift-exchange, while negative reciprocity refers to profit-orientated exchange and also includes theft. Sahlins has, however, been accused of differentiating reciprocity to such an extent as to have deprived it of its key element-that of mutuality. ${ }^{167}$

In the field of social anthropology, the problematic definition of reciprocity has led to renewed attempts to distinguish between gift-exchange and

164. Thompson 1977: 258.

165. Bohannan 1955; 1968.

166. Sahlins 1984: 184-275.

167. Ganzer 1981: 23-41. MacCormack 1976: 89-103 and criticises this lack of clarity. 
the exchange of goods, in which the type of relationship that underlies the transaction is taken to be the distinguishing criterion. Thus Chris Gregory describes gift-exchange as a 'debt economy' which is not concerned with exchanging commodities but with establishing obligations. ${ }^{168}$ In the field of ancient history Ian Morris especially has taken up this model. ${ }^{169}$ Bloch and Parry distinguish between long-term and short-term transactions in a model applied to early Greece by Sitta von Reden in her analysis of gift and goods exchange. ${ }^{170}$ Ancient historians nonetheless overwhelmingly work with Sahlins's typology and with the Maussian concept of the gift as a form of social integration to interpret evidence from antiquity. ${ }^{171}$ Émile Benveniste's study of the Indo-European vocabulary of gift-exchange is based on an understanding of the socially integrative function of gifts, but in the search for linguistic origins it tends, like other such studies, to lose sight of the historical and social contexts of the terms under investigation. ${ }^{172}$ By contrast, Évelyne Scheid-Tissinier pays proper attention to the historical and social contexts of Homeric terminologies of giving and exchanging, but the interpretative range is limited by her acceptance of the Maussian and Lévi-Straussian positions which view all gifts as means of establishing alliances and obligations. ${ }^{173}$ Scheid-Tissinier analyses the process of giving and taking by starting with the use of the term didōmi (to give), its derivations dōron, dosis, and dōtinē (gift), and a series of synonyms (porēn, tithēmi, pherō, teleō, etc). She considers the process within the frameworks of marriage, guest-friendship, safe passage, and rulership and interprets gifts (especially bridal and guest-gifts) as means of forging alliances and

168. Gregory 1982: 18 follows Mauss when he argues that things and persons are not separated in a 'gift-economy'. He characterises gift-economy as 'debt-economy' whose aim it was to create bonds of obligations. According to Gregory, commodityexchange and gift-exchange exist side by side and complement each other. Cf. also Godelier 1969: 5-37, who argues that the salt-money of the Baruya people of Papua New Guinea served both as a gift and as a commodity. This idea is not new. Cf. Schurtz 1898: 170, who notes that salt functioned as a gift within the society of the Baruya but was used as money outside it. While this exchange of goods could not be defined as an exchange of equivalence, the Baruya people took payment in return for their monopoly on the specialised knowledge required for the production of salt. For similar emphasis on the porous boundaries between gift and commodity see also Appadurai 1986: 11-16; Elwert 1991: 159-77. For the relationship between money and gift in ancient Rome see now Coffee 2017.

169. Morris 1986: 1-17.

170. Von Reden 1995: 3.

171. Cf. e.g. von Reden 1995: 3 and 79-81.

172. Benveniste 1951: 7-20, reprint 1966: 313-26; 1969: 65-101.

173. Scheid-Tissinier 1994: XII, 158. 
relationships between different communities. The most important area in which she sees the ethics of the gift and its two obligations (generosity and reciprocity) unfold most clearly is in the warrior community assembled at the feast. ${ }^{174}$ Drawing on Sahlins, Walter Donlan's typology of reciprocities in Homer seems to run entirely counter to ancient Greek concepts, raising some doubt as to its usefulness. Thus he places terms for debt (chreios), payments of penalties and ransoms (poinē, apoina, ōnos), and bridal and guest-gifts (dōra, hedna, xeinia) in the category of balanced reciprocity, even though their social contexts are fundamentally different. ${ }^{175}$

In order to regain a different perspective that allows us to appreciate the many facets and meanings of gifts in premodern societies, I propose to follow quite a different strand of thinking, one that calls for a complete departure from the concept of reciprocity. ${ }^{176}$ This will allow us to return to a key turning point in the debate, namely to the Argonauts of the Western Pacific, and to pick up once more the threads which Malinowski wove to connect the world of the Greeks with the world of the 'savages'.

In the 1970s, the American sociologist Annette B. Weiner examined the classical sites of gift-exchange in the Southern Pacific, the Trobriand Islands, and Samoa and reanalysed Malinowski's material in light of her own field work. ${ }^{177}$ The result of her research is a revision of the concept of reciprocity and a new perspective on the question of the value of gifts. She suggested that traditional concepts such as 'balanced reciprocity', 'pure gift', or 'generosity' reduced the complexity of the processes of exchange, which should not be divided into linear sequences of giving, receiving, and returning. What appears superficially as a pure gift, without any compulsion to give in return, may in fact be the start of a long-term process of mutual obligation that may 'switch back and forth between giver and receiver through time'. ${ }^{178}$ Weiner starts from the fundamental supposition that gifts may be reciprocated or retracted, although she rejects the widespread assumption that the expectation of a counter-gift is undefined. ${ }^{179}$ In her view,

174. Scheid-Tissinier 1994: 251-84.

175. Donlan 1982: 137-74. In his article 'Scale, Value, and Their Function in the Homeric Economy', he uses Bohannan's concept and differentiates between gifts of food for the poor and gifts of precious objects circulating amongst the warrior elite. Donlan 1981: 101-17.

176. Weiner 1980: 72.

177. Weiner 1976.

178. Weiner 1980: 73 .

179. On equivalence between gifts and counter-gifts cf. Racine 1987: 97-118, who distinguishes between elementary and complex forms of reciprocity. 
the expectation tied to a gift is clearly defined and is expressed through the form of the objects which are given. She proposes that the materiality of the object itself conveys the message with regard to future expectations, which may not always be articulated openly in words. ${ }^{180}$ The crucial point for Weiner is that exchange is a long-term process regulated by a process of social reproduction. ${ }^{181}$ She observes that in the society of the Trobriands it is the funeral ritual that sets in motion the process for the compensation of wealth and the renewal of social relations through gifts. ${ }^{182}$

Weiner demonstrates that Malinowski's classification of the different types of gifts among the Trobriand islanders according to their relation to equivalence, distinguishing between pure gifts, which compelled little or no reciprocation, and gifts which more or less aimed at equal value, ${ }^{183}$ is misleading. For example, Malinowski designated as pure gifts those allocations which a father made to his son, such as the right to trees in village groves and in garden lots belonging to the matrilineage of the father. However, with the death of the father, these 'pure gifts' were demanded back from the son through gifts (sagali) given by the members of the father's matrilineage because according to the matrilineal ideology of the Trobriand people, the son belonged to the matrilineage of his mother. Bundles of banana leaves and fibrous skirts, which in older literature also had been seen to act as a limited currency, symbolized these claims for the return of 'pure' gifts. ${ }^{184}$ The bundles and skirts were produced by the deceased's matrilineal descendants or exchanged with other women for food, preferably yams, which they received from their brothers. Such 'textile' gifts for the dead are distributed during funeral celebrations to all those who had received or given valuable objects or obligations to the deceased during their lifetime. Weiner proposes that women guarantee the return of resources into their own familial groups through the production of funeral gifts. They also renew alliances forged between different familial groups, which are otherwise threatened with dissolution by the death of one of

180. Weiner 1980: 76 .

181. Cf. also Bloch and Parry 1990: 23-25, who differentiate between short-term and long-term transactional orders, an approach now used by many scholars. See e.g. von Reden 1995: 3; Foxhall 2007; Widzisz 2012: 154.

182. Weiner 1989: 63 .

183. Malinowski [1922] 1999: 177-91. Malinowski revised his ideas about the pure gift after noting Marcel Mauss's work on the gift. See Malinowski's Crime and Custom in Savage Society (London 1926: 41). Mauss 1966: 71 (see n. 2) had criticized Malinowski on this point.

184. Schurtz 1898: 127-33. See also Ella 1899: 165-70; Krämer 1902. 
their members. A large proportion of the gifts is handed to the deceased's spouse and to his or her father, in order to replace the provision made for them (referred to as mapula) by the deceased during their lifetime. When sons wish to enter into their father's matrilineal group and share in its resources, they need, according to Weiner, to bring gifts of food to the funeral celebration organised by the head of the deceased father's matrilineage and by his sisters. ${ }^{185}$

The compensatory or return gifts of banana leaf bundles and skirts occasioned by a death have great symbolic character. They stand for material resources as well as for the social network of a matrilineage. Weiner describes them as a kind of currency that represents circulating wealth. This wealth is not, however, permanent. Weiner emphasises the levelling effect of the rituals of redistribution that take place during funeral rites as a 'replacement process'. According to her observations, this process effects both an inflow and an outflow of matrilinear resources, since the distribution of the gifts for the dead (sagali) is preceded by a continuous process of transformation in which other forms of wealth (from agriculture and craftwork, which are the domain of men) are converted into the textile wealth produced by women (an individual woman needs 1,0oo banana leaf bundles and twenty or thirty skirts for one funeral). Weiner shows that it is the women's textile wealth that renews social relations between clans. Mauss had been interested in just these groups when he made use of Malinowski's research into the Kula ring for his concept of the gift as a collective treaty. According to Weiner, the goods exchanged in the ring are employed by men to make claims on the resources of the father's matrilineage, but they establish personal obligations and lend social prestige only to individuals. The position of 'chief' does give a man the right to distribute the resources of a matrilineage, but these must be reclaimed through women's textile wealth. Thus, textile wealth represents the inalienability of a group's identity and the social and economic power of matrilineage. ${ }^{186}$

Weiner offers a second, quite different, example to illustrate the unsuitability of the concept of reciprocity for explaining exchange processes in premodern societies. While the Trobriand symbols of the social and economic power of matrilineage cannot be converted into permanent power, she suggests that in Samoa the possession of such symbolic goods (finely woven mats made from pandanus leaves) is tied to actual means 
of power. The difference is made by the objects themselves, as Weiner indicates: 'Samoan cloth has much greater longevity, giving it a measure of inalienability and historical authority, which can support more formal levels of rank'. ${ }^{187}$ This means that fine mats tend to be stored up rather than exchanged. In Samoa the mats are circulated at occasions such as births, marriages, funerals, and enthronements but also as compensation gifts in cases of murder. Like the Trobriand banana bundles and skirts, the distribution of these fine mats serves to renew social relationships and to support the cohesion of splintered family groups. Distribution is organised by the highest-ranking titleholder in a descent group and by his oldest sister, who herself may be a titleholder. It is she who, with the wife of the highest-ranking titleholder, organises the manufacture of the mats when these are made by groups rather than by individuals. The mats are viewed as the property of the descent group, but they are kept by the women (who may work on one mat for as long as a year), and handed over, albeit with a right of refusal, on demand from the highest-ranking titleholder, or in support of a husband or brother. According to Weiner the collaboration of titleholders and their sisters reflects the branches of descent groups whose members trace themselves back to either the founding father of their line, or the mother, with the two thought of as siblings. Both the titleholder and his sister may collect mats from relatives in both branches of the descent group in order to distribute them at weddings and funerals according to criteria of rank and status. Weiner clarifies how rank and power are visualized in this way. The finest and oldest mats-heirlooms that contain the history of past relationships and are passed on only under special circumstances-are especially expressive with respect to rank and power. Weiner tells us that they are sometimes given names and function as a 'material archive'. ${ }^{188}$

Both types of cloth-banana leaf bundles and pandanus mats-are also linked to their society's conceptions of time in that they absorb time and give it visual form. ${ }^{189}$ In both societies time is conceived as duration and is manifested in the durability of objects. Thus, we find that Trobriand exchange processes are tied to life cycles, and that the role of the textile bundles featured in the funeral rituals does not reach beyond the ceremony itself. By contrast, in Samoa there is a constant striving to transcend the individual's lifespan so that the textiles involved in distribution ceremonies

187. Weiner 1989: 70.

188. Weiner 1989.

189. Weiner 1989: 71. 
have longevity and are stored for generations. Genealogical memory is structured accordingly in each society: while in Trobriand matrilineal genealogy, the ancestor (or their spirit) returns directly into the body of a woman without building a long chain of ancestry, Samoan descent groups have considerable genealogical depth, often tracing themselves back as far as fifteen generations. ${ }^{190}$

I will now return from the South Pacific to the ancient Mediterranean world. My aim is not to compare Trobriands and Samoans to Greeks and Romans but to make use of Weiner's methodological and analytical framework, which I think is applicable. What is particularly inspiring is her attempt at symbolic interpretation of the materiality of gifts and her concern to understand individual exchange transactions in relation to the social structures in which they take place as well as in relation to symbolic and material production. Of course, contextualising transactions of exchange within their social context is a widely accepted principle within our field of research, but Weiner's focus on reproduction and on the question of the replacement and regeneration of material and immaterial values is especially valuable. By discarding the perspective of the giving and taking individuals, Weiner's study reveals relationships between apparently discrete exchange transactions and renders modern classifications of types of reciprocity obsolete. Reciprocity is a characteristic of the exchange relations she describes, but it is recognised in long-term relationships and relates to structural unities. In view of Weiner's work, a historical analysis needs to take seriously the material character of gifts, and to seek to understand the message that is expressed through their materiality. Most importantly, however, her method suggests that it is important to consider exchange transactions not as discrete acts but to look for relationships between them. This means that any question about the function of gifts in antiquity must always entail a social analysis.

\subsection{Gift-exchange in the Greek world: The debate over the formation of state and polis}

The interpretation of gifts as a form of social integration means that gift theory has some bearing on the discussion over the emergence of the state which, at its beginning, was concerned with the question of the 
subordination of individual interests under a central power. ${ }^{191}$ Sahlins drew an analogy between the Maussian concept of gift-exchange and Thomas Hobbes's concepts of the 'commonwealth' and 'common power', to which individuals surrender their self-interest in the interest of social and political peace. He concedes that the gift in Mauss does not structure society in a corporate sense but only in a segmentary sense and that this would not involve surrender to a central authority as in Hobbes. Instead the individual surrenders to an irrational power, the spirit of the gift. ${ }^{192}$ In Sahlins's interpretation Mauss joins the social contract theorists ${ }^{193}$ who distinguish between a primitive anarchy and a state of civilisation created through agreement and contract. The more recent debate about the origins of the state is more prominently marked by conflict theory. Here, the formation of the state is a matter of overcoming internal and external social conflicts. Recent theories stress consensus rather than conflict, in contrast to both Marxist theories of class-struggle (the state viewed as a means for enforcing the interests of the ruling class) and conquest theories (the state is formed through the conquest of agricultural cultures by nomadic tribes) that gained in influence towards the end of the nineteenth century. ${ }^{194}$ The key question here is 'how personal power become[s] depersonalized power' and how 'an egalitarian, segmental society become[s] an hierarchical society with permanently ascribed differential ranks of high and low statuses'. ${ }^{195}$ Elman Service argues that institutionalised leadership emerges through the fulfilment of administrative functions that serve the maintenance of the community. ${ }^{196}$ Gift-exchange is, therefore, important to Service's argument in two ways. On the one hand he suggests that reciprocal exchanges play a vital role in the creation of status hierarchies; on the other hand, he stresses the role of gifts in the creation of external alliances which may also strengthen the status of officials. ${ }^{197}$

191. For an understanding of the state as centralised power, a concept which was developed by Thomas Hobbes, cf. van Creveld 1999: 195-218 and Hölscher 1979: 6o-69, who discusses the invention of the term 'state' in the seventeenth century. Different definitions of the state are discussed by Stagl 1974: 311-22 and Service 1975: 43-46.

192. Sahlins 1984: 167-80.

193. For another view see Giddens 1976: 706-14.

194. For an overview see Service 1975: 21-46.

195. Service 1975: 71-72.

196. Service 1975: 8. Similar Stahl 2003: I, 110-13.

197. Service 1975: 6o-63, 73-75. 
Moses Finley's 1954 work The World of Odysseus plays a key role in the application of theories of gift-exchange to understanding the formation of the state in antiquity. While previous ancient historians, working with a concept of reciprocal gift-giving within the tradition dominated by Bücher, had assumed the existence of a state from the beginning of written accounts, ${ }^{198}$ Finley considered the social circumstances of the Iliad and Odyssey to belong to a pre-state era: 'a large measure of informality, of fluidity and flexibility, marked all the political institutions of the age', Finley argued. ${ }^{199}$ He exemplifies this through the uncertain position of the king, who was not able to rely upon regular taxes or tributes and had to secure his position through warfare and external alliances. ${ }^{200}$ In Finley's view, Homeric society was structured around oikoi, individual households that came together to collaborate for communal good only in times of crisis. ${ }^{201}$ He viewed gift-exchange as a key means for the formation of alliances between different households and leaders:

No single detail in the life of the heroes receives so much attention in the Iliad and the Odyssey as gift-giving, and always there is frank reference to adequacy, appropriateness, recompense [...] There was scarcely a limit to the situations in which gift-giving was operative. More precisely, the word "gift" was a cover-all for a great variety of actions and transactions which later became differentiated and acquired their own appellations. There were payments for services rendered, desired, or anticipated; what we would call fees, rewards, prizes, and sometimes bribes [...] The whole of what we would call foreign relations and diplomacy, in their peaceful manifestations, was conducted by gift-exchange. ${ }^{202}$

Finley illustrates the relationship-building functions of gifts especially through examples of bridal gifts and gifts of hospitality. ${ }^{203}$ Unlike Rudolf Köstler, who had interpreted reciprocal gifts in Homeric marriage

198. Cf. also Laum 1924: 160 and Köstler 1950: 7-25. Both are consulted by Finley. According to Köstler the description of the world of the Cyclops gives an idea of a pre-state-reality, characterised as based on primitive tribal law (11: 'urtümliche Sippenrechtsordnung auf natur und vernunftrechtlicher Grundlage’).

199. Finley [1954] 1967: 84 .

200. Finley [1954] 1967: 100-3.

201. Finley [1954] 1967: 103.

202. Finley [1954] 1967: 63-64.

203. Cf. Finley 1955: 167-94. 
laws and politics in terms of legal history as forms of contract, ${ }^{204}$ Finley views gifts of guest-friendship in particular as predecessors of contractual agreements: 'What other firm proof could there have been, in that unlettered world, that a relationship had been established, creating obligations and responsibilities'? ${ }^{205}$ According to Finley, these archaic forms of agreement were formed between individuals rather than groups, as Maussian theory would suggest. This stress on personal relationships distinguishes Homeric alliances from agreements made in classical Greece: 'Croesus exchanged oaths of guest-friendship with the Spartans but Homer knows of no such tie between Argives and Lycians or Taphians and Ithacans-only between individuals, Diomedes and Glaucus, "Mentes" and Telemachus.' ${ }^{206}$

Indeed, Finley did not refer to Mauss in The World of Odysseus but instead to the tradition founded by Bücher, which in ethnology had been continued by Malinowski and had been taken up in the field of ancient history by legal historians such as Rudolf Köstler. It is only in his 1974 appendix The World of Odysseus Revisited that Finley referred to Mauss's research: 'Fifty years ago the French sociologist Marcel Mauss published his famous account of the integral role of gift-giving in a large range of societies. Twenty years ago I showed that gift-giving in the Homeric poems is consistent, I might even say absolutely consistent, with the analysis made by Mauss (who, curiously, ignored the ancient Greeks in his study)'. ${ }^{207}$ Finley thus joined this line of tradition rather belatedly-although he was well aware of the significance of the work of Louis Gernet, which stood at its beginning.

Gernet, a student of Durkheim just like Mauss himself, had taken on the task of collating the evidence on gift-exchange in ancient Greece, which Mauss had largely left untouched-with the exception of a brief study on the potlatch in Thrace ${ }^{208}$ and on the Roman nexum. ${ }^{209}$ There is, therefore, nothing strange about the absence of ancient Greece from Mauss's work. ${ }^{210}$ Mauss had assumed that already in antiquity there had been a division

204. Köstler 1950: 22-23.

205. Finley [1954] 1967: 133.

206. Finley [1954] 1967: 105.

207. Finley [1954] 1978: 151.

208. Mauss 1921: 388-97.

209. Mauss [1923/4] 2016: 146-56.

210. Cf. Ulf 1990: 212 arguing that Mauss neglected the ancient Greek world because he could not find in it a system of 'prestations totales', which the French scholar considered as the basis for complete material reciprocity. 
between contract and moral obligation, and that trade was independent of gift-exchange. ${ }^{21}$ Gernet is less inclined than Mauss to modernising interpretations of ancient practices and laws, preferring to assume that there is no division between law and religion in early Greece. Gernet recognises allusions to the practice of gift-exchange, especially in the mythical tradition, interpreting this as competitive much as Mauss had argued for the Tlingit and Haida potlatch. ${ }^{212}$ Above all, Gernet highlights the role of gifts in forging alliances in Greek international relations ('l'ordre international'). ${ }^{213}$ Finley too refers to this in his article 'Marriage, Sale and Gift in the Homeric World', which appeared a year after The World of Odysseus and in which he highlights the significance of gifts and counter-gifts in Greek social and political relations. Finley, however, does not agree with Gernet on the competitive character of gift-giving, and he also takes a more 'primitivist' position on the subject of rulership. ${ }^{214}$

Moses Finley may appear today as the founding father of ancient historical gift-exchange debate, but the debate's prehistory is in fact far more complex. ${ }^{215}$ Not unlike Malinowski, Finley sketches out the picture of a homogeneous society (albeit a fictional one) which he locates in the tenth and ninth centuries BCE. ${ }^{216}$ In doing so, Finley rejected the then widely accepted consensus that located Homeric society in the Mycenaean age and viewed Homeric rulership as based on feudal models or on sacred kingship. ${ }^{217}$ Finley's colleague George D. Thomson had attempted to build support for James Frazer's concept of sacred kingship only a few years earlier in his Prehistoric Aegean (1949), about which Finley maintains a studious silence. ${ }^{218}$ Having adopted a school of thought founded by Henry Morgan and Friedrich Engels according to which the state was an instrument for securing the rule of one social class, Thomson saw the development of

211. Mauss [1923/24] 2016: 157 .

212. Gernet 1948: 415-62.

213. Gernet 1951: 21-119, reprint 1982: 17 .

214. Finley 1955: 179, n. 35.

215. This is the argument of Qviller 1981: 112, who praises the revolutionary character of Finley's discovery, and of Donlan 1989: 2.

216. For this he is criticised early on. Cf. Snodgrass 1974: 114-25; Whitley 1991: 35-37; Raaflaub 1998: 169-93.

217. For more detail see ch. 4 .

218. The opposition against Thomson can be derived from his critique of 'a repressed memory of ancient matriarchy [...] reflected in some verses' of the poem. He does not name any of his opponents: 'Some scholars have seen in it [i.e. Penelope's and Arete's power] a confused vestige of a mother-right system that prevailed among the Greeks centuries before.' Finley [1954] 1967: 92-93. 
private property as the decisive catalyst for the emergence of the state in antiquity. He was working with the evolutionary model designed by Morgan in which primitive society is matriarchal and characterised by communal property and group marriage, while the final stage sees a class structure characterised by private property and patriarchal family structures. He thought that this final stage was reached by the Greek polis. Thomson interpreted the system depicted in Homeric epic as a primitive ancestral monarchy with elements of sacred kingship inherited from the Minoan and Mycenaean era; he too located it in the Dark Ages, the tenth to ninth centuries BCE. ${ }^{219}$

Thomson is on the side of the conflict theorists who explained the emergence of the state from inner and outer contradictions, ${ }^{220}$ while Finley clearly shows more affinity with contract theorists. For instance, Finley explains the necessary forging of obligations through gift-giving or marriage through an ongoing state of war, although the causes of this are not made clear. ${ }^{221}$ Despite the peace-making function he ascribes to ancient gift-giving, Finley does not arrive at a picture of the Homeric world as a positive antithesis to modernity. This is because of his opposition to Thomson's model, which embodies most clearly such a prehistoric utopia. ${ }^{222}$ Thomson describes the history of human civilization as a story of decline from a matriarchal paradise of communal property, whose return was promised by Socialism. Finley rejects both the evolutionary theory that underlies this concept and the description of the ancient Greek world as a tribal society. ${ }^{223}$ For him, the key criterion for

219. Thomson [ $\left.{ }^{1} 1949\right]{ }^{4} 1978: 416-32$.

220. Thomson 1978: 430 combines the Marxist theory of class-struggle with the concept of invasion: 'Behind the work of the humane poets who composed the Iliad and the Odyssey', he argued, 'lies an age of brutality and violence, in which the bold pioneers of private property had ransacked the opulent, hieratic, sophisticated civilisation of the Minoan matriarchate'. For a critique of the concept see WagnerHasel 1992: 320-21.

221. Finley [1954] 1967: 103.

222. See Wagner-Hasel 1992: 320-23.

223. Cf. Finley 1985: 90-93, arguing against the traditional evolutionary view of a regular evolution from an early 'tribal' organization of society, based on kinship groups, to a political, territorial organization, and Finley 1983: 44-45. Whereas in the 1970 s the concept of tribal societies was deconstructed by Felix Bourriot (1976) and Denis Roussel (1976), current research is beginning to reevaluate the role of kinship-relations. See Dmitriev 2018 who stresses a strong connection between kinship and democracy in Solonian Athens. Duplouy 2006 discusses the role of genealogical prestige in archaic and classical Athens. For an overview of the debate see Varto 2017. 
distinguishing between state and pre-state is the binding implementation of decisions. ${ }^{224}$

In contrast to The World of Odysseus, research into early Greek giftexchange in the 1980s and 1990s makes explicit reference to evolutionary theory. ${ }^{225}$ It favours various typologies of stages in the emergence of states (such as 'bands, tribes, chiefdoms, states'; 'egalitarian, ranking, stratified society'; and 'kinship society' and 'stratified society') developed by Elman Service, Morton Fried, and Jonathan Friedman. ${ }^{226}$ The Homeric world is usually assigned a position between 'ranking society' and 'stratified society', a stage somewhere between chiefdom, clan society, and state. Along with this change in perspective, we also find a renewed interest in the competitive aspect of gift-giving underlined by Mauss and Gernet as well as in the Marxist theory of class-struggle.

In a 1981 essay, 'The Dynamics of Homeric Society', Bjørn Qviller argued that the disappearance of Homeric kingship and the emergence of the aristocratic polis were caused by the Homeric leaders' competitive displays of wealth. In his view, ' $(\mathrm{t})$ he importance of redistribution and gift-giving in the activities of a Homeric king places him between the big-man and a chieftain in a continuum of political leadership. ${ }^{227}$ In contrast to Finley, Qviller stresses the role of kinship in social organisation and sketches out the image of a society consisting of 'small groups based on kinship' and a

224. Finley 1983: 51-52: 'Three distinctions seem to me be necessary. [...] The second is between states in which decisions are binding and enforceable and pre-state structures in which they are not'.

225. Cf. Qviller 1981: 145, who talks of a 'multi-linear evolution'. Donlan 1981: 2 describes the Homeric world as 'simple societies in evolution'. Cf. also Morris 1986: 4; Ulf 1990: 230-31.

226. Service 1975: 80; Fried 1967: 182-84; 224-26; Friedman 1975: 161-202.

227. Qviller 1981: 120. His view is based on the observations made by Jonathan Friedman with the Kachin in upper Burma (now Myanmar) during a similar transition from 'kinship society' to state (111-12). According to Friedman, kinship structures are broken up when one of the lineages manages to make a surplus which is distributed at feasts, in return for which they may require other, lower-ranking, lineages to provide surplus labour. This stimulates local population growth, which exceeds what the region is able to sustain, and thus leads to territorial expansion and in turn to conflicts with other expanding populations. The search for internal solutions such as intensive land cultivation and reduced fallow periods results in exhausted soils and indebtedness of the poorer lineages. The dependence of the indebted, lower ranking lineages provokes internal conflicts and revolts, which result in the reestablishment of the former conditions. This is the situation Qviller claimed for the Homeric world which he located at the end of the ninth or the beginning of the eighth century (113-45). 
system of ranking 'based on generosity'. ${ }^{228}$ He views generosity at feasts and the distribution of gifts as means for the creation of obligations and the recruitment of followers. Qviller argues that the competition for followers created pressure on the king to keep on generating new wealth-be it through seizing wealth from others or through claiming it from his people-which led to internal and external instability. Among the destabilising factors are 'revolts caused by exploiting kings', when population growth is stimulated beyond the capacity of the area by the king's competitive activities, which in turn leads to conflict over territorial expansion with neighbouring communities, weakening the king's position. This ultimately contributes to the replacement of structurally weak kings through the emergence of an aristocratic order. ${ }^{229}$

Walter Donlan similarly assigns Homeric society to the historical stage of chieftain societies, ${ }^{230}$ although he also recognises elements of the polis, and thus the state, in Homeric epic. ${ }^{231}$ Donlan is primarily interested in institutional aspects of state formation rather than the question of social inequalities that Qviller stresses. It is in the development of formal administrative and military structures, and in the formalising of political bodies such as the assembly and council, that Donlan sees the state emerging-although it is still overlaid with personal forms of rule in Homeric society. ${ }^{232}$

Since Qviller and Donlan's work of the early 1980 a series of further contributions have similarly considered gift-exchange within the framework of a minimal degree of institutionalisation in Homeric society. In his 1986 study Individual and Community: The Rise of the Polis, 800-500 BC, Chester G. Starr assumed strong personal leadership, an unstructured political system lacking taxation, and an effective assembly were key features of these communities. Starr too speaks of an 'age of chieftains' and refers to anthropological studies on the emergence of institutionalised leadership. But he limits the role of gift-exchange to relationships between leaders only, and he stresses the role played by profit-oriented thought, especially in the Odyssey. ${ }^{233}$

228. Qviller 1981: 112.

229. Qviller 1981: 113, 126-27. The assumed agonistic character is stressed by Beidelman 1989: 250 who also claims that Finley underestimated this aspect of Homeric gift rituals.

230. Donlan 1982: 2; 1981: 137-38.

231. Donlan 1989: 5-29.

232. Donlan 1989: 13. See also Whitley 1991: 39-45, 198, who underlines the diversity of institutions and practices that were part of poetic reflection.

233. Starr 1986: 17-32. See also von Reden 1995: 58-76. 
In contrast to Starr, Michael Stahl emphasises the importance of the rules of reciprocity for establishing peaceful external alliances in goods exchange and marriage. Internal conflict was, according to Stahl, the responsibility of individuals with high social status. Based on this, he argues that the manner in which such societies maintain cohesion is personal rather than institutionalised, but that it nonetheless creates binding and therefore effective obligations. ${ }^{234} \mathrm{He}$ assumes various elements of statehood, such as the establishment of anonymous political roles, the celebration of state identity through festivals, the maintenance of political stability through a state judiciary, and-connected to this-the concentration of power, during the age of tyranny. ${ }^{235}$ Following Stahl, Karl-Wilhelm Welwei also argued in his 1992 monograph that Homeric Greece did not yet have institutionalised forms of office holding and decision-making and thus no state, although he rejected the characterisation of Homeric rulership as a 'chiefdom'. ${ }^{236}$

In a 1990 study of Homeric society, Christoph Ulf saw the world of Odysseus placed between an egalitarian-segmental society and an organised state marked by central political institutions. Signs of this intermediate status include 'the emergence of status-roles, and the beginnings of institutionalised leadership including privileged access to basic resources and prestige goods'. ${ }^{237}$ Ulf rejected the political character of guest-friendship proposed by Finley and Donlan and refused to speak of a 'gift-giving society' since, in his view, there is no competitive aspect to Homeric gift-giving and no connection between a person's status and their giving. But he did consider the Homeric leader's obligation to generosity to be an essential feature of Homeric rulership. ${ }^{238}$ This demonstrates the extent to which the potlatch, represented by Mauss as the most highly developed form of a system of total services, had become synonymous with gift-exchange itself-despite the fact that from a modern perspective it should be considered atypical. ${ }^{239}$

234. Stahl 1987: 141.

235. Stahl 1987: 141-42, 181; 2003: I, 201-51. Linking on to Stahl, recent research has come to use the term 'citizen state' ('Bürgerstaatlichkeit') and to study practices of being a citizen, e.g. athletic contests, common meals, civic feasts. See Walter 1993; Blösel et al. 2014; Seelentag 2015.

236. Welwei 1992: 78-80 with n. 9.

237. Ulf 1990: 230.

238. Ulf 1990: 206, n. 73; 211; 195-96. See also Ulf 2011: 302. Here he uses the term 'Gabenökonomie' to characterise Dark Age-societies.

239. Cf. ch. 1.1. 
While the majority of studies cited above consider practices of giftexchange in close connection with the pre-state organisation of the Homeric age, there is a tendency in more recent scholarship to recognise similar informal practices in later sources too. According to Gabriel Herman's research in Ritualised Friendship (1987), guest-gifts continued to play a role in building external alliances in classical Greece beyond the frontiers of one's own polis. ${ }^{240}$ Also, relations of friendship and of patronage have been gaining attention. ${ }^{241}$ Earlier views of a strong connection between reciprocity and statelessness have been abandoned. ${ }^{242}$ Ian Morris distinguishes between 'clan-society' and 'state communities' and characterises the poleis of early Greece as 'nascent state communities'; he also assumes that gift-exchange continues into post-Homeric times. Like Thomson, Morris sees early Greek society as marked by slavery, private property, and the descriptive terminology of kinship. In keeping with Finley's antimodernist position, Morris also sees elements of a clan-society manifested in gift-exchange rituals which he argues were a means of establishing social hierarchy. In Morris's view, gift-exchange and commodity-exchange exist in parallel in archaic Greece, although the fact that land is not yet a commodity at this time supports the idea that the society depicted in Homeric epic evokes a transitional phase between clan-society and state. ${ }^{243}$

For most of the research discussed here, Homeric epic forms the primary evidentiary basis for reflections on the emergence of the state in ancient Greece, although Morris also draws on archaeological findings, such as forms of burial, the spread of ceramics, and other artefacts. While the distribution of Attic and other Greek pottery or metal vessels (bronze tripods, cauldrons, bowls) was considered as evidence of trade in the past, Morris

240. Herman ${ }^{2}$ 1989; 2006. Cf. also Mitchell 1997; Low 2007: 37.

241. Cf. Mann 2007: 98-123; Domingo Gygax 2016; Maehle 2018.

242. For a connection of reciprocity and statehood see van Wees 1998: 13-49.

243. Morris 1986: 4. His point of reference is not Thomson, but Karl Marx, Claude Lévi-Strauss, and the ethnological study of Chris Gregory on the society of Papua New Guinea (Gifts and Commodities 1982). Cf. also Morris 1987: 475 and Sakellariou 1989. Sakellariou uses the Marxist theory of class struggle (see Breuer 1990: 7-16) but also the three-elements theory, i.e. unity of people, power, and territory ('Staatsvolk', 'Staatsmacht', 'Staatsgebiet'). See also Hansen 1998. For a Marxist approach see now Rose 2012: 11-17 who criticises former research for its lack of interest in exploitation and the neglect of the productive role of women. For current debates on statehood in ancient Greece see Stahl 2003: I, 94-116; Fraß 2014; Lundgreen 2020. 
and others now view such distribution as indicative of a wide network of guest-friendships and aristocratic exchange of prestige goods. ${ }^{244}$

Instead of continuing to outline this research, I will draw attention to an opposing view. In a 1991 essay Fritz Gschnitzer points to a whole range of institutions in the Homeric world that indicate the existence of the public rule of law and, thus, a state. Refuting the notion of Homeric Greece as a pre-state community, Gschnitzer refers to examples such as the council ('Ratsversammlung'), compensation for expenses incurred through hospitality that can be demanded from the community, the existence of personified justice (Themis), of penalties ( $\theta \circ$ n) imposed by the community on individuals, the liability of communities for the debts of their members, and, finally, alliances forged by oaths of obligation. In commenting on Nestor's warning to the Greek army not to desert Agamemnon and the war for Troy, he states: 'This is a matter of the validity and permanence of obligations entered upon. They have sworn oaths and have confirmed these through shaking hands and through ritual and sacred celebrations; the respective partners rely on all this; if it were suddenly to become invalid the entire world would collapse. ${ }^{245}$

Underlying Gschnitzer's critique is a concept of statehood that goes back to Eduard Meyer and which implies that the existence of a legal system effectively equals the existence of a state. ${ }^{246}$ In his own time, Meyer too had been reacting against assumptions of an original pre-state phase, by inferring that where rules for communal living existed, there is statelike organisation; in effect, Meyer's view equated state with society. ${ }^{247}$ This ahistoric concept of statehood that gained influence during the nineteenth century is a flaw in Gschnitzer's work too. Nevertheless, the significance of the law for archaic Greece should not be denied. ${ }^{248}$ Gschnitzer's argument sheds some light on the oath as a means of obligation that serves precisely the purpose assigned by Mauss to the gift, namely the forging of peaceful alliances between different communities. Medievalists are well aware of the importance of oaths for the creation of obligations between

244. Cf. e.g. Coldstream 1979: 334-8; 1983: 201-6; Whitley 1991: 9-10; Langdon 1987: 107-13.

245. Gschnitzer 1991: 197.

246. Meyer 1910: 11-15. On Meyer see Nippel 199ob. Even Köstler (1950: 15-16) understood the Homeric state as 'Rechtsgemeinschaft', but also underlined the supplementary role played by religion.

247. For a critique see Stahl 2003: I, 104-9; Nippel 1990: 311-28.

248. Cf. Stahl 2003: I, 213-19; von Ungern-Sternberg 1998: 85-107; Hölkeskamp 1992: 87-117; 1999 . 
nonfamilial groups. But the existence of oaths does not necessarily prove the existence of a state. ${ }^{249}$ In Promise-Giving and Treaty Making, Peter Karavites demonstrates the role played by agreements or treaties described as horkia in making peace between enemy camps. Karavites acknowledged fully the informal, although nonetheless binding, nature of such treaties while also presupposing the existence of sovereign states in the Homeric era. ${ }^{250}$ By contrast, the medieval historian Gerd Althoff took the forging of alliances via such treaties (be they between communities or between leaders) to indicate an absence of statehood and of centralised state power. ${ }^{251}$

Little attention has been paid, however, to these kinds of pre-state alliances in the context of scholarship on gift-exchange. Herman does acknowledge oaths alongside gift-exchange as a part of the rituals of politically motivated hospitality. ${ }^{252}$ But since hospitality is thought of as making alliances between individuals rather than between communities, it occupies a separate realm from that of treaties and alliances. Thus, informal treaties forged between communities are not acknowledged as independent forms of alliance alongside individual guest-friendships. This is the case, despite the fact that forming obligations by oaths is an essential characteristic of personal forms of rule, which in turn are acknowledged as characteristic of the pre-state era in Greece. Such oaths rely on a concept of personal rulership that is based on reciprocal obligation between ruler and subjects. In the Early Modern Period, individual subjects offered personal oaths of allegiance on the occasion of installing a new king in the form of a 'Huldigungsumritt' ('or royal progress'). ${ }^{253}$ Gift-giving formed part of this ritual of personal obligation to the individual ruler up until the seventeenth and eighteenth centuries when such gifts became monetised and were transformed into taxation, as Richard Meyer and Karl Bücher have stressed. ${ }^{254}$ The ruler received gifts, foodstuffs, textiles, and tableware but also carried the cost of providing hospitality for the citizens whose homage he

249. See Althoff 1990: 119-33. According to Raaflaub (1997: 1-27), Finley had underestimated alliances between societies.

250. Karavites 1992: 8. Baltrusch 1994 understands alliances created by oaths as forerunners of international treaties.

251. Althoff 1990: 217. The concepts go back to Max Weber. Cf. Oexle 1994: 154-56. According to Hattenhauer (1992: 2-15), in ancient law the oath was, next to the gift, one of the most important means for the creation of obligations.

252. Herman 1987: 49. Cf. also Low 2007; Sommerstein and Torrance 2014.

253. Holenstein 1991: 433-85. Cf. also Prodi 1997.

254. Holenstein 1991: 460-72. For the Ancien Régime see Guery 1984: 1241-69; 1997: 154-62. 
received. ${ }^{255}$ From the seventeenth century onwards, this reciprocity-based concept of rulership began gradually to be replaced by a more abstract idea of sovereignty, which went hand in hand with a more defined sense of territorial rule. ${ }^{256}$ This is also the period during which the concept of homo oeconomicus arose, as Werner Plumpe has shown. ${ }^{257}$ During this time of change from personal to abstract rule, we also find the emergence of the term 'state' that eventually replaced the ancient term res publica. The new term defined the state in the sense we see in the arguments of Eduard Meyer and Fritz Gschnitzer, as a legal state, while eliminating some older meanings such as 'common wealth' and 'common good' that had been tied to the use of the term res publica. ${ }^{25}$

The focus of contemporary ancient historical scholarship on the personal character of rulership as a yardstick for evidence of pre-statehood reflects the emergence of the state in modern times and projects this back onto antiquity. Contemporary debates on statehood are overly concerned with the distinction between personal/informal and impersonal/institutional forms of rule; they neglect the fact that ancient systems of rulership, not unlike those of the early modern age, may have been personal in character but highly varied in their institutions. This is as true of Imperial and Republican Rome as it is of classical Athens. The ability to establish personal networks was indeed an essential precondition for the achievement of leadership positions. Whereas in Rome one individual and one family eventually succeeded in monopolising such networks, Athens used ostracism and other institutional means as a way of preventing the centralization of allegiances around one individual. The existence of such processes must not, however, be taken to prove the existence of statehood, as Jochen Martin has rightly insisted. ${ }^{259}$ If we can speak of statehood at all in antiquity, then it must be in the sense of the old term res publica, with its orientation towards the common good. The history of the ancient polity is to a great degree a history of the opposition between the common good and self-interest. ${ }^{260}$ Self-interest in antiquity is not individual self-interest but the interest of the social grouping to which an individual belongs,

255. Holenstein 1991: 472-78.

256. Holenstein 1991: 486-503.

257. Plumpe 2007.

258. See Hölscher 1979: 60.

259. Martin 1990: 229. Recently Arjan Zuiderhoek (forthcoming) has stressed the stateless character of the Greek polis and even the Roman empire.

26o. Cf. Schmitt-Pantel 1992: 108-13; Patzek 1992: 133. See now Fraß 2014: 6-28. 
the oikos, familia, or domus-the household. Unlike modern households, ancient households had political functions. It therefore makes sense to differentiate, as historians of the Medieval period do now, between different community groups or, preferably, between different 'Zugehörigkeiten', ${ }^{261}$ or 'Bindungsverhältnissen', that is, different allegiances and relationships. These groupings could form a hierarchical structure as they did in classical Athens, where the community of citizens was more powerful than the community of the oikos. In Rome, the system of patronage meant that the domus became the dominant grouping. The point is that there was no centralized state power in antiquity. As von Jhering has shown, political office was considered an honour bestowed by the people to an elite group. In return, office holders were required to provide political services and financial outlay. In his work on statehood in Rome, Jochen Martin defines the political order of ancient communities as a system of acceptance, which presented itself, even in late antiquity, through the traditional structures of gift-exchange. ${ }^{262}$

In view of the fact that the idea of statehood is so deeply marked by modern ideas and developments, I prefer to avoid the term 'state' altogether. I am also not interested in situating the gift in a pre-state era, as most recent scholarship has done. Given the problematic definition of the concept of gift-exchange, which I have demonstrated in my discussion of the history of Maussian gift theory, I do not advocate for the general presence of gift-exchange in the ancient world. It seems to me to make a lot more sense to consider the emergence of the polis from a spatial perspective. Even though immediate analogies between modern and ancient processes of state-building are not possible, the ancient process of structuring allegiances hierarchically does have a spatial component, which we can see from the location of tomb monuments by roadsides and temples on the periphery of poleis. ${ }^{263}$ The concept of the territorial state, which implies spatial enclosure through the drawing up of boundaries, is not especially useful for understanding this process. It is more useful to think in terms of centre formation, a concept from settlement geography which has long been used by prehistorians and archaeologists and has gained prominence

261. Stein-Hölkeskamp 1989: 52 also uses the term 'belonging' ('Zugehörigkeit'). Looking back to Finley she also assumes that guest-gifts form bonds by creating obligations and founding loyalties between hosts and visitors, and that they enable a relatively durable relationship to be formed between two oikoi.

262. Martin 1994: 108. Cf. also Veyne [1976] 1990; Winterling 1999.

263. Cf. de Polignac [1984] 1995. For more detail see ch. 5.4. 
in ancient history too. In settlement geography, centres are places that fulfil central economic, administrative, or religious functions within regions. According to Colin Renfrew, centres emerge from increasingly intensive interaction for which there can be a variety of explanations. He views reciprocal and redistributive forms of exchange as typical for the types of centres he calls 'early state modules.'264 According to Michael Rowlands, who uses the term 'centre' for the ancient Near Eastern cultures of the second millennium, centres are where networks of alliances come together and allow optimal access to resources. In Rowlands's interpretation, the circulation of gifts, here understood as prestige goods, is less a matter of status than of control of resources. ${ }^{265}$

The spatial concept underlying this definition of centres focusses on communication and routes rather than boundaries. It allows us to conceive of Greek poleis as networks of open communication with one or more centres and subcentres, ${ }^{266}$ emphasising exchange relations much more than in the debate on state-building. While scholars interested in statehood consider gifts primarily from a political perspective as either a pre-state means of forging alliances or as a means of displaying status or obligation in hierarchical relations, the concept of centres allows more emphasis on economic factors. Another advantage is that this approach does not conflict with a view of ancient rulership as personal and informal, while also allowing a broader consideration of the material aspects of rulership. Rulership can then be considered as not a matter of obedience and subjection ${ }^{267}$ but more as a question of the disposal of labour and the control of resources.

The concentration on the institutional aspects of the formation of the polis has meant that the material and economic aspects of gift-exchange have receded somewhat into the background. When economics was brought into the picture, this was often limited to investigating whether guest-gifts were primarily intended as initial gifts to establish trading relations, ${ }^{268}$ or whether they had other purposes such as the acquisition of prestige

264. Renfrew 1978: 12; 1986: 1-18.

265. Rowlands 1987: 5-6.

266. See Rihll and Wilson 1991: 59-95 for the geometric period. Cf. also Cavanagh 1991: 97-118; Osborne 1994: 143-6o.

267. This is Max Weber's classical definition of power, although he also stressed another feature, that of the existence of a monopoly of power ('Gewaltmonopol'). Cf. Reinhard 1999: 9-11. For more detail see ch. 4.1.

268. Stanley 1986: 5-15. A similar view can be found in von Jhering 1887: 387 and Bolkestein 1939: 222-23. According to Morris 1986: 5 , the exchange of gifts served to create personal relationships which preceded any trade exchanges. 
or status and the forging of political alliances. The world of material production, that is, the realm of the actual production and materiality of the gifts and the procurement of the raw materials needed for them, has been largely ignored. This is, however, largely connected to the interpretation of Homeric society as a conglomerate of economically independent households, which goes back to Finley and is based on Bücher's model of a closed economy: 'With their flocks and their labour force, with plentiful stones for building and clay for pots, the great households could almost realize their ideal of absolute self-sufficiency' ${ }^{269}$ Felix Somló had rightly argued against Bücher's model of original self-sufficiency, when he assumed that the very first phases of development relied on economic collaboration. ${ }^{270}$ Homeric households consisted of, as we will see, a multitude of relationships of obligation, both hierarchical and equal. It is precisely the size of their flocks and herds that forced early Greeks to establish wide networks of communication; the effects of this on the process of polis formation have not to date been adequately acknowledged. ${ }^{271}$

Against the background of this overview it makes sense to return once again to Homeric epic and the origins of the gift-exchange debate, to reconstruct anew the patterns of communication that underlie the distribution of gifts in the poems, and so to arrive at a new interpretation of the significance of gifts in the process of polis formation. This is also a question of the dating of the world of Homeric epic. Since Finley, there has been a tendency to assume that the world of the epics represented the social realities of the early Iron Age. Other researchers, investigating connections between hero-cults and the emergence of the polis, have suggested a dating of the Homeric world to between the eighth and sixth centuries instead. ${ }^{272}$ Questions remain, however, as to whether hero-cult

269. Finley 1967: 57-58. According to Finley, only the trade with metals required external contacts. Donlan 1982: 151 stresses the mutual exchange of 'food, shelter, protection and favors'. For the economic aspects of gifts see Veyne 1976, who discusses the Roman evidence. On Bücher's concept see Wagner-Hasel 2011; 2014.

270. Somló 1909: 177.

271. For further detail see ch. 5.4.

272. See Antonaccio 1994: 79-104. Arguments for dating the epics into the seventh century BCE can be found in Andersen and Dickie 1995 and Crielaard 2002. For an overview see Ulf 2011: 294 with n. 12. The majority of scholars choose the eighth century. See Raaflaub 1991: 205-56; Latacz 1988: 153-83 and Latacz 2001: 56-69. Latacz dates the written text around $730 \mathrm{BCE}$, but he does not consider hexameter poetry as such as a new creation and does not exclude the possibility of elements of Mycenaean tradition being present. Cf. also Pöhlmann 1990: 11-17. For a later dating in the sixth century see Jensen 1980: 164-71; Burkert 1976; Boyd 1995. 
was a consequence of the spread of heroic epic, ${ }^{273}$ or whether the spread of epic beyond Ionia went hand in hand with the emergence of hero-cults around Mycenaean tombs. ${ }^{274}$ There are also significant local variations in the practices of heroic cult, as James Whitley's comparison between Argolis and Attica has demonstrated. ${ }^{275}$ What we can be certain of is that epic provides a picture of the social practice of hero-cults and therefore provides an essential source of information about the process of spatial communication. Such imagined practice can only provide an idealised image of reality; but in order to be comprehensible it must have some roots in the lived experiences of its recipients, notwithstanding some conscious archaising tendencies. ${ }^{276}$ This must be true, whether the poems represent a purely aristocratic imagination, as Ian Morris has argued, ${ }^{277}$ or whether they are to be seen as a general repository of cultural knowledge. ${ }^{278}$ Of course it must be assumed that representation will be influenced by the multiple poets' own points of view and by the expectations of audience and patrons. ${ }^{279}$ This is not to suggest literary homogeneity or unbroken congruence between poetic tradition and society, but it does assume that the poems refer to lived experience. It is necessary, however, to explore the internal logic of the circulation of gifts before any attempt can be made at a concrete historical categorisation. As will become apparent in what follows, the hero's burial is the central, crystallizing event in the Homeric world. It is here that things come together in such a way as to allow us, through studying the circulation of gifts, to gain insight into the ideal or typical circle of reproduction of an ancient society.

273. See Coldstream 1979: 341-46.

274. See Snodgrass 1982: 107-19.

275. Whitley 1988: 173-82. Cf. also de Polignac 1994: 3-18.

276. Cf. Kullmann 1988: 184-96.

277. Morris 1986: 81-129; Latacz 1989: 26, 40-47, 63-68 = 2001: 32-35; 1984: 15-39.

278. See Havelock 1963; 1978: 10-14. Cf. also Thomas 1992: 116, who views the poet as the trustee of cultural heritage. For another view see Kullmann 1988: 187-90. The fact of literary borrowings from the ancient Near East is a key counter argument for Kullmann, although he does not consider that such borrowings must also be integrated into the poet's social world in order to gain acceptance. Within a culture of increased communication between the Greek and Near Eastern worlds, which reaches its apex during the seventh century, there is clearly room for such 'orientalising' elements. These borrowings do not undermine Havelock's thesis that the Homeric epic is an 'oral encyclopedia'. Cf. Burkert 1984; 1991: 155-81.

279. See Svenbro 1976: 16-34. 


\subsection{Methodological reflections: The sensory world of signs and the imagery of Homeric epic}

Although the history of gift-exchange scholarship has ignored the sensory world since Mauss, we do find much more sensory reflections in older work. In his study Ueber schenken und geben, published in 1848 and examining the reciprocity of medieval and ancient gift-giving, Jacob Grimm sets his agenda as follows: 'Having made these preliminary remarks, I can now develop the customs of the past by speaking about individual objects as gifts: apart from land, by preference food and drink, livestock, clothing, rings, weaponry and other equipment'. ${ }^{280} \mathrm{He}$ then proceeds to examine individual objects, using ancient and medieval sources, in order to develop an etymology of the terms schenken ('to make a gift') and geben ('to give') that leads directly back to the objects discussed. Thus, he derives schenken from einschenken ('to pour'), the word used for serving food and drink, and geben from binden, anheften ('to bind', 'adhere'), used of clothing and jewellery. ${ }^{281}$ I have no intention to pursue etymological research into the primary meanings of terms for gifts in Homeric epic, nor to order such terms into a historical sequence as Grimm does. We are, however, looking at a world in the poems in which concrete action and abstract meaning may come together in one term, that is, a world in which intellectual and sensory perception are on the whole not distinct from one another. ${ }^{282}$ Indeed, it was only the philosophers of the late fifth century who separated the mind from the senses, as Eric A. Havelock has shown. ${ }^{283}$ This is significant for understanding the message contained in the materiality of gifts.

In a series of studies Havelock pursued the connection between ways of speaking and ways of thinking in Greek poetry and philosophy. He argued that the connection between the senses and the mind is characteristic of the distinctive oral literacy of Homeric epic, which, although a result of early literate culture, maintains many features of oral poetry. ${ }^{284}$ One

280. Grimm 1865: 175 .

281. Grimm 1865: 210.

282. Onians ${ }^{3} 1989$; Dihle 1985.

283. Havelock 1986: 115-16.

284. Havelock 1986: 13 and 101. Here, he characterises Greek literature as 'written orality', although he had originally assumed entirely oral composition based on Milman Parry's research. German philologists increasingly emphasise the presence of elements of literary composition in Homeric epic. Cf. Latacz 1989: $83=2001$ : 66; Heubeck 1974: 146-52; Kullmann 1988: 193 with at times vehement rejection of Havelock's previous position. Cf. also West 1990: 33-50. On the transition from orality to literacy see Thomas 1992. 
of these features is a poetics of visualization that is rooted in oral forms of transmitting knowledge. When knowledge is not transmitted through handbooks or other written means, there is a need for special memorizing techniques which are in keeping with oral ways of transmitting knowledge. This means that tradition is not illustrated through ideas and principles but through action. ${ }^{285}$ Such action elucidates the rules of participation in civic life, both in the daily cohabitation of generations and in ritual actions. In poetic retellings of series of events this process of learning through participation is reenacted. Visuality and a focus on individual personalities are both key characteristics of early written as much as of oral poetry.

The German philologist Horst Wenzel applied Havelock's ideas to his analysis of medieval poetry, and in doing so he paid special attention to strategies of visualization. Wherever writing plays a secondary role in the transmission of knowledge, so Wenzel argues, there is a dominant focus on eyes, ears, gestures, facial expression, dress and bodily presentation, and the placement of people in space. According to Wenzel, the collective traditions of preliterary communities, and their entire social order, are visible 'in the organisation of settlements, houses, paths, and clothing, and especially in the configurations formed by people. ${ }^{286}$ Wherever poetry has to fulfil its function as the repository of memory, Wenzel suggests, poets need to create mental images that reproduce the bodily perceptions in the world of literature. Narrated events and phenomena need to take concrete form in order to make a strong visual impression and thus be memorable. ${ }^{287}$ According to Wenzel, poets achieve vividness and visuality through a range of aesthetic means: a language rich in metaphor and allegory, vivid images, emphasis laid on gesture, bearing, and the dress of characters. ${ }^{288}$

For the present question, such a poetics of visualization is not without importance. In order to fulfil their memorializing function, poetically produced worlds of imagery must be distinguished by a clear reference to lived experience. Although Albin Lesky claimed that Homeric similes open a window onto the world outside the epic, ${ }^{289}$ it seems, in fact, that connection

\section{Havelock 1986: 15 .}

286. Wenzel 1994: 421.

287. Wenzel 1994: 422.

288. Wenzel 1994: 10 and 340.

289. Lesky 1971: 85: 'Hier öffnet der Dichter die Grenzen der Heroenwelt und läßt die Fülle des Daseins ein, in dem er selber lebt.' Lonsdale 1990: 125 discusses how animal similes serve to visualize the emotions of the warrior: 'The vivid depiction of the boar's furor in the simile is then metaphorically transferred back to the 
to the real world is a characteristic of epic poetry itself. The representation of a heightened, heroic reality must be recognisable in such a way as to enable participation through the interpretation of the poetic images, and to allow an audience to acquire knowledge from these images. When the scholiasts began their work on the exegesis and interpretation of the epics, they needed to renew and reestablish those references to the lived world that had been guaranteed by the participation of the original audiences. ${ }^{290}$

If the epics belong to a world in which social order is visualized, then it makes sense that this order should be recognisable in the material world represented in the poems. This has long been proven for individual objects, such as the shield of Achilles, which contains a pictorial representation of the entire cosmos. ${ }^{291}$ The same could be done for other objects that as gifts in social communication have significant memorial functions. Amongst them are textile gifts whose symbolic value is known to us from other societies. ${ }^{292}$ Ioanna Papadopoulou-Belmedhi has shown the central role played by Penelope's shroud in the poetics of the Odyssey by drawing out the symmetries between the trick of the weaving and the poet's own ambiguities. ${ }^{293}$ Material signs and poetic images may not be repositories of memory like the epic itself, but they do serve as thinking aids to memorise specific circumstances. ${ }^{294}$ For this reason it is such images that provide a key to the world of the epic and its values. As we will see, there are certain terms used for gifts in which it is possible to find concrete manifestations of that world and its materiality. This is

human counterpart in the narrative in such a way as to exhort him to unleash his anger against his opponent' (125). On similes in the Iliad see now Ready 2011. On similes of weaving see Bergren 1980; 2008; Clayton 2004.

290. Theagenes is said to have been the founder of the tradition of Homeric commentary. The development is discussed by Svenbro 1976: 108-20. See also Rösler 1980: 283-319; Pöhlmann 1990: 11-17; Feeney 1991: 5-56. For further arguments that an epic poet has to take 'his inspiration from the contemporary world' see Crielaard 2002: 242.

291. Cf. e.g. Stanley 1993 who analyses correspondences between narrative structure in the epic poems and the pictorial representations of the cosmos. Cf. also Becker 1995.

292. See Weiner 1976; 1989 (cf. ch. 1.3); Wunder 1994; Kahn-Majlis 1991; Slanicka 2002.

293. Papadopoulou-Belmehdi 1994. Cf. also Winkler 1990: 129-61. See now Canevaro 2018.

294. Wenzel 1994: 65-66 with respect to medieval memory signs. I will return to this in ch. 4.1. 
especially true of the term charis because it denotes a gift of thanks but also in its more abstract meaning suggests the grace or radiance that emanates from a person. Since this abstract meaning draws on the effect created by crafted images, it also becomes a metaphor of the power of visualization that is connected to poetry itself. ${ }^{295}$

My primary method is entirely text-based and focussed on determining the material significance of terms for gifts as they occur in the epics. The selection of terms is determined by the research questions set out above. The starting point is an examination of the term xeinion, used for guestgifts thought to support the forging of political alliances. Along with this, we will consider other terms sometimes used as synonyms, such as the general term for a gift, dōron, as well as the terms dosis and dotinē. The analysis of the concept of charis, which occurs in the context of every type of relationship, allows us an insight into Homeric society's internal structures of exchange. The problem of the nature of Homeric rulership, outlined above, is illuminated through examination of the terms used for gifts of honour, geras and time. These play an important role in the relationships between Homeric leaders and collectives such as the army or the entire demos. In addition, in discussing the trading terms prēxis, chreios, amoibē, kerdos, and onos, we will consider the economic aspects of rulership, not at least those that are concerned with access to external resources. The growth of communication that can be viewed as a consequence of interest in these external resources forms the subject of the final part of this investigation through an examination of the symbolic function of the tripod and the emergence of a central location at which the exchange of resources takes place. Thus, we return to the initial question around which the debate about gift-exchange grew: the problem of the emergence of the state and the formation of the polis.

295. For further detail see ch. 3 . 


\section{CHAPTER 2}

\section{Guest-Gifts and Relationships in Homer: Xeinia and Phila Dōra}

$\mathrm{I}$ $\mathrm{n}$ his study on guest-friendship in antiquity, published in 1887 , the Romanist Rudolf von Jhering proposed a utilitarian interpretation of the institution. He illustrated this with a striking contemporary example: 'The anxious care with which he [the guest] was looked after finds its exact ethical parallel in the care with which bathers are looked after in spa-towns, or students at universities. There is the utmost concern for their safety and comfort, they are the darlings of public interest, but the motivation for this is not disinterested benevolence, or sheer love of mankind, but naked egoism. They are looked after because they must be kept satisfied: everyone is aware that if the reputation of the place were to suffer, so would the visitor numbers, and thus everything possible is done to maintain them.. ${ }^{1}$ In von Jhering's view, which was developed in opposition to the ethical idealism that prevailed amongst his philosophical colleagues, it was public interest, and specifically interest in trade, that was responsible for alleviating the stranger's rightlessness through religion and custom. The development of guest-friendship was for von Jhering the beginning of 'international rights in antiquity' and, indeed, of 'civilisation' as a whole, since he takes the concept of guest-friendship to be the origin of sociability. ${ }^{2}$

Almost a century later, in his 1978 essay 'From Xenophobia to Altruism: Homeric and Roman Hospitality', Ladislaus J. Bolchazy takes the opposite perspective to von Jhering. For Bolchazy, progress is not to be found in the stranger's change of status from rightlessness to right, or in the pursuit of the selfish interest of the community (rather than the individual). According to Bolchazy, progress is made when magico-religious xenophobia is overcome and its place is taken by forms of guest-friendship which are at first self-interested and contractual and later become altruistic. In the

1. Von Jhering 1887: 380. Cf. also Finley 1967: 103-5, where fear of the stranger goes hand in hand with his rightlessness.

2. Von Jhering 1887: 357-58, 374, 381. 
world of Odysseus, he sees just this stage of altruistically motivated hospitality: 'In the Odyssey, to conclude, we find that hospitable treatment of strangers is a distinguishing mark of civilization. To offer hospitality in all its refined aspects is the right and the wise thing to do. A stranger is to be treated like a brother. In Homeric culture we see, in other words, the conceptualization and the practice of altruistic hospitality'. ${ }^{3}$ In this case it is not the stranger who initially needs to be fearful because of his powerlessness, as is the case in von Jhering's concept. It is society itself which confronts the stranger with irrational fear and rejection. ${ }^{4}$ Progress is not found in the rule of law or in the realisation of economic interest but in ethics.

With these two positions the entire spectrum of the debate on Homeric guest-friendship is sketched out: self-interest against altruism, economics against ethics. Although von Jhering's position is focussed on the law, he did not, unlike his colleague and contemporary Theodor Mommsen, ${ }^{5}$ consider guest-friendship to be purely a judicial matter but thought of it instead as a social institution. We can thus see in von Jhering the beginning of the interpretation of guest-friendship as a mechanism for social integration. ${ }^{6}$ While von Jhering's legal argument is linked with one of economic purpose, his followers see social alliance itself as the main objective and do not pursue the issue of economic advantage. So Évelyne Scheid-Tissinier is able to conclude in her study on the use of the gift in Homer that the gift of guest-friendship 'normally sanctions the establishment of a bond of alliance or friendship. 7 Emphasizing the contractual aspect of guestfriendship, Scheid-Tissinier, like von Jhering and Mommsen, the nineteenth-century law historians, stresses the necessity of reciprocity while keeping ethics and altruism at arm's length. ${ }^{8}$ Bolchazy, on the other hand, looks back to the ethical position and places altruism above reciprocity.

In more recent conceptualisations, the stranger is no longer viewed, as in the nineteenth century, as the weaker party to whom security and rights

3. Bolchazy 1978: 63. Donlan 1982 combines the idea of altruism with the concept of 'balanced reciprocity'.

4. See also Pitt-Rivers 1977: 95-112. Here too emphasis is put on the perceived menace of the stranger in archaic societies, often ascribed to the stranger's possession of occult powers.

5. Mommsen 1859: 334 .

6. See ch. 1.2, p. 31-34.

7. Scheid-Tissinier 1994: 158 (sanctionne normalement l'instauration d'un lien d'alliance ou d'amitié).

8. Mommsen 1859: 330; von Jhering 1887: 370. 
are granted because he proves useful. Instead, he is viewed as one who represents a fundamental threat. To overcome this threat through altruistic behaviour is a mark of progress. In this view, von Jhering's contemporary example of purpose-driven motivation is no longer applicable, not because there is no experience of strangeness but because strangeness is everywhere. What remains is the appeal to individual conscience, while the nineteenth-century legal scholar's view still testifies to the self-awareness of a society that grants rights.

This is not the place for pursuing further the tendencies towards presentism that are part of such changes in perspective; instead we want to map the coordinates for an examination of ancient hospitality. Did Homeric guest-friendship possess the economic purpose suggested by the nineteenth-century legal scholar ${ }^{9}$ Or was political alliance the driving factor in guest-friendship, as is now argued with more frequency? And is guest-friendship an expression of progress as the rightlessness of the stranger is gradually eliminated, while irrational xenophobia changes into welcoming hospitality and into a more generally philanthropic attitude?

Viewed from the perspective of the material content of gifts, it becomes quite clear that Homeric guest-friendship must be multifunctional. Gifts in epic poetry can be natural produce or manufactured goods such as foodstuffs, weapons, metal vessels, and textiles. The technical term for them

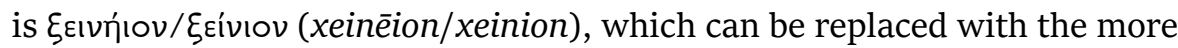
general term for a gift $\delta \tilde{\omega} \rho \circ v$ (dōron) when the gifts are household treas-

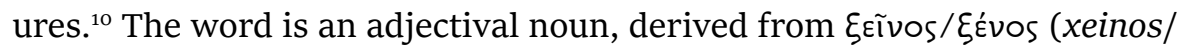
xenos), and it is mostly used in the plural. The term xeinos is ambiguous and can describe a stranger, a guest, or a host. ${ }^{11}$ The host can be described

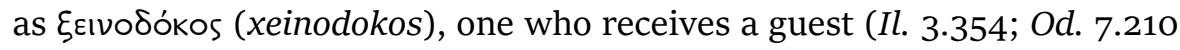

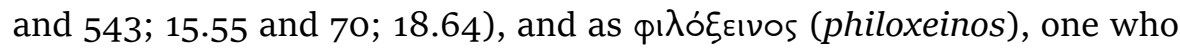
observes the divine rule of hospitality in caring for strangers (Od. 6.121 and

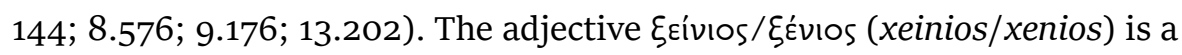

9. Von Jhering (1887: 387) did, however, contradict his main position by ascribing to Greek hospitality a more convivial and friendly character, distinguishing it from the more commercial guest-friendships of the Phoenicians.

10. On the terminology of guest-friendship see Stählin 1954: 1-36; Hiltbrunner et al. 1972; Scheid-Tissinier 1994: 115-76.

11. See Scheid-Tissinier 1994: 115-29. On the ambiguity of xeinos cf. Gauthier 1972 and van Wees 1992: 228-37, who speaks of the hospitality-racket. See now Tracy 2014. She operates with the game theory, which is based on the idea of egoistic exchange, and argues that self-interest of strangers does not contradict cooperative behaviour. 
frequent epithet for Zeus, underlining his role as the protector of strangers (Il. 13.625; Od. 9.271; 14.284 and 389). ${ }^{12}$ Several times a table prepared for a stranger is described as xeinios (Od. 14.148; 17.155; 20.230). ${ }^{13}$ The verbs

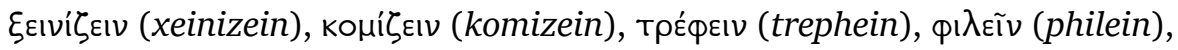
and Tíєıv (tiein) are used to describe the range of activities involved in the process of receiving a guest: the serving of food, the provision of clothing, bath and bed, the reception into the domestic community, the giving of gifts. ${ }^{14}$ The handing over of xeinia is expressed with the verbs tí $\eta_{\mu \mathrm{I}} /$

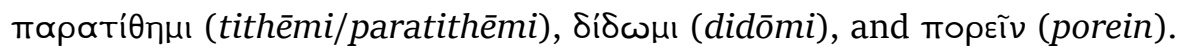

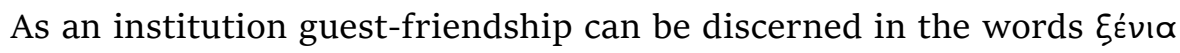

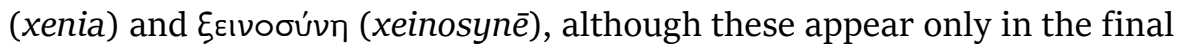
books of the Odyssey (Od. 21.35; 24.286 and 314). The usual term for this relationship in epic poetry is фı $\lambda$ ótns (philotēs), which expresses a sense of belonging to a community based on ritualised guest-friendship, and also on the giving of gifts that serve to strengthen the bond between guest and host (Il. 3.354; Od. 15.55). ${ }^{15}$

The structure of the present examination of Homeric guest-friendship is based on the range of material contents of xeinia (natural goods, weaponry, and metal or textile goods), which represents the types of relationships characterised by exchange and alliance. We begin with the natural xeinia and in this context discuss the exchange-relationship between the herdsmen's community and the household of a basileus, and the question of the stranger's rightlessness. Next we find that when xeinion takes the form of a weapon, military alliance and the question of gift-giving as a form of political treaty are addressed. Finally, when xeinia are treasures of metal and cloth, the issues at hand are bonds between individual households and internal domestic structures.

\subsection{Xeinion and dōtinē: The hospitality of the herdsmen Eumaeus and Polyphemus}

Xeinion is that which is due to the stranger, and in most cases in epic poetry it takes the form of food and drink. The word is used with this meaning in classical literature too, although here xeinia may also be

12. For further examples see Scheid-Tissinier 1994: 136-43.

13. Ibid.

14. On xeinizein and philein cf. Scheid-Tissinier 1994: 129-35.

15. Cf. Konstan 1997: 33-37. 
tribute or levies in the form of natural produce. ${ }^{16}$ There is a hint of this double meaning in the epic, albeit in a different context, where xeinion does not only occur when meeting with strangers but also as part of the formalised exchange of goods between the world of the herdsmen and the household of a basileus.

In both the Iliad and Odyssey, xeinia can describe a meal given to gods or humans. In the divine sphere, this meal will be nectar and ambrosia, while for humans it will be a sacrificial or otherwise carnivorous feast to which strangers are invited. The hosts therefore tend to be those persons who have access to livestock, both owners and herdsmen. The guests include envoys seeking military assistance, friends and relatives of guestfriends looking for support, and also the (high-ranking) visitors of herdsmen, most importantly Odysseus in disguise.

In the Iliad we have two instances of xeinion as a feast granted to strangers. The first, remembered by Nestor in conversation with Patroclus, is Nestor's visit to Peleus in search of support and troops for the campaign against Troy-the occasion of his, Nestor's, first meeting with Achilles. He remembers that Achilles led him straight into the courtyard (aulē) and placed before him the xeinia due to the stranger according to

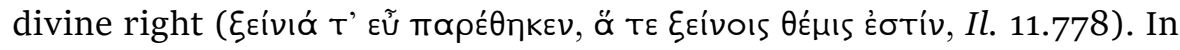

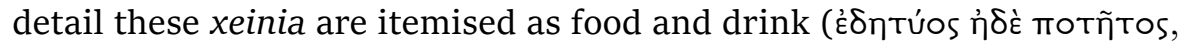
Il. 11.780), and specifically as wine and a portion of sacrificial beef (Il. 11.773-75).

While this example shows a guest participating at a sacrificial feast that would have taken place in any case, the other instance is one where the guest is treated to exclusive hospitality. When Thetis arrives to visit Hephaestus to place her order for new weapons for her son Achilles, Charis asks her divine visitor to follow her so that she may place the xeinia be-

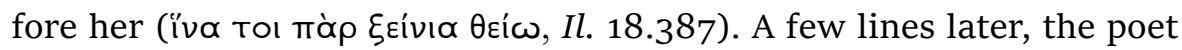
has Hephaestus repeat this invitation and request that Charis prepare the

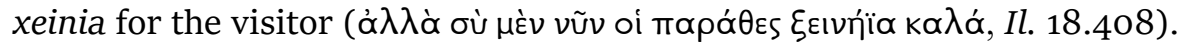
The verb used is tithemi (to place) and then paratithēmi (to place beside), both used multiple times in the Odyssey for the serving of dishes by

16. Plato describes fruit picked at the roadside by travelling strangers as xeinia (Laws 845a). Herodotus (7.29) and Xenophon (Hell. 1.1.9) use the term to describe natural produce provided for travelling armies. Rich Athenians such as Miltiades are said by Herodotus (6.35) to keep an open house, offering shelter (katagōgē) and hospitality (xeinia) to strangers. The construction of lodges for strangers seems to be a development of Late Antiquity. See Hiltbrunner 2005; Constable 2003. 
the female housekeeper (tamiē). ${ }^{17}$ There can be no doubt then that xeinia tithèmi/paratithèmi must be taken as the providing of a meal, even in instances where the precise content of xeinia is not made explicit. ${ }^{18}$

In the Odyssey too, the presentation of xeinia as food and drink takes place both in the human and in the divine sphere. In Book 4, when Telemachus arrives with Peisistratus, the son of Nestor, to visit Helen and Menelaus in Sparta, Eteoneus, a retainer ( $\theta \varepsilon \rho \alpha \dot{\pi} \pi \omega \nu)$ of Menelaus is doubtful about whether to admit the recent arrivals. Menelaus reminds him of

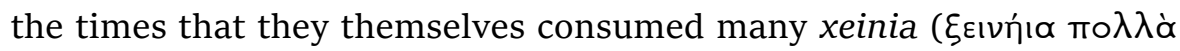
фayóvtes, Od. 4.33) and asks the servant to lead the two strangers to feast

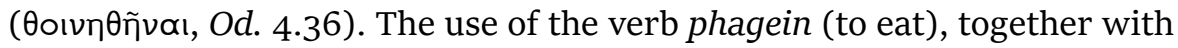
the invitation to the thoine (feast), leave no doubt that xeinia in this case is the meal offered to the strangers.

Such a meaning of xeinia can also be inferred from the nymph Calypso's invitation to the divine messenger Hermes to follow her so that she may

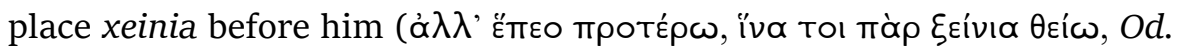
5.91). Indeed, the goddess fetches a table and serves the food of the immortals, nectar and ambrosia (Od. 5.92-93). A similar turn of phrase is used to describe Telemachus's and Peisistratus's stay at the home of Diocles on the way from Pylos to Sparta and on the return journey. Here, shelter for the night is granted as well as xeinia: 'There they spent the night, and he

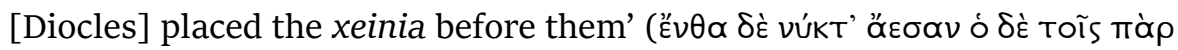

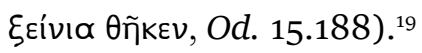

We can also conclude indirectly that xeinia involved a meal from the remark made by the swineherd Eumaeus to his master Odysseus, who is disguised as a beggar. When Odysseus asks to be thrown off a cliff should his prediction of the return of the missing master (anax) not come true, Eumaeus answers:

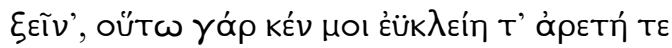

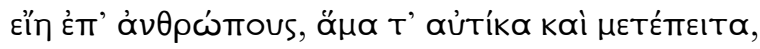

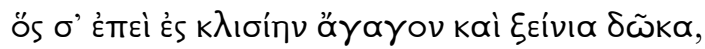

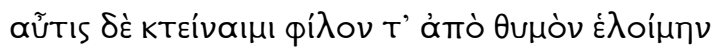

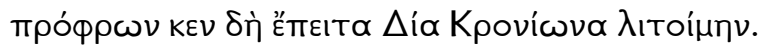

17. Compare, e.g.: Od. 10.371-72; 4.57-58; 4.65-66; $3.40=20.260 ; 14.76 ; 17.258$; 20.28-29. Herodotus uses a similar expression for the hospitality offered to Spar-

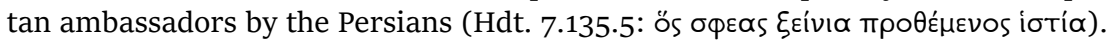

18. See Scheid-Tissinier 1994: 139. On xeinia as meaning food and drink see also Bolkestein 1939: 219 and 231.

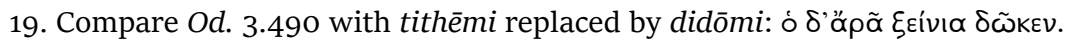


vบ̃v $\delta$ '

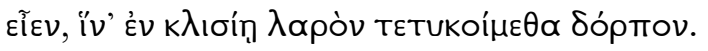

Stranger (xeinos), that would earn me a fine reputation for virtue amongst men, both right now and hereafter, if I brought you into my hut (klisia), and provided hospitality (xeinia dōka), and then I killed you and seized your dear life from you. And then I would be happy to go and pray to Zeus, the son of Cronos. But it is supper-time now, and my companions should be here any moment so that we may get a tasty meal ready in the hut (Od. 14.404-8).

The swineherd then gives his disguised master the prime cut of a haunch of the slaughtered boar to honour him (Yépaıpev, Od. 14.437-38) and serves him bread and wine (Od. 14.447-49). The context in which the phrase xeinia didōmi is placed leaves little doubt as to the interpretation of xeinia as a meal served to the guest. Eumaeus's response to Odysseus's suggestion also makes it clear that the sharing of a meal implies a bond of protection which is subject to public scrutiny, and that Eumaeus would be putting his reputation at risk were he to do any harm to the stranger. ${ }^{20}$ The underlying relationship between Eumaeus and Odysseus as master and servant adds a further dimension to this guest-friendship, which is alluded to with the characterisation of Odysseus as master, anax, and the designation of his portion of meat as that given to a guest of honour. In this scene a hierarchically structured bond such as the one between a warlord and his warriors, or a landowner and his herdsmen, is alluded to, which indirectly also applies to Odysseus's visit to the Cyclops Polyphemus. ${ }^{21}$

In the Polyphemus episode we find the notion of xeinia as a meal offered to strangers turned on its head. Upon arrival at Polyphemus's cave, Odysseus's companions suggest that they should take away the cheese that is stored there along with the lambs and kids. Odysseus rejects this proposal because he is curious to know whether the Cyclops would offer xeinia

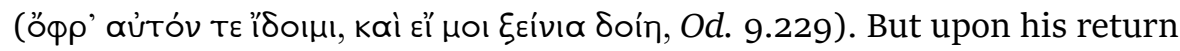
to the cave, Polyphemus refuses Odysseus's request for xeinion, or any

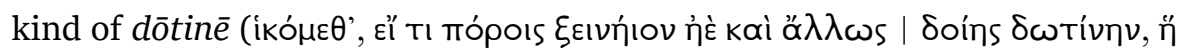

20. On guest-friendship as divine law see Flückinger-Guggenheim 1984; ScheidTissinier 1994: 143-48. Therefore, Eumaeus is considered the ideal host. See Newton 2015: 257 with further references.

21. See ch. 4.1. 


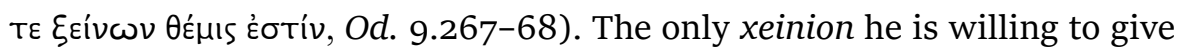
is to grant Odysseus the favour of eating him last (Od. 9.376). Only after he has been blinded by Odysseus does Polyphemus promise xeinia: 'Come here', he invites Odysseus, 'so that I may place the xeinia before you' ( $\dot{\alpha} \lambda \lambda$ '

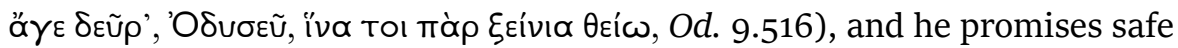
passage too (Od. 9.517). The formulaic turn of phrase is identical to that used when Calypso receives her visit from Hermes cited above (Od. 5.92). Polyphemus's refusal of a meal to Odysseus contravenes the laws of hospitality, and this contravention marks the Cyclops out as the incarnation of the wild and uncivilised. ${ }^{22}$ Nonetheless his behaviour as represented in the poem moves within the framework of the logic of hospitality, albeit in an inverted form: he refuses a meal to the stranger, but he makes a meal of the stranger. ${ }^{23}$

This logic of inversion also applies to the case of the Laestrygonians,

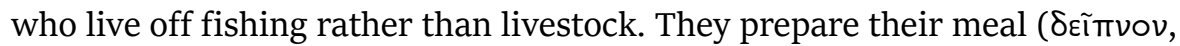
Od. 10.116) from the companions of Odysseus, as the Cyclops does, and they

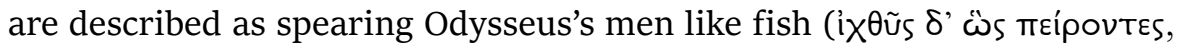
Od. 10.124).

A similarly upside-down sense of xeinion is at play in Ithaca, where the positions of host and guest have become reversed: here the suitors act as hosts to the real master of the house, Odysseus, in his disguise as a beggar. $^{24}$ Just like the Cyclops, they also refuse Odysseus the xeinion that is due to him. When the suitor Ctesippus finally offers a xeinion ( $\dot{\gamma} \gamma \dot{\omega} \delta \tilde{\omega} \xi$ Eiviov, Od. 20.296), this generous offer turns out to be the cow's foot (ßoòs mó $\delta \alpha$ ) he throws at Odysseus's head (Od. 20.299). This guest receives payment in kind for his presumption: the xeinion of the cow's foot is repaid when Odysseus's cowherd pierces Ctesippus's breast with an arrow (ToũTó тo ávтi

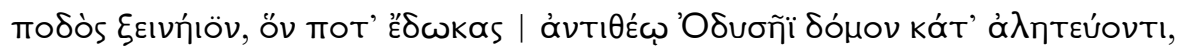

22. See for example: Hiltbrunner 1972: 1078; Scott 1982: 12; Gauthier 1972: 5; Bolkestein 1939: 216; Scheid-Tissinier 1994: 141-42.

23. Compare the argument in Reece 1993: 142 according to whom Polyphemus 'has perverted the normal diction of the hospitality-scene and generally turned the typescene on its head.' Vidal-Naquet 1983: 53-56 similarly categorises the Cyclops and the Laestrygonian episodes as being in line with a model of 'le thème du renversement' (54). Podlecki 1961: 125-33 sees the wordplay with the name outis as part of a logic of inversion. According to him, Odysseus responds to the nongiving of xeinia by being nobody. See also Lavelle 1980-81: 197-99 on ironic use of the word xeinia in the Cyclops episode.

24. See Pitt-Rivers 1977: 112, who draws attention to this role reversal. 
Od. 22.290-91). Just as Polyphemus promises to eat Odysseus last, the cowherd will give death as xeinion to the presumptuous guest. ${ }^{25}$

The game of inversions does not only take place on a linguistic level; it is continued also in the various connections that are drawn between individual scenes. In studies of Homeric guest-friendship, the Polyphemus episode has held a prominent position. Negative characterisation of the $\mathrm{Cy}$ clops accounts for the concept of a primitive magico-religious xenophobia as well as for the assumption of an early stage during which strangers possessed no rights. ${ }^{26}$ Equally, structuralist interpretations of mythology have shown how fruitful comparisons can be made regarding the treatment of strangers in the world of the Cyclops and the world of the heroes. ${ }^{27}$ These comparisons are in no way limited to the general oppositions between nature and culture, or the wild and civilisation, as is often suggested..$^{28}$ The real common denominator in the various scenes of natural xeinia granted are not abstract values but rather concrete problems of exchange which exist between the pastoral world and the household of a basileus.

It is striking that natural xeinia are mostly granted in places associated with herdsmen. So, when Eumaeus, Odysseus's swineherd, lets his master participate in the herdsmen's supper and promises to provide xeinia, they are at a herdsman's station, stathmos, or hut, klisia (Od. 14.381 and 404). The upside-down game of xeinia between Polyphemus and Odysseus takes place in a grotto (speos) or cave (atron) used as shelter (aulē) for goats and sheep in the mountains (Od. 9.462 and 216-18). Calypso, too, places her xeinia for Hermes in a remote island grotto surrounded by flower-meadows (Od. 5.57 and 72). As a nymph she belongs, like Hermes the divine protector of herds, to the pastoral world; but unlike Eumaeus and Polyphemus she also has at her disposal the sorts of goods usually only available at the palaces of wealthy men: garments and textiles for bedding. ${ }^{29}$ On the other hand, there are herd-owners, such as Peleus who looks after his guest in just such a courtyard (aulē) as is used at Eumaeus's farm as shelter for the

25. Polyphemus's 'raw eating' also belongs in this context. It is to be understood as a metaphor of revenge for death, and as anticipation of Odysseus's actions towards the suitors who consume his goods. In Iliad 24 Hecuba wishes to avenge her son by eating the liver of the man who killed him (Il. 24.212-14). See ch. 4.4.

26. Bolchazy 1978: 46-47; von Jhering 1887: 367; Bolkestein 1939: 216; Köstler 1950: 17-20.

27. Vidal-Naquet 1983: 39-68 (Valeurs religieuses et mythiques de la terre et du sacrifice dans l'Odyssée).

28. Calame 1976: 311-28; O'Sullivan 1990: 7-17.

29. Cf. ch. 2.3. 
animals (Il. 11.774). The only time an actual house (dōma) is mentioned is in the case of Diocles of Pherai, who provides xeinia for Telemachus and Peisistratus (Od. 3.488). ${ }^{30}$ It is therefore possible to conclude that where the offering of natural xeinia is described we are dealing with a specifically pastoral form of hospitality, especially as whenever xeinia take the form of manufactured goods such as textiles or metal objects in the epic poem, the hospitality in question is offered by high-ranking basileees. ${ }^{31}$

Polyphemus's negative depiction notwithstanding, there is an ancient tradition of pastoral hospitality. Vidal-Naquet has drawn attention to the fact that Homer knows of a kindly species of Cyclops, 'the abioi (without food), who milk mares and live on milk and are "the most just of humans" (Il. 13.5-6)'. ${ }^{2}$ They also feature in a fragment from Aeschylus's drama Prometheus Unbound, where they are called the Gabioi (Prometheus Unbound fr. 196). Here they are referred to as hospitable as well as just and are granted nourishment from the earth without knowledge of agriculture. ${ }^{33}$ Hellenistic poetry especially features hospitable herdsmen. ${ }^{34}$

Eumaeus represents the hospitable herdsman who shares all his available resources with the stranger. The Cyclops, who disregards or inverts the norms of hospitality, is in a sense antithetical to Eumaeus while also resembling him. While Polyphemus is autonomous, Eumaeus's position is part of a herd-owner's household. Eumaeus had originally been procured by Laërtes for an ōnos (Od. 15.483; 15.452-53) ${ }^{35}$ and was then sent by

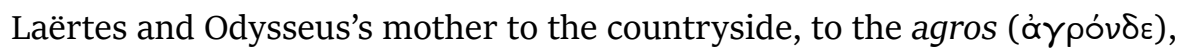
as a youth. They provided him with a cloak, chlaina, and a tunic, chitōn, and

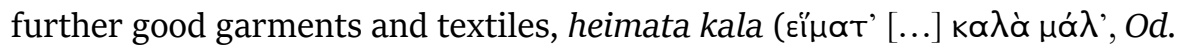
15.370). Eumaeus complains, however, that this provision with textiles is no longer possible since Penelope's suitors at Odysseus's house are eating up all the cattle, pigs, goats, and lambs. His work ("̌pyov) brings in enough to eat and drink, which he is able to share with strangers (Od. 15.372-73).

30. Compare the reference to the hospitality of Axylos whose house was by the road-

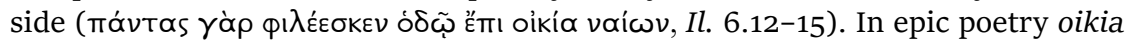
can refer to the herdsman's station, the animal shelter, or the house itself. See Knox 1970: 117-20.

31. See in more detail ch. 2.3.

32. Vidal-Naquet 1986: 22 (= 1983: 52: 'Homère [...] connaît en quelque sorte de bons Cyclopes, les Abioi (sans nourriture), trayeurs de juments galactophages, qui sont

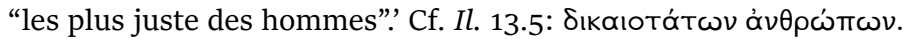

33. Vidal-Naquet 1983: 52.

34. See Hiltbrunner 1972: 1083.

35. Cf. ch. 5.2. 
But from the mistress, despoina, nothing is forthcoming:

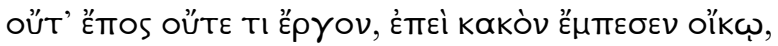

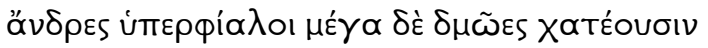

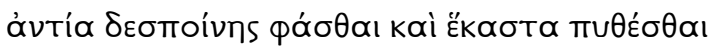

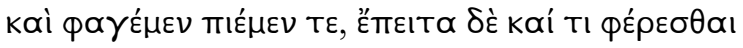

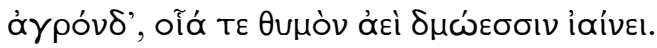

There is no getting a kind word or deed [...], for the house has fallen into the hands of wicked people. Servants want sometimes to see their mistress and have a talk with her; they like to have something to eat and drink at the house, and something too to take back with them into the country (agros). This is what will keep servants' hearts (thumos) warm (Od. 15.374-79, tr. Butler, modified).

This 'something' that keeps 'servants' thumos warm' could be agricultural goods such as grain or wine, or textile goods such as those the young Eumaeus received from Odysseus's mother when the mechanism of exchange between the herdsmen's station and the main household was still functional. Now the flow of goods between the herdsmen's station in the countryside (agros) and the herd-owner's household, represented by the despoina, has become one-sided. Eumaeus sends animals for slaughter but receives nothing himself by way of food and drink or those other items that warm the thumos.

While at Ithaca the breakdown of the exchange is caused by the despoina's problems in the household; in the case of the Cyclopes, it is the herdsmen who are not fulfilling their side of the relationship. The Cyclopes live by themselves without exchange amongst one another and lacking rules that govern relationships beyond individual households. As Odysseus tells the Phaeacians:

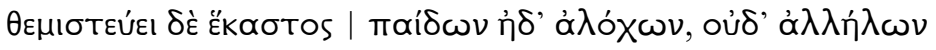

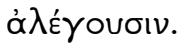

Each makes the rules for his children and his wife, but they do not care for each other (Od. 9.114-15) 
Polyphemus even lives without a wife and children (resembling Eumaeus in this aspect). This has been taken as a sign of his uncivilised character, ${ }^{36}$ but it is well suited to the narrative context. When Odysseus brings the dark sweet wine into Polyphemus's cave, he is inverting the logic of guest-friendship, but his action is in keeping with the logic of exchange between the herdsmen's station and the farmer's household in bringing goods produced in the home to the herdsman's shelter. Odysseus had received the wine from Maron (Od. 9.196-215), ${ }^{37}$ a priest of Apollo, along with other goods as a form of ransom for protecting the priest (Od. 9.197-200)..$^{38}$ Polyphemus consumes the drink which is unknown to him (but significantly not unknown to the other Cyclopes $^{39}$ ), but he offers none of his own goods (milk, cheese, and meat) in return.

There are significant points of contact between the depiction of Polyphemus and Odysseus's stay with Calypso. As a nymph she belongs, just like the Cyclops, to the pastoral world. Nymphs are guarding the cattle of Helios when Odysseus's companions commit their fatal mistake by slaughtering the holy animals (Od. 12.134-36). There is also an uninhabited island near the dwellings of the Cyclopes, where nymphs are hunting goats (Od. 9.15456). At the same time, however, Calypso also represents that part of the exchange-relationship between farmer's household and herdsmen's station occupied by Penelope, the despoina, in the Eumaeus episode (Od. 14.127 and 377).$^{\circ}$ This becomes clear when Hermes arrives and finds her singing and working at the loom (Od. 5.61-62). As she does so, she produces just those goods which Eumaeus had received from Odysseus's mother, and which presumably are those goods that warm the hearts of the servants (dmōes), namely woven cloths and garments. She compares herself with Penelope, telling Odysseus, whom she wishes to keep as her own bed-fellow

36. O’Sullivan 1990: 9.

37. This state of affairs irritates those who view the Polyphemus episode as conforming to a universal narrative pattern of the hero's return, from which, however, the giving of wine is omitted. Compare, e.g., Page 1955: 7-8; Schein 1970: 78. According to Calame 1976: 328 , from a structuralist point of view, the wine episode radicalises the confrontation between 'sauvagerie et civilisation'.

38. Odysseus is represented as more generous than Agamemnon, who denies Chryses, another priest of Apollo, the return of his daughter in return for apoina. See Nestle 1942: 60.

39. Od. 9.109-10. According to Kirk 1970: 169, this indicates that the other Cyclopes possess a modicum of civilisation.

40. On the parallels between Calypso and Penelope, see Papadopoulou-Belmehdi 1994: 105-8. Belmehdi sees the similarity between Penelope and Calypso in the status of the nymph as a much-desired bride. 
(Od. 5.120), that 'surely not inferior to her do I declare myself to be either in form or stature' (Od. 5.211-12). Here, too, the flow of goods is one-sided. Calypso provides food and drink for Odysseus (Od. 5.68-69; 196-97; 265), gives him clothing and wine for the journey, and makes a sail for the raft he builds for himself (Od. 5.165-67; 258-59; 264-67). Odysseus himself is damned to inaction during his stay with Calypso, spending his days sitting by the shore and grieving. ${ }^{41}$ In the meantime, Penelope, by contrast, is not keeping up with her obligation of weaving and does not complete the cloth on her loom. ${ }^{42}$

The disturbed flow of goods between the world of the herdsmen and the farming household corresponds to a double break of the rules of guestfriendship caused by the shepherd Polyphemus and, in the house of Odysseus, by the suitors. They not only refuse xeinion, in this case participation in their meals, to the disguised Odysseus, but they also plunder their host's house. The suitors' consumption of Odysseus's livelihood (biotos) and goods (ktēmata) without reimbursement or compensation is a cause of constant complaint for the loyal Eumaeus as well as for Telemachus and Penelope. ${ }^{43}$

The comparison will allow us to understand the meaning of another term: dōtinē. The suitors' excessive consumption and Polyphemus's inhospitable behaviour stand in direct opposition to the hospitable Eumaeus and the welcoming Phaeacians. Like the Cyclops's inhospitality, their hospitality is played out in a mythic landscape so that it, like Polyphemus's behaviour, functions as an inverted image. While Eumaeus offers natural xeinia to the disguised Odysseus, the Phaeacians give him xeinia in the form of textile and metal treasures; they also grant him the dōtine which Odysseus had vainly asked the Cyclops for (Od. 9.268). The Phaeacians thus afford Odysseus with the honours promised in Agamemnon's conciliatory

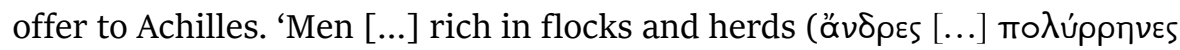

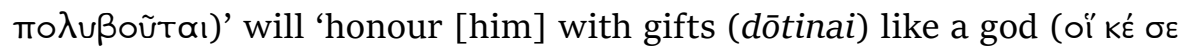

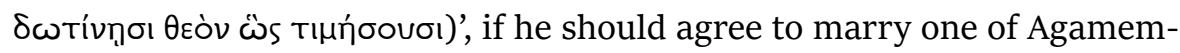
non's daughters (Il. 9.296-97). Interpreted as extraordinary devotion by

41. On the grief of Odysseus, which is equated to death, see Vernant 1982: 15. Crane 1988: 20 draws a parallel between Odysseus's stay with Calypso and Persephone's stay in Hades. See also ch. 3.3.

42. See in more detail ch. 4.2.

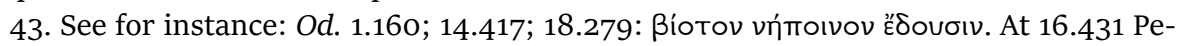

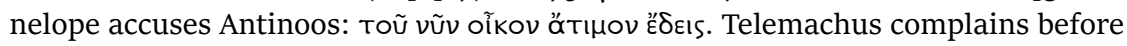

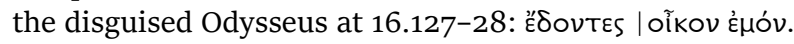


the community to kingly households, ${ }^{44}$ or as special gifts associated with obligation or contract, ${ }^{45}$ it appears that these honours are, in the epics, specific benefits or services afforded by people who are in a position to grant safe passage to strangers. When the blinded Polyphemus promises to provide the benefits he had previously refused, he does not offer dōtinē alongside xeinion but safe passage or conduct (pompe)). This is also granted to Odysseus by Alcinous when he declares: 'I shall complete our dōtinē'

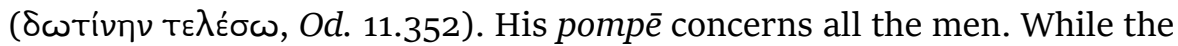
Phaeacians accomplish the task of pompe with their ships, it can be assumed that the herdsmen like Polyphemus will make use of their animals for the purpose. More concretely this will mean, in the case of Odysseus, the transport of the xeinia given to him by the Phaeacians; in Achilles's case it means the themistes who are proposed to him so that he may carry out his judiciary tasks. ${ }^{46}$

The episodes concerned with hospitality granted to Odysseus are not solely interested in the treatment of the stranger but also, and indeed more so, with the cessation of the orderly exchange between domestic production and the world of the herdsmen, that is between, on the one hand, grain and bread, wine, and cloth, and on the other hand the sheep and goats and their products such as milk, cheese, and wool. Since Odysseus is a stranger, xeinos, and master of his herdsmen, anax, at the same time, the question arises whether the natural xeinia he is given should really be seen as gifts for a guest. They might equally be the goods given by economically independent herdsmen to strangers in exchange for other goods. This might also explain why Polyphemus is asked for both xeinia and dōtinē, even though dōtinē is usually only afforded by owners of livestock or ships in epic and has therefore been interpreted above as safe passage. Unfortunately, the epic is extremely unclear in this respect.

Homeric epic knows of three different types of herdsmen. First there are sons, such as the sons of Priam, who take herds out to pasture in the valleys of Ida (Il. 11.104-6). Second there is the hired herdsman, who gives his services for a certain amount of time and in exchange for a

44. See the argumentation of Andreades 1931: 19; Bolkestein 1939: 221.

45. So Benveniste 1969: I, 69: 'C'est pas seulement un présent, un don désinteressé; c'est un don en tant que prestation contractuelle, imposée par les obligations d'un pacte, d'une alliance, d'une amitié, d'une hospitalité: obligation du xeinos (de l'hôte), des sujets envers le roi ou le dieu, ou encore prestation impliquée par une alliance'. Scheid-Tissinier 1994: 225-26 also stresses the obligatory character.

46. Posthomeric usage also fits with this interpretation. So, in Herodotus (6.89) dotine means the fee charged for ships loaned to strangers. See in more detail ch. 4.1. 


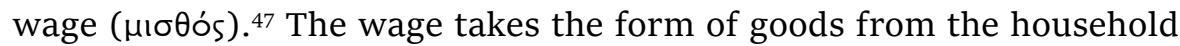
of the herd-owner; in one case these are specified as the sorts of goods Eumaeus may expect to receive from Odysseus's household in exchange

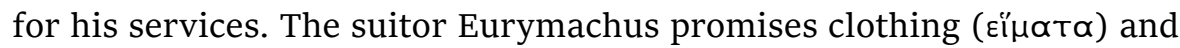
bread or grain (бĩtov) for the work on the agros in the eschatia, to the

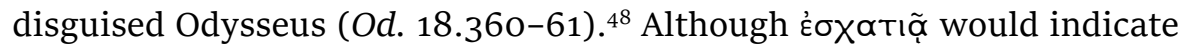
that the work should be pastoral, since this is normally the location for taking animals out to graze, the work is actually to gather stones and plant trees (Od. 18.357-59). ${ }^{49} \mathrm{~A}$ third type of herdsman has a permanent and open-ended exchange-relationship with the herd-owner, as is the case for Eumaeus and Odysseus's other herdsmen. This type of herdsman is socially dependent but economically autonomous and is tied into a reciprocal exchange-relationship between the herding station and the herd-owner's household, where goods of agriculture and craftsmanship are produced. These herdsmen may have permanent dwellings on the borders of a region or they may, like Philoetius, Odysseus's cattle-herdsman, travel through strange lands (Od. 14.96-104; 20.209-20). The reward for their labour is described in one instance with the same word as that for the reward given for a warrior's labour, namely ká $\mu$ atos (kamatos), ${ }^{50}$ while the profit earned by herd-owners who leave their herds to in-

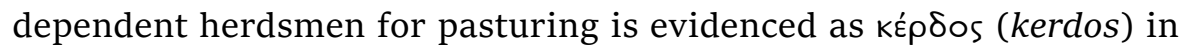
the Homeric hymns. ${ }^{51}$ Given his location some way removed from the dwellings of the other Cyclopes, Polyphemus is closest to this third type of herdsman, who is represented by Eumaeus. Polyphemus's situation also approximates that at Ithaca, where animals are kept for both the

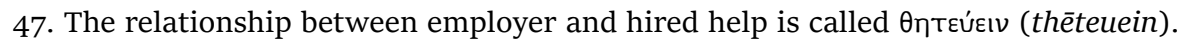
See Poseidon, reminding Apollo of their time serving the Trojan leader Laomedon, Apollo as shepherd and Poseidon building the wall: 'we served the lordly Laome-

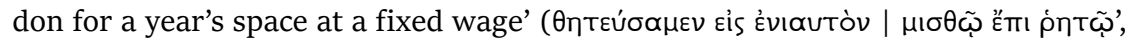
Il. 21.444-45). See also the double misthos that a sleepless man is able to earn in the land of the Laestrygonians, 'one by herding cattle, and one by pasturing white sheep; for the paths of the night and of the day are close together' (Od. 10.84-86). On the seasonal aspects of such work see Walcot 1970: 37-44.

48. A misthos is also given to warriors, such as Dolon who keeps look-out for Hector

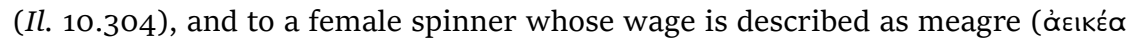

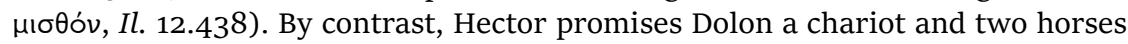
as his wage. The watchman hired by Aegisthus to look out for Agamemnon's arrival receives an especially generous misthos of two talents of gold (Od. 4.525-26). 49. On eschatia as pastureland see Audring 1989.

50. Od. 14.417. In more detail ch. 3.2.

51. For evidence see ch. 5.2. 
consumption of meat ${ }^{52}$ and the production of wool. ${ }^{53}$ Thus Polyphemus with his animals represents a multiplicity of possible preferences for breeding livestock, which a single herdsman would not in fact be able to

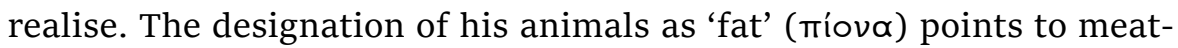
production (Od. 9.217 and 315). On the other hand, the animals are also

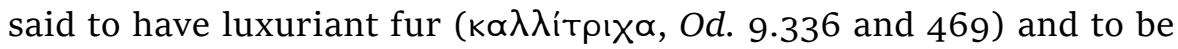
thick-fleeced ( $\delta \alpha \sigma u ́ \mu \alpha \lambda \lambda \circ$ o, Od. 9.426), which would indicate an interest in the production of wool. The male gender of the sheep would also point

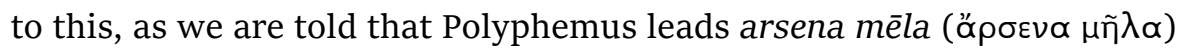
to pasture in the morning (Od. 9.438). Male, especially castrated, sheep are thought to have thicker fur than ewes. ${ }^{54}$ But Polyphemus's animals are milked in the evening (Od. 9.244 and 219), which would indicate a different composition of the herd and would lead us to expect the mention of ewes rather than rams. ${ }^{55}$ With this lack of clarity the circumstances in the world of the Cyclopes are almost identical to those in Odysseus's world. While at Ithaca the multitude of herdsmen associated with the household makes the existence of a variety of herds and flocks feasible and realistic; the depiction of Polyphemus's circumstances with its contradictions evokes a utopian and hostile imaginary.

Were we to view the behaviours of Polyphemus and Eumaeus as expressing a fundamental opposition between xenophobia and hospitality, between savagery and civilisation, this would mean falling into the trap of the inversions created by the poet to indicate the cessation of orderly exchange between the pastoral world and agricultural production. It would also mean that this cessation is reproduced through the use of universal categories in which any concrete reality is destroyed beyond

52. Philoetius brings lambs for the consumption of meat from the mainland (Od. 20.209-10). Brendel 1931: 6-8 assumes an interest in wool as well as milk and meat.

53. On the other hand, the metaphorical use of the 'shearing' of the goods of Odysseus through the suitors' constant feasting alludes to the breeding of sheep for wool, especially as the mistress and maids are busy with spinning and weaving. See Od.

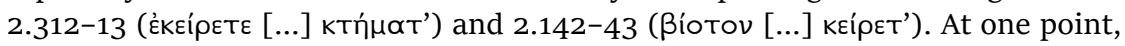
Telemachus specifies the livelihood which is 'shorn off' by the suitors as sheep, wine, and bread (Od. 20.312-13).

54. The explicit reference to uncastrated rams in the Iliad (23.147) is also an argument for the existence of castrated animals. On the quality of the wool of castrated sheep see Halstead 1987: 77.

55. Halstead 1987: 77-83. 
recognition. This is not to deny that factual experience with strangers influenced the tales. ${ }^{56}$

Such experience, however, does not rule the logic of the depiction nor the image of the person of Polyphemus. The Cyclops's main distinguishing feature, his single eye, characterises him as one who can only half see. Norms and values, such as the law of hospitality guarded by Zeus, are thought of as clearly understandable in the epic. ${ }^{57}$ Yet Polyphemus does not

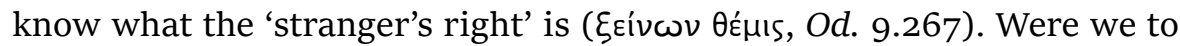
take him as a prototype, the Cyclops, because of his lack of insight, would embody the not-seeing of the very values the poem defends through the design and structure of the episode.

\subsection{Exchanging arms: Glaucus and Diomedes}

The exchange of armour between the Argive Diomedes and the Lycian Glaucus in Iliad 6 is often referred to when scholarship ascribes a peacemaking or bond-forming function to guest-gifts. In Bolchazy's scheme, this exchange conforms to the contractual rather than altruistic forms of guest-friendship; $;^{58}$ Walter Donlan places it into the category of balanced reciprocity and views it as possessing the character of a peace-treaty.59 For Finley, the exchange of arms between Glaucus and Diomedes gives rise to fundamental thoughts on guest-friendship and the forging of bonds and alliances in the early Greek world. Finley views this critical moment as the most dramatic possible test of the cohesion of the network of personal alliances established through guest-friendships. ${ }^{60}$ Significantly, the arms-exchange occurs in the midst of battle, just as the opponents trade insults intended to lead up to a duel. When Diomedes, fighting with the Achaeans against the Trojans, recognises his opponent Glaucus as a guestfriend, a xeinos going back to their grandfathers' generation, he suggests the exchange of arms:

56. The word ó $y$ piol, used for the Cyclopes and the Laestrygonians (Od. 10.100-32; 11.175), does not describe savages as Gauthier 1972: 5 claims but the inhabitants of the agros, i.e. pastureland. See also Audring 1989. The classical term barbaros to identify a stranger who does not speak Greek does not occur in Homeric epic, although we do find the epithet $\beta \alpha \rho \beta \alpha \rho o ́ \phi \omega v o$ ( $I l .2 .867$ ). The epic term for this kind of stranger is allothroos. Compare Vasilescu 1989: 70-77.

57. Compare ch. 3 .

58. Bolchazy 1978: 57. See also Gauthier 1972: 10.

59. Donlan 1982: 145.

6o. Finley 1967: 104-8. See also Hands 1968: 28. Similar Herman 1987: 2: '[...] the guest-friendship he [the heros] contracted were his own private affair'. 


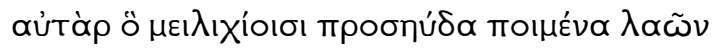

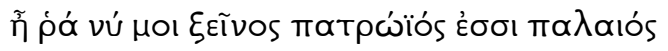

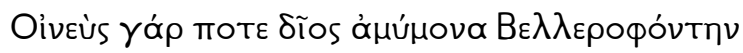

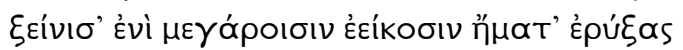

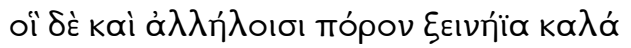

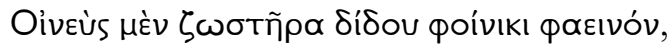

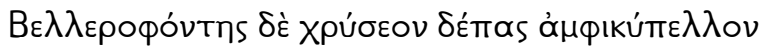

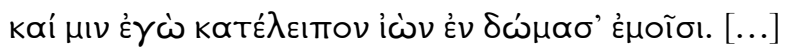

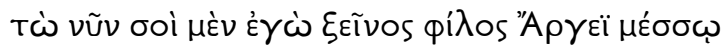

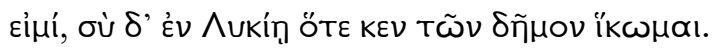

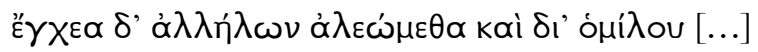

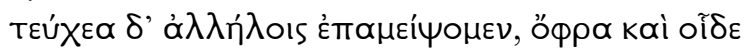

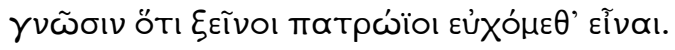

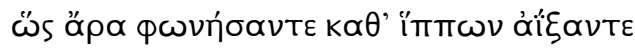

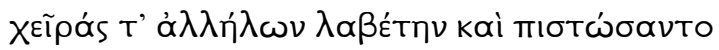

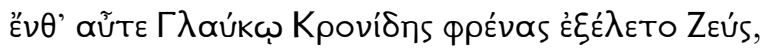

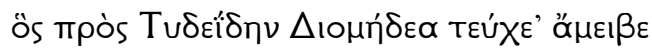

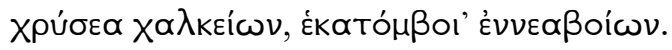

And so he [Diomedes] spoke gently to the shepherd of people [Glaucus]: 'Truly, you are a guest-friend of my father's from the old days (xeinos patrōios [...] palaios)! For godly Oineus once entertained the blameless Bellerophon in his halls, and kept him there for twenty days. And they gave each other beautiful guestgifts (xeineiia kala): Oineus gave a shining crimson belt, and Bellerophon a golden double cup, which I left behind in my palace when I came here. [...] So now I am your dear guest-friend in the heart of Argos, and you mine in Lycia, if I ever travel there. Let us avoid each other's spears, even in a crowd! [...] Let us exchange arms with each other (teuchea d'allēlois epameipsomen), so that these men may know that we are guest-friends since our fathers' time.' When they had talked in this way, they both leapt down from their chariots and clasped each other's hands and pledged their faith (pisteusanto). And Zeus, the son of Cronos, took away Glaucus's wit (phrēn), when he changed arms (teuchea ameibe) with Diomedes, son of Tydeus, giving gold for bronze (chrysea chalkeiōn), the value of a hundred oxen for that of nine (Il. 6.214-21; 224-26; 230-36). 
The final statement, in which the unequal nature of the exchange is pointed out, was duly noted by Finley: 'The poet's editorial comment, so rare for him, reflects the magnitude of Glaucus's mistake in judgement'. ${ }^{61}$ But the statement did not have any influence on Finley's view of the character of gift-exchange as a kind of exchange without profit. In the meantime, the question of value has received much more attention. So the anthropologist Thomas $\mathrm{O}$. Beidelman sees it as a clear indication of the originally agonistic character of gift-giving in the Greek world. ${ }^{62}$ Ancient historians argue in a similar vein, as when William M. Calder III, following Marcel Mauss, interprets the unequal exchange of arms as a vague memory of the custom of an 'Indo-European potlatch', still practised in Mycenaean times but no longer intelligible to the poet and thus giving rise to the comment about Glaucus's unwise conduct. ${ }^{63}$ Mauss himself had argued similarly in his essay on Thracian potlatch: 'So the Greeks of the Homeric period observed the customs and considered them insane. ${ }^{64}$ Starting with the assumption that gift-exchange is always competitive in character, Chester G. Starr even arrives at the conclusion that the poem contains no reference to the practice of gift-exchange apart from the arms-exchange between Diomedes and Glaucus. ${ }^{65}$

Both models of interpretation are beset with internal contradictions. To my mind, the arms-exchange is not adequately characterised either as an expression of the binding powers of guest-friendship, or as an evocation of an obsolete form of potlatch. Rather, the exchange of unequal arms enacts a contradiction between status and achievement which is also emphasised in Diomedes's aristeia. On the one hand this demonstrates the close link between person and object that is often pointed to in scholarship on giftexchange: the value of a person can be demonstrated through objects. On the other hand, however, the arms-exchange as it is depicted has no causal link with the guest-friendship, which is portayed as hereditary, and it does not prove the binding force of guest-presents. In the poem, compacts are not formed by giving arms but by swearing oaths. Gifts of arms appear in the poem to act as substitutes for personal armed service, tending more to

61. Finley 1967: 63. See also Herman 1987: 61.

62. Beidelman 1989: 236-42 referring to the conflict between Agamemnon and Achilles. See also Hiltbrunner 1972: 1981.

63. Calder 1984: 31-35. Similar Redfield 1983: 243.

64. Mauss 1921: 391.

65. Starr 1986: 32. Recently the unequal exchange is again interpreted as an example of asymmetrical reciprocity. See Bertelli 2014 and Domingo Gygax 2016: 35. 
resemble tributes. To expand on this view, it is important first to discuss the competitive character of gift-giving and then to turn to the problem of guestfriendship as a binding force by analysing further examples of arms-gifts.

To insist on the idea that the inequality of the arms indicates the competitive character of gift-giving is to contradict the explicit statement which points to the lack of consideration ( $p h r \bar{n} n$ ) shown by Glaucus when he exchanges the more valuable arms for the less valuable ones. This contrast gave rise to irritation even in antiquity and has led to various interpretations. So Plato makes use of the turn of phrase chrysea chalkeiōn as a metaphor for cheating or doing someone down in the Symposium. ${ }^{66}$ In contrast, Aristotle argues in the Nicomachean Ethics that Glaucus did not suffer injustice because of the inequality in value because it was in his power to give the gift, voluntarily ${ }^{67}$ Alexandrian commentators thought that Diomedes faked the ritual of guest-friendship in order to cheat Glaucus. ${ }^{68}$

In present scholarship there are two lines of debate. According to Calder, Diomedes, as the one who gives less, recognises Glaucus's superiority. ${ }^{69}$ Donlan's opinion is that the scene expresses the opposite state of affairs: The superior partner, in this case Diomedes, receives more, and Glaucus's gift is to be seen as a gesture of subordination. ${ }^{70}$ Donlan identifies a similar imbalance in the gift-exchange between Oeneus and Bellerophon. Bellerophon is at a disadvantage here as he receives, with the purple belt, a lesser gift than the one he gives, while the gift of gold given to Oeneus indicates his higher status. ${ }^{71}$ With this interpretation Donlan rejects the categorisation of the arms-exchange as part of the tradition, assumed by Calder, of an Indo-European potlatch. Donlan does not absolutely reject such a 'true potlatch', but for him the representation of such a practice is not a mere relic but a reflection of the circumstances of the Geometric period. ${ }^{72}$ However, Donlan's view is that competitive giving applies only to

66. Plat. Symp. 219 a.

67. Arist. Eth. Nic. 1136 b.

68. The sources are collected by Maftei 1976 and Fornaro 1992. On the Roman reception of the scene, see Behrends 2002.

69. Calder 1994: 34: 'Diomedes, after hearing the glorious lineage and noble attainments of Glaucus, whom momentarily he had thought a god (Il. 6.128-9), admits by his offer of the unequal exchange Glaucus's superiority.'

70. Donlan 1989: 11-12.

71. Donlan 1989: 12.

72. The competitive character is also stressed by Qviller 1981: 124-27; even Finley 1967: 125 hints at this: 'Gift-giving too was part of the network of competitive honorific activity. And in both directions: it was as honorable to give as to receive'. 
bridal gifts and prizes handed out at funeral games, and he exempts the arms-exchange from this pattern. He interprets most gifts handed out in the poem, including the gifts of arms, as 'gifts of submission', with which the more generous giver intends to secure the good will of the recipient. The poet's final remarks on Glaucus's behaviour do not, according to Donlan, signal a lack of knowledge of the practice of gift-exchange but instead demonstrate bias: Homer intends to show his audience that the Achaeans are superior to the Trojans and their allies not only in strength (biē) but in cunning (mêtis) too. ${ }^{73}$

In essence, Donlan's argument is based on the inequality of the exchanged objects from which he draws conclusions regarding the status of the giver and the receiver. It is more persuasive than Calder's in so far as it assumes the coherence of the poetic world, while Calder needs to draw on the notion that the gift ritual is a relic from a different time. This idea goes against the conclusions drawn by research into oral poetry, which make it highly improbable that the epic contains a layer of tradition from Mycenaean times, as Calder suggests..$^{74}$ More recent research into the distribution of gift-exchange rituals also casts doubt over the suggestion of exchange as a relic. ${ }^{75}$ Apart from all this, the notion of competitive giving is amongst the most dubious aspects of gift-exchange theory, especially in view of Mauss's discussions of the North American potlatch, as I have shown in chapter $1 .^{76} \mathrm{I}$ will therefore, with some essential modifications, follow Donlan's argument.

When he infers a difference in status between Oineus and Bellerophon from the difference in value between the gold cup and the purple belt, Donlan overlooks the significance of purple for the visual demonstration of status in antiquity. In the poem the colour purple is associated with high status, with leaders in battle and in the assembly, such as

73. Donlan 1989: 2 and 6. See also Scott 1982: 1-19, who interprets the generous giving of Glaucus as loss of honour. According to Sitta von Reden (1995: 26) the gift was transformed into booty.

74. Calder 1984 follows Nilsson 1933. The Swedish scholar stressed the connection of the epos with Mycenaean times. Actually, the link with the rise of the polis (eighth century BCE) is widely accepted (see Patzek 1990 and 1992: 136; Latacz 1988; Raaflaub 1991; 1998; Anderson and Dickie 1995). For discussion see now Crielaard 2002; Osborne 2004; Ulf 2011.

75. Cf. e.g. Herman 1987; von Reden 1995; Domingo Gygax 2016.

76. The potlatch developed its agonistic character in the context of competition between different lineages of the Kwakiutl to increase their influence on the sea-otter skin trade near Fort Rupert in the nineteenth century. Cf. Wolf 1982: 182-92. For further references see ch. 1.2, n. 130. 
Agamemnon and Nestor. ${ }^{77}$ Obtaining the purple dye from sea snails was a time-consuming process and hardly less difficult than mining for gold. ${ }^{78}$ In Athenaeus's discussions on luxuries, purple and gold are at the top of the hierarchy of status symbols (Ath. $12.526 \mathrm{c}$ ). In Attic tragedy purple fetches its weight in silver. ${ }^{79}$ In the visual arts, when the sheen of gold cannot be represented, it is marked by the colour purple. ${ }^{80}$ There is no reason to suggest that the purple belt is any less valuable than the gold goblet. Any inequality in value becomes explicit only in the exchange of the arms, and even then its function is narrative. It is my thesis that the question of unequal values is intended to highlight a contradiction between status and achievement, which serves to emphasise Diomedes's aristeia, as Donlan rightly notices.

Both the context of the scene and the character of the objects suggest this interpretation. The arms-exchange in Book 6 is preceded by a series of duels in Book 5, from each of which Diomedes emerges as victor. Despite the reminder of inherited guest-friendship, Diomedes's actions in the arms-exchange scene, which is depicted from an Achaean point of view, point to victory over the opponent here too. The opponent's arms form one visible sign of this victory. They are collected with zeal and industry by the heroes. They are fought over even after the opponent's death because they carry the message of the warrior's glory or kudos. ${ }^{81}$ When Hector obtains the beautiful and famous arms of Patroclus, he wants the Trojans to take

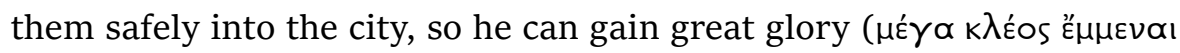

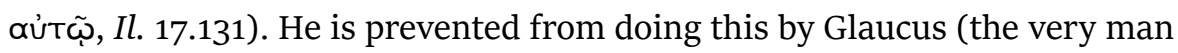
who exchanged weapons with Diomedes), who demands that Hector fight for the weapons and the body of Patroclus in order to be able to exchange them for the body of Sarpedon, which is in the hands of the Achaeans. At this, Hector decides to exchange (ameibō, the same word as that used for the exchange between Diomedes and Glaucus) Patroclus's arms for his own

77. Stulz 1990: 96-120. See ch. 3.2.

78. Stulz 1990: 103; Reinhold 1970: 17; Blum 1998.

79. Jenkins 1985: 124; Flintoff 1987: 126; Wagner-Hasel 2007: 325.

80. Stulz 1990: 88.

81. See for example Il. 11.110 and 247 (Agamemnon); 11.432 (Odysseus); 11.334 (Diomedes); 16.664-65 (Patroclus); 13.181 (Teucer); 17.125 (Hector); 17.536-37 (Automedon); 17.6o (Menelaus); 21.183 (Achilles). The aim to visualise military success by the trophy is stressed by Finley 1967: 128: 'there could be no honour without public proclamation, and there could be no publicity without the evidence of a trophy'. See also Willenbrock 1969: 59: 'Der Waffenraub am Schluß des Kampfes besiegelt die Schmach des Unterlegenen, so wie in unserer Zeit der Verlust der Fahne als größte Schmach gilt'. 
and to have the latter taken to Troy (Il. 17.192-94). Similar to the arms of Glaucus compared with those of Diomedes, these enemy arms too have a higher value. They are not made of gold but of bronze (Il. 16.130) and

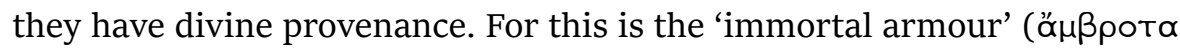

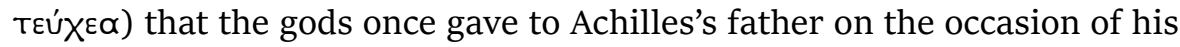
marriage to Thetis, and which Achilles has now furnished Patroclus with (Il. 17.194-97). In this armour, taken from his enemy, Hector now shows

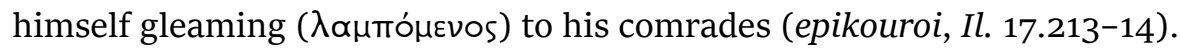

Looking back to earlier work, Barbara Patzek has drawn attention to the high significance of the sheen attributed to heroes' armour in the poem. Gold or bronze do not represent the actual materials of the objects but are to be understood as metaphors of differences in status. ${ }^{82}$ Gold armour has the highest sheen and thus the highest status, reserved almost exclusively for gods. When the sheen of Achilles's or Hector's armour is referred to then this is an expression of their success in battle and of their newly acquired status, just as it is for the characterisation of Diomedes's and Glaucus's arms as, respectively, made of gold and bronze.

Success in battle and social status tend to coincide in the poem and are visually represented by the sheen of armour. It is assumed in recent scholarship that individual achievement in battle justifies social status. ${ }^{83}$ But looking closely at the battle scenes it instead becomes clear that success is frequently justified by genealogical proximity to the gods. ${ }^{84}$ So, when fighting Polydorus, the son of Priam and Laothoë (Il. 21.85), Achilles throws his descent from a divine mother into the balance (Il. 21.109). Before his victory over Asteropaius, whose family line goes back to the river god Axius (Il. 21.140-43; 157), Achilles boasts about his paternal lineage, which goes back to Zeus via Peleus and Aiacus (Il. 21.185-90). Duelling with Aeneas, whom Achilles must recognise as a darling (philos) of the gods (Il. 20.347), both maternal and paternal lineages are drawn on. The Trojan's closeness to the gods stems from the maternal side, as he is the son of Aphrodite and the shepherd Anchises. He boasts about this to Achilles, while also mentioning the latter's descent from the goddess Thetis, making sure to point out her inferior rank (Il. 20.206-9). On the paternal side Aeneas, like Achilles, claims descent from Zeus (Il. 20.214-41). The heroes are potentially of equal status, and a victory thus is impossible

82. Patzek 1992: 188-93. She follows Willenbrock 1969: 19.

83. See Ulf 1990: 110-13 who denies any correlation between status and birth.

84. See Svenbro 1976: 124-27 and 135-38. 
for either of them. ${ }^{85}$ When Achilles is hit by Aeneas's spear, the new gold armour provided by Thetis protects him (Il. 20.268). But this does not equate to success in battle. At the moment when Achilles's arms become a danger to Aeneas, the gods intervene directly to remove him from battle, as they do with Paris in the duel with Menelaus (Il. 20.309-12).

The principle of genealogical proximity to the divine and support in battle is knowingly used by the gods. In cases of conflict, Hera makes the decision in consultation with the other gods. When Zeus wishes to save Sarpedon, to him the 'dearest among men' ( Hera stops this but allows the body to be saved by Apollo in order to give it the proper honour of burial (Il. 16.431-61). Similarly, Hera agrees to Poseidon's removing Aeneas from battle (Il. 20.309-12). When it comes to removing Hector's abused body, Hera is keen to deny this because of the Trojan hero's lowly descent from a mortal mother (Il. 24.55-63). On this occasion the solution is arrived at through Zeus, who concedes the inequality in familial status between Hector and Achilles but nonetheless achieves the release of the body through Thetis's mediation (Il. 24.55-76). In the theomachy Hera usually either personally defeats other gods like Artemis (Il. 21.512-13) or achieves victory with Athena's help over Ares and Aphrodite, and Hephaestus (Il. 21.391 and 330). Knowledge about genealogical status and its consequences lies with Hera as the highest-ranking goddess; both maternal and paternal lineage may play a role in decisions over victory or defeat. ${ }^{86}$

Against this background the unequal exchange between Diomedes and Glaucus makes much more sense. In terms of lineage, Glaucus initially appears the likely victor, as he is Bellerophon's grandson and can trace his line back to Aeolus. Glaucus's genealogy takes up a whole sixty-six verses (Il. 6.145-211). Diomedes on the other hand claims not to know much about his father, Tydeus, whose father, Oineus, exchanged gifts with Bellerophon (Il. 6.222). This status difference is also underlined through the sheen of the heroes' armour. Glaucus's proximity to the divine is demonstrated

85. When a duel ends in stalemate, it is clear that both parties are equally close to the gods. So, Ajax and Hector whose duel ends without a winner, are both loved by Zeus.

86. For the correspondence between status and success in the battle of the gods, compare Svenbro 1976: 136. He stresses the closeness to Zeus as decisive. But this close relationship to Zeus is important only for the decision whether a fight should take place. Apollo refuses to fight with Poseidon because he is a brother of his father (Il. 21.469). Hermes accepts Leto as victor without fighting because of her status as his divine father's alochos (Il. 21.497-501). But the decision of the victory lies in Hera's hands. 
through his gold armour, while Diomedes's bronze armour, appropriate for a mortal, shows his inferior status. The arms-exchange inverts the principles of status and achievement, and the final comment on its inequality shows that this inversion is established knowingly by the poet. The genealogically inferior man, who is thus also subordinate in terms of the unity between status and success in battle, receives the gold armour. The genealogically superior man, who is also the stronger in battle, makes do with the bronze armour. With this inversion Diomedes's aristeia, the theme of the previous book, is given greater prominence. Unlike Hector, who exchanges his armour for that of the defeated enemy, Diomedes receives his opponent's armour without a fight. The gleam of the armour distinguishes him as the real victor. ${ }^{87}$

The comparison of value undertaken by the poet at the end of the depiction of the arms-exchange cannot then be put down to forgetfulness. Nor does it point to any essential superiority or inferiority on the part of the recipient of gifts. Instead, it highlights what is unusual about the situation: the inversion of status and achievement. It is possible that this also points to a difference between Greek and Trojan practice. Arguments against this are as follows: (1) in the theomachy the principle of unity of genealogical superiority and superior fighting skills applies; (2) the genealogical principle is applied in order to establish decisions in conflict situations. ${ }^{88}$ It is more likely that there are a number of different criteria for establishing rank and that the poet chooses from case to case which one to emphasise. Without a thorough examination of the principles of familial relationships represented in the epic, any conclusions can only be preliminary. ${ }^{89}$

If we can firmly establish that the arms-exchange scene is not evidence for competitive giving, we can further discuss whether it provides evidence for the binding function of guest-friendship. The context within which the unequal exchange is described argues against this.

As Diomedes underlines, the effects of guest-friendship are felt at each guest-friend's home: in Argos and in Lycia (Il. 6.224-25). It is not unusual in antiquity to find that such guest-friendships bear consequences in battle-situations. Even Pausanias, centuries later, in observations on

87. The connection between the gleam of the armour and strength in battle is underlined by the semantic meaning of the term for success, kudos, which lies according to Greindl (1938: 30-51) in the shine emanating from things.

88. Cf. ch. 4.2.6.

89. After the revision of the idea of a tribal stage in early Greece (see Finley 1985 and Bourriot 1976) kinship was no longer a central focus of research. See ch. 1.4, n. 223. 
the wall-painting by Polygnotus in the Cnidian treasury at Delphi, can be found speculating that Laodice was spared slavery after the fall of Troy because her father-in-law, Antenor, had been a guest-friend of Menelaus and Odysseus (Paus. 10.26.8). Pericles's offer at the start of the Peloponnesian War, of his own land as public property (demmosia), if his Spartan guestfriend Archidamos spared his agros when the Spartans invaded Attica, shows how common the convention of sparing guest-friends was. It should be noted, however, that in Pericles's case there is a conflict between two loyalties: the obligation to the demos, and the connection with the guestfriend (Thuc. 2.13)..$^{\circ}$

Gabriel Herman's study of ritualised friendship in Greece shows that guest-friendships played an essential role in military conflicts in Greek poleis of the fifth and fourth centuries. ${ }^{91}$ According to Thucydides, one such guest-friendship between the Spartan Agis and the Argives Thrasyllus and Alkiphron even led to the cessation of war between Sparta and Argos in 419 BCE. This did, however, result in the confiscation of Thrasyllus's property as a consequence (Thuc. 5.59-60). Such grave consequences of guest-friendship are unknown, however, in epic. The armsexchange between Glaucus and Diomedes does not exclude the continuation of battle and in no way cancels out the obligation each warrior has to his respective leader. ${ }^{22}$ The Odyssey gives us only one instance of guest-friends who do not fight one another, and this is not in battle but in a competition: it is Odysseus's refusal to fight the son of his host Alcinous, since he is a xeinos to him: 'He is my guest-friend. Who would

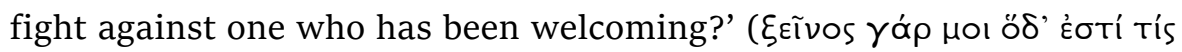

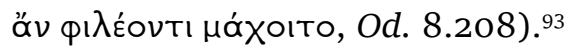

An existing guest-friendship may, however, result in support in the case of war, as is demonstrated a number of times in the poem. Agamemnon spurns Diomedes on to fight in Iliad 4 by evoking the shining example of Tydeus, who had once come to Mycenae with Polyneices as xeinos, in order to win allies (epikouroi) for the battle against Thebes

90. For further examples see Herman 1987: 3-4 and 142-61. See now Domingo Gygax 2016.

91. Herman 1987: 155-56 does not see any relevant difference between Homeric and classical practices of ritual friendship.

92. See Scheid-Tissinier 1994: 160: 'Ce pacte ainsi renouvelé devra cependant coexister avec les alliances qu'ils ont l'un et l'autre conclues avec Priam et Agamemnon et qui ne sauraient être remises en cause'.

93. Compare the translation of Benveniste 1969: I, 342: 'qui pourrait lutter contre son hospiteur'. For the meaning of phileō see ch. 2.3. 
(Il. 4.376-79). ${ }^{94}$ Nestor and Odysseus had enlisted followers, laoi, for the expedition to Troy in Phthia and had won over Achilles (Il. 11.765-70). On the Trojan side we see Paris wishing to avenge the death of Harpalion, who had once been his xeinos (Il. 13.66o-1). Phainos, the son of Asios of

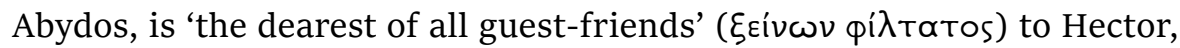
for whom he fights, and from whom he receives rich gifts (dōra) in return (Il. 17.584). We hear in Book 18 of the many goods already spent on the allies by once-wealthy Troy (Il. 18.287-92).

Charis, the word for this form of military support, and also for the thanks given for it in the form of goods and gifts, will be the subject of chapter 3 . Here, it is important to discuss further the role played by xein $(\bar{e})$ ion as a gift of arms. When xeinion is given in the form of arms, it is in most cases a substitute for personal military support or service. So, the armour, a thōrax, handed as a favour to Agamemnon by Kinyras is described as a xeinion (Il. 11.20-23). ${ }^{95}$ The boar's tusk helmet worn by Odysseus at Troy had been given by Amphidamas to Melos's father as a xeinion (Il. 10.26o-71). Both objects are described in detail, and both have a history which lends them a particular quality. Kinyras's thōrax, with which Agamemnon arms himself for battle, is described using images of battle captured in a rainbow simile: 'Truly, there were ten bands of dark blue enamel, and twelve of gold, and twenty of tin. Blue serpents writhed up towards the neck, three on each side, like rainbows that Zeus placed among the clouds, a sign to mortal men' (Il. 11.24-28). ${ }^{96}$ The boar's tusk helmet given to Odysseus by Meriones was 'made of leather and made stiff inside with many tight-stretched thongs. Outside the bright teeth of a white-tusked boar were set close all around it, well and cunningly, and inside it was lined with wool. Autolycus stole this out of Eleon when he broke into the well-built house of Amyntor the Ormenid. And he gave it to Amphidamas of Cythera to take to Scandeia, and Amphidamas gave it to

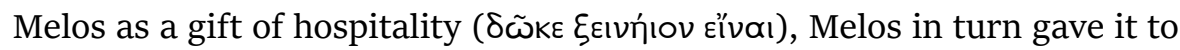
Meriones his son to wear. And now, placed around it, it covered the head of Odysseus (Il. 10.262-70). ${ }^{97}$ The genealogy of the object described here takes

94. For the recruitment of epikouroi see Ulf 1990: 157-64; van Wees 1992.

95. For the role of Cyprus in the epics see Giuffrida 1985: 15-39. In Iliad 15.529-33 a thōrax is called a gift (dōron) of a xeinos. Cf. the horse of Echepolos, which functions as gift of compensation for personal service. Menelaus uses it for his chariot (Il. 23.296-97). See Ulf 1990: 161.

96. The rainbow functions as a sign of battle. See $I l .17 .547$.

97. Grave finds indicate that helmets were part of standard Mycenaean warriors' equipment and were still in use during the eighth century BCE by the Greeks' northern and eastern neighbours. Cf. Patzek 1992: 193-94, who interprets the description as acknowledgement of the handicraft. 
it from plunder to guest-gift, from guest-gift to heirloom, and finally to a gift of arms given as support to a battle ally. This underlines the connection between guest-friendship and battle alliance, but it does not lend the gift itself any bonding function.

There is only one example in the poem of an object that does function as a bond: this is the sword Odysseus gives to Iphitos as the start of a close

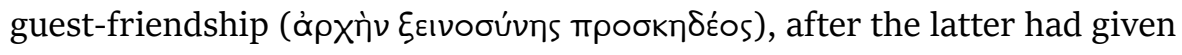
him the bow of his father, Eurytos (Od. 21.31-35). This is the only occasion outside of battle situations that we hear of an exchange of arms as gifts (xeinia). Unlike the arms gifts discussed earlier, which are always given only by one party for the purpose of immediate support in battle, the bow

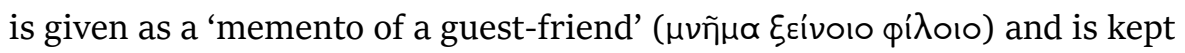
along with other treasures inside the home (Od. 21.40).

Besides this example there are only two instances of reciprocal armsexchange, both as interruptions of battle action in the Iliad. We have already discussed the first of these exchanges; the second exchange takes place between Hector and Ajax and is no less anachronistic than that between Glaucus and Diomedes. ${ }^{98}$ When nightfall necessitates the cessation of fighting, Hector suggests to Ajax that they should exchange 'gifts full of

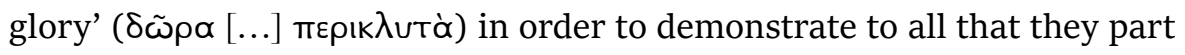

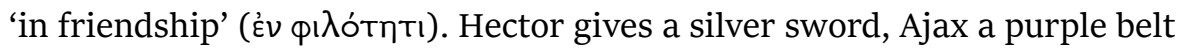
(Il. 7.299-305). Despite this friendly conclusion to the fighting, Ajax is characterised as the victor (Il. 7.312). The explicit pointer to the victorious party suggests irony, similar to that we have already seen in the exchange between Diomedes and Glaucus.

While in the case of Glaucus and Diomedes the unequal exchange is made against the background of inherited guest-friendship, Hector's purpose in visualising a bond of friendship is to evoke the earlier bond made between Achaeans and Trojans in Book 3. In both cases the bond is described as pı $\lambda$ ótns (philotēs). In Book 3, the establishment of philotēs was intended to restore the state of play as it was before Paris had wronged his host, xeinodokos, Menelaus, who had extended philotēs in the form of hospitality (Il. 3.345). The term philotês combines hospitality and friendship (or better: closeness or kinship). Yet, while the bond of guest-friendship is constant, the establishment of philotēs amongst warriors tends only to have a temporary effect. This type of bond is not secured through the exchange of gifts but through oaths, libations, handshakes, and through 
sacrifices to Gaia, Helios, and Zeus. Such gestures oblige warriors to a leader (Il. 2.339-41), and they perform the ritual of peace-treaties between groups such as the Achaeans and Trojans (Il. 3.94-105). ${ }^{99}$ Such obligation lasts no longer than Hector's promise of philotēs. In both cases, fighting continues. Hector announces the resumption of battle on the following day; the Achaeans and Trojans resume hostilities after the treaty is broken by a Trojan and Menelaus is hit by an arrow. Agamemnon puts it to his wounded brother that the Trojans have 'trodden on the trusted oaths' (öркıа тıота̀) and threatens:

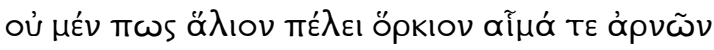

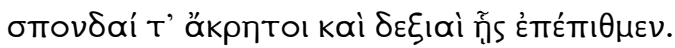

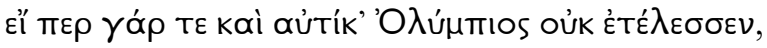

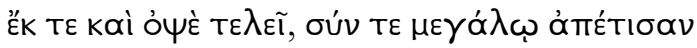

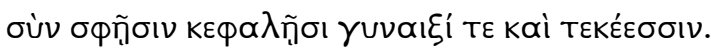

The oath once made is never in vain, and the blood of the lambs, and the offerings of unmixed wine, and the hand-shakes in which we put our trust. For even if the Olympian does not fulfil it straightaway, he will do so, even after a long time, and they will pay a big price, with their own heads, and their wives and children' (Il. 4.158-62).

We see, when Agamemnon first swears the oath, that cursing the potential oath-breaker is an essential part of it: 'Zeus, Father, who reigns on Ida, noblest and greatest, and Helios, you who see everything and hear everything! And rivers, and earth, and you underneath who punish those who swear falsely. Be witnesses and keep watch over the trusted oaths (

This form of agreement through a sworn oath is ultimately also in play between Glaucus and Diomedes, who not only exchange arms but also clasp

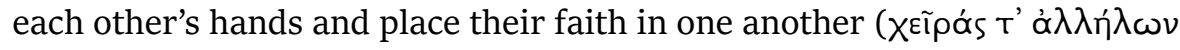

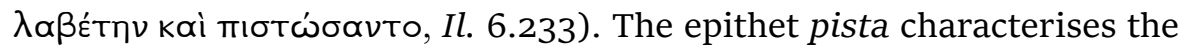
horkia sworn by the Achaians and the Trojans-or indeed the sacrifices made, as is suggested by the verb tamnein (to cut) taken with horkia (Il.

99. For the difference between horkia and philotēs see Karavites 1992: 48-73; Cohen 1980: 49-68; Taillardat 1982. On the narrative aspects of oath-making rituals see Kitts 2005 . 
3.94). ${ }^{100}$ In the context of hospitality we do not find such a ritual except for the pouring of libations to the gods. ${ }^{101}$ When individuals commit to one another through oaths, this is done with the intention of preventing harm and keeping a promised favour, without the need for establishing guest-friendship. ${ }^{102}$ So Eumaeus's Sidonian wet-nurse demands that the Phoenician sailors who are to take her home should swear an oath (öpкw

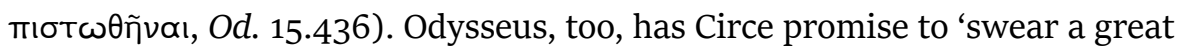

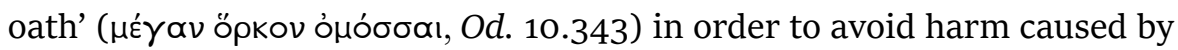
her sorcery.

I am inclined therefore to doubt the idea that the arms-exchange between Glaucus and Diomedes has a causal connection with the inherited guest-friendship and thus proves that guest-friendship forms the basis of political ties and treaties. ${ }^{103}$ It is clear from my observations above that the arms-exchange is not based on guest-friendship but is a form of horkia, a bond made specifically between combatants, and which is demonstrated

100. For the meaning of horkia as oaths ('Eidschwüre') and sacrifices ('Eidopfer'), see Cohen 1980: 55, who interprets horkia tamnein as 'cutting of the hairs' of the sacrificed animals 'as well as of the cutting of their throats at the end of the ceremony. Further, the hairs are distributed to all Greeks and Trojan leaders [...]'. The ritual will bind the people to the pact (56). On the meaning of oaths as contract in ancient Greece see also Hirzel 1902: 65-75. For evidence in classical Greece see Sommerstein and Torrance 2014.

101. Cf. ch. 2.3.

102. The term is öркоv óнóøøaı. See Od. 5.178 (Calypso); Od. 12.298 (Eurylochus); Il. 20.313: (Hera and Athena). Only individuals swear oaths, horkoi, whereas oaths connected with sacrifices, horkia, are sworn by collectives. This is the case even in Ithaca where the families of the killed suitors finished the battle by horkia (Od. 24.546). Cf. Cohen 1980: 49-52. For a different view see Herman 1987: 49-54. According to him clasping each other's hands (dexiai) and pledging faith (pisteuesthai) were typical elements of the ritual of friendship between individuals. This is true in classical times but does not correspond with epic evidence. Taillardat 1982: 1-14 interprets dexiai and oaths as elements of the ritual of guestfriendship with contractual value. But in the epics, handshakes (dexiai) are only used when individuals are received by collectives. Cf. the invitation of Telemachus by the Pylians to their sacrificial meal (Od. 3.35). Normally guests were taken by the right hand. Cf. e.g. the reception of Odysseus and Nestor by Achilles (Il. 11.778) of Thetis by Charis (Il. 18.385), of Mentor by Telemachus (Od. 1.121) and of Odysseus by Alcinous (Od. 7.168). This can be read as a gesture of protection. It is not a sign of a contract.

103. According to Widzisz 2012: 166-67 the simultaneous character of the exchange makes it impossible to create a gift-exchange relationship between Glaucus and Diomedes. Cf. also van Wees 1992: 228. 
in all its fragility and ambivalence on a number of occasions. Even when horkia are not broken, as in the cases I have discussed, they are often intended to be only of limited duration. This is the case when agreements are entered into for the purpose of burying the dead, or when obligations are entered into for the duration of a particular campaign of battle. ${ }^{104}$ I do not mean to support the notion that oaths such as those sworn between Greeks and Trojans should be interpreted as treaties between nations, or as an early form of 'international law', as some have done in the past. ${ }^{105}$ Instead, I wish to go beyond this and to argue that such agreements by oath between warriors merge together with guest-friendship to form one institution only after the point at which those who assume the political character of guest-friendship see it as having been replaced by institutionalised forms of treaty-making. ${ }^{106}$ Even alliances of the classical period that are made in writing still represent bonds of friendship. Described as xenia, philia, or symmachia, the treaties of the classical period still share the constitutional elements of oath and sacrifice with the Homeric horkia. ${ }^{107}$ The need for written contracts in the classical period can be explained, as has been done for the medieval period, through the increasing complexity of the agreements made. ${ }^{108}$ This does not result in a new character of 'international law' for this form of bond. All we have is a blending of the individual and collective forms of bond, which in their Homeric form are still differentiated.

Such continuity, to be expected at the level of collective alliances, is mirrored in observations made by Gabriel Herman on the subject of personal

104. Il. 7.69; 411; 2.110. Cf. the reintegration of Achilles into the army of the Achaeans, which was sealed by horkia (Il. 19.190-91). Cohen (1980: 52-53) therefore differentiates between temporary and permanent existing contracts, called horkia. This is correct, insofar as in some cases permanence is aimed for. In these cases, the term philotēs is used additionally to denote this permanence. See further below. 105. For a discussion see Phillipson 1911: I, 46-66 who stresses the principles of juridical equality and reciprocity of nations as main features of international law (60). For evidence in the epics see Köstler 1950: 18-19; Wéry 1967: 169-205 against Audinet 1914: 29-63. Gschnitzer 1991: 182-204 interprets the oath as an institution of law and stately order. For a middling position see Karavites 1992: 8-9 who stresses the informal and personal character 'of international law'. A system of reciprocal obligations is assumed by Cohen 1980: 52. See now Elmer 2013 who underlines the reciprocal aspects in situations of collective decision-making in the Iliad.

106. Donlan 1982: 149.

107. See Baltrusch 1994: 5-15, 66-68, 144.

108. Althoff 1990: 88. 
friendships in the classical period. ${ }^{109}$ His results prove a close connection between individual guest-friendships between leaders and the forming of military alliances between collectives. I will conclude with an example from Xenophon's Hellenica (4.1.29-40) in which a meeting is arranged by Apollophanes of Kyzikos between the Persian Pharnabazus and the Spartan king Agesilaus. Apollophanes, a guest-friend (xenos) of both the Persian and the Spartan, suggests to Agesilaus that he should establish a bond of friendship (philia) with Pharnabazus, against whom he is currently engaged in warfare. Agesilaus grasps the opportunity of a truce, which is sealed with a handshake (dexia), and he is led to meet Pharnabazus. The latter reminds Agesilaus that he had been a friend (philos) and ally (symmachos) of the Lacedaemonians when they had been at war with Athens, and that he now expects a favour in return (charis) from Agesilaus. The Spartan king counters by explaining that in the Greek states guest-friends (xenoi) still have to fight one another when their poleis are at war. Nonetheless, he suggests that they should become philoi and symmachoi. Pharnabazus, in turn, has to reject this out of loyalty to the Persian king, as he is his general. Despite this, Agesilaus is able to promise to spare Pharnabazus's possessions, and to enter into guest-friendship with the Persian's son, sealed with an exchange of gifts: Agesilaus gives his horse's headgear and Pharnabazus's son gives his javelin.

The example demonstrates clearly the personal character of military alliance, here described as philia; it also shows the decisive role played by existing guest-friendships in the establishment of such alliances in the fourth century. ${ }^{110}$ The fact that a military consensus between Pharnabazus and Agesilaus is not realised is attributed to the existence of alternative, civic ties and obligations that affect both leaders. Significantly, however, the Greek's loyalty to his polis is not seen as preventing him from forming an alliance with the Persian satrap; rather it is Pharnabazus who brings the superiority of his obligation to the Persian king to bear on the situation. ${ }^{111}$ The satrap's loyalty to his king may prevent the two leaders from becoming allies (symmachoi and philoi). This does not stop them from establishing guest-friendship on a personal level and sealing it, in the same manner as the bond of friendship between Iphitos and Odysseus, with an exchange

109. Herman 1987.

110. For evidence of philia as term for 'Bundesgenossenschaft' see Dirlmeier 1931: 34. According to him philia is not used in political contexts before Herodotus. He considers earlier references in poetry to be 'Attizismus'.

111. For another view see Herman 1987: 2. He stresses ties with the polis. But such ties are not relevant in this episode. 
of arms. The guest-friendship established between Agesilaus and the son of Pharnabazus becomes effective when the latter loses his throne to his uncle and is able to count on the hospitality and support of his Spartan guest-friend, Agesilaus (Xen. Hell. 4.1.40) ${ }^{112}$

In the classical period the term used to describe such personal guestfriendships that often occur in military situations is xenia, which is frequently used by Herodotus in particular. So Herodotus tells of Xerxes form-

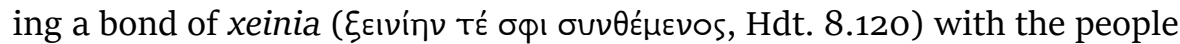
of Abdera on the Hellespont and making them gifts of a golden sword and a gilt headdress. Herodotus also claims that Amilcas was induced to act as commander for Terillus because of guest-friendship (7.165). According to Herodotus, guest-friendship can lead to alliance, which can then result in obligation to provide military assistance (Hdt. 7.27-39). As Gabriel Herman has convincingly argued, classical xenia is not just guest-friendship but a kind of 'ritualised friendship'. ${ }^{113}$ In Homeric epic there is, however, no specific word for guest-friendship apart from xeinosyne. The noun xenia is used only in the final book of the Odyssey to describe proven hospitality (Od. 24.286 and 314). This would suggest that guest-friendship that specifically includes military and political alliance comes into being only in the classical period. Such a formalisation of guest-friendship in terms of military alliance is merely suggested when the term xeinosyne is used to describe the relationship between Iphitos and Odysseus in Book 21. As in classical xenia, this relationship is sealed with an exchange of arms. When such relationships between guest-friends are formed elsewhere in the epics, gifts (for instance golden vessels or textiles) are given as pledges, such as those exchanged by the ancestors of Glaucus and Diomedes. I will be examining the function of such gifts in what follows, before returning to the various forms of relationships and bonds formed in the epics.

\subsection{Goblets and textiles: Xeinion as keimēlion and the ritual of guest-friendship}

'There are no whole oxen here, no gold (öute Xpuбós), no bright red car-

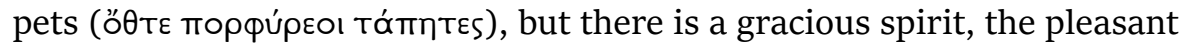

112. Cf. the description of guest-friendships by Herodotus, which existed between the Alcmaeonids of Athens and the Lydian king Croesus. The Alcmaeonids received gifts of gold and supported the embassy of Croesus on their way to Delphi in return (Hdt. 6.125).

113. Herman 1987: 7. 
Muse and sweet wine in Boeotian cups.' This is Bacchylides's promise to the Dioscuri, Helen's brothers, in a fragmentary lyric (Bacch. fr. $21=$ Ath. 11.500 a). The contrast between the display of items associated with Homeric hospitality-the sacrificial feast, golden apparel, and purple clothand the less ostentatious values represented by spirit, song, and the simple Boeotian cups clearly implies the superiority of the latter. This is especially clear when Bacchylides is read against the background of fifth-century ideas of equality, which go hand in hand with the negative valuation of conspicuously luxurious dress. ${ }^{114}$ By contrast, heroic epic never questions differences in status and their display. When it does thematise a contrast similar to that just seen in Bacchylides, between inner value and outward appearance, it never represents the former as superior to the latter. Rather, such contrast will always take the form of a critique of the insufficiency of the display with a view to the demands made by social status. In Homeric epic the appearance of a hero or heroine, and of the objects they surround themselves with, are visible markers of their social status. This indicative function is seen especially clearly in the gifts handed to guests as mementoes of existing guest-friendships. Such guest-gifts bear symbolic significance and are distinguished from other gifts described as xeinia and which belong (along with natural xeinia and with the gift of arms as xeinion) in the context of relationships of service. The word used for symbolic mementoes or guest-gifts is therefore not xeinion but dōron. I will now first discuss these differences and will then pursue the function of different gifts in the ritual of friendship, along with the terms used to evoke this ritual.

\subsubsection{Mementoes and tributes: Tripods, goblets, mixing bowls, and cloth}

There are only three instances in the Odyssey of xeinia that are neither natural goods nor weapons. These are the textile and metal goods Odysseus receives from the Phaeacians, and the gifts reportedly given to Odysseus by an alleged guest-friend. Let us begin with the Phaeacians. After Odysseus has proven himself to the hospitable Phaeacians as both a delightful speaker and a good fighter in contest (Od. 8.186-236), Alcinous requests that each of his twelve chieftains (basileees) grant a xeinion to their guest:

114. For this interpretation see Stulz 1990: 148. For the discussion on luxury in the fifth century BCE see Geddes 1987: 307-31. On aristocratic cloth luxury of the sixth century BCE see Stein-Hölkeskamp 1989: 104-10; Bernhardt 2003; WagnerHasel 2007; Lupi 2019. 


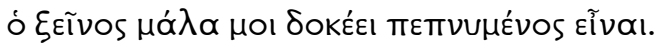

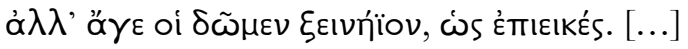

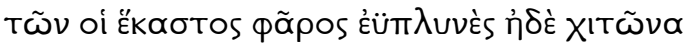

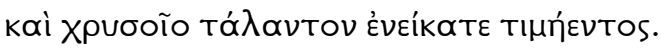

The guest (xeinos) seems to me to be a man of understanding. So, come on, let us give him a guest-gift (xeinēion) as is fitting. [...] Let each give him a well-washed cloak (pharos), and a tunic (chitōn), and a talent of precious gold (Od. 8.388-89 and 392-93, tr. E. Theodorakoulos).

The queen, Arete, places these golden and textile xeinia-later also described as klyta and kallima dōra, glorious and very beautiful gifts (Od. 8.417 and 439)-in a trunk, which she locks (8.438-39). ${ }^{115}$ She herself has added, at her husband's request, a particularly beautiful cloak or cloth (pharos kalon, 8.425) and a chitōn (8.441). While the gold is specified by weight, the textile goods are differentiated according to types into pharea and chitōnes. A chitōn is an item of male clothing, while the pharos is a large rectangular piece of cloth used as a cloak for both sexes and also as a coverlet at night or as shroud or pall. Both can be made from linen, ${ }^{116}$ the weaving of which Phaeacian women appear to specialise in (this is indicated by their looms dripping with oil, which was used as a form of finish in linen production). ${ }^{117}$ These types of textile gifts are also described

115. Such chests are placed in the thalamos, the only room which could be locked with a key and used for storing textiles as we see in the Odyssey $(15.104-5 ; 2.345)$ and in the Iliad (6.286-95; 24.228).

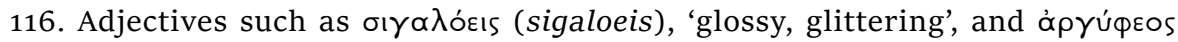
(argypheos), 'silver-shining', may be read to suggest the gleam of linen. See the argumentation of Studnizka 1886: 13; Abrahams: 1964: 19-27; Evans 1964: 5; Bieber 1977: 16; 1967: 23. For another position see Marinatos 1967: 8, who does not deny the use of linen but argues in this case that the men's chitōn was made

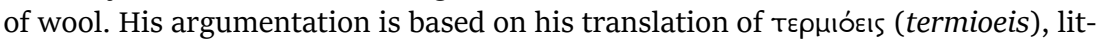

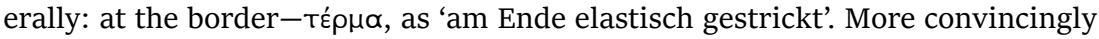
Bieber 1967: 23. She argues that this type of chitōn had a patterned or coloured border as seen on vases. This is now proved by Ellen Harlizius-Klück 2016. See my argumentation in ch. $5 \cdot 3$.

117. Blümner 1912: 196. Cf. the description of the chitōnes of the young men on the

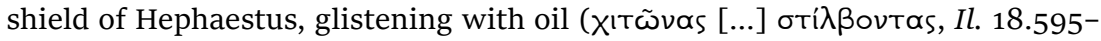
96). Fragments of linen were found in the graves of Lefkandi (tenth century BCE) and in Gordion (seventh century BCE). Cf. Blome 1984: 12; Lemos 2007; de Vries 1980: 35; Burke 2010. For more detail see ch. $5 \cdot 3$. 


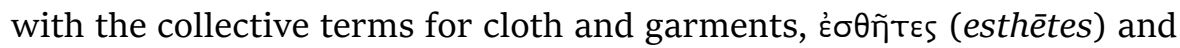

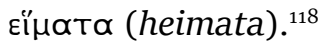

Another gift-giving scene occurs during Odysseus's tale in Book 11, when Arete, reminding the Phaeacian lords of the many riches (ktēmata) they

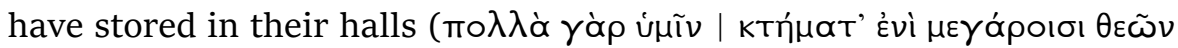

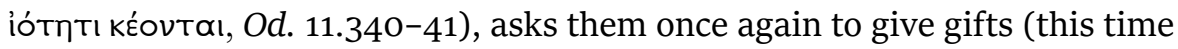

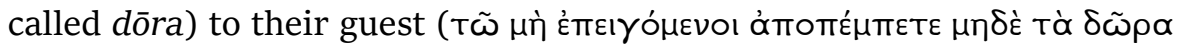

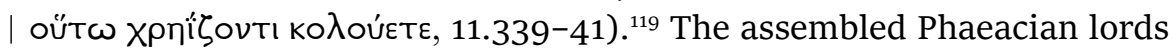
and Alcinous himself agree to give these gifts, which are characterised as mobile goods through the use of the term ktēmata. ${ }^{120}$ Alcinous uses the word dōtine, which we have met already in the context of natural goods given as xeinia. Here again the word is ambiguous and could be taken to mean the gifts as a whole or the escort (pompē) promised by Alcinous:

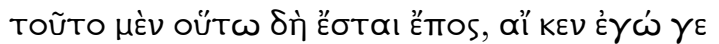

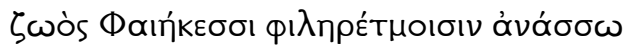

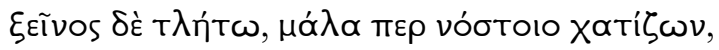

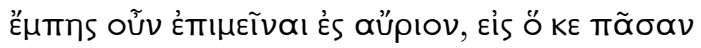

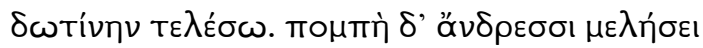

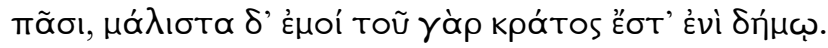

Let this word of hers hold true, while I live and rule over the oarloving Phaeacians. But let the xeinos for all his craving for home, stay put until tomorrow, until I shall have completed the entire dōtinē. His passage (pompē) shall be the men's responsibility, all of them, but most of all mine, for the power in the dēmos is mine (Od. 11.348-53).

In his reply to this offer, Odysseus refers to the pompe as well as to the

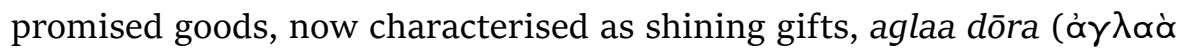
$\delta \tilde{\omega} \rho \alpha$, Od. 11.357). It is not until Book 13, after Odysseus has completed his story, that we find out the exact nature of these gifts, with talk of a tripod ( $\tau$ pímous) and a cauldron ( $\lambda \varepsilon \dot{\beta} \eta \varsigma$ ), the cost of which will be collected from the people, and the already promised cloths (heimata) and gold (13.10-15).

118. Od. $8.440 ; 13.137 ; 13.218$.

119. For interpretation of the question of Arete see ch. 4.1.

120. The term ktêmata denotes mobile goods which are deposited inside houses (Od. 7.150; 15.11; 17.532). It is Penelope who takes care of them (Od. 23.354-6o). Cf. ch 5 . 
Arete repeats that she will contribute a well-washed pharos and a chitōn, and also at this point bread and wine for the journey (13.66-69). Both the pompe $\bar{e}$ and the tripod and cauldron are afforded by the collective, the dèmos of the Phaeacians, while the individual chieftains, the basilees, and the hosts themselves, Arete and Alcinous, contribute the textiles. When the packing of the goods is described, the gifts are listed in terms of materi-

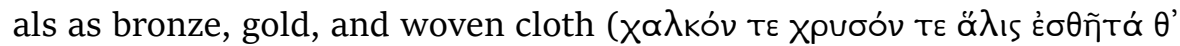

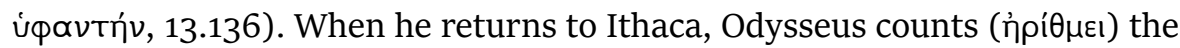
goods, this time listing them in terms of their use as tripods (трітоб $\alpha$ ),

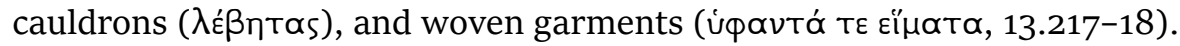
It is noted that there is more than Odysseus could have obtained at Troy in spoils (13.137). In receiving these gifts, Odysseus achieves a godlike position, as Zeus had prophesied (5.36-38): 'They will honour him like a god

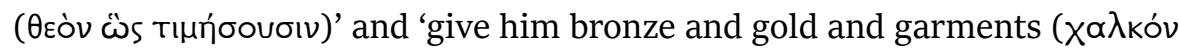

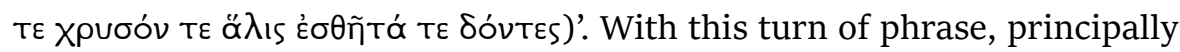
used for basilees, Odysseus is characterised as not just a guest but as a basileus similar to Alcinous himself. He too holds a godlike position; the dēmos listen to him as to a god. ${ }^{121}$ As in the Polyphemus episode, Odysseus plays a double role as a stranger, xeinos, and as basileus, receiving tributes from the dèmos (with Polyphemus his other role had been that of the master, anax, over his shepherds). This is also supported by the listing of the goods in terms of their materials-this represents a form of abstraction which must indicate that it is not the individual gift and its significance that counts but the quantity of goods and the wealth that they represent.

Odysseus receives two separate types of gifts: one is the xeinion, consisting of cloth (chitōnes and pharea) and gold, and it comes from the basilees' homes; the other type are gifts described as dōra, which consist of bronze articles (tripods and cauldrons), and which are given by the people. Added to this is the escort, that is, the granting of a ship and rowers. The overall term for these gifts from the people is dōtine, although we cannot say for certain whether this means just the escort or also includes the other gifts made by the people.

A gift from Alcinous, a dōron, is distinct from those just listed. This is a gold goblet, handed over with an appeal to be remembered: 'I will

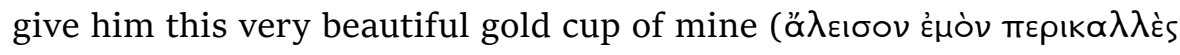

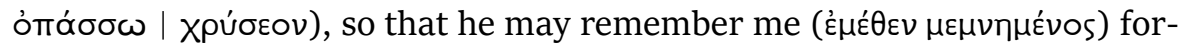
ever when he pours libations in his palace to Zeus and to the other gods' 
(Od. 8.430-32). Elsewhere Odysseus promised to remain a xeinos after

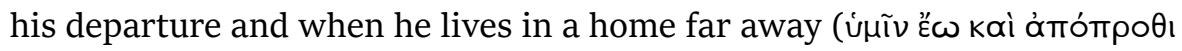
$\delta \omega ́ \mu \alpha \tau \alpha$ vaíwv, Od. 9.18). The clothing Nausicaa gives to the shipwrecked Odysseus functions similarly as a memento, if indirectly: when Odysseus has been handed the clothing, and has bathed and dressed, Nausicaa asks him to remember her in the future, as it is to her first that he owes his

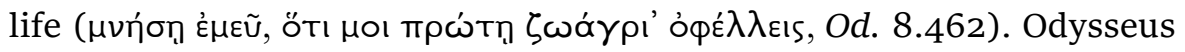
promises to appeal to her every day as to a goddess, since she saved his life (Od. 8.467-68).

Telemachus, too, receives gifts as mementoes when he renews the former guest-friendship between Odysseus and Menelaus during his expedition in search of his father. Although the term xeinion is not used here, Menelaus offers Telemachus 'gleaming gifts', aglaa dōra, in the form of three horses and a chariot, and a beautiful cup (Od. 4.589-91). Once Telemachus's identity has been established and the banquet finished, Menelaus announces the gifts, along with the same injunction to remember the giver that we have just observed with Alcinous's cup, given to Odysseus. 'I will give you a beautiful cup so that you may pour libations to the immortal gods and remember me in forever ( $\delta \omega \sigma \omega k \alpha \lambda \lambda^{\prime} v a ̈ \lambda \varepsilon ı \sigma o v$,

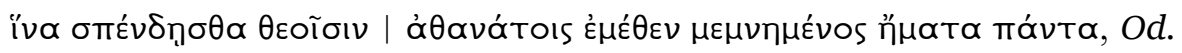
4.590-92). Telemachus finds himself unable to accept the horses, since Ithaca lacks the necessary conditions to keep them, so that Menelaus promises him instead the most beautiful and valuable piece from his treasures (keimèlia): a finely wrought mixing bowl, a kratēr, made of silver and

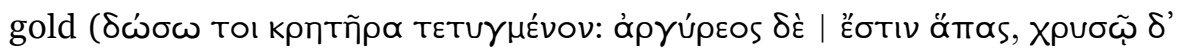

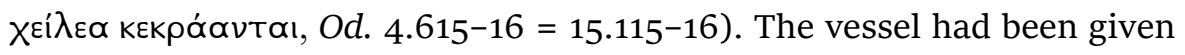
to Menelaus by Phaedimus, the king of the Sidonians, when Menelaus had been a guest in his house (Od. 4.617-19 = 15.117-19). When Telemachus is ready to depart, Menelaus and Helen go down to the thalamos in which the keimèlia are kept, where Menelaus gets the promised objects, the doublehandled cup and the silver mixing bowl (Od. 15.99-104). Helen adds a

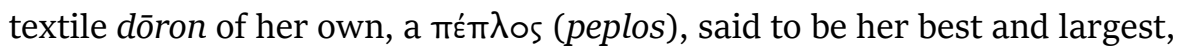

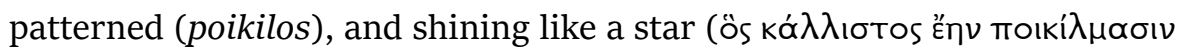

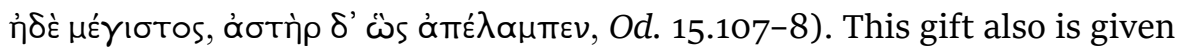
with a request for remembrance, as Helen addresses Telemachus with the robe in her hands: 'I give you this, a remembrance of Helen's hands for your bride to wear on the day of your longed-for marriage' (тoũTo $\delta i \delta \omega \mu$

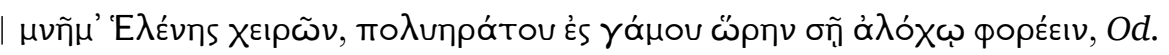


15.125-27). This request is confirmed as a norm, just before the handing over of gifts of remembrance, in the advice given to Telemachus by his companion Peisistratus, who reminds him that a xeinos will always remem-

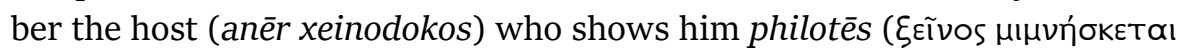

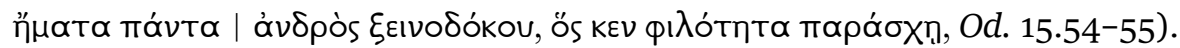
While it is possible that philotēs in this case means just hospitality, it is clearly endowed with the more concrete sense of the giving of gifts, since Peisistratus is also asking his friend not to leave without the promised gifts

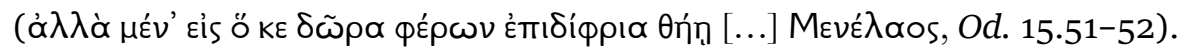

Besides the gifts of remembrance, other possible gifts are mentioned at Sparta, similar to those given to Odysseus by the Phaeacian dēmos: bronze tripods and gold (here given in the shape of cups) as well as mules (omitted by the seafaring Phaeacians). When Telemachus announces his intention to return to Ithaca, Menelaus suggests a tour of Hellas and Argos, promising to escort the younger man himself and to lead him to all the cities: 'Nor will anyone send us away empty-handed, but they will give us something to take away with us, a tripod made of good bronze, or a cauldron, or a pair of mules, or a golden cup' (Od. 15.82-85). Telemachus turns this offer down and returns home to Ithaca bearing only the textile and golden gifts of remembrance. These are described similarly to Odysseus's own xeinia,

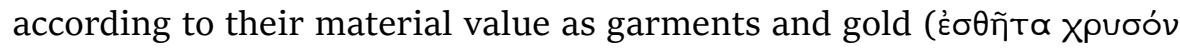
тع, Od. 15.206-7).

Both episodes of memory-related gift-giving appear to display a genderspecific pattern in which metal memorial items are given by men while textile mementoes are given by women. ${ }^{122}$ The latter are also mentioned as intended recipients, as when Helen's peplos is intended for Telemachus's future wife and is to be kept in storage by his mother until it is needed (Od. 15.127-28). ${ }^{123}$ Thus the relationships formed when gifts of remembrance are given involve not only the individuals who are present themselves but also their absent and their future relations. Helen is named as a direct

122. See Pedrick 1988. The commemorative function is now stressed by Mueller 2010, Karanika 2014: 39, and Canevaro 2018: 51. According to Canevaro, Helen's behaviour is unusual 'within their society'. Karanika, however, observes the association of weaving with memory and authoritative female speech and argues: 'The product of one woman's work becomes the locus of memory making'. Mueller (2010: 11) stresses the female character of the network created by textile gifts.

123. Papadopoulou-Belmehdi (1994: 123) interprets the gift of cloth by Helen as a hint at the reconstruction of the bond between Odysseus and Penelope. According to her, both Sparta and Pylos were characterised as places where the ritual language, which was disturbed at Ithaca, is still known. 
recipient of kallima dōra, the golden distaff and the silver wheeled basket that Alkandre, the wife of Polybus, a guest-friend of Menelaus from Egyptian Thebes, had given her (Od. 4.130-32). Polybus himself gave Menelaus two silver baths, two tripods, and ten talents of gold (4.127-28). Later texts also mention feminine objects associated with spinning as gifts given to women. So Herodotus has golden spindles and distaffs as gifts from Euëlthon of Salamis in Cyprus to Pheretime of Cyrene (Hdt. 4.162). ${ }^{124}$ Theocritus has a spindle given as a memento to the wife of the Athenian Nicias (Id. 28.1-25). In Xenophon's Anabasis we find garments given as gifts to Thracian women with the intention of forming a bond of philia (Xen. An. 7.3.17 and 27). ${ }^{125}$

All these types of metal and textile gifts-be they golden cups, bronze tripods and cauldrons, silver mixing bowls, woven chitōnes, pharea, or peploi-are mentioned as xeinia in Odysseus's lying tales when he impersonates the Cretan Aëthon upon his return to Ithaca. He lists an especially long list of gifts when speaking to his father: 'I gave him fitting gifts of

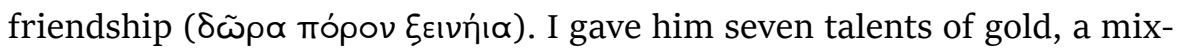
ing bowl made of silver and decorated with flowers, and twelve single-

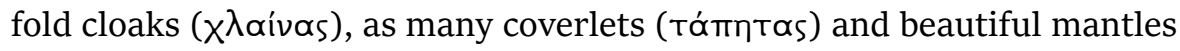
( $\phi \alpha ́ \rho \varepsilon \alpha)$ and as many tunics ( $\chi(T \tilde{\omega} v \alpha \varsigma$ ), along with this he could select for himself four beautiful women skilled in excellent handiwork' (Od. 24.273-79). ${ }^{126}$ The differentiation between the specific types of garment would usually occur only when ransom payments are described, while the giving of skilled women usually occurs when prizes or war-booty are distributed; it is thus fair to assume that the wealth of xeinia listed here are not intended to evoke only guest-gifts but also goods obtained as booty. ${ }^{127}$ The xeinia Odysseus enumerates to his father are predominantly material objects. Speaking to Penelope in the guise of the Cretan, Odysseus also mentions natural xeinia, such as grain, wine, and cattle, which he claims

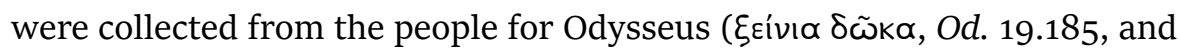

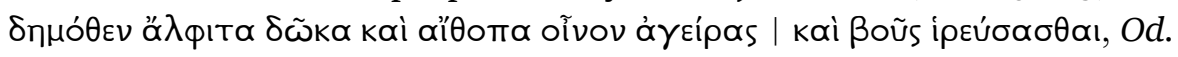
19.197-98). He also mentions specific objects, such as a bronze sword, a

124. An ironic reference to the system of gender roles in the epics cannot be excluded here: Pheretime had asked for an army and received a golden spindle like Helen's in the Odyssey.

125. Barber 1991: 299 interprets spindles of gold and ivory, found in bronze-age graves, as gifts between women.

126. For the different types of clothes see Bieber 1977: 23; Marinatos 1967: 6-15.

127. See ch. 4 . 
beautiful purple cloak, a double diplax such as shepherds and warriors wear, and a bordered chitōn (kaí oi éy

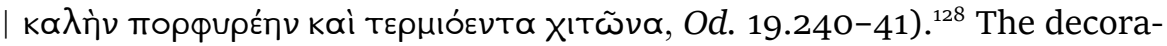
tive epithets point to similar memorial functions as those attributed to Alcinous's golden cup and Helen's peplos.

In Odysseus's house, guest-gifts are spoken of but never described with the term xeinēion or xeinion. So Penelope promises many gifts, polla dōra, to her husband's supposed guest-friend in the event of Odysseus's return (Od. 19.130). These include a sword, clothing, and an escort pledged to Odysseus disguised as the beggar, should he win the bow contest (Od. 21.339-42). Telemachus promises the same-using the same words-when he meets the beggar at Eumaeus's hut (Od. 16.79-81). It is striking that none of the gifts announced by Penelope or Telemachus actually materialise: not a chitōn, nor a chlaina, nor any of the promised garments is handed over, and no promised sword reaches its recipient. The gift, the dōron, offered to Athena in her guise as Mentes by Telemachus is also not actually handed over. Mentes refuses to accept it and promises instead to take a dōron with him on the way back which 'will bring its worth in

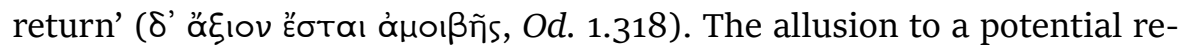
turn gift or reciprocation, entailed in the word amoibe, reminds us that guest-gifts, whether natural goods or material objects, are not part of a one-way flow. ${ }^{129}$ However, just as the exchange of goods between the household and the herdsmen is disturbed at Ithaca, so the normal exchange between guest-friends is also in disarray in Odysseus's household because the suitors are not abiding by the rules of reciprocity, and they do not, as

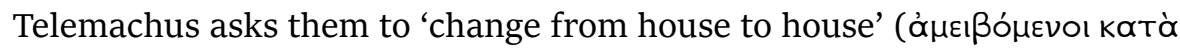
oikkous, Od. 1.375). Similarly, the supposed guest-friend of Odysseus may

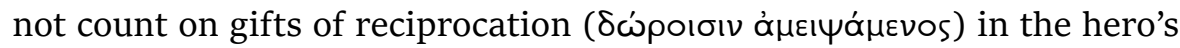
absence, as Laërtes makes sure to tell him (Od. 24.285).

Just like the scenes of granting natural xeinia, scenes of hospitality involving the giving of material goods and gifts of remembrance seem to complement each other. The hospitality of the Phaeacians, unlike the

128. Such a diplax is also worn by Athena at her meeting with Odysseus after his return to Ithaca. Od. 13.222-24. According to Marinatos (1967: 10) and Bieber (1977: 24) a $\delta i ́ \pi \lambda \propto \xi$ was a double $(\delta เ \pi \lambda \tilde{\eta})$ folded $\chi \lambda \alpha i ̃ v \alpha$. See now Harlizius-Klück 2016 and 2019 who has proven by experimental weaving that the diplax must have been a double-faced woven cloth.

129. For the meaning of amoibē as counter-gift see Laum 1924: 31 and Scheid-Tissinier 1994: 37-40. 
Polyphemus episode, acts as a kind of positive antithesis to the disturbed hospitality in Odysseus's own home. ${ }^{130}$ A long time ago, John A. Scott asked why the many and generous gifts of the Phaeacians play no role after the return to Ithaca, even though the hero himself had anticipated that they would bring him much honour when he came home (Od. 11.360). 'Did Homer forget', Scott asked, 'or did he leave all this to the imagination of the hearers?' ${ }^{131}$ The answer has to be: neither.

The bond of guest-friendship with the Phaeacians is not real because they, like Calypso and Polyphemus, belong to mythical landscapes. Therefore, neither Alcinous's cup nor Nausicaa's garments, though handed over as gifts of remembrance, can play any further role as the epic narrative progresses. Through them, and through the xeinia and dōtinē given by the Phaeacian dèmos, Odysseus regains his identity after the shipwreck and his stay in the in-between world of Calypso. The golden cup returns to him his identity as a member of the banqueting community of the kings, or of an aristocratic symposium; ${ }^{132}$ the fresh clothing returns him to his identity as a member of a domestic community; the ability to attract tributes of xeinia and dōtinē confirm his identity as basileus. ${ }^{133}$ The gifts and the godlike honours bestowed on him anticipate the developments in Books 23 and 24: Penelope recognises her husband from the precise description of garments she made herself and of their joint bed and its coverings (Od. 19.215-35 and 23.206). ${ }^{134}$ To his father, Odysseus gives an unmistakable sign of his identity through the memory of the fruit and fig trees, and the vines that he had once given him (Od. 24.336-46). Both times, it is

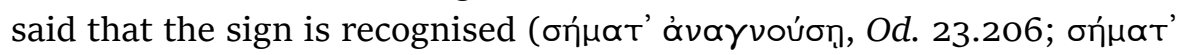
ávarvóvtos, Od. 24.346). In Book 24, Odysseus is reinstated as basileus on Ithaca, and with this regains his position amongst the local leaders and with regard to the demos. Zeus orders the swearing of solemn oaths, which restore the peace between the embattled families of Ithaca and the

130. See the argumentation of Vidal-Naquet 1983: 6o-68. According to him Scheria represents an ideal society. Cf. also Scheid-Tissinier 1994: 171. Doherty (1992: 170) hints at the complementarity in the description of the couples in Scheria and Ithaca. The harmony between Alcinous and Arete can be seen as a prediction of the relationship between Odysseus and Penelope.

131. Scott 1938/39: 103 .

132. Following Gras (1986: 353) Scheid-Tissinier (1994: 115) stresses the connection with the aristocratic symposium.

133. For another view see Scheid-Tissinier 1994: 173. According to her, the xeinia of the Phaeacians were symbols of the warlords' wealth.

134. Wagner-Hasel 1988: 72. 
nearby islands, and orders that Odysseus shall rule for the rest of his life: basileue (Od. 24.483). This is the reason why only Odysseus brings home gifts collected for him by a demos, while Telemachus, who had such gifts offered to him, brings only gifts of remembrance by means of which he has reestablished his father's guest-friendships. Only the basileus has a right to collect gifts from the people. ${ }^{135}$

Just like the fictitious gifts enumerated in the Cretan's tale, the gifts of the Phaeacians never need to be presented at Ithaca because once the hero's position as king and his relationships with Laërtes and Penelope have been reestablished, the domestic community is completely restored. And with this restoration the availability of domestically produced goods, and of tributes paid by the people, is secured.

\subsubsection{The ritual of guest-friendship: Bathing, libation, and dressing}

Almost all those material gifts that hold symbolic significance through their function as mementoes also have specific utilitarian functions within the ritual of guest-friendship. Textiles (chlainai, pharea, rhègea, and tapetes) are used to prepare beds for guests. Chlainai and pharea are used as cloaks as well as coverlets, and chitōnes serve to dress guests in fresh clothes. Linen peploi decorate the chairs used for guests at the Phaeacians' banquet. Golden cups (depas, kypella) such as those given as mementoes to guests are used for drinking wine at the banquet, while a mixing bowl (kratēr) such as that given to Menelaus by Phaidimus, is used to mix the wine. Baths (asaminthoi), tripods, and cauldrons (lebētes), such as those given to both Odysseus and Menelaus, are used for the rituals of bathing and handwashing before the meal. Horses and mules, as promised by Menelaus, are used for the guest's escort or conduct, for the pompe (Od. 15.81 and 17.116-17).

Amongst the paraphernalia of guest-friendship textiles are especially distinguished by qualifying epithets similar to those used for the textile mementoes and xeinia, such as 'purple-coloured', 'finely-wrought', or 'made from wool'. Indeed, ownership of such items is a prerequisite for guestfriendship, as is made clear when Nestor reminds his guest, Telemachus, that it is not possible to host a guest in an appropriate fashion if you have no clothing (aneimōnos), cloaks, and coverlets (chlainai, rhègea). These are Nestor's words on the subject, delivered after the shared banquet at Pylos: 


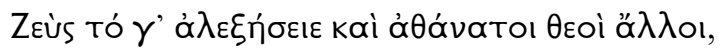

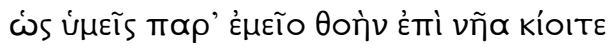

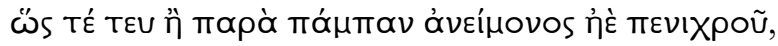

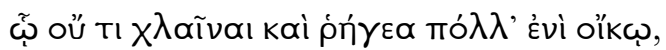

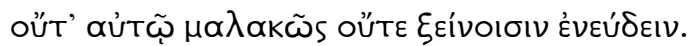

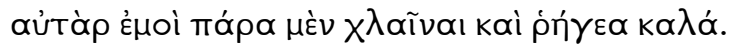
oủ $\theta \eta v \delta$

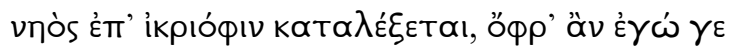

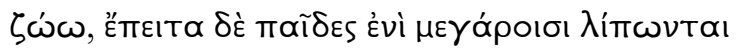

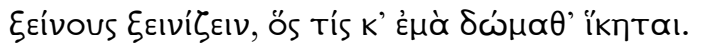

May Zeus forbid this, and the other immortal gods, that you should go from me to your swift ship as from one completely without clothing (aneimōnos), and poor, who does not have plenty of cloaks (chlainai) and coverlets (rhēgea) in his house (oikos), on which he and his guests may sleep softly. But in my house, there are cloaks and beautiful coverlets. Surely the dear son of Odysseus shall never lie down upon the deck of a ship, while I live and while there are children of mine still in the palace to welcome guests (xeinous xeinizein), whosoever may come to my house (Od. 3.346-55).

Eumaeus's shepherds suffer from just such a lack of textile wealth, as they have no chlainai or chitōnes to spare to make up a bed for Odysseus

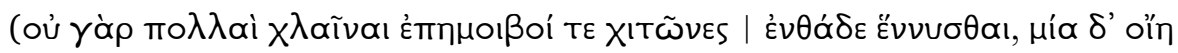

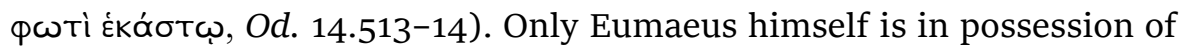
one spare chlaina, which he is able to give to Odysseus as a blanket for the night (14.420). The generous and hospitable Phaeacians have garments to

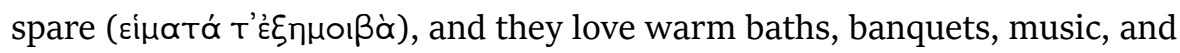
dance, of which the bath especially plays an important role in the ritual of hospitality. ${ }^{136}$ There are two elements to the hospitality ritual in a house such as Nestor's. To begin with, the guest is bathed and dressed, after which there is the communal feast. Both genders are involved, as the bath is the business of either the daughters of the house, or of servant women, variously called dmōiai, dmōiai gynaikes, or amphipoloi. For Telemachus, the ritual is performed by the youngest daughter: 


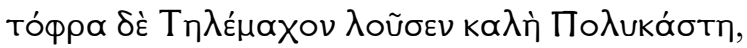

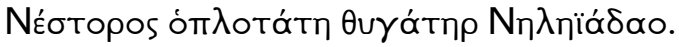

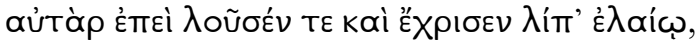

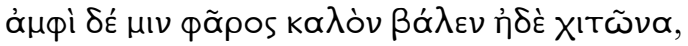

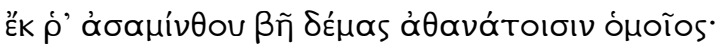

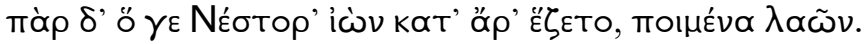

Meanwhile beautiful Polycaste bathed Telemachus, the youngest daughter of Nestor, son of Neleus. Once she had bathed him and anointed him with rich oil and put a beautiful pharos around him and a chitōn, he emerged from the bath looking like the immortals, and he went and sat down by Nestor the shepherd of the people (Od. 3.464-69).

The bath is followed by a feast attended only by men (Od. 3.470-72), with meat roasted on spits and shared out, and wine served in golden cups

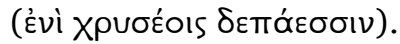

In Sparta the ritual is enacted in a similar manner. Bathing and dressing are dealt with by the dmoiai and amphipoloi, servants whose status is not clear. Telemachus and his companion Peisistratus climb into wellpolished baths; the serving women wash them and oil them, and then clothe them with woollen chlainai and chitōnes (Od. 4.48-50). During the

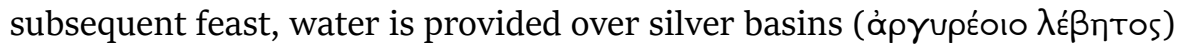

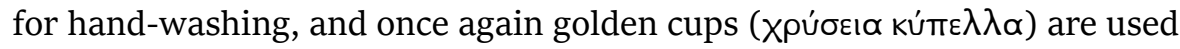
for drinking wine. The carver places platters of meat before the guests, while the tamie, who is in charge of provisions, provides bread and other items (Od. 4.51-55). ${ }^{137}$ Finally (Od. 4.297-99) the women make up bed-

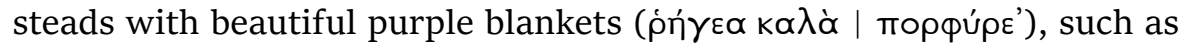
those mentioned by Nestor, along with rugs (tapētes) and woollen cloaks or coverlets (chlainai).

Hospitality rituals at the homes of Circe and Arete follow a similar pattern. In these mythological landscapes, the serving women tend to be called amphipoloi, a term found as early as the Linear B tablets from Mycenaean Greece. ${ }^{138}$ At Circe's house four amphipoloi are responsible for the ritual, each of them in charge of a separate object. Drinking vessels are mentioned, as are textiles, used not only for clothing but also as home decoration, and tripods such as those mentioned as tributes 
from the people. As in Scheria, so here too these are used for heating the bathwater for the guest:

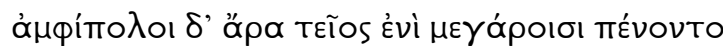

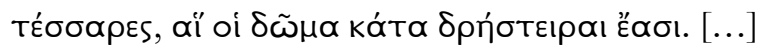

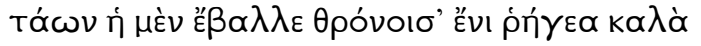

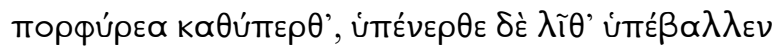

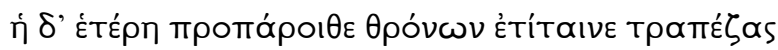

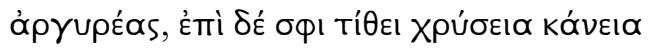

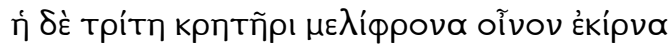

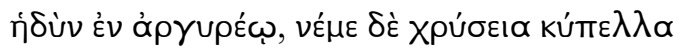

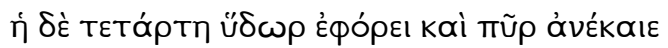

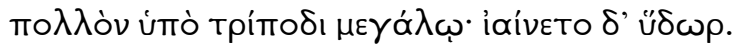

In the meantime her handmaids toiled in the halls, four of them who were her working women in the house. [...] one of them threw beautiful purple rugs (rhègea kala porphyrea) over the top of the chairs, and placed linen cloth (lita) beneath them. Another placed silver tables in front of the chairs, and put golden baskets on them. The third mixed pleasant, honey-sweet wine in a silver mixing bowl and poured it into golden cups. The fourth brought water and lit a fire under a great tripod to heat up the water. (Od. 10.348-59).

The purple rhègea, which had been used for Telemachus's bedstead, as seen above, now serve to decorate the hall in which Odysseus will take his meal. Before this, he is bathed by one of the amphipoloi who heats up his bathwater in the tripod. She places the guest in a bath and then pours the water over his head and shoulders, relieving his weariness (10.361-63). She also dresses him, as Odysseus tells the Phaeacians (Od. 10.364-65): 'When she had bathed me and anointed me with rich oil, she placed a beautiful cloak (chlaina) around me, and a tunic (chitōn)'. His companions, whom Circe has initially turned into swine, will also, in due course, be dressed and receive woollen chlainai and chitōnes (Od. 10.451). Water for hand-washing is brought in a silver basin here, just as in Sparta ('́ayupéoı $\lambda \dot{\varepsilon} \beta$ Tos, Od. 10.369). The tamiē responsible for food brings bread and other items (10.371-72). Bread, meat, and wine are served at the farewell meal (Od. 12.18-19). Calypso, too, grants her guest Odysseus a bath, a 


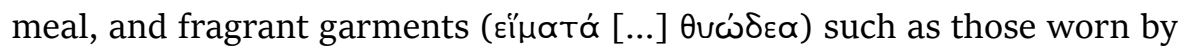
the gods (Od. 5.264; cf. 5.167 and 7.259-6o).

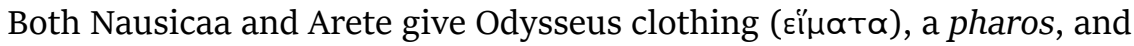
a chlaina and chitōn, respectively, when he arrives on the island of the Phaeacians. On first meeting Nausicaa on the beach, Odysseus considers

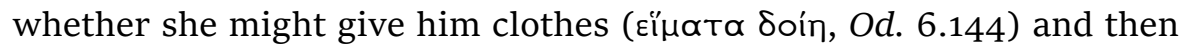
asks for only a rag (ṕókos, Od. 6.178) such as beggars wore. Nausicaa promises clothing (esthètes) if he will come to the city (6.192) but gives him initially, as a small gift (dosis, Od. 6.208), a pharos and chitōn (Od. 6.214), items which Arete will later recognise as garments made by herself and her amphipoloi (Od. 7.234-35). Nausicaa asks her amphipoloi to bathe Odysseus and to give him food and drink (Od. 6.209-10); he will later tell Arete that he received bread and wine (Od. 7.295). Just like Telemachus, whose appearance is enhanced after Polycaste bathes and dresses him, so Odysseus also appears taller and more beautiful after bathing (unassisted) in the river (Od. 6.227-28). The ritual of bathing and dressing is repeated in Alcinous's palace, where Arete's dmōiai bathe and oil him and clothe him in a beautiful chlaina and chitōn (Od. 8.454-55). As at Circe's, the handmaidens, on Arete's orders, place a tripod over a fire in order to heat the bathwater (Od. 8.433-36). After he is washed, Odysseus rises from the bath (asaminthos) and joins the men drinking wine (Od. 8.456-57). The guests' chairs are draped with linen cloths ( $\pi \varepsilon \dot{\pi} \lambda$ o $\lambda \varepsilon \pi т \circ$ i, Od. 7.96-97). Finally, Arete has Odysseus's bed made up with beautiful purple cover-

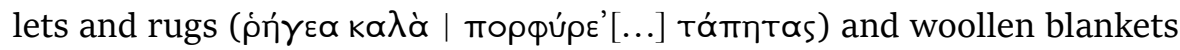
( $\chi \lambda \alpha^{\prime i v a s s ~ o u ̈ \lambda \alpha s, ~ O d . ~ 7.335-38) . ~}$

At Odysseus's house, the suitors take advantage of the rituals of hospitality as they are bathed and provided with chlainai and chitōnes by Penelope's dmōiai (Od. 17.89). But their presence denies the ritual of hospitality to guest-friends of Odysseus, just as it makes impossible the handing over of gifts. Mentes is promised a bath by Telemachus, an offer he rejects just as he rejects a gift from the treasures kept in the house (Od. 1.311-12). Similarly, the supposed guest-friend of Odysseus to whom

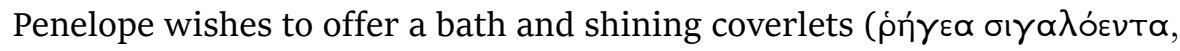
Od. 19.318) must refuse this ritual and make do with a footbath, a bedstead of sheepskins, and a chlaina (Od. 19.335-48; 20.3-4 and 141-43). ${ }^{139}$ Only once he has revealed his identity can the ritual of bathing and dressing be performed in his own home. He emerges from the bath, fitted out 
with a beautiful pharos and chitōn, to be tested one last time by Penelope (Od. 23.154-63). After Odysseus's return, his father also allows himself to be bathed and newly clothed, as he, like his son, had been wearing a filthy old tunic (Od. 24.227-28). His Sicilian maid bathes and oils him, and clothes him in a beautiful chlaina. When he emerges from the bath, Laërtes is also transformed in appearance, and, like Odysseus, he regains his old identity (Od. 24.366-70).

The hospitality rituals described here involve more than merely supplying strangers with appropriate care in providing water and nourishment and a bed for the night. Bathing and dressing are an act of transformation, which effects the acceptance and (re)integration of the stranger into a domestic community. Scholarship has frequently pointed out the transforming effect of the bathing and clothing scene. Wolfgang Schadewaldt and Hans Schwabl and, more recently, Elizabeth Block note the way in which the giving of clothes, especially in the Phaeacian episode, is connected to reestablishing dignity and identity. ${ }^{140}$ In his examination of ancient hospitality, Cristiano Grottanelli discusses the role of the bath as 'ritual of purification and incorporation' comparable to Christian baptism. ${ }^{141}$ Gabriel Herman also describes the hospitality ritual as a 'rite de passage' in his study on ritualised friendship. ${ }^{142}$ But it is not only a matter of the creation of individual identities. What matters is that individual identity is realised through the forging of bonds that emerge through belonging to a household. In keeping with the structure of the Homeric household, both its male and its female members take part in the act of welcoming the new member. But it is through the women's action especially that the transformative effect takes place. The particular bonding function that is ascribed to textiles in the world of Homeric epic goes some way towards explaining this. This is demonstrated through the material content of the word for friendship or belonging, philotēs, and through the terminology used to describe hospitality.

\subsubsection{The terms of hospitality: Xeinizein, komizein, phileein}

The ritual of hospitality is described in terms of $\xi \varepsilon ı v^{\prime} \zeta \varepsilon ı$ (xeinizein),

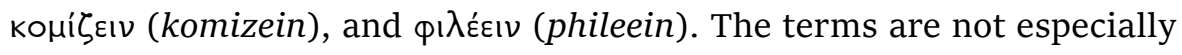

140. Schadewaldt 1959: 13-26; Schwabl 1982: 13-33; Block 1985: 1-11.

141. Grottanelli 1976-77: 191.

142. Herman 1987: 69.

143. The evidence was collected by Landfester 1966: 108-9. 
sharply differentiated from one another, with xeinizein and phileein being treated as identical by ancient lexicographers ${ }^{143}$ and most modern authors. ${ }^{144}$ On closer inspection, however, a tendency towards genderspecific differentiation emerges in these terms, much as it did in the giving of memorial gifts and in the performance of the hospitality ritual. So xeinizein never refers to female actions but only and specifically describes the male act of sharing out meat at the sacrificial banquet, while komizein mostly refers to women's provision of goods from the home, such as food, bathwater, and garments or other textiles. Both terms are linked to phileein, which has a more abstract significance and can describe both the ritual as a whole and its result, the formation of a bond of belonging. Used in connection with xeinizein, phileein can also take on the meaning of the supply of the very items that enable the transformation of the stranger and his integration into a household member, namely the bath and garments.

A striking aspect of the use of xeinizein is that it is often linked to location: mostly this will be the main hall, the megaron, where guests are looked after, but it can also be the oikos, the house itself, or the land or estate. So Penelope questions the Cretan Aëthon, her husband's supposed guest-friend, on the veracity of his claims, and asks if he really 'entertained

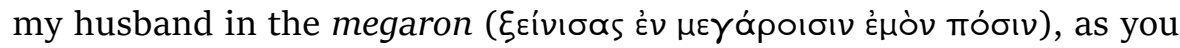
say' (Od. 19.217). ${ }^{145}$ Oineus also entertained Bellerophon in the megaron

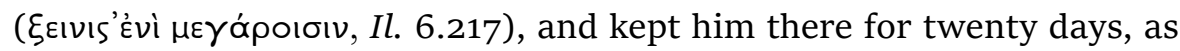
Diomedes reminds Glaucus in the arms-exchange scene discussed earlier. The specification of time is here linked to a specification of the quantity of oxen sacrificed: 'he entertained him for nine days, and sacrificed nine

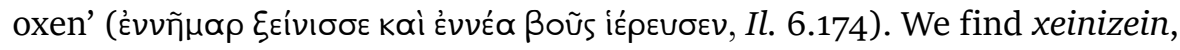
which I translate here as 'entertain', linked explicitly with the formal meal and sacrifice, when Alcinous encourages the Phaeacian leaders to offer hospitality to Odysseus: 'we will entertain the stranger in the megaron and

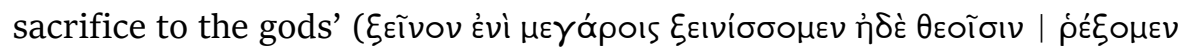
iєpò $k \alpha \lambda \alpha$, Od. 7.190-91). When Nestor speaks of the ability to entertain guests, xeinous xenizein, he links this to the fact that he has sons precisely in the megaron, the place where men feast together (Od. 3.354-55).

When Helen recalls hospitality at Sparta in Iliad 3, it is not the megaron she mentions but the oikos. Whilst watching the battle from the top of the

144. Scheid-Tissinier 1994: 129-35.

145. Cf. Od. 24.288-89. Laërtes asks the stranger how long it was when he entertained

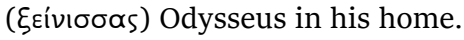


city walls with Priam and Antenor, and identifying the Greek warriors for them, she says of Idomeneus that Menelaus often entertained him in their

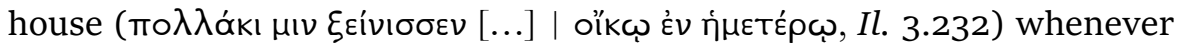
he would come from Crete. However, when Antenor tells of entertaining Menelaus and Odysseus when they came as ambassadors to Troy, he speaks

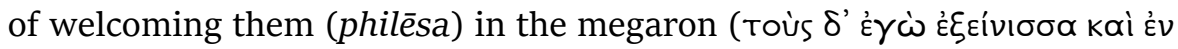

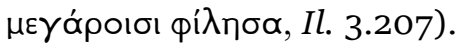

Menelaus also uses the term phileein with reference to Helen's actions. Facing Paris for their duel, Menelaus appeals to Zeus for revenge, so that future men should be afraid to do harm to the host (xeinodokos) who granted them philotēs (Il. 3.354). After the agreement between Greeks and Trojans has been broken, and he has an enemy at his mercy, Menelaus does not spare him, recalling how the Trojans carried off his wife and much treasure, even though, or after, they had been welcomed by her ( $\dot{\varepsilon} \pi \varepsilon \dot{i}$

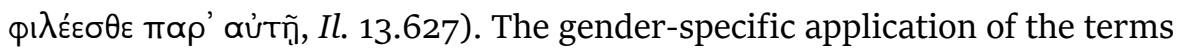
xeinizein (used by Helen for the actions of Menelaus) and phileein (used by Menelaus for the actions of Helen) suggests that the terms refer to two different aspects of the hospitality ritual: bath and dressing, as carried out by women, and the sacrificial feast, as arranged by men. This interpretation is further confirmed by the use of phileein in connection with goods stored in the house, which may allude to the wealth of garments spoken of by Nestor in his welcoming of Telemachus. In his Cretan guise, we find Odysseus telling Penelope (Od. 19.195) how he brought her husband into this house, entertained him well (

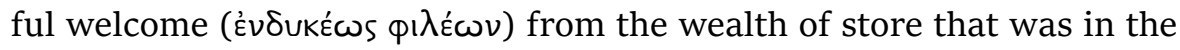

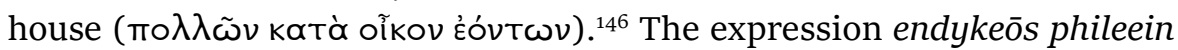
is used also by Telemachus with the seer Theoclymenus. To begin with, Telemachus simply asks the seer to follow him with the promise that he

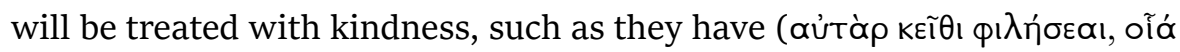
K' É $\chi \omega \mu \varepsilon v, ~ O d .15 .281)$. Subsequently he asks his companion Peraeus to look after Theclymenus in his stead: 'Give him kindly welcome and show him

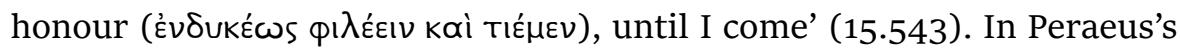
response (15.546) the expression endykeōs phileein is replaced by komizein:

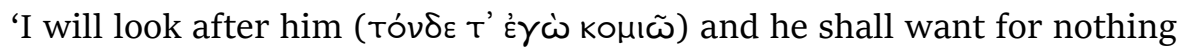

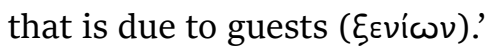

In the context of hospitality komizein is frequently used instead of phileein, often with the concrete meaning of bathing, dressing, and nourishment. 
Telemachus uses both terms, each time with the adverb endykeōs when he tells his mother of the treatment he received at Nestor's home: 'He gave me

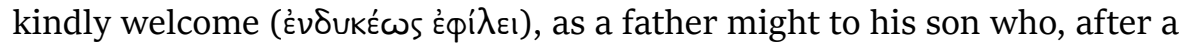
long time, has newly returned from far away. So kindly did he look after me

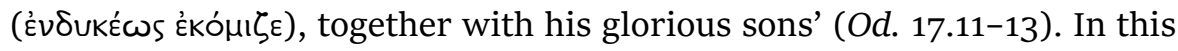
instance it is not possible to say which aspects of hospitality are referred to specifically with the uses of phileein and komizein. There are, however, two other instances that do allow us to define komizein specifically as the provision of bathing and dressing for the guest. Odysseus uses the term in his report to Eumaeus about his stay with the Thesprotians, whose king

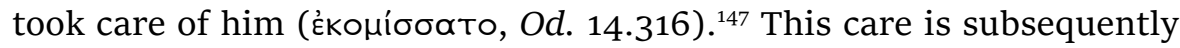
specified in terms of clothing prepared, not as in Phaeacia by the daughter of the house, but by the son who is said to have provided the stranger with chlaina, chitōn, and heimata (14.320). The connection between komizein and bathing is made through the remembrance of Odysseus's stay with Calypso. When he is pleased to see the hot water made ready in Scheria for

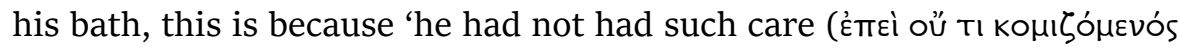
$\gamma \varepsilon \theta$ ám $\zeta_{\varepsilon v)}$ ) since he left the house of fair-haired Calypso, but until then he

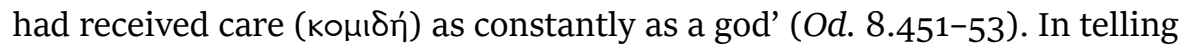
the Phaeacians about Calypso's hospitality, Odysseus uses both komizein

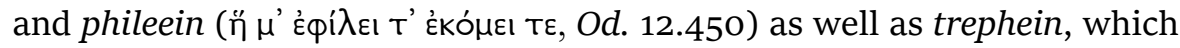
is interchangeable with komizein, to refer specifically to nourishment (

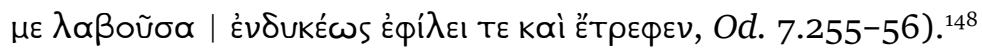

Both clothing and nourishment come into play when komizein and phileein are used for Eumaeus's acts of hospitality when he receives Odysseus in his hut. Odysseus announces his departure in order to test the hospitable

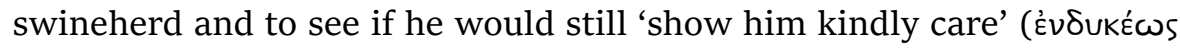

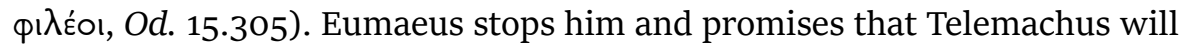
bring him a new cloak and tunic when he comes (Od. 15.338). Once Telemachus arrives at the hut, he lets the swineherd decide whether to keep the

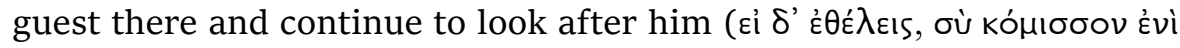

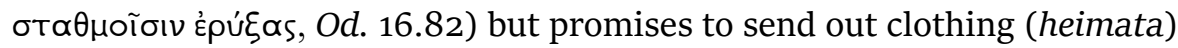
and bread (sitos) so as not to put a strain on the meagre provisions available at the hut (16.83-84). But this is Penelope's business. Eumaeus has

147. See also Od. 16.322. Here the terms phileein and xeinizein are used to describe the hospitality of the Thesprotians.

148. For the meaning of trephein as 'nourish' see $I l .5 .71$. Here it is said that Theano kindly nourished ("̈трєфE) the child of her husband, a nothos. For further mean-

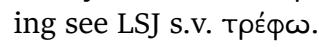


told the disguised Odysseus that strangers come and tell Penelope all manner of stories about Odysseus for the sake of komide, 'care' or 'provision',

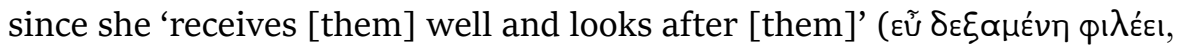
Od. 14.128). The fact that clothing is involved in this case of komide and phileein becomes clear from Eumaeus's next remark, when he suggests that Odysseus also would make up a story if he could get a chlaina, chitōn, and heimata for it (14.132).

While in the two preceding examples we find phileein in a more concrete sense as a synonym for komizein and with the meaning 'to provide with garments', the term mostly encompasses the entire hospitality ritual. This is especially the case when we find phileein on its own and connected to an indication of time, or accompanied by an allusion to the host's wealth: so Odysseus says of his stay at the home of Aeolus, where there was plenty of food and blankets (tapetes) for the beds that 'for a whole month he looked

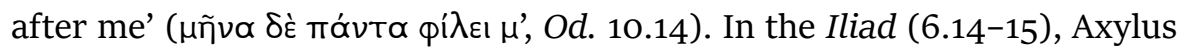
of Arisbe is described as rich in goods (ápveı̀s ßıótoı) and as a friend

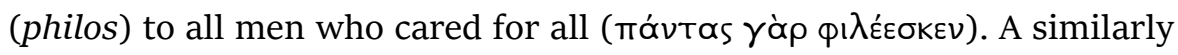
all-encompassing use of phileein is found in Eteoneus's use of the word when the steward goes to ask Menelaus whether he should send the new arrivals, Telemachus and Peisistratus, to someone else who might look after

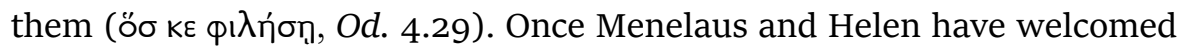
Telemachus, they dress him and feed him, and give him gifts. And Menelaus assures the young man that if Odysseus himself were to come that he would look after him ( $\phi ı \lambda \eta \sigma \varepsilon ́ \mu \varepsilon v, ~ O d .4 .171)$ above all the other Argives. In this case phileein is not meant as temporary hospitality only. 'For I would have given him a city in Argos to live in, and built him a house, after I had brought him from Ithaca with his goods and his son and all his people' (Od. 5.174-76); so, Menelaus offers thanks for Odysseus's support at Troy.

Such a permanent welcome is extended in the Iliad to Phoenix by Peleus in Phthia, after he had fled there in fear of his father (whose lover he had become involved with on his mother's request). Phoenix tells Achilles that Peleus received him with a ready heart and was kind to him (kaí $\mu$ ' '̇ $\varphi^{\prime} \lambda \eta s^{\prime}$ ), as a father is kind to his child ( $\left.\phi ı \lambda \operatorname{rin}^{\prime}\right)$, his only darling child, 'the heir to many possessions'. He adds to this, more concretely, that Peleus 'made me wealthy, he gave me many people, and I lived on the outer border of Phthia, ruling over the Dolopians' (Il. 9.481-84). In this case phileein expresses the formation of a close bond, compared to that with a blood-relative, from which material wealth and a high position ensue. ${ }^{149}$

149. See ch. 4.1. 
Such a close relationship between guest and host is envisaged by Alcinous, when he asks Demodocus to cease his song after Odysseus has broken down in tears:

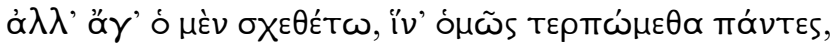

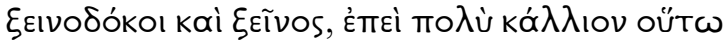

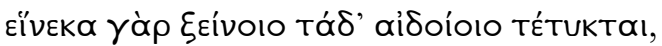

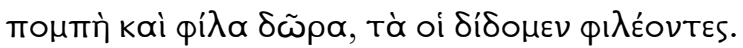

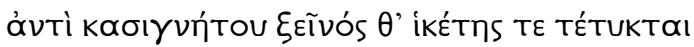

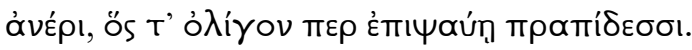

Let the bard stop playing, so that we can all be merry, hosts (xeinodokoi) and guest (xeinos) alike. How much pleasanter this is! For it was on account of our worthy guest (xeinos aidoios) that all this has been arranged, this farewell (pompē) and these friendly gifts (phila dōra) that we give as welcoming hosts ( $t a$ hoi didomen phileontes). To any man with the slightest claim to common sense a guest (xeinos) and a suppliant (hiketēs) is as close as a brother (kasignētos) (Od. 8.542-46, tr. Rieu).

Both the suppliant (hiketēs), such as Phoenix for instance, and the guest (xeinos) are put on a par with the brother (kasignētos), putting the relationship with the guest, and with the suppliant, on an equal footing with blood-relationship. ${ }^{150}$ Furthermore, in this last case, the relationship is also endowed with benefits (phila dōra and pompē). The emotional content of the process, as suggested by E. V. Rieu's translation of phila dōra as 'friendly gifts' is only one aspect of a complex state of affairs. ${ }^{151}$ Both

150. Such a transformation of the foreigner into a temporary relative which took place among the Tallensi in Northern Ghana in 1934 is described by Meyer Fortes 1975: 229-53.

151. Cf. Scott 1982: 9, who argues against a purely emotional meaning and against any connection with altruism: 'Philein is to bring a person within [...] a circle of cooperation whose members have a right to feel mutual reliance, and a right to whatever basic necessities are available for consumption'. Similarly, Dirlmeier (1931: 2829): 'Bei Homer sind auffallend häufig solche Stellen, die einen Affekt ausdrücken und gleich daneben ein Verbum aufweisen, das tatkräftige Hilfeleistung, Fürsorge usw. ausdrückt. [...] Von dieser Einstellung aus, die wir also als ganz ursprünglich ansehen dürfen, ergibt sich ungezwungen die Wertschätzung des Nutzens. Der Utilitarismus bleibt in der griechischen Freundschaftsethik auch in den feinsten Verzweigungen bei Platon und Aristoteles. [...] Wo der Nutzen betont ist, muß folgerichtig auch die Gegenseitigkeit der Leistung verlangt werden'. In more recent studies the emotional aspect is stressed once again. Cf. Hooker 1987a: 55-56. 
phileein and the adjective philos express a social relationship which leads to the giving of gifts such as are deemed fitting for the guest. ${ }^{152}$

To sum up, I would define phileein as acting within the framework of a relationship or bond that goes hand in hand with supplying goods as appropriate to the respective competencies of the man or woman initiating the bond. Furthermore, phileein can also express actions taken in order to form the relationship or bond. ${ }^{153}$ The overall term for all this is philotēs, which we now turn to in conclusion of these reflections on hospitality.

\subsection{Woven textiles, sacrifice, and the formation of bonds: Philotēs}

In epic the key term for friendship is pı $\lambda$ ótns (philotēs). Mary Scott summed up its meaning thus: 'There is either active warfare or philotēs'. ${ }^{154}$ A. W. H. Adkins, who produced a series of examinations of Homeric friendship sees philotès as an opposite of competition and views the essence of philotēs as cooperation. ${ }^{155}$ Peter Karavites emphasises the transformative character of philotēs as a transition from negatively defined relations to positive: 'Philotēs changed the status of the parties from a state of enmity to one of explicit and steady friendship. ${ }^{156}$ Émile Benveniste highlights the

152. Cf. Landfester 1966: 31. He translates phila dōra as 'Gaben an ihn'. Benveniste (1969: I, 348) interprets them as 'cadeaux d'hospitation'. The idea that philein is used to express the existence of a close relationship, implied by the provision of appropriate gifts, is also supported by the use of the term in other contexts. For example: Hermes is said to give property ( $\kappa T \tilde{\sigma} \sigma / 5)$ to Ilioneus, whom he loved

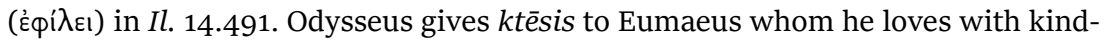

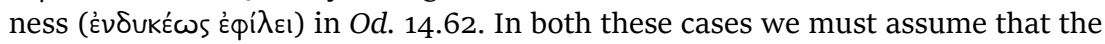
gift in question is cattle. When philein is used in connection with gifts given by women, these will be textile gifts. So Odysseus's mother, who is also said 'to love' ( $\left.\varphi^{\prime} \lambda \varepsilon \mathrm{s}\right)$ Eumaeus, gives him chlainai and heimata (Od. 15.368-70). Where we hear of gods loving their favourites, philein takes the concrete form of success in battle (Il. 7.204 and 280; 16.64). When Odysseus (Il. 10.280) and Diomedes (Il. 5.117)

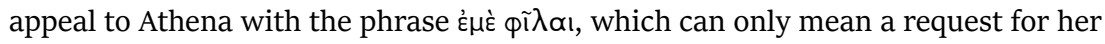
support in battle. Agamemnon and Odysseus can count on gleaming gifts (aglaa dōra) because Hera and Athena favour them respectively (Il. 1.196 and 209 and 213: $\phi ı \lambda \varepsilon ́ o v \sigma \alpha)$. Phoenix allows Achilles to take part in the men's banquet because

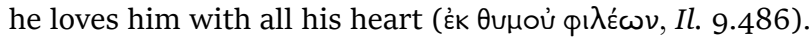

153. For the basic meaning of $\phi ı \lambda \varepsilon \dot{\omega} \omega$ (phileō) as 'gastlich aufnehmen, bewirten, freundlich behandeln', see Landfester 1966: 109. According to Benveniste (1969: I, 344) phileein always goes ahead with reciprocity. For a similar argument see Scott 1982: 9 .

154. Scott 1982: 15 .

155. Adkins 1971: 4; 1963: 34-35; 1960.

156. Karavites 1986: 479. 
reciprocal character of friendship in his examination of the term philos. ${ }^{157}$ In his view, philotēs encompasses the household ('foyer') and hospitality ('hospitalité') within which he includes relations between warriors. A close examination of the term philotēs reveals, however, that its true framework is not hospitality but the integration of strangers in relationships between warriors and within household communities. It is striking that the word is not used for relationships that exist by virtue of bloodline or convention but those which are formed by means of a specific ritual: between men and women belonging to different families, between members of different communities, between strangers and enemy warriors.

In the Iliad the word philotès is frequently used to express belonging to a warrior community. Bonds formed between enemy parties are also defined as philotēs. A warrior's belonging to a community is visible through external signs. So, when Patroclus, equipped with Achilles's armour, joins the ranks of the Achaeans, the troops believe that Achilles has chosen

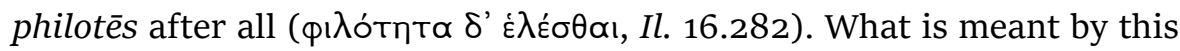
is belonging to the Greek army, from which Achilles had withdrawn after his quarrel with Agamemnon. This belonging cannot only be freely given up, it can also be taken away, as happens to Paris after Aphrodite removes him from the duel with Menelaus. No Trojan would then have hidden him

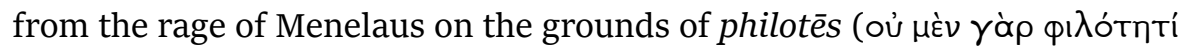

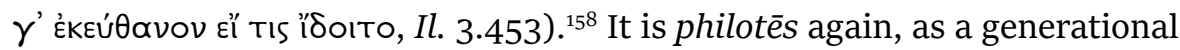
bond, that motivates Ithaca's young men to follow Telemachus to Pylos (oi

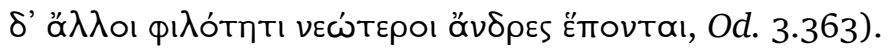

With reference to military enemies, philotēs is arranged by the gods. So, Greeks and Trojans together pray for philotēs after Hector and Paris have

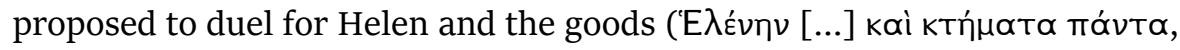
Il. 3.282). In the joint prayer philotēs is used together with horkia, another significant term that points to the means by which the bond of philotess is formed, namely oath and sacrifice: 'grant us friendship and oaths of

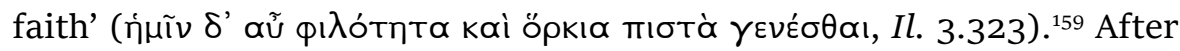
Aphrodite's removal of Paris from the battle, the gods discuss whether to

157. Benveniste 1969: I, 335-53. Cf. Scheid-Tissinier 1994: 133-35. She prefers to differentiate between several social levels of philotēs, the relationship between equals and the ties with people of lower status.

158. Cf. Hector's failed attempt to obtain a guarantee from Achilles that he will return his body in case of a defeat. Achilles rejects the plea, arguing that there cannot be

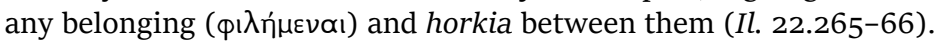

159. Cf. Il. 3.73; 94; 256. 


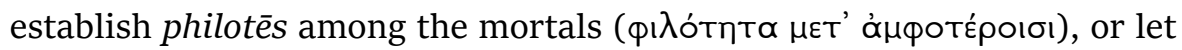
the battle continue (Il. 4.14-16). ${ }^{160}$

The realisation of philotēs, however short-lived, involves objects we are already familiar with from the hospitality ritual. The herald, Idaeus,

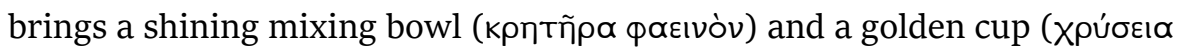
кú $\pi \varepsilon \lambda \lambda \alpha$ ) to the assembly (Il. 3.247-48). Wine and water are mixed in the kraterr and the leaders wash their hands as guests do before a meal (3.269-70). Agamemnon slaughters the sacrificial victims with his sword, just as Nestor does when he receives Telemachus at Pylos, and the others pour libations for the gods (3.292-95). The terms of the agreement are stated, and Zeus and Helios, as well as the shades of the dead, are called upon to witness the oath and to take revenge upon anyone who breaks it (3.267-91). The curse on those who break oaths is repeated during the libations by the warriors on both sides (3.295-301). The swearing and cursing distinguish the ritual performed on this occasion from a hospitality ritual. Nonetheless, there is a connection to the bond of guest-friendship.

The forming of philotēs between Greeks and Trojans serves to restore philotēs between guest-friends. This becomes clear when we see Menelaus, before the start of the duel with Paris, demand punishment for his opponent, so that in the future men should be afraid to do harm to a host who

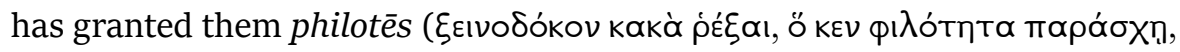
Il. 3.354). In this case, philotēs may allude to the concrete act of hospitality or to the bond that results from it. In the Odyssey we find the latter

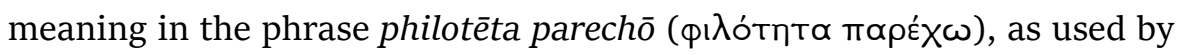
Peisistratus in persuading Telemachus not to take off for Ithaca without allowing Menelaus to complete his hospitality:

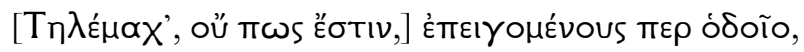

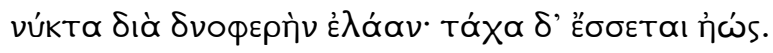

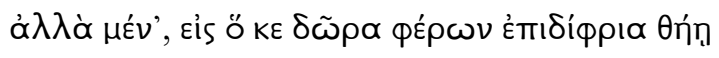

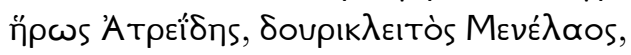

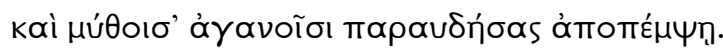

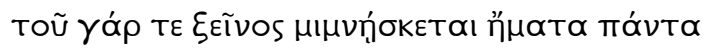

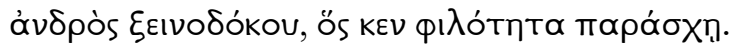

16o. The term used by the gods for the establishment of philotēs is ballein, which is also used for the dressing of a stranger after the ritual bath. When the Greeks and Trojans worry whether the war will continue, or whether Zeus will establish

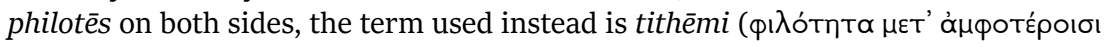
тí⿴囗十。, Il. 4.83-85). 
[...] However eager we may be to start, we cannot possibly drive in complete darkness. It'll soon be dawn. Wait and give the famous spearman Menelaus the chance of putting some presents (dōra pherōn) for us on the chariot and sending us off with a friendly farewell. All his life a guest remembers the host who had treated him kindly (philotēta paraschē) (Od. 15.49-55, tr. Rieu). ${ }^{161}$

The granting of philotēs is linked here to the memory of the host, which leads us to suspect that there is more involved than just the friendly gestures of bathing, dressing, bed, and supper: there must be a specific allusion intended here to the gifts of remembrance which we see in the same book. This would suggest that philotēs, within the framework of hospitality, should be understood concretely as the giving of gifts as well as in a more abstract sense as the bond formed through those gifts.

There are further passages in the Odyssey that show philotēs in its concrete sense as the giving of gifts. Both Penelope and Telemachus promise philotēs and many gifts ( $\gamma$ voíns Theoclymenus (Od. 15.337) and to the beggar in the event of Odysseus's homecoming (Od. 17.164; 19.310). In these instances, philotēs must be understood as emphasising, or doubling, the offer of gifts, without clearly indicating whether a lasting bond is anticipated. In another example of concrete philotēs, Odysseus asks Eumaeus's shepherds for the grant of a

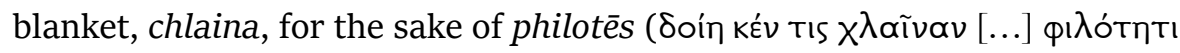
kaì aíరoĩ, Od. 14.504-5). Aeolus lets Odysseus have the bag of winds out

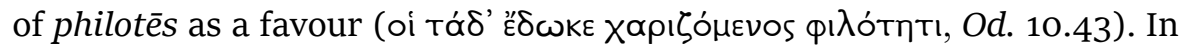
the last two examples philotēs denotes the state of mind that leads to the handing over of gifts by the host. Philotēs may be understood then, within the framework of hospitality, as the concrete granting of a gift which has the effect of a bond or obligation, and also as the state of mind which leads to the granting of the gift.

As we are aware, it is impossible for strangers to receive philotēs at the house of Odysseus while the suitors are freely availing themselves of his goods. Just like Paris's injury of his host Menelaus, the suitors' trespass will be avenged with violence. The threatened outbreak of war after the killing of the suitors, however, is prevented by the formation of philotès between Odysseus and the relatives (philoi) of the suitors, and

161. Scheid-Tissinier 1994: 133 translates: 'qui a donné l'hospitalité' instead of 'who had treated him kindly'. 
their children (paides) and brothers (kasignètoi). This peace is made possible through divine intervention. Using the same words as those used by the warriors in the Iliad, Athena asks Zeus whether he wishes to allow the war to continue or whether he will establish philotēs instead: 'Will you further this evil war and the grim battlecry or will you establish philotēs

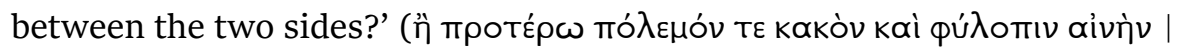

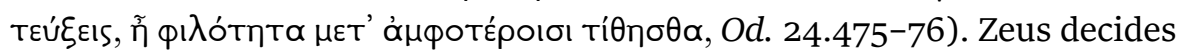

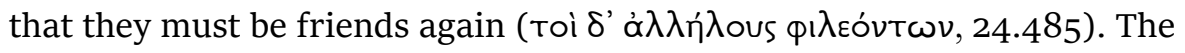
bond between the two sides, described through the noun philotēs and its verb phileein, is established, as in the Iliad, through binding oaths and sacrifice (horkia pista). Zeus adds the decree that Odysseus should rule

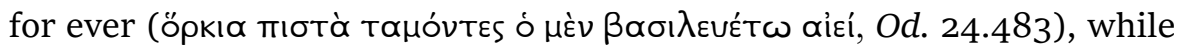
for the other side Zeus decides that they must forget the killing (фóvoı

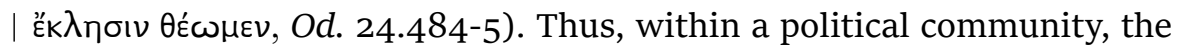
bond is guaranteed not only by ritual but by people, and by the person of the basileus.

While philotēs between enemies is finally realised in the Odyssey, it is made impossible in the Iliad through the interference of a different bond. When Aphrodite has whisked Paris off the battlefield and into Helen's bedroom, he reminds her of the bond of love, which he calls philotēs, that they established on the island of Cranaë after he abducted her:

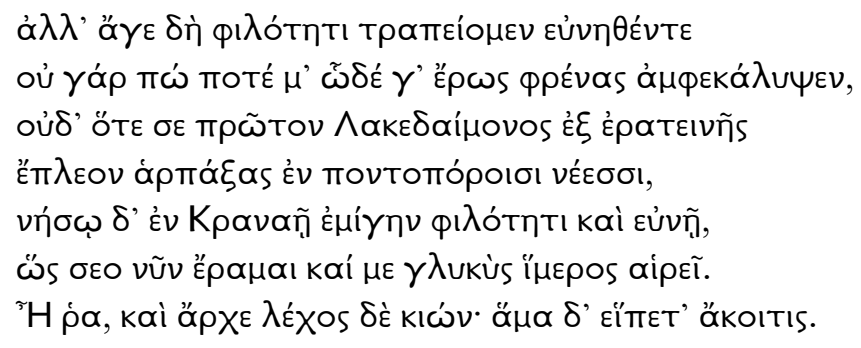

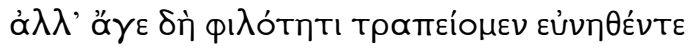

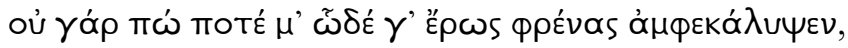

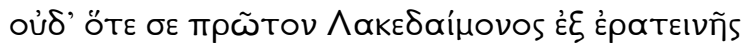

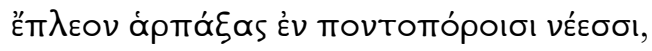

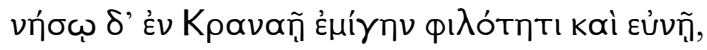

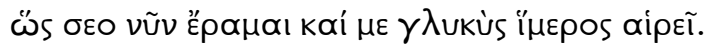

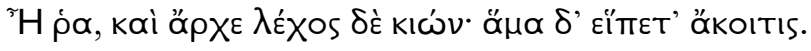

Come, let us go to bed together and enjoy the pleasures of love (philotēs). Never has such desire overwhelmed me, not even in the beginning when I carried you off from lovely Lacedaemon in my seafaring ships and spent the night making love to you (emigēn philotēti kai eunē) on the isle of Cranae-never till now have I felt such desire for you, or has such sweet longing overwhelmed me (Il. 3.441-46; tr. Rieu). 
In the main, philotēs is used as here to denote sexual union. ${ }^{162}$ To exercise this, there is need for a bed, eưví (eunē), and the textiles with which it is dressed. Hera's famous seduction of Zeus gives us an instance of this connection between philotēs and textiles, when Hera turns to Aphrodite for help, under the pretext of wishing to reunite Oceanus and Thetys, but in reality intending to seduce Zeus and keep him off the battlefield:

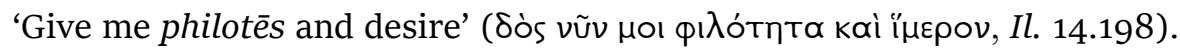

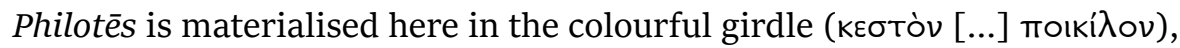
into which is worked philotēs as well as desire, intimacy, and persuasion

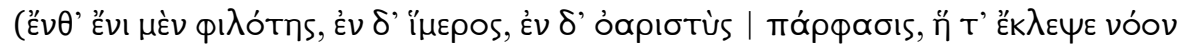

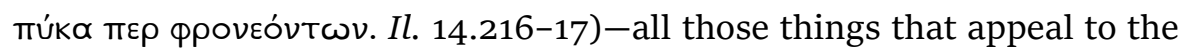
senses: touch, sight, and hearing. Such a girdle is also amongst the items Nausicaa is laundering in anticipation of her wedding (Od. 6.38). In epic poetry and in later texts 'loosening the girdle' often denotes the consummation of sexual intercourse. ${ }^{163}$ Before being married, brides offer their girdle to the goddess Artemis. On vase-paintings depicting wedding rituals, images are occasionally found of brides handing bands, which may depict such girdles, to a man. ${ }^{164}$

The bed and the joint coverlet or cloak are similarly laden with erotic symbolism. Penelope recognises her husband from his knowledge of the bed (eunē), which was fitted out with furs, coverlets (chlainai), and shim-

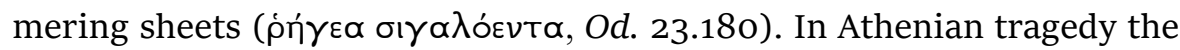

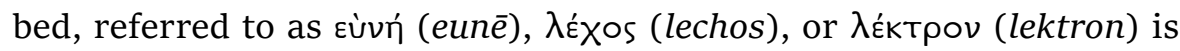
the term used for the bond of marriage (e.g. Eur. Med. 206, 265, 436). In red-figure vases of the same period the bridal procession leading to the wedding couch, dressed with coverlets and patterned cushions, is a

162. Other examples of philotēs as sexual union: Laomedon and the Naiad Abarbarea

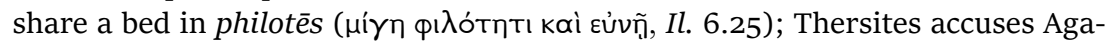

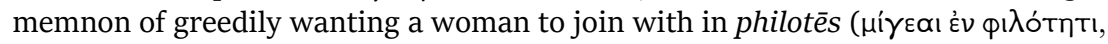
Il. 2.232); the Phoenician nurse of Eumaeus joins in philotēs with the sailors ( $\mu$ í $\eta$

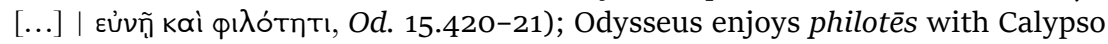

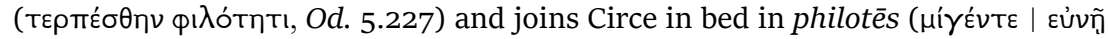

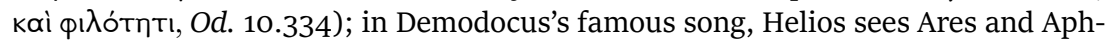

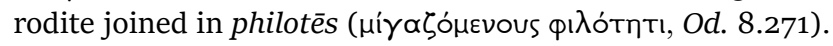

163. Cf. e.g. Hom. Hymn Aphr. 164; Eur. Alc. 177; Anth. Pal. 7.164. For further evidence see King 1983: 120-21; Speyer 1983.

164. Cf. Lissarrague 1991: 169-71, Fig. 5; Oakley and Sinos 1993: Fig. 9; Hampe and Simon 1985: 27-28; Foxhall and Stears 2000: 5 (dedication of the girdle to Artemis). Onians 1989: 368 considers the girdle as an object with magical properties. For the symbolic meaning of the girdle see now Schmitt Pantel 2019. 
prominent motif. ${ }^{165}$ The coverlets themselves have their own symbolism. In Apollonius's Argonautica a peplos like the one given to Telemachus for his future bride serves as the wedding bed for Ariadne and Dionysos (Ap. Rhod. Argon. 4.423-34). Hellenistic epigram has examples of a coverlet, a chlaina, that enfolds two lovers (Anth. Graec. 5.165; 169). In Theocritus's Idyll 18, we find Helen lying with Menelaus underneath a coverlet (ن́riò

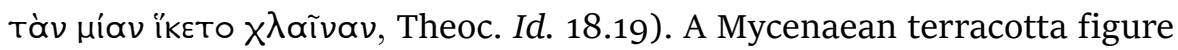
(thirteenth century BCE) depicts a couple in a bed underneath a coverlet. ${ }^{166}$ In classical times, the joint coverlet is found as a motif on drinking bowls (Figure $1 \mathrm{a}$ and b). ${ }^{167}$ It is little wonder then that for Hesiod philotēs is a

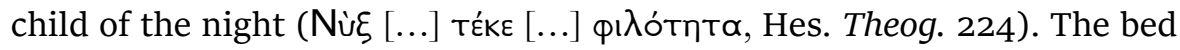
reveals itself as the specific locus of philotēs between the sexes.

We are dealing then with different relationships in epic, which are all formed through specific rituals and symbolised through different objects. Homeric friendship has a material dimension insofar as philotēs is thought of as materialised through objects. The practice of hospitality is only one aspect of the concrete meaning of philotēs. It is true that some of the objects we meet in the ritual of hospitality are also found in the formation of philotēs. When philotēs takes on a concrete meaning, however, it does not mean only guest-friendship but beyond that the bond formed by marriage, and specifically the sexual union of the couple and the symbols of the bond, the girdle, and the joint coverlet. This explains why presents are given to guest-friends when they have a memorial function (as is the case with Helen's peplos given to Telemachus) that consists of just such textile items which symbolise a couple's union. With these items the guest becomes integrated into the bond between the couple, whereas the golden cups, with which libations are poured by leaders and warriors, bind into the supraregional community of warriors. As a relationship, guest-friendship is subordinate to the two central forms of bonds between people: the bond between warriors and that between a couple. It follows then that epic lacks an independent term for guest-friendship, with the one exception discussed in the context of the exchange of arms.

165. Oakley and Sinos 1993, Fig. 24, 104, 109, 122. Xenophon of Ephesus 1.8.2 (ed. G. Dalmeyda, Paris 1962) describes the bed of the bride as golden kline covered with purple cloth (strōma). The canopy (skenē) was a patterned Babylonian fabric with pictures of Aphrodite, Eros, and Ares.

166. Vermeule 1979: 54, Fig. 10.

167. Koch-Harnack 1989: 137, Fig. 6 and 7. Whereas Koch-Harnack stresses the erotic meaning of the common mantle (109-95), Buchholz 1987: 1-20 interprets the garment as a symbol of belonging ('Zugehörigkeit'). 


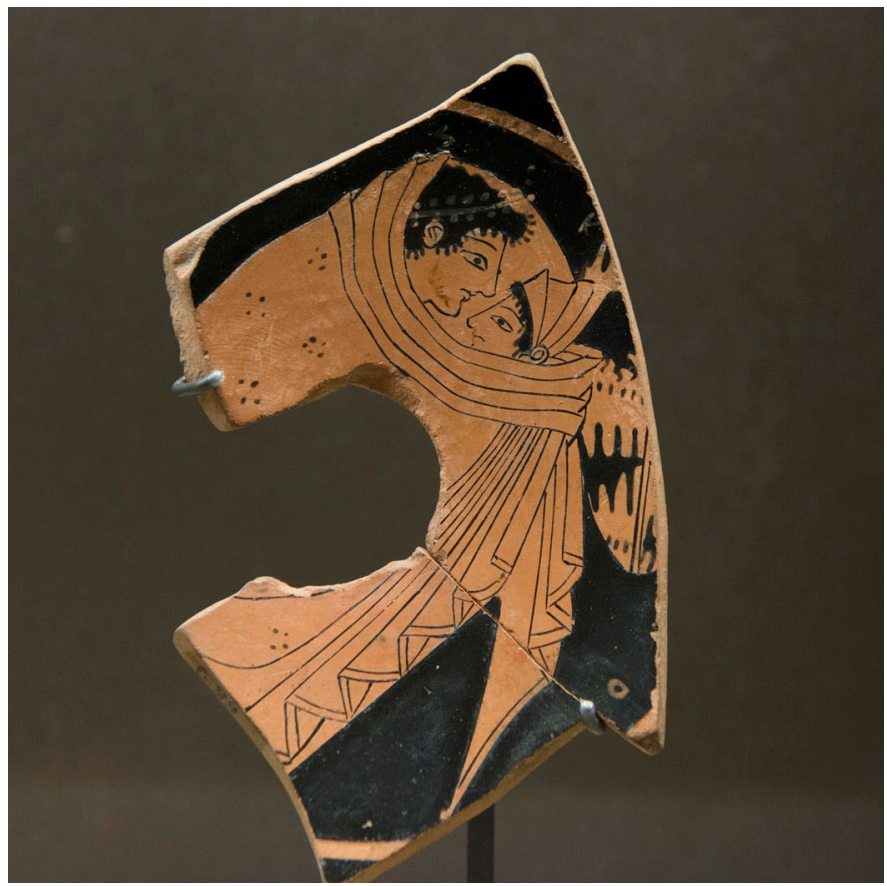

Figure 1a: The joint coverlet. Red-figure kylix. Paris. Louvre G 99. Photo: Egisto Sani, https://www.flickr.com/photos/69716881@No2/9195936448

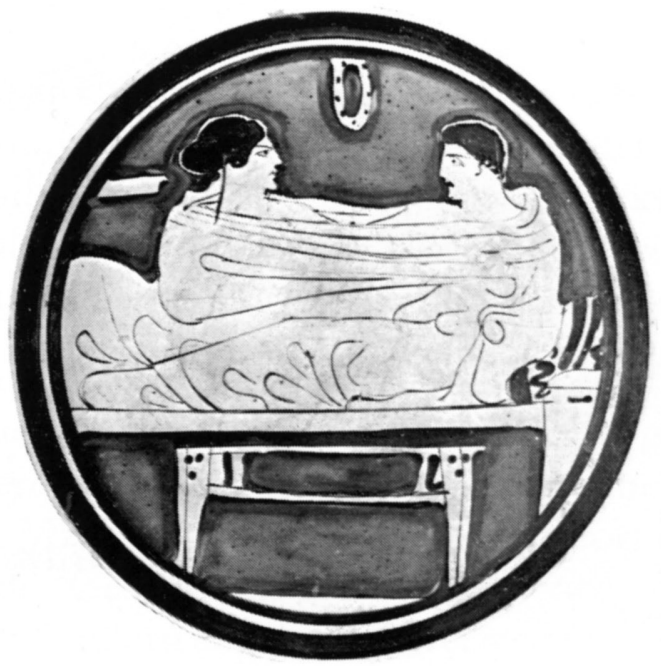

Figure 1b: Couple sitting on a klinē and wrapped in a common mantle. Attic red-figure kylix of the Marlay painter, ca 430 BCE. Vienna, Kunsthistorisches Museum 131. After Koch-Harnack 1989: 137, Fig. 7. 
The gods are approached via both types of bond, through gender-specific means in the forms of animal sacrifice and donation of garments. When the Greeks threaten to overwhelm Troy, the dedication to Athena of a garment or veil is called for by a prophecy, and Hector asks his 'honoured

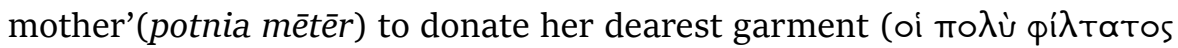
aủTñ). Of the many patterned peploi brought back from Sidon by Paris, Hecuba selects one described as particularly richly coloured and shining like a star (Il. $6.90=271 ; 288-95) .{ }^{168}$ The superlative, philtatos, used here of the peplos in question, usually refers only to relationships between people. ${ }^{169}$ The nouns philos and phile are used in epic poetry to denote all members of a bond called philotēs: these can be participants in a bond formed between warriors via oath-swearing, or relations bound by birth or marriage, or guest-friends, or lower-status members of a household. ${ }^{170}$ Used in apposition, philos or phile are frequent epithets for a guest-friend or for the

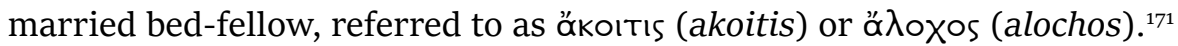
Especially close friends and relations are referred to with the superlative philtatos. ${ }^{172}$ Used in apposition, philos does not have just emotional meaning (as in 'dear') but expresses belonging (as 'own' in English or suus in Latin). ${ }^{173}$ This is true of the passage just quoted where philtatos tells us

168. For the title potnia mètēr, see ch. 4.2.

169. Landfester 1966: 89-99.

170. The most frequent occurrence of philos in the epics is the vocative addressing warriors (see Landfester 1966: 31-33 and 73-74). Priam's philoi are his paides and gambroi, that is direct descendants and in-laws (Il. 24.327 and 331). After he is welcomed in Alcinous and Arete's home, Odysseus is called a philos of the Phaeacians (Od. 13.302); Nestor also calls Telemachus a philos (Od. 3.198). Penelope refers to her servant women as philoi (Od. 4.722).

171. For evidence see Landfester 1966: 21-22; Benveniste 1969: I, 345-46.

172. Dead members of a group of warriors or dead relatives connected by marriage are esteemed as philtatoi. Cf. e.g. the mourning of Achilles after the death of Patroclus (Il. 9.198) and Helen's mourning after the death of Hector (Il. 24.762).

173. There is much debate on the interpretation of philos, and its meaning which can vary between 'one's own' and 'dear to one' or 'loved'. Some see the reasons for this difference in historical change, suggesting either that possessive meaning (one's own) gave way to emotional meaning ('dear to one') or vice versa. Paul Kretschmer 1927: 267-71 and Eric Hamp 1982: 251-62 assume an original meaning in the sense of the Latin suus. Hooker 1987a: 44-45 argues the opposite, assuming that philos originally had emotive meaning which became attenuated over time. In this he disagrees with Adkins who argues that philos denotes anything used in battle to protect the oikos. Hooker also disagrees with Benveniste (1969: I, 341-43) according to whom philos plays a role wherever there are reciprocal relationships of obligation. Such contradictions dissolve if one understands philos as used for the purpose of denoting belonging, so that both emotional and material 
that the item to be gifted to the goddess is close to the person dedicating it, that it is her own (suus). ${ }^{174}$

With the dedication of the peplos, carried out by the priestess Theano, the Trojan women place themselves and the community under the protection of the goddess. They promise the sacrifice of twelve oxen in the event of a good outcome (Il. 6.274). Such animal sacrifices are also described as phila dōra. And philos in this case does not denote just worth: we may understand phila dōra as gifts that are dear to the gods as well as gifts that are their own, or belong to them. ${ }^{175}$ When Zeus expresses himself in favour of an appropriate burial for Hector during the quarrel over his body, the god's reason is that Hector always provided phila dōra ('̇твi oú

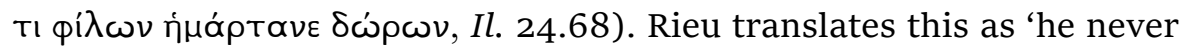
failed to give me what I like', suggesting both the personal and the possessive meaning of phila in this context. ${ }^{176}$ What is meant, however, is the portion of the sacrificial meal that forms the tribute to the gods, the geras (Il. 24.69-70). ${ }^{177}$ Hector's closeness to the gods is achieved through this geras, as Zeus makes clear in stating that of all those who live in Troy, he is the dearest and the closest to the gods (

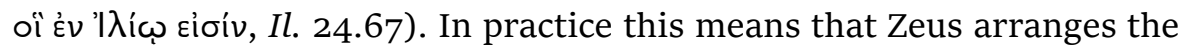
release of Hector's body in exchange for goods (metal and textile) from

or possessive connotations are relevant. Dirlmeier (1931: 7) argued this in defining philos as a pronominal possessive adjective that expresses a relationship of belonging, although he rather overemphasises familial blood-ties.

174. See Willenbrock 1969: 61 in the context of weaponry.

175. Gifts owed to the gods and to Odysseus the stranger are described as qi $\lambda \alpha$ (Il. 24.68; Od. 13.41; 8.545). The gift (dosis) Odysseus receives from Nausicaa (Od. 6.208) and Eumaeus (Od. 14.58) is said to be modest but phile. The geras Achilles wishes to take home with him is also small but phile (Il. 1.167). Where the term philos is used adjectivally to describe objects or material goods, it mostly refers to things that are close to, or belong to, an individual-be that the home (Od. 18.421) or the paternal lands (Il. 9.414), one's bed (Od. 8.277) or one's own clothes (Il. 2.261). Used predicatively, the term philos also denotes fields of activity related to the bonds between warriors and guest-friends. So strife, war, and battle are as dear to Hera and Ares as they are to Achilles (Il. 5.891; 2.177) The hospitable Phaeacians on the other hand are fond (phile $)$ of banquets, music, dance, clothes, warm baths, and beds (Od. 8.247-48). Speeches are dear (philoi) to Priam, although given the impending attack by the Greeks, this fondness cannot be indulged (Il. 2.796). On the phrase qí̉ov Ěstív see more fully Landfester 1966: 95-98; 105-8.

176. Landfester (1966: 30) here translates phila as follows: 'denn er hat es nicht an Geschenken an mich fehlen lassen'.

177. See ch. 4.2. 
Priam's household (Il. 24.229-35). ${ }^{178}$ In moving the angry Achilles, through Hermes, to accept the lavish goods, Zeus is keeping his bond of philotess with Thetis, who acts in support of her son. It is because of this bond that Zeus rejects the other gods' idea of removing the body in secret from the Greek camp (Il. 24.211).

The dedication of garments and the sacrifice of animals complement each other. Both rituals establish close relationships with the gods, based on (not always realised) reciprocity. ${ }^{179}$ The dedication of the peplos is intended to establish a relationship, but the intention is not achieved, as the goddess denies her protection. ${ }^{80}$ The sacrifice promised by the women is meant as thanks for the favour expected as a result of the relationship. In using the specific symbols associated with the two central forms of bond between humans to establish closer ties with the gods, the gods are themselves integrated into the system of philotēs, allowing it to gain its own transcendence. We will discover that the death ritual aims to reproduce just this structure.

178. These goods are called apoina. For the meaning of this term see ch. 5.2.

179. Benveniste (1969: I, 343-44) rightly underlines reciprocity, without excluding an emotional component. See also the following chapter.

180. In the Odyssey Aegisthus unsuccessfully seeks divine protection by hanging up fabric offerings (hyphasmata) in the temple (Od. 3.274). 


\section{CHAPTER 3}

\section{Structures of Reciprocity and the Production of Signs: Charis and the Charites}

W hile Zeus keeps watch over the laws of hospitality, reciprocity is the business of the Graces, the Charites, who almost always appear as a group and are similar to the Muses. Aristotle tells of shrines dedicated to them in order to ensure the maintenance of antapodosis, or recompense

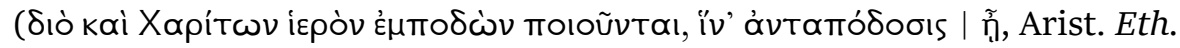
Nic. 1133a3-4). 'For this is the special characteristic of charis', Aristotle says, 'since it is necessary not only to repay the person who has shown charis, but another time to be first in giving charis oneself' (тoũ to yà $\rho$

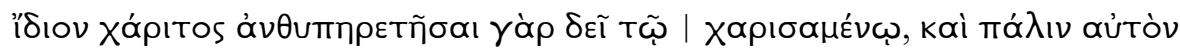

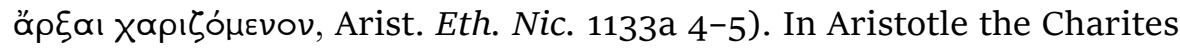
embody charis, the action or attitude which can denote a service rendered, a favour, or a material gift, and the action or state of mind described by the verb charizomai. Karl Polanyi calls this 'reciprocity on the square'. ${ }^{1}$ The Charites guarantee the flow of giving and reciprocation which for Aristotle is a matter of just balance. Stoic philosophy accordingly receives the Charites as the personification of reciprocity. ${ }^{2}$

In epic charis occurs in the context of any relationship or bond: between warriors, in marriage, and in relationships between humans and gods. ${ }^{3}$

1. Polanyi 1957b = 1968: 110. See also Vernant 1966: 131; Meier 1985: 29-30; Bodei Giglioni 1989-1990: 55-64; and MacLachlan 1993: 49-51. According to Jesper Svenbro (1976: 164), Aristotle's remark is relevant to the ethics of repayment of services by a misthos rather than to the concept of gift-giving. For the worship of the Charites in Athens, see Pirenne-Delforge 1996: 195-214, who discusses their role in the context of marriage and the oath of the ephebes. For the relationship of the Graces with civic festivals see Fisher 2010.

2. MacLachlan 1993: 51. For the reception of the Charites in Greek philosophy, see Deichgräber 1971: 51-59. For archaeological findings, see Schwarzenberg 1966.

3. On the connection of charis with philotēs see Scott 1983: 12: 'charis is used of the pleasure to be found still within the relationship of philotēs, friendship, but outside the context of an exchange of gifts [...] the exchange of charites arises as a consequence of the realisation that one cannot survive alone, that one needs others'. 
Charis can here denote a variety of acts: a military service rendered, and the thanks expected for it; a labour of love; divine favour. ${ }^{4}$ The Charites themselves are connected with the more specific field of the production and giving of textile gifts whose symbolic meanings were discussed in the previous chapter. In the divine sphere the Charites see to Aphrodite's bathing and dressing, and they produce her patterned garments. In the world of epic they do not, then, represent a personification of abstract ideas but embody concrete actions, which in the human sphere are undertaken by amphipoloi and serving women. ${ }^{5}$ In what follows I will investigate the three forms in which charis is afforded: the warrior's service, the favour of the gods, and the service rendered by amphipoloi and Charites. Following from this, I will turn to the role of the Charites and to the significance of their services in Greek memorial culture.

Apart from its range of meanings connected to the senses of 'favour', 'grace', 'kindness', and 'thankfulness', charis has a further semantic dimension as the visual effect emanating from a person or speech. This is often rendered as 'loveliness' or 'charm'. Joachim Latacz rightly characterises this aspect of charis as 'drawing-all-eyes'. ${ }^{6}$ Scholarship is divided on the question of priority between the two semantic fields of charis. Évelyne Scheid-Tissinier assumes an original meaning connected to favour and thanks, ${ }^{7}$ while others focus on the visual aspect of charis and propose an original meaning of 'shine' or 'light'. ${ }^{8}$ Bonnie MacLachlan's interpretation of charis as reciprocal 'social pleasure' is an attempt to contain the range of meanings within one common idea. ${ }^{9}$ But the contradictions can be more easily resolved through a focus on the concrete actions of the Charites, and in particular by considering the central importance of their weaving. A careful analysis of those situations in which charis acquires the meaning of

4. For evidence see Latacz 1966: 78-98 and Scheid-Tissinier 1994: 30-36.

5. See the argumentation of Deichgräber 1971: 9. Zilienski 1924: 158-63 identified them as goddesses of the dead (Totengöttinnen); their chthonic character is stressed by Scott 1983: 1-2. MacLachlan 1993: 39-54 underlines their connection with festivities, especially with marriage and the cult of the dead. Like Athena they are worshipped as patrons of the skill of weaving. See Anth. Pal. VII 726. In Sicily their names are found on loom-weights. See Isler 1994: 104-6.

6. Latacz 1966: 82.

7. Scheid-Tissinier 1994: 35-36, 258-61.

8. See Borgeaud and MacLachlan 1985: 5-14, who stress a connection between bal-

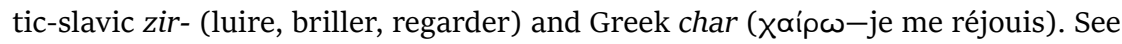
also MacLachlan 1993: 4-7, 52. According to Scott (1983: 2) charis goes back to the verb chairō (I rejoice). She defines charis as 'source of pleasure'.

9. MacLachlan 1993: 147. 
an outward shine or luminosity shows that the brightly patterned weavings produced by the Charites can be interpreted (alongside images and reliefs worked in metal) as a significant medium for the visual power of charis. Once charis is understood as the light or visual power that radiates from a woven image, especially of a red colour, it is easy to see how such visual power can also be spoken of with reference to the charis of a speech or song (as for instance in Homer, Pindar, or Bacchylides). As we saw in the first chapter, poets also create images, or visual effects, which are inscribed in the memories of their audiences.

To properly illustrate the material dimensions of this meaning of charis we must consider ancient techniques of polychrome weaving, which have acquired new cultural significance through research by Elizabeth Wayland Barber. ${ }^{10}$ Scholarly research into cultural memory has mostly turned to the medium of writing as a form of storing such memory. It is clear from the observations made here, however, that patterned weaving provides another form of storing and commemorating knowledge. This memorial function helps to explain the prominent role played by the Charites in classical Greek festival culture. Alongside the recitation of memorial texts of social significance (as for instance the epics recited at the Panathenaia), the Charites were responsible for visual aspects of the festival. In charge of the proper arrangement and ritual configuration of the participants, and of the effectiveness of the poetically produced images, they contribute significantly to society's sense of its own order. Misunderstood as goddesses of death or fertility, the Charites' responsibility for the visual in fact means that they possessed an important integrative function, which is inadequately described through the notion of reciprocity.

\subsection{The warrior's service and the gods' favour}

In epic poetry charis frequently denotes a military service rendered and the thanks given for such service. The phrase Xápıv фépєıv (charin pherein) describes the performance of a military service or favour for a person (or in the case of the gods, the granting of favour) which may ensure success in battle. The giving of thanks for military success or for divine favour is

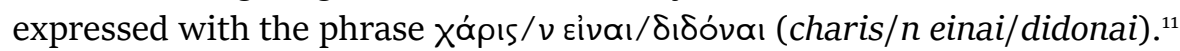

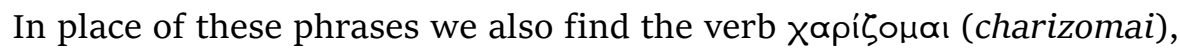

10. Barber 1991.

11. Scheid-Tissinier 1994: 30-36. 
rendered by Joachim Latacz as 'eine erfreuende Leistung erbringen' ('to afford a pleasing or agreeable service'). ${ }^{12}$ Used with the dative, charizomai denotes kindness or favour done for a person's benefit; with the accusative it frequently expresses the offering of favours or gifts in return for favours or gifts received.

Pandarus, for example, comes from Lycia to support the Trojans against the Greeks 'to do a favour to heavenly Hector' ( 5.211). The Trojans themselves, when they set fire to the Greek ships, are fighting 'to please Hector, stirred up by him' ( $\chi$ ápıv "Ектороs óтрúvavтоS, Il. 15.744). Odysseus's support of Agamemnon is also described with the phrase charin pherein. Odysseus, in danger of shipwreck and drowning, laments his imminent fate and praises the Greeks who found honourable death at Troy as they were 'doing a favour to the sons of Atreus' ( $\chi$ ópıv

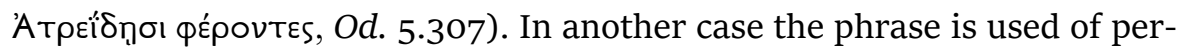
suasive speech in the leader's favour rather than military support. When Phoenix attempts to persuade Achilles to abandon his wrath and return to arms, Achilles accuses his friend of doing Agamemnon a favour ('Aтреí $\delta$ n] ñ and sorrow.

The verb charizomai is also used in the context of armed service, as in the cases of Cleitus and Hippomachus who fight against the Greeks 'doing

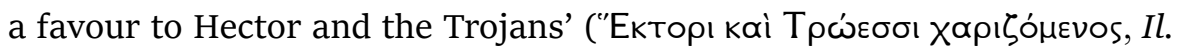
$15.449 ; 17.291)$. There is one single occurrence of charizomai describing the granting of a material gift in the context of military support. The thōrax worn by Agamemnon in Iliad 11 is a gift, xeineion, from Kinyras of Cyprus, sent 'to give pleasure to the king' ( $\chi \alpha \rho ı \zeta$ '́ $\varepsilon$ vos $\beta \alpha \sigma ı \lambda \tilde{i} i, ~ I l .11 .23$ ) when the news of the campaign against Troy had reached Cyprus. It is not clear whether Cinyras's gift is in fulfillment of obligation as a form of tribute, or a service for which he might expect to receive a return. It is possible that Cinyras's gift is in lieu of actual military service, similar to the gift of the horse Aëthe, given to Agamemnon by Echepolus of Sikyon so that he might stay at home and enjoy his wealth instead of joining the campaign to Troy (Il. 23.293-300). ${ }^{13}$ We also hear, however, of the similarly wealthy

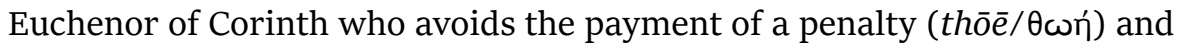

12. Latacz 1966: 104 .

13. Therefore, he is characterised as 'Ahnvater der Drückeberger' ('father of all shirkers') by Andreadas 1931: 14, n. 14. Nilsson 1927: 29 deduced a feudal system of military service, which is now replaced by the idea of reciprocal relationship. See Scheid-Tissinier 1994: 256. 
joins the campaign even though his death is foretold (Il. 13.663-72). The thōe is a penalty imposed by a collective-in this case it would be the Danaans-which in classical times became due when, for instance, the laws of mourning were contravened. ${ }^{14}$ The seer Halitherses is also threatened with thōe by Penelope's suitors when he speaks in favour of Telemachus (Od. 2.192). It makes sense then to assume that there are degrees of obligation to support a military campaign, as we also see in the Odyssey. Odysseus distinguishes between giving service to others, for which charizomai is used, and taking part in war independently and with one's own allies, when he says that he did not wish to offer service to Idomeneus's father as an

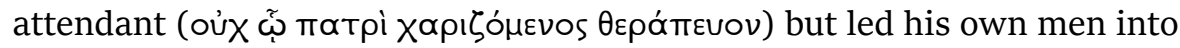
battle against Troy (Od. 13.265).

Warriors are described on a number of occasions with the perfect participle form of charizomai, suggesting a relationship of service between war leaders and between a leader and his men. Close companions are of-

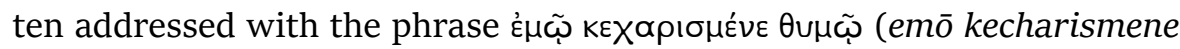
thumō) which carries emotional overtones suggesting intimacy and can be rendered as 'dear to my heart'. ${ }^{15}$ Diomedes is such a kecharismenos to Agamemnon, as are Sthenelus and Patroclus to Achilles (Il. 10.234; 5.243; 11.608). The phrase is also used for bonds between humans and gods, as when Athena describes Diomedes as kecharismenos (Il. 5.826). Since the perfect tense denotes an action completed or repeatedly completed in the past, the effects of which continue in the present, a kecharismenos (literally: one who has provided a service or favour) must be, in a military context, one who continues to do military service. ${ }^{16}$ The term is used in the context of other bonds, such as those between or within households, which are also characterised by continuity but which are initially formed by performance of a ritual (e.g. the bond between a father-in-law and his potential son-in-law, offering bridewealth). ${ }^{17}$ Emotional bonds form a part of such lasting relationships of service, and a kecharismenos must

14. See Vatin 1987: 275-80, with further evidence.

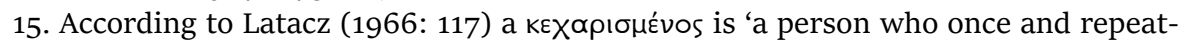
edly rendered me a service which was pleasing to me, and who is therefore now himself pleasing, welcome, dear, etc'. The transition from 'one who rendered me something pleasing' to 'one who is pleasing to me' may not make strict grammatical sense, but psychologically it is immediately understandable.

16. Latacz 1966: 116-20. See also MacLachlan 1993: 29, n. 23.

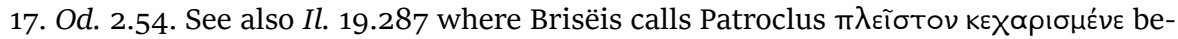
cause of his promise to arrange her marriage to Achilles. Patroclus would have taken the role of the father of the bride. 
be considered someone whose service gives rise to positive emotion; this becomes clear in a remark made by Alcinous when Odysseus is crying during Demodocus's recital. Alcinous asks Odysseus whether a companion of

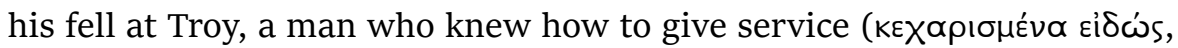
Od. 8.584). In this instance it is not the warrior himself but his service that is described using the perfect participle of charizomai. The choice of the participle instead of the noun charis clarifies that the service is not rendered once but repeatedly and continuously. Odysseus's grief shows that such service given continuously is understood in terms of an emotional bond, which also fits with the fact that the life of the warrior involves not only fighting together but also communal feasting. ${ }^{18}$ The idea of a continuous bond is also strengthened by the fact that comrades in arms can be described in terms of blood-relations, such as kasignetos (brother), even though kinship does not feature in the structure and organisation of the Homeric armies. ${ }^{19}$

In the past, scholars such as Martin P. Nilsson, Gustave Glotz, and Henri Jeanmaire interpreted Homeric armed service in terms of feudal military obligation and thus considered Agamemnon as an over-lord over the vassal-kings subordinated to him. ${ }^{20}$ The model of military obligation, and of Agamemnon as feudal lord, seemed unlikely to scholars like Erich Bethe and Gunther Jachmann who believed that alliances were formed through missions sent abroad. ${ }^{21}$ Moses I. Finley, whose rejection of the idea of feudal kingship was the most radical, argued in a similar way in his study The World of Odysseus. ${ }^{22}$ Since then a number of studies have underlined the mostly voluntary character of Homeric military service with its emphasis on reciprocity; most recently the observations made by Hans van Wees show that it is best understood in terms of friendship (i.e. philotēs). ${ }^{23}$

As military service charis may then also be denied when it is not appropriately returned, for instance with a portion of booty or with a return service. So when Hector hesitates to fight over the body of Patroclus whose armour he has already appropriated, he is taunted by the Lycian

18. Il. 17.576. For further evidence see Ulf 1990: 132-33; Scheid-Tissinier 1994: 27274. See also ch. 4.

19. Ulf 1990: 131.

20. The former positions are presented by Carlier 1984: 179-82.

21. Bethe 1931: 229-30; Jachmann 1953: 243. See also ch. 4.1.

22. Finley 1967: 109-11.

23. Van Wees 1992: 44-48. The concept of feudal kingship is rejected by Ulf 1990: 85-98, who denies that there is complete reciprocity between warrior and leader (128), whereas Scheid-Tissinier 1994: 258-59 stresses the reciprocal relationship. 
chief, Glaucus, who announces that no Lycian will continue to fight since

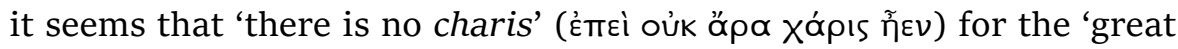

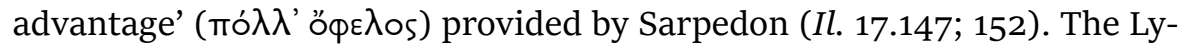
cians want Patroclus's body in order to exchange it for that of Sarpedon, which is in the hands of the Greeks. Achilles too justifies his own refusal to fight for Agamemnon after Brisëis has been taken from him by pointing out that there is no charis (oủk öpa Tis Xápıs ñ£v, Il. 9.319). ${ }^{24}$ In both instances charis is easily rendered as 'thanks'. There are, however, two types of thanks suggested. In the Lycians' case it is a matter of returning the favour of military support in kind, by fighting for the body of Patroclus; in Achilles's case charis is a portion of booty due to the warrior as a gift of honour (geras) in the form of a woman. ${ }^{25}$ For Pandarus, there are more material gifts in play, when the Trojans promise him thanks ( $\chi \alpha \dot{\alpha} \rho\llcorner$ )

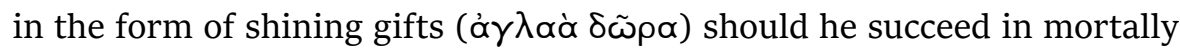
wounding Menelaus with an arrow (Il. 4.95-97). ${ }^{26}$

Reciprocity is especially prominent when charis is demanded for a previously offered service. In such cases charis as thanks does not take the form of a service rendered or gift given in return for military service. Instead, in a kind of inversion, charis can involve refraining from violent or military action. This happens on a number of different occasions when the Trojans Adrastus, Dolon, and Hippolochus ask Achilles to spare their lives, offering a ransom (apoina) in return. Each time, the immeasurable apoina of bronze, gold, and iron is the means by which the warrior's father will show his charis (Xapíoaıto: Il. 6.49; 10.380; 11.134). The potential offer of material goods is clearly meant to be understood as based on reciprocity: it would only be realised if Achilles were to agree to spare the life in question. Another example of charis in the sense of sparing is seen when the suitor Leiodes asks for charis from Odysseus for good deeds done in the past on the grounds that he did not, like the other suitors, avail himself of the women in the house (Od. 22.319). ${ }^{27}$ Odysseus rejects this plea for charis and kills Leiodes since he did not show similar restraint when it came to wooing Penelope (Od. 22.320-25). Penelope had already reproached the

24. See also van Wees 1992: 48.

25. See ch. 4.

26. Latacz 1966: 85 interprets charis here as 'Beliebtheit', 'Anziehung', 'Geltung', and 'Prestige' (popularity, charm, status, and prestige) without discussing the role of the aglaa dōra.

27. See also Latacz 1966: 92 who interprets the charis Leiodes asks for as a service in return for a past favour. 


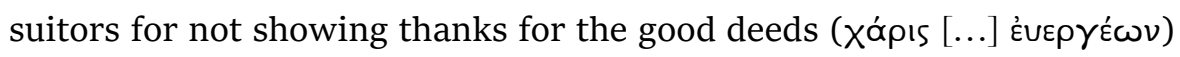

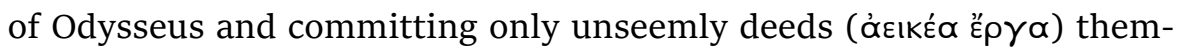
selves (Od. 4.694-95). These unseemly actions, with which the suitors in essence deny Odysseus the charis due to him for his good deeds consist of the abuse of the (sexual) services of the women in the house, and the appropriation of Odysseus's property. Not only do they consume without recompense, they also use goods that are not theirs in order to give charis

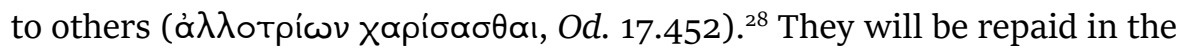
end for their behaviour when Athena and Odysseus prepare a banquet for them that could not be more lacking in charis (áxapíotepov, Od. 20.392). This use of the comparative form of the adjective acharis may well allude to the usual function of the feast as a return gift for military service, or to the normal reciprocity of hospitality which of course the suitors did not keep to. ${ }^{29}$ Equally the denial of charis here may suggest the relationship to a king, who takes on the role of war-lord (anax) and political leader in the community and as such receives gifts such as those due to the gods. ${ }^{30}$ Such divine charis operates in a similar framework to that shown by warriors to one another.

Reciprocal bonds of service, such as those between leaders in war and between a leader and his companions, also exist between men and gods. The help given to fighters by the gods is even described with the same phrase: charin pherein. Charis given to fighters by the gods can take the form of actual divine engagement in battle or that of favour shown to their own. It is striking that divine charis is given to a group rather than an individual. So Ares, wounded while fighting against the Trojans complains to Zeus: 'We gods always suffer most horribly for you [...] when showing

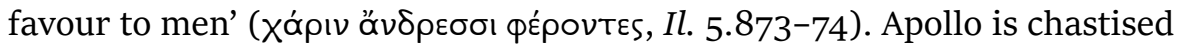
by Poseidon for his support of the Trojans and reminded that the Trojan ruler Laomedon once cheated them of their shepherds' wages. For that reason Poseidon considers the Trojans undeserving of divine charis in the form of victory over the Greeks and demands their downfall: 'That is the

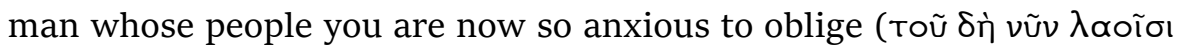
фépєıs Xápıv) instead of joining us and trying to ensure that these insolent

28. See Scheid-Tissinier 1994: 31, who translates: 'à être généreux avec le bien d'autrui'.

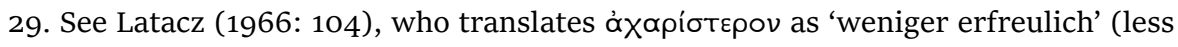
pleasing). His translation is based on his interpretation of charizomai as 'eine erfreuende Leistung erbringen' ('to render a pleasing service'). According to him the comparative ax $\alpha$ pís does not underline the lack of beauty but the emotional effect. On the duty to provide food and drink see Ulf 1990: 132-33. 
Trojans are utterly wiped out, together with their children and their honoured wives' (Il. 21.458-6o; tr. Rieu). Elsewhere, Zeus is also said wrongly to favour the Trojans ( $\chi \alpha \rho i \zeta \varepsilon \alpha ı, ~ I l .13 .633$ ).

There is a case of charis as a reward assured by the gods, when Odysseus tells Eumaeus that Hermes grants charis and glory for their deeds to all

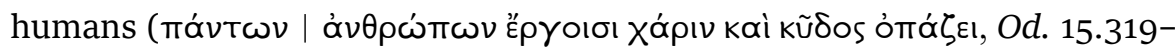
20). With Joachim Latacz this would mean that Hermes lends lustre to the deeds of men; in my view, given the context, it means that Hermes affords recompense to men for their deeds. ${ }^{31}$ Odysseus is considering putting himself into the suitors' service for the sake of a meal, which suggests charis is viewed almost as a payment (Od. 15.315-16). Such payment, usually called misthos, is received in archaic and classical times by mercenaries, called misthotes, in return for military service to foreign rulers in Egypt, Persia, Macedonia, and even in Athens..$^{32}$ But relationships involving misthos are only temporary, lacking the sense of permanence implied by charis. ${ }^{33}$

The goodwill of the gods, their charis, is won through the offering of sacrificial gifts, which are themselves characterised as $\chi \propto \alpha^{\prime}$ íı (charieis). According to Scheid-Tissinier the word indicates the joy or satisfaction the gifts evoke in their recipients. ${ }^{34}$ The sponsors of such gifts can be individuals or collectives, or individuals representing collectives. In lliad 8 Hera reproaches Poseidon for not helping the Greeks, who have already

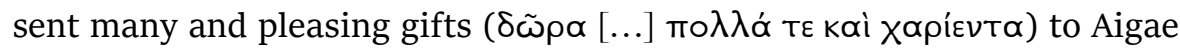
and Helice. These gifts entitle the Greeks to victory in Hera's view (Il. 8.203-4). A similar scenario presents itself when the people of Pylos offer sacrifice to Poseidon in Odyssey 3, and Athena asks the god on their

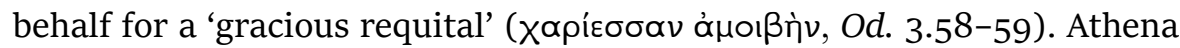
also argues that the sacrifice Odysseus had offered long ago by the Argive

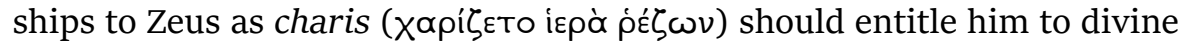
favour and to a successful return home (Od. 1.61). Chryses is able to count

30. See Scheid-Tissinier 1994: 259-61. She underlines the reciprocal meaning of charis euergeōn in the relationship between king and dēmos. On the difference between basileus and anax see ch. 4.1.

31. Latacz 1966: 86-87.

32. For evidence see Herman 1987: 10 and Domingo Gygax 2016. This contrast is an interesting one in the Athenian context because it implies that wealthy citizens' relationships with the polis are shaped by permanence, receiving charis as they do (at least following Ober 1989) for their services such as liturgies, whereas ordinary citizens have only a temporary relationship with the political institutions shaped by misthos. I thank Claire Taylor for this comment.

33. See Scheid-Tissinier 1994: 266. For more detail see ch. 5.1.

34. Scheid-Tissinier 1994: 33. 
on Apollo's support in avenging the rape of his daughter because he put a

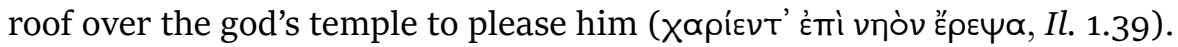
The plague which decimates the Achaean army until Agamemnon finally returns Chrysëis is Apollo's favour to Chryses. ${ }^{35}$ The gods' favour can also be begged by third parties on behalf of others. So Nestor, after Achilles has awarded him a prize at Patroclus's funeral games, wishes that the gods may

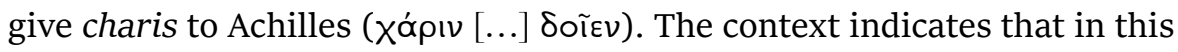
case charis is the favour of success in battle, which the gods will indeed afford Achilles. In their roles as leaders in battle in the case of Odysseus and Achilles and as intermediary to the gods in the case of Chryses, all three are examples of figures who do not act in their own interest, although they are all seen to gain advantage from divine gifts and support.

Further evidence for the reciprocal relationship between gods who grant charis and the men who give them pleasing sacrificial gifts can be found in the use of the middle perfect participle $\kappa \varepsilon \chi \propto \rho \rho \sigma \mu \varepsilon ́ v \propto$ (kecharismena) to characterise those gifts. As Latacz puts it 'when $\kappa \varepsilon \chi \propto \rho ı \mu \mu$ 'v $\alpha$ is used of objects, these are validated as [not only] concrete signs of the personal effort and attitude of the offerer. ${ }^{36}$ The use of the perfect tense also draws attention to the recurring character of the offers, and to the expectation of reciprocity. So for instance, Aeneas can count on divine assistance in a dangerous situation in battle because of the gifts, described as kecharismena,

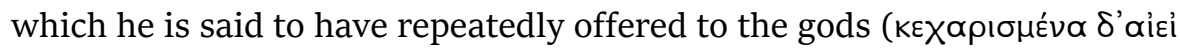
$\delta \tilde{\omega} \rho \alpha$ $\theta \varepsilon о \tilde{\sigma} \sigma \mathrm{\delta} \delta i ́ \delta \omega \sigma \mathrm{l}, \mathrm{Il}$. 20.298-99). Autolycus, Odysseus's maternal grandfather, was taught to swear and to deceive by Hermes, to whom he gave

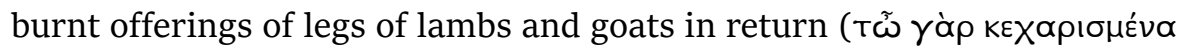

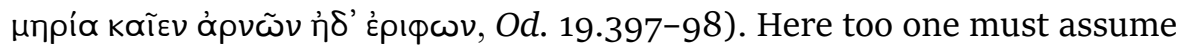
that the offerings are recurring.

There are two cases of gifts owed to men and described with the adjective charieis and the participle kecharismena. Both instances involve the relationship between a high-status, godlike individual and a collective. In Phoenix's story of Meleager (told to persuade the sulking Achilles to rejoin

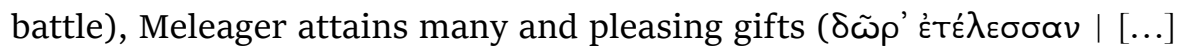

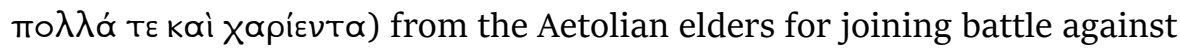
the Curetes (Il. 9.598-99; see also 9.576). The gift offered here is land (a temenos) for the cultivation of wine and grain (Il. 9.576-79). Such gifts are otherwise offered only to gods and to godlike kings. The story of Meleager

35. See ch. 4.1.

36. Latacz 1966: 117. 
alludes to the godlike status of the gift's recipient in so far as Achilles-for whom the story is intended as encouragement to abandon his current stance-is offered the expectation of similarly godlike honours: 'No, come for the gifts (dōra)! The Achaeans will honour you as a god!' (Il. 9.602-3).

The second example relates more directly to the godlike status of the recipient. Here Telemachus on catching sight of Odysseus, whose appearance has been changed by Athena with new attire, believes him to be a

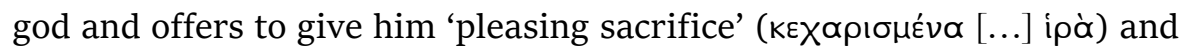

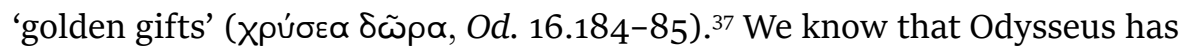
already received similar gifts from the Phaeacians, albeit without the use of words such as charieis or kecharismena. Alcinous does, however, use the verb charizomai for the recompense which the Phaeacian leaders may count on in return for their tribute to Odysseus. The king explains that the tripods and cauldrons can be recouped through the people, for it would be burdensome for individuals to be expected to bear the price of such gifts

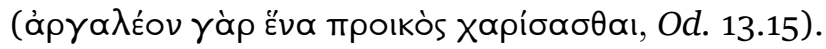

Reciprocal relationships between warriors and their leaders and between men and gods are part of epic's structure of reciprocity and are based on, or mediated, by rank. So reciprocal relationships between different leaders in war, or between leaders and their troops, are mirrored in the system of divine charis: the very services and favours given by warriors to one another may also be offered by the gods. The system of divine charis is not identical, however, to that which takes place between warriors, because divine charis is not granted to individuals but to the collective. So when high-ranking individuals are said to have been rewarded by the gods with a favour in return for their actions, it is by no means certain that this happens as part of a purely personal reciprocal relationship with the gods. This is especially true in cases where sacrificial offerings have been given, and where the sacrifices are carried out by the whole group. It can be assumed that individuals who claim a particular proximity to the gods (such as priests or those in kingly positions) act as mediators on behalf of a group of warriors or a demmos. But such kingly figures, or basileis, whose roles I will return to in more detail, can appear as godlike and can accept offerings which are comparable to those given to gods; through this there is a tendency to transcend, by which I mean to eternalise, their function. Before we return to this idea, we must first explore the significance of

37. See also Il. 24.661, where the ceasefire agreed for Hector's funeral is seen as a favour. 
charis in domestic contexts, since this is where the status symbols that enhance the rank of the basileis are produced.

\subsection{Women's thanks and the weaving of amphipoloi and Charites}

There is one sole instance of the use of the word charis in connection with a relationship of philotès between men and women. In this instance, charis is not given but seen. In Iliad 11 we hear of the Thracian Iphidamas:

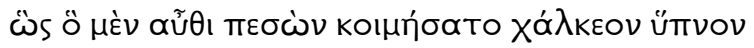

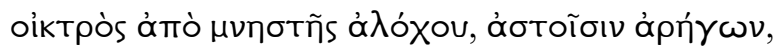

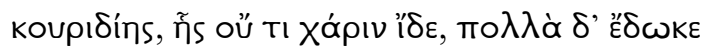

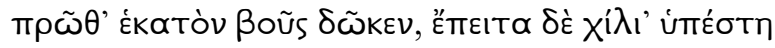

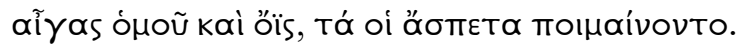

So there he [Iphidamas] fell, to sleep the unbreakable sleep-a pitiable end, helping his fellow Trojans, far from his wife, the new bride from whom he had seen no charis, though he had given so much to her. He had already handed over a hundred head of cattle and promised a thousand more sheep and goats from his countless flock (Il. 11.241-45; tr. adapted from Rieu).

We are dealing here with a reciprocal relationship between partners in marriage and their families; Homeric epic mostly describes only the male part of this relationship: the transfer, пореĩv (porein) of 'bridewealth' by

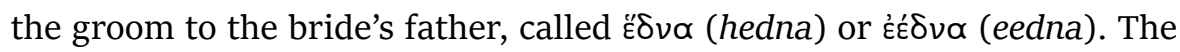
bride's transfer to the groom's household takes place as a consequence of the delivery of gifts by the groom, which is why Rudolf Koestler refers to the hedna as 'Heimfuehrungsgaben' ('bringing-home-gifts')..$^{38}$ It is assumed that these gifts took the form of herds and flocks as seen in the cited passage on the gifts given by Iphidamas. ${ }^{39}$ These were presumably handed over to the father of the bride, while the bride was given gifts of jewellery and clothing, described as $\delta \tilde{\omega} p \alpha$ (dōra). As I have shown elsewhere, both types of gifts ensured the husband's possession of the wife's children and of her handiwork as well as of the work of her servant women: those woven works with their symbolic and practical functions in the ritual of

38. Köstler 1950: 48 and 60.

39. Leduc 1990: 270; Scheid-Tissinier 1994: 113. 
guest-friendship..$^{40}$ In the context of marriage, charis can then mean both thanks and benefit, with the former made concrete by the service of love and the latter by that of weaving..$^{41}$ The wife's thanks are made visible in the woven works which are sometimes characterized by charis in the sense of a shine or lustre. Charis is also made visible in the very person of the wife, who herself, in the divine sphere, can embody charis.

When Hera, for instance, wants to distract Zeus from the battlefield at Troy she does not collect only Aphrodite's famous girdle with its power of philotēs..$^{22}$ She also turns to Hypnos to ask him to put Zeus to sleep, and in return she promises him charis:

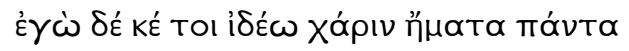

and I shall show you charis for ever. (Il. 14.235)

Indeed, as it turns out, Hera will need to show Hypnos charis, by making her visible: he turns down the offer of a golden chair, because he is afraid to incur the wrath of Zeus, and agrees to help Hera only when she promises to give him one of the Charites as wife (Il. 14.265-75). In this way charis will really be visible to Hypnos forever-and Hera literally shows him her thanks.

The Charites are Aphrodite's divine entourage and provide service in bathing and dressing her as well as weaving for her (Od. 8.364-66; Hom. Hymn Aphr. 61). So for instance, the peplos worn by Aphrodite when she storms into battle to protect Aeneas is said to have been made by the Charites (Il. 5.338). In the Hymn to Aphrodite, she offers woven clothing

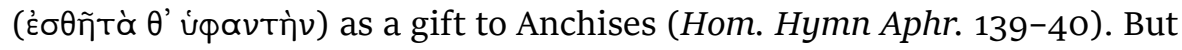
this service also implies a social bond, as we hear in the Odyssey that Aphrodite joins in dance with the Charites (Od. 18.192-94).

40. Wagner-Hasel 1988. These brides are often characterised as objects. See e.g. Lyons 2003: 101, who argues that '(i)n marked contrast to the Iliad [...] the Odyssey represents women not merely as objects but also as participants in gift exchange'. Gifts of clothing made to brides also appear in later times, e.g. a woman complaining in a twelfth-century Byzantine epic about the lack of gifts of clothing made to her by her husband (Ptochoprodromos 1.45, ed. Eideneier 1991).

41. See Scott 1983: 5. Cf. also Latacz 1966: 95-97. In this context he understands charis as the pleasure of a counter-gift. Reciprocity is also emphasised by MacLachlan 1993: 27 who speaks of 'mutual benefits'. The raising of illegitimate children (described by the verb charizomai) is one of the benefits of marriage. See Theano rais-

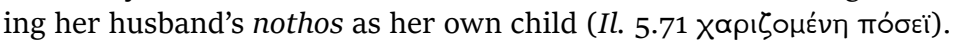


As a divine personification we meet charis in the figure of Hephaestus's wife, whose name in the Iliad is Charis (Il. 18.382). In the Theogony, it is Aglaia, 'the shining one' (Hes. Theog. 945-46). She embodies the lustre of the aglaa dōra, the 'gleaming' gifts of metalware and textiles received by guests. In the Odyssey it is of course Aphrodite, the leader of the Charites, who is the wife of Hephaestus. ${ }^{43}$

In the mortal sphere we see this structure replicated in the domestic

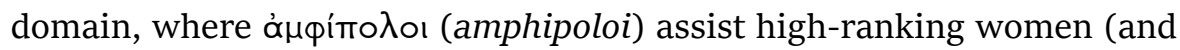
in two cases also men). ${ }^{44}$ Amphipoloi provide service when it comes to bathing and clothing, and weaving. ${ }^{45}$ Like the Charites, amphipoloi also appear almost always in groups. Their plurality is suggested in the word

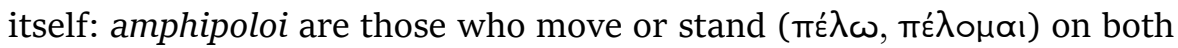
sides ( $\left.\alpha^{\prime} \mu \varphi^{\prime}\right)$. Stefan Hiller has proposed a connection to the Mycenaean term a-pi-qo-ro, a collective term for groups of female workers, which also appears at Thebes in the context of textile work. Because of the word's association with a potnia on the Linear B tablets, Hiller suspects a religious origin and interprets amphipoloi/a-pi-qo-ro as the attendants of a priestess. ${ }^{46} \mathrm{~A}$ connection with weaving is more likely, however, and is also suggested by pictorial evidence: the only extant ancient Greek depiction of weaving shows women walking up and down on both sides of the loom, although it is unclear whether the two women depicted on the sixthcentury Attic Lekythos meet in the middle of the loom or walk on past one another. ${ }^{47}$ We know from modern parallels, as well as from ancient depictions found in Egypt, that two people may work together on one piece of weaving. ${ }^{8}$ What is striking about the image on the Lekythos is that other aspects of the work (the weighing of the wool, spinning, and the folding of the finished product) are also represented as activities undertaken by two women together. It has also been suggested that the image on our vase is

42. See ch. 2.3.

43. On Aphrodite and Charis see Simon 1985: 236.

44. Laërtes has two amphipoloi (Od. 1.191; 6.209; 24.366), and Hephaestus is supported by two golden amphipoloi (Il. 18.417-18).

45. See ch. 2.3.2.

46. Hiller 1987: 239-55.

47. New York, Metropolitan Museum 31.11.10; von Bothmer 1985: 185-86. No. 48. A similar interpretation is suggested by the use of the verb erchomai for Calypso's weaving in the Odyssey (although it is debatable whether the verb refers to the weaver's movement or to the shuttle's). See also Wace 1948: 55. For weaving pictures on vases see Ferrari 2002.

48. Barber 1991: 81 and 105. 

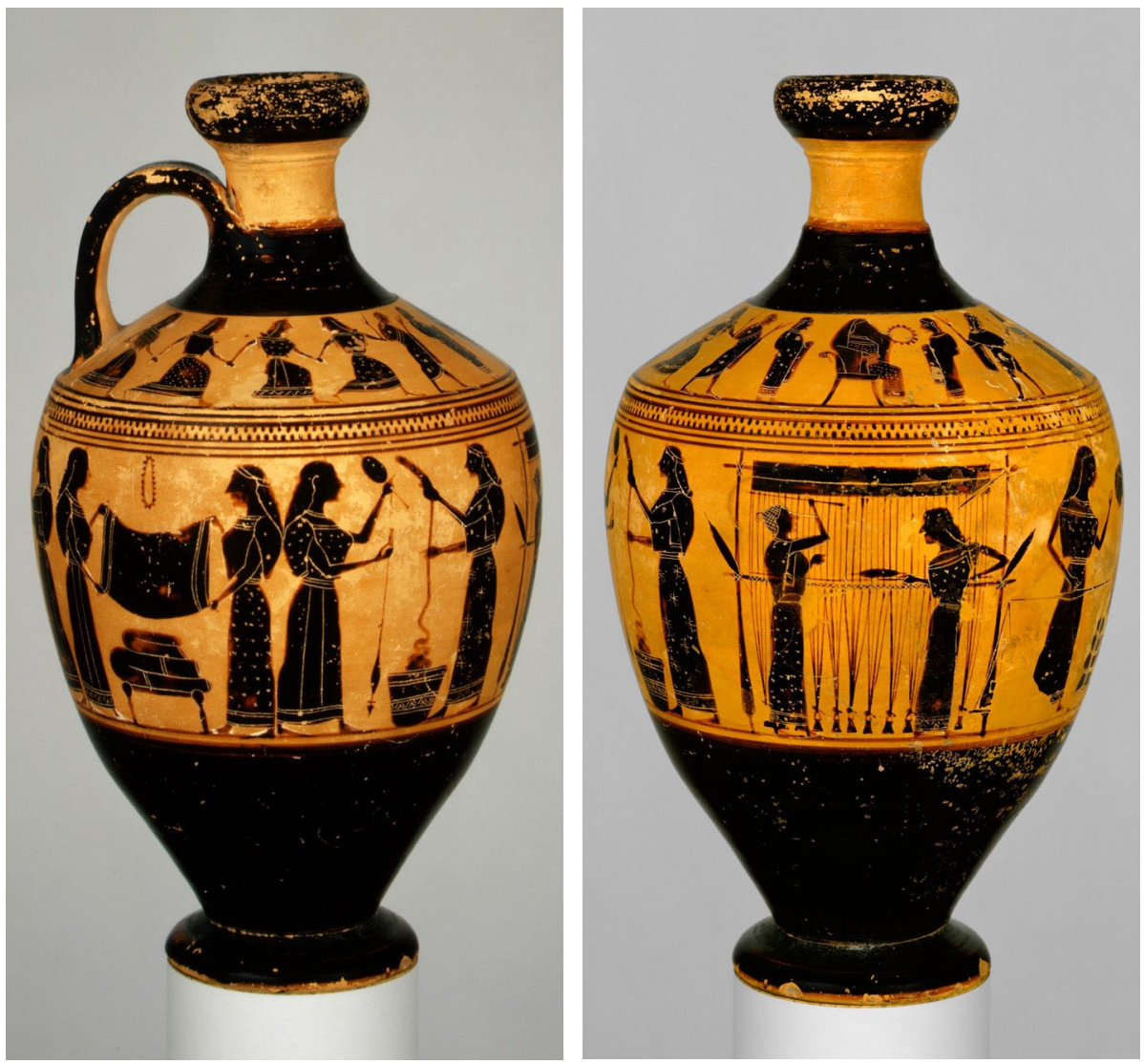

Figure 2: Wool working at Athens. Attic black-figure lekythos of the Amasis painter. 540 BCE. New York, The Metropolitan Museum of Art, Fletcher Fund 1931, 31.11.10. https://www.metmuseum.org/en/art/collection/search/253348.

connected to the weaving of Athena's peplos for the Panathenaia..$^{49}$ Even if we must assume a cultic connection, we may suppose that working in pairs made sense for textile workers (Figure 2).

Another noteworthy aspect of our image is the combination of scenes of socialising with the representation of a female sphere of work: on the vase's shoulder there is a group of eight dancing girls. This combination of work and play can be observed also in our literary sources: Nausicaa and her amphipoloi, for instance, play a ball game when they do the laundry at the beach (Od. 6.100). And the girl's relationship with one of these companions, Dymas, who guards the entrance to Nausicaa's bedroom, is described 
with the verb charizomai (КЕXápı the case of the relationship between a warlord and his companions, the pluperfect tense (kecharisto) once again is used to express the lasting character of the pleasing service which the amphipoloi render their mistress..$^{50}$

Not unlike the warriors, the women too receive divine support. So Nausicaa's two amphipoloi received their beauty from the Charites (Od. 6.18). And when she wishes to stir the suitors' desire for Penelope, Athena anoints the mortal woman with just that ambrosial oil used by Aphrodite when she goes to dance with the Charites (Od. 18.192-95).

It is not clear whether such divine support is earned through offerings and whether this divine-mortal collective is governed by the same reciprocity we assume for a warlord and his companions. We know that warlords provide their troops with meals. Nausicaa also eats together with her amphipoloi (Od. 6.97). Penelope laments her fate before her amphipoloi, who are also addressed as philai (Od. 4.722). The verb philein which, like the address by the noun philos, indicates a close relationship, is also used for the relationship between Helen and a wool-worker from Sparta who is

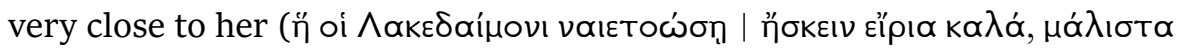

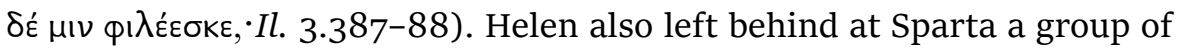
friends she had grown up with; it is possible that this was also a team who worked together at weaving, as male hetairoi collaborated in battle

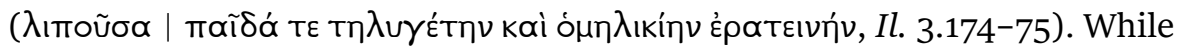
the women who work for Arete and Nausicaa in the Phaeacian kingdom are said to be free women, Penelope's working women are not: they are said to have been acquired in battle or gained as gifts..$^{51}$ Eurycleia who, alongside Penelope, taught the servant women in the household how to go about

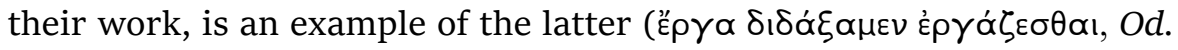
22.422). Such unfree women are rarely called amphipoloi; more often they

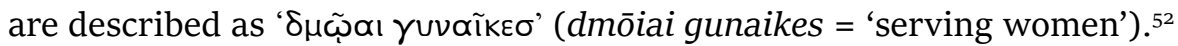

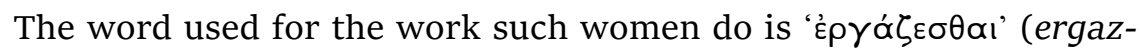
esthai), which Raymond Descat views as indicating work carried out for others. ${ }^{53}$ The word is also used in the context of metal-working, such

50. On the relationship of Nausicaa and her maidens see now Karanika 2014: 46-66, who stresses the performative character of the washing-scene and interprets Nausicaa as leader of a chorus of young girls.

51. See Wickert-Micknat 1982: 40; Uchitel 1984: 257-82; Wagner-Hasel 1988: 61; Battegazzore 1987: 30-40; de Fidio 1979: 188-217.

52. For evidence see Gschnitzer 1976: 68-73, Scheid-Tissinier 2015 (on Eurycleia).

53. Descat 1986: 48-58, suspects a Mycenaean origin. 
as when the goldsmith Laërkes calls Menelaus to work ( $\kappa \varepsilon \lambda \varepsilon \dot{\sigma} \theta \omega$ [...]

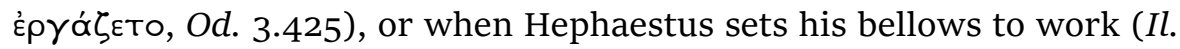
18.469). This does not automatically imply unfree status. In the context of labour carried out by prisoners of war, ergazesthai is supplemented with

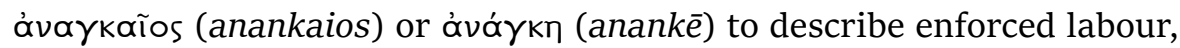
as when Odysseus's companions are said to have been taken prisoners in

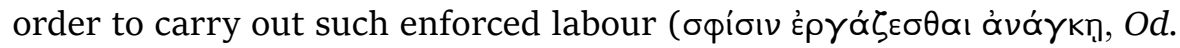
$14.272=17.441)$. At Ithaca, only Laërtes's male labourers are described in this way (Od. 24.210), ${ }^{54}$ never Penelope's dmōiai gunaikes, even though they are at times descended from the male dmōes. This is, for instance, the case for Melantho, of whom it is said that Penelope cared for her as a child, and gave her toys as gifts (Od. 18.322-23). ${ }^{55}$

In the divine sphere, the daughters of Pandareus enter the type of labour described as ergazesthai after they are orphaned and Aphrodite and Athena look after them. They are taught, just as we are told the maidservants of

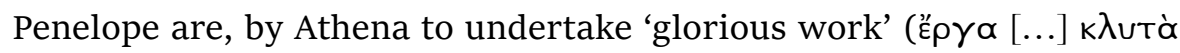

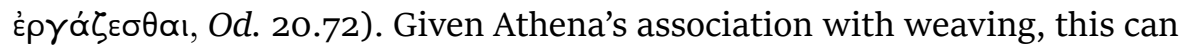
only mean that they were taught to work as weavers. ${ }^{56}$ The fact that this work is characterized as 'kluta' (glorious), clarifies that the work of weaving cannot be regarded as dishonourable-unlike the work imagined by Andromache in case of the enslavement of her son Astyanax, described as

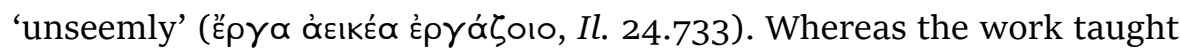
to Penelope's women is not called 'kluta', the word is used for the work

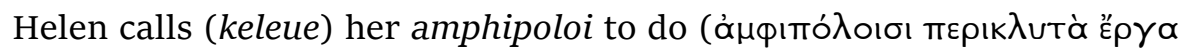

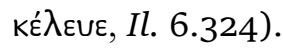

The same term $\kappa \varepsilon \lambda \varepsilon \cup \varepsilon^{\prime} ı \nu$ (keleuein) is used for calling warriors to battle and amphipoloi or serving women to work. So we hear in Iliad 4 that

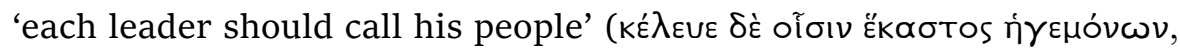
Il. 4.428-29) when battle recommences after the truce. ${ }^{57}$ This is exactly what women such as Helen, Arete, Andromache, or Penelope do when it is time to get amphipoloi to make up beds for guests or to send dmōiai

54. See also the remarks made by Eumaeus about Odysseus's dmōes: that they will not work unless masters enforce their power (Od. 17.320-21).

55. Lenz ([1790] 1976: 41) is already aware that these are hired workers. According to Beringer 1985: 47 the use of the terms dmōes and dmōiai does not suggest enslaved status.

56. Cf. Il. 5.735; 8.384; 9.390; 14.178; Od. 7.110; 2.116; 20.72; Hom. Hymn. Aphr. 1415; Hes. Op. 63-64.

57. Cf. Il. 13.230 where Idomeneus asks Thoas that everyone must 'give orders' (Кદ́ $\lambda \varepsilon \cup \varepsilon)$. Hector gives orders to his brothers (Il. 16.545) and Ajax to the Danaans (Il. 15.586). 
gunaikes off to work at the loom or the spindle..$^{8}$ This symmetry between service given in battle and service given on the loom is especially pronounced in Hector's farewell to Andromache, when he designates their two separate spheres of responsibility: his is war, and hers is weaving:

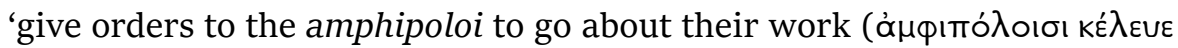

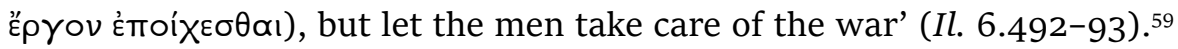
The activities to which amphipoloi, warriors, and in one case smiths (Od. 3.425), are called are all specialized, skilled labour. ${ }^{60}$ The words ergazesthai, keleuein, and charizomai suggest the relationships within which such skilled labour is carried out, while the effort and technical skill afforded to carry out the work is described by the word kó $\mu \nu \varepsilon ı v$ (kamnein). According to Felix Eckstein, kamnein represents 'careful work and detailed technique'. ${ }^{61}$ The term is used in the context of war as well as weaving, and especially for metal-working, and frequently with reference to divine activity in the spheres of textile and metal work. ${ }^{62}$ The peplos worn by Aphrodite as she hurries into battle to help Aeneas has been carefully worked by the Charites (öv oi Xápıтєs káuov aưtaí, Il. 5.338). Athena loses her peplos twice in battle: she had made it herself and crafted it carefully

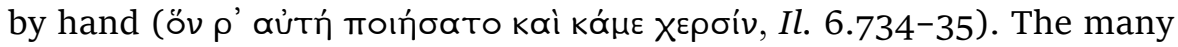
peploi that Helen keeps in her trunk when Telemachus is visiting at Sparta are also worked carefully by herself (кó $\mu \varepsilon v$ aútŕ, Od. 15.105). Whenever kamnein is used, we are dealing with objects made with especially elaborate care, be they textiles or metalwork such as the armour or shields made by Hephaestus. These are qualified as exceptional by adjectives such

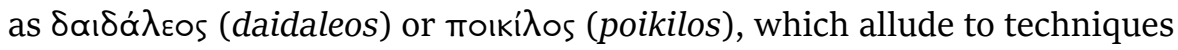

58. Od. 7.335 (Arete); Od. 4.296; Il. 6.324 (Helen); Od. 1.357 and 21.351 (Penelope); Il. 6.491 and 22.442 (Andromache).

59. See also Il. 22.442 for Andromache's orders to her amphipoloi. Telemachus's words to Penelope are almost a verbatim repetition of Hector's to Andromache (Od. 1.35758; 21.351-52). See Hölscher 1983: 106, suggesting this is a direct reference rather than characteristic of the formulaic nature of oral poetry. For the phrase as indicative of the patriarchal nature of Homeric society see e.g. Finley 1967: 91; Wöhrle 1999: 122; Clark 2001; Gottesman 2014; Beard 2017. For critique and discussion see Wagner-Hasel 1997: 127-46; 2018.

6o. This is stressed by Wickert-Micknat 1982: 38-45 who counts weaving as one of the technai that needs to be learnt. See also Schneider 1989: 11-31.

61. Eckstein 1974: 6. See also Schneider 1989: 17-18. Another term, used for the Phaeacian women's skilled weaving, is technasthai (Od. 7.110).

62. When it is used for metalwork, the term mostly refers to the labour of Hephaestus (Il. 2.201; 8.195; 18.614; 19.368. See also unnamed chalkēes in Il. $4.187=216$, and the smith Tychios (Il. 7.220). 
of depiction developed in the arts of metalwork and weaving. This applies to the thörax made for Diomedes by Hephaestus, which is referred to as

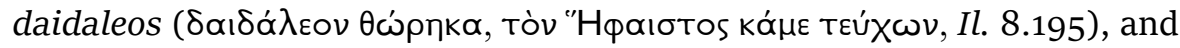
to the shield of Achilles, also made ( $(\alpha \dot{\alpha} \mu \varepsilon)$ by Hephaestus (Il. 18.614). The shield is said to be adorned with many pictures (daidala), and to be illustrated (daidaleos). ${ }^{63}$ As Françoise Frontisi-Ducroix has shown, the term daidaleos is mostly used in the context of metalwork and carpentry to refer to inlaid patterns or plastic images, such as are seen in archaeological evidence from the geometric and archaic periods. ${ }^{64}$ This kind of technique is clearly employed by Tychios who furnishes Ajax's oxhide shield with its layer of bronze (Il. 7.220).

We can assume that a similar technique is referred to when kamnein is used of woven images. Daidala are often also seen on textiles, such as those worked by Athena into the veil (heanos) worn by Hera at the seduc-

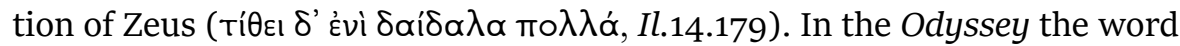
daideleos is used for the cloths which are draped over the chairs in Odys-

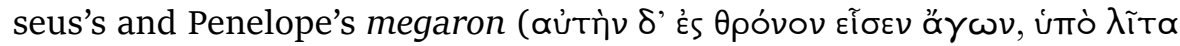

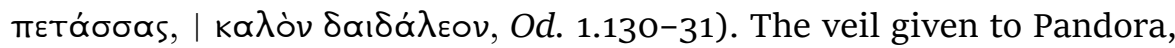
the first woman, by Athena in the Theogony is also called daidaleos (katà

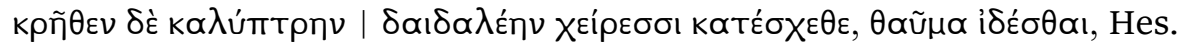
Theog. 574-75), while in Works and Days Athena is said to have taught

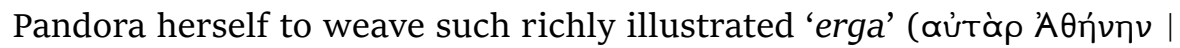

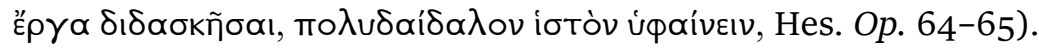

In the context of weaving, daidaleos can be replaced by poikilos, which indicates a colourful or patterned cloth, especially when textiles feature at special occasions such as sacrificial offerings, weddings, or when receiving guests. The adjective is used for the peplos dedicated to Athena by the women of Troy and for the belt worn by Hera for the seduction of Zeus (Il. 6.289; Il. 14.220). Poikilos features especially when kamnein is used to refer to textile production, such as for Athena's handmade peplos ( in Helen's storage chest, one of which she gives to Telemachus as a gift for

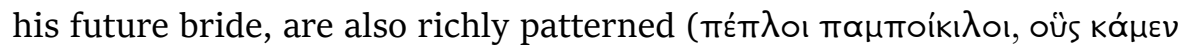
ơutń, Od. 15.105).

Next to the general kamnein, the technical term used for the produc-

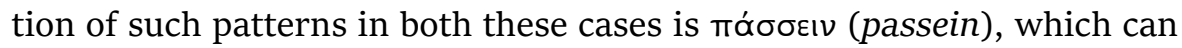


be translated as laying on, or sprinkling. ${ }^{65}$ This is used of Andromache decorating the purple mantle, a diplax, she is weaving for Hector with multicoloured roses, or rosettes, called throna (Il. 22.440-41). ${ }^{66}$ Similarly we see Helen applying images of the battles between Trojans and Achaeans on a purple diplax she is weaving (Il. 3.125-27) ${ }^{67}$ In the past, poikilos was erroneously thought to refer to embroidery placed on woven cloths because of the mistaken assumption that the warp-weighted loom commonly used in Greece did not allow patterned weaving. ${ }^{68}$ Arguments against this were raised by Margarete Bieber and Alan J. B. Wace, who assumed a technique similar to that used for Kelims, where threads are worked in by hand in smaller areas. ${ }^{69}$ This theory was revised by Elizabeth Wayland Barber in the 1990s. Experiments and observations in other cultures have shown her that patterns can be made on a warp-weighted loom by lacing the additional pattern weft into the warp-this would explain the use of the term passein, to lay on or sprinkle, for the production of pattern. ${ }^{70}$ Such a technique was used in Norway until the 1950 s for the production of patterned blankets on warp-weighted looms (Figure 3 and 4 )..$^{11}$

65. Buschor 1912: 46 views this as a weaving term, while Marinatos 1967: 3-4 assumes that it describes the art of embroidery. For the metaphorical use of the term see Bergren 1980.

66. There is debate over the meaning of throna, with some ancient commentators suggesting roses, others poisonous plants. See Buschor 1912: 30-31, who suspects a palm motif that Andromache might have learnt from her Sidonian slaves. Marinatos 1967: 4 interprets it as a poisonous plant. Barber 1991: 372-73 suggests roses, as a traditional magical motif. Winkler 1990: 172-74 also makes a connection with magic. Others see a rosette-motif in keeping with geometric vase painting (Wickert-Micknat 1982: 46-50; Koch-Harnack 1989: 24-32, 168-71). Such rosettes can be seen on a fifth-century BCE carpet, traditionally thought to be of PhrygianAnatolian origin, now viewed as Lydian (Greenewalt and Majewski 1980: 134). For an image of this carpet see Bennett 1977: 39.

67. For passein connected with daidala see Apollonius Rhodius, Argonautica 1.728-29. On this see Levin 1970: 17-36; Shapiro 1980: 263-86.

68. See Blümner 1912: 158 .

69. Wace 1948: 51-55; Bieber 1928: 10-11; 1934: 26. Cf. Pekridou-Gorecki 1989: 41-44. 70. Barber 1991: 91-113. See also Barber 1992: 103-17. Barber describes her own experiments in her popular book, Barber 1994: 17-27. There is, however, no evidence from ancient textile finds to support her thesis. But new experimental research has proved the possibility to weave pattern even with warp-weighted looms. See now Harlizius-Klück 2016. For the new results in research on textile technology, see Anderson and Nosch 2003; Michel and Nosch 2010.

71. In addition to Barber see also Carroll 1983: 96-98. On pattern weaving with the warp-weighted loom in ancient Greece see now Spantidaki 2016: 48-70. 


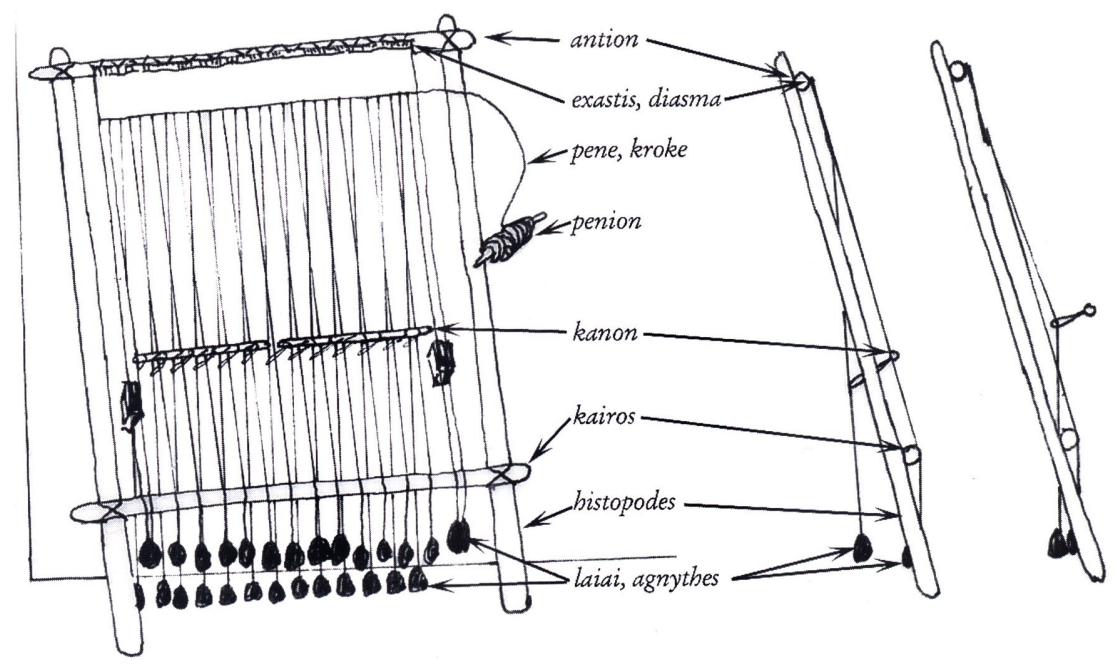

Figure 3: The warp-weighted loom. Harlizius-Klück 2004: 103, Fig. 11, cf. also Barber 1991: 270, Fig. 12.3 with modifications.

Even today, in Indonesia, such techniques of supplementary pattern weaving are used for the production of ceremonial cloths, whose patterns bear remarkable similarities with depictions in geometric vase painting. ${ }^{72}$ Barber's research now may provide a technical explanation for the old (nineteenth-century) assumption that geometric vase painting might have its origins in the art of weaving..$^{73}$ The stylized character of geometric vase paintings comes about as a result of the imitation of the technique of adding in the pattern weft. ${ }^{74}$ We cannot be certain that the situation here is comparable to that found in Palmyra, where a wealth of textile finds provide good evidence for a clear congruence of patterns in textiles and architecture during the early centuries of the post-Christian era. ${ }^{75}$ The very sparse textile finds (such as the fragment of a shroud from Vergina) from ancient Greece provide evidence for the existence of pattern-but they do not allow us to draw conclusions regarding the appearance of the entire

72. Kahn Majlis 1991: 41 and 100; Hecht 1989: 36-38 (Figure 5 and 6).

73. Conze 1870: 522; Semper 1878: 12. Buschor 1912: 5-10, without wishing to exclude the independent development of geometric vase painting, also thought textile models a possibility.

74. Barber 1991: 365-75.

75. Schmidt-Colinet 1995; Schmidt-Colinet 2019. 


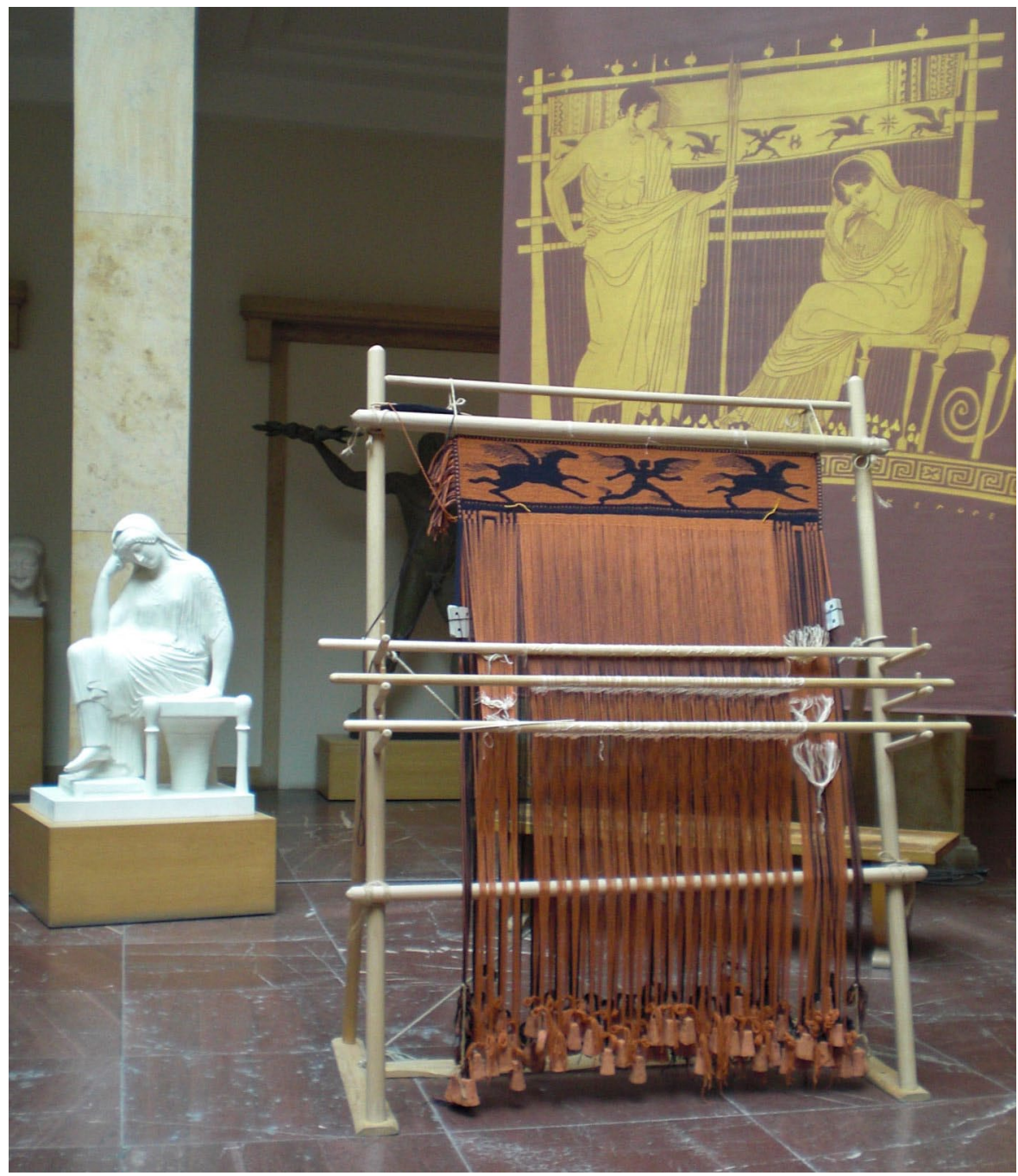

Figure 4: Warp-weighted loom with figured weave. Ellen Harlizius-Klück 2016: 70, Fig. 5.2.

pattern. ${ }^{76}$ Our only idea of the kinds of motifs that might have been used is to be found on depictions of garments in vase paintings. Here we do find patterns not unlike the rosettes and the battle-scenes used by Andromache

76. Barber 1991: 145-208. On the textile find from the Philip tomb see Andronikos 1980: 48 and Andronikos 1984: 25 and 233. Textiles are also found in Geometric graves in Attica. Andronikos 1968: 74. See now Spantidaki 2016: 5-8 with a catalogue of textiles found in graves (106-44); Gleba 2018; Gleba, Marín-Aquilera and Iacona 2018. See also Shaw and Chapin 2016 on the reconstruction of pattern in the Minoan and Mycenaean period. 


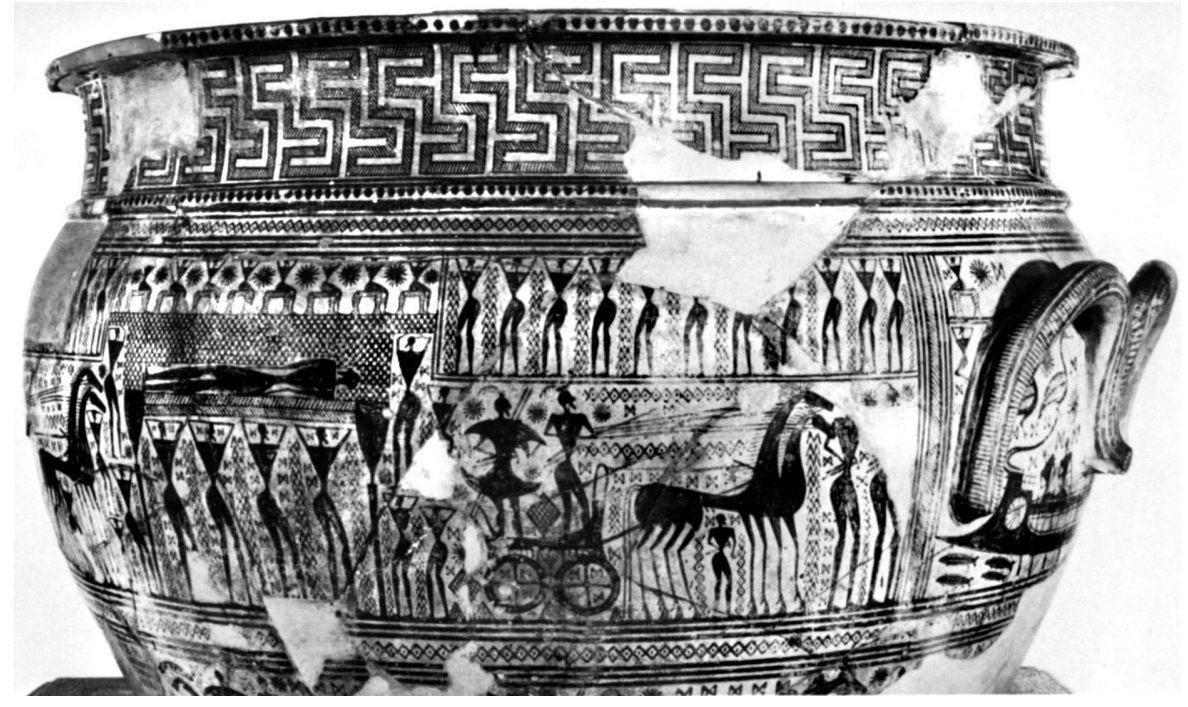

Figure 5: Prothesis. Geometric Attic mixing bowl, ca 750 BCE. Paris, Louvre A 517. After Kurtz and Boardman 1971: Fig. 7.

and Helen, so that at least we can see some commonality between painted and poetic representations. ${ }^{77}$ Since the rosettes motif is often found in wedding scenes, ${ }^{78}$ we may suspect that, in epic poetry, specific patterns are associated with different contexts or relationships, as we know to be the case in tragedy..$^{79}$ In any case, the results of this research on the uses of supplementary pattern wefts and its parallels in inlaying techniques used in metal-working underlines the significance of textile and metal gifts discussed earlier.

Since the words kamnein and passein are used in epic mainly for the production of patterned clothing by goddesses or high-ranking women, the

77. On findings from vase painting see Carroll 1965: See now Spantidaki 2016: 71-77; Harlizius-Klück 2019.

78. On the rosette-motif see Koch-Harnack 1989: 109-85. For literary descriptions of patterned clothing see e.g. Shapiro 1980 (Jason's cloak in Apollonius's Argonautica); Harich-Schwarzbauer 2011 (Claudian's description of the cloak of Proserpina).

79. See Aesch. Cho. 231-32 where Orestes asks Electra to inspect his woven cloth (hyphasma) which is decorated with animal patterns. In Eur. Ion 224 and 1413-28, Creusa recognises Ion as her son from the detailed description of the clothes in which he was found (the head of a Gorgon had been woven into the cloth). In Eur. IT 814-17 Orestes's knowledge of the patterns woven by Iphigenia proves he is her brother. See now Gherchanoc 2019. 


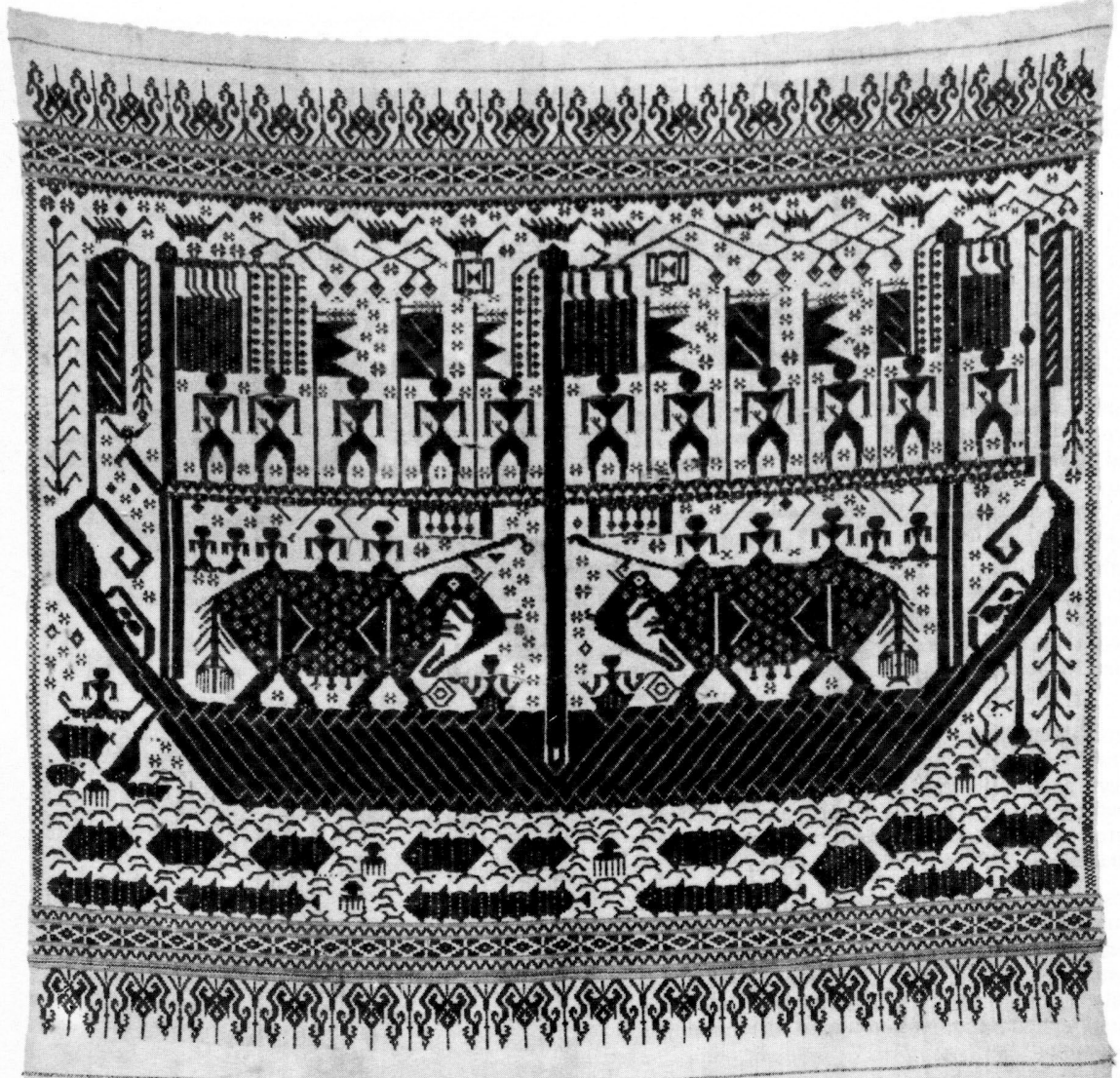

Figure 6: Indonesian ceremonial cloth. Supplementary weft weave. Sumatra, Lampung, late nineteenth century CE. After Kahn-Majlis 1991: Fig. 78.

work of weaving acquires a similarly high status to the masculine arts of warfare and metal-working. Reciprocity inheres not only in the services rendered in warfare, and is described with the words charis and charizomai; it is equally a factor in the arts and crafts for which kamnein is used. The careful labour described as kamnein, invested by Hephaestus into the production of the shield for Achilles, is to be understood as a return for previous favours rendered. This work is Hephaestus's repayment to Thetis for saving his life and welcoming him after his fall from Olympus; he has already been making many items of jewellery for her during his nine-year stay but views the shield as his way of repaying her fully (Il. 18.394-400). 
In battle contexts, kamnein is often used to describe the physical efforts of the heroes who carry weapons and then relax while drinking wine. ${ }^{80}$ The labour of grieving is also once described as kamnein, with the return service here being a meal: when Achilles invites the grieving Priam to share a meal, he reminds him of the example of Niobe, who also turned her mind to eating when she was weary from the shedding of tears ( $\dot{\varepsilon} \pi \varepsilon \dot{i}$

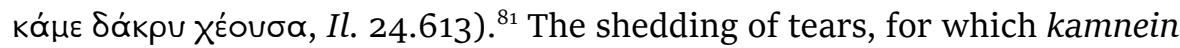
is used here, is a gift for the deceased; mourners are given sustenance in return for their labour. There is explicit reference to recompense for the careful labour of an individual in the case of Eumaeus, who complains to Odysseus that 'others are consuming our kamatos without compensation'

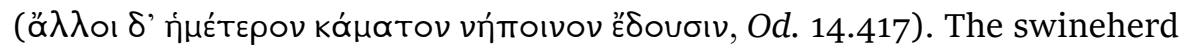
is referring to the suitors consuming the animals he had raised without giving anything in return, so we may assume that kamatos refers to the result of Eumaeus's careful labour. Normally, Eumaeus would be able to count on some return for such kamnein. As he tells the disguised Odysseus, a benevolent master will compensate a man who labours with care (ös oi mo $\lambda \lambda$ à kó $\mu \eta ̣ \sigma l)$ with a house, some land, and a wife sought by many wooers (Od. 14.65). Such women are also proffered as compensation to warriors who labour for their leaders, as Achilles reminds his men during the funeral rites for Patroclus (Il. 18.341). And of course, Achilles's withdrawal of his own kamnein in the service of another is the result

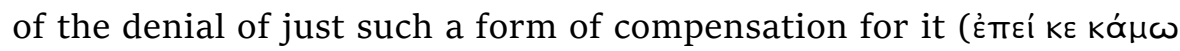
$\pi \circ \lambda \varepsilon \mu i \zeta \omega \nu, I l .1 .168) .{ }^{82}$

Following these observations, we can regard the relationship of the married couple which forms the basis of the domestic community as one of reciprocity, similar to that between the warlords. A warrior who renders service in battle to his leader, and thus shows charis, is supported by comrades-in-arms; a wife who renders charis to her husband in recompense for the bridewealth given is similarly supported by a group of women who help her with her work at the loom and on the spindle. We will see how this work is related to a third form of charis: the aura which emanates from a person. This is communicated through the woven images whose production was discussed in the present chapter. The asymmetry in the relationship

8o. See for example Il. 4.230; 5.797 and 811; 13.485 and 711; 15.365; 16.106; 19.170; 21.52; Od. 12.332. Recovery with wine: $I l .6 .261$.

81. On Niobe, and on tears and food see Monsacré 1984: 191-96. On geras for the dead see in more detail ch. $4 \cdot 3$.

82. In detail, see ch. 4.1. 
between a high-ranking woman and her female entourage is greater than that between a war leader and his men because war is, according to Homeric epic, the chief means for the recruitment of women weavers. These captured women are a benefit for the warriors whose beds they share, at least during times of war; but they also benefit the warriors' wives. In war, women are captured and subjected by male violence-but they end up in the service of other women. Hector knows this, as he refers not only to the sad fate of the captured woman who must weave for another ( $\pi \rho$ òs ö $\lambda \lambda \lambda \bar{s}$ iotòv úqaívors, Il. 6.456) but also to the joy of the mother at the booty brought home by her son (

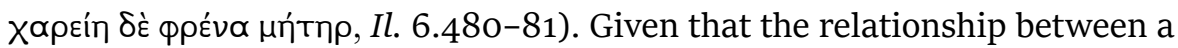
woman and her amphipoloi and dmōiai gynaikes is mirrored in the divine sphere by Aphrodite and the Charites, we might assume that in the divine working-group some form of transcendence takes place. The relationship between Aphrodite and the Charites appears to take on a model structure, the normative significance of which can also be observed in poetry and in images of weddings in classical vase painting. ${ }^{83}$

\subsection{Visualizing status: Charis in appearance and speech}

Charis is not only a pleasing service rendered with a view to a return gift or service; it is also a visual power or effect owned by objects and people. In the Iliad charis mainly emanates from precious objects, while in the Odyssey we also find people who are radiant with charis, although here too it seems likely that a person's charis actually emanates from their clothing. Jewellery with charis is worn exclusively by women, while people who emanate charis are exclusively men. The bestower of such charis is always Athena, although her action in these cases is described using the terminology of metal-working rather than weaving.

Odysseus is the primary recipient of such charis. When he is stranded at Scheria and has bathed and dressed himself in the clothes given him by Nausicaa, Athena ensures he looks bigger and stronger, and that his hair falls on his shoulders like a Hyacinth flower:

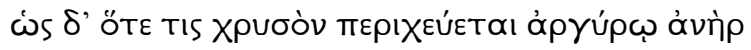

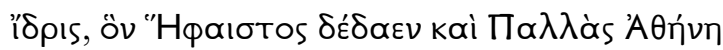

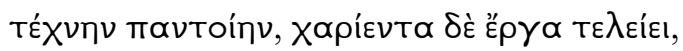




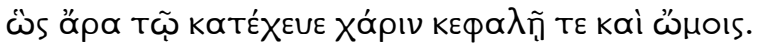

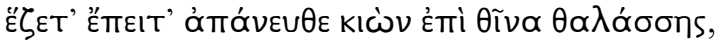

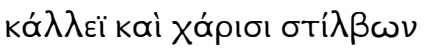

Just as a craftsman trained by Hephaestus and Pallas Athene in the secrets of his art puts a graceful finish to his work by overlaying silverware with gold, she endowed his head and shoulders with charis. When Odysseus retired to sit by himself on the seashore, he was radiant with charis and beauty (Od. 6.232-37; tr. adapted from Rieu).

Seeing him like this, Nausicaa is overcome with admiration and desire, and wishes to make Odysseus her husband (Od. 6.237 and 244).

In this example charis is a radiance which adheres to the body like an ennobling shine or polish, the crowning of external beauty, which gives rise to desire in observers. ${ }^{84}$ Although attributed explicitly to the work of the goddess, charis is also connected in the narrative to the change in Odysseus's appearance effected practically by the processes of bathing and dressing. At Ithaca these processes are ministered for Odysseus by Eurynome, the highest-ranking of the servant women, significantly a namesake of the mother of the Charites (Od. 23.153-63). ${ }^{85}$ In this case the effect of charis is aimed at Penelope, who is meant now to recognize her husband once he is clean and dressed appropriately. She had not recognized him

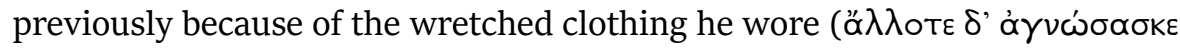

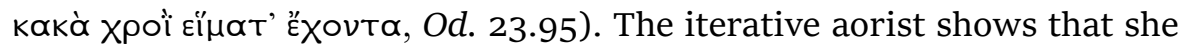
had repeatedly failed to recognise him.

While in these two cases charis has an effect on the other sex, there are three other examples in the Odyssey where it affects others of the same gender. In these cases, there is no need for bathing or anointing, but charis is mobilised instantly by Athena. So Athena pours divine charis over Odysseus's head and shoulders, and makes him look bigger and fuller, when he is to appear before the assembled Phaeacians (Od. 8.19-21). She does this in order to ensure that her protégé is treated by the Phaeacians as philos and accepted into their community.

Telemachus undergoes similar treatment when he takes up his father's place at the assembly in Ithaca: 


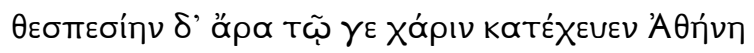

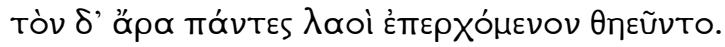

Athena endowed him with such supernatural charis that all eyes turned on him in admiration as he came up (Od. 2.12-13; tr. Rieu).

The same phrasing is used when Telemachus appears before the suitors upon his return from Pylos and Sparta, when Athena again endows

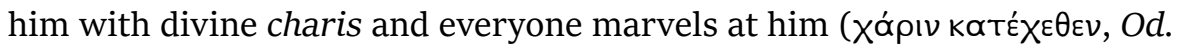
17.63-64).

In all these cases, charis is a visible radiance manifested publicly: before Nausicaa and her companions, at the assembly of the Phaeacians, in front of Penelope, and at the assembly in Ithaca. Its character is exhortative: in the kingdom of the Phaeacians it effects the acceptance of Odysseus as philos; at Ithaca its consequence is support for Telemachus's trip to Pylos. When dealing with the opposite sex, it arouses desire, and in the case of Penelope leads to the restoration of her marriage and the bond of philotēs.

Even if charis always emanates from men, women also possess a radiance that affects the other sex and results in the giving of gifts of jewellery, which in turn radiate charis. ${ }^{86}$ The medium of radiance for women is usually their clothing, and specifically a veil described with the adjective liparos, which suggests gleam or shine. Here too Athena's intervention is needed. The goddess alters Penelope's appearance, to make her look taller and fuller, as we have seen already, by the application of the ambrosial oil used by Aphrodite when she goes to dance with the Charites (Od. 18.195) ${ }^{87}$ When Penelope later appears before the suitors, flanked by two amphipoloi, she is not endowed with charis but is wrapped in a gleaming

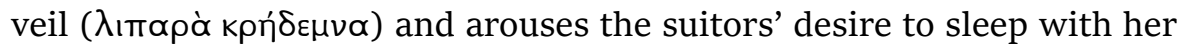
(Od. 18.210-19). Following this, one of the suitors, Eurymachus, praises Penelope: 'you surpass all women in appearance and size, and in the wisdom within you' (Od. 18.248-49). His praise conforms to the female ideal Agamemnon subscribes to in the Iliad when he refuses to return Chrysëis, as she is equal to his wife Clytemnestra in appearance, size, and wisdom or knowledge: phrēn (Il. 1.115). As in Odysseus's case, the radiant appearance of Penelope is also exhortative: she receives gifts of jewellery, including a

86. See MacLachlan 1993: 32.

87. For height as a sign of status see Ulf 1990: 224. For the meaning of liparos see ch. 4.2.2., n. 67 . 
pair of earrings of which it is said that they shine with much charis ( $\chi$ ópıs

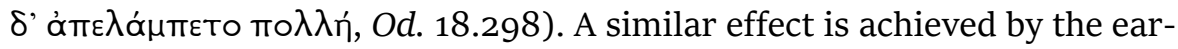
rings worn by Hera during the seduction of Zeus: these too are intended to have an effect on the opposite sex and they shine with much charis ( $\chi$ óp 15

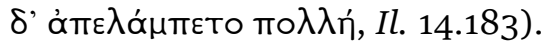

Charis therefore has an effect on both women and men. Joachim Latacz was keen to see in charis an accidental effect which causes joy or desire. But our findings show that charis is the property of a lustrous body or object. This can of course be jewellery, whose shine is produced by the smith working with gold and silver. But the effect of charis is not only caused by the shine of the metals; it must also be produced by the artistry and skill discussed earlier, with which the smiths work images into the metal. The hairband given to Pandora by the Charites and Peitho in Hesiod's Works and Days is such a jewel (Hes. Op. 73-74).$^{88}$ In the Theogony, where Athena places the hairband on Pandora's head, it is decorated with pictures, and it is from these that charis emerges: ${ }^{89}$

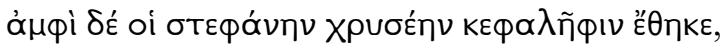

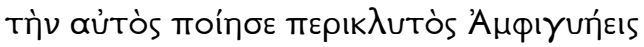

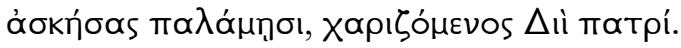

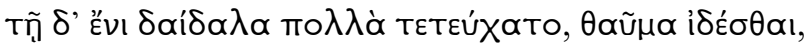

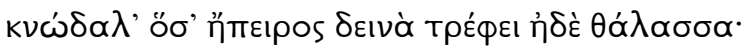

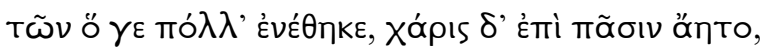

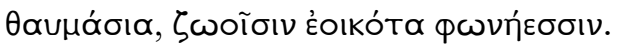

(a)nd about her head she placed a golden diadem, which the renowned Ambidexter made with his own hands to please (charizomenos) Zeus the father. On it were many designs (daidala) fashioned, a wonder to behold (thauma idesthai), all the formidable creatures that the land and sea foster: many of them he put in, charm (charis) breathing over them all, wonderful designs, like living creatures with a voice of their own (Hes. Theog. 578-84, tr. West).

88. According to the lexicographers, Peitho is one of the Charites. For references see Schwarzenberg 1966: 20 and Solmsen 1954: 5. The role of Peitho in marriage rituals and democratic speech is discussed by Meier 1985: 11-13 and Pirenne-Delforge 1996: 199.

89. On the connection between daidala and charis see Frontisi-Ducroix 1975: 72. She understands the gleam of charis here as the result of craftsmanship. 
It is not just the connection with the female business of bathing, anointing, and dressing that suggests that clothing is the medium of charis when it is radiated by people with an effect on the opposite sex. Just as Odysseus gleams with beauty and charis after bathing and dressing in the house of

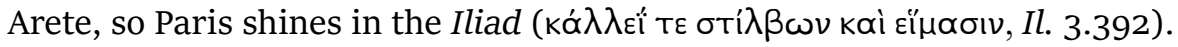
Charis is only here replaced by a garment: heima. A glance at Pandora's outfitting allows us to see that such textile media of charis must be colourful and patterned garments. In Works and Days Pandora receives charis from Aphrodite, who pours it on her head just as we have seen Athena

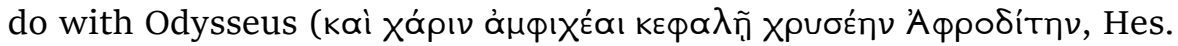
$O p$. 65). More concretely, in the Theogony, she is given a patterned veil instead of charis; the gift comes from Athena, quite appropriately, who is also said in Works and Days (Hes. Op. 63-64) to have taught Pandora the art of colour weaving:

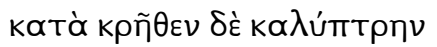

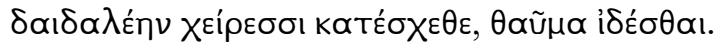

down over her head she drew a patterned veil (kalyptrēn daidaleēn) with her hands, a wonder to behold (Hes. Theog. 574-75).

Penelope's gleaming veil is not the only example of visually effective clothing in epic poetry. The garments placed on Aphrodite by the Charites after her bath are also a 'wonder to behold' (Od. 8.366). The same thing is said of the purple textiles woven by the Nymphs at Ithaca (Od. 13.108), and of the threads on Arete's spindle (Od. 6.306). Athena, the goddess who endows men with charis, is also responsible for giving the Phaeacian

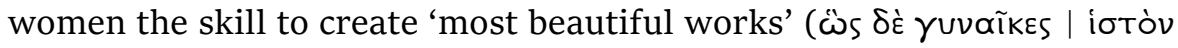

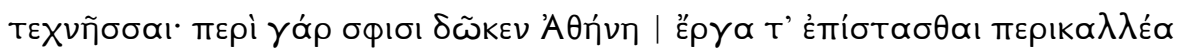

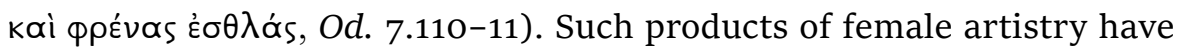
a similar effect to charis on the opposite sex. The clothes in which Paris gleams with charis, like Odysseus, are intended to maximize his attractiveness to women. Aphrodite gives them to him when she removes him from the battleground and places him in the bedroom to await Helen and renew their love (Il. 3.374-446). In the Hymn to Aphrodite, Anchises is aroused not only by the beauty of Aphrodite's body but also by the gleam of her clothing (Hom. Hymn Aphr. 85-91). In Aristophanes's comedy 
Peace (859) the groom, who is represented in patterned garments on

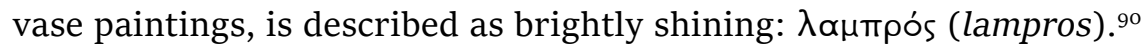

In epic poetry, garments are often described with epithets that point to the shine or gleam associated with charis. So Odysseus leaves Ithaca

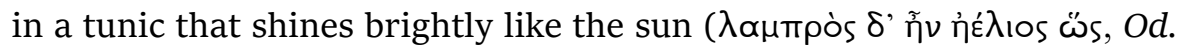

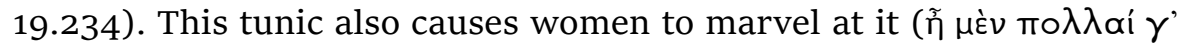

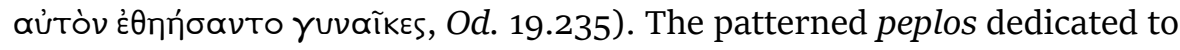
Athena by Hecuba (Il. 6.295), and the one given to Telemachus by Helen

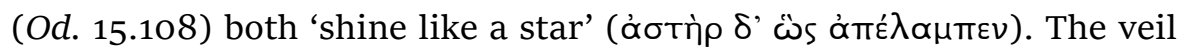
thrown aside by Hecuba when she hears of Hector's death is described as

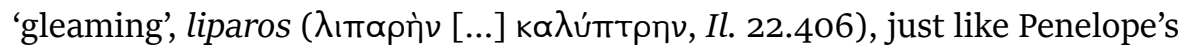
veil. A similar gleaming veil is also worn by Charis, Aphrodite's double, and the wife of Hephaestus, when she receives Thetis (Il. 18.382). Additionally, the city of the Charites, Orchomenos, is also given this attribute by Pindar

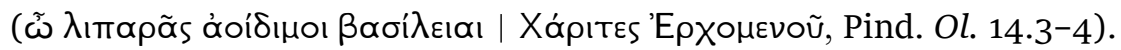

It is possible to attribute the lustre associated with garments and their effect described with $\lambda \alpha \mu \pi \rho o ́ s ~(l a m p r o s), \lambda ı$ ıтрós (liparos), бтí $\lambda \beta \varepsilon ı v$ (stilbein), and $\lambda$ á $\mu \pi \varepsilon ı v$ (lampein) to the fact that linens were finished with oil so as to give them a kind of water-repellent coating. ${ }^{91}$ This is said of the tunics worn by the youths on the shield of Achilles: the tunics have a gen-

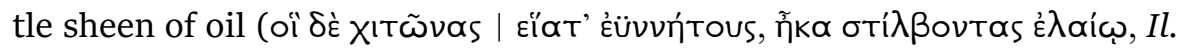
18.595-96). But such linen clothing is also often described as colourful, so that the lustrous effect might also refer to effects caused by the patterns, which as we have seen earlier was the business of the Charites. ${ }^{92}$

In ancient colour theories, which in fact represent theories of perception, colour was thought to be an emanation of light which either originates from an object or flows through it (so Aristotle), or a stream of light or fire that emanates from the eye and meets the light emanating from the perceived object, thus making it visible. ${ }^{93}$ This would explain the lustre of garments: lampein and stilbein would then signify both the light streaming

90. Cf. also Waldner 2000a: 211-213 on the Attic heros Theseus as ideal groom who receives his wedding cloth from the goddess Amphitrite. For evidence in vase-painting see Oakley and Sinos 1993.

91. Thus Blümner 1912: 196 and Bieber 1967: 23. Marinatos 1967: 4 takes a different view, assuming that the garments are woollen and that their shine stems from treatment with lanolin during the dyeing process, which ensures that colours stay vibrant and lends them a metallic sheen.

92. On the evidence of linen see ch. 5.3.

93. For detail on pre-Socratic colour theory see Stulz 1990: 23-64; Hagner 1987: 22-25. On ancient colour theory and on colour and brilliance see also Gage 1993: 11-27. 
from the eye and the return stream of light from the object. Greek colour adjectives never convey a clearly defined colour, such as 'white' (though lampros and leukos are often translated thus), or purple or violet as porphyreos is sometimes translated. Rather such terms indicate different intensities of shine or gleam. ${ }^{94}$ The same doubleness applies to charis. Just like the light of colours, charis does not emanate only from objects, it also radiates from the eye. In the Homeric Hymn to Demeter, in Metaneira's address to the goddess, charis is a power manifested in the goddess's eye

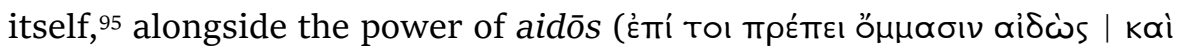
Xópis, Hom. Hymn Dem. 2.214-15). It is a power held by kings who watch

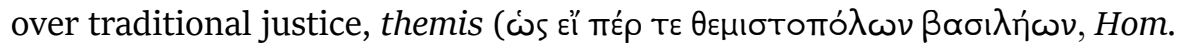
Hymn Dem. 2.215). Pindar refers to the Charites who reign over Orchomenos as episkopoi, or 'sharp-eyed', thus referring to the moral dimension of charis (Pind. Ol. 14.4).${ }^{96}$ For Xenophanes the eye itself, which judges the effect of charis, has divine qualities. ${ }^{97}$

All this suggests that we must see charis, especially as it is given to Odysseus, as the radiance that emanates not only from the gleam of gold and silver but also from colourful patterns on clothing made using the techniques described earlier. This is not just a matter of observing patterns and images in clothing and jewellery. In the sense of radiance, charis makes status visible through the medium of dress or jewellery; it ensures the right perception of a person in the eye of the beholder. Thus the term has both aesthetic and moral connotations. ${ }^{98}$

The impact of colourful clothing and jewels is evidenced in many recognition scenes as well as in situations when military decisions are taken. ${ }^{99}$ So in the Achaean assembly the gleam of the golden sceptre and the purple colour of his clothing ensure that the decision-maker stands out and that his performance makes an impact. The effect of the colour purple is like

94. Stulz 1990: 25-28, 71; MacLachlan 1993: 65-68; Gage 1993: 12-14. See also Handschnur 1970: 74-78; Dürbeck 1967: 61-70. For a collection of groups of colours see Moonwoman 1994: 37-65. See now Grand-Clément 2011; Spantidaki 2016: 86-90.

95. See ch. 4.1.

96. See Sappho fr. 151 (Diehl), where charis emanates from the eye.

97. See Svenbro 1976: 99.

98. See MacLachlan 1993: 149, who stresses the ethical-aesthetic dimension of charis without considering the material meaning.

99. For instance, Athena transforms herself into a woman skilled in 'lustrous work'

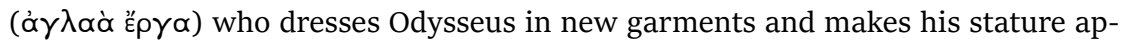
pear larger (Od. 16.172-74). The use of aglaa to describe Athena's work points to the impact and attraction achieved by means of the clothing. 
'the spotlight which picks out a new protagonist just before the action'. ${ }^{100}$ Purple is worn in the Odyssey precisely by those who emanate charis: Odysseus (Od. 14.462; 19.225) and Telemachus (Od. 8.114-16; 21.118). ${ }^{101}$ In the Iliad, purple is worn on the Greek side by high-ranking leaders such as Agamemnon (Il. 8.221) and Nestor (Il. 10.133-34). ${ }^{102}$

Special garments displaying the kinds of colour and shine seen in those worn by Odysseus and Agamemnon may also be described with the adjective charieis. But those who wear them are-almost without exception-of divine descent. This includes gods who have powers of transformation, such as Circe, Calypso, and Hermes. So Hebe, working for the Charites,

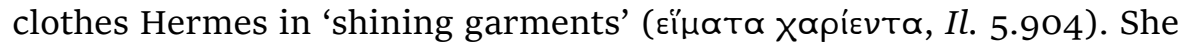
herself is the embodiment of youth, which also carries the adjective char-

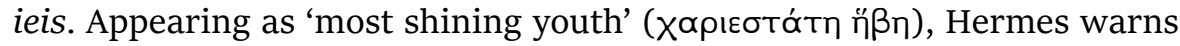
Odysseus of Circe's magical potions (pharmaka) with which she has already transformed his companions into swine (Od. 10.279; cf. Il. 24.348). Circe herself wears a garment described as charieis, a 'delicate and shining

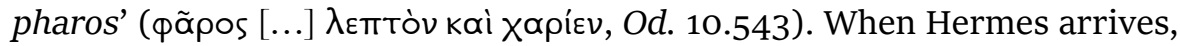
he finds Circe walking up and down at her loom singing, while weaving an 'immortal web, like the works of the goddesses, delicate and shin-

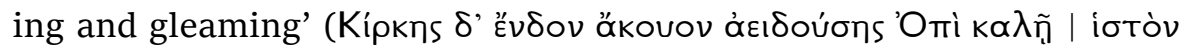

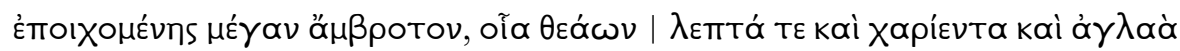

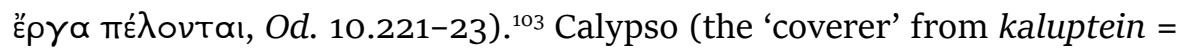
to wrap up or cover) also wears such a fine and shining garment ( $\phi \tilde{a} \rho \circ$

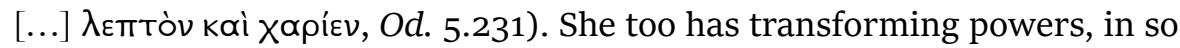
far as she furnishes Odysseus with the sail which transports him from the world of the immortals back to the world of mortals. ${ }^{104}$ Among garments used by mortals the description charieis is used only of textiles which are closely connected with the divine or with death. These would be the

100. Stulz 1990: 120. See Willenbrock 1969: 19; Patzek 1992: 188-93, on the dramatic use of the imagery of metallic shine.

101. The pharos Odysseus receives from Nausicaa is also purple (Od. 8.84).

102. The epithet porphyreos is associated with patterned garments woven by Helen and Andromache (Il. 3.126; 22.441).

103. On the relation between singing and weaving see now Karanika 2014: 71. She refers to Anthony Tuck (2006) who has argued that weavers 'use song as a memory aid: like a counting system, the rhythm helps them remember the pattern'. The research on rhythm and work goes back to Karl Bücher's Arbeit \& Rhythmus (1896). See Wagner-Hasel 2011: 188-94.

104. On the relationship of Calypso with death see Vernant 1982: 147-48; Crane 1988: 20; Murnaghan 1992: 250; Papadopoulou-Belmehdi 1994: 171-80. 
patterned peplos intended as an offering for Athena, and the garments Andromache wishes to burn after the death of Hector (Il. 22.511; 6.90 = 271). This suggests that such garments, similar to charis itself when it is poured by Athena over someone's head and shoulders, effect a transformation of status intended to recognize immortality. This is precisely what happens, as will be shown in more detail, during rituals for the dead. ${ }^{105}$

Death itself is described as the loss of charis in its sense of radiance, both in epic and in later literary sources. So Hector's once radiant head lies in the dust on the ground after his defeat by Achilles: its radiance is

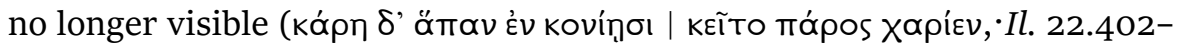
3). ${ }^{106}$ It appears here that Hector's hair is the seat of his radiance, as we have seen how the appearance of hair is changed when Athena pours charis over her protégé's head (káp円) and shoulders in the Odyssey. We also hear that Euphorbus's hair is decorated with gold and silver like that of the Charites (Il. 17.51). ${ }^{107}$ Kare $/$ kara is not necessarily only the head but can encompass the whole figure and its clothing, as can be seen in a different passage. ${ }^{108}$ When Patroclus falls by Hector's hand we hear that Apollo removes from Patroclus's head the helmet that once protected the 'radiant

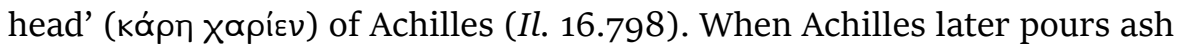
over his 'radiant head' ( $\kappa £ \propto \alpha \lambda \tilde{n} \varsigma, \chi \alpha \rho i ́ \varepsilon v$ ), the ash stays on his tunic and so robs not only his head but also his clothing of radiance (Il. 18.24-25).

When the dead lose their radiance, it is restored to them in different form through the rituals of washing, anointment, and dressing in garments described as charieis or ambrotos. These do not confer charis, but they do confer immortality and they heighten kleos, the glory of the dead. By contrast, while Hector's radiant head lies covered in dirt on the ground, Andromache laments as though the 'radiant clothing' can be a substitute for the dead:

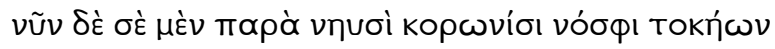

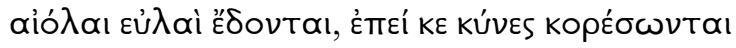

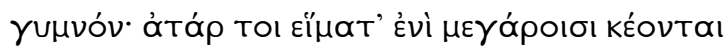

105. Cf. ch. $4 \cdot 3$.

106. See also Stesichorus fr. 68 (D. L. Page, Stesichorus, The ГEPONEI $\Sigma$, in: JHS 93, 1973, 138-54); Eur. fr. 736.3-6 Nauck; Soph. Aj. 1266-67. For discussion see MacLachlan 1993: 75; Morris 1989: 307-10, n. 78.

107. In ancient literature the Charites are often praised for their marvellous clothing and their wonderful hair. Sappho (fr. 9o Diehl) und Pindar (Pyth. 5.45) call them к $\alpha \lambda \lambda i ́$ коноı. For further evidence see Simon 1985: 236-41; Deichgräber 1971: 402. 108. Vernant 1986: 19-46. 


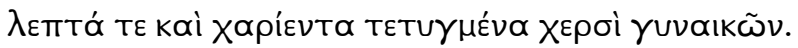

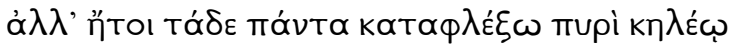

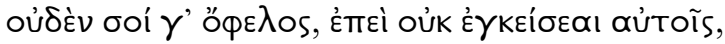

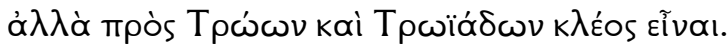

And you, by the beaked ships, far from your parents, naked, will be eaten by maggots when the dogs have had their fill. Yet delicate and radiant (lepta te kai charienta) clothing made by women's hands is still stored at home. I am going to burn it all in the consuming fire. It is of no use to you: you will never be buried in it. But the men and women of Troy will do that for you as their last mark of honour (kleos einai) (Il. 22.508-15, tr. adapted from Rieu).

From the account of Achilles' burial in Odyssey 24 we learn that the dead were burnt in their clothes, described here as ambrota heimata, immortal clothing (Od. 24.59). The same phrase is used for the clothes the gods place on the dead Sarpedon when they take him off the battlefield to give him an honourable burial (Il. 16.670 and 680). The clothing of the dead is also distinguished by colour and shine and is described as purple or as shining brightly (leukos) or gleaming (aglaos). ${ }^{109}$

In Democritus's colour theory leukos and lampros are synonymous and signify a bright translucent light which turns a reddish black to purple. ${ }^{110}$ The shroud Penelope weaves for Laërtes is also described in terms of the lustre associated with burial clothes: it shines like the sun and the moon

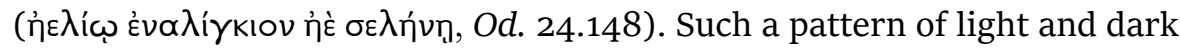
may be observed on shrouds in representations of death rituals on geometric vase paintings (Figure 5). ${ }^{111}$ The garments of the dead associated with the attribute charieis seem to promote a change in status, just as charis does when poured by Athena over the heads and shoulders of her

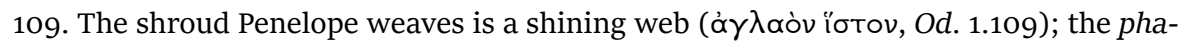
ros used to cover the body of Patroclus is leukon (Il. 18.353). The peploi used to wrap Hector's remains are purple (Il. 24.796).

110. Stulz 1990: 38-39.

111. Marwitz 1961; Barber 1991: 358-83. Papadopoulou-Belmehdi 1994: 118 reads gender-specific symbolism into the imagery of the sun (Odysseus) and moon (Penelope). Lewis 1981: 95 stresses a fundamental connection between geometric vase-painting and social values: "What we see in the full range of Geometric designs is nothing less than icons of spiritual meaning central to the life of the culture.' See also ch. 4.3. 
protegés. The transition of the dead corpse from the world of light and life to the darkness of Hades is guided by Hermes, who himself is dressed in charienta heimata. ${ }^{122}$ A substantial portion of the ritual of transition, namely the washing and dressing of the dead, is carried out by the women of the household; their divine representatives, the Charites, also form the entourage of Hermes in post Homeric literature. ${ }^{113}$ Charon only appears in fifth-century literature. ${ }^{114}$ Since the glory and reputation of the dead is associated with these lustrous garments, they function as emblems of immortality, they represent 'immortal garments' as a form of memorial ('Gedächtniszeichen'). It would make sense to attribute this special quality of remembrance not only to the lustre and colour of the fabrics but also, and indeed especially, to the coloured patterns and images which are produced thanks to the skill of the Charites and their human representatives.

Such an interpretation of charis as a visual effect emanating from coloured images worked in weaving or metalwork is linked to a further function of charis, that of the radiance, or charisma, associated with speech or song. This latter form of charis is also visualized as an object-a garland or wreath. So, Odysseus berates Euryalus because 'charis does not garland

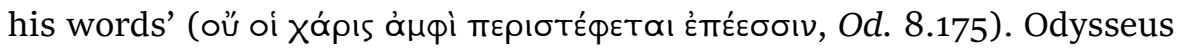
himself is confirmed by Alcinous as speaking 'not without charis' (oủk

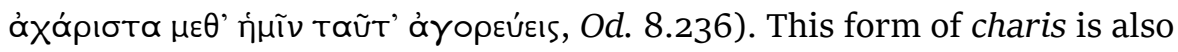
a divine gift, as Odysseus reminds Euryalus: 'the gods do not give lustre to every man: not in appearance, not in sense, not in speech' (oưt $\omega_{S}$ oú

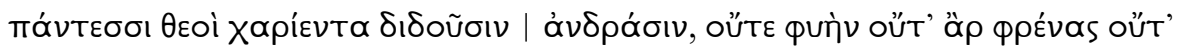

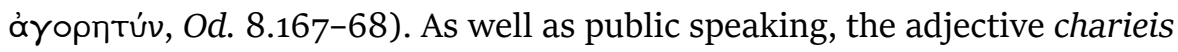
also qualifies the performance of divinely inspired song. So Agamemnon in the underworld praises Odysseus when the dead suitors report on Penelope's constancy: 'The immortals will make a lustrous song about sensible

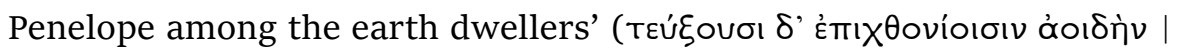

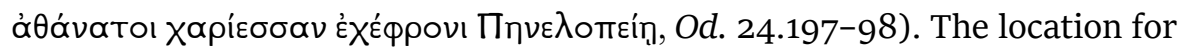
the performance of such songs is the banquet, which too is characterized with the comparative form of charieis. So Odysseus comments on Demodocus's song in Phaeacia:

112. So say the suitors in the underworld (Od. 24.1-14). For life as light see Griffin 1984: 90 .

113. Zilinski 1924: 159 .

114. See e.g. Aesch. Sept. 850-6o. For further evidence and discussion see SourvinouInwood 1995: 303-61. 


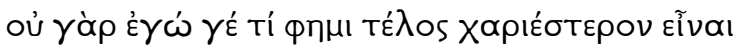

ก๊ öT’ '̇ü

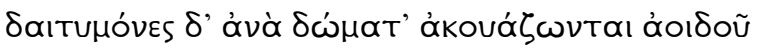

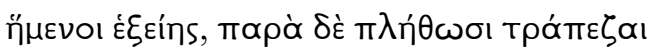

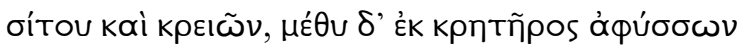

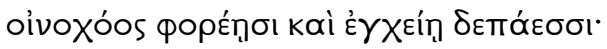

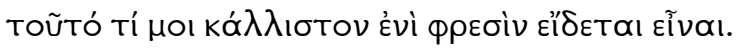

I myself feel that there is nothing more delightful (chariesteron) than when joy (euphrosyne $)^{115}$ reigns in the hearts of the entire people and banqueters listen to a singer form their seats in the hall (dōma), while the tables before them are laden with bread and meat, and a steward carries round the wine he has drawn from the bowl and fills their cups. This, to my way of thinking, is perfection (Od. 9.5-11, tr. adapted from Rieu). ${ }^{116}$

According to Joachim Latacz the image of the garland points to the idea that charis in speech or song is a quality of form rather than content: 'Attraction [i.e. charis] is placed on the words [...] as it is on the body [...] like a garland. ${ }^{117}$ This is a matter of the effect of speech or song, rather than the specific content. Content is the business of the Muses, while their

115. In Hesiod the name of one of the three Charites is Euphrosyne, which means 'Joy'. Joy is the goal (telos) of the poet's song which functions as medium to reach a higher measure of pleasure, that means: charis (Hes. Theog. 908). Here the Charites are spatially associated with the Muses (94), who inspire the bards in epic and even chant the dirge for the dead (Od. 24.60). Pindar (Isth. 7.16-19; Pyth. 11.5558) and Sappho follow Hesiod in their interpretation of the Charites. See Scott 1983: 11; Deichgräber 1971: 29-36; MacLachlan 1993: 76 and 93-98. On the link between the Charites and feasting see Meier 1985: 50 and Fisher 2010.

116. In the Homeric Hymn to Hestia, which celebrates the goddess's service (amphipoleuein) at Delphi, charis is a quality of song (Hom. Hymn Hestia 24.5: Xápıv

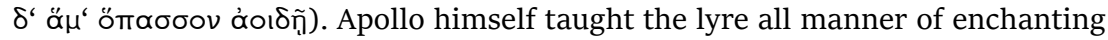
charienta (Hom. Hymn Hermes 4.485). In visual representations the Charites are by Apollo's side. Compare for instance the statue of Delian Apollo with a statue group of the Graces placed on the right hand. Fehr 1979: 72.

117. Latacz 1966: 86: 'Wie Xápıs dort nur eine Vervollkommnung der Form bewirkte, nicht auf das Wesen ging, so auch hier: auf den Inhalt der Reden kommt nichts an, "Lustbereitung", "Anziehung" geht von ihnen nicht ihres Inhalts willen aus,

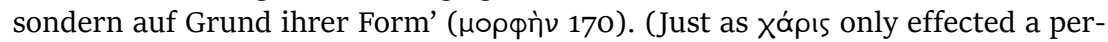
fection of outward form rather than essence there, so here too: it is not about the content of the speeches. Their attraction and the pleasure they provide stems from their form ( $\mu$ opфìv 170) not from their content). 
immediate neighbours (according to Hesiod), the Charites, take charge of the delivery and effect of that content. In a fifth-century hymn we find Bac-

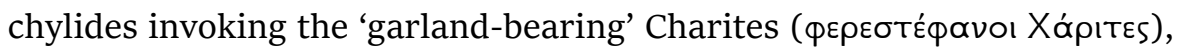
who wreath his hymns with honour (Bacchyl. Dith. 19(5).6-8, ed. Maehler 1997: 26-27). Elsewhere the poet has Menelaus's winning rhetoric in a

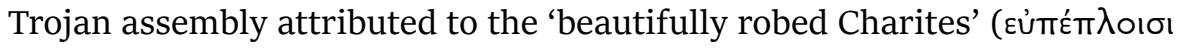

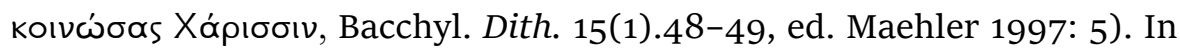
Pindar, the tongue draws words of praise and memorial from the mind (phrēn) by favour of the Charites (Pind. Nem. 4.6-7) ${ }^{118}$ Both poets make use of the terminology of pattern-weaving to refer to their own activity. So Pindar speaks of a 'Lydian crown, woven through with sound' presented for Deinias of Aegina ( Nem. 8.14-16). For the sons of Amythaon he weaves a colourful headband

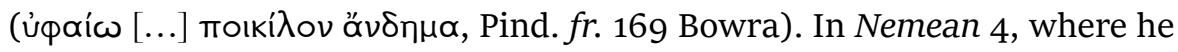
also refers to the favour of the Charites, Pindar exhorts the lyre to 'weave out' his song ('̇£úqaıve, Pind. Nem. 4.44-45). In Bacchylides's Ode 19, in praise of the Athenians, we find further weaving imagery: 'weave some-

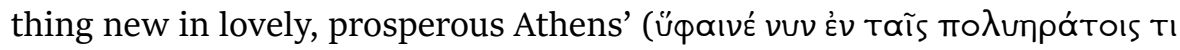

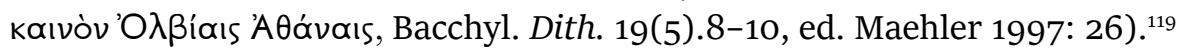

Jane McIntosh Snyder views this use of weaving metaphors as evidence of a new self-awareness on the part of the poets, who see themselves as independent and skilled producers of their songs, and view poetry as a learnt techne, akin to the craft of weaving. ${ }^{120}$ The key to the use of the metaphor is, however, not merely techne itself but more specifically the technique with which pictures are crafted. This technique then is not only the domain of skilled weavers and smiths, whose products exude charis, but also belongs to poets and singers. Through their crafting of visual images that are no less persuasive than the decorative images on metal objects and textiles, the poets, too, partake in the poetics of visualization that has been discussed. ${ }^{21}$ In this context charis must again be interpreted as a visual power that ensures the emotional effect of the images created by poets and orators. The fact that these images produced by poets and singers are described in terms of weaving by Pindar and Bacchylides is not

118. See also Pind. Isth. 7.16-19; Pyth. 11.55-58. On the ability of charis to grant memory see MacLachlan 1993: 87-98.

119. See MacLachlan 1993: 63.

120. McIntosh-Snyder 1980: 196.

121. On the similarities between woven and poetic pictures, see Bergren 1980: 22. For a poetic of visualization in oral poetry see ch. 1.5 . 
so much due to any similarity in the effect of woven and literary images as it is connected to the emergence of the new medium of writing. Unlike Homeric bards, the poets of the fifth century create a written text which they send to their patrons (cf. Pind. Nem. 8.46). ${ }^{122}$ In this sense, they produce, metaphorically, a piece of cloth, a text into which they weave, through the use of words, mental images. Both texts and woven textures are associated with memorializing. Even if the woven image may only strengthen and support the viewer's own imagination and so support memory, without being able to take the place of highly differentiated images created in poetry, both types may function as bearers of glory and memory. While the memory in Pindar's woven hymn is of the individual glory of the winners in panhellenic contests, in epic poetry the glory of the dead hero is conveyed through the patterned garments and shrouds connected to the funeral ritual alongside grave memorials and prizes. ${ }^{123}$

Following these observations, charis emerges as a central term in both social and symbolic exchange. In examining the terms for guest-gifts, we were able to gain insight into the various temporary ties and relationships forged between strangers. Charis shows us more of the reciprocal structure that governs these ties and relationships: reciprocity in the exchange of services and favours and gifts of gratitude in warrior communities and domestic communities as well as in relation to the gods. When a warlord renders charis to another warlord in the form of some service in war, there is a collective of warriors behind him; similarly, a wife who owes charis to her husband as thanks for his bridal gifts is backed up by a group of dependent women who perform services for her. If woven images are as much bearers of charis as are works of metal, then work on the loom is a part of this female charis-and this work in turn is responsible for charis in the sense of the lustre or radiance, the visual power, with which certain persons are endowed. We also find this feminine form of charis in the garments of the immortals, which are described as charieis. Charis then shows itself also to be connected to the production of textile and metal gifts which circulate in various ties and relationships. The reciprocal structure of a relationship is visualized doubly in that both genders present each other with the lustre and sexual attraction of charis in the form of jewellery and garments endowed with charis. This form of charis is, in turn, a part of charis in the sense of services recruited by high-ranking women and men

122. Scheid and Svenbro 1996: 117-22; Pöhlmann 1990: 11-30; Thomas 1992, ch. 4. 123. Ch. 4.3 . 
from smiths and skilled weavers, and the products of which, jewellery and clothing, they offer to one another as gifts. It is because of this hierarchical structure, to which I shall return, that this form of charis which adheres to the objects and images is represented as divinely mediated. Since gods appear as producers of charis, we see a close connection between the spheres of production and consumption, which is also evidenced in the fact that high-ranking individuals are also represented as skilled craftsmen and craftswomen.

This underlying, mutual code governing the production of charis is reflected in the way in which the metaphors used to evoke charis in woven garments, jewellery, and poetic texts are interchangeable. ${ }^{124}$ In epic poetry, charis adheres to images created by words, to the songs of bards delivered at banquets, and to the speeches of men in assemblies; this creates a sense that material as well as verbal signs form the components of a basic structure which is determined by visibility. In sum, the term charis encompasses appearance and being, achievement and status made manifest through external appearance, aesthetically pleasing speech, and ethical content.

However, this is also problematic. Hector's reproach to Paris, that the Greeks had assumed him to be brave in battle because of his beautiful ap-

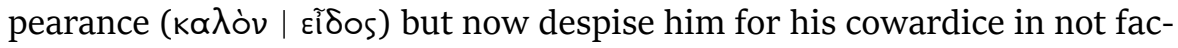
ing Menelaus in a duel, is underscored by the assumption that moral virtue is linked to beauty (Il. 3.44-45). An individual whose actual achievements do not measure up to the status suggested by their physical appearance is threatened with stoning. This punishment is invoked with a striking image that underlines the link between achievement and appearance, when Hector warns that it is only the Trojans' cowardice that has saved Paris from

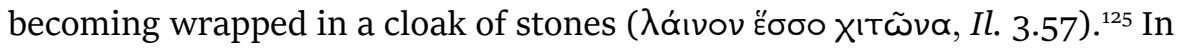
response to this, Paris does indeed prepare to face Menelaus but not without first defending the gifts of Aphrodite to which he owes his beautiful appearance and his lovely hair (Il. 3.55). In Hesiod's Theogony (585-99) a similar criticism is levelled at Pandora, in whom outward beauty does

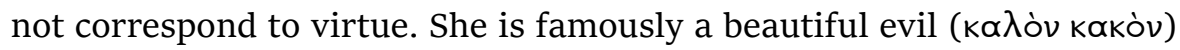

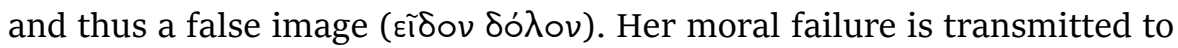
the whole race of women, who feed like drones off the labour of others.

124. Dougherty 1993: 157-63: 'Metaphor, one word colonizing another's space, helps the Greeks negotiate their place in an alien environment-both in trying to understand the new world and in staking out a place for themselves in that world.' See also Lonsdale 1990: 125, and-more generally-Haverkamp 1996.

125. On the connection between status and physical appearance see Cobet 1981: 25-26. 
In both cases, Paris and Pandora, the aesthetic problem-that beautiful appearance does not correspond to virtue-suggests that charis, the radiance or lustre which ought to guarantee the correct perception, fails to do so. In both cases, the problem arises because of a failure in the reciprocal exchange of charis in the sense of services or goods between warriors or between man and woman.

The following chapter will focus on conflicts in the operation of networks of charis. In epic narrative such conflicts tend to centre on the breakdown of reciprocities of service rendered on the battlefield or at the loom. 


\section{CHAPTER 4}

\section{Timē and Geras: Gifts of Honour and Structures of Power}

\subsection{Homeric kingship}

The flow of gifts and services we observed through the analysis of the 1 terms xeineia and charis is not without conflict. Indeed, the Iliad begins with a refusal of service, when Achilles withdraws from war duty (charis) for Agamemnon because he feels dishonoured (atimos) by the loss of his share of the spoils and his gift of honour, his geras, in the form of Brisëis. The Odyssey ends with the punishment of Penelope's suitors, who had aimed to obtain Odysseus's privileged position (geras) by marrying his wife, and who had availed themselves of his goods without recompense (atimos). The restitution of Odysseus is made possible by Penelope's refusal of service at the loom, by her trick of unravelling her day's weaving at night and thus delaying the promised remarriage. Through this focus on Penelope's trick, the Odyssey-called by some scholars the Penelopeiabecomes the feminine counterpart to the Iliad. ${ }^{1}$

The key terms for understanding these conflicts are tím (timē) and

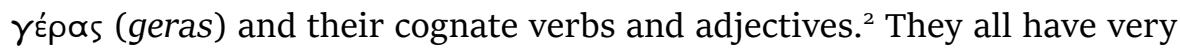
strong material connotations. ${ }^{3}$ Timē can be rendered as either 'honour' and 'esteem' or as 'status'; geras may describe a concrete prize or gift awarded

1. See Finley Jr. 1978: 3; Murnaghan 1987: 103-15; Winkler 1990: 133, who discuss the idea of female authorship of the Odyssey developed by Samuel Butler in the nineteenth century. Although they do not follow this concept, new research has underlined Penelope's role for the narrative composition of the Odyssey. See Katz 1991; Papadopoulou-Belmehdi 1994; Clayton 2004 and Canevaro 2018.

2. For evidence see Greindl 1938: 59-82; Riedinger 1976: 244-64; Katluhn 1914: 1-63; Schmidt 1982: 133-36.

3. This is underlined by many authors. See Greindl 1938: 67-68; Katluhn 1914: 1-6 and 76, Schmidt 1982: 134-35; Steinkopf 1937: 17-23; Benveniste 1969: I, 68-69; Vleminck 1982: 151-64; Cobet 1981: 30; Ulf 1990: 4-12; Scheid-Tissinier 1994: 196203, 234-44. 
to an individual as well as the status conferred through the receipt of the gift. The status or esteem conveyed in the terms time and geras is always measurable and quantifiable: honour and dishonour are always tied to giving and withholding, while an individual's status is always connected to the goods or services the individual receives. Hence Jean-Claude Riedinger views time $\bar{e}$ as a key term for the manifestation of a Homeric ethics of reciprocity. ${ }^{4}$

Terms of honour and esteem, such as tímav (timan), tíєıv (tiein), and

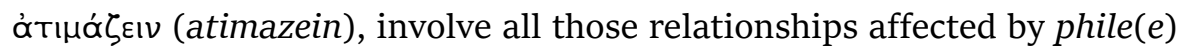
in, the term that expresses the sense of belonging as discussed above: relationships between men and gods, warriors and their leaders, men and women, parents and children, women and their servants, masters and servants, and finally between guest and hosts. We may add to this another relationship which we have only touched on so far, but which is of some significance for an understanding of timē and geras: that between a high-

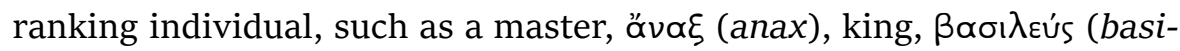
leus), or queen, $\beta \propto \sigma i ́ \lambda \varepsilon ı \alpha$ (basileia) and their people, described as a $\delta \tilde{n} \mu \circ$

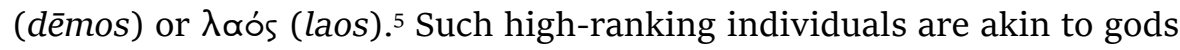
and appear alongside the singer of songs and elder councillors (the bard Demodocus: Od. 8.480, and Nestor: Il. 23.648) as owners of timē. Their

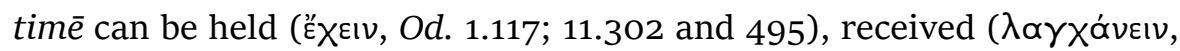

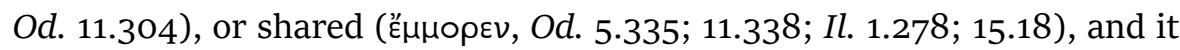
is possible to rule or master it (ávóoofıv, Il. 20.181). Timē may be shared

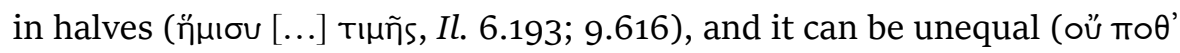

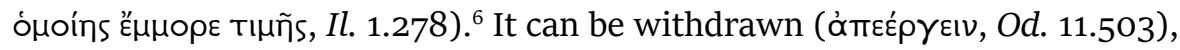

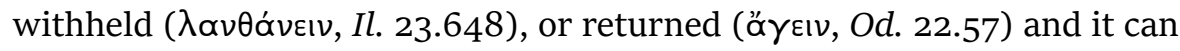

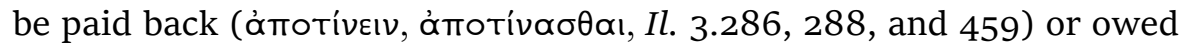
(óøé $\lambda \lambda \varepsilon$ Ev, Il. 1.353 and 510). It is owed to the gods, from whom it originates

4. Riedinger 1976: 251-52: 'Il ne faut pas se la représenter comme un fait d'ordre psychologique, un sentiment d'honneur, mais pas d'avantage comme un objet, une sorte de capital qui comprendrait les possessions et le courage qui les défend. Tím est en fait conférée par les autres, elle désigne une relation. Elle reconnait à celui qui la reçoit une valeur, et, pour l'obtenir, une qualification est nécessaire'. 263-64: 'Deux éléments apparaissent donc ici, et qui sont indissociables. D’un côté l'exploit crée une obligation, attend une réciprocité. Mais cette obligation fonctionne comme un appel à une réponse généreuse, aussi bien dans son intention que dans sa dimension [...] Réciprocité et générosité: telles sont les deux composante du lien de timè [...] Et dès lors on peut parler sans hésiter d'une morale de la timè'.

5. Riedinger 1976: 247.

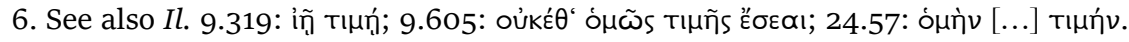




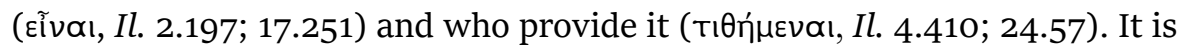

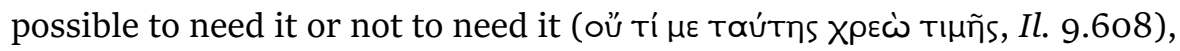

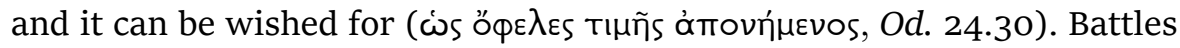

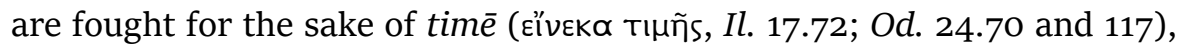

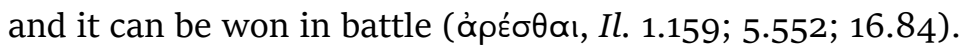

Because of this clustering of time around high-ranking individuals and because of its divine origins, past scholarship took timē, like geras, to mean the privilege of kings, ${ }^{7}$ and by extension such scholarship was keen to distinguish between public and private or domestic time.$^{8}$ Epic, however, does not draw the modern distinction between public and private spheres. It is true that terms such as ísıos (idios), 'pertaining to oneself', and $\delta$ 'ń difference between action taken on behalf of the individual and on behalf of the demos. ${ }^{10}$ Although this distinction may correspond to the contrast between the good of the community and the pursuit of individual benefit common in later sources, it does not suggest a division into public and private spheres for Homeric society. Given that the honouring or dishonouring of an individual always takes place in the public eye, the crucial aspect of visibility connected to the public sphere ${ }^{11}$ is a significant factor

7. According to Finsler 1906: 319-20, time denotes the royal dignity bestowed by the dēmos. Fanta (1882: 49) understands timē as an institutional ('staatsrechtlich') term which does include not only honour but also obedience. Riedinger (1976: 246) interprets timē as 'dignité royale' in a nonjuridical sense (261). Cobet (1981: 82) argues that timē has the meaning of an office. Carlier (1984: 141) sees geras as the real term for the office. No institutional relevance is accepted by Ulf (1990: 4) who argues that time was esteem available to everybody.

8. See Riedinger 1976: 247. He classifies the relationship between hetairoi, between parents and children, between couples, and between servants and masters, as private.

9. Cf. Gschnitzer 1991: 198; 1992: 158-59; Ceccarelli, Létoublon and Steinrück 1998: 47-58.

10. The juxtaposition of demios und idios occurs twice in the Odyssey: once when Telemachus explains to Nestor that he is travelling on his own 'private' business and not for affairs of the dēmos (Od. 3.82: $\pi \rho \tilde{\xi} \xi 15$ ' when Menelaus draws the same distinction asking Telemachus upon the latter's arrival if his own need or that of the dēmos has brought him to Sparta (Od. 4.312-

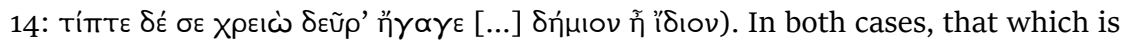
described as idios is the anxiety about the missing father and the state of affairs at home. Elsewhere we find the state of affairs at home forms the subject of discussion at an assembly of the demos (Od. 2.44), while by contrast the approach of an army is seen as communal (dèmios) business (Od. 2.43). For more detail see ch. 5.1. 11. For the meaning of 'public' as the 'visible' see Habermas 1968: 11; Hölscher 1979: 37-39. 
in estimating the time accorded an individual. Both time and geras require the gaze of others, of the community, in order to be effective. There can be no such thing as private, or hidden, time .

This public effect is expressed through the term aíó's (aidōs). Aidōs denotes both shame and fear of public opinion and incorporates the attention paid to the perception of those who observe time or geras. Since the demos both bestows the material goods by which time and geras are demonstrated, and represents the public opinion by which status is measured, time is clearly connected to communal action. Both time and geras denote not only esteem but also authority ('Herrschaft'). By authority I am not here suggesting Max Weber's sense of the chance to command obedience for certain actions from specific individuals. ${ }^{12}$ In the Homeric world the reciprocal aspects of rulership are more important than elements such as obedience and command. Time and geras do not denote such one-sided dominance; instead they form the foundations of a reciprocal system for the provision of gifts and services we have discussed in previous chapters. We will see that this same reciprocity (even if it is not always entirely symmetrical) applies also to the relationships between the demos as a whole and the high-ranking kings and queens who rule over it.

Discussion of the terms time and geras must involve discussion of the character of Homeric kingship, which has a long and varied history in scholarship. Interpretations of the status of the Homeric basileus range from 'patriarchal kingship', ${ }^{13}$ 'oriental despotism' and 'divine kingship', ${ }^{14}$

12. Hilger 1982: 99-100; Rebenich 2012: 1113.

13. This position was widely accepted at the end of the nineteenth century. See e.g. Fanta 1882 and Bréhier 1904: 1-34. Both underline obedience as a key element of the patriarchal kingship, but they differ in their concept of the state. Fanta assumes a developed form of statehood and sees kingship as a public office. Bréhier questions the public character of kingship and views the state in Homer as a confederation of families, one of which stands out as royal (13-14). He sees kingship as legitimated by religion rather than law.

14. Finsler 1906: 412 argues that in Homer a rudimentary form of divinely sanctioned kingship ('Königtum von Zeus' Gnaden') is contrasted with oriental tyranny at Troy. In his view, however, Homeric kings are merely regents within a system of aristocratic rule. The concept of divinely sanctioned kingship ('Gottesgnadenkönigtum'), in that the role of the king is legitimated as divine, differs from the idea of sacred kingship where the king is imagined as a representative of the divine. The concept of sacred kingship goes back to James Frazer's Golden Bough (1912) and has been particularly influential in studies of Mycenaean rulership. See Puhvel 1958: 327333; Mondi 1980: 203-216; Vernant 1962. 
to 'feudal rule', ${ }^{15}$ 'chiefdom' or the 'big-man' system. ${ }^{16}$ Contradictions and inconsistencies in any given model are often attributed to the Mycenaean past, ${ }^{17}$ or to the lack of institutionalization in Homeric kingship..$^{18}$ The argument over Achilles's geras, and the suitors' competition for Penelope, are key events in terms of the understanding and evaluation of Homeric kingship. Agamemnon's taking of Achilles's prize is seen by some as evidence for the existence of a form of oriental despotism; the suitors' behaviour at Ithaca is conversely read as pointing towards the fundamental instability of a king's status, and the predominance of a 'big-man' system.

I do not want to add a further model to the various current images of Homeric kingship. In what follows I am taking my lead only from what the epics tell us about themselves. This does not mean a refusal to clarify the positions suggested by terms of ranking such as basileus, basileia, and anax. But given that my point of departure is the content of the honours awarded to high-ranking individuals, as expressed in the terms time and geras, there is no need to fall back on typologies of kingship, nor indeed on

15. Martin P. Nilsson's concept of feudal kingship (1927: 23-40) has long been controversial. Cf. e.g. Bethe 1931; Jachmann 1953. Feudal kingship was often seen as a peculiarity of Mycenaean times, with military kingship following in later eras. See Deger 1970; Thomas 1966: 387-407; 1978: 187-204; Andreev 1979: 361-84 working with this model. The latter envisages a hereditary monarchy contrasted with Mycenaean theocracy and oriental tyranny. For a critique of the concept of oriental despotism which goes back to Montesquieu see Venturi 1963 and Harbsmeier 1994. Cf. also Demand 1996 who rejects the concept as not useful to understanding ancient Cypriot kingship.

16. See e.g. Qviller 1981: 109-55; Donlan 1982: 34; 1989: 5-29; Halverson 1985: 12945; 1986: 119; Ulf 1990: 213-31; Sancisi-Weerdenburg 2000: 5-8.

17. The differences and continuities between Homeric and Mycenaean rule have been the subject of several studies since the deciphering of the Linear B-tablets in the 1950s. Cf. e.g. Gschnitzer 1965: 99-112; Thomas 1978; Starr 1961: 129-38; Descat 1979: 229-40; Carlier 1984; Barceló 1993: 24-48. Barceló assumes that Mycenaean society is monarchical, with divinely sanctioned kingship and lacking central and territorially expansive power (27-30). For the Dark Ages he argues for a big-men model (48); for the subsequent era for aristocratic rule. He draws on Homeric evidence for this but assumes the eighth century as a reference point. See also Hildebrandt 2007 and Crielaard 2011: 87-103, who stresses the differences in rulership but the continuity of the bureaucratic system.

18. See Finley 1954, who first argued that the Homeric basileus was not a king but only the head of the oikos. For another view see also van Wees 1992: 282 who argues that the rulers at Troy, Lycia, Mycenae, and Ithaca have an institutional status. In current research the existence of monarchy is more and more denied, and the idea of collective leadership as a common feature has been seeing acceptance. See e.g. Morris 2003: 17-21. Cf. also ch. 1.4. 
constitutional terms such as 'monarchy' or 'aristocracy' which arise only once Greek culture comes into contact with Persian systems during the sixth and fifth centuries. ${ }^{19}$ Indeed, it will become clear that inconsistencies and contradictions, which are so often a mere side-effect of the scholarly application of typologies and models of kingship and constitutions, can be resolved upon close consideration of the concrete terms within the poems themselves. I am thinking of contradictions such as that between the rule of a single basileus and several basilees, or that between a basileus, a basileia, and an anax. Such apparently contradictory manifestations of leadership are not to be explained by historical change from monarchy to aristocracy or from great Mycenaean kingship to lesser Homeric kingship or a 'big-men' system. In fact these inconsistencies are expressions of the functional differentiation in terms of areas of competence according to which values, gifts, and services are afforded and recruited, and according to which decisions are taken. Such decision-making is expressed in the term basileuein, which I want to consider as the key term concerning leadership and power. The term anassein, connected with the title anax, is more representative of the socioeconomic aspects of rulership involving the recruitment of gifts and services. ${ }^{20}$

Power, here, is not regarded in Weber's sense, simply as the chance of an individual to achieve their own goals even against the resistance of others. ${ }^{21}$ What is of far more interest here are the mechanisms by which consensus is reached..$^{22}$ Especially in systems based on reciprocity, there is a need for processes by which the higher ranking of specific individuals is determined and agreed upon. This is particularly true in the epics, where there are a range of different rankings and areas of power so that we are dealing with a number of different fields of authority or power. The distribution of power in different fields demands processes for achieving consensus and balance. ${ }^{23}$ These processes, which include ritual practices as well as institutions such as council assemblies, achieve harmony and

19. Drews 1983 and now Meister 2020.

20. One can argue with Pierre Bourdieu's ([1972] 1977) view on economic and social capital. Social capital can be understood as the resources an individual has access to because of belonging to a group.

21. Weber 1980: 28.

22. For a critical view on the Weberian concept of authority and power based on obedience see Hilger 1982: 100.

23. This is underlined by Lenz 1990: 47 drawing on Eleanor Leacock 1978 and 1981. Generally, Mann 1986. 
sanction social ranking via communal activity and speech. ${ }^{24}$ It is no coincidence that no one clear term for power and rule developed in Greek; instead Greek has a number of terms, alongside timē, to describe functional aspects of the exercise of power such as leadership (hègemonia, archē) or the use of strength (bia, kratos). ${ }^{25}$ What is lacking is the institutionalisation and centralisation of power, which would have given rise to the development of more abstract terminology. Hence the distinction made in Homeric scholarship between anax and basileus as, respectively, a leader generally and the leader of a community, is too generalised and requires reference to concrete spheres of power. Thus, when we discuss power in this chapter, it is not in the sense of the individual process of achieving dominance over others but in the sense of the social mechanisms by which leadership responsibilities are distributed and justified.

Beginning with the dispute over Achilles's geras, I will now proceed to outline the semantic field of the terms geras and timē, taking my lead from the poems' own narrative logic. This examination concludes with a consideration of the geras of the dead, which of course also forms the conclusion of both epics. Both poems end with funerals: the Iliad with Hector's funeral, the Odyssey with Agamemnon's account of the funeral of Achilles. The honouring of the dead is thus given an important position within the narrative. My discussion of the specifics of the gifts afforded the dead will show that the epics reflect the significance of such honours for the dead in the social system they celebrate. Here we will encounter again both key forms of relationship bonds: the warrior community and the domestic community. We will also see again, as gifts for the dead, or as prizes awarded in funeral games, all those goods we came across in our discussion of guest-gifts and services. Some of these have special symbolic significance. In his book, The Sources of Social Power, the American sociologist Michael Mann asks whether human societies should be understood as 'seamless webs spun of endless multicausal interactions in which there are no overall patterns' or whether there are 'keystones' which ultimately determine the shape of society. ${ }^{26}$ To answer this question Mann uses two images which are representative of society in Homeric epic: the woven work (or shroud) and the stone monument (or grave

24. On the meaning of the principle of consensus in Homeric society see Flaig 1994: 13-31; Raaflaub 1997: 1-27; Schulz 2011: 6o-62, 66-69.

25. This is stressed by Meier 1982: 820 .

26. Mann 1986: I, 3. 
monument). By considering these images we open up a view of Homeric society in time and space which is of central significance for understanding Homeric rulership, and which will lead us back to our original question regarding the place of Homeric epic within a society of hero-cults, and the development of the polis.

\subsection{The visibility and socioeconomic value of honour: Fighting for Agamemnon's timē and the geras of Achilles}

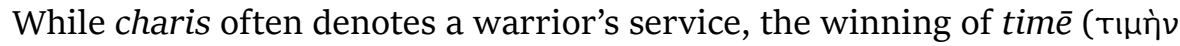

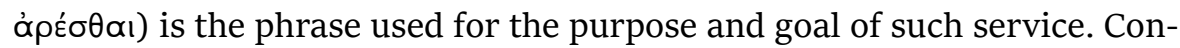
cretely, in the Iliad, timē consists of Helen and her goods, which the Greeks aim to reclaim from the Trojans. In return for his efforts in battle, a warrior can count on receiving his portion of time. This includes geras in the form of a woman taken captive as well as an honour paid to him, Tízıv (tiein) in the form of a special share of the sacrificed animal at the banquet. We are not dealing here with a simple reciprocal arrangement between leader and follower in battle. Rather, this is a network of relations between leaders and collectives. In this network it is collectives who are the sponsors of honour in the form of shares in the feast and in whose eyes a

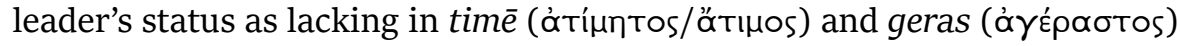
is determined. Success in battle, kúbos (kudos), manifested in the quantity of weaponry taken as booty, and the (re)gaining of time become impossible when relations between leaders and collectives are out of balance. At the start of the Iliad, we are presented with a lament for the loss of many souls that have descended to Hades after the argument between Agamemnon and Achilles over their respective prizes. Achilles withdraws from battle having first been assured of time by the gods who now give the winning power (kpótos) to the Trojans (Il. 1.1-7 and 509-10). ${ }^{27}$ Both Agamemnon's time and the geras of Achilles are connected to the feminine form of charis in so far as both cases involve the producers of material and symbolic charis.

This chapter is divided into three parts: the first clarifies the material content of time and of the honours connected with the words timan and tiein. The second considers the relationship between the recipients and the sponsors of honours, and in particular the relationship between a basileus

27. See Patzek (1992: 130), who interprets the epic plot as a tragic conflict between 'heldenhaftem Durchsetzungsvermögen und der Schuld des Helden gegenüber der Gemeinschaft'. 
and the demos. The concluding third part deals with the returns offered by those in possession of time and considers the nonmaterial significance of timē and geras.

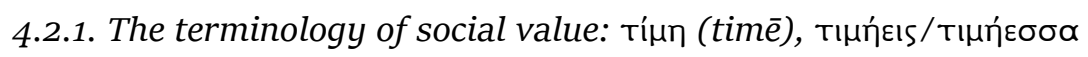
(timēeis/timēessa), tímıs (timios), and ớtıоos (atimos)

Conflict breaks out when Agamemnon refuses to return his own prize for a ransom..$^{28}$ The prize in question is Chrysëis, the daughter of Chryses, a priest of Apollo, who has come to the Greek camp to attempt to retrieve his daughter. Agamemnon is forced to return Chrysëis only once Apollo has sent a plague on the camp as punishment for the initial refusal, and the prophet Calchas, summoned by Achilles to the assembly, has made the connection between the two events. Agamemnon then seeks compensation for his loss from the prizes of Ajax, Achilles, or Odysseus. Achilles, of course, rejects his claim:

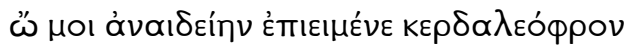

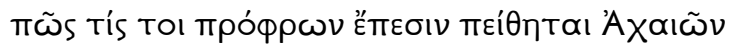

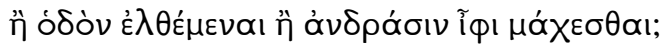

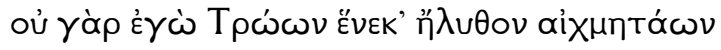

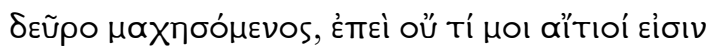

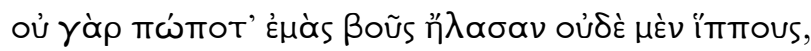

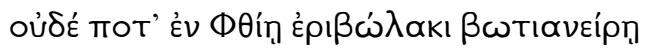

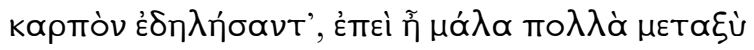

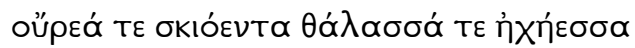

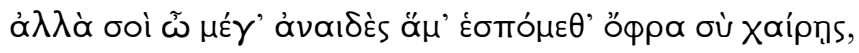

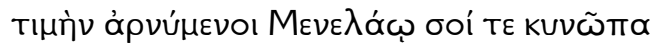

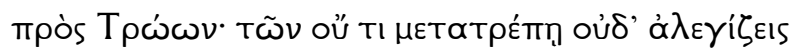

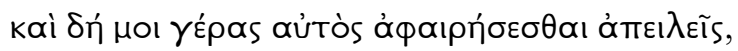

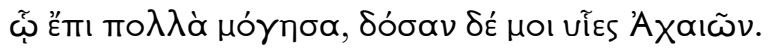

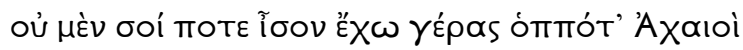

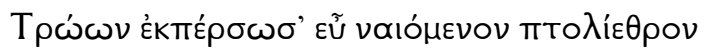

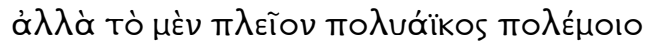

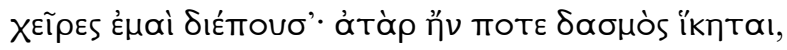

28. Apoina always means goods offered for a raped or killed person. For evidence see ch. 5.2. The goods are often identical with the xeineia presented to guest-friends. See e.g. Il. 6.46 and 49; 10.380; 11.131 and 134. For further evidence see ScheidTissinier 1994: 184-88. 


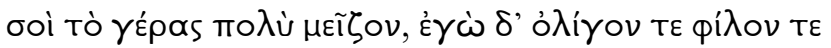

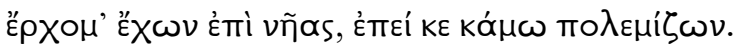

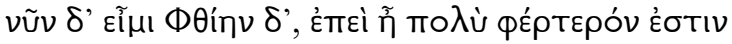

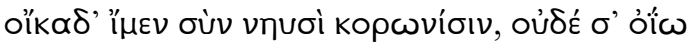

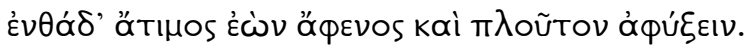

You shameless, self-centred [...] ! How can you expect any of the men to comply with you willingly when you send them on a raid or into battle? It was no quarrel with Trojan warriors that brought me here to fight. They have never done me any harm. They have never lifted oxen or horses of mine, nor ravaged my crops back home in fertile Phthia, nurse of warriors. The roaring seas and many a dark range of mountains lie between us. We joined your expedition, you shameless swine, to please you, to get satisfaction (timēn arnymenoi) from the Trojans for Menelaus and yourself, dog-face-a fact you utterly ignore. And now comes this threat from you, of all people, to rob me of my prize (geras), in person, my hard-earned prize which was a tribute from the army. It's not as though I am ever given a prize (geras) equal to yours when the Greeks sack some prosperous Trojan town. The heat and the burden of the fighting fall on me, but when it comes to dealing out the spoils, it is you that takes the lion's share (geras poly meizon), leaving me to return to my ships, exhausted from battle (kamō polemizōn), with some pathetic portion to call my own. So, I shall now go back home to Phthia. That is the best thing I can do-to sail home with my beaked ships. I can see no point in staying here to be insulted (atimos eōn), while I pile up wealth (aphenos) and luxuries (plouton) for you (Il. 1.149-71; tr. Rieu).

Achilles's rejection of Agamemnon's claim clearly sets out the basic rules that govern the Greek warrior community. The battle at Troy is fought in

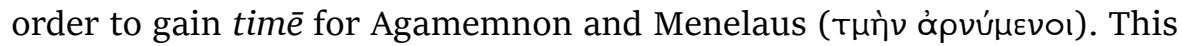
is not true only for Achilles but for others too. So Krethon and Orsilochus die at Troy, having come to win time for the sons of Atreus, Agamemnon,

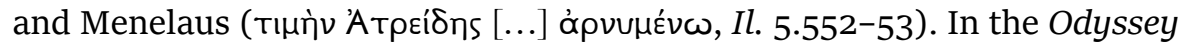
we hear that Odysseus himself went to Troy for the sake of Agamemnon's

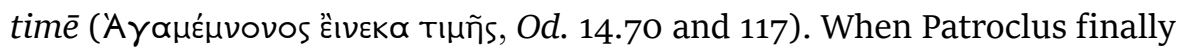
joins the Greeks in battle, he too fights and dies for the time of Menelaus, 
for which Achilles had refused to work in the passage just cited. Menelaus reflects on this after Patroclus has fallen:

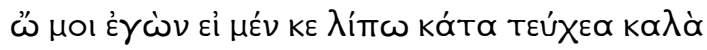

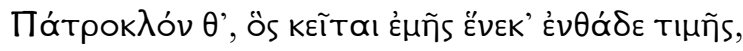

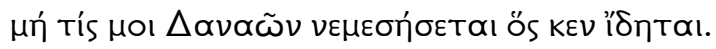

Ah woe is me! If I leave behind the beautiful arms, and Patroclus, as he lies there for the sake of my timē, I fear that some Danaan will see it and resent me for it (Il. 17.91-93).

Both sides are aware that efforts on the battlefield (kamnein polemizōn) on another's behalf must be compensated. Such compensation may consist of honourable burial, as we gather indirectly from Menelaus's words just cited, in which he worries about his own loss of face were he not to extricate the dead warrior and his arms from the battlefield. In his own speech, also cited above, Achilles points clearly to his entitlement to geras-to be provided not by Agamemnon or Menelaus but by the Greeks as a whole. This geras is a manifestation of Achilles's time so that he sees himself as atimos if he is deprived of the prize. His speech points to both the material and the symbolic value of time. That value is manifested in the female gera, Chrysëis, whom Agamemnon must give up in order to lift the plague from the camp, and Brisëis, Achilles's prize, whom Agamemnon wants to claim as compensation for himself. But the value of time can also be found in the material goods suggested by the terms aphenos (hinting at wealth of cattle) and ploutos used by Achilles. ${ }^{29}$

With regard to an opponent, timē must be repaid in the form of satisfaction or retribution or moıví (poinē). But unlike poinē, which suggests quit-money for spilt blood, time aims at the return of the taken object or person..$^{30}$ Time $\bar{e}$ takes on the form of poine only when an agreement for the restoration of time is broken. A clear example of this can be seen in

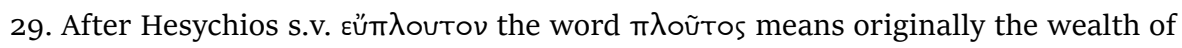
corn. In tragedy ploutos also denotes textile wealth (Aesch. Ag. 1383: $\pi \lambda$ oũtov Eı̊matos kakóv). On cattle raiding see ch. 5.1.

30. See Vatin 1982: 276-77. It is not necessary to differentiate between two roots of

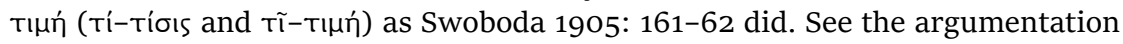
of Greindl 1938: 6o-61, who does not see any contradiction between the double meaning of timē as honour and compensation or fine because of the material character of honour. 
Menelaus's words before the duel with Paris. Were Menelaus to win, the

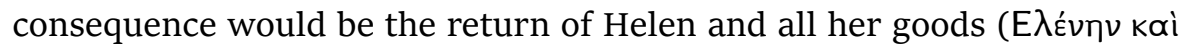

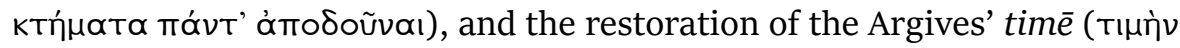

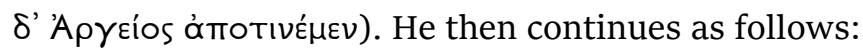

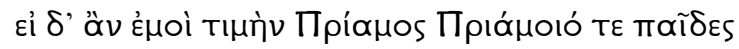

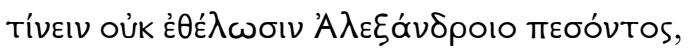

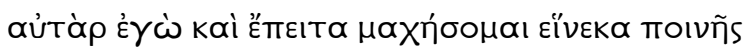

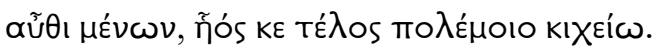

But if Priam and Priam's sons are not willing to compensate ( $t i-$ nein) my time once Alexandros has fallen, then I will continue to fight for the sake of poine and stay here until the war is finished (Il. 3.288-91; cf. also 3.459)

There is some scholarly dispute over the meaning of time in this passage: is it only a matter of the return of the stolen goods (and the wife of Menelaus) or is additional compensation suggested? ${ }^{31}$ Since the agreement between the Trojans and the Greeks, as initially suggested by Paris, then mediated by Hector and finally announced by the herald Idaeus, makes no mention of any additional compensation, it is possible that time , here, represents the abstract value of Helen and her goods..$^{32}$ Time is used in such a sense in the context of the punishment of the suitors at Ithaca, who have been consuming goods there without poine (vímoıvov) or timē (ä́ı

31. Greindl 1939: 67 speaks of compensation or reparation for the costs of war ('Kriegskostenersatz'). Benveniste 1969: II, 50-55 reads the passage to tell of a tribute which acknowledges Agamemnon's power. Vatin 1982: 276-78 argues from the evidence of the narrative itself that the duration of the war has made additional contributions necessary. Vatin suggests that both the return of goods taken and the additional contributions are referred to as time, and poine becomes due when there is failure to offer timē. He points to the additional gifts offered to Achilles when Agamemnon returns Brisëis as well as to post-Homeric practice.

32. This is stressed by Vatin 1982: 275 .

33. In the constant complaints about the suitors' behaviour the dominant term is nēpoinos (e.g. Od. 1.16o; 2.142 and 145; 14.377 and 417; 18.280) Only Penelope

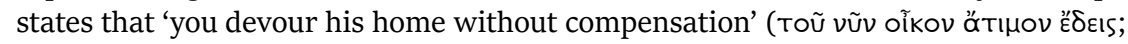
Od. 16.431). Swoboda (1905: 152) translated 'dessen Haus du ohne Ersatz aufzehrst' and saw here the original meaning of atimos as 'outlawed' and thus excluded from the rule of law and free to kill without punishment. Swoboda sees no contradiction between this and what he considers the later meaning of atimos as 'without honour' because of the material connotations of honour. (Cf. Greindl 1938: 68). 
One of the suitors, Eurymachus, promises timē as compensation: 'We will make amends to you by a public levy for all the food and drink that has

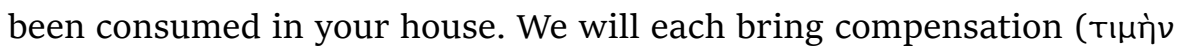

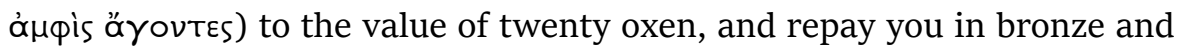
gold' (Od. 22.55-58). In this example timē clearly takes the shape of compensation for the cattle and wine consumed. It is not quite clear whether time is repaid in metal goods, or actually with cattle (the term agein suggests driving animals to slaughter). ${ }^{34}$ After the killing of the suitors, the talk is only of the sheep Odysseus aims to obtain from the Greeks to replenish his estate (Od. 23.355-58).

We must consider also a third meaning of timē. Compensatory timē may substitute not only what was taken unlawfully but also such goods as were prevented from accruing to their owners because of the taking of Helen or because of the continuing consumption of the possessions of Odysseus. This would be, for instance, textiles woven by Helen and her women, or the meat and wool of the sheep, which Odysseus was not able to make use of for himself. The complaint about the suitors 'shearing' the goods of Odysseus seems to underline this interpretation: кєıрє́єı oĩkov (Od. 2.142-43; $4.686 ; 2.313-14 ; 22.36) .{ }^{35}$

The adjective тıйєı (timēeis) also suggests a meaning of value or compensatory value for timē. It is used to describe gold, for instance, but also appears in connection with people, especially in the comparative form. ${ }^{36}$ In such cases the adjective suggests the increased value of a person, which is achieved through the receipt of goods. When, for example, Athena makes Penelope show herself to the suitors in order to enhance her value in the

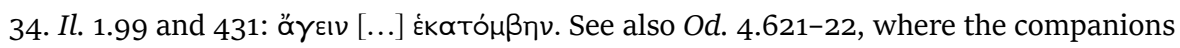
of Menelaus bring sheep (mēla) and wine (oinon) for the wedding of his daughter and son whereas their women send corn (siton): oi $\delta$ ' ñyov $\mu \dot{\varepsilon} \nu \mu \tilde{\eta} \lambda \alpha$, , $\varepsilon \dot{\rho} \rho \nu \delta^{\prime}$

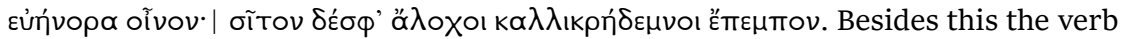
agein is also used to denote the rape of human booty. For evidence see ScheidTissinier 1994: 27.

35. Cf. ch. 2.1.

36. In these cases, timeeis appears to be linked to processes of measuring or valuation, as in the following examples: valued gold and silver, used by Hephaestus for

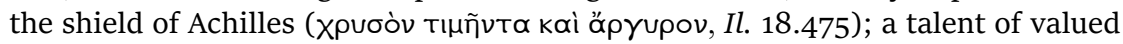
gold, received by Odysseus from each of the Phaeacian basileis ( $\chi$ pvбoĩo tá $\lambda \alpha v$ tov

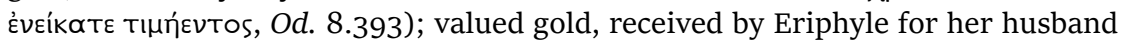

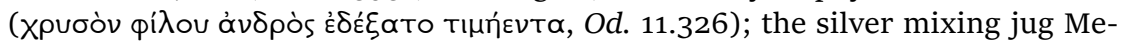
nelaus gives to Telemachus is described as very highly valued (тıйбтатоv, Od. $4.614=15.114)$; the treasure kept back for Mentes by Telemachus is also qualified

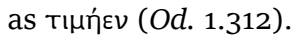




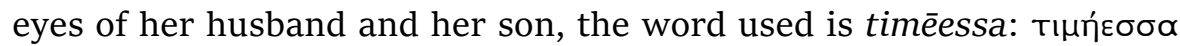

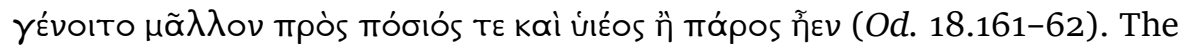
enhancement of Penelope's worth in her husband's and son's eyes follows as a result of the gifts of jewellery and clothing offered by the suitors (Od. 18.291-301). The perception of Penelope as timeessa in the sense of 'valued' can be measured through the worth and quantity of the gifts she receives.

A similar connection with material gain is suggested in Telemachus's speech to the suitors, when the esteem afforded him as timeeis is connected to the position of basileus. I will return to this later. Telemachus says (Od. 1.392-93) that it would be no bad thing to be king ( $\beta \alpha \sigma ı \lambda \varepsilon \cup \varepsilon \varepsilon \varepsilon \varepsilon v)$ because this would see him enriched (áqveı̀̀) and his value enhanced

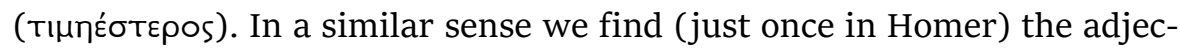
tive timios. It is used by Odysseus's men (Od. 10.38) to characterise their leader who has an enviable amount of treasure because so many hold him in high esteem (Tímıs). ${ }^{37}$

Among the gods, Poseidon's rule over the sea, received as honour (timē), is connected with his status as timeeis (Il. 15.189-90). When the Phaeacians help Odysseus, Poseidon complains to Zeus that he will no longer be held as timēeis by the gods (Od. 13.128-30) if mortals do not respect him (ôv TI Tíovol). Poseidon is entitled to revenge for the loss of status he experiences as a result of the wrongful giving of gifts by the Phaeacians, and he will take this revenge by hiding their city behind a mountain so that they may no longer offer help to seafarers (Od. 13.139-86).

The term for this loss of status is ótımos (atimos), as used by Achilles in his accusation against Agamemnon cited above. Deprived of the appropriate compensation for his efforts in battle, Achilles sees himself as atimos. The loss of status expressed by the term is manifested in the loss of the prize and is equivalent to a form of social death. We find Achilles return to this subject in Book 9 when he complains that Agamemnon treats him as if

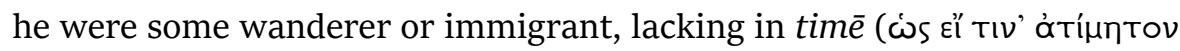

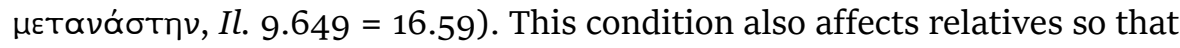
his mother, Thetis, finds herself reduced in status to become atimotate 'least respected' amongst the gods (Il. 1.516). There is a danger that this loss of status could be exacerbated if Patroclus were to fight in battle for his personal success instead of recovering Achilles's timē and kudos. Achilles warns him to refrain from seeking kudos for himself, as this would

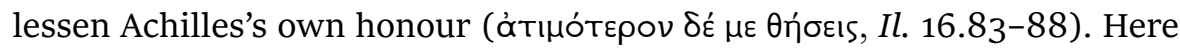

37. This is the only place where tímıs is used. Only goods are denoted by the adjective Építımos: Il. 2.447; 15.361 (the Aegis of Zeus); 9.126 and 268 (gold). 
too the object of the battle for time is the recovery of a woman, although she is not an embodiment of timē. Brisëis is a part of the gera, which are not themselves to be counted as timeenta but whose value is measured in cattle which would otherwise be given as bridewealth. Given as first prize at the funeral games, alongside a bronze tripod, a captive woman who is a skilled weaver is said to have the worth of four oxen (Il. 23.704-5).38 Brisëis is part of the spoils of war, but she determines Achilles's timē because she is a manifestation of what he is able to gain in status and value from fighting. This should be distinguished from kudos, which Patroclus might gain if he fought in his own interest and which is manifested in the capture of an opponent's arms. ${ }^{39}$

While Achilles suffers a social death through becoming an atimos or atimètos, the insult to his timē causes the actual death of a great number of Greeks. ${ }^{40}$ After Brisëis has been taken from his tent, Achilles turns to

38. For discussion see Scheid-Tissinier 1994: 50-54. On the material meaning of bridewealth (hedna) see Wagner-Hasel 1988: 41-50; Leduc 1991: 270.

39. See Greindl 1938: 50 on the case of Achilles, with whom Athena promises to collabo-

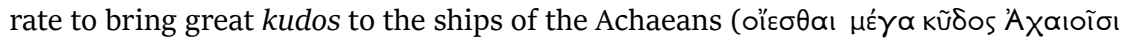
троті vп̃ $\varsigma_{s}$, Il. 22.217). 'Da das Medium von pherein nach Ameis-Hentze oftmals vom Davontragen der Kampfpreise verwendet wird, kann hier bei dem mega kydos durchaus an die Rüstung des Hektors gedacht werden, welche sie so als äußeres sichtbares Zeichen gleichsam ihres ruhmvollen Erfolges zu dem Schiffslager der Danaer bringen würden'. Greindl tends to emphasise the visible character of kudos, as it also occurs outside battle scenes, in cases where it often suggests external shine (ibid. 38-40). Steinkopf (1937: 24-25) also emphasises the visibility of kudos and suggests that it means a form of elevation that results in visibility. In passages where this is the case, we find kudos used in combination with charis. While charis refers to the gleam of clothing, it is worth considering whether $k u$ dos may in these passages refer to the gleam of armour. Gruber (1963: 73-89) interprets kudos as both success in battle and as the precondition for it, valour in battle, as well as the resulting prestige. Benveniste (1969: I, 60-62) points out the divine provenance of kudos, which he views as a kind of talisman of superiority.

40. Post-Homeric sources use the term atimos in the sense of political exclusion, together with material connotations. With the creation of the right of citizenship (through Solon's reforms, according to Philip Brook Manville (1990: 124-56), or through those of Cleisthenes, according to Raphael Sealey (1983: 97-129), an atimos becomes a person lacking citizen's rights, evidenced through the disenfranchisement of atimia. Atimia often affected people who had leased land from the polis and could not pay their lease (Hansen 1982: 113-20). Robin Osborne (1988: 279323) shows that these were by no means the poorest of citizens. Atimia implied a prohibition against entering the agora, or sanctuaries, and against taking part in any of the institutions of the polis. (Hansen 1976: 61-63; Manville 1980: 213-21). In epic poetry the term occurs only once, when Zeus argues against dishonouring Poseidon because it would be hard to assail the eldest and the best with atimia

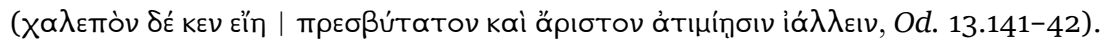


his mother to remind her he is owed some time by Zeus in return for the

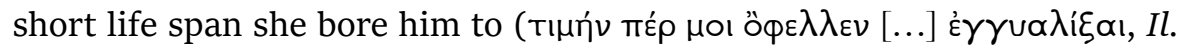
1.353). The reversal of Agamemnon's timē and of the Greeks' fortune in battle will restore time for Achilles, as we see in Thetis's appeal to Zeus:

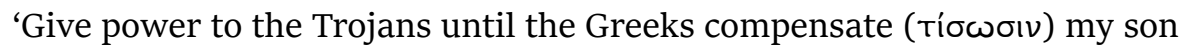

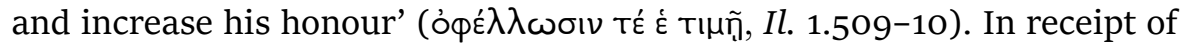
such time from the gods (тєтı the time he would achieve if he were to accept the precious compensatory gifts finally offered by Agamemnon in order to persuade him to return to

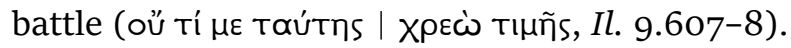

\subsubsection{The economic meaning of honour: Dōtinai, themistes, temenos}

The gifts offered by Agamemnon give a good idea of the varied sources of worth and status in the Homeric world, and they also lead us to consider the character of Homeric rulership. Agamemnon offers Achilles ten talents of gold, seven tripods, and twenty cauldrons, twelve horses, seven women skilled in handiwork, and, in the case of victory, twenty Trojan women. In addition, he offers marriage to one of his own daughters upon their return to Greece. This last offer is linked to the promise of further riches, suggested by the terms dōtinai and themistes:

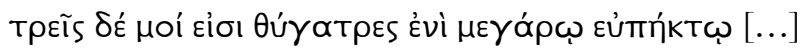

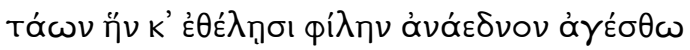

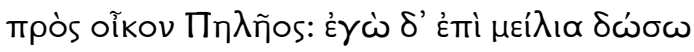

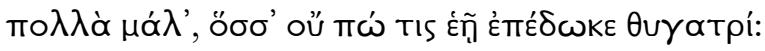

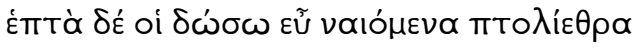

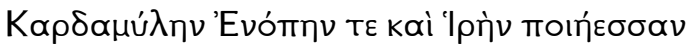

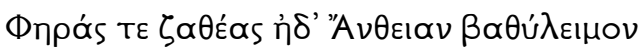

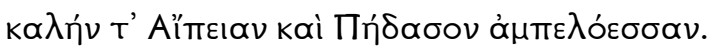

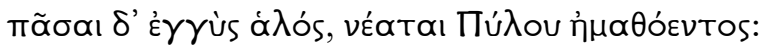

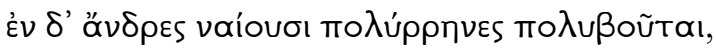

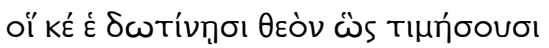

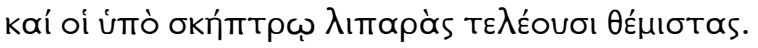

I have three daughters in my strong palace [...] Of these he shall choose for his own whichever he likes best and take her back to Peleus's house, without the usual bride-gifts (anahednon). Indeed, I will give him gifts (meilia dōsō), generous ones, more than anyone has ever given with his daughter. Not 
only that, but I will give him seven prosperous towns: Cardamyle, Enope and grassy Hire; holy Pherae and Antheia with its deep meadows; beautiful Aepeia and Pedasus rich in vines. They are all near the sea, in the farthest part of sandy Pylos. Their people are rich in flocks and cattle. They will honour him with their gifts (dōtinai) as though he were a god and, being under his authority, give him rich dues (liparas teleousi themistas) (Il. 9.144 and 146-56; similar Il. 9.286 and 288-98; tr. adapted from Rieu).

The offer of seven cities has caused scholars some difficulty since land is never handed over by an individual in Homeric epic and is never part of compensatory offers (apoina) such as those offered here by Agamemnon (Il. 9.180). Some scholars therefore view this passage as a recollection of Mycenaean kingship. Juri V. Andreev argues: 'Only under the conditions of Mycenaean monarchy with its complex hierarchical structure and its comparatively large territories would such an act of generosity be a natural expression of the power and authority of a head of state..$^{41}$ Leaving aside the difficult question of whether Homeric epic has any awareness of the sociopolitical conditions of the Mycenaean era, more recent research on Mycenaean rulership suggests that the structures were far smaller in scale than Andreev presupposes. ${ }^{42}$ Even in Mycenaean times giving seven whole cities to one individual would be an unlikely act. ${ }^{43}$ Christoph Ulf, who has rejected the principle underlying Andreev's interpretation, proposes that the passage suggests a-somewhat hyperbolic-promise of dowry in the form of temenos ('a piece of land cut off, assigned as a domain to kings and chiefs'). ${ }^{44}$ It should be noted, however, that in most cases dowries are mobile goods (ktēmata) rather than land (cf. Od. 7.314).

41. Andreev 1979: 365. See also Vlachos 1974: 278. He suspects that the offer points to the existence of a state of Pylos in Mycenaean times. Finsler 1906: 410 views it as the private property of Spartan kings. Nilsson 1927: 32 sees the offer as an allusion to vassal kings installed in conquered territories. Havelock 1978: 92-93 views the offer as pure fantasy based on the idea of oriental tyranny. Beidelman 1989: 23638 interprets the passage within the framework of gift-exchange and suggests that Agamemnon's intention is to shame Achilles with the offer.

42. See ch. 1.5.

43. Cf. Darcque 1987: 185-205. Darcque argues that the distribution patterns of grave types must throw some doubt on the idea of the unity and the monarchical organisation of Mycenaean society. Cf. also Hooker 1995: ch. 1 and Schmitt 20o9. For discussion of female rulership see Rehak 1995; Morris 2003; Maran and Stavrianopoulou 2007.

44. Ulf 1990: 96, 124. Finsler (1906: 410) and Bethe (1931: 224) both view Agamemnon as the embodiment of a Spartan king and the offer as a dowry. 
In cases where a temenos is given as a form of dowry, this is offered by a collective, rather than by the father of the bride, as happens in Bellerophon's marriage to the daughter of the Lycian basileus. The Lycian dēmos cuts him off a piece of land to cultivate (Il. 6.192-93). His descendants, Sarpedon and Glaucus, also receive such a temenos for their efforts in warfare, as we see in Sarpedon's appeal:

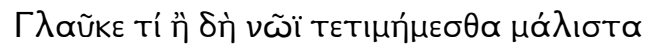

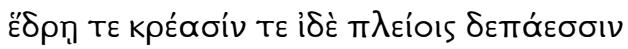

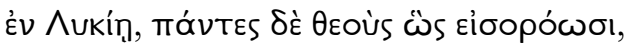

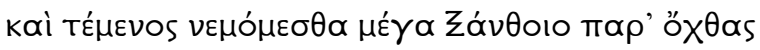

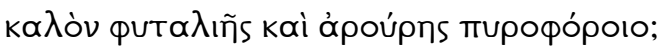

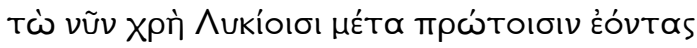

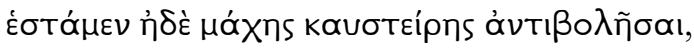

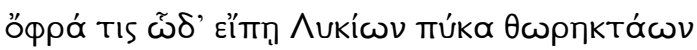

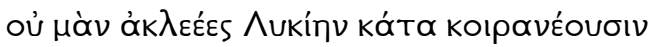

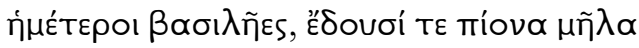

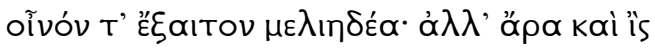

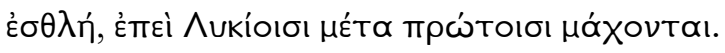

Glaucus, why are we most of all singled out for honour (tetimēmestha) at home in Lycia, with pride of place, the choicest meat and never empty cups? Why do they all look up to us as gods? And why do we cultivate a great estate (temenos) on the banks of the River Xanthus, with lovely orchards and splendid fields of wheat? All this now obliges us to take our places in the front ranks of the Lycians and fling ourselves into the flames of battle. Only then will our Lycian men-at-arms say to us: 'Well! These are no dishonourable lords (basilees) of Lycia that rule over us (koiraneousin) and eat fat sheep and drink the best sweet wine: they are indomitable and fight in the forefront of the Lycians (Il. 12.310-21; tr. Rieu).

We have here a relationship of immediate reciprocity between the Lycian community and the two warriors described as basilees. The use of the verb timan for the honours paid at the feast suggests the perception of the two recipients as godlike, which in turn appears to justify the grant of a temenos. Service in battle pays for both the honours of the feast and the grant of the temenos. 
Other heroes distinguishing themselves in battle also receive such cutoff pieces of land. This is true for Meleager (Il. 9.576-80) and possibly for Aeneas, whom Achilles taunts by suggesting he is fighting only in expectation of a temenos (Il. 20.389-92). In all these cases land is granted by an ethnically defined group, such as the Lycians, the Trojans, or the elders of the Aetolians. In the Odyssey both Alcinous (Od. 6.293) and Odysseus (Od. 11.185; 17.299) have charge of a temenos, although here a connection seems to be made with the recipient's legislative functions, since in both cases the recipient of the temenos is described as dikaspolos. ${ }^{45}$

Finsler, Fanta, and more recently Carlier consider temenos to be identical with geras, as offered by the demos to basilees such as Alcinous (Od. 7.150). ${ }^{46}$ In this case, the geras is a woman (Od. 7.8-10). An identification of the geras with a temenos can be deduced from the reassurance given to Odysseus by his mother when she tells him that his fair geras is safe

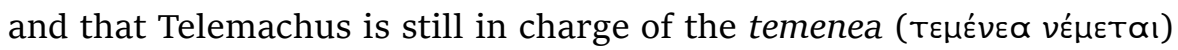
and taking part in banquets, as is proper for a man who deals judgement

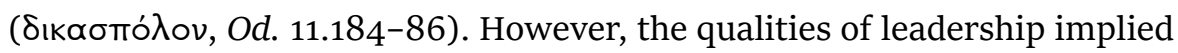
in the geras of the elders (Il. 4.323; 9.422) are necessary for looking after the temenea and for dealing out justice, and thus should be assumed to underlie Odysseus's geras here. It is up for debate whether temenea are the property of those honoured with them, or whether they are just to be managed by such individuals. The range of meanings associated with the term nemeomai ('to dispense', 'to manage', 'to possess') allows both possibilities

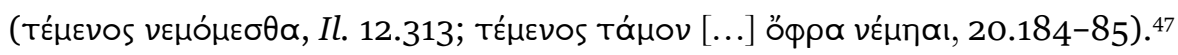

Even if we must then exclude the father of the bride-and thus Agamemnon-as a sponsor of temenea, he does still play an important role. In Bellerophon's case the bride's father apportions the groom half of his

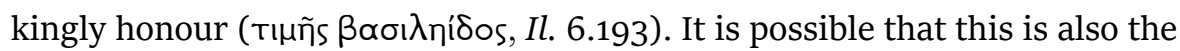

45. In the description of Achilles's shield, we find a temenos basileion (Il. 18.550). In the Iliad temenos mostly denotes divine realms (Il. 2.696; 8.48; 23.148 ; see also Od. 8.363).

46. Finsler 1906: 328; Fanta 1882: 50 and 80; Carlier 1984: 160.

47. Laroche 1949: 10 reads nemeomai to mean 'posséder'. Carlier 1984: 153-6o also assumes permanent possession, while Fanta (1882: 50; 80), Finsler (1906: 328) and Finley (1967: 99) view the arrangement as temporary. Link 1994: 241-45 suggests that the temenea are an anachronism, alluding to Mycenaean practice. Van Wees 1992: 297 differentiates between private lots of land (klëroi) and communal temenea, which can be seen as a 'gift of the community to an individual'. According to him ' $(t) h e$ existence of such crown-land confirms that the Homeric monarchy has an institutional character'. 
timē Agamemnon is offering to Achilles. Within the context of Sarpedon's testimony, we can take this to include the honours enjoyed by the basileees at the Lycian feast (Il. 4.247-64). It is also possible, however, to understand time here as an entitlement to the kind of labour that is necessary to enjoy the usufruct of the apportioned land. ${ }^{48}$ Such an interpretation of Agamemnon's offer explains why there is mention of themistes and dōtinai in the passage but not of temenea. Agamemnon is not offering to give Achilles possession of the land as such but instead offers him the benefit of the labour of those who work the lands mentioned, or the right to the fruits of that land and labour. ${ }^{49}$

Homeric scholarship has long viewed the services described by the terms dottinai and themistes as formally voluntary and unregulated. The difference between this system and modern taxation or feudal 'dues' has been underlined, although not always with sufficient specificity and detail..$^{\circ}$ In my own analysis of the Polyphemus episode, and of Odysseus's stay with the Phaeacians, I suggested that dōtinē offered by Alcinous and putatively promised by Polyphemus is to be understood as the granting of safe conduct. ${ }^{51}$ This conclusion can be drawn for the present passage, too, in so far as the coastal location of the places mentioned and the characterisation of the inhabitants as owners of herds suggest that they have at their disposal both ships and pack-animals. The granting of such safe conduct may also involve offers of material goods, which may equally be evoked by the term dōtinè. So dōtinai may take the form of specific resources such as

48. See my arguments in Wagner-Hasel 1988: 44-50 and 57-58.

49. See also Cobet 1981: 31-32.

50. Finsler 1906: 410 saw the cities as the private property of Spartan kings, and the dues paid as private donations. Fanta 1882: 53 sees them as tributes paid to a Spartan ruler by the perioeci of the surrounding towns. He assumes that generally such tributes were formally voluntary and irregular, and that they were given as gifts (for guests or towards the equipment of an army) rather than taxes. Andreades (1931: 19) differentiates between regular payments (themistes) and extraordinary expenses (dotinai) and assumes that a change takes place as tributes initially voluntary become obligatory. Finley (1967: 100-1) speaks of occasional and voluntary gifts, and emphasises reciprocity, underlining the military services provided by leaders in return for the tributes paid by the people. Qviller (1981: 117) and Morris (1986: 4) concur. Qviller assumes that '( $m$ )ost of the king's income came from raiding abroad and his own household production. In addition, he demanded and received occasional "gifts" from his subjects. There were no regular revenues like taxes or feudal dues' (118). Benveniste (1969: I, 69) considers dotinai to be gifts that have a binding character. See now Domingo Gygax 2016: 63 who interprets dotinai and themistes as 'chiefly dues'.

51. See ch. 2.1. 
wool, cheese, meat, and wine (one of the places mentioned by Agamemnon is described as rich in vines) but also material goods such as the tripods collected by Alcinous from his fellow Phaeacians once the promise of dōtinē has been made. ${ }^{22}$ When Achilles rejects the gifts offered by Agamemnon he underlines his rejection by saying that he would not take the gifts even if Agamemnon offered all the treasures of Orchomenus or Thebes where the houses are filled with the greatest treasure (ktemmata), thus emphasising the close link between the places and the treasures offered (Il. 9.381-84). There is no contradiction between this interpretation and Pierre Carlier's suggestion that Agamemnon's offer implies a migration or move to the territory of the seven cities..$^{53}$ Menelaus makes a similar offer to Odysseus (Od. 4.174-76). The practice is known to Achilles himself, whose father Peleus had settled Phoenix on the edge of his own territory (the eschatia) and had granted him rule over the Dolopians (Il. 9.484). In both cases, settling in the new territory goes hand in hand with gaining the benefit of the resources of the local population.

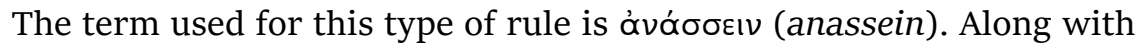

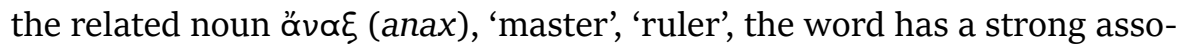
ciation with groups. In the Iliad oै $\alpha \propto \xi$ à $v \delta \rho \tilde{\omega} \nu$ (anax andrōn) is often used to characterise Agamemnon. ${ }^{54}$ The term is also used to denote Idomeneus (Il. 13.452), Augias (Il. 9.701), Euphetus (Il. 15.532), Ortilochus (Il. 5.546), Eumelus (Il. 24.288), Anchises (Il. 5.278), and Aeneas (Il. 5.311). Therefore the term is often interpreted as one that denotes personal rule. ${ }^{55} \mathrm{In}$

52. In the Odyssey the guests of Menelaus are also said to bring wine, lambs for slaughter, and bread (Od. 4.621-23). See n. 34. In Odysseus's story about the Cretan Aëthon, the demmos provides flour, wine, and cattle for the feast (Od. 19.197-98). It is unclear who provides the eight boars, twelve sheep, and two oxen for Alcinous's feast for the young and the old men (Od. 8.57-60). For discussion of these demia see Donlan, 1970: 384; 1982: 164 .

53. Carlier 1984: 179-80.

54. Carlier 1984: 216 counts 38 examples.

55. See Descat 1979: 231, who argues that anax has no political meaning. According to him, anax denotes the personal authority but not the title of the king. For a similar argument see Cobet (1982: 15-16) who interprets anassein as personal leadership in the sense of 'Herr sein': 'Herren sind offenbar all die, denen viel zu Gebote steht, als Besitzer von Schätzen, Häusern, Herden, Sklaven’ (16). See also Yama-

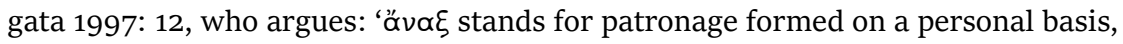
while $\beta \propto \sigma 1 \lambda \varepsilon \cup$ s stands for a social status, objectively defined by birth and wealth.' On the other hand, anax is proved as an old Mycenaean title in Linear B tablets. Here, it appears to be associated with dues, a clear reference to the economic side of rulership. See Vlachos 1974: 107, who calls the anaktes 'rois souverains'. Similarly, Havelock 1978: 95. 
both the Iliad and Odyssey this rulership is mostly over a group of people characterised either by its ethnic name, or by their male gender. ${ }^{56}$ Often this group of people is identical with the group of warriors recruited for service and under obligation to an anax. ${ }^{57}$ The term used for recruitment

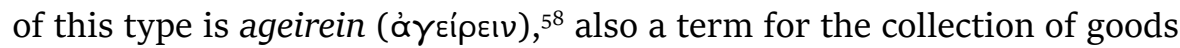
in the Odyssey..$^{59}$ Another group of people over whom it is possible to rule is formed by herdsmen and house servants form. ${ }^{60}$ Animals, such as sheep,

56. Thoas rules over the Aetolians (Il. 2.643; 13.218); Peleus (Il. 24.537) and Achilles (Il. $1.180 ; 21.188$ ) rule over the Myrmidons; Phoenix the Dolopians (Il. 2.643; 9.480); Altes over the Lelegans (Il. 21.86). Diomedes (Il. 23.471), Agamemnon (Il. 14.94), and Eurystheus (Il. 19.129) rule over the Argives. In the Odyssey Mentes (Od. 1.181 and 419), Alcinous (Od. 7.10-11; 11.349), Laërtes (Od. 24.378) and Theoclymenus (Od. 15.240) rule over the Taphians, Phaeacians, Cephallenians, and Argives. Andromache's father Eëtion ruled over the Cilicians (Il. 6.397), the Phocian Schedius is said to have ruled over many men ( $I l$. 17.307). Agamemnon rules over many ( $I l$. 1.281; 9.73; Od. 24.26). In Nestor's case we hear about the duration of his rule over three generations (Il. 1.252; Od. 3.245). The good basileus rules over many brave men (Od. 19.110). Priam rules over his own (Il. 24.202), Eurystheus will rule over all of those who dwell in the surrounding areas (Il. 19.109).

57. Thrasymelos is described as therapōn to his anax Sarpedon (Il. 16.464). Leaders in battle are often described as anaktes: Idomeneus (Il. 10.112; 15.301), Sarpedon (Il. 12.413-14), Menelaus (Il. 24.588), Philoctetes (Il. 2.725), Asius (Il. 12.139).

58. Collectively these warriors are called laos, e.g. when Nestor and Odysseus travel to

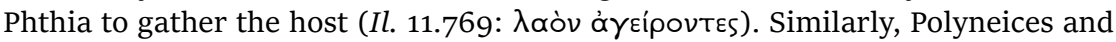

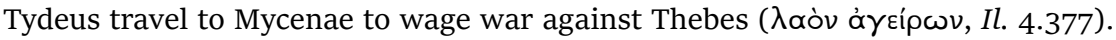

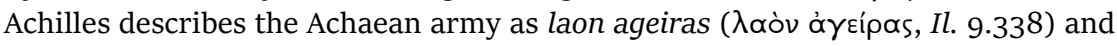

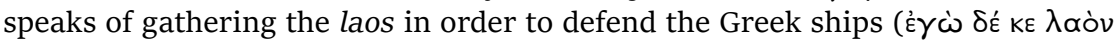

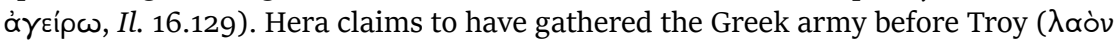

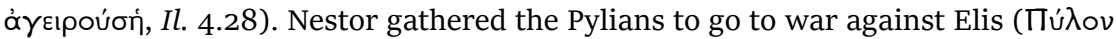

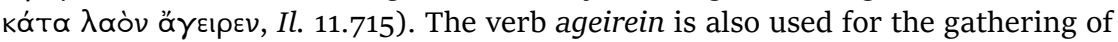

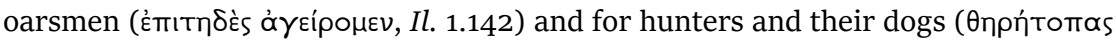

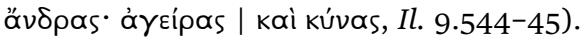

59. Here ageirein occurs in connection with the term dēmos, e.g. to collect repayment

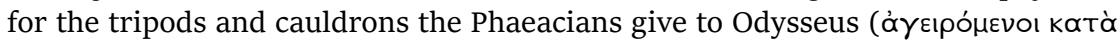
$\delta \tilde{n} \mu \circ v \mid$ твıбó $\mu \varepsilon \theta^{\prime}$, Od. 13.14). Athena suggests that Odysseus should gather loaves

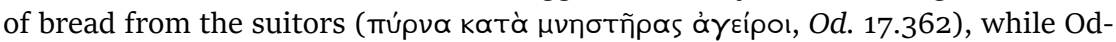
ysseus claims to have gathered unspecified goods, chrēmata, abroad (Od. 3.301; 14.285-86).

6o. See Telemachus (Od. 16.14; 17.186) and Odysseus (Od. 1.397-98; 14.8; 40; 60; 63; $139 ; 170 ; 366 ; 376 ; 395 ; 398 ; 438 ; 450 ; 15.557 ; 17.201 ; 255 ; 320 ; 20.216 ; 21.395$ ) who rule over the herdsmen Eumaeus, Philoetius, and other dmōes. Odysseus is also anax of the female servants: dmōiai gynaikes (Od. 18.313; 19.358; 392; 475; 20.111; 21.9). Anaktes are principally masters of those who bring labour services, called ergazesthai (Il. 24.733-34; Od. 17.320-21). 
horses, and dogs, ${ }^{61}$ and material goods may also be ruled over, ${ }^{62}$ as may territories such as Mycenae, Pylos, or Troy. ${ }^{63}$ In these cases, we are dealing with places which are located on popular shipping routes or crossroads. Controlling access to the Black Sea, Troy especially must have profited from its position, either through toll charges or by charging for navigation services. ${ }^{64}$ But Pylos and Mycenae also occupy key geopolitical positions, with Pylos dominating access to the shipping routes to the west, while Mycenae's location allowed it to control access points to and from the Argolid and the mountains of Arcadia. ${ }^{65}$ This means that in such cases anassein suggests access to resources via the granting of safe conduct, which in turn would mean that anassein includes economic aspects of rulership.

The themistes, also offered by Agamemnon to Achilles, are similar to the dōtinai in their double meaning. Usually in epic poetry, themis denotes the customs or traditional norms according to which basilees take their decisions. In our passage, themistes may be understood as services offered in return for the exercise of legal authority. This is how the scholiasts interpret the word when they explain it as phoroi (tributes/dues). ${ }^{66}$ This would

61. Polyphemus is anax of his sheep (Od. 9.440 and 452); Mentor resembles the sons of anaktes (Od. 13.223). In Libya there is no anax and no herdsman who suffers from a lack of milk and cheese (Od. 4.87). Horses: Il. 13.38; 16.371 and 507; 23.417; 446; 517. Dogs: Il. 23.173; Od. 10.216; 17.296; 303; 318. Herds: Od. 15.397.

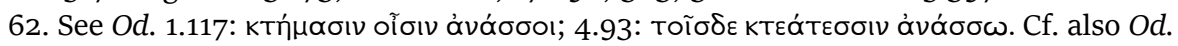

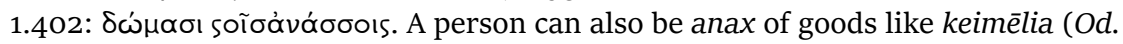
21.9), prizes (Od. 21.62) or weapons (Od. $21.56=83$ ).

63. Menelaus rules over plains (Od. 4.604), Agamemnon over islands and over Argos (Il. 2.118); for seven years Aegisthus ruled over Mycenae rich in gold (Od. 3.304). Dmetor ruled over Cyprus with strenght (Od. 17.443) and Amphion over Orchomenos (Od. 11.284). In Thebes Oedipus ruled over the Cadmeans (Od. 11.275-76). Achilles's son rules in the city (asty) of the Myrmidons (Od. 4.9). Troy is described as asty or polis and Priam its anax (Il. 4.18; 7.296). Nestor was anax of Pylos (Il. 6.173), Lobates anax of Lycia (Il. 6.173).

64. For the geographical situation and control of access to the Dardanelles see Korfmann 1986: 1-16. For Troy as the end point of trade routes see also Zengel 1991: 30-67, whose argumentation is marked by modernism. For discussion see Wagner-Hasel 2002.

65. Mycenae controlled the pass of Dervenaki and therefore the entrance into the Argolis as well as the path to Corinth and to the Arcadian mountains. Three routes meet at Mycenae, 'the main highway, the Koatoporeia, and the Nemean hill route'. Adshead (1986: 10) argues: 'Mycenae was a foothills state and her early power rested on the control to the mountain passes.' For Pylos, which has a similar function, see Agourides 1997: 13 and 18-20.

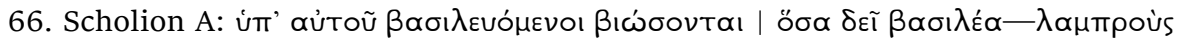

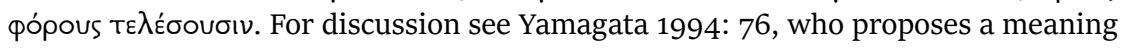


also explain the linking of tributes to places, since court proceedings such as that depicted on the shield of Achilles take place in the central location of the agora. On the shield there is payment in gold due to the man who pronounces the most righteous judgement (Il. 18.497). This mention of gold may help to explain the use of liparos (bright or brilliant, shiny with oil, oily) we find with the themistes in our passage. However, it must be borne in mind that liparos is normally used of linen clothing, so that our themistes in this case may also be tributes of linen, such as those raised in the Odyssey by the Phaeacians. ${ }^{67}$ The fact that our seven cities are located in Messenia would support this since this is the only region of Greece that is suited to the cultivation of flax. ${ }^{68}$

The many varied meanings associated with the terms themistes and dottinai finally suggest that their use is intended to convey the entire spectrum of privileges and offices that contribute to a person's timē. These would include honours paid in the form of safe conduct and attendant material and natural goods as well as the exercise of legal authority and the material compensation due for this. Before considering the social or normative aspect of time more closely, I want to reflect on the role of the community.

of themistes as 'god-given customs'. She translates the phrase oi úmò бкńாтрफ

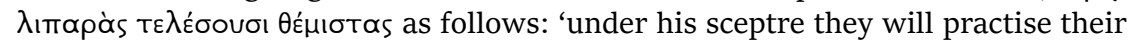
pleasant customs'.

67. The adjective liparos is used for the veils of high-ranking women like Penelope (Od. $1.334 ; 18.210$ ) or Hecuba (Il. 22.406) and the veil of the goddess Charis (Il. 18.382). For men, liparos must describe the gleam of the lower hem of a chitōn or pharos, which were made of linen, as we saw earlier. It is possible that this is meant to de-

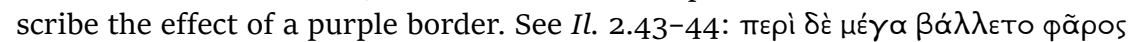

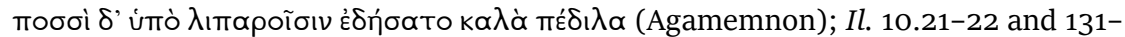

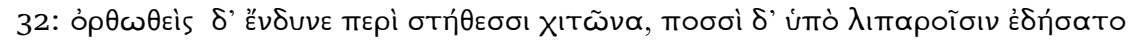

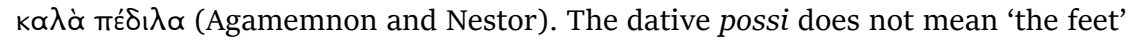
as often translated but 'the hem': see Pollux 7.62. For discussion see Stulz 1990: 140-45; Buschor 1912: 24-25. The adjective liparos is derived, like the adverb lipa ('unctuously, richly with oil'), from the noun lipos ('fat'). The oily shine can refer to ointments or oils (Handschur 1970: 78). We know that oils were used in linen production (cf. ch. 3.3. n. 91). The word is also used for the shine of the head or hair (Il. 19.126; Od. 15.322). In such instances it might refer to the shine of hair, or of gold decorations placed in it (see Il. 17.51, where we hear that Euphorbus's hair was braided with gold and silver like the hair of the Graces). We also find liparos connected to old age, gēras (Od. 11.136; 19.368; 23.283) or to aging, gerraskein (Od. 4.210). In these instances, there is a connection made with the spinning of the thread of life, which will be of interest in our next section (4.2, n. 148).

68. See Robkin 1979: 469-74; Barber 1991: 12-19. In Mycenaean times Messenia was a centre of linen production. See Rougement 2007: 46-49. Cf. also ch. 5.3. 


\subsubsection{Rulership and social control: Aidōs}

The gifts Achilles rejects are not only of material value; they are meant to demonstrate his status visually. A look at Agamemnon's geras shows this clearly. Just as Achilles seems himself as atimos after the loss of his geras, so Agamemnon complains that to return Chrysëis to her father would leave him agerastos in the eyes of the Argives. This loss of face is the reason for his demand for compensation after he agrees to give up his prize:

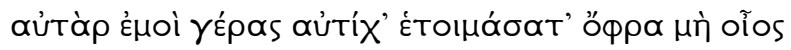

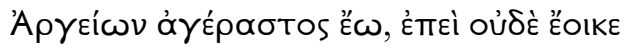

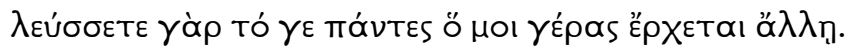

But give me another prize (geras) at once or I will be the only one of us without one. That cannot be right. You can all see for yourselves that the prize (geras) I was given is on its way elsewhere (Il. 1.118-20; tr. Rieu).

The main insult is the visibility of Agamemnon's loss, which threatens to diminish his status in the eyes of the community. In this sense, the hero's geras is not unlike the female form of charis in its concrete and abstract manifestations. ${ }^{69}$ Like the gleam of charis that shines forth from clothing, geras also makes visible the hero's value. Indeed, Chrysëis, Agamemnon's geras, is valued by him as equal to his wife, Clytemnestra, as he announces to the assembled Argives: 'for she is not inferior to her, in beauty or stature, or in mind or in handiwork' (Il. 1.115). Earlier, Agamemnon had told the girl's father, Chryses, that his daughter was destined to walk to and

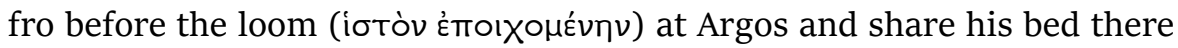
(Il. 1.31).

69. In the Iliad geras normally denotes a woman taken captive as booty: Il. 1.118; 123; $133 ; 135 ; 138 ; 161-62 ; 163 ; 9.344 ; 367 ; 16.54 ; 56 ; 18.444$ (Brisëis and Chrysëis); Il. 11.626 (Hekamede of Nestor). In the Odyssey Eurymedusa, the tamie in the house of Alcinous, is called a geras (Od. 7.10). See also Od. 11.234, where the booty of Neoptolemus is characterised as geras. Besides this, geras denotes the honouring portion of the sacrificial meal for the gods (only Il. $4.49 ; 24.70$ ) and for men (only Od. 4.66; 20.297). The geras of the elderly can be identified as the competence to weave a plan (only Il. 4.323; 9.422). Finally, there is also the geras of the dead, which is materialised as tears (Il. 16.457 and 679; 23.9; Od. 4.197; 24.190 and 296). No specific meaning is given to geras in Il. 20.182; Od. $11.175 ; 184 ; 534 ; 15.522$. 
When Agamemnon and Achilles are finally reconciled, it is important that the return of Brisëis and the presentation of the many other gifts offered in compensation take place in full view of the entire community. So Odysseus demands of Agamemnon: 'As for the gifts, let Agamemnon, the leader of men, bring them to the middle of the assembly place so that all the Achaeans may see them with their own eyes' (ó $\phi \theta \alpha \lambda \mu \circ$ ĩoı 'í $\delta \omega \sigma \mathrm{l}, I l$. 19.172-74).

The 'eyes' of the people provide the proof or evidence of a man's time and geras. By taking place in full view of the assembled community, the presentation of the gifts offers a visible measure of the time of Achilles. ${ }^{70}$ In watching the presentation, the assembled community also watches over the maintenance of established norms of behaviour. Status and norms are maintained by being enacted and also by being seen to be enacted.

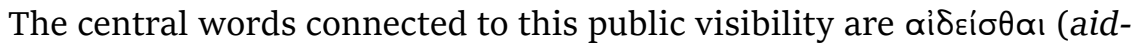

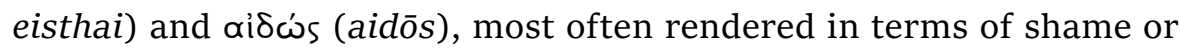
shaming. ${ }^{71}$ Their opposite is ớvaı $\delta$ ín (anaideiē), the word used by Achilles to describe Agamemnon's behaviour and often translated as 'shameless'. It expresses a demonstration or spectacle of wrong behaviour resulting from the inability to see what would be the correct or normative choice. Metaphorically, Achilles describes Agamemnon as 'clothed' or 'wrapped'

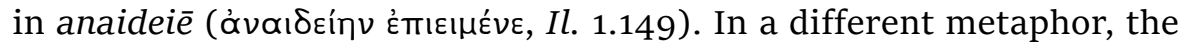
slave girls in the Odyssey who disobey Penelope and Eurycleia and sleep

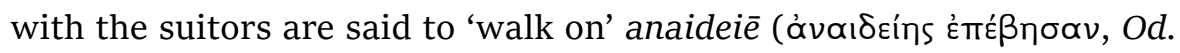
22.424-25). It is a matter then of seeing and of proceeding, that is of insight into what is right, and of observing the appropriate behaviour. There is no question or doubt over the correct path or the proper insight. It is assumed that these are recognisable, so that any divergence from the proper code of conduct is viewed as blindness or a state of being blinded. ${ }^{72}$

Such blindness or delusion, ärn (atē), is the cause of the conflict between Agamemnon and Achilles. Agamemnon's explanation for taking away Achilles's geras is that Zeus, Moira, and Erinys cast atē onto his mind, phrēn

70. Cf. Linden 1992: 111, who assumes a regular procedure. For the public character of timē see Ulf 1990: 41-49.

71. See Erffa 1937: 4-43; Verdenius 1944: 47-6o. Hooker 1987b: 121-25 assumes an original religious meaning.

72. See Erffa 1937: 8-9. For the metaphor of social blindness in tragedy see Flaig's analysis of OT (Flaig 1998). Here, correct behaviour is hidden rather than visible, as it is in epic. 
(Il. 19.88). ${ }^{73}$ Achilles, too, is subjected to this form of blinding. In his case ate $\bar{e}$ is connected with the Litae, the goddesses of supplication, described as daughters of Zeus. When Achilles refuses to accept Agamemnon's compensatory gifts, Phoenix warns him of the Litae's power to invoke ate in pur-

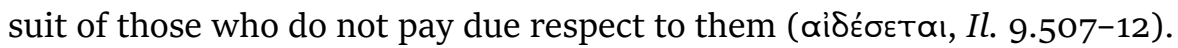
Phoenix exhorts Achilles: 'You too must give to the daughters of Zeus, so that time may attend you'.74 Achilles's timē depends on his preparedness to supplicate the Litae. They represent Agamemnon's plea for Achilles's return and thus the correct behaviour that is under the control of public opinion.

The terms aideisthai and aidōs express the moral force that enables and governs Homeric society. Aidōs is found alongside dike in Plato's Protagoras as an ordering principle of the society of the polis (Pl. Prt. 320c-323a). Understood as a public form of conscience, ${ }^{75}$ aidōs also has a distinctly

73. Cf. Il. 9.115. Agamemnon admits that Nestor has laid bare his 'blind folly'. All the major conflicts in the epics are considered to be the results of atē. The Trojan war itself is blamed on the blindness of Paris in Il. 6.356 and 24.28, and on the blindness of Helen in Od. 4.261 and 23.223. I do not agree with Richard E. Doyle (1984: 14-16) who suggests that in this case atē must be interpreted as 'infatuation' rather than one of the other three meanings he gives for the word (blindness, folly, ruin). Even where ate takes effect between men and women, it still evokes the impossibility of perceiving the proper course of action-thus a state of blindness. See also Gruber 1963: 57-61 who shows how in all its different effects on people, ate is always a state of being blinded.

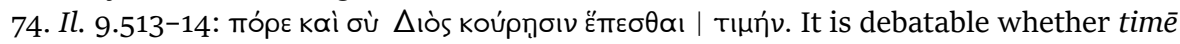
in this passage belongs to Achilles. I follow Andersen's rejection (1982: 7-13) of the widespread translation 'you also give, so the time may attend the daughters of Zeus'. Anderson takes the accusative тı which fits the context of the scene better. Also see Doyle (1984: 9-12) for whom the

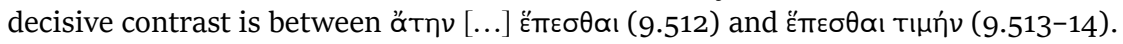

75. Dihle (1985: 35) defines aidōs as 'kollektives, prospektives Gewissen'. Similarly, Erffa 1937: 36; Verdenius 1944: 50. Verdenius argues against a metaphysical meaning of aidōs as religious behaviour or metaphysical order and timeless possibility of the cosmos, proposed by Karl Kerenyi (1942: 88-99). For a different view see Cairns 1993: 139-46 who argues that it is not right to call aidōs 'a public form of conscience [...] as it suggests complete reliance on external standards. [...] Even where aidōs refers quite straightforwardly to anxiety occasioned by the prospect of others' disapproval, there is not absolute dichotomy between the internal and the external, the personal and the public' (141-42). According to Cairns public standards have to 'become part and parcel of the individual's character' (144). He prefers to understand aidōs as 'an internal state of conscience which is based on internal standards and an awareness of the values of society; these standards will have become internal to the individual precisely because of their uniformity and of the power of popular opinion to enforce them, and will have been imparted early in the process of socialization' (144). Cf. also Stahlmann 1997: 103 who argues: “"mit einnehmender Scheu (bzw. Scham) sprechen“ heißt die Normen der Gemeinschaft kennen und in öffentlicher Rede für alle einsichtig und konsensfähig ausdrücken’. 
visual component, as demonstrated in a proverb cited by Aristotle: 'shame belongs to the eyes' (тò દ̇ contrast with anaideie, due respect for aidōs means avoidance of that which 'must not be seen' (a literal translation of $\alpha-i \delta \varepsilon i ́ \sigma \theta \propto \mathrm{l}$ ). Thus, aideisthai is best understood as a fear or shame of the judgement of others. ${ }^{76}$ So when Hector says that he 'would be ashamed before the Trojans and their wives'

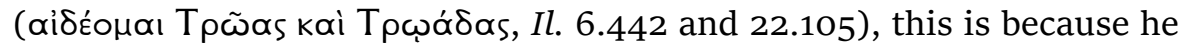
knows that he needs to stand up in battle in order to retain kleos for himself and his family (Il. 6.446). For Penelope, a sense of shame about her

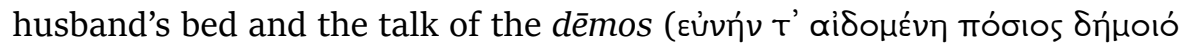
$\tau \varepsilon \phi \tilde{n} \mu \mathrm{I})$ means that she must continue to look after the house of Odysseus rather than accept one of the suitors (Od. 16.74-75). ${ }^{77}$ The thought of aidōs also keeps soldiers in battle when they are ready to take flight (Il. $5.787 ; 8.228 ; 13.95 ; 16.422)$. When Agamemnon spurns on the Greeks by reminding them of the deeds of their ancestors we see Diomedes throw himself into battle (Il. 4.402) out of awe ( $\alpha i \delta \varepsilon \sigma \theta \varepsilon i \varsigma)$ for the awe-inducing

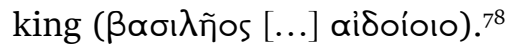

In all these situations, aideisthai, a sense of awe or shame, is displayed in relation to others and out of a sense of obligations to others-be they the obligation of a warrior to his leader or a wife to her husband. The term aideisthai has a bearing on all those relationships contained by the idea of philotēs.79 That sense of shame or awe never involves only the two people in the relationship but always includes the presence of an observing third party in the form of a community.

The conflict between Agamemnon and Achilles is less about achieving equilibrium between two leaders and more about the relationship between the leaders and the Greek army in front of whose eyes the argument is played out. This collective is not only the judge of Achilles's time $\bar{e}^{80}$ it is also said to be the sponsor of his geras. Both Achilles and Nestor say that it is the sons of the Achaeans who gave Brisëis to Achilles (Il. 1.162 and

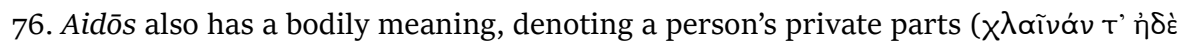

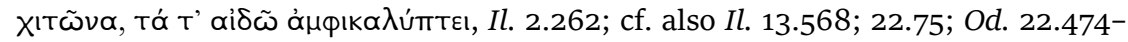
77). Erffa (1937: 39) argues that the concrete meaning is derived from a more abstract meaning in the sense of 'awe'. Beil 1961: 51-64 views it as a term suggesting a fear of bodily exposure. On phèmis see now Gödde 2011.

77. For the connection between aidōs and phèmis see Verdenius 1944: 6o; Greindl 1938: 82-86.

78. For further evidence see Erffa 1937: 5-43 and Cairns 1993: 68-146.

79. For evidence see Erffa 1937: 12-14.

80. For the relationship between aidōs and timē see Riedinger 1980: 62-79. 
276 ; 1.278) ${ }^{81}$ It would be the same sons of the Achaeans who would have to compensate Agamemnon for the loss of Chrysëis (Il. 1.123 and 135). Agamemnon, named once by Achilles as the giver of his geras (Il. 9.367), is responsible for the distribution of gera when he hands them out to the 'best men' (aristoi), and to basileees, and when he distributes portions at the feast (Il. 9.334). ${ }^{82}$

It has been suggested that granting temenea to basilees provides them with the wherewithal to hand out honours at feasts. Agamemnon fulfils this function at Troy-although here the origin of the natural resources is unclear:

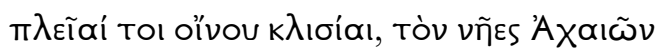

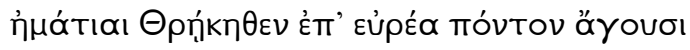

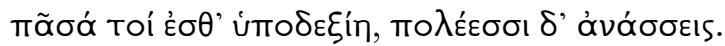

Day by day Greeks ships bring wine to you over the broad seas from Thrace. Your huts are full of it; and as a ruler over many people (polessi d' anasseis), it is for you to offer hospitality (Il. 9.71-73, tr. Rieu).

With these words Nestor asks Agamemnon to offer up a feast for the council of elders so that they may offer advice and discuss the situation (Il. 9.69-70). It is not clear whether Agamemnon is in a position to host the feast because he can commandeer wine from the many people he rules over, or if he can use the many people he rules over in order to transport the resources from his temenea. The use of anassein certainly allows both possibilities. Elsewhere there is mention of a xeinos, a friend of Agamemnon's from Lemnos who is named as providing a delivery of wine. This wine, commandeered from abroad, is distributed by Agamemnon to the troops. They have to give some compensation in return (Il. 7.467-75), while the select circle of counsellors is honoured with the wine without being required to pay back compensation.

The term used for such honours at the feast is Tíєıv (tiein) or Tínav (timan), denoting a visible distinction through special treatment of a

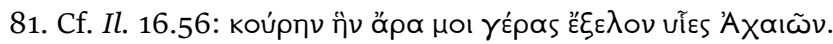

82. Évelyne Scheid-Tissinier argues-following Louis Gernet and Marcel Detienne-that the 'chef' represents the collective of the warriors (1994: 443-44). According to Bjørn Qviller (1981: 129) the distribution of booty by the leader denotes the beginning of exploitation. For the dèmos as sponsor see Carlier 1994: 152-54. 
distinguished individual at the feast. Such special attention is usually earned through service in battle; when it is administered by a leader such as Agamemnon or Hector the term tiein is used. So Agamemnon is able to motivate the Cretan Idomeneus to fight with a reminder of tiein at the feast:

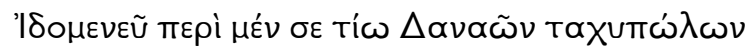

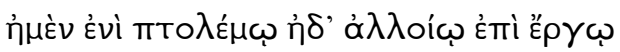

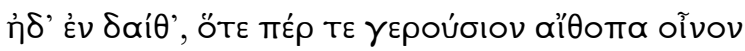

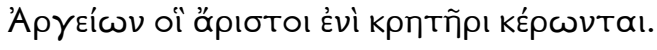

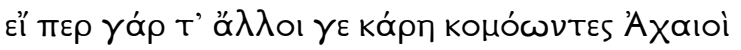

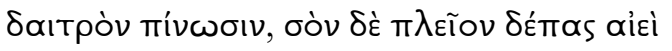

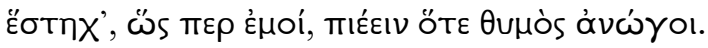

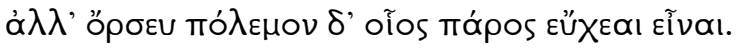

Idomeneus, of all my Greeks (Danaoi) with their swift horses, there is not one I honour more than you, on the battlefield, on other missions and at feasts for senior advisers when the Greek (Argeioi) leaders mix themselves sparkling wine. When the rest of the long-haired Greeks (Achaioi) have drunk up their portion, your cup stands full, like mine, to drink from as you wish. Off, then, into battle and be the man you have always said you were! (Il. 4.257-64; tr. Rieu).

The means for such special treatments of individuals-in this case the ever-full drinking cup-are provided by a group, not by a single individual. This is clear when Menelaus addresses his fellow warriors and reminds them that their wine comes from the people:

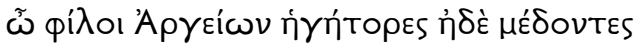

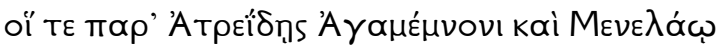

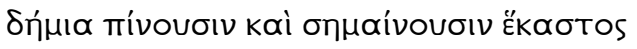

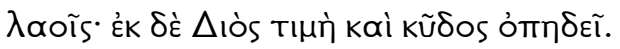

Friends (philoi), rulers and leaders of the Greeks (Argeioi)! All you who drink your wine at the public cost (dēmia) by the side of Agamemnon and Menelaus; who share in the command (sēmainousin) and derive your honour (timēe) and glory (kudos) from Zeus (Il. 17.249-52, tr. Rieu). 
Hector similarly refers to the Danaans as the sponsors of honours given to Diomedes in his taunting speech: 'Son of Tydeus, the Danaans with their swift horses would honour you ( $\sigma \varepsilon$ tíov $\Delta \alpha v a \circ i)$ above all others with a seat of honour and portions of meat, and a full cup' (Il. 8.161-62). Defeat in battle will mean a loss of these honours: 'The Danaans will scorn you

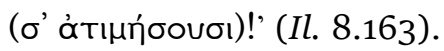

When Hector treats his fellow fighters with honours (tiein), he also has recourse to the means of the demos (Il. 18.300-1). Elsewhere, Hector spurs on his allies by letting them know that he is using up the resources of his own people to provide them with gifts and food (Il. 17.225-26). After Hector's death, when Priam denounces his sons as robbers of lambs and kids

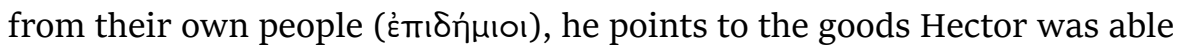
to claim from the demos, the animals available for slaughter at the feast (Il. 24.263). The point is that the remaining sons will not be able to repay the goods received from the people, the demia, with the kind of performance in battle of which Hector or Deïkoon, Aeneas's comrade, were capable. The Trojans honoured him like the sons of Priam because he always fought in

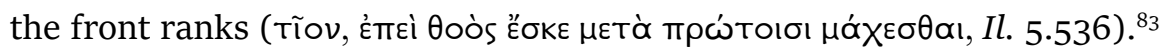

While tiein describes the distribution of public goods, timan is used to describe the honours due to a person who takes on the role of distributing these goods, which will range from special 'portions of honour' offered at the feast to pieces of land and its produce. ${ }^{84}$ All this is offered in return for service in war as well as for leadership and judicial functions, as we have seen in connection with Agamemnon's offer. Only in the Odyssey do we find the portion of honour given at the feast to an individual described as geras (Od. 4.66)-and in one case the term is used ironically (Od. 20.297).

\subsubsection{Honouring the basileus and the basileia}

In Homeric epic, individuals to whom honours and attention are paid in the form of timan are always either of divine descent or in possession of

83. Qviller's suggestion (1981: 123) that the passage hints at a development of the reciprocal relationship into one of exploitation is not convincing.

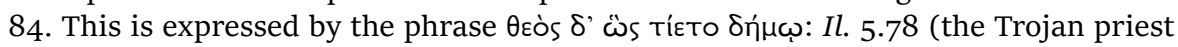
Hypsenor); 10.33 (Agamemnon); 11.58 (Aeneas); 13.218 (Thoas in Aetolia); 16.605 (the Trojan priest of Zeus, Laogonos); Od. 14.205 (the Cretan Castor). The phrase can be translated as 'he was honoured like a god with fat' (cf. $\delta \eta \mu$ ó $=$ fat) or 'he was honoured by the people as a god' (cf. $\delta$ ñuos = people). For the first meaning see Paola Ceccarelli, Françoise Létoublon, and Martin Steinrück (1998: 47-58). 
the title of basileus or its feminine form basileia. ${ }^{85}$ This is true of Sarpedon and Glaucus (Il. 12.319; 16.66o) as much as of Agamemnon, who is most frequently described as basileus in the Iliad. ${ }^{86}$ After Achilles's withdrawal, Agamemnon announces that there will be others prepared to honour him

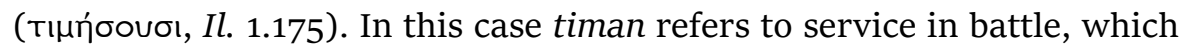
Achilles has refused to give, although as a basileus himself he can expect it to be rendered to him by the Myrmidons (Il. 1.331; 16.211). Both timan and tiein are used of Achilles's relationship to his comrades, the Myrmidons. We find Patroclus, for instance, calling on the Myrmidons to honour Achilles

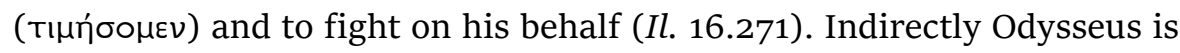
described as a basileus, whom the Phaeacians are expected to honour as

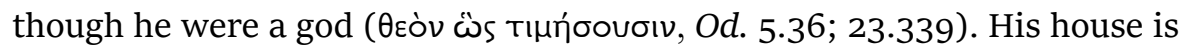

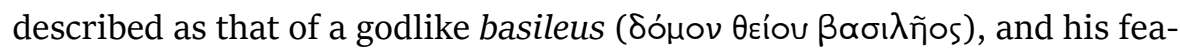

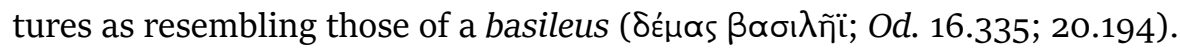
Of Arete we hear in the Odyssey that she is honoured (твті́ children, her husband, and the people. In the case of the people, we are told (as with Sarpedon and Glaucus in the Iliad) that they view her as a

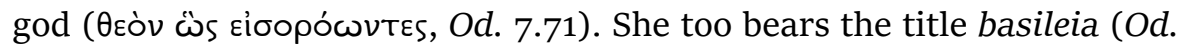
$7.241 ; 11.345 ; 13.59)$.

In all these cases, the honours described by timan are paid by a collective: the group of comrades, the hetairoi and philoi, in the case of Achilles (Il. 16.269-70); unspecified 'others' (alloi) who are part of the army in Agamemnon's case (Il. 1.174); in Arete's case, the collective is the people, laoi (Od. 7.71). These laoi may denote the Phaeacian community in its entirety, or may refer to those men whose disputes she adjudicates elsewhere

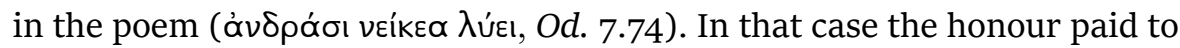
her is in return for the judicial functions we have discussed in connection

85. Where this is not the case, the honoured individuals are backed by gods (e.g. Athena in the case of Deiphobus honoured ( as in the case of the beggar Odysseus, when Telemachus asks whether Eurycleia

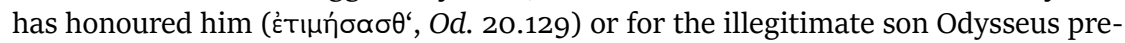
tends to be in his Cretan tale and who is honoured by his father (દ̇тína, Il. 23.649). Nestor is honoured with a prize by Achilles (тєтı particular connection to the gods, whom he can ask for grace on behalf of the spon-

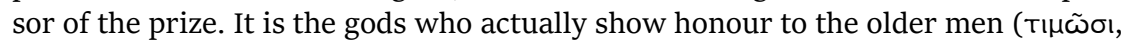
Il. 23.788). In Eumaeus, honoured like a son by Odysseus's mother, we have a true

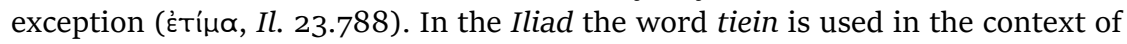
honouring sons-in-law (Il. 9.142), the offspring of concubines (Il. 13.176), shepherds (Il. 15.551), or suppliants (Il. 1.439).

86. For evidence see Carlier 1984: 142; 222-25 and Finsler 1906: 401-7. 
with the offer made to Achilles by Agamemnon. This role is also mentioned in the praise of Penelope, when the disguised Odysseus compares her to a good king:

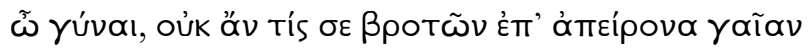

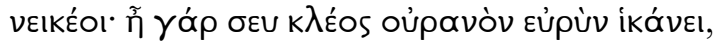

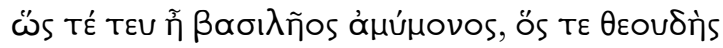

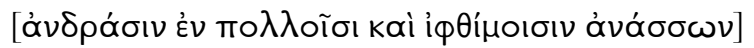

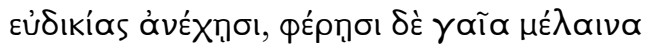

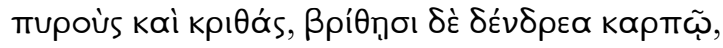

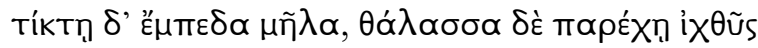

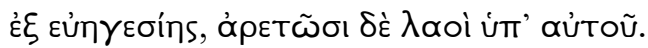

'My lady', answered the resourceful Odysseus, 'there is not a man in the wide world who could find fault with you. For your fame (kleos) has reached broad heaven itself, like that of some illustrious king (basileus), ruling (anassōn) a populous and mighty country with fear of the gods in his heart, and upholding justice (eudikia). As a result of his good leadership (euēgesiē), the dark soil yields its wheat and barley, the trees are laden with rope fruit, the sheep never fail to bear their lambs, nor the sea to provide its fish, and his people (laoi) prosper under him' (Od. 19.107-14; tr. Rieu).

Odysseus speaks here of the king's role in upholding justice (eudikiai) as well as of good rulership more generally (euégesiē), both of which contribute to the prosperity of his people. ${ }^{87}$ It fits with this model of rulership that Telemachus is also referred to as a dikaspolos, a judge, when Odysseus's mother in the underworld responds to her son's enquiry about the fate of his geras (Od. 11.186). Similarly, the twelve basilees who collect contributions to the gifts for Odysseus from the Phaeacian demmos (Od. 13.14) are referred to as counsellors (ßoùnфópoı).

These roles are also relevant in wartime, as we see when Odysseus refers to the good king's ability to lead and to judge when the army threatens to disband after the withdrawal of Achilles from battle. Inspired by Athena, Odysseus seizes Agamemnon's sceptre and urges the troops to return to

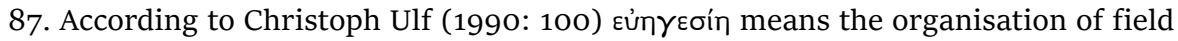
work. Cobet (1981: 20) views the term more generally as collective responsibility and the king's role as helping to bring communities together. 
the assembly and listen to Agamemnon, rather than incur his wrath, because 'the heart of god-reared kings is great, their honour is from Zeus

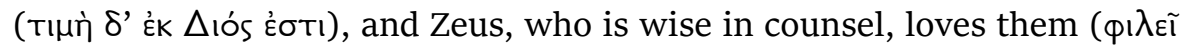

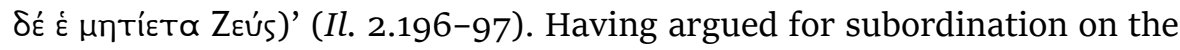
grounds of the power of Zeus and timē, Odysseus then moves on to invoke Agamemnon's position as basileus (Il. 2.203-6): 'We cannot all be leaders

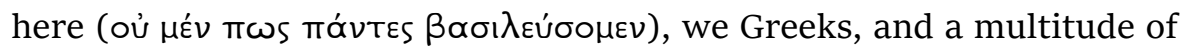

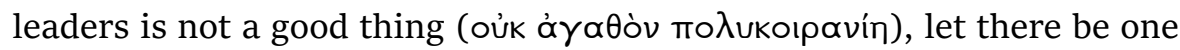
koiranos only, one basileus to whom the son of crooked-counselled Cronos has given the sceptre and themistes so that he may rule ( $\beta \propto \sigma ı \lambda \varepsilon u ́ n)$.' While a koiranos is primarily a military leader, the terms basileus and basileuein refer to political leadership. When an individual is described as a basileus, this is frequently found in the context of political counselling. ${ }^{88}$ Similarly, the verb basileuein is found in connection with assemblies (Il. 2.203 and 206) or linked to particular places. ${ }^{89}$ It is at such named locations that decisions are taken, be that in the context of political assembly, by counsellors, or in the form of judgements in legal proceedings..$^{90}$ The exercise of such decision-making must be guaranteed by the gods. As we see in the passage just cited, timē is represented as having been granted by Zeus. Minos, for instance, who ruled ( $\beta \alpha \sigma i \lambda_{\varepsilon \cup \varepsilon)}$ in Knossos is said to confer with Zeus every nine years (Od. 19.178-79). The decision over who will rule at Ithaca also

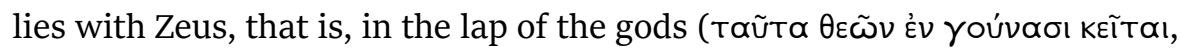

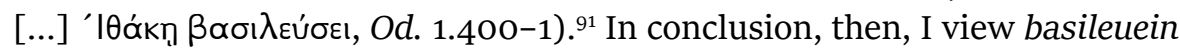
as an act of decision-making that expresses the nonmaterial aspect of time .

88. Cf. Il. 2.196 and 205 (Agamemnon); 2.54 (Nestor). Descat 1979: 232 and Cobet 1981: 13 interpret basileus as a term of political leadership, not as a term of personal rule. According to Drews (1982: 104-5) the term is linked with leadership. Carlier (1984: 143) translates the verb basileuein as 'régner'. According to him the basileees were 'chefs héréditaires d'une communauté'. The term for military leadership is koiranos. See Finsler 1906: 331-32; Carlier 1984: 202; Ulf 1990: 88-89. According to Cobet (1981: 16-17) koiranos denotes the high-ranking position of the basileus.

89. Il. 6.425 (Plakos); 2.572 (Sikyon); Od. 1.401; 22.52-53 (Ithaca); 11.285 (Pylos); 19.179 (Knossos).

90. According to Telemachus it is not bad to 'rule' because goods come in and one be-

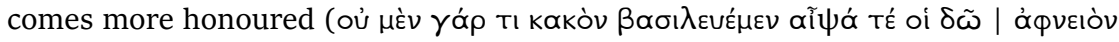

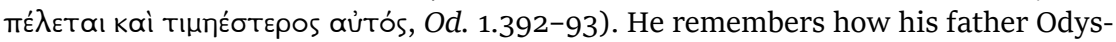

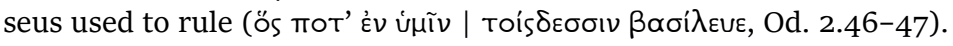

91. Telemachus would happily accept from Zeus the position of basileus at Ithaca, for which he is qualified by heredity and by his rhetorical ability (Od. 1.383-86; 390).

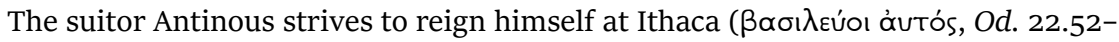
53). For the symbolic meaning of the knees see ch. $4 \cdot 3$. 


\title{
4.2.5. Themistes and the sceptre
}

The power to make decisions is symbolised by the sceptre, given by Zeus, and by the grant of themistes, perhaps best translated as 'customary rules'. ${ }^{22}$ The sceptre conveys the right to speak, and it is also the means by which to say the correct or appropriate thing, in accordance with the themistes. Predominantly, sceptres are carried by basilees and lawgivers (Il. 2.206; 9.99), but we also see this with priests such as Chryses or the prophet Teiresias, who speak on behalf of the gods (Il. 1.15; 28; 374; Od. 11.91), and indeed with any speaker in the assembly, such as a herald (Il. $10.328 ; 23.567$ ) or Telemachus at Ithaca (Od. 2.37). In the situation discussed above, the significance of the decision is emphasised through a detailed account of the sceptre's provenance which, just like a hero's family tree, leads back to the gods:

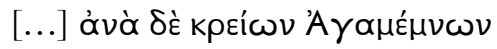

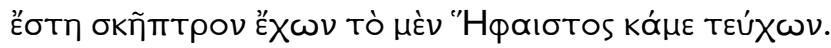

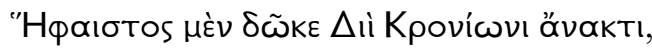

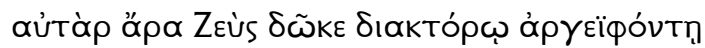

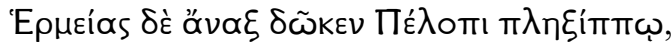

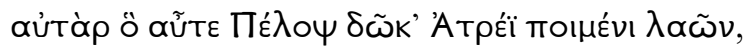

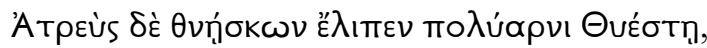

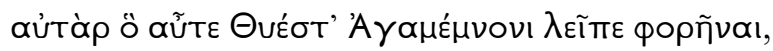

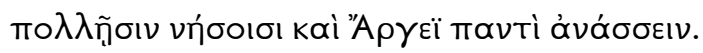

[...] Lord Agamemnon rose holding his sceptre (skēptron), which Hephaestus himself had made. Hephaestus gave it to lord (anax) Zeus son of Cronos, and Zeus to Hermes, the guide (diaktoros) and slayer of Argus. Lord Hermes presented it to Pelops the great charioteer, and Pelops passed it on to Atreus, shepherd of the people (laoi). When Atreus died, he left it to Thyestes rich in flocks; and he in turn left it to Agamemnon to carry, to be a token of his lordship (anassein) over many islands and all Argos (Il. 2.100-8, tr. Rieu).

The human possessors of the sceptre are distinguished in this account through excellence in charioteering, wealth in flocks, and rulership over

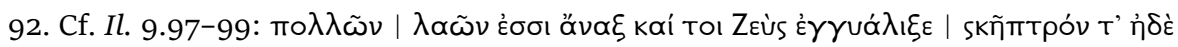

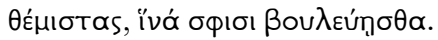


people and places-all of which are captured in the phrase 'shepherd of the people' and the term 'anassein'. The transition from the human to the divine sphere is effected by the figure of Hermes, the guide of men and herds (diaktoros). ${ }^{93}$

The history of the sceptre's provenance suggests a world in which winning prestige in competitions and accumulating wealth and resources are key. ${ }^{94}$ The themistes, on the other hand, stand for societal coherence. Responsibility for the latter lies with Themis, the personification of divine law or, as Rudolf Hirzel put it, of 'good counsel'. 95 Themis opens and closes the assemblies of gods and men (Il. 20.4; Od. 2.68-69), and she welcomes participants with a full cup (Il. 15.87). She ensures that there is balance between antagonists in the assembly and between strangers as well as between the living and the dead. It is themis to welcome a stranger and to grant him xeinia in the form of a meal or of gifts and dōtine..$^{96}$ When someone dies, it is themis for women to shed tears (Od. 14.129-30), while it is also themis for men not to wash the dirt from their head until the dead have been cremated and the grave monument erected (Il. 23.44) $\cdot{ }^{97}$ It is also themis that a son recognises and welcomes his father (Od. 11.451). In the warriors' assembly it is themis to persuade with words and to speak out in opposition (Il. 2.73; 9.33). Fundamentally, themis is connected with the coming together of men, hence agora and themis belong together (Il. 11.807). Ares, the god of war, does not therefore know what themis is (ös

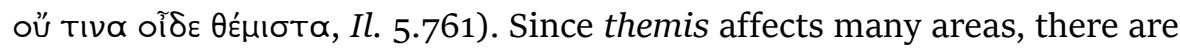

93. Eumaeus (Od. 15.319) calls him a guide (diaktoros), Priam, guided safely by Hermes to the camp of Achilles, refers to him as hodoiporos (traveller) (Il. 24.374). For more detail see ch. 5.1, n. 63 .

94. The sceptre was interpreted as a sign of primitive sacral kingship. Cf. e.g. Mondi 1980 (following the tradition of J. G. Frazer) and Vernant 1962. Fanta 1882: 46-49 and Köstler 1950: 9 understood the sceptre as symbol of a divinely sanctioned kingship and as a sign of state power. This tradition is taken up again by Carlier 1984: 191, who characterises the sceptre as a sign of monarchic authority. According to Finsler 1906: 405-8 and Nilsson 1927: 27 the sceptre denotes military leadership or hereditary kingship. More convincingly is Bethe 1931: 22. He hints at the practical use of the sceptre as the sign of the speaker in the assembly, which accounts for its frequent use by the basilees, who are qualified by their rhetorical ability. For a similar argument see Qviller 1981: 119 and Easterling 1989: 115.

95. Hirzel 1907: 17-21. Cf. also Köstler 1950: 9-13. According to Yamagata 1994: 76, ' $\theta$ é $\mu$ ıs is always a public matter'.

96. Xeinia: Il. 11.779; Od. 24.286; dotinē: Od. 9.268; 24.286. See also Od. 14.56.

97. Cf. Il. 16.796. Here themis means the recognition of the moment of dying, associated with the loss of gleam from the head or hair. 
a range of themistes which lawgivers must be aware of, but which they may also at times pervert (Il. 1.238; 16.387). On the shield of Achilles, we find a visual component of the process. In the court scene, the term used to describe the wise man who adjudicates between the two quarrelling parties is íotwp (istōr) -that is, translated literally, one who is able to see, ¡' $\delta$ Elv (idein) or recognise what is right, or themis (Il. 18.501). ${ }^{98}$

As divine law, as social norms, or as mere 'décisions politiques', the themistes do not represent an abstract legal system. ${ }^{99}$ In my opinion, the themistes offer a view of human society as it could actually be seen on decorated objects. This is not, however, to be understood in a figurative sense. Given my reflections on the charisma of images in the previous chapter, we may assume that such decorated objects helped to remember social norms and rules. The shine-adjective liparos, associated with Themis in Hesiod's Theogony, suggests this too. In the Theogony (135 and 901), Themis is the mother of the Moirae and of the personifications of Order (Eunomia), Justice (Dike), and Peace (Eirene). The notion that the future of Ithaca's rule lies in the lap of the gods (literally, 'on the knees of the gods') suggests a connection to wool, the raw material from which the textile images we have already discussed are created, because wool is laid out on the knees for carding before it is spun into the thread of life by the Moirae, the daughters of Zeus and Themis. ${ }^{100}$

In the Iliad we find the order of the cosmos represented in metalwork on the shield of Achilles. In later literature, we find descriptions of the representation of such symbolic worlds on textile objects. The images on Jason's cloak in Apollonius's Argonautica are a good Hellenistic example. ${ }^{101}$ Later still, an epigram from the Greek Anthology speaks of a tapestry that represents the Roman Empire given to the emperor Caligula by the wife

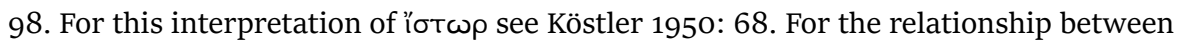
the verbs of seeing and recognition see Bechert 1964: 22.

99. See Carlier 1984: 193-94 who argues against the meaning of themistes as divine laws. According to him the decisions of the basilees can be interpreted as inspired by the gods, but they cannot be understood as divine laws because the basilees did not see themselves as gods. He interprets the themistes as political and legal decisions as well as social customs ('les règles de la vie en société'). For a similar argument see Hirzel (1907: 21), who interpreted the themistes as decrees or counsels but not as laws. His view is that Agamemnon's power over the themistes suggests the fact that he has foresight such as befits a leader, which inspires him to know what must be done.

10o. Cf. Il. 17.514; 20.535; Od. 1.267; 16.129. For the meaning of this phrase see Onians 1989: 303. See also ch. 4.2, n. 150.

101. Levin 1970: 21-32; Shapiro 1980: 287. 
of king Herod (Anthologia Graeca IX 778). We know of similar tapestries from other cultures: Tibetan temples are decorated to this day with Thangkas, paintings on silk, which depict scenes from the life of the Buddha. ${ }^{102}$ Medieval and Early Modern Europe prized tapestries depicting historical and religious motifs often created by groups of women in convents. ${ }^{103} \mathrm{Gar}-$ ments given as offerings to the dead and to the gods must have had similar functions. Athens is a particularly important example of the significance attached to the images depicted on such garments, since in classical Athens it was the council's business to approve the pattern for the robe offered to Athena. ${ }^{104}$

\subsubsection{The distribution of timē and the character of Homeric kingship}

The symbolic meaning of the themistes may also offer an explanation for the differentiation in the distribution of time amongst the Homeric basilees. We see Nestor, for example, call on Agamemnon to leave Brisëis to Achilles but at the same time also place some limitations on Achilles:

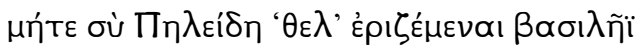

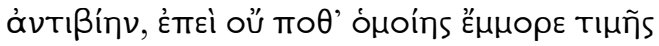

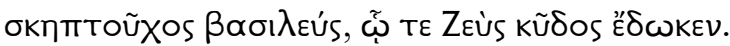

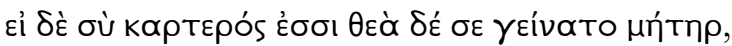

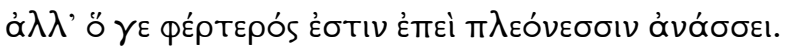

And you, Achilles, give up your desire to cross swords with your leader (basileus). Through the success (kudos) he derives from Zeus, a leader (basileus) who holds the sceptre of power has more claim to our respect (timē) than anyone else. Even if you, with a goddess for mother, are the better fighter (karteros), yet Agamemnon is your superior since he rules (anassei) more people (Il. 1.277-81, tr. adapted from Rieu).

According to Nestor, there are three different ways to gain timē: through service in war as indicated by the description of Achilles as karteros (strong), through divine ancestry, and through the number of

102. Lavizzari-Raeuber 1989: 142.

103. Wunder 1994: 324-54.

104. [Arist.] Ath. Pol. 49 and 6o; Eur. Hec. 466-474; Eur. IT 218-24. For offering the robe to the gods see Barber 1992: 103-17 and now Brøns 2017. 
people under one's command-for which the word anassein is used here. Nestor is here measuring Achilles's timē against Agamemnon's and pointing out the two leaders' different circumstances. This has led some scholars to assume that there are competing ways to gain time when in fact these are merely three aspects of the same rationale. While it is true that service in battle is an essential precondition for gaining the material side of $t i m \bar{e}$, it is also true that the number of those under a leader's command can enhance the potential for success in battle-the kudos mentioned by Nestor. This means that Agamemnon's timē must be greater. The mention of the sceptre, on the other hand, points to the nonmaterial side of time $\bar{e}$, the possession of divine wisdom that enables good judgement. This is needed in wartime too. Menelaus, called basileuteros, addresses this when he calls upon his fellow warlords to join in battle, reminding them of the contributions made by their people, and of their power to command (onuaívovoiv) their people, and also emphasising that their time and their kudos stem from Zeus (Il. 10.239; 17.249-51). In the midst of battle, divine wisdom is needed in order to succeed. This is the point made by Sthenelus in his rebuttal of Agamemnon's attempt to inspire him and Diomedes to fight by citing the example of their ancestors: 'Do not

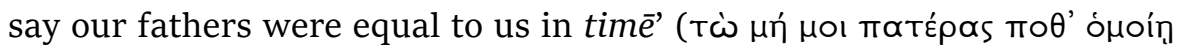

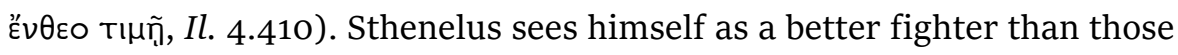
of his father's generation and also as better guided by the support of Zeus and signs sent by the gods (Il. 4.404-8).

The mention of the divinity of Achilles's mother as the third aspect of his time need not necessarily suggest that time is hereditary, especially as there is no instance of direct transfer of time from a father to a son. We do find it in the hands of sons whose fathers are also in possession of time ${ }^{.105} \mathrm{But}$ when it is handed from one generation to the next, then this takes placeas we have seen in the case of Bellerophon-only through marriage. ${ }^{106}$ For Christoph Ulf, this is a reason to doubt the hereditary character of time $\bar{e}$ and to assume that in the case of the dispute over the time of Achilles, there is a failure of rational arguments. ${ }^{107}$ Pierre Carlier, on the other hand, suspects that 'dignité royale' (which he links to geras rather than timē) was

105. Peleus, the father of Achilles, is still in possession of the time, as the shadow of Achilles considers in the underworld. Od. 11.495 and 503. In the Iliad Achilles offers half of his timē to his teacher Phoenix (Il. 9.616).

106. See Bellerophon, the ancestor of the Lycian basilēes Glaucus and Sarpedon. Il. 6.192-195.

107. Ulf 1990: 10-11, 80 . 
'le privilège collectif de la maison royale'. ${ }^{108}$ This is not altogether wrong, except that the royal house is constituted by the bond between the couple and by the different groups that support them and are responsible for the production of the goods and services connected to them. The word tiein describes not only the relationship between a leader and his troops or a master and his servants but also that between a mistress, called a basileia, and her serving women. ${ }^{109}$

In the Odyssey, the title basileia is given to Arete and Penelope, and to Tyro, the mother of Neleus (Od. 11.258). Arete is seen as basileia from the point of view of Nausicaa, Odysseus, and the basilees (Od. 6.115; 7.241; $11.345 ; 13.59)$, while Penelope is seen as basileia by the suitors, by Eumaeus, and by Medon, the herald (Od. 4.770 and 697; 16.332 and 337; 17.370 and $583 ; 18.314$ and $351 ; 21.275 ; 23.149$ ). In the Iliad, high-ranking women are always called potnia, never basileia. ${ }^{110}$ Usually, this is from the point of view of their children, or with respect to their children, in the context of mourning or lamentation (Hecuba: Il. 22.341 and 352; 24.70; Thetis: 18.35 and 70; 24.126; mother of Socus: 11.452; mother of Deiphobus: 22.239; Andromache: 6.471; Althaea: 9.591 and 584). ${ }^{11}$ Some women are, however, said to rule (basileuein). In the Iliad, the mother of Andromache

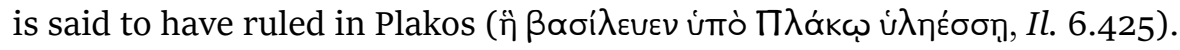
In the Odyssey, Chloris, the mother of Nestor, is said to rule in Pylos (í $\delta \dot{\varepsilon}$

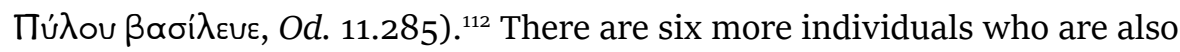

108. Carlier 1984: 190. He argues that birth qualifies to rule (basileuein) everywhere. The heroes lost their kingdom and gained a new one through marriage.

109. Together with Telemachus, Odysseus wants to prove which of his dmōes andrōn

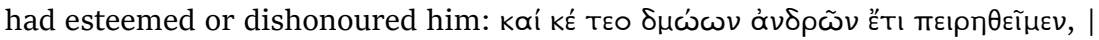

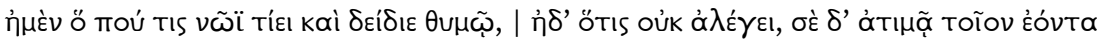
(Od. 16.305-307). While still disguised as the beggar, Odysseus orders the handmaids, the dmōiai gynaikes, to follow their honoured basileia ( $\alpha i \delta$ oin $\beta \alpha \sigma i \lambda \varepsilon ı \alpha$ ) to her rooms and see to their work (Od. 18.314). Eurycleia reports that in all there were twelve women, taught to work by herself and Penelope, who did not hon-

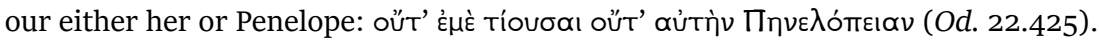
For discussion of this passage see Wagner-Hasel 1988.

110. Mothers in the Odyssey are also called potnia: Od. 6.30 and 154 (Arete); 15.385 (mother of Eumaeus); 18.5 (mother of Arneus); 19.462; 11.180 and 215; 24.333 (Penelope). Elsewhere potnia refers to goddesses: Athena (Il. 6.305), Circe and Calypso (Od. 8.448; 1.14), especially Hera (Il. 8.472; Od. 4.513, etc.).

111. Hiller 1987: 350 thinks it an old Mycenaean title. According to Rehak (1995) the potnia ruled at Pylos; Maran and Stavrianopoulou (2007) assume that the potnia shared the throne with a potnios anēr. Havelock 1978: 95 n. 12 only sees potniai as housewives.

112. Later commentators derive basileuein from the position of Neleus (Eustath. p. 1685.61; Paus. 9.36.8). 
said to basileuein: Agamemnon, Adrastus in Sikyon, Odysseus, Minos, and Eurymedon, an ancestor of Alcinous and Arete who is said to have been king over the giants (Od. 7.59), and finally, Achilles.

This participation in rulership and honour would suggest that time was distributed between the genders, and that the female part of the time of men, required for their proper exercise of rulership, was provided by their wives or their mothers.

We find such a gender-specific distribution of time in the household of Alcinous and Arete, where it corresponds to the symbolism of the sceptre and themistes discussed above. We have already seen that Arete is seen as a god by the people. ${ }^{113}$ The Phaeacian demmos listen (akouen) to Alcinous like a

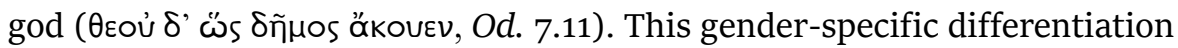
also applies to the distribution of timē in Phaeacia. When Odysseus has completed his tale, Arete is the first to speak, and she judges the stranger's inner and outer appearance, his eidos and his phrēn:

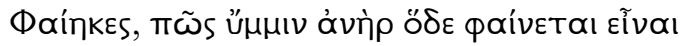

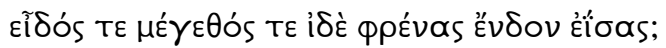

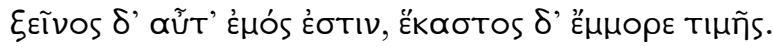

Phaeacians! How does this man seem to you in his appearance (eidos), his stature, and the inner workings of his mind (phrēn)? He is my guest, but each of you has a share of time (Od. 11.336-38). ${ }^{114}$

After this, the queen calls on the collected basilees not to send Odysseus off without gifts:

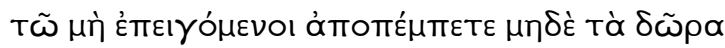

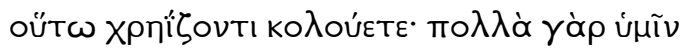

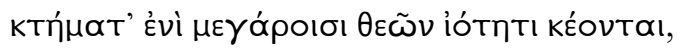

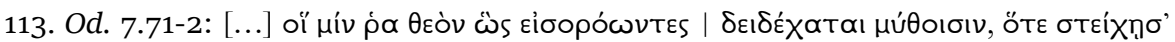
óvơ ơotu. Besides this, the phrase is also used in the context of military (Sarpedon und Glaukos: Il. 12.312;) or rhetorical ability (Od. 8.167-83). See also Od. 15.520 (Eurymachos). Cf. Bechert 1964, vol. 2: 414-16.

114. Ulf 1990: 4 misses the point when he argues that everybody, even a stranger or a beggar, is in the possession of timé. 
So do not send him on his way with undue haste, nor stint your generosity to one who stands in such need. For the gods have filled your homes with riches (Od. 11.339-41, tr. Rieu).

The final judgment is then spoken by the aged Echeneus, who confirms:

oủ $\mu$ àv ก๊

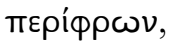

The wise queen has not spoken against our own views (Od. 11.344-45).

He asks the other basilees to go along with the queen's request (' $\dot{\alpha} \lambda \lambda \dot{\alpha}$ $\pi i \theta \varepsilon \sigma \theta \varepsilon, O d .11 .345)$, but he also immediately gives the power of both word

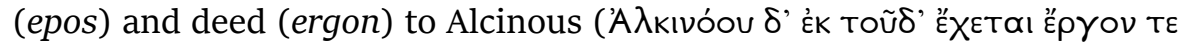

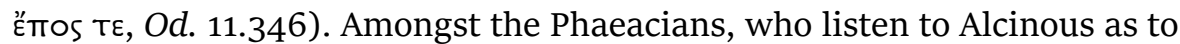
a god, the king's word is command. And so it is Alcinous who sees to Odysseus's safe passage-a task which he sees as exclusively male:

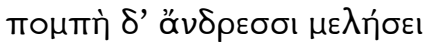

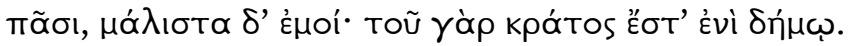

The passage shall be men's business, all men's, but most of all mine, since mine is the kratos in the demmos (Od. 11.352-53).

The interplay between basileia, basileus, and the assembled basilees in this situation clarifies the different aspects on which the possession of time is based. ${ }^{115}$ Judgement through sight is the basileia's business, while the implementation of the judgement is up to the basileus, who is in charge of directing through speech (epos). Both need to be affirmed by the other basileees represented by Echeneus. ${ }^{116}$ On a different occasion we find the

115. See Od. 6.289-315; 7.139-71. Here Nausicaa first refers Odysseus to Arete, whom he should ask for hospitality. Eventually it is Alcinous who leads the stranger from the hearth to his seat, after Echeneus asks for the king's counsel.

116. See Ruzé 1989: 216 and 222-23 who stresses the importance of the agreement of the Phaeacian basileees. The consensual manner of the king's decision-making is discussed by Flaig 1994: 13-31 and Schulz 2011: 73 who neglect the role of the queen. Most scholars interpret the action of Alcinous as an attempt to put Arete back in her place (see e.g. Clark 2001: 346) and do not see the interaction 
inclusion of the demmos and the laoi, the Phaeacian community (Od. 8.1-44). Here too the sceptre, carried by all the Phaeacian basilees, symbolises their power to give direction, as we see when Alcinous addresses them as

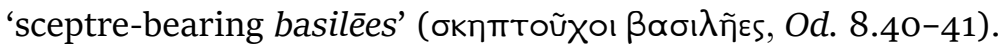

In the description of the provenance of Agamemnon's sceptre, we saw a clear indication of the fields of influence and authority connected with it: rule over individuals (contained in the metaphor of the shepherd of people), ownership of herds and flocks, and possession of land and its resources, islands, and named places. In Alcinous's case, his authority is over the granting of safe passage across the sea, the sphere granted as time to Poseidon (Il. 15.189-90). Arete's evaluation by sight suggests to me an authority over the social aspects of 'safe passage'. She is able to recognise a stranger's background and social network by evaluating the clothing that lends him his outward appearance (eidos). She also has knowledge of the correct patterns of gift-giving for guests, as it is she who calls on the Phaeacians to offer gifts.

A second hospitality scene helps to confirm the gender-specific distribution of competencies between evaluation by sight and directive speech. When Telemachus arrives at Sparta, it is once again the female partner in the hosting couple, Helen, who identifies the guest and recognises Telemachus as the son of Odysseus (Od. 4.138-46). Penelope displays a similar ability to judge by sight when she welcomes the disguised Odysseus, although at Ithaca there is no one to grant safe passage and gifts, as Penelope points out in answer to the stranger's prophecy:

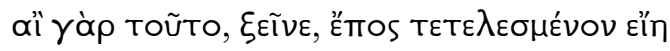

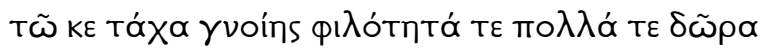

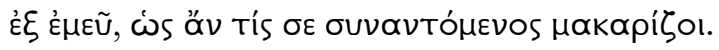

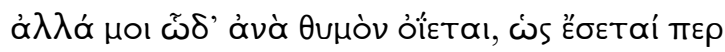

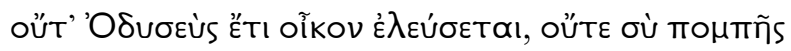

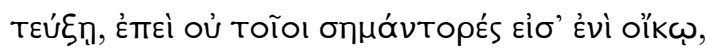

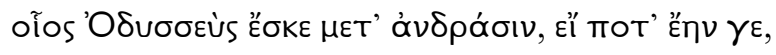

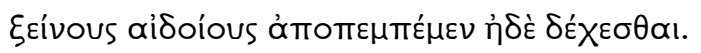

between the couple, as I have argued in Wagner-Hasel 1997. See now Canevaro (2018: 58) who has taken up the argument in her study on Women of Substance. Homeric Epos, Objects, Gender, Agency: 'Arete and Alcinous are working together towards the same goal, Arete coming up with the idea and Alcinous using his way to validate it.' 
Friend (xeinos), may what you say (epos) prove true! If it does, you will soon receive from me such friendship (philotēs) and generosity (polla te dōra) that anyone who meets you will call you a fortunate man. But what my heart forebodes is this, and this is how it will be. Odysseus will not come home nor will you secure your passage (pompē) from here; for we have no leaders (sēmantores) of men like Odysseus (if ever there was such a man), to receive strangers (xeinoi) with proper respect and send them on their way (Od. 19.309-16, tr. Rieu).

Here, too, safe passage or convoy (pompē) is men's business, and it re-

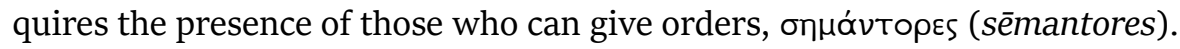
The absence of masters does not stop Penelope giving her guest such goods, as she is in charge of blankets for his bed and the promise of clothing (Od. 19.317-22). ${ }^{117}$ Her granting of these is described with the same words used of the honours paid to warriors at the feast: tiein and timan. ${ }^{118}$

This literary presentation of the female power of decision-making does not appear to be an exception. A Corinthian kratēr of around 560 BCE depicts the Greek envoys to Troy wanting to negotiate the return of Helen. Their counterpart in these negotiations is not Priam, or one of the elders, but the Trojan priestess Theano with two of her companions. According to

117. The role of the semmantores is discussed by Cobet 1981: 18 and Winkler 1990: 152 . On Penelope's authority in this scene see Chaston 2002: 13: 'She cannot provide an escort to her guest as Odysseus would [...] but she can bestow the hospitality of bed, bath, and meal [...]'.

118. See Telemachus, who asks the old Eurycleia, whether the guest was treated well

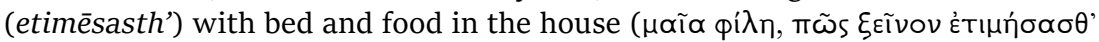

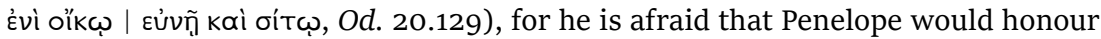
(tiei) a person of lower status and dishonour a high-ranking person (atimēsaso). Eurycleia gives a list of the food and clothing which she had wanted to give to the guest but which were refused by him (Od. 20.142-44). On the other side the beggar's poor clothing could be the reason for dishonouring the guest, as Od-

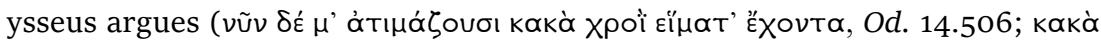

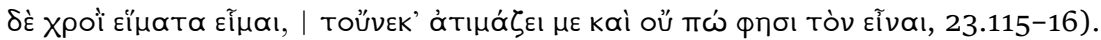
In fact, his worry is unfounded: Penelope promises him beautiful clothing, heimata kala, a chlaina, and a chitōn (Od. 17.550) in the event that his prediction should come true. Dressed in these, he would be able to ask for bread in the demos (Od. 17.557-59). Penelope also wants to reward his victory in the contest with clothing as well as arms and an escort (Od. 21.338-42). Similarly, Telemachus asks his companion Peraeus to honour (tiemen) the seer Theoclymenus (Od. $15.543=17.56)$. Bellerophon is honoured (tiein) by the Lycian king with a nine-day long feast (Il. 6.173). 
Sarah Morris, this representation corresponds to the cultic origin of positions of rank in early Greece. ${ }^{19}$

While the women in the Odyssey are in charge of welcoming strangers and providing them with textile gifts, the Iliad's high-ranking women are in charge of funeral arrangements. Such arrangements are always made by mothers, potniai mètēres, whose own status is decisive for the degree of time owed to their dead sons. In the conflict over the proper burial of Hector, we find Achilles's divine mother once again to be a key factor in the measuring of timē. According to Hera, it is not right that Achilles, the son of a goddess raised by Hera herself, should be considered by Zeus as equal with Hector in timē. Hector, she argues, was fed at only a mortal woman's breast (Il. 24.57-6o). She will not therefore permit the gods to take Hector's corpse away and protect it from further abuse by Achilles. Zeus confirms that indeed Hector and Achilles are not equals in timē (oú

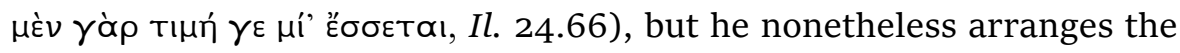
ransoming of the body on the grounds that Hector always paid the due geras to the gods at sacrificial feasts (Il. 24.70). Zeus negotiates this with Thetis, whose philotēs and aidōs he wishes to preserve (Il. 24.111). When Thetis persuades her son to accept the compensatory gifts, these consist partly of textile goods (peploi, chlainai, tapētes, pharea, and chitōnes) and partly of metal objects such as tripods, cauldrons, a drinking cup, and gold (Il. 24.229-35). Textile goods, which touch upon the time of women, thus make up half of Achilles's greater timē in this exchange. ${ }^{120}$

The epics present us with a plurality of uses of the term basileus, corresponding to a range of different spheres of influence and areas of responsibility; this variation has supported the idea that Homeric epic presents a shift from monarchy to forms of aristocratic rule. ${ }^{121}$ However, this is not an adequate interpretation. The title of basileus denotes persons assembling in order to take decisions; only in wartime does it become necessary to decide who amongst the basilees is the most powerful, that is, basileutatos. ${ }^{122}$ In both conflict situations in the assembly in the Greek camp outside

119. Morris 2003: 15 .

120. Achilles has a trunk full of textiles, which Thetis has given him. He takes the pieces needed for making up his guests' beds from this. Il. 16.221-24; 24.643-46.

121. See Barceló 1993: 72-74, for whom the basilees of the Odyssey are simply landed gentry, and Ruzé 1989: 211-23, who attempts to place them into a hierarchy between archontes and tyrants.

122. See Ulf 1990: 85-98. The special situation is also stressed by Ruzé 1989: 215 and Carlier 1984: 144. Carlier supposes that Agamemnon is seen as the plus noble because of his wealth and the number of ships and at last because of the origin of his sceptre. 
Troy, that person is Agamemnon to whom the warriors are all bound by oath. ${ }^{123}$ As Erich Bethe argued back in 1931, when he rejected contemporary ideas about feudal kingship, Agamemnon's superior power in these instances need not imply a form of Großkönigtum. ${ }^{124}$ In effect, Agamemnon only temporarily holds the high command that would ordinarily be shared between the basileees who make up the council. Similarly, when the seer Theoclymenus refers to the genos of Odysseus as basileuteron (Od. 15.533), this is not a reminiscence of a past Großkönigtum but instead suggests the restoration of the former position of Odysseus's house-or possibly anticipates the Peisistratid tyranny and its alleged sponsorship of the edition of the Homeric epics. ${ }^{125}$

The divine provenance of time and of the symbols of the power or the basileus, the sceptre and themistes, just like the divine provenance of charis, appear to suggest that positions of power are transcendent and eternal. However, the presence of a community in charge of the distribution and evaluation of time implies that positions of power encompassed by timai remain connected to social controls.

Yet the Iliad tells us that divine timē must always be greater than human (Il. 9.469). This makes sense, since divine timē represents the principle according to which time is distributed among humans. ${ }^{126}$ Thus the distribution of time amongst the Phaeacians, as spoken of by Arete, follows the model suggested by Poseidon in Iliad 15 when he speaks of the distribution of time between the three sons of Cronos: 'Each has his portion of time

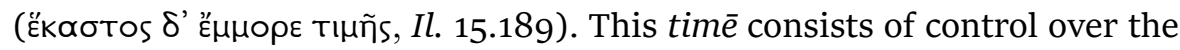
three domains:

123. Il. 2.206; 9.69. Cf. the use of the comparative basileuteros for Agamemnon (Il. 9.160). Besides this the comparative is only used for his brother Menelaus (Il. 10.239) and for the future son-in-law of Agamemnon (Il. 9.392).

124. Bethe 1931: 223.

125. Carlier 1984: 214 sees aspects of an idéologie tyrannique. On this argument see Svenbro 1984: 49-63. For the imitation of Odysseus by Peisistratus see Blok 2000. Cf. also note 44 in my introductory remarks.

126. There is no scholarly consensus on the role of the gods in epic narrative. There are those who view the gods as mere poetic devices whose actions serve as a foil to human action (see Bremmer 1987: 31-46), and those who argue that epic needs the gods because humans were not thought to have free will (see Kullmann 1956 and Erbse 1986). Graf (1991: 331-64) offers a good survey of the scholarly field. My position here is based only on examination of the text itself, and my focus is on the role of the gods with respect to gifts and giving. In the tradition of Weber, Durkheim and Geertz, I do see the gods in epic as embodying human principles and central social values rather than confining them to the sphere of the irrational and the unreal. See Kippenberg 1971: 54-82, esp. 59-63; 1997. 


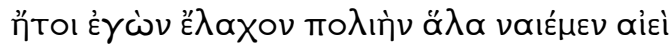

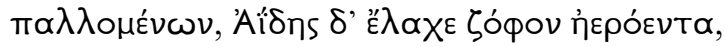

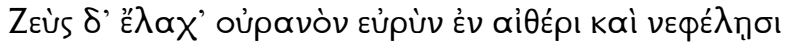

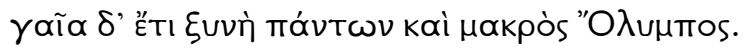

We cast lots, and I received the grey sea as my inalienable realm, Hades drew the darkness below and Zeus was allotted the broad sky in the upper air among the clouds. But the earth was left common to all of us, and high Olympus too (Il. 15.190-93, tr. Rieu).

Poseidon's point here is to reject Zeus's claim to sole rulership and to demand to be equal in honour (ómótınov, Il. 15.186). This separation of the domains is seen by some as a borrowing from Akkadian epic and, therefore, as belonging to a comparatively younger version of the Iliad, since it appears to contradict the usual separation of the cosmos into heaven, earth, and underworld. ${ }^{127}$ The fact that the passage addresses the distribution of divine time distinguishes it from other passages involving the cosmic domains, which are usually connected to sacrifice; thus it is possible that the variation is due to the context, although this does not exclude Ancient Near Eastern influence. ${ }^{128}$ Taken against the background of the distribution of time amongst men within the poem, the divine distribution of time certainly seems coherent.

The presentation of the cosmos as divided into separate domains corresponds to the way in which time amongst humans is distributed into different spheres and areas of responsibility. In Poseidon's account we find that the unmovable elements, earth and Mount Olympus, belong to all. The waters of the sea, and the light and darkness of the sky, however, are subject to individual deities, so that the three gods are not in charge of specific territories but of permeable spaces. This may be understood in cosmological as well as in topographical terms. The darkness allotted as the time of Hades suggests the loss of light associated with death in Greek thought, ${ }^{129}$ while

127. See Burkert 1984: 87-88.

128. Il. 3.277-279 (Helios, Gaia, rivers, shadow of the dead); Il. 15.36-40 (water of the Styx, Gaia, Ouranos); Il. 18.483 (Gaia, Ouranos, Thalassa, Helios, Selene); Od. 5.184 (Gaia, Ouranos, water of the Styx). Cf. also Hes. Theog. 736 (Ge, Tartaros, Thalassa, Ouranos); similar: 839-49.

129. This may be a possible explanation for the name 'Hades' = a-ides. See Griffin 1984: 9o, n. 25; Vermeule, 1979: 29. Death itself is imagined as a dark cloud in the epics: melan nephos (Il. 5.68; 16.350 and 502; Od. 4.180). 
Zeus's rule over the sky contains his responsibility for the light of life. ${ }^{130}$ The grey colour of the sea represents an intermediate stage inhabited by the nymph Leucothea. She gives Odysseus the veil which enables his passage from the world of the immortals to that of mortals (Od. 5.367). As we shall see, the potniai metteres with their shrouds enable the reverse version of this transition during the burial rituals. As we already know, responsibility for safe passage across land and sea is the responsibility of basilees in Homeric epic. Our examination has also shown that the granting of safe passage, both spatial and social, is a nonmaterial part of time, shared between basileus and basileia at Phaeacia. The divine distribution of timai as outlined by Poseidon reflects the two aspects of safe passage, which correspond to two key spheres of power: social or generative and spatial power.

To encapsulate Homeric rulership in one term, I want to propose the word Geleitherrschaft, that is, rule over safe passage or convoy ('Geleit'). My investigation so far has shown that control over safe passage is the defining element of Homeric rulership, which subsumes all the aspects of time we have determined without supposing any hierarchy between them. This time is not the honour of kings, nor is it the respect shared by all, be they beggars or high-status individuals. This timē belongs only to those who have control over safe passage in space and those who mediate between the human and the divine sphere: basilees in charge of taking decisions according to divine wisdom and collecting goods in return; the basileia who welcomes strangers and makes goods available to them; the potnia mètēr who-as we shall see-conducts the dead safely towards immortality; the elders who receive prizes from Achilles as time and in return pray for divine favour (Il. 23.648); and finally, the bards who also have a share in time since they sing in keeping with divine wisdom (Od. 8.480).

\subsection{Penelope's trick and the geras of Odysseus: Weaving as a symbol of power}

While the Iliad is concerned with the refusal of service in war, the Odyssey tells of what happens when the service of women is disrupted. ${ }^{131}$ This is

130. On the meaning of light as life see Griffin 1984: 90.

131. See Linden 1992: 110-114, who argues that the main theme of the Iliad was the restitution of honour (timē), whereas the Odyssey deals with the restitution of marriage. According to Papadopoulou-Belmehdi (1994: 169) the Odyssey is about memory (mémoire) through mêtis. She argues that the shroud of Penelope functions as 'Leitmotiv' and interprets Penelope as incorporating both cunning (mêtis) and memory. 
when time and geras cannot be accessed, and a man's goods are consumed without compensation: atimos.

At the beginning of the Odyssey we find Telemachus complaining to Mentes, his father's guest-friend, and to the assembled Ithacans about the conduct of the aristoi of Ithaca and its surrounding islands who are wooing his mother and consuming his economic resources, his oikos: each day they slaughter cattle, sheep, and goats and drink sparkling wine, showing no sense of shame in the face of local public opinion (Od. 1.245-51; 2.55-66). The suitors reject the accusation: 'It is not the Achaean suitors who are the cause of this', Antinous objects, 'it is your own mother, who is looking to your profit' (Od. 2.87-88). He then proceeds to tell of Penelope's trick, which had linked her remarriage to the completion of a shroud for Laërtes, Odysseus's elderly father:

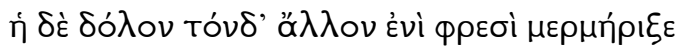

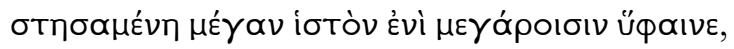

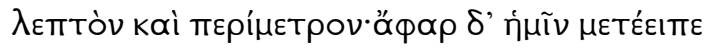

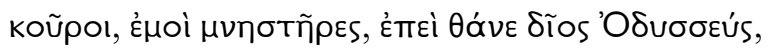

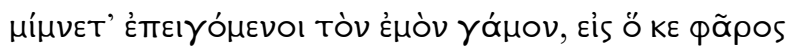

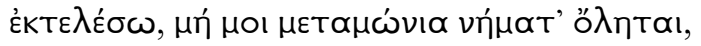

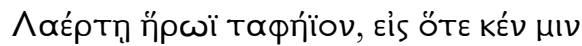

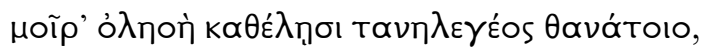

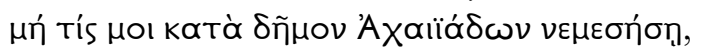

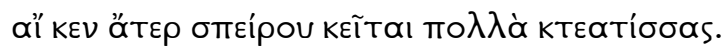

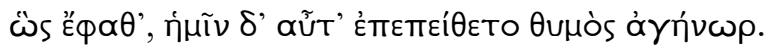

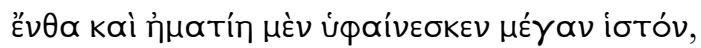

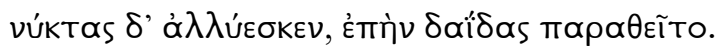

And here's another example of her duplicity (dolos). On her loom in her house (megaron) she set up a great web (histon) and began weaving a large and delicate piece of work. She said to us: 'My lords (kouroi), my Suitors, now the noble Odysseus is dead, restrain your ardour, do not urge on this marriage till I have done this work (pharos), so that the threads I have spun may not be altogether wasted. It is a shroud (taphēion) for Lord Laërtes. When he succumbs to the dread hand of remorseless Death that stretches all men out at last, I must not risk the scandal there would be among my countrywomen here if one who had amassed such wealth were laid to rest without shroud (speiron)'. That's 
what she said; and we magnanimously consented. So by day she used to weave at the great web (histon), but every night had torches set beside it and undid the work (Od. 2.93-105 = 24.128-40, tr. Rieu).

By undoing at night what she has woven during the day, Penelope effectively halts the passage of time and makes it impossible for the suitors to obtain Odysseus's geras, which they hope to gain through marriage to her. ${ }^{132}$ Unlike Clytemnestra, whose marriage to a new husband, Aegisthus, results in the loss of Agamemnon's time (Od. 3.304; 24.30), ${ }^{133}$ Penelope stays on the side of her husband, who returns home just as she has been forced to complete the shroud. Indirectly, her delay enables the restitution of Odysseus to his rightful position and the killing of the suitors. The final book of the Odyssey begins with a reprise of the complaint about Penelope's trick and its consequences, told to Agamemnon in Hades by Amphimedon, one of the recently dispatched suitors:

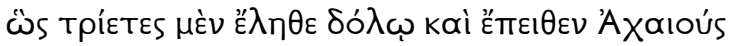
à $\lambda \lambda \lambda^{\prime}$ öt

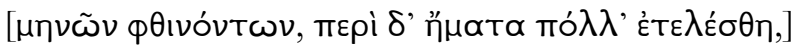

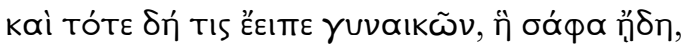

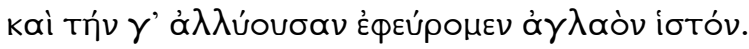

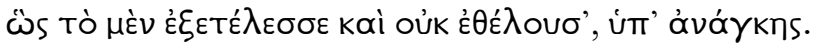

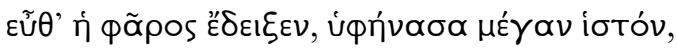

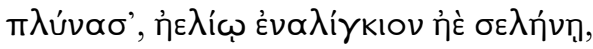

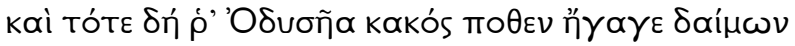

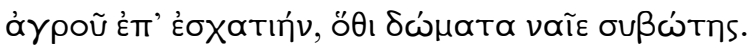

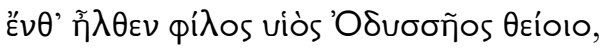

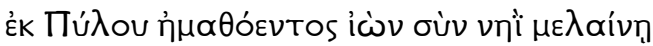

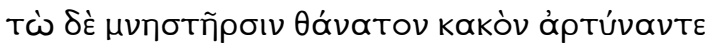

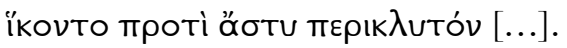

132. The connection between wooing and gaining access on the geras is stressed by Telemachus talking with the seer Theoclymenus: Od. 15.521-22. Cf. Wagner-Hasel 1988: 54-55. Foley (1978: 11) speaks of Penelope's power 'to stop change'. Similar Papadopoulou-Belmehdi 1994: 46. See also Heubeck 1990: 136-37.

133. Penelope contrasts herself with Helen, who was affected by atē and followed a stranger (Od. 23.218-24). See Morgan 1991: 1-3. For comparison between Clytemnestra and Penelope see Katz 1991: 6-7; 48-53. 
For three years she took us in by this stratagem (dolos). A fourth began, and the seasons were slipping by, when one of her women, who knew all about it, gave her mistress away. We caught her unravelling her beautiful work (aglaon histon), and she was forced reluctantly to complete it. But no sooner had she woven the great web (pharos), laundered the robe and shown it to us gleaming like the sun (Helios) and the moon (Selene), than some evil god landed Odysseus out of the blue in a distant corner (eschatia) of his estate (agros) where the swineherd had his hut. Noble Odysseus's son, just back from sandy Pylos in his black ship, made for the same place. The two of them plotted our assassination, and made their way to the famous city of Ithaca [...] (Od. 24.141-54, tr. Rieu).

Agamemnon responds to Amphimedon's account of the suitors' demise

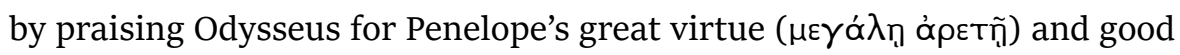

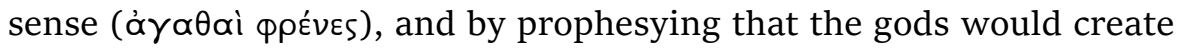
songs of charis in praise of Penelope (Od. 24.191-98). The Odyssey ends with the reinstating of Odysseus's rights as the son of Laërtes (Od. 24.336-

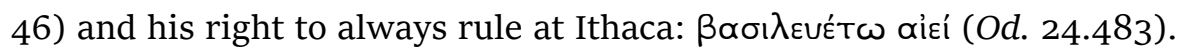
This end is preceded by Penelope's recognition of her husband and thus the restitution of his geras-which Odysseus had asked about when he met his mother in the Underworld (Od. 11.175 and 184).

Unlike the geras fought over by Agamemnon and Achilles, the geras of Odysseus does not consist of a share of booty such as a captured woman. Nor is it a portion of meat such as that received by Telemachus and Peisistratus at Sparta as geras at the feast (Od. 4.66). In the Odyssey geras takes a more abstract form and should be understood as a collective term to capture the status and rank of Odysseus. In speaking to Arete, Odysseus expresses the idea that such geras should be maintained and passed on through the generations:

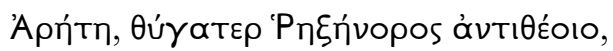

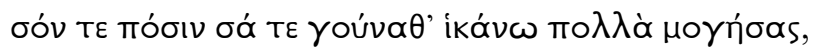

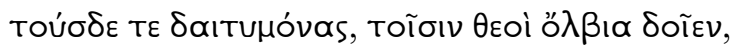

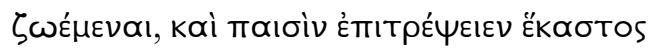

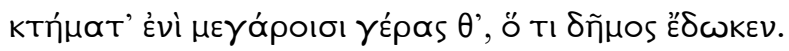


Arete, daughter of godlike Rhexenor, I come to your husband and to your knees after much suffering and to these banqueters, to whom the gods may grant happiness (olbia) in life, and may each of them hand down to his children the wealth in his halls and the geras that the dèmos have given him (Od. 7.147-50).

Pointing out the futility of striving for the time and the geras of Priam, Achilles reminds his opponent, Aeneas, of Priam's heirs who stand to receive what he has: 'Priam shall not hand you the geras, for he has his own children and he is strong and sound of mind' (Il. 20.182-83). Ulf sees in this remark an anticipation of the institutionalisation of rank, while Justus Cobet takes Hector to be the obvious heir to Priam and considers geras to be attendant on the office, expressed through the word time $\bar{e}^{134}$ Penelope's role in the securing of geras in the sense of a position of privilege has caused some consternation in scholarship but not, as yet, a satisfactory explanation. Neither Bachofen's search for the lost original matriarchy ${ }^{135}$ nor Finley's (and more lately Carlier's or van Wees's) total rejection of any form of power held by Penelope ${ }^{136}$ do justice to the question. It is indeed the basilees who are in control of geras; but mothers and wives are aware of geras and they seek to preserve it. In the case of Odysseus, this attempt at preservation is done by means of Penelope's shroud weaving, and we shall see that this involves precisely the generative power that enables the transferral of Odysseus's position of honour, his geras. In order to understand this, it is important to conceive of the temporal dimension incorporated in the shroud.

As she works on the shroud, Penelope causes time to stand still; the shroud embodies this time. Epic does not conceive of the passing of time in a linear fashion; indeed, within the poems time is represented merely as duration, or as an allotted fate. The narrative itself circles around

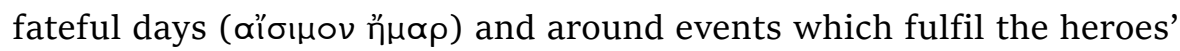

134. Ulf 1990: 11 and 106-17; Cobet 1981: 25.

135. See Thomson [1949] 1978: 416-20.

136. Finley 1967: 91: 'There was nothing about the woman Penelope, either in beauty or wisdom or spirit, that could have won her this unprecedented and unwanted right of decision as a purely personal triumph.' Carlier 1984: 207, n. 340: 'Il est arbitraire d'interpréter le rôle de Pénélope comme un vestige de matriarcat primitif.' Van Wees 1992: 288: 'The traditional notion that they [the suitors] court Penelope because whomever she chooses to wed will be the new monarch, is mistaken. This view would give her a surprising amount of power, and in any case is not borne out by evidence'. 
fate. ${ }^{137}$ These lie ready on Zeus's scales, like wool ready for weighing and working. In a warning to Achilles, who refuses a meal before going to battle, Odysseus compares Zeus to a housekeeper, a tamie, who allocates the household's provisions (Il. 19.223-24). In Book 8 Zeus places the lots of the Greeks and the Trojans onto his scales: ${ }^{138}$

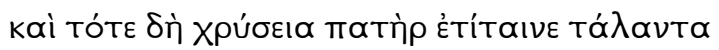

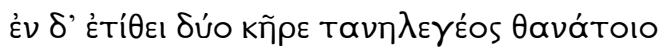

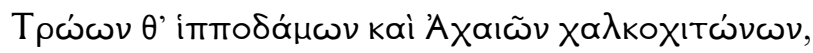

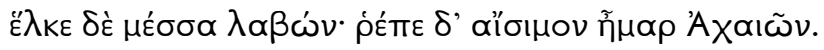

But when the sun was high in the sky, the Father held out (epitaine) his golden scales (chryseia [...] talanta), and putting death that lays men low in their pan, on one side for the horse-taming Trojans, on the other for the bronze-armoured Greeks (Achaioi), raised the balance by the middle of the beam. The beam came down on the Greek's side, spelling doom for them (Il. 8.69-72, tr. Rieu).

The metaphor of weighing alludes to the weighing of wool. This is clarified by the simile of the wool-worker used in Book 12 to illustrate the precarious balance of the battle: ${ }^{139}$

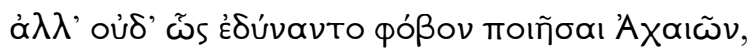

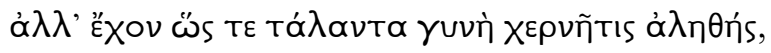

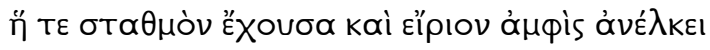

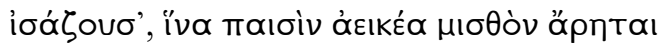

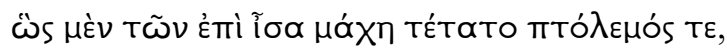

137. Onians 1989: 411-15; Fränkel 1955: 1; Patzek 1992: 179-80; Garcia 2013: 232. This symbolic meaning of the web makes it possible to interpret the pharos of Penelope as Odysseus's wedding robe, and in doing so she reconfirms his identity as her husband: see Yamagata 2005: 544.

138. The image is also used in advance of the final duel between Hector and Achilles (Il. 22.209-12). Hector is not to be sent to Hades against fate (aisa), but no one escapes fate (moira) (Il. 6.487-88). There is a little room for manoeuvre. When Hector recognises the sacred scales of Zeus (hiera talanta), he turns to flight (Il. 16.656-58).

139. This amount of wool is mentioned again in a subsequent simile when Hector picks up a heavy rock that is as light to him as the wool shorn from a ram is to a shepherd (Il. 12.451). 


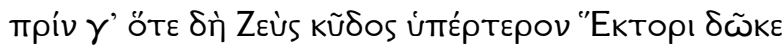

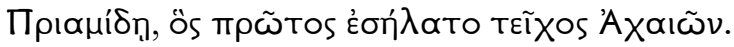

The Greeks held on, like a careful wool-worker who holds up her scale (talanta) to balance the wool against the weights and check the accuracy of the meagre pittance she is earning for her children. The struggle was as tight and even as that, till the moment when Zeus gave the upper hand (kudos) to Hector son of Priam, who was the first to leap inside the Greek wall (Il. 12.432-37, tr. Rieu).

A person's life is determined by what Zeus takes for them from his storage jars-these contain good as well as bad gifts (Il. 24.527-29). The thread of life is spun from these gifts as Achilles tells Priam: 'This is how the gods

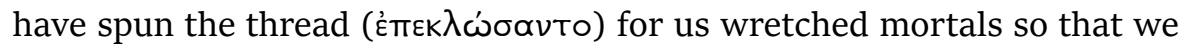
may live in grief' (Il. 24.525-26). The necessary amount of these gifts is described by the word olbos; Peleus is distinguished by this alongside his wealth, ploutos (Il. 24.535-36). It is allotted twice, once at birth and again upon marriage: Menelaus says to Nestor's son Peisistratus that Zeus had

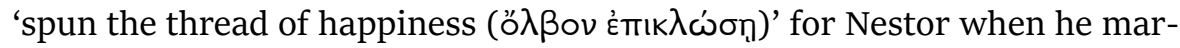

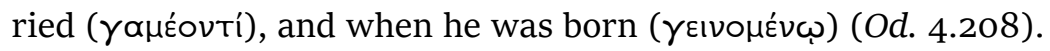

Most frequently the thread of life is said to be spun by the Fates, Moira, Aisa, and Clotho. So Hecuba says that it was Moira who spun for Hector,

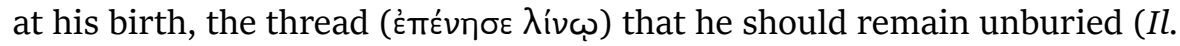
24.209-10). The use of the past tense here is typical and expresses the notion of fate as already complete, merely waiting to be fulfilled. According to Hera, Achilles will also suffer the fate ( $\alpha i ̃ \sigma \alpha)$ that was spun for him

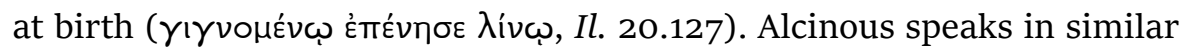
terms of the fate of his guest as the Phaeacians prepare to send him off:

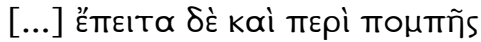

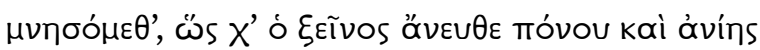

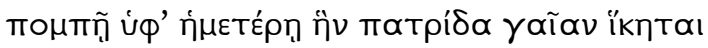

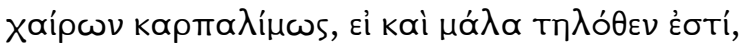

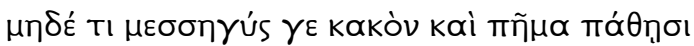

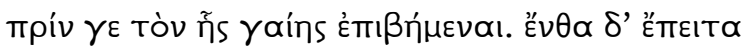

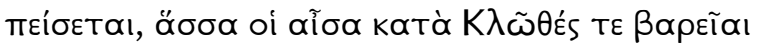

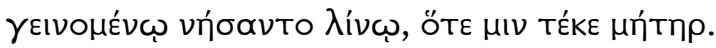


We will then take up the matter of his passage (pompē) so as to ensure him without trouble or anxiety the happiness of a speedy return to his country under our escort (pompe) ), however far away it is. We will safeguard him on the way from any further hardship or accident till he sets foot on his own land. After which he must suffer whatever Destiny (Aisa) and the restless Fate (Clotho) spun for him with the first thread of life when he came from his mother's womb (Od. 7.190-98, tr. Rieu).

The image for the conflict between Zeus and Poseidon over the outcome of the war also refers to the processes of weaving, as the mighty struggle is

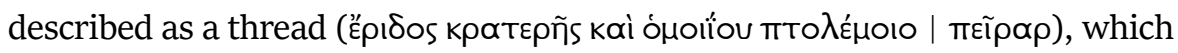

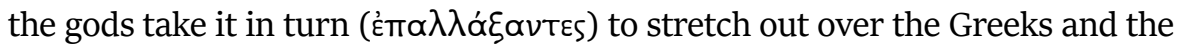

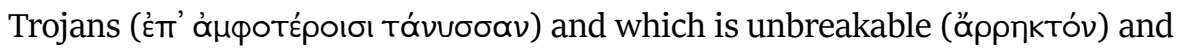

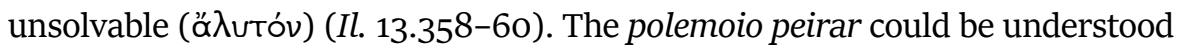
as a rope, such as one might use to tie up a person. ${ }^{140}$ But it may also be understood to mean the woof thread (or weft thread), which is drawn through or crosses the stationary warp thread in both directions on the loom. ${ }^{141}$ This

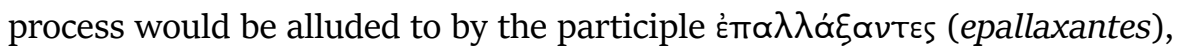
which I translated above as 'taking it in turns' but which actually suggests the crossing of warp and weft. ${ }^{142}$ The verb tanyein, used elsewhere for the stringing of a lyre and for the stretching of the weft thread across the loom, here must refer to the drawing of the weft thread through the 'shed' created by the heddle-rod. ${ }^{143} \mathrm{~A}$ tightly stretched weft thread will result in a strong woven fabric, which will, as in the simile above, be unsolvable. ${ }^{144}$ Of course,

140. This is the meaning of peirar in Od. $12.51 ; 162 ; 179$.

141. Cf. Onians 1989: 338; Bergren 1975: 8-11; 177. The later term for the weft thread is krokē. See Blümner 1912: 128; 142.

142. See Onians 1989: 311-14; 318. Bergren (1975: 172) translates: 'having crossed over'.

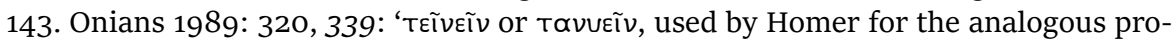
cesses of stringing a lyre or bow, naturally describes the stretching or drawing of the woof thread across the warp'. See also Bergren 1975: 177. Tanyein has a special meaning in Il. 23.760-63, tr. Rieu: ' [...] like the rod (kanōn) near the breast of a girdled weaving-woman: she carefully draws (tanyssei) it along with her hands to get the spool (pēnion) out past the warp (miton) and brings it right up to her breast [...]'. For the meaning of the weaving terminology used here see Blümner 1912: 148-49; Barber 1991: 270. Mitos is also the heddle.

144. A further meaning of peirar is the cosmological border, Oceanus. Onians 1989: 316; Bergren 1975: 22-28. This meaning as border fits with the textile meaning of peirar. According to Ellen Harlizius-Klück, peirar denotes the starting-border of the fabric ('Gewebeanfangskante') that is produced separately before being fixed at the loom (Harlizius-Klück and Fanfani 2016). 
patterns are created with the weft thread, so that it makes sense to qualify the thread with a reference to the kinds of patterns seen on woven fabrics, which include battle-scenes. ${ }^{145}$ Thus it is the polemoio peirar, which 'loosens the knees', that is, brings death, for many men (Il. 13.359-60). If we stay within the weaving image, it is clear that death occurs when the weft thread has been used up and the fabric is completed, like Penelope's shroud, anticipating death and completed under duress. Elsewhere in the Iliad, when heroes' knees are loosened in death, we also hear of telos thanatoio, the completion of death. That telos covers the eyes and nose of the dying heroes like a shroud:

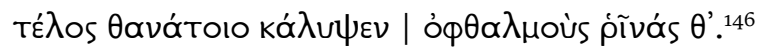

These similes make reference to various stages in the preparation and working of wool into a fabric. A portion (moira) of unspun wool is weighed on the scales (talanta). ${ }^{147}$ This amount or weight (aisa) determines fate, which is called either moira or aisa. The Fates, Moira or Clotho (later Lachesis), personify fate. ${ }^{148}$ Fate, which men cannot predict, lies on the knees of the gods, ${ }^{149}$ just like wool placed on the spinners' knees for carding before it is spun. ${ }^{150}$ The process of carding is described as neein, epineein, and nethein, while the word for the spinning of a thread (linon) or a weft thread (peirar) is klothein. ${ }^{151}$ The to-and-fro of the weft on the loom ultimately makes up the fabric of life, the fulfilment of fate, the ré $\lambda_{\text {os }}$ (telos). Fate is weighed with the help of the kēres. In the singular, Kēr (Kńp) is a

145. See my discussion in ch. 3.2.

146. Il. 16.502 (Sarpedon); 5.553 (Krethon and Orsilochus); 16.855 (Patroclus); 22.361 (Hector).

147. Plato (Resp. 620e) uses moira for wool. See Onians 1989: 404.

148. Plato (Resp. 617c) differentiates between several phases of time. Clotho, the spinner, represents the present (ta onta), Lachesis, first seen in the Theogony (219; 905) as the personification of destiny, sings of what has happened already, the past, (ta gegonota) and Atropos, who turns the spindle, knows what will happen, the future (ta mellonta). They all sing like the Sirens, the daemons of death. In Theocritus (Id. 24.51-59) the moirai are spinning the thread of fate. See also Seneca (Apocol. 3.1-5.2), where the spindle represents fate and the span of life. Here, the wool is handed out by Lachesis. For the Homeric belief in fate see Dietrich 1957: 289-94; Erbse 1986: 276-78; Yamagata 1994: 105-20.

149. Il. $17.514 ; 20.535$; Od. $1.267 ; 16.129$. Vernant (1982: 140) defines the knee as a symbol of male power (puissance virile).

150. See e.g. Theocr. Id. 24.76-78: 'Many an Achaean woman will sing your name,

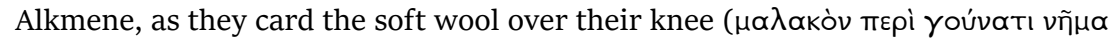

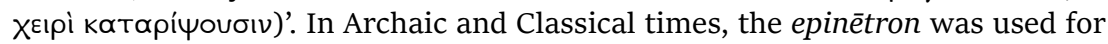
carding. For evidence see Lissarrague 1991: 179, fig. 10; 230, fig. 48; 247, fig. 61. Barber 1991: 77-78 hints at Mycenaean traditions.

151. For the terms of spinning and weaving see Blümner 1912: 98-170. 
goddess of doom who brings death for the warrior; used in the plural they

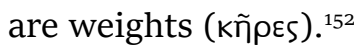

In his analysis of Greek notions of the body and death, Richard Onians interprets telos as a band which encloses and binds a completed whole. ${ }^{153}$ Given how concrete and technical the similes are, I think it more likely that telos, like the other terms we have considered, refers to a specific phase in the weaving process, namely, to the completion of the fabric which contains the shape of a life. It is striking that the word telos, which may mean an ending as much as goal or completion, is frequently used in situations involving transformation and in which textiles are used to effect or to visualize that process. Primarily this applies to death, which will be addressed in chapter $5 .{ }^{154}$ We do, however, have one example where the transformation in question is marriage, when Aphrodite prays for the telos of marriage for the daughters of Pandareus (Od. 20.74). Generally, we find telos and the verb ré $\lambda_{\varepsilon \omega}$ (teleō) associated with periods of time, to do with days (Od. 5.390; 10.470), nights (Il. 7.282), years (Il. 19.32), and age (Od. 23.286), but also with passage through space, such as homecoming (Od. 22.323), journeys (Od. 2.256), horse-racing (Il. 23.373), the return of booty to the homeland (Il. 12.222), and seafaring. Time spent in

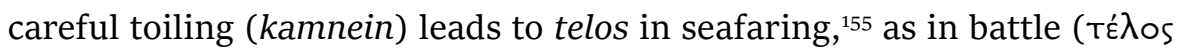

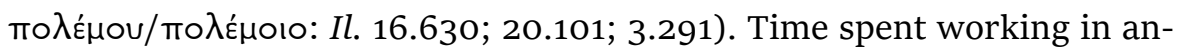
other's service may also lead to telos in the form of remuneration, the misthoio telos. The Horae, who are in charge of the passage from day to night, bring this misthos to Poseidon and Apollo in payment for their

152. For the daimon of death see Neumer-Pfau 1987: 21-23; Vernant 1982: 140; Erbse 1986: 280.

153. Onians 1989: 463.

154. Odysseus escapes the telos of death (Od. 5.356: telos thanatou) with the help of the veil (krēdemnon) of Leucothea. The suitors experience the evil telos of death (Od. 24.124: thanatoio kakon telos). Zeus knows for whom the telos of death is prepared (Il. 3.309). Achilles knows from Thetis about the telos of death that awaits him (Il. 9.411), and he knows that that telos will not come so swiftly if he returns home (Il. 9.416; 13.602). Odysseus warns Socus that the telos of death is upon him (Il. 11.451), although he also recognises that the telos has not pierced the kairos (Il. 11.439), that is, the row of thrums in a loom, through which the threads of the warp are attached. So Onians 1989: 346; Blümner 1912: 145-46, who also gives alternative interpretations.

155. The Cyclopes do not have tektones able to build ships (ká $\mu \circ เ \varepsilon v)$ and to accomplish

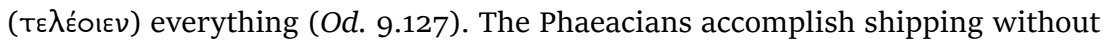

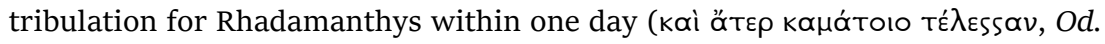
7.325-26). 


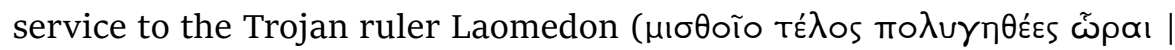

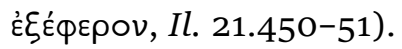

Finally, there is the telos of words, mythoi, which may not achieve their goal, however finely spoken, as Nestor tells Diomedes (Il. 9.56), or words which will not be fulfilled, as is the case for Achilles (Il. 19.107; 20.369). Words may be either completed or cut off midway (Il. 20.370). Words may be good or bad, but Agamemnon accuses Calchas that he has 'never spoken a

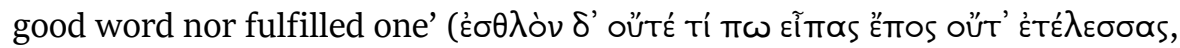
Il. 1.108). Mythos is powerful (karteros) when given as a leader's command to be fulfilled (Il. 16.199; 1.25; 326; 379). The fulfilment of such words lies in the hands of the gods, as for instance in the case of the suitors' plan to kill Telemachus (Od. 4.699). ${ }^{156}$ Occasionally their fulfilment may be predicted by prophets or by individual leaders (Il. 2.330; 14.48). A plan, such as that of the suitors who seek to murder Telemachus (Od. 4.774-76), may be woven like a web. Odysseus and Menelaus weave words (mythoi) and

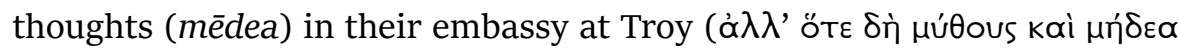

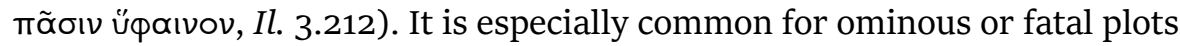
or plans (dolos or mêtis) to be described as woven, as is the case for the

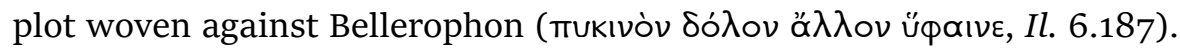
When Odysseus is shipwrecked, he fears that the immortals may have wo-

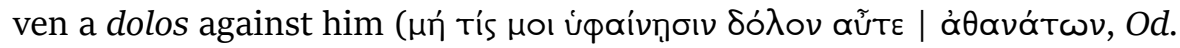
5.356-57), and he himself is said to weave a plot as he fears for his life in

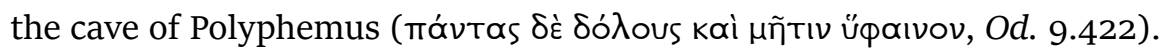

Whenever a plan (mêtis) or plot (dolos) is woven, the object is the death and destruction of the person for whom it is woven. This is true of the mettis the suitors weave for Telemachus ( $\mu$ ñтıv úpaıvov, Od. 4.678) and of the mêtis woven by Athena and Odysseus for the suitors (Od. 13.303; 13.386). All these plans bring the telos of death-like the doloi Penelope winds for

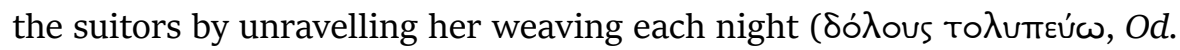
19.137). The physical place of this metaphorical weaving is the phrēn, the spirit or wit located in the lungs or in the diaphragm, and of which women who are valued for their weaving skills are especially possessed. ${ }^{157}$ Penelope

156. Cf. Od. 2.34: Zeus fulfils (teleseien) the good, Aegyptius says in the Ithacan assembly. See also Il. 1.5 .

157. It is Penelope who is especially characterised as periphrōn (e.g. Od. 21.321). Chrysëis, whom Agamemnon is unwilling to give up, is also equipped with a good mind phrēn (Il. 1.115). Whereas the adjective periphrōn is used only for women, echephrōn denotes both sexes. For evidence see Papadopoulou-Belmehdi 1994: 185-89; Ceccarelli 1995: 186-91. 
hopes to discover if Laërtes has woven some mètis in his phrēn when she asks the shepherd Dolius to take a seat next to Odysseus's aged father ( $\dot{v i}$

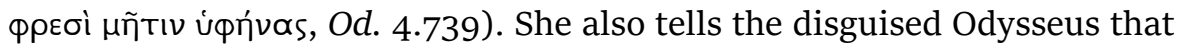
she herself was unable to come up with further metis after the suitors

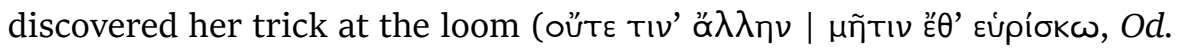
19.157-58). In Penelope's weaving trick the concrete and the metaphorical come together. ${ }^{158}$ Her mètis and her dolos, which, together with the mètis of Odysseus, bring about the demise of the suitors, are a concrete version of the metaphorical fabrics woven (hyphainein) by gods for men, and by cunning men for their enemies. The gods and Odysseus weave their meetis and their dolos; the word used for what Penelope does with her dolos is tolypeuein, which means to wind or wind off a skein of wool. Only her mêtis is metaphorically woven. The difference is significant, as in reality she unravels her weaving and winds the threads off again. ${ }^{159}$ This action is also suggested by the ancient etymology of Penelope's name: the loosener of threads (from mínn, thread, and $\lambda \varepsilon \dot{\pi} \pi \omega$, to peel, to thrash, and/or $\lambda \omega \dot{\pi} \eta$, robe, mantle). ${ }^{160}$

In the Iliad the ability to weave a plan metaphorically for another is a geras which belongs to the elders. Thus we hear that in the council of

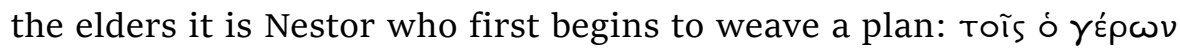

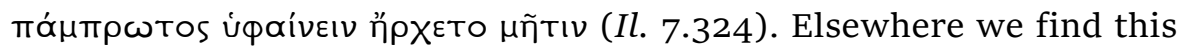
activity described as geras, when Nestor draws the difference between the elders' functions and the young men's prowess in battle: 'I guide with counsel and words, for that is the geras of the elders', $\kappa \varepsilon \lambda \varepsilon \cup$ o $\sigma \omega$ ßou $\lambda \tilde{n}$

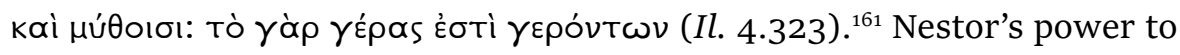
give counsel rests on the same preconditions as those which enable the basileees to take proper and wise decisions, that is, knowledge of social norms and conventions. Through his advanced age, Nestor practically embodies a store of divine wisdom, or themistes. The metaphor of weaving makes all the more sense then since woven cloths are also seen as stores of memory and wisdom, as discussed earlier. Thus, the adjective liparos,

158. Papadopoulou-Belmehdi 1994: 83 draws attention to the fact that metaphorical weaving of a plan is attributed only to men. Besides this, Penelope is also sending written messages to the suitors. See Marquardt 1993: 153.

159. The deceiving character of weaving is often stressed. See e.g. Murnaghan 1987: 110; Papadopoulou-Belmehdi 1994: 57-58; 155-58.

16o. Kretschmer 1945: 80-93; Papadopoulou-Belmehdi 1994: 81.

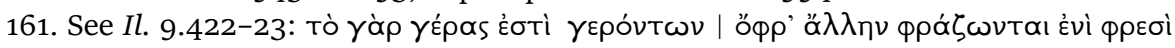

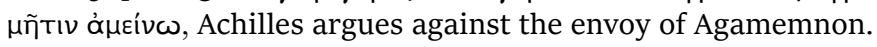


which suggests the visual power of these stores of memory, is used for old age, for illustrated weaving, and for the themistes. ${ }^{162}$

Building on this interpretation, we can add further concrete meaning to geras, which will explain both the parallelism of the terms time and geras, and the role played by Penelope in securing the geras of Odysseus. Just like time, geras also has both a material and an intangible meaning. On the one hand, geras denotes the concrete privileges of a high-status leader, a woman skilled in weaving, and a portion at the feast, which give visible expression to his status. On the other hand, geras can be understood as the ability to store or memorise social norms and knowledge and to use these stores of wisdom in counsel and decision-making. In this way geras is the precondition for the achievement of timē, which distinguishes basileus and basileia: the right to offer safe conduct in social and geographic space and to recruit goods and services for this. Carrying out this function requires knowledge of social norms such as we saw in our analysis of the distribution of timē between high-ranking men and women.

The female contribution to this is not only to help the basileus enjoy his privilege, his geras. Women's weaving of winding sheets, of the fabric of fate, whose completion (telos) signifies the completion of life, and so death, is a parallel to the elders' weaving of plans in speech. And this too can be understood as geras, since providing a corpse with such fabric is a part of the gift of honour, the geras, given to the dead. ${ }^{163}$ We know from our examination of charis that such winding sheets have important transformatory powers, since they bear the dead man's posthumous fame and thus contribute to the transformation of the mortal body into an immortal one. This is the reason why it is not only Penelope who preserves the geras of Odysseus but his mother, too, is able to pass on information about his beautiful geras (Od. 11.175 and 184). Indeed, his mother tells

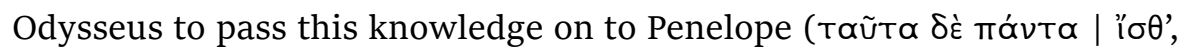

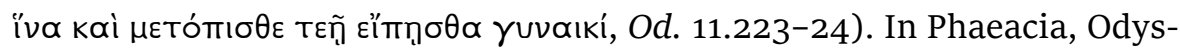
seus turns to Arete rather than Alcinous when asking to be taken in and expresses his good wishes to the other basilees for the preservation of their geras (Od. 7.147-50). It is mothers and wives who have the power,

162. For $\gamma \tilde{n} \rho \alpha s$ in the sense of a long life surrounded by blessed people (laoi olbioi) see Od. 11.136; 23.293; in connection with raising a son see Od. 19.368 and 4.210 (linked to the verb aging: gēraskein). Nestor's shining old age (liparōs gēraskemen) is a consequence of the plenty (olbos) spun out for him by Zeus at his birth and wedding (4.208).

163. See the following chapter. 
made manifest in their weaving, to bridge the discontinuity of experience and memory and to ensure the handing on of status and rank to the next generation. ${ }^{164}$

This state of affairs also explains the use of the term tiein, which usually refers to material gifts given as tokens of respect in guest-friendships or between spouses. In Phaeacia, where the position of the basileus is safe,

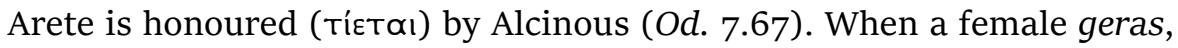
an enslaved woman who must weave for another and share the master's bed, is brought home, a couple's relationship is shaken, as happened when

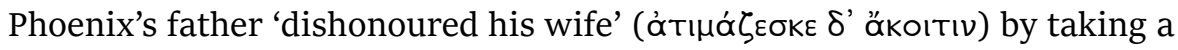
concubine (Il. 9.450). In contrast, Laërtes honoured Eurycleia as much as his wife but never went to bed with her for fear of his wife's wrath (ĩod

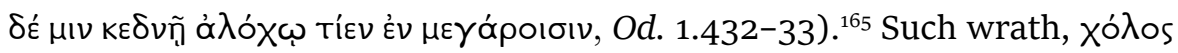
(cholos), like that of Achilles, has dire consequences for the sons in these circumstances: Phoenix must flee the country after taking his mother's side, since he does not wish to commit patricide (Il. 9.458-83). We find Orestes praised at the beginning of the Odyssey, his fame resting on the fact that he slew his mother's new husband (Il. 1.29-30; 196-98; 298-300; 305-10). In the Oresteia Clytemnestra's plot (dolos) against her returning

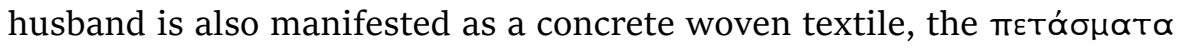
(petasmata) or eilua (heima) which is spread on the ground before him and forms the purple path (торфupóotpwtos mópos) upon which Agamemnon will be led into the house and to his death (Aesch. Ag. 908-10). ${ }^{166}$ In the Odyssey as in the Oresteia, the poets side with sons and fathers whose relationships are seen as endangered by the woman's taking a new spouse, rather than by any of the fathers' own actions. There is repeated mention of the misfortune that befalls husbands when their wives receive gifts from strangers (Od. 11.326-27; 11.251). To view this as the beginning of a tradition of misogyny, as Sheila Murnaghan has proposed, is to give the problem a moral dimension that the text does not justify. ${ }^{167}$ The problem is the fragility of the relationship of philotēs between the sexes, which is of interest not only to male audiences, as Lilian Doherty has shown. ${ }^{168}$

164. See also Papadopoulou-Belmehdi 1994: 183 and 199-203 who emphasises the relationship between memory and power.

165. According to Scheid-Tissinier (2015) Eurycleia was a high-ranking woman originally chosen as second wife by Laërtes to secure transmission of the oikos.

166. See Seaford 1984; Wagner-Hasel 2006.

167. Murnaghan 1987: 108-10. 
This is why Agamemnon may claim in the final book of the Odyssey that the kleos of Penelope, who was faithful to her husband and preserved the geras, will be the subject of songs. He is referring, of course, to the Odyssey itself (Od. 24.196). ${ }^{169}$

\subsection{The geras of the dead and the process of renewal in the death ritual}

The death of warriors in battle and their burial are central events in the epic narrative. There are two important burials depicted in the Iliad: Patroclus's and Hector's. The burial of Patroclus is the catalyst for the reintegration of Achilles into the Greek army and initiates a turn of events that ultimately concludes with the death and burial of Hector. In the final book of the Odyssey, the burial of Achilles is recalled. The honours paid to the deceased warrior during burial rituals are denoted with the same term as the privileges of the basileees and kings: once again, we are dealing with geras, a gift of honour. Once again both key communities, the domestic and the military, partake in the presentation of the gift.

The lament for the dead, for which the terms goaein (Yoógıv), klaiein ( are used, is a prominent part of the geras of the dead, performed during the laying-out (prothesis). When Penelope's suitors arrive in Hades, they complain that their relatives (philoi) are not aware of their misfortune. If they knew, the relatives would have 'wash[ed] the black blood off our wounds, and laid out our bodies and lamented (Yoóolev)'. For that is the geras of the

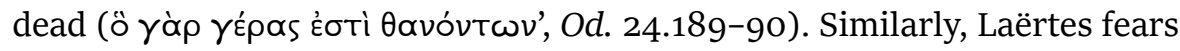
for Odysseus that he may have died without his parents' weeping ( $k \lambda \alpha \tilde{\sigma} \sigma \varepsilon$ ) for him, or his wife wailing for him ( $k \omega ́ k v \sigma$ '), nor closing his eyes when he is laid out for burial as is proper. He too concludes: 'For such is the geras

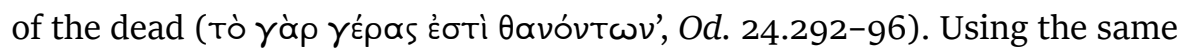

168. Doherty 1992: 161-77. While Doherty does not assume that women were present as audiences, she considers them none the less as implied or external audiences. She runs into difficulties explaining the presence of Arete at Demodocus's performance. It seems to me to make more sense to consider that different occasions allowed for different audiences. Cf. also McIntosh Snyder 1989 and Chaston 2002: 6. Chaston stresses Penelope's authority to speak to a male audience and to be heard by them.

169. For the kleos of Penelope see Katz 1991: 25 (she 'becomes the celebrator of her own kleos' by her weaving trick). Pantelia 1993; Papadopoulou-Belmehdi 1994: 185-91; Felson-Rubin 1994: 125-44, 178-85; Chaston 2002: 7. 


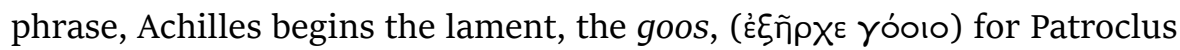
at the start of the funeral: 'Let us weep ( $\kappa \lambda \alpha i \omega \mu \varepsilon v)$ for Patroclus, for that

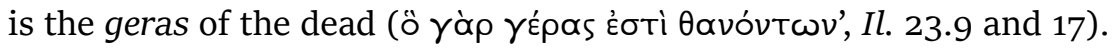

Such gooi are performed only by the deceased's close relatives, and they contain the value system of Homeric society. In Patroclus's case the lament is led by Achilles and Brisëis. Achilles's theme is the fulfilment of vengeance for his beloved friend:

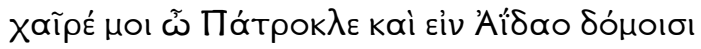

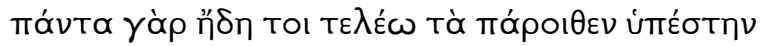

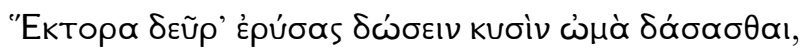

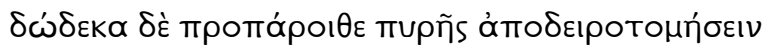

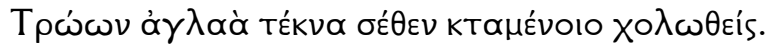

Farewell and rejoice, Patroclus, even in the halls of Hades. I am now keeping all the promises I made you: I have dragged Hector's body here for the dogs to eat raw; and at your pyre I am going to cut the throats of a dozen splendid sons of Troy to vent my anger at your death (Il. 23.19-23; tr. Rieu).

Achilles's revenge fantasies attach to the obligations which attend the bond between warriors; Brisëis, however, laments the loss of the protection she received from Patroclus:

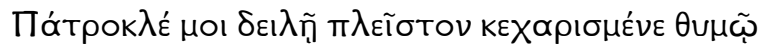

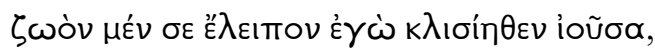

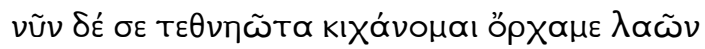

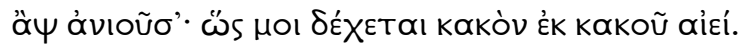

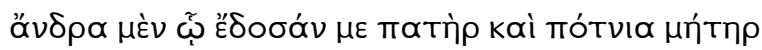

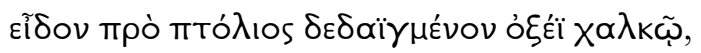

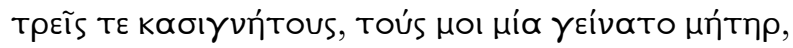

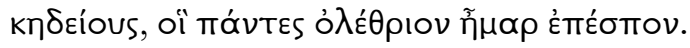

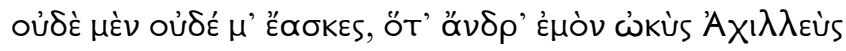

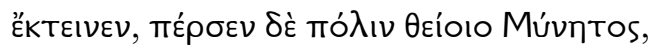

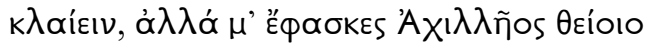

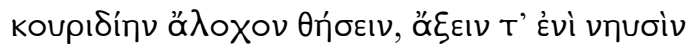

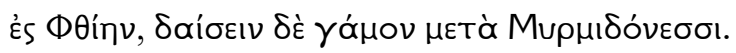

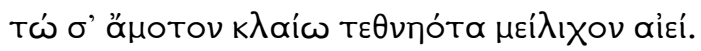


Oh Patroclus, my heart's delight! Oh, my misery! I left you in this hut alive when I went away; and now I have come back, commander of men, to find you dead. Such is my life, an endless chain of disaster. I saw the husband to whom my father and my lady mother (potnia mètèr) gave me mangled in front of his town by the cruel spear; and I saw my three brothers, my dear brothers, borne by the same mother as myself, all meet their doom. But you, when swift-footed Achilles killed my husband and sacked lord Mynes' town, you would not even let me weep (klaiein); you said you would make me Achilles' lawful wife (kouridiē alochos) and take me in your ships to your home in Phthia and give me a wedding-feast among the Myrmidons. You were always so gentle (meilichos) with me. So in death I mourn (klaiō) you inconsolably (Il. 19.286-300; tr. Rieu).

The other women in the Myrmidon camp join in with this lament, as we understand from the narrator's comments after the conclusion of the speech:

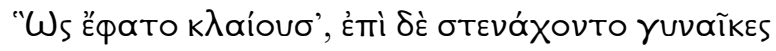

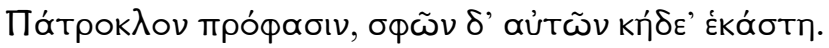

So she spoke in tears (klaiousa), and the other women took up the cry (stenachonto), each one recalling through Patroclus her own misfortunes (Il. 19.301-2; tr. Rieu).

The lament of Brisëis has been considered as atypical by some scholars, ${ }^{170}$ not least because of the narrator's comment that follows it. But the qualities ascribed to Patroclus by Brisëis, the taking on the role of a parent, and his mild personality (meilichos), are not unique to this lament.

Andromache, Hecuba, and Helen all perform gooi for Hector. When his body is returned, Cassandra's lament resounds throughout the city:

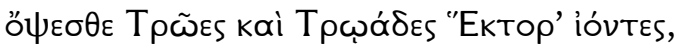

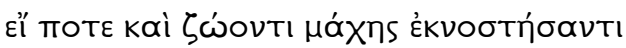

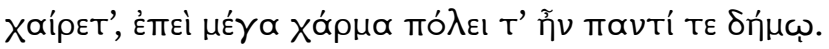


Trojans and women of Troy, if ever in the past you welcomed Hector back when he came home safe from battle-a moment for everyone in the town to rejoice-come out and see him now! (Il. 24.705-7, tr. Rieu).

Andromache and Hecuba, the wife and the mother, are the first to rush to the procession, while the women bystanders are weeping ( $k \lambda \alpha i \omega v, I l$. 24.710-12). The body is then laid out in Priam's house, with singers standing by its side and sounding the songs of lamentation, called thrēnoi (Il. 24.720-22). The content of these songs is not specified. But the laments of the relatives, the gooi, are cited in detail. Here, too, the problem of vengeance is addressed, albeit from the perspective of the relative threatened by revenge. But the more harmonising or equalising aspect of the hero's personality that we saw mentioned in the lament of Brisëis is a factor in the laments for Hector as well.

Andromache's goos is the first:

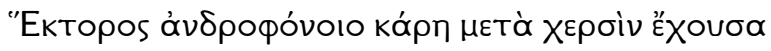

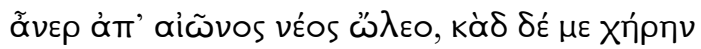

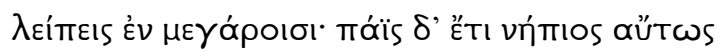

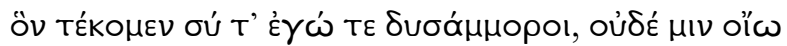

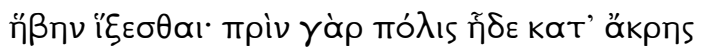

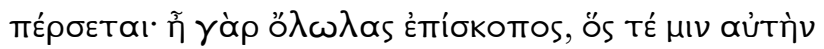

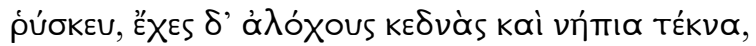

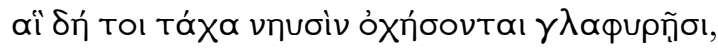

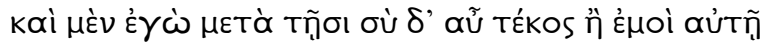

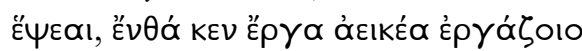

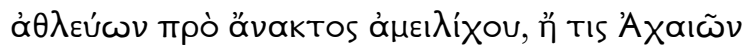

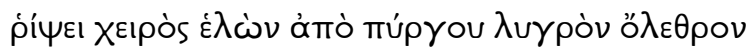

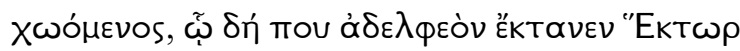

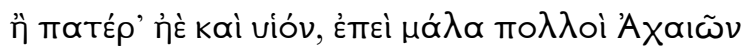

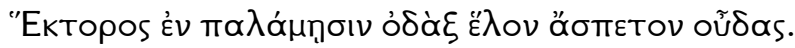

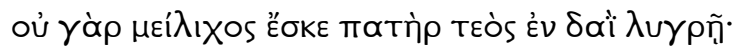

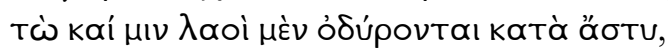

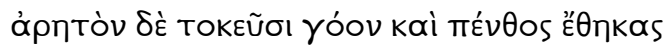

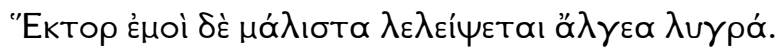

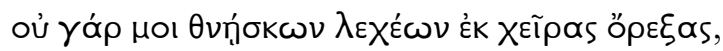

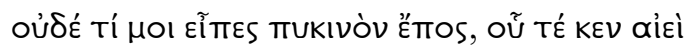

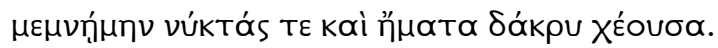


Husband, you were too young to die and leave me widowed in our home. Your son, the boy we luckless parents brought into the world, is but a little baby. And I have no hope that he will grow to manhood: Ilium will come tumbling to the ground before that can ever be. For you, her guardian (episkopos), have perished, you that watched over her, you that kept her cherished wives and little babies safe. They will be carried off soon in the hollow ships, and I with them.

And you, my child, will go with me to labour somewhere at degrading tasks under the eye of a merciless master (anax ameilichos); or some Greek will seize you by the arm and hurl you from the walls to an ugly death, venting his fury on you because Hector perhaps killed a brother of his, maybe, or else a father, or a son. Yes, at Hector's hands many a Greek bit the dust of the broad earth; for your father was no gentle soul in the cruelty of battle.

And that is why everyone in Ilium now laments him. Ah, Hector, you have brought untold tears and misery to your parents. But my grief is cruellest of all because you did not die reaching out from our bed to me with your arms, or utter some memorable word I might have treasured night and day through my tears (Il. 24.724-45; tr. Rieu).

Next is the potnia mètēr, Hecuba:

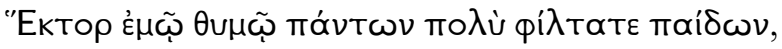

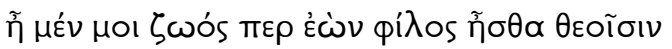

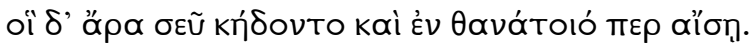

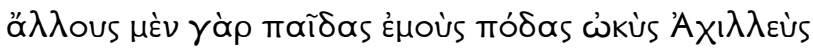

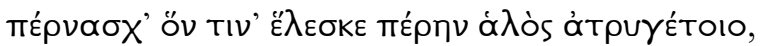

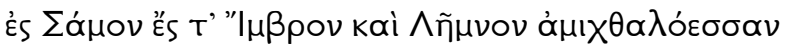
бєŨ $\delta$ '

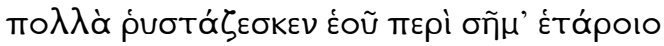

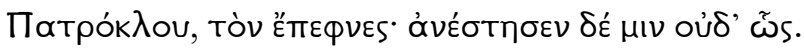

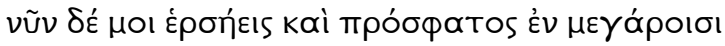

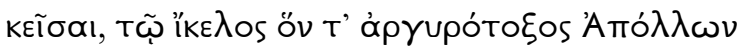

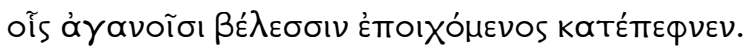

Hector, dearest (philtate) to me of all my sons, you were dear (philos) to the gods too while you were with me in the world; 
and even now you have met your destiny and died, it turns out that they still care for you. Swift-footed Achilles took other sons of mine and sent them over the murmuring seas for sale in Samothrace or in Imbros or in misty Lemnos. And he took your life with his long spear; but though he dragged you many times round the grave-mound of Patroclus, the companion of his you killed, that did not bring Patroclus back to life. But you have come home to me fresh as the dew and lie in the palace (megaron) like one whom Apollon lord of the silver bow has visited and put to death with his gentle shafts (Il. 24·748-59; tr. Rieu).

The final goos is that of Helen:

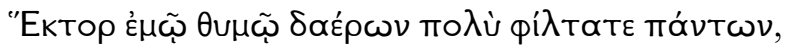

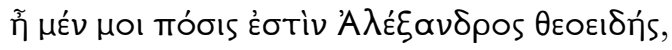

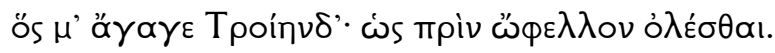

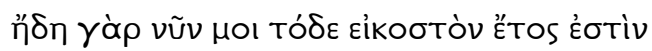

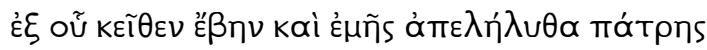

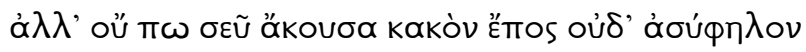

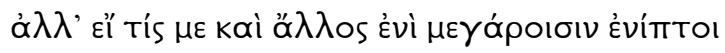

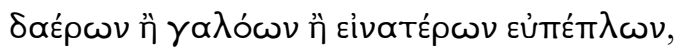

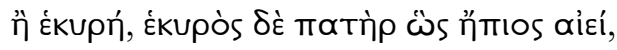

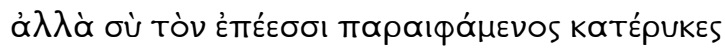

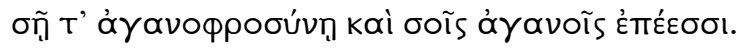

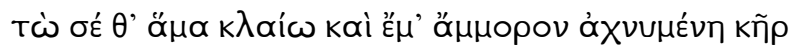

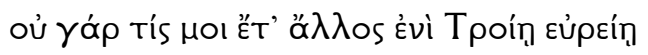

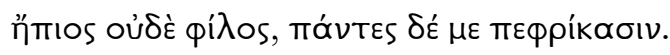

Hector, dearest to me of all my Trojan brothers, godlike Paris brought me here to Troy and married me-I wish I had perished first-but in all the nineteen years since I came away and left the land of my fathers, I never heard a single harsh or spiteful word from you. Others in the Palace insulted me-your brothers, your sisters, your brother's well-robed wives, and your mother, though your father was the soul of kindness. But you calmed them down every time and stopped them out of the gentleness of your heart (aganophrosynē), with your gentle words (agana epea). So these tears of sorrow I shed (klaiō) are both for you and for my luckless self. No one else is left in the wide realm of Troy to treat me kindly (ēpios) and befriend (philos) me. They all shudder at me (Il. 24.762-75; tr. Rieu). 
The three women's laments are accompanied by the groaning and lamentation of the other women assembled around the body (бтєváxovтo Yuvaĩkes, Il. 24.722 and 746), and at the end the lament involves the entire

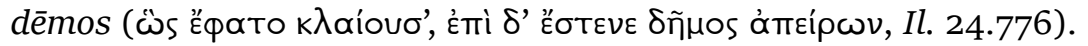

In lamenting the loss of a husband, a son, and a brother-in-law, the three women also bewail their own fate, just as Brisëis had done. For Andromache and her son, this loss means the threat of enslavement, possibly death; for Helen it is the loss of protection from insults. Hecuba weaves her sorrow over the loss of her other dead sons into her lament. But the gooi reveal more than just personal grief. They address three social functions of the deceased: Hector's role as warrior and as the protector of the city, as darling of the gods, and as solver of conflict. His toughness in battle and the worry about resulting acts of vengeance are at the centre of his wife's lament as she grieves that the city has lost its protector, its episkopos (Il. 24.729). In Helen's speech the key point is Hector's gentleness, his aganophrosyne, that is, his ability to make use of gentle words (agana epea) to make peace between people. ${ }^{171}$ This is the gentleness of which Brisëis speaks in her lament for Patroclus (Il. 19.300). Hector's role as philos of the gods is the concern of his mother, whose own status, as we know, is decisive for proximity to the gods. Such proximity to the gods is necessary for the Homeric hero since only those who are 'loved' by the gods are successful in battle and gain lasting fame amongst the living when they are dead and buried. ${ }^{172}$

The laments, therefore, address three qualities of a Homeric leader and basileus. These we have already seen, in part, as a precondition for and measure of time: bravery in battle, the power to resolve conflicts through speech, and the favour of the gods. ${ }^{173}$ Despite the individual esteem expressed in each lament, each one also refers to the community. Military prowess serves to protect both the immediate family and the community or polis; the ability to solve conflict through speech ensures peace within a wide network of relations. Burial guarantees the lasting memory of the dead and ensures lasting bonds among the living. The laments performed by the three women not only announce the deceased's identity for all to see and hear, they also set out the social values of the community to whom the deceased belongs. Although at first it appears as though the laying out and

171. For the term aganos see Scott 1981: 1-15.

172. See ch. 2.4 and 3.1. Thucydides (1.10) argues in a similar way when he stresses the responsibility of the gods for gaining booty.

173. For the meaning of the mediating speech see Cobet 1981: 22-23; Qviller 1981: 119. 
the laments take place in the privacy of Priam's home, it becomes apparent during the course of the laments that the entire demos forms the audience for them. Indeed, later scholiasts assume that the prothesis took place in front of the house rather than inside. ${ }^{174}$

There is no basis for the contrast often drawn in earlier scholarship between the three women's laments, taken solely as expressions of their personal grief, and the thrēnoi performed by hired singers. ${ }^{175}$ Formally, the goos most resembles a well-composed, balanced funeral eulogy, such as the public funeral orations held in honour of fallen soldiers in the fifth century. ${ }^{176}$ The primary focus of the public funeral oration was to praise the excellence of the polis and the warrior as a member of that community, ${ }^{177}$ while the Homeric goos revolves around praising the individual warrior's glory. This need not constitute a contrast, however, since the goos directly addresses the warrior's contributions to the community. He is praised as a member of the city (asty and demos), the community of Trojans whom he protects, and as a husband and member of the wider family which constitutes the domestic community at Troy. ${ }^{178}$ The two groups, the local community (dèmos) and the family, come together to mourn the dead communally-with the women's actions being markedly emphasised in the narrative.

Despite its formal and public character, it is important not to underestimate the emotional impact the lament for the dead has on its audiences. In Troy the women of the city accompany the lament with their groans, and the entire dēmos ends up joining in the lamentation (Il. 24.722; 746; 776). During the lament for Patroclus, his comrades wet their armour and the ground with their tears (Il. 23.15-16). When the Muses sing the

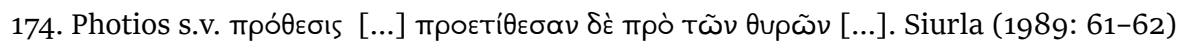
supposes that the prothesis took place indoors (Il. 24.719); Boardman 1955: 5566 and Seaford 1994: 90 argue that the prothesis was carried out in public places.

175. See e.g. Andronikos 1968: 13-14; Vermeule 1979: 15; Siurla 1989: 93-94. The separation between poetic thrēnoi and emotional gooi goes back to Nilsson, who interpreted the goos as relic of primitive lament. Similarly, Reiner 1938: 8-18. In the absence of contemporary evidence such notions may only be speculative. The earliest evidence for elaborate threnoi are those of Simonides in the fifth century. Past scholarship erroneously interprets the fact of payment offered to the singer of the thrēnoi as a pointing to greater professionalisation.

176. See the judgment of Weber 1935: 28. Cf. also Holst-Warhaft 1992: 118; Monsacré 1984: 57-75. Easterling 1991: 149 stresses the 'unexpected authority to what women say and create'.

177. Loraux 1981: 56-75; Wagner-Hasel 20oob.

178. Cf. the description of the household of Priam in Il. 6.243-50. 
lament for Achilles, called a thrēnos here, there is not a man left dry-eyed

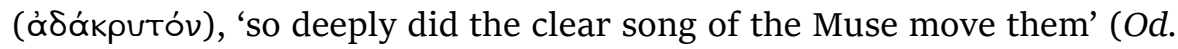
24.62). This emotional effect-the production of tears-must have been an essential purpose of the lament. The shedding of tears (dakryein, or once kamnein) forms a part of the relationship of obligation between the family of the dead and the community of mourners, who receive a place at the feast in return (Il. 24.613). ${ }^{179}$ Communal weeping and communal feasting both strengthen solidarity among the survivors, which is manifested in concrete actions. Revenge, such as Achilles promises and fantasises in his lament for Patroclus (Il. 23.17-24), is the most important of these actions and forms the obligation of male friends and family. Hecuba too is preoccupied with thoughts of vengeance and indeed imagines eating Achilles's innards in order to take revenge for her son (Il. 24.212-14). ${ }^{180}$

Another part of the geras of the dead is the erecting of the grave monument or funeral mound, which is the responsibility of male family members

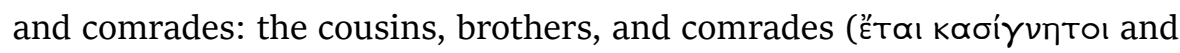
Étaıpol). Hera suggests to the council of the gods that the brothers and comrades of Sarpedon should bury their leader underneath a grave-stone

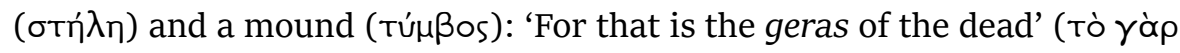

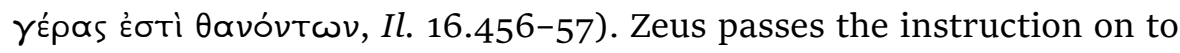

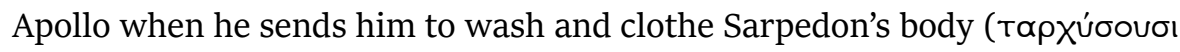

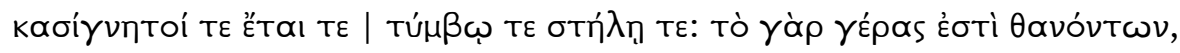
Il. 16.474-75). The brothers and comrades of Hector similarly build a grave mound for him, as do the Achaeans for the dead Achilles. ${ }^{181}$ These men also then come together for the feast in honour of the dead (Il. 24.802).

Another word used for the graves of the heroes is oń $\mu$ a (sēma), a 'sign'. These are not just memorials, $\mu \nu \eta \dot{\mu \alpha}$ (mnēma), like later gravestones, but also spatial signals. ${ }^{182}$ Unlike the lament, which addresses only the deceased's immediate community, the sēma sends its message to strangers

179. Achilles remembers the fate of Niobe, who lost her twelve children but did not forget to eat after the lament for the dead. For further detail see ch. 3.2.

180. In tragedy, swearing revenge is a feature of gooi performed by the chorus. See Holst-Warhaft 1992: 128-33; 147-49. For the obligation to avenge the dead in classical times see Plato, Nomoi 866b; Dem. 43.57; IG I ${ }^{3}$ 104, 20-23.

181. Il. 24.792-80o (Hector); Od. 24.80 (Achilles). Stēlē and tymbos are built by Odysseus for his hetairos Elpenor (Od. 12.14). At Troy, the Dardanids' ancestor Ilos has such a tymbos (Il. 11.371). Cf. 17.434.

182. See the grave of Hector: Il. 24.801. For further evidence see Andronikos 1968: 3234; Grethlein 2008: 30-32 stresses the connection between poetry and tombs. Both functioned as 'commemorative media'. Cf. also Garcia 2013: 131-57. 
and passers-by into future generations. This is apparent from the account given in the Odyssey of the funeral mound erected for Achilles and Patroclus:

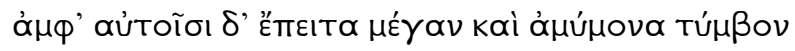

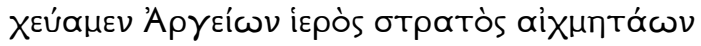

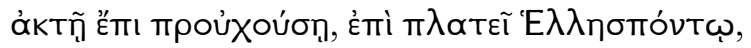

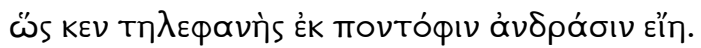

Over their bones we soldiers of the mighty Argive force built up a great and glorious mound (tymbos), on a foreland jutting out over the broad waters of the Hellespont, so that it might be seen far out at sea by the men of today and future ages (Od. 24.80-84; tr. Rieu).

Archaic funerary epitaphs confirm this, although here the word mnēma is more commonly used for the memorial. These inscriptions address a passing stranger, asking for remembrance of the dead. ${ }^{183}$

The grave of Achilles on the Hellespont serves as a signpost for seafarers, while the semma of the Dardanid ancestor Ilus in the Trojan plain serves both as signpost (Il. 11.166 and 371; 24.349) and as a political monument where Hector assembles the council (Il. 10.414-15). ${ }^{184}$ Erected by male relatives and comrades-in-arms, the monument forms a fixed point for their communal activity, and as such it serves to preserve the warrior's kleos. Menelaus erects such a monument in Egypt for his brother Agamemnon so that his fame (kleos) might never be extinguished ( $\chi \varepsilon \widetilde{u}$ 'A $\gamma \propto \mu \varepsilon \varepsilon_{\mu \nu}$ ovı

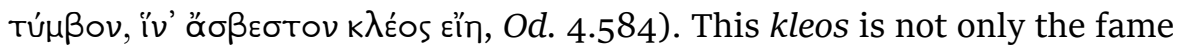
of the deceased but also that of the man who caused his death. In case he is victorious in the duel, Hector promises to deliver his opponent back to his comrades so that they may build him a sēma on the Hellespont; he anticipates that this will be a memorial also to his own glory:

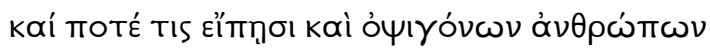

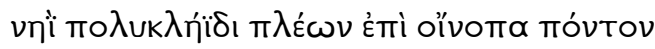

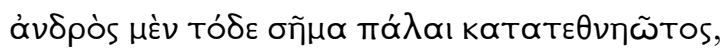

183. For evidence of grave inscriptions see Humphreys 1983: 91-95. See also Garcia 2013: 151: "[...] the $\sigma \tilde{\mu} \mu \alpha$ can only function as a "sign" which conveys meaning as long as it is connected to a living memory or tradition of memory'.

184. See Bérard 1982: 92. 


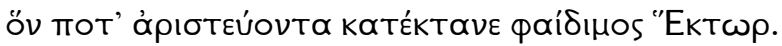

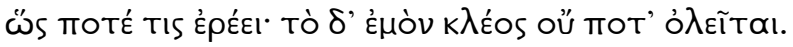

Then one day some future traveller, sailing by in his many-oared ship across the wine-dark sea, will say: 'This is the monument (sēma) of some great warrior of an earlier day who was killed in action by glorious Hector'. That is what he will say, and my fame (kleos) will never die (Il. 7.87-91; tr. Rieu).

Like the sēma, the prizes awarded at funeral games also contribute to the posthumous fame of the fallen warrior. At the funeral of Achilles, the prizes are sponsored by his divine mother, Thetis, as we hear from Agamemnon in Hades: ${ }^{185}$

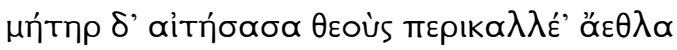

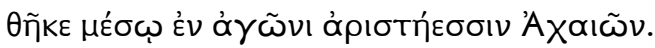

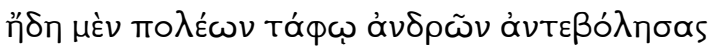

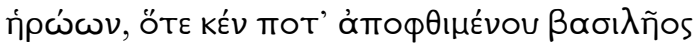

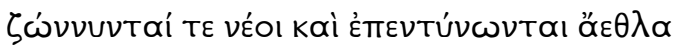

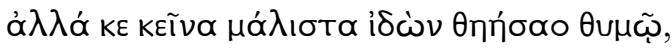

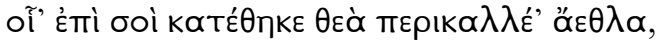

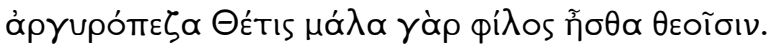

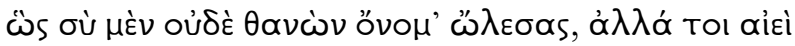

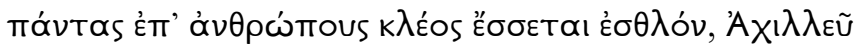

Then, in the middle of the arena where the Achaean champions were to test their skill, your mother placed the magnificent prizes (aethla) she had asked the gods to give. You have attended the funeral of many heroes, when young men strip and make ready for the games in honour of their dead king, but if you had seen the splendid prizes offered in your honour by the divine silver-footed Thetis you would have marvelled at them as the most wonderful you had ever seen. For the gods loved you very dearly. So even death, Achilles, did not destroy your name, and your great glory (kleos) will last forever among all mankind (Od. 24.85-94; tr. Rieu). kleos is created by the games. Morris 1989: 308 . 
Like the kleos proclaimed by the gravestone, the fame connected to the prizes becomes known to a very wide circle: in this case, to all mortals.

At Patroclus's funeral games, we find as prizes all those objects we have already encountered in the context of guest-friendship: tripods, cauldrons, and mixing bowls as well as goblets of silver and gold, armour, and horses and mules. ${ }^{186}$ In addition, there is an ox, an iron disc, and a two-handled urn $^{187}$ as well as captured women. A woman, 'skilled in flawless work', is the first prize in the chariot race and in the wrestling match. Alongside tripods, such skilled women come top in the hierarchy of prizes (Il. 23.263-65; 704-5). Achilles proffers all of them from his own and Patroclus's property. This property in turn consists of guest-gifts, booty, and items inherited from his father. The iron disc was looted from Eëtion, Andromache's father (Il. 23.827), while the horses, which are the second prize in the chariot race, are inherited from his own father Peleus (Il. 23.276-78). A Sidonian silver mixing bowl, the prize for the fastest runner, used to belong to Thoas and ended up in Achilles's possession when it was used as ransom, or ōnos, for Lycaon, a son of Priam (Il. 23.740-47). ${ }^{188}$ The armour looted by Patroclus after his victory over Sarpedon is the first prize in the sword duel (Il. 23.798-804). These gifts, sponsored from the estate of the fallen man and his comrade, serve to confirm and strengthen the bond between the warriors and the hierarchy which underpins it. ${ }^{189}$ The distribution of gifts in the form of prizes, or aethla, at the games is perhaps best described as a process of collective inheritance, as it enables the circulation of gifts to transcend death and carry on into the following generation.

Although textiles also circulate as guest-gifts and are used during the burial ritual, there are none amongst the prizes distributed at the games. Nonetheless, they emanate kleos comparable to that associated with aethla and the sēma. Before the return of Hector's body to Troy, Andromache laments his nakedness and speaks bitterly of the fine and lustrous garments in her house: 'I will burn all of them in a blazing fire, not to benefit you, since you are not laid out in them, but as honour (kleos) before the

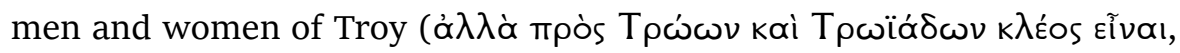

186. Il. 23.263; 702 (tripods); 267-68; 885 (cauldron); 656; 740; 751 (mixing bowls and cups); 809; 851; 885 (weapons); 265; 654 (horses and mules).

187. Il. 23.750 (cattle); 826 (iron); 270 (phialē).

188. For the meaning of onos see the following chapter.

189. Sourvinou-Inwood 1995: 42 also emphasises the notion that the competitive games increase solidarity within the group. See also Siurla 1989: 142 and Ulf 2011. 
Il. 22.513-15). The ancient scholiasts regard it as typically female that Andromache believes the clothes could be of use if Hector lay in them. ${ }^{190}$ Modern authors are less sceptical and assume that the garments were intended to provide clothing for the dead in Hades and/or to represent his wealth and status. ${ }^{191}$ Textiles have symbolic as well as practical functions-this is true of the burial ritual as much as it is true of the rituals of guest-friendship. During burial they serve to conduct the deceased to a new stage, and they thus function as the bearers of a new-immortal-identity.

After washing and embalming, the corpse is wrapped in sheets. After his comrades have covered him with a fine linen robe (heanos), Patroclus's body is covered in a sheet, described as a gleaming (leukos) pharos, such as those handed to guests on other occasions. After cremation the bones are placed in a golden bowl (phialē) and once again wrapped in a linen heanos (Il. 18.346-53; 23.254). ${ }^{192}$ In Hector's case, a pharos is placed over the body once the serving women of Achilles have washed him and dressed him in a chitōn (Il. 24.587-88). ${ }^{193}$ After the lament and the cremation of the body male relatives collect the bones and store them in a golden casket (larnax)

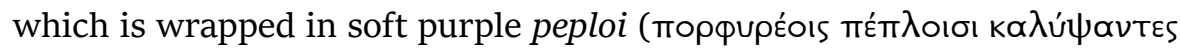
$\mu \alpha \lambda \alpha$ ко о̃ $v$ ) and then placed into a grave over which the comrades erect a gravestone (Il. 24.796). In the case of Achilles, the Nereids dress him in 'im-

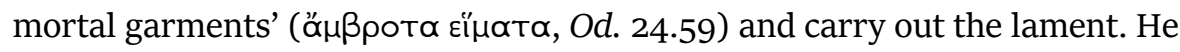

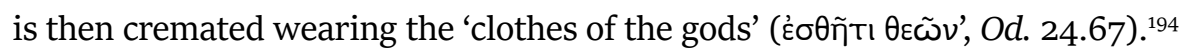

190. See the bt-Scholia: Il. 22.513. Cf. de Jong 1991: 19. For a different argument see Papadopoulou-Belmehdi 1994: 119, where Andromache's declaration refers to the breaking of the bond between the couple, and the uselessness of the clothing laments the fact that Hector and Andromache will not be reunited.

191. See Helbig 1901: 237-53; Marwitz 1961: 8; Andronikos 1968: 27; Griffin 1984: 3 . See now Mueller 2010: 13 who stresses the function of the cloth to contribute to the making of Hector's kleos.

192. Helbig (1901: 218) suspected that the heanoi were used for the purposes of mummification, although there is no evidence for such forms of post-mortem conservation in Greece (Andronikos 1968: 3-7). There are some suggestions, however, that measures were taken to preserve bodies for the duration of the prothesis. For instance, the ambrosian oil used on Hector's corpse is presumed to have been a mixture of oil and myrrh that is used for embalming in other cultures (Berg, Rolle and Seemann 1981: 100). Similarly, 'nectar', which was probably honey, has antibacterial and dehydrating effects. Honey was also used as a preservative when dyeing textiles, so that the symbolic use of nectar may also allude to clothing. Cf. Kardara 1961: 265.

193. Priam had kept back two such pharea and a chitōn when he set out to ransom Hector's body with textiles and other valuables. Il. 24.228-35; 580 .

194. Odysseus's companion Elpenor wants to be cremated wearing his armour. Od. 11.74 . 
The washing, embalming, and clothing of the dead is equivalent to the treatment of guests as a ritual of integration during which a new identity is formed. In the rituals of guest-friendship, a stranger (xeinos) is transformed into an insider (philos), while the rituals for the dead effect their transition into immortality, and thus the transformation of a lifespan into eternity. ${ }^{195}$ Shrouds and winding sheets, carriers of that lifespan, accompany the deceased on the journey and are burnt along with them. ${ }^{196}$ Cremation accelerates the process of transformation. It was common in parts of Greece from late Mycenaean times and practised in Attica during the seventh century $\mathrm{BCE}$, and it is not considered an act of destruction but of preservation. ${ }^{197}$ During cremation the body is liberated from its perishable parts (Richard Onians calls this 'drying'), ${ }^{198}$ and the remaining bones have an improved consistency. ${ }^{199}$ In Homer, the psyche, that intangible part of life often translated as 'soul', can leave the perishable body only once the process of cremation is completed. Such psychai then wander

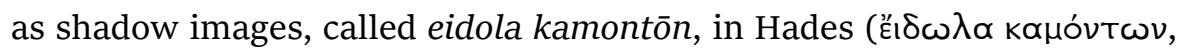
Il. 23.72-74; Od. 24.14). ${ }^{200}$ In seventh-century clay tablets, these images, which in Homer are able to fly, are depicted as birds or Sphinges. ${ }^{201}$ Such

195. See Humphreys 1981: 269: '[...] allowing the bones of the dead to become separated from the flesh which once encased them is only one of a number of ways representing the separation of a part of the person which is capable of achieving immortality from the parts which are subject to destruction by time'. See Sourvinou-Inwood (1981: 38), who interprets the ritual as change of status expressed by cloth.

196. The burning of cloth at death is known until Hellenistic and even Roman times. Cf. e.g. Xen. Eph. 3.7.4; Suet. Iul. 84.

197. Cremation is common in Attica between 1100 and 900, and again from 700. Homeric funerals appear to resemble most closely the practices seen in Cyprus during the middle of the eighth century BCE. Finds from Lefkandi from the eleventh and tenth centuries BCE also correspond closely to Homeric descriptions. Cf. Andronikos 1968: 21-32; 51-69; Coldstream 1977: 34; Blome 1984: 18-19; Hägg 1987: 207-11; Morris 1987: 32-35.

198. Onians [1951] 1989: 254-70.

199. Burnt bones are more resistant than unburnt skeletons. Cf. Hägg 1987: 208-9.

200. On the eidolon see Bremmer 1987: 73; Sourvinou-Inwood 1995: 89-92. On images of Hades, compare Garland 1985: 48-76.

201. Vermeule 1979: 7-11, 23-24; Peifer 1987: 15-16; Niemeyer 1996: 72. For Homeric evidence see Od. 11.218-22 (tr. Rieu): the mother of Odysseus knows: 'It is the law of our mortal nature, when we come to die. We no longer have sinews keeping the bones and flesh together; once life has departed from our white bones, all is consumed by the fierce heat of the blazing fire, and the soul (psychē) slips away like a dream and goes fluttering on its way'. In the Iliad (23.71; 76, tr. Rieu) Patroclus asks Achilles: 'Bury me as quickly as possible and let me pass the gates of Hades. [...] for once you have passed me through the flames, I shall never come back again from Hades'. 


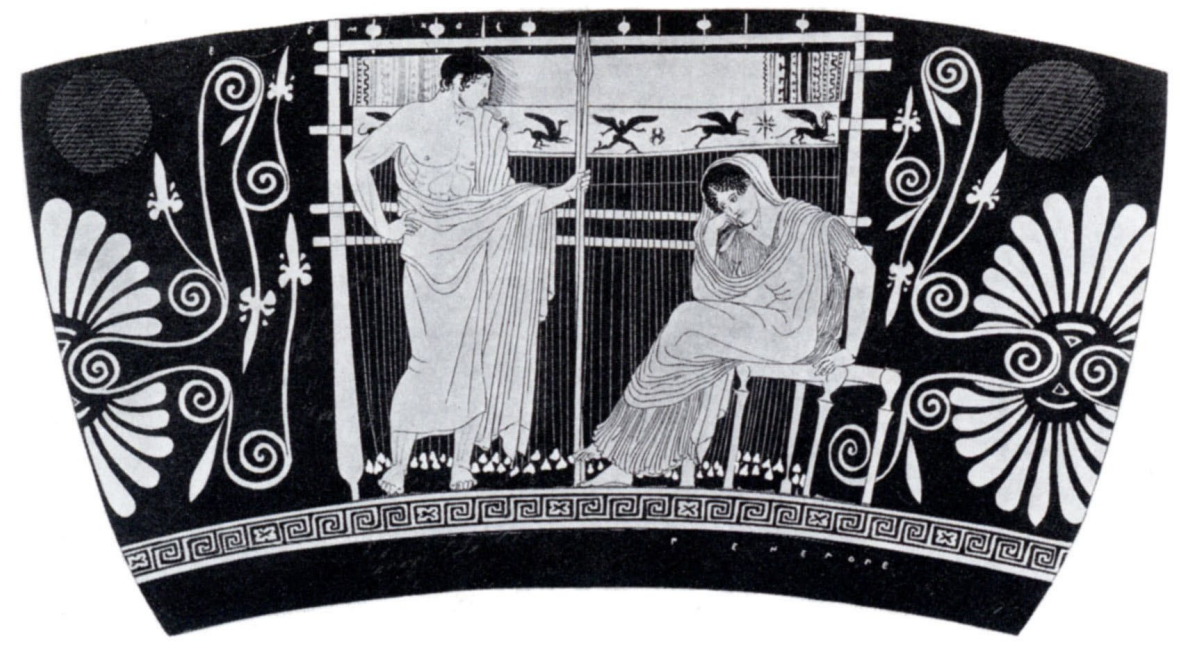

Figure 7: The mourning Penelope. Red-figure skyphos of the Penelope painter, ca 440 BCE. Chiusi, Museo Nazionale Archaeologico Inv. 1831. After Boardman 1989: Fig. 247 (= J. D. Beazley, Attic Red-figure Vase-paintings 1963: 1300, 2 = A. Furtwängler and K. Reichhold, Griechische Vasenmalerei, 1904-32).

Sphinges, assumed to be Eastern borrowings, ${ }^{202}$ decorate Penelope's shroud on an early fifth-century vase painting (Figure 4 and 7). ${ }^{203}$ These winged eidola can also be weighed (Figure 8)-just like the fate of heroes, which we have seen can be measured according to the wool required to make one shroud. ${ }^{204}$ Just as clothing established the appearance (eidos) of the living, so these shrouds seem to lend the shades of the dead their own postmortal appearance. Indeed, the widely used ancient metaphor of the 'garment of the soul' appears to confirm this function of the shroud. ${ }^{205}$

Leucothea's 'immortal veil' conducts Odysseus, clothed in Calypso's 'fragrant garments', along a reversal of this journey-from the threat of death

202. See Vermeule 1979: 17-19, 56, 69, 212, who stresses Egyptian influence, and Neumer-Pfau 1987: 19-20.

203. Boardman 1989, fig. 247.

204. Vermeule 1979: 161, fig. 14 and 15. According to Peifer (1987: 33-43), who interprets the eidola as lots of death (Todeslose) and identifies the Keres with the psychai, the motive of the kerostasia starts in the last quarter of the sixth century $\mathrm{BCE}$ in black-figure vase painting.

205. For evidence see Kehl 1978: 945-1025, who interprets the phrase as just a manner of speaking, without any deeper meaning (1023). 


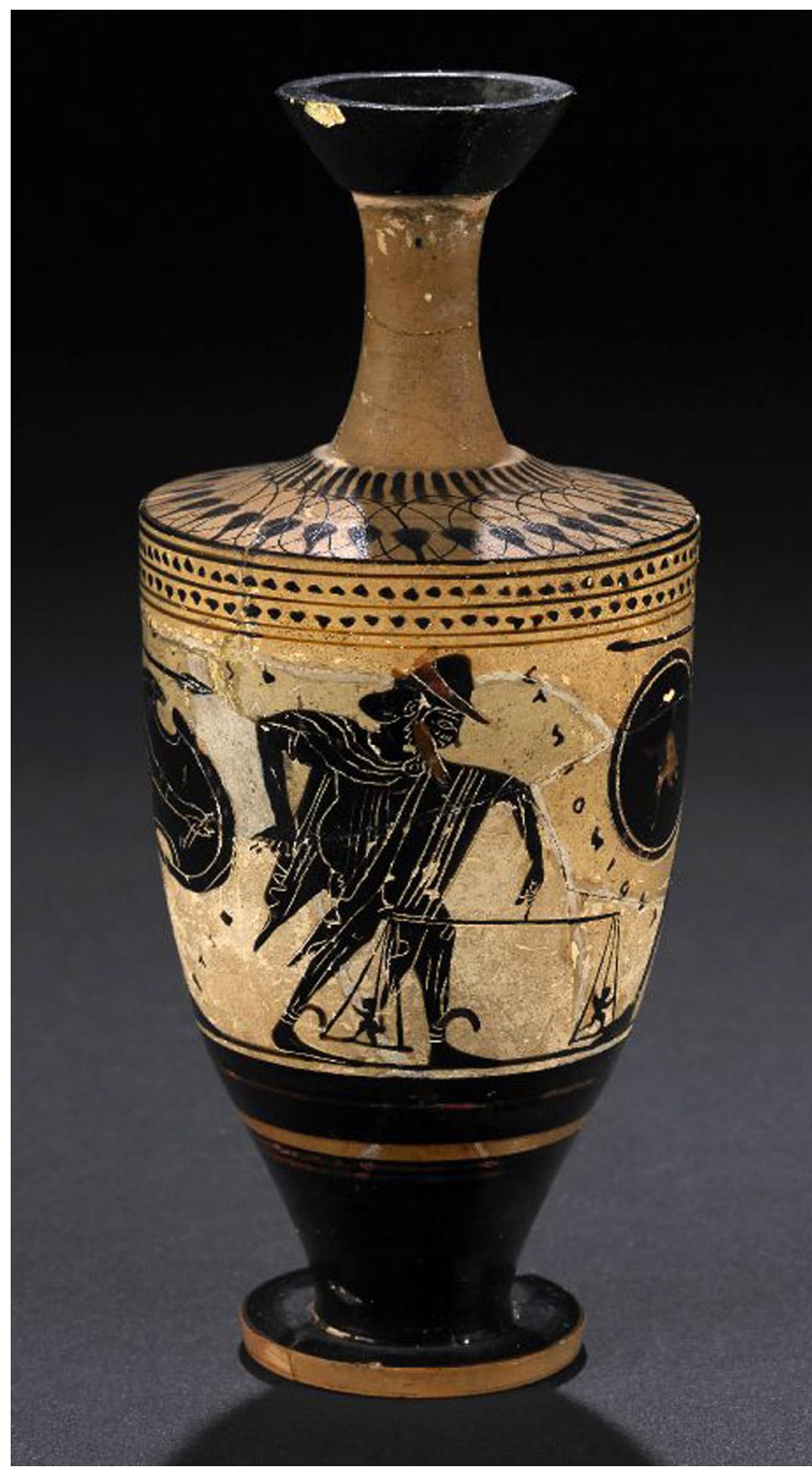

Figure 8: Hermes

weighing eidola. Attic black-figure lekythos, 5 th century BCE. London, British Museum B 639. https://research. britishmuseum.org/ research/collection online/collection object details/ collection image gallery.aspx?partid $=1$ \&assetid $=1305668001$ \&objectid $=459047$

by drowning back to life (Od. 5.367).$^{206}$ The veil does not dress Odysseus; it merely conducts him safely to shore, where he receives his new garments from Nausicaa and Arete. While the welcoming and dressing of the

206. I do not agree with Mueller 2010: 6 who (mis)understands the veil as a gift of hospitality: 'Ino's gift extends hospitality to Odysseus for as long as he remains in her dominion'. 
stranger is part of Arete's time, the time of safe conduct across the threshold of death belongs to Ino Leucothea. Leucothea had received a portion of the time of the gods when she herself died by drowning (vũv $\delta^{\prime}$ a $\lambda \lambda$ òs $\varepsilon^{\prime} v$

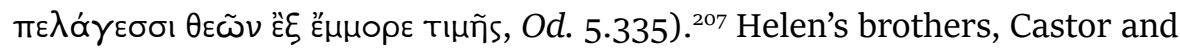
Polydeuces, have the time of conducting the journey both ways, since they receive time from Zeus even beneath the earth, that is, after death (oi kai

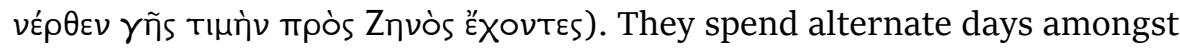
the living and the dead. Their ability to complete the transition between life and death in both directions means that their time is equal to that of

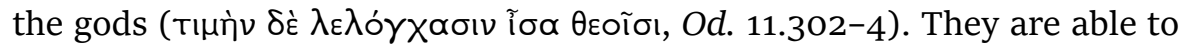
walk along the path of the gods and partake in the transformation of a human lifespan into immortality.

Immortality should not be understood as a state of being but as a lasting act of visualization and memorialisation of the dead by the living, which in turn ensures the order of the living. That is why it requires memorials and why the kleos of the dead is attached to objects such as the prizes at the funeral games, the grave-markers, and textiles. ${ }^{208}$ Just as the communal activity at the funeral games and the erection of a grave-stone renew the bond among the warrior community, so the work on the clothing for the dead strengthens bonds within the domestic community and amongst the women who collaborate within it. The production of these clothes requires lasting cooperation and the expense of time and energy over years, while by contrast the erection of the tomb-stone and the transformation of the deceased's goods into aethla requires only temporary cooperation amongst the men. Despite this, a moment of permanence attaches itself to the materiality of both the metal aethla and the stone semma, while the textile memorials, which are burnt with the body, require periodic renewal. It would be interesting to determine whether the annual offering of garments in memory of the battle of Plataea, recorded by Thucydides, was an example of a more widely spread practice connected with perpetuating the kleos of the dead through textile memorials. ${ }^{209}$ Homeric epic does not inform us about this.

207. Indonesian textiles from southern Sumatra decorated with a pattern of ships have functions similar to those attributed to shrouds in the epics. See Kahn Majlis 1984: 47-53.

208. Cf. Murray 1991: 27-30.

209. Thuc. 3.58. It is possible this is a reference to the classical practice of winding patterned ribbons around grave stēlai. Cf. Mitchell and Havelock 1981: 103-18, fig. 93; 96. 
The geras for the dead reflects the social structures of Homeric epic. Both military and household communities need to work together in order to provide the geras that is due to the dead. We can see images of both types of cooperative labour on the large funerary amphorae and kraters used as grave-markers in Attica and other parts of Greece during the eighth and seventh centuries. The bottom half of the vases shows warriors with chariots and horses, while the top part depicts the prothesis and lament for the dead. At the centre of the prothesis image we can see the shroud raised for all to see and distinguished by its pattern (Figure 5). ${ }^{210}$ Scholarship has long suspected that geometric vases imitate textile patterns, and Elizabeth $\mathrm{W}$. Barber has now produced plausible arguments for this theory. ${ }^{211}$ If it is true, then it is also the case that the shrouds, like the laments of female relatives, depict communities working together and therefore thematise not individual glory but social cohesion. ${ }^{212}$ This need not contradict the fact that clothing for the dead is also a way to demonstrate status, as we have seen in Penelope's intention to ensure that Laërtes, who possessed so much in life, should not lie naked in death. The following chapter will show the degree to which the status of basileees was based on access to foreign resources. Indeed, the use of purple dye for the garments of the dead, as in Hector's case, suggests access to precious goods.

In current scholarship Homeric burial practices have come to be seen in the context of hero-cults developed during the course of the eighth and seventh centuries around Mycenaean grave sites. ${ }^{213}$ The heroes' tombs, and the temple structures that develop alongside them, are taken as signs of the demarcation of territories that accompanies the emerging process of polis-formation. ${ }^{214}$ Scholars posit that the hero-cult served to create local

210. Kurtz and Boardman 1971, fig. 4 and 5; Andronikos 1968, fig. 2; Marwitz 1961: 7-18; Huber 2001: 61-86.

211. Barber 1991: 365-72. See now Harlizius-Klück 2019. For further discussion see ch. 3.2 .

212. Whitley (1991: 45-53) reads such geometric vase painting as social code. Despite referring to a striking anthropological parallel, the geometric patterning of clothing in Nuristan which is controlled by the older women in family groups, he does not connect geometric vase painting to the art of weaving. See now HarliziusKlück 2019.

213. This is the case in Mycenae (Peloponnese), in Menidi (Attica), in Prosymna near the Argive Heraion, in Eretria (Euboea) and in Messenia. For evidence see Coldstream 1977: 341-57; Patzek 1992: 162-85; Whitley 1988: 173-82.

214. See esp. Snodgrass 1982: 107-17, who stresses a change from pastoral to farming economy, which went ahead with the internal colonisation of Attica. Cf. de Polignac 1984: 47-48, whose research underlines the symbolic meaning of the spatial order of this process. For more detail see ch. $5 \cdot 4$. 
group identities and to consolidate power. ${ }^{215}$ Such power can be thought of as being concentrated in the hands of aristocratic families and local elites who used the hero-cult as ideological justification for their own influence. ${ }^{216}$ On the other hand, the power associated with hero-cults is identified with the emergence of the polis as a new type of community. ${ }^{217}$

My observations on Homeric death rituals confirm and modify these categories. The supraregional orientation of the permanent memorials, prizes, and tomb-markers points towards peaceful communication and military cooperation that transcend regional and local boundaries rather than towards the protection of territories. In Homeric epic, the tombs of heroes do not mark boundaries but signpost places and pathways of communication. This corresponds to the practice of the eighth to the sixth centuries in so far as they can be discerned from the position of excavated tombs such as the Heroon at Eretria, or Attic hero tombs situated by the city gates, as well as from the grave epitaphs mentioned earlier. ${ }^{218}$ This supraregional orientation supports the process of polis-formation, but it does not express it. A reference to the polis in the sense of a community that reaches beyond the household is found more clearly in the women's rituals, the lament, and the presentation of the shroud, which address a local community, a dēmos, as a whole. ${ }^{219}$ There is no evidence for the idea of a claim to power made by individual groups of descendants, such as Ulf connects to Homeric cults of the dead. ${ }^{220}$ It is true that it is female relatives

215. Cf. Antonaccio 1994: 103. According to her, hero-cult symbolises the authority of the polis and a collective identity. See also Bérard 1982; Snodgrass 1982.

216. This is assumed for Attica. See Snodgrass 1980: 23; Morris 1977: 133-37.

217. According to Whitley (1988: 181) this was the case in the Argolid. A conflict between 'Dark Age aristocratic structures and the emergence of the polis' is expressed by the cult of the hero (Morris 1988: 768).

218. Patzek 1992: 168; Whitley 1991: 41-45; Hölscher 1998: 70-72 suspects they may serve to protect the polis. See ch. 5.4 .

219. There is a debate over the existence of the polis as a political community in the epics. Cf. e.g. Scully 1990 [1994]: 6 and Seaford 1994: 1-10, neither of whom considers the Homeric polis as a political community. Raaflaub 1991: 246, on the other hand, is correct to draw attention to the political roles played by the council and assembly. In my view the decisive differences between the Homeric polis and the polis of archaic and classical times are: the subordination of the domestic or household community to a larger civic community, and-from the point of view of the geography of settlements-the spatial integration of different communities. See Wagner-Hasel 2017: 52-60, 100-1.

220. Ulf 1990: 245-50. Compare Humphreys 1983 for a critique of the interpretation of grave cults as ancestor cults. See now Humphreys 2018. Cf. also ch. 2, n. 89. 
who cooperate in the lament for the dead, and that the textile offerings at the funeral display the wealth of a household. But the lamented deceased is never in Homeric epic the head of a greater family. Here, the lamented is an idealised young warrior who earns his kleos through dying for the community and who embodies the central values of Homeric society. The contrast between community and household we see in the fifth century after the Persian wars is not present in Homeric epic. 


\section{CHAPTER 5}

\section{The Benefits of Travel and Supraregional Exchange in the Archaic Age}

$\mathrm{M}$ any of the objects and persons circulating as gifts in the epics are not locally sourced but stem from abroad. This is true of the enslaved women offered as prizes at the games and as gera to leaders in war as much as it is for raw materials which these women, working at the spindle and the loom, make into gifts for guests, for the dead, and for the gods. Dyes, especially purple, as well as flax, which is required for the production of linen fabrics, are available only in particular regions, as we can see in a late fifth-century description of Egypt that tells us of a place 'where flax is plentiful, the land is flat and lacking in timber' (Ps. Xen. Ath. Pol. 2.12). The production of metal objects also requires the addition of 'imported' components such as tin to be added to copper. Nor is the cultivation of grain and vines equally possible everywhere, and the drought-prone regions of Eastern Greece lack sufficient pasture for livestock farming.

Homeric epic contains numerous indications of supraregional exchange of resources, especially in the Odyssey, which can be viewed, by contrast with the Iliad, as a poem marked by the ethics of trade rather than battle. ${ }^{1}$ The question of who carried out such trade, whether it was handled by aristocrats themselves or, out of necessity, by lower and poorer strata of the population, is up for debate. In a series of studies on trade in archaic times from the 1970 and 1980s, Benedetto Bravo assumed two types of trader: the aristocrat, trading through an agent and aiming to purchase grain with a view to creating bonds with clients, and the nonaristocrat, driven by poverty and exemplified, for instance, by the father of the poet Hesiod. An example of an aristocratic trader is seen by Bravo in Euneos

1. See e.g. von Reden 1995: 58-76. She argues that kleos is associated with property in the Odyssey and with honour in the Iliad. 
of Samos, who provides wine for Agamemnon to give to his army. ${ }^{2}$ Paul Cartledge has objected that Bravo's model is altogether too modernist and excludes political aspects of archaic trade while also taking a 'too minute and not always relevant philological approach', and neglecting archaeological evidence. ${ }^{3}$ Like Anthony Snodgrass, Cartledge recognises evidence of transport by sea for the archaic period but not for extensive trading by sea. Both deny the need for a typology of traders, and, in so far as they accept the existence of trade, they define it as import rather than export trade. ${ }^{4}$

Against this antimodernizing view in the tradition of Karl Bücher, Johannes Hasebroek, and Karl Polanyi, ${ }^{5}$ Robin Osborne took the view in the 1990 s that archaic Greece did have a complex exchange network comparable to a modern system of interdependent markets. ${ }^{6}$ By contrast, Lin Foxhall does not see any tangible evidence in the archaeological sources for the existence of supraregional markets allowing for profitable trade. She considers trade not as a matter of supply and demand but takes instead as her starting point the notion of desire, asking why goods that were in fact available locally, such as grain, wine, or clothing, were imported at all. Foxhall argues that these are 'semi-luxuries' which were often consumed especially in ritual contexts and contributed to the development of a set of values that transcended regional boundaries. ${ }^{7}$

Building on these reflections, I want to place less emphasis on the issue of status but consider more closely the traded goods themselves and their uses and ask further questions regarding the character and the necessities of exchange. The terms at the centre of my analysis are $\pi \rho \tilde{n} \xi 15$ (prēxis),

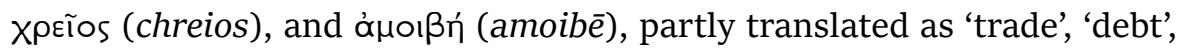

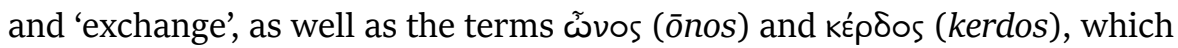
are sometimes rendered as 'price' and 'profit'. Most of these terms, or their derivatives, appear in the famous diatribe in Odyssey 8, launched by the Phaeacian Euryalus because he suspects Odysseus of foul play:

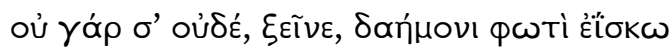

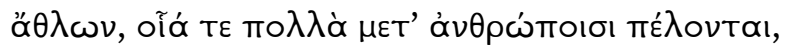

2. Bravo 1983: 17; 1977: 3-4. Cf. also Kopcke 1990: 123-24; Mele 1979; Reed 1984: 31-44.

3. Cartledge 1983: 8 and 12.

4. Cartledge 1983: 12; Snodgrass 1983: 16-28 and 182f.

5. Cf. Wagner-Hasel 2011: 315-40; Morley 2007: 2-16.

6. Osborne 1996: 31-44.

7. Foxhall 1998: 295-309. Cf. also Morley 2007: 36-39. 


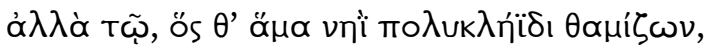

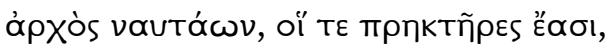

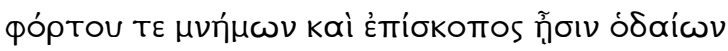

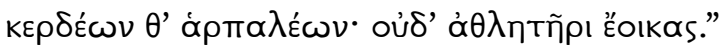

You are quite right, sir (xeinos). I should never have taken you for an athlete, good at any of the games men play. You are more like a skipper of a merchant crew (archos nautaōn [...] prēktēres), who spends his life on a hulking tramp, worrying about his outward freight (phortos), or keeping a sharp eye on the cargo when he comes home with his extortionate profits (kerdos hodaiōn). No: one can see you are no athlete (Od. 8.159-64; tr. Rieu).

We find in this passage almost all those terms that have been taken as evidence for the existence of trade in the poem: прпктñ (prēktēr), the

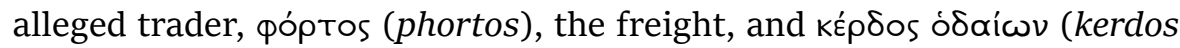
hodaiōn), home-bound cargo or profit. ${ }^{8}$ None of these terms, however, are exclusively applied to trade. To anticipate one result of my examination: kerdos is a general term for advantage, found in a number of contexts, but predominantly connected to journeys, both metaphorical and literal.

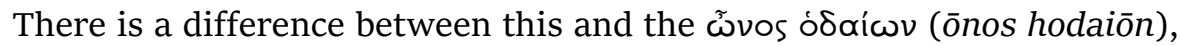
which can be understood as the proceeds or profit made on a journey, and with one exception represents the value of a captured person, such as a shepherd or a skilled weaver. In this, onos resembles the apoina, the goods handed over as ransom by families in return for a captured relative. In the case of onos, the ransom is paid by strangers in order to purchase the right to the captured person's slave-labour. Such traffic in humans, goods, or animals is contrasted in the epic to prēxis, which is practised with a view to personal or communal requirements such as the reclaiming of a debt, a chreios. This may at times demand the undertaking of a journey by

8. For the terminology of trade see Bravo 1984: 129-36 (prēktēr, phorton agein, phortizesthai, hode/hodaia, empolē/empolon/emporo/emporiē). He assumes that prēktēres were kakoi, working for the aristocrats (ibid. 138), whereas Reed (1984: 34) sees them as 'independent maritime traders' called emporoi (Semonides), phortēgoi (Theognis), or nauklēroi (epigraphic evidence of the fifth century BCE) and who had become increasingly specialised since the seventh century. For a different view see Humphreys 1978: 167. According to her a class of traders cannot be identified terminologically or socially in the archaic period. See also Reed 2003: 70-71 who argues that the transformation of the Greek aristocracy 'from a warrior elite to one preoccupied with international games [...] was hardly compatible with regular maritime trading' 
sea, which is the business of a prēktēr. ${ }^{9}$ A prēktēr may also be one who accomplishes military deeds. ${ }^{10}$ There is a difference between the two types of prēktēr-but it is not one of status. Furthermore, the contrast in Euryalus's speech is not one between traders and fighters as most translations suggest; what matters is the contrast between intended plunder and peaceful undertakings, such as athletes travelling to contests. This must be what Euryalus has in mind when he claims that Odysseus does not look like an athlete. Despite the insult, Odysseus does in fact distinguish himself as an athlete, excelling at the discus and in wrestling (Od. 8.186-94) ${ }^{11}$

The combination of mobility and plunder is distinctive of the character of exchange as represented in epic and elsewhere. This chapter therefore begins with an examination of the terms prēxis, chreios, and amoibe in the context of the pastoral economy. The exchange of grazing lands plays a key role in the supraregional exchange of resources, and yet its political and economic significance has hitherto received little attention. When it comes to the creation of networks across regional boundaries, such as we observe in the context of gift-exchange, grazing land is probably of much greater significance than the frequently overestimated sea-trade. Following on from this discussion we will consider the terms onnos and kerdos as two forms of yields connected to mobility of herdsmen and pirates. In connection to the pastoral economy, kerdos represents the yield gained by the owners of herds and flocks and their shepherds and herdsmen working under supervision. Indeed, as will become clear, it is mainly the lone shepherds or herdsmen who are at risk of being kidnapped and exchanged for onos. The final part of this chapter is concerned with the exchange of resources beyond Greece and especially where it relates to livelihood, Bíotos

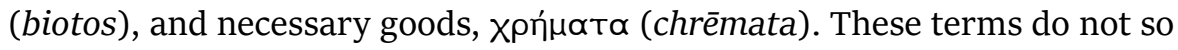
much refer to the supply of grain needed by basilees to feed their people, as to goods required for the production of signs of status and memorials: alum, the secretion of the murex snail for dying textiles, linen fabrics, and metals. These are goods that feature in ritual contexts and they provide evidence for the emergence of a set of values which transcends regional

9. See Descat 1986: 282-85.

10. Phoenix teaches Achilles to be a prēktēr in war and in rhetoric. Il. 9.443. The goaldirectedness of prēxis is understood in a remark made by Achilles to Priam: oú

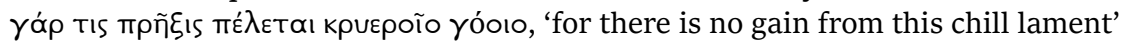
(Il. 24.524).

11. The Phaeacians themselves are praised as good dancers, singers, and players of the kithara; in addition, they were excellent runners and oarsmen (Od. 8.246-48). 
boundaries. ${ }^{12}$ The implementation of this form of exchange confirms the necessity of ritual communication, to which we will turn in the final chapter. We will draw on post-Homeric sources more frequently for this part of the discussion than in the previous chapters.

\subsection{Paying debts of cattle and exchanging pasture lands: Prēxis, chreios, and amoibē}

During Odysseus's stay in Phaeacia, his son Telemachus goes in search of his missing father. Before his departure he asks the Ithacan assembly for

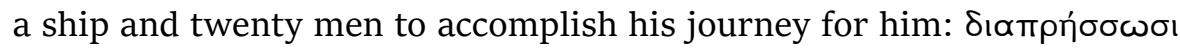

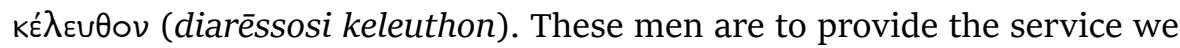
saw provided by the prēktēres in our initial passage: they are to do the rowing (Od. 2.213). In return Telemachus is obliged to supply food and wine, which he asks to be brought from the thalamos where they are stored (Od. 2.290; 349-55). Upon Telemachus's arrival at Pylos, Nestor asks the young man the same question posed by Polyphemus to Odysseus:

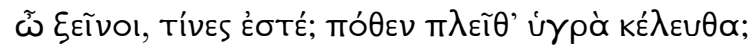

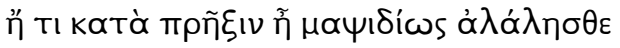

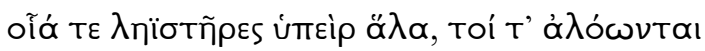

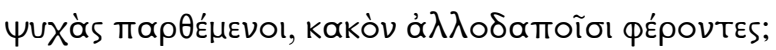

Who are you, friends (xeinoi)? From what port have you sailed over the highways of the sea? Is yours a trading adventure (kata prēxin); or are you sailing the seas recklessly, like roving pirates, who risk their lives to ruin other people? (Od. 3.71-74=Od. 9.252-55 = Hom. Hymn Ap. 452-55, tr. Rieu).

The translation of prēxis as 'trading adventure' does not adequately capture the full meaning. It seems that chreios (perhaps an unresolved debt or an emergency) can often be substituted. Both terms describe matters undertaken in one's own interest or that of the community. For example, in his answer to Nestor's question Telemachus differentiates between his own prēxis and a communal one: 'It is my own prēxis I speak of, not that

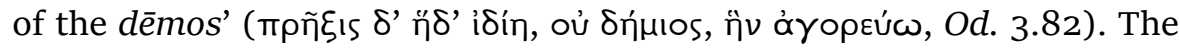
same distinction is also drawn by Menelaus when he, like Nestor, enquires

12. See Foxhall 1998: 306. 
after the purpose of Telemachus's journey, albeit using the word chreios rather than prēxis:

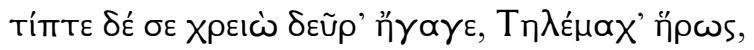

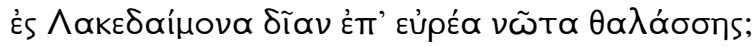

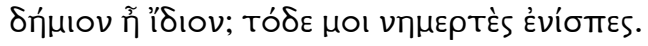

Telemachus, what kind of chreios brought you here over the wide seas to our pleasant land of Lacedaemon? Was it public business (dēmion) or private affairs (idion)? Tell me the truth (Od. 4.312-14; tr. Rieu with modification).

Telemachus, too, uses the word chreios when he calls an assembly at Ithaca to discuss an emergency of his own:

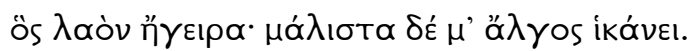

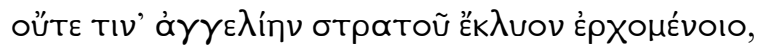

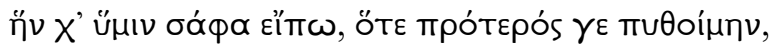

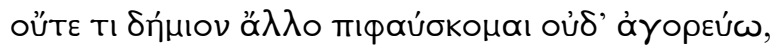

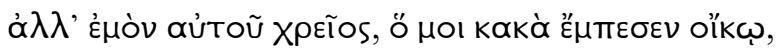

The man who summoned this gathering is not far to seek. It was I-I am in great distress. Of an army's approach I have heard nothing to tell you. Nor is it some other question of public concern (demmion) that I propose to bring forward, but my own business (emon autou chreios), the affliction, the double affliction, that has fallen on my house (oikos) (Od. 2.41-46, tr. Rieu).

As in the chreios Menelaus enquires after, this chreios concerns his search for his missing father, but above all it refers to the damage done to Telemachus's estate by the suitors' consumption of his cattle (Od. 2.51; 4.316-31). Prēxis is, then, a more general term that expresses an action with a specific goal, ${ }^{13}$ while chreios is more concrete and can often be understood as a loss of livestock ('Viehschuld'), as in Telemachus's situation. After dinner at Pylos, Telemachus's friend Mentor takes off to visit the

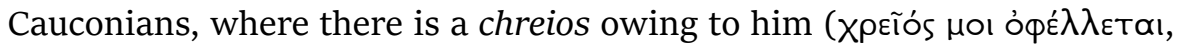

13. Descat 1986: $282-85$ sees prēxis as a deed achieved rather than a vain effort. Bravo 1984: 105 similarly understands prēxis as involving more than just trade, while Mele 1979: 58-6o takes prēxis as the term for aristocratic trade. 
Od. 3.367). We can assume this kind of chreios to be a debt of cattle, on account of the literal meaning of the verb ophellein as 'grow' or 'increase.. ${ }^{14}$

The use of the same turn of phrase refers to a conflict over cattle in two other instances. One is the dispute between the Ithacans and Messenians, the other between the inhabitants of Pylos and those of Elis. A digression in Odyssey 21 gives an account of the provenance of Odysseus's famous bow. It was a gift from Iphitos, a guest-friend whom Odysseus met at Messene

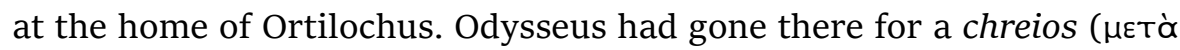

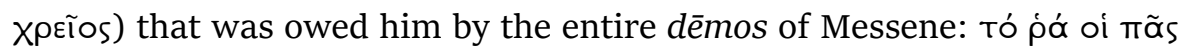

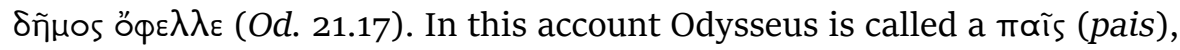
a word which can mean a child but also a shepherd boy or shepherd, and it is this sense that is evidently the case here (Od. 21.21). The context tells us once again that the debt in question is flocks, namely three hundred sheep that had been taken from Ithaca, along with their shepherds, by men from Messene travelling on ships (Od. 21.18-19). Iphitos had come to Messene on similar business, following the loss of some mules and horses. He meets his death on this expedition, being slain by his xeinos Heracles who intends to keep the livestock for himself, regardless of the convention of hospitality symbolised by the loaded table the hero offered his guest-

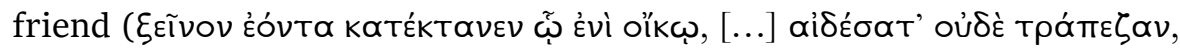

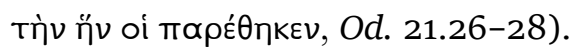

A similar debt of livestock is referred to as chreios in the conflict between Pylos and Elis recounted by Nestor in Iliad 11. According to Nestor, the military conflict between the two peoples breaks out over a row about some stolen cattle-although it is unclear who were the perpetrators and who were the victims:

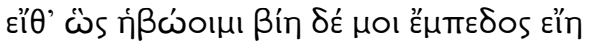
ஸ́s ómót' 'H

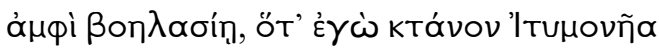

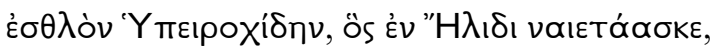

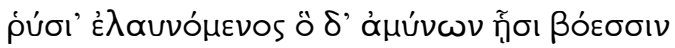

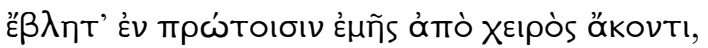

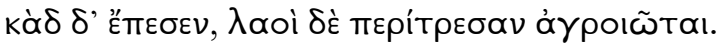

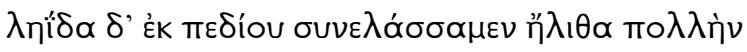

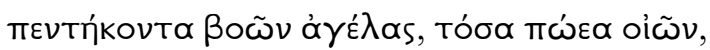

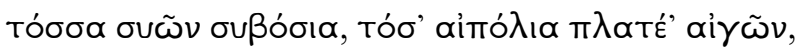

14. LSJ s.v. ő $థ \varepsilon \lambda \lambda \omega$. 
Ah, if only I were still as young and with all my powers intact, as I was when we and the Eleans came to blows over some cattleraids, and I killed strong Itymoneus who lived in Elis. I was raiding his herds by way of reprisal (rhysion) for what the ruler Augias lord of the Eleans had done to us, and while Itymoneus was defending them I hit him with a spear and killed him, and his rustic followers scattered in panic. We drove off a vast quantity of booty from the plain-fifty herds of cattle, and as many flocks of sheep, droves of pigs and scattered herds of goats (Il. 11.670-79, tr. Rieu).

Nestor describes himself as raiding the herds of the Eleans in reprisal, but rhysion can mean both 'that which is dragged away' and that which is seized as pledge or surety, that is, in lieu of that which was dragged away. ${ }^{15}$ It is unclear, therefore, whether Nestor is recovering his own stolen cattle, or whether he is seizing Elean property in lieu. ${ }^{16}$ In any case, the assault on Itymoneus's cattle develops into a full-blown raid, as Nestor describes how the Pylians drove a great quantity of booty from the plain of Elis to the Pylian citadel: fifty herds of cattle and as many flocks of sheep, herds of goats and swine, as well as horses (Il. 11.677-83). The livestock is dis-

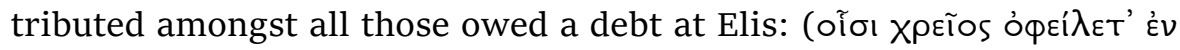

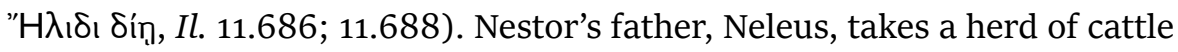
along with three hundred sheep and their shepherd, since 'a great chreios was owed to him at sacred Elis' (Il. 11.698). This chreios was a four-horse chariot that had been sent to race at Elis to compete for a tripod but had been kept instead by Augeas, the ruler of the Eleans (Il. 11.699-702). It is not clear whether this chariot was the rhysion originally fought over by Nestor, nor is there any further information that would explain how the other Pylians' chreios came about. The only background given in Nestor's account is the weakened state of Pylos resulting from attacks by Heracles which had emboldened the Eleans to plunder and insult the Pylians (Il. 11.695). ${ }^{17}$

A possible hint at the cause of the conflict may be given by the location of events at sacred Elis. The livestock represented as chreios is located in the plain of Elis and driven to the citadel of Pylos. According to Stefan

15. LSJ s.v. púsıov. See Jackson 1993: 73 hinting at a similar wording in Polyb. 22.4.

16. See now McInerney (2010: 99) who examines the background of Nestor's tale and reconstructs several attacks and counter-raids.

17. On cattle-raiding as rite de passage see now Newton 2015: 266. 
Hiller's examination of the geography of Pylos in Mycenaean and Homeric texts, Homeric Pylos is not the Mycenaean excavation site of Ano Englianos but Pylos in Triphylia. ${ }^{18}$ The area of Triphylia stretches out to the south of the river Alpheus and is both more mountainous than Elis and less rich in water. ${ }^{19}$

With Peneus in the north and Alpheus in the south, Elis has two rivers that are abundant in water year-round. In this western part of the Peloponnese, average annual precipitation today is $1000 \mathrm{~mm}$, while in the east, in the region of Attica, it is only $400 \mathrm{~mm}$. Thus Olympia, at present located in the flood zone of the Alpheus, but two metres lower in antiquity, is green even in summer, while the eastern and southern Peloponnese are very dry during the summer months. ${ }^{20}$ Geographic and climatic conditions make the plain around Olympia ideal for year-round pasture, which must have been very attractive for inhabitants of dryer regions. Ancient authors from Homer to Strabo repeatedly emphasize the significance of Elis as an area for pasture (Homer, Od. 21.347). ${ }^{21}$ There is a detailed description in Theocritus of herds and flocks pasturing all over the area at the river-banks and being driven back at the end of the day for milking, with the noise of the animals resounding throughout the entire plain and all the paths (Theoc. Id. 26.96). All this points to a dispute over the use of Elean pasture for Pylian herds as the root cause of the conflict in Nestor's story. On his visit to Messene, Pausanias suspected this much:

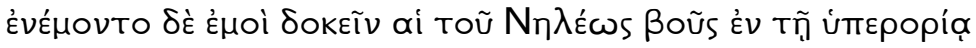

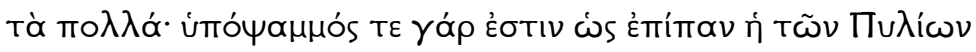

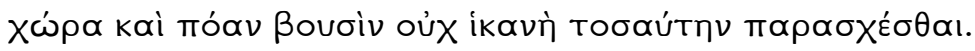

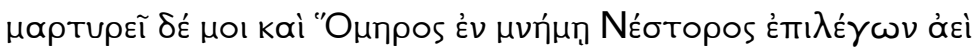

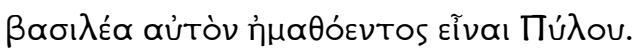

But the cattle of Neleus were pastured for the most part across the border, I think. For the country of the Pylians in general is sandy and unable to provide much grazing. Homer testifies to this, when he mentions Nestor, always adding that he was king of sandy Pylos (Paus. 4.36.5; tr. Jones). ${ }^{22}$

18. Hiller 1972: 214-16.

19. For the geology of Elis see Lienau 1989: 93.

20. Lienau 1989: 250-51, 264; Gehrke 1986: 103-4.

21. For further evidence see Semple 1922: 26. According to Semple, Elis has the best pastures in the Peloponnese.

22. By Pylos Pausanias means the foothills of Koryoasia (4.36.1). 
Around the time of Polybius Messenian flocks and herds were grazing around the area of Phigalia, which had been claimed by the Aetolians during the second century BCE (Polyb. 4.3). Today Sarakatsani shepherds from the Pindus mountains settle in the hills of northern Elis for the winter, while the local population graze their livestock around their villages all year long. ${ }^{23}$

The movement of herds and flocks for pasture is well documented for classical and Hellenistic times and is mentioned in Homeric epic too. ${ }^{24} \mathrm{Eu}-$ maeus, for instance, states that Odysseus's herds graze both on the mainland and on Ithaca, and that they are tended by local as well as foreign shepherds. Indeed, Eumaeus lists a dozen each of cattle, sheep, goat, and swineherds (Od. 14.96-104). The shepherd Philoetius brings a regular delivery of cattle and sheep from the mainland to the suitors feasting at Odysseus's house (Od. 20.185-88). He tells the disguised Odysseus how he was sent as a young boy to herd cattle at the demos of the Cephallenians (Od. 20.209-10), and that out of loyalty to Telemachus, he is not now moving away with the herds. It would be dishonourable in his view to depart to foreign lands with the cattle, while his old master's son is still alive (Od. 20.218-20). Noëmon, who lets Telemachus use his ship, also has horses and mules grazing at Elis (Od. 4.635-37). Close ties to the mainland are found too in the catalogue of ships in the Iliad, which has Odysseus leading soldiers from the mainland facing the islands of Ithaca, Samos, and Zakynthos (Il. 2.631-37). Pylos and Elis are mentioned as potential places of refuge for Odysseus (Od. 24.430-32).

The use of pasture in alien lands gives rise to conflict, not only in Homeric epic. Pausanias for instance gives the unlawful taking of livestock grazing in Lacedaemonian territory as one of the causes for the outbreak of the Messenian War that is dated around the time of the fourth Olympiad (c. 764 BCE). According to Pausanias the Messenian Polychares, lacking his own grazing land, gave his cattle to the Spartan Euaephnus for grazing on his land, promising a share (moira) of the produce or offspring ( $\mu$ ĩ pav

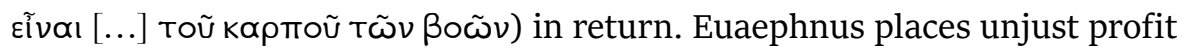

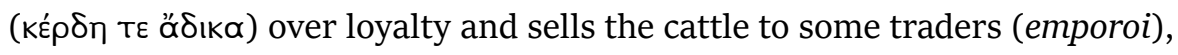
pretending to Polychares that he had been robbed by pirates. The fraud is uncovered by one of the herdsmen who has managed to escape from the

23. Lienau 1989: 217 and 149. Büdel 1976: 18-40 describes the varied history of the use of Elis.

24. Cf. Georgoudi 1974; Petropoulou 1985: 54; Chaniotis 1995: 39-89. Chandezon 2003. 
merchants, and Euaephnus promises to repay the price (timē) he received

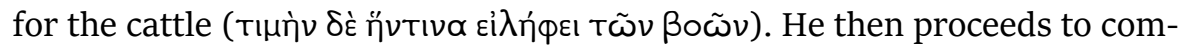
mit an even greater crime by killing the son of Polychares when he comes to collect the time. Polychares now takes his complaint to the Lacedaemonian basilees and ephors, lamenting and recounting the wrong done to him by one who he had made his friend and trusted above all Lacedaemonians

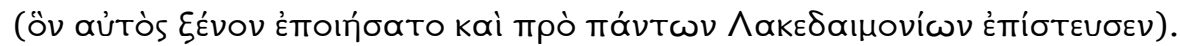
Since he is unable to gain redress, war eventually breaks out between Messene and Sparta (Paus. 4.4.5-8).

Against this background it is possible to get a clearer sense of the meaning of chreios. Quite apart from the question of whether the story is a true account of the outbreak of the Messenian War, it does explain why we hear in Homer that a debt of livestock 'grows'. This must refer to the increase in the size of the herd, of which Euaephnus in Pausanias's story is promised a portion. It seems likely then that Mentor, himself described as a shepherd (Od. 13.222), intends to collect just such a portion, described by Pausanias as moira and kerdos, on his trip to the Cauconians. In Pausanias we see the exchange based on a guest-friendship. Just such a guest-friendship (xeinosynē) is initiated by the exchange of weapons between Odysseus and Iphitos when they meet, both searching for their livestock (Od. 21.35). ${ }^{25}$ Since this is the only instance in Homeric epic of the institution of guest-friendship encapsulated in one term, I suspect that we are not here dealing with a military cooperation but that this guestfriendship enables a peaceful exchange of pasture and the safe migration of livestock and herdsmen.

The term for such mutual exchange is ánoıß ' (amoibē), with its verb

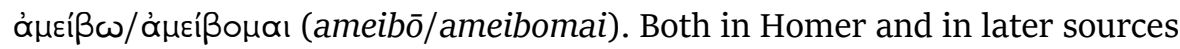
amoibe describes the compensation people may expect for services rendered to guest-friends and for sacrifices made to gods as well as divine retribution for wicked deeds. Frequently the context is the pastoral economy or a sacrificial feast. So we find Athena asking Poseidon for a 'pleasing

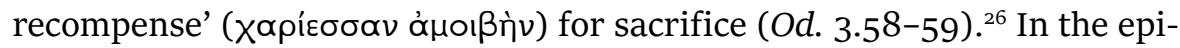
sode about the cattle of Helios, the word amoibe is used to mean the compensation for his stolen cattle in the threats made by Helios to Zeus (Od.

25. For more detail see ch. 2.2.

26. Manticlus asks Apollo for a counter-gift, called chariessan amoiban, for his offer of a bronze statue. Lexikon Iconographicum Mythologiae Classicae 11, Zürich 1984, s.v. Apollon No. 40. See Plato, Symp. 202 E. For further evidence see Laum 1924: 31; Jeffrey 1961: 94, n.1. 
12.382). ${ }^{27}$ In the context of guest-friendship amoibe and the verb ameibō/ ameibomai appear in situations in which reciprocity has failed. Mentes, whose father Anchialus once provided goods from his resources (pharmaka) to Odysseus because he loved him ( now expect from Telemachus a gift that is worthy (axion) of amoibe, that is, of compensation (Od. 1.318). ${ }^{28}$ This exchange is not ultimately realised because of the problematic situation at Ithaca, but it is based on an existing bond, as is made clear by the use of philein to characterise Anchialus's relationship with Odysseus. ${ }^{29}$ Guest-friendship is also the background when Laërtes assures the supposed Cretan Aëthon that if he were at Ithaca Odys-

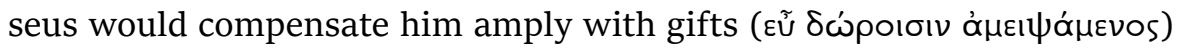
for the many presents and hospitality he received (Od. 24.273 and 285). Telemachus's plea to the suitors not to consume the property of just one

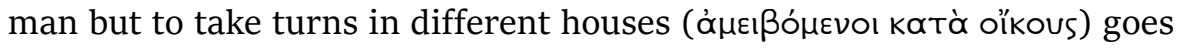
unheeded (Od. 1.375). The verb ameibomai and ameibō is otherwise often used for the exchange of words and song, either in council, in hospitality situations, or during burial rituals. ${ }^{30}$ Here its metaphorical use depends especially on the idea of endangered grazing livestock. Visually ameibo carries the meaning of a concrete change of location, or the crossing of a boundary, as in the much-used formula 'to cross the barrier (herkos) of the teeth'. Achilles makes use of this turn of phrase when he wants to emphasise that not even all the treasures of Delphi will be sufficient to

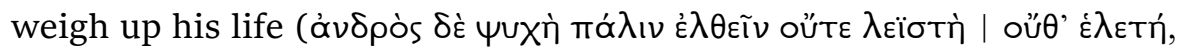

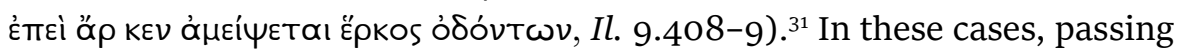
through the herkos, the fence or boundary, means death, just as would be suffered by livestock if they left their enclosures. In other instances, the passing (ameibein) into an enclosure may equally be imagined as transformation into livestock. Such a transformation takes place when Circe's potions (pharmaka) turn men into swine when they cross 'the barrier of

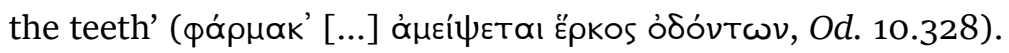

27. For a stronger meaning in the sense of revenge (tisis) see amoibe in Hes. Op. 32734 or Pind. Pyth. 2.24 .

28. Scheid-Tissinier 1994: 37-40 underlines the reciprocal aspect.

29. See ch. 2.3.

30. For evidence see Scheid-Tissinier 1994: 38.

31. Herkos is the fence around the yard (Il. 9.472; 976; Od. 24.442 and 449) and the yard itself (Il. 16.231; 24.306), where Eumaeus's pigs are held (Od. 20.164). The fence encloses fields (Il. 5.90; Od. 21.191; 240) and orchards (Il. 18.564). In Linear B herkos (we-re-ke) is a fold for animals. See Hiller and Panagl 1976: 135-37. For a linguistic connection between herkos and horkos, 'oath', see Hiersche 1993: 30-31 and Hirzel 1912: 153. 
We can therefore say that ameibē and ameibō/ameibomai occur in epic in connection with the crossing of boundaries, albeit metaphorically as in rituals, in speech, and in the exchange of weapons and gifts. Etymologically, an idea of movement is inherent in the term, which would suggest an ultimate derivation from the Indogermanic root ${ }^{*}$ mei $=$ migrare.$^{32}$ The fact that in Homer ameibō also has this concrete meaning of movement in the context of pastoral farming allows for the possibility that the migration of livestock is the core from which the term's various uses have developed. ${ }^{33}$ The fact that the only exchange of weapons in Homeric epic that results in the creation of a bond between people is occasioned by the practice of moving livestock for pasture fits well with this. The exchange of grazing lands may also have helped with the exchange of other resources, usually subsumed under the term of trade, as well as with pacts and agreements, and the exchange of oaths.

Such a connection between the pastoral economy and the exchange

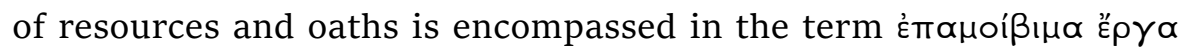
(epamoibima erga), which refers to the responsibilities of Hermes. According to the Homeric Hymn, deeds of mutual exchange, or barter ( $\dot{\pi} \pi \alpha \mu \hat{\beta}_{\beta} \beta_{\mu \alpha}$ Ép $\alpha$ ) are conducted under the supervision of Hermes, who also rules

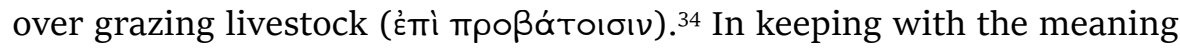

32. See Prellwitz 1905: 32; Bosacq 1916: 51-52; Hofmann 1950 s.v. áuḱı $\beta \omega$; Frisk 196o: 90; Benveniste 1969: I, 96-98; Chantraine s.v. áuźı $\beta \omega$.

33. Alongside Il. 9.408-9 compare also Il. 11.547, describing the retreat of Ajax as that of

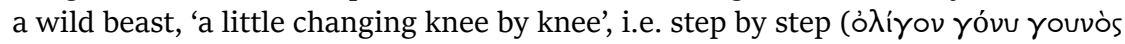
á $\left.\mu \varepsilon^{\prime} \beta \omega \nu\right)$. The composite parameibō is used for changes of location, as Nausicaa

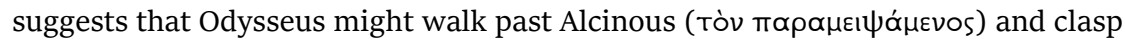
her mother's knee instead (Od. 6.310). A similar sense occurs in the Homeric Hymn to Apollo where parameibō describes the circumnavigation of Maleia (Hom. Hymn

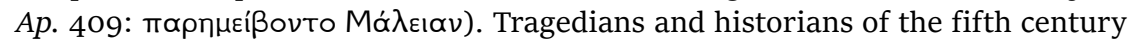

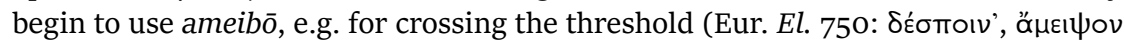

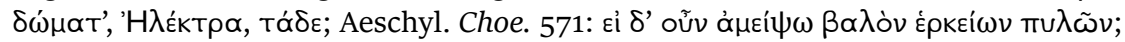

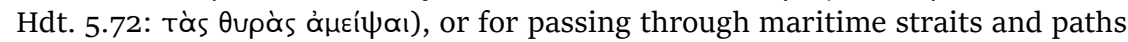

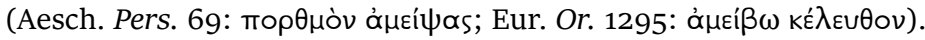

34. Hom. Hymn Herm. 516. In archaic art Hermes is usually a messenger, or companion to heroes. His role as messenger from Hades only begins in fifth-century Attic art. The name psychopompos occurs only in Roman times. See Zanker 1965: 56-59; 104-6; Simon 1985: 302; Kahn 1979: 201-11. Strauss Clay 1989: 98 views Hermes as embodying the principle of movement. For hermai serving as road markers at crossings and boundaries see Osborne 1985a: 48-73; Athanassakis 1989: 33-49. Simon (1985: 301) suggests that these stēlai, or heaps of stones, may have served to mark boundaries between different pasture regions but assumes that they were originally used as memorials for the dead. Athanassakis argues for the reverse. 
of probata, these animals tend to wander ( $\pi \rho \circ \beta \alpha i \beta \varepsilon ı v) .{ }^{35}$ In both literature and iconography, Hermes is predominantly pictured as a shepherd, which suggest that probata are usually sheep..$^{36}$ Yet Hermes is also the herdsman who promises to take the cattle of his master Apollo to graze in pastures on mountains and in the plains and who will receive a portion of Apollo's treasure in return (Hom. Hymn Herm. 491-92; 529). ${ }^{37}$ According to the myth of Hermes dated to the sixth century BCE he achieves this through a trick. As a child Hermes steals Apollo's cattle as they graze in the untouched pastures in the mountains of Pieria. Swapping their hooves around so that their traces appear to go in the opposite direction, Hermes leads the cattle over Mt Onchestos into the plain and all the way to the shore at Pylos (Hom. Hymn Herm. 70-96). The journey he makes is of course that of the transhumant shepherd who leads animals from mountain to plain and vice versa. ${ }^{38}$ On the banks of the river Alpheus, he lets the animals graze and drink. In the evening he drives them into an enclosure and slaughters two of them as a feast for the gods, during which, in keeping with his role in presiding over the gods' banquets, he gives to each his portion or geras (Hom. Hymn Herm. 104-29). ${ }^{39}$ Hermes intends to put himself in charge of the finest art of cattle farming through his theft (Hom. Hymn Herm. 166-67; 172-73). The hymn ends once Hermes and Apollo come to

35. On the derivation of probata from probainō see Shipp 1979: 474; Orth 1921: 382.

36. Post-Homeric sources use probata as well as mēla for sheep (see e.g. Dem. 47.52; Arist. Pr. 893a17; Polyb. 9.17; Athenaeus 5.219a; 9.402d-e). According to the ancient commentators Homer includes sheep, goats, and pigs in the term probata (see Schmidt 1979: 174-82). On Hermes as shepherd see Brendel 1934, fig. VII 1; XXX 1 and 2; XLVI-XLIX; Simon 1985: 300, fig. 287; Orth 1924: 602 and 6o9; Athanassakis 1989: $33-49$. There are numerous references to the many flocks found in Hermes's birthplace Arcadia (Hom. Hymn Herm. 1-9), e.g.: Hom. Il. 2.605; Pind. Ol. 1.669; Theocr. Id. 22.157; Apoll. Rhod. Argon. 1.575. See also Pausanias (2.3.4) on a Hermes statue in Corinth: 'Proceeding on the direct road to Lechaeum we see a bronze image of a seated Hermes. By him stands a ram, for Hermes is the god who is thought most to care for and to increase flocks, as Homer puts it in the Iliad', (tr. Loeb). The passage cited from the Iliad by Pausanias associates Hermes with the adjective polymēlos (wealthy of flocks), lent to him by Eudoros (the good gift), the son of Polymele and Hermes: Il. 14.490; 16.174-92.

37. The terms for this treasure are ploutos or olbos, most likely alluding to wealth amassed at Delphi. Apollo also profits from the shepherd's labour in that he has a share in income from the livestock (Hom. Hymn Herm. 493-95).

38. For a similar argumentation see Hodkinson 1988: 51, although he denies the importance of transhumance for ancient Greece. See ch. 5.4.

39. See Clay 1989: 117-25: she sees this as staging the typical human feast such as that prepared by Eumaeus for Odysseus (Od. 15.319) from which the gods (in the case of Eumaeus it is Hermes and the Muses) receive a portion. 
an agreement, expressed through the exchange of the lyre for the whip, and the swearing of oaths, and finally through Zeus granting the charge of epamoibima erga as the timē of Hermes (Hom. Hymn Herm. 514-20).

There is no reason to assume that the term 'deeds of exchange' applies exclusively to bartering, as the dictionaries suggest. ${ }^{40}$ Just like the underlying verb ameibo the term has a wider meaning that corresponds to the spheres associated with Hermes and encompasses the exchange of livestock and pasture as well as oaths exchanged between people and the reciprocal relations between gods and men. Jenny Strauss Clay sees in 'movement and passage' the theme that unifies the various manifestations of epamoibima erga (theft, exchange, verbal communication in the form of lies, oaths, and treaties). ${ }^{41}$ Viewed against the Homeric uses of the verb ameibō, this is not merely an abstract point. With his epamoibima erga Hermes is responsible for the concrete movement of livestock and commodities across boundaries, which in turn necessitates agreements in the form of oaths and rituals (such as the exchange of arms) in order to avoid the ever-present dangers of robbery, deceit, and lies so familiar to Hermes and to the Homeric heroes.

Before moving on to illustrate the connection between transhumance and exchange, it is first necessary to consider the profits resulting from exchange across boundaries.

\subsection{Kerdos and ōnos hodaiōn: Pastoral yields and profits from kidnapping}

\subsubsection{Kerdos, kerdea, kerdios, kerdaleos}

The distinction made in the Odyssey between the athlete and the man who has an interest in the kerdea hodaiōn is not a social one between a class of traders and a class of aristocrats distinguished by their participation in athletic and musical competitions. The warriors competing at the funeral games for Patroclus certainly have an interest in kerdea. The term Képठos (kerdos) tends to apply to profit or gain made without battle and in secret. Since there are a number of instances of deliberation around the potential

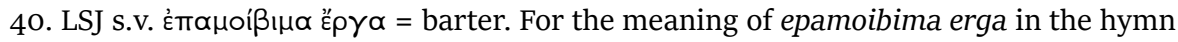
see Clay (1989: 145), who interprets the epamoibima erga of Hermes as 'theft' and 'exchange', whereas Viechnicki (1994: 113-32) underlines a connection with 'gift-exchange'.

41. Clay 1989: 146. 
kerdos to be made through a particular course of action, it makes sense

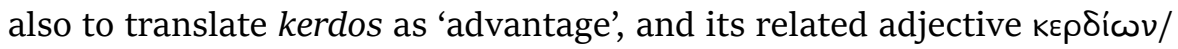

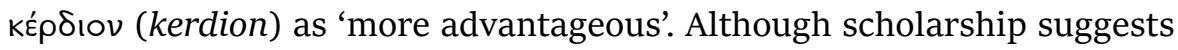
that kerdos is a term for trading profits, we will see that this is only indirectly the case..$^{2}$ The advantage expressed by kerdos is achieved through cunning and depends on intellectual power or perception, referred to as vóos (noos) and associated with mobility. ${ }^{43}$ Since kerdos is used especially in the context of taking a metaphorical or physical journey or path, we may also take kerdos to mean the advantage or profit gained by choosing the correct path, which includes journeying by sea. A person described as kerdaleos is one who has the wisdom to choose the right path. By contrast, someone described as kerdaleophrōn is entirely and exclusively directed at achieving kerdea and thus lacking in wisdom. Hesiod's treatment of reciprocal ethics between neighbours clarifies the differences between good and bad kerdea alluded to in the Odyssey.

I will begin by examining the warriors' quest for kerdea and what in the Iliad is considered kerdion, and will then move to the kerdea sought in the Odyssey by Penelope and Odysseus. The key contexts for the quest for kerdea are to be found in competitions, the reconnaissance of the Trojan camp, in the provision of goods from shepherds, and in the weaving trick. In Hesiod's Works and Days we find kerdea connected to a sea journey, although here, as in Euryalus's speech in the Odyssey, a connection is made to athletic and musical competitions.

In the Iliad, an understanding of kerdea is primarily necessary during competitions, as Nestor suggests when he states that success in the chariot race depends not merely on the speed of the horses but also on knowledge

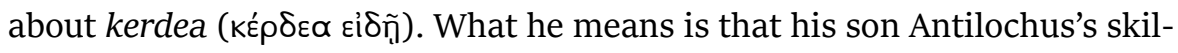
ful driving will compensate for the fact that Antilochus's horses are slower than those of Menelaus (Il. 23.322; 515). Odysseus, too, is said to have

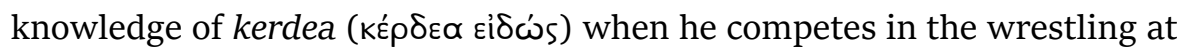
the funeral games and resorts to cunning in order to defeat his opponent Ajax, whom he cannot match in strength (Il. 23.709; 725-26).

42. See de Jong 1987: 79-81 for the difference between kerdos as advantage for oneself, by contrast with ophelos as 'advantage for another'. Bamberger 1976: 1-32 differentiates between three aspects of kerdos: profit (Od. 8.164), advantage (Il. 10.225; Od. 16.311) and cunning plan. Descat (1986: 286-88) differentiates between the spheres of trade and exchange, in which kerdos is respectively 'profit' and 'use' (besoin).

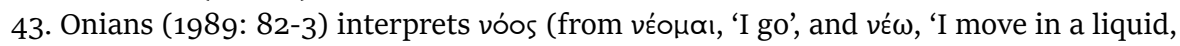
swim') as dynamic and movable power. 
In battle, too, kerdos is not gained through the use of physical power, as we see when Menelaus and Agamemnon are in need of counsel described

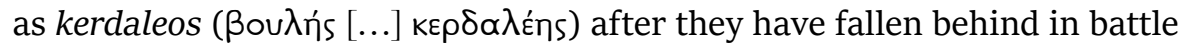
against the Trojans (Il. 10.44). The plan is to send a scout into the Trojan camp for reconnaissance. Diomedes volunteers as the scout, asking for a companion to go with him since 'when two go together, one will notice

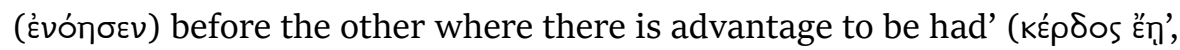
Il. 10.224-25). The ability to discern advantage, kerdos, depends on agility of noos, the intellectual power of perception. It also depends on strength in cunning (mêtis), as we see in Diomedes's subsequent remarks: 'If one

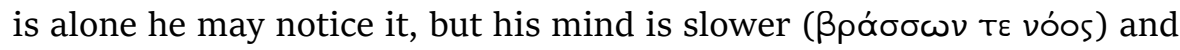

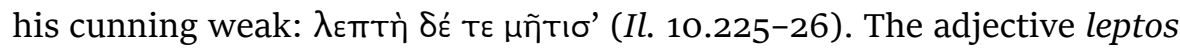
used here to describe mêtis is more commonly used to describe the fine and transparent texture of woven fabrics such as those worn by Calypso

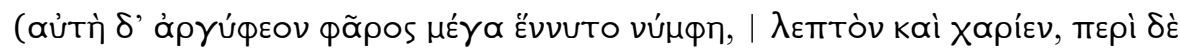

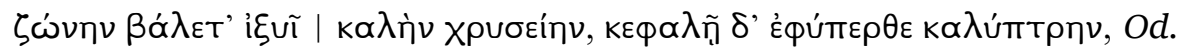
5.230-31). Diomedes, of course, decides on Odysseus as his companion, as the most skilled when it comes to the kind of perception described with the

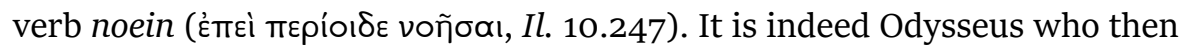
discovers the Trojan spy Dolon as they make their way to the enemy camp. The two companions manage to outrun Dolon, who is then persuaded by polymētis Odysseus to provide information about the situation in the Trojan camp (Il. 10.339-445).

In all three cases kerdos/kerdea may be rendered as advantage(s), resulting from the mastery of routes or paths taken at the chariot race or on the reconnaissance expedition. The advantages are seized for the sake of a gain or profit consisting in the prize at the competition (aethlon) and in glory or fame (kleos). The material gift promised in return to the scout is a black ewe with her lamb as well as a standing invitation to the feasts to be given by each of the leaders in charge of ships (Il. 10.213-17). This places the capacity to gain kerdos and the compensation given for gaining it into a close semantic relationship with each other. The common denominator is movement in space and in spirit.

Predominantly in the Iliad we are dealing with deliberation about which is the 'more advantageous' or 'more profitable' ( $k \dot{p} \rho \delta ı v$ ) path to take. Here, the more advantageous path is retreat. The gods themselves consider it so, as when Zeus states that it would have been much more advantageous (poly kerdion) for himself as well as for Poseidon if Poseidon had thrown 
himself in the sea instead of supporting the Greeks (Il. 15.226). This is also true for Athena, to whom Zeus indicates that withdrawing from battle would be poly kerdion (Il. 7.28). In the mortal sphere a preference for retreat as the kerdion option is similarly expressed by Deiphobus when he opts to withdraw and seek reinforcement through Aeneas in the face of the Greeks' superior power (Il. 13.458). ${ }^{44}$ The advantage does not only adhere to those who retreat. According to Achilles his own withdrawal from battle was kerdion for Hector and the Trojans because during that time victory was on the side of the Trojans (Il. 19.63).

It may, however, also be kerdion to stand up and fight-although a negative outcome is implied in such cases. So, Hector considers it kerdion to go into combat against Achilles and die; equally the Achaeans risk their lives to recover the body of Patroclus because it is kerdion. The warrior's kleos

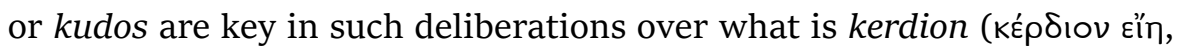
Il. 22.103-110: Hector; 17.417-19: Achaeans). When Paris reveals his cowardice in combat, Hector claims it would have been better (poly kerdion) if Paris had never been born, or had died unmarried (Il. 3.41). The weighing up of the more advantageous option does not take place without a normal system of social values-even if the means by which advantages, kerdea, are gained may at times lead one to suspect this. Thus, Antenor's sense of what is the more advantageous option takes into account the obligations between Trojans and Greeks, the horkia pista. He proposes to the Trojan council that Helen and her goods should be returned because otherwise no

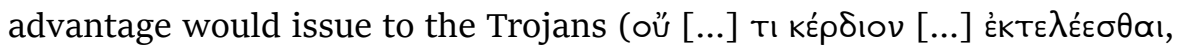
Il. 7.351-53).

Andromache, too, has a negative definition of what is kerdion, when she fears for Hector's life and calls it kerdion if she were to sink into the earth after his death since she has no father or mother (Il. 6.410). While in this example it is the loss of protection that leads to the consideration of what is kerdion, a lack of military equipment can provoke similar thoughts. Pandarus reflects in Iliad 5 that it would have been more advantageous, poly kerdion, if he had not left his horses at home in order to spare them. Without them he is afraid he is not properly armed and may not see his home and his wife again (Il. 5.201; 213).

The accusation of being $\kappa \varepsilon \rho \delta \alpha \lambda \varepsilon$ có $\rho \omega \nu$ (kerdaleophrōn) made by Achilles against Agamemnon and again by Agamemnon against Odysseus is one of the rare instances of a negative judgement made of the consideration of 
kerdion (Il. 1.149; 4.339). ${ }^{45}$ In both cases the accusation refers to a neglect of reciprocal obligation: in the case of Agamemnon the taking of Achilles's prize, and in the case of Odysseus the apparent reluctance to fight despite having received honours at the feast. The attitude described as kerdaleophrōn suggests deception-a skill that of course particularly distinguishes Odysseus.

Penelope and Odysseus are the experts on kerdea in the Odyssey. There is one case of kerdea achieved by taking paths physically-in this case profits made from trading in livestock. In Book 19, when Odysseus in his guise as the Cretan Aëthon promises the imminent return of Odysseus, he also tells Penelope that her husband has chosen to gather wealth (chrēmata) by roaming widely because he considers it kerdion to do so ('a $\lambda \lambda \lambda^{\prime}$ 'ápa oi tó

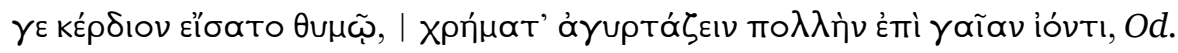
19.283-84). The Cretan then adds, by way of explanation, that 'Odysseus

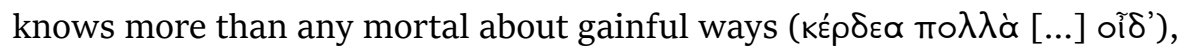
nor could any other mortal compete with him there' (Od. 19.285-86)..$^{6}$ Since Aëthon alleges that Odysseus takes the decision to travel farther after leaving the Phaeacians, we might assume that the chrēmata he mentions are different in type from the keimēlia Odysseus has received in Phaeacia, unless they refer back to the previous mention of Odysseus asking around the dēmos for many rich keimēlia (Od. 19.272-73). Some specificity may be found in Telemachus's explanation that there is no kerdos to be gained

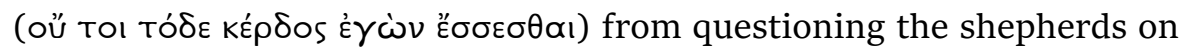
whether they honoured (Tíєl) their master during his absence or dishon-

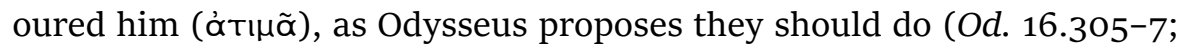
311). Here too we find a mention of the path that needs to be taken in order to achieve kerdos: Telemachus points out that they would waste a lot of time walking around in search of each man at his pasture while the suitors would continue to feast on the household goods. Telemachus suggests that they should postpone checking up on the men at their shepherds' stations until a later time (Od. 16.313-15; 318-19). Given that these considerations have demonstrated that the honour (tiein) and dishonour (atimazein) in question always involve material benefits, we must assume that the kerdos Telemachus temporarily rejects must be whatever profit the shepherds have made from their journeys to different pastures on behalf of Odysseus. When father and son eventually travel to the countryside after the punishment of the suitors, and Odysseus wonders what kerdos the 


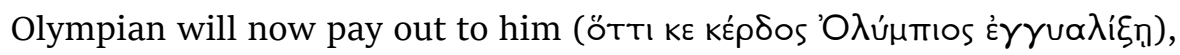
this too is connected with profit made from livestock trading. We know that Odysseus is concerned to recover the flocks consumed by the suitors without payment, vท́moıvov (nēpoinon), and without compensation, árıо v (atimon) (Od. 23.140; 356-58).

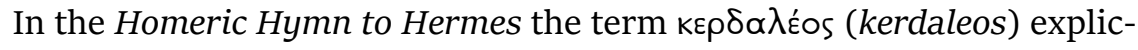
itly refers to profit made from trading in livestock. The adjective is used of Apollo who here appears in his role as the owner of herds, which he leaves Hermes to tend. The latter will lead the animals to graze on mountains and in plains and will guarantee the herds' growth for Apollo: 'We will graze the pastures of the hill and of the horse-feeding plain with the cattle penned in the agros. There cows covered by bulls shall bring forth male and female progeny abundantly. There is no need for you, who are kerdaleos, to be furiously angry'. ${ }^{47}$ The term kerdaleos here describes an attitude specifically interested in the profit to be made from cattle which, like that of Odysseus, grazes in a variety of pastures.

In the Odyssey a lot of kerdea are gained through thinking and through weaving. Like Odysseus in the Iliad, Penelope has a reputation, attested by Antinous, for knowing about kerdea. She too achieves her goal through the cunning trick (dolos), which enables her to postpone remarriage (Od. $2.88 ; 105)$. Penelope's knowledge of kerdea, just like the good sense which she needs for her weaving work, and her ability to fashion fabrics of outstanding beauty, stem from Athena (Od. 2.116-18). The goddess is praised amongst all the gods for her cunning intelligence (mêtis) and for her ker-

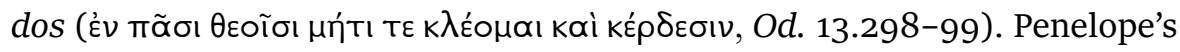
kerdos too can be understood as a concealed form of thought which, along with cunning intelligence, leads to advantage.

While Penelope's wisdom about kerdea refers to her weaving work, Odysseus's knowledge of kerdea involves the use of thought and words.

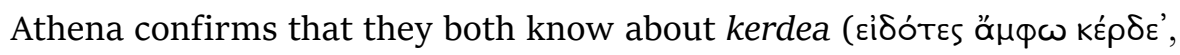
Od. 13.296-97). Penelope is famed for this amongst the immortals, while Odysseus is renowned amongst the mortals when it comes to counsel and speech (ßou $\lambda$ ñ kaì $\left.\mu{ }^{\prime} \theta o ı \sigma ı\right)$. The goddess tells him this while at the same time gently mocking him for attempting to deceive her without recognising her divine status behind her disguise as a shepherd (Od. 13.222). These

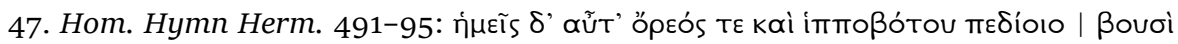

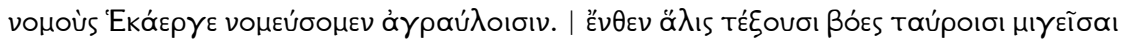

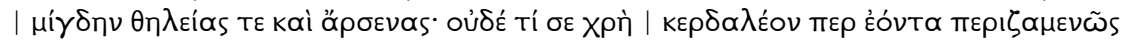

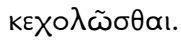


qualities earn him the description of being like a kerdaleos, that is, according to Athena, one who exceeded Odysseus in all manner of cunning ( $\dot{\varepsilon} v$

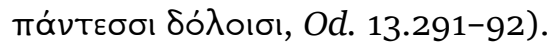

Counsel, words (mythoi), and thoughts (noèmata) are also described with the adjective kerdaleos. Thus, the speech (mythos) addressed by Odysseus to Nausicaa to gain her support is kerdaleos (Od. 6.148), as is the thought which Odysseus must not conceal when asked by Alcinous for his

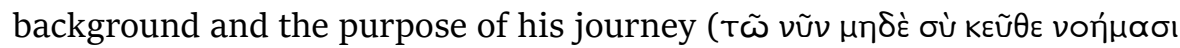

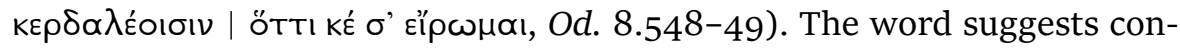
cealed interests and deception, such as are associated with Odysseus and his guile and cunning. With kerdalea noēmata, Odysseus could easily deceive Alcinous. When meeting Nausicaa, Odysseus considers it kerdion not to take the customary position of a suppliant by grasping the girl's knees but instead to address her with words alone in order not to unsettle her. He also addresses her as ( $w$ )anassa, a term used predominantly for goddesses and alluding to the notion of human fate lying on the knees of the gods; thus in his address, characterised as kerdaleos, he is able to mention her knees, without touching them: 'By your knees, I beg, mistress' (Youvoũuaí $\sigma \varepsilon$, äv $\sigma \sigma \sigma \alpha$, Od. 6.149)..$^{8}$

The ability to conceal personal interest is described with the term

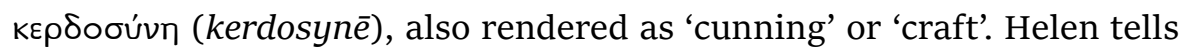
Telemachus at Sparta how Odysseus used kerdosyne to avoid meeting her and being discovered at Troy (Od. 4.251). In his own home Odysseus has to act with kerdosyne in order to stop the dogs from uncovering his disguise in their joyful recognition of their master (Od. 14.31). Athena leads Hector into the duel against Achilles and thus to his destruction with kerdosyne (Il. 22.247).

Penelope demonstrates her knowledge of the deception and cunning involved in the achievement of kerdea, which she refers to as kaka, wicked, when she explains to Odysseus her hesitation and reticence in finally recognising him as her lost husband. She was afraid because there are many

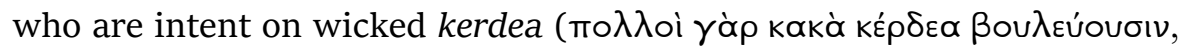
Od. 23.217). Her fear was that she might be taken in by lies and made to believe that Odysseus had returned. Mostly the perception of kerdea is positively valued. Thus, Penelope chides her son that he had better sense (phrēn) for perceiving kerdea as a child and that he would not have allowed

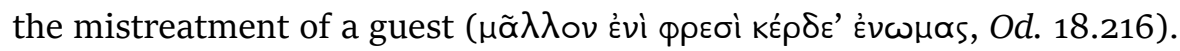


Her remark suggests that here too advantage, kerdea, has its place in the proper order of things in which respect for a guest is valued.

In Hesiod's Works and Days, we find explicit condemnation of wicked kerdea. The issue is that a breakdown in neighbourly reciprocity results in endangering the safety of livestock:

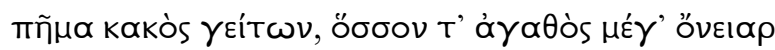

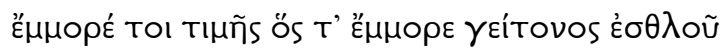

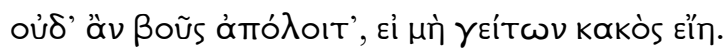

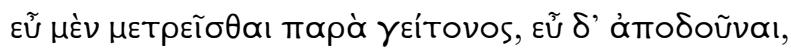

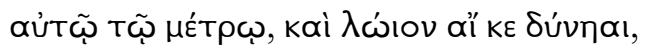

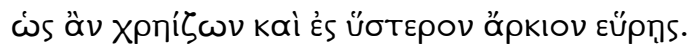

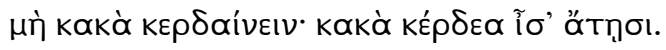

A bad neighbour is as big a bane as a good one is a boon: he has got good value who has got a good neighbour. Get good measure from your neighbour, and give good measure back, with the measure itself and better if you can, so that when in need another time you may find something to rely on. Seek no evil gains ( $k a k a$ kerdainein): evil gains (kaka kerdea) are no better than losses (atai) (Hes. Op. 346-52, tr. West).

Base kerdea are similar to the atai which cause states of blindness in the epic that then lead to insults of individuals' timē. Possession of timē in turn justifies a claim on goods and services. Here the balance of time ('respect') between neighbours forms the point of reference for judging kerdea as wicked or devious (kaka). Timē is materially represented here in the form of agricultural goods, especially cattle, that neighbours give to one another. These goods must also be the substance of the kerdea, which are better rendered as 'benefits' rather than 'profits' since the context is not one of trade and selling, but of neighbourly exchange. ${ }^{49}$

The kerdos that Hesiod recommends can be made through seafaring, $5^{\circ}$ is understood as profit made from trade:

49. According to Descat 1986: 291 we have here a hint at a change in reciprocal relations towards measurability and contractual obligation, but the use of the term time $\bar{e}$ in epic contradicts this. Hesiod simply considers the problem with respect to different groups from those the epics are concerned with. For the morality of reciprocity in Hesiod's poems see Millett 1984: 84-115 and Schmitz 2004: 63-82. 50. Solon (fr. $1 \mathrm{D}$ 41-46) and Alcaeus (fr. 45 D) also gain kerdos from sea journeys. 


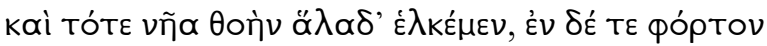

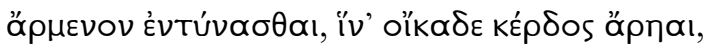

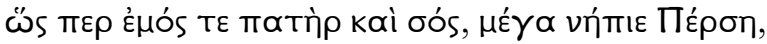

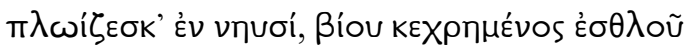

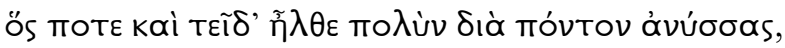

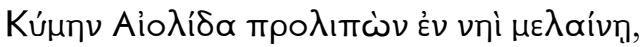

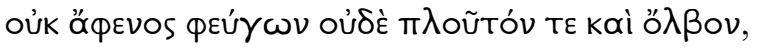

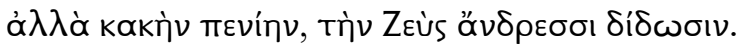

Then drag the swift ship to the sea, and in it arrange your cargo (phorton) fittingly so that you may win profit (kerdos) for your return: just as my father and yours, foolish Perses, used to sail in ships in want of fair livelihood. And one day he came here, making the long crossing from Aeolian Cyme in his dark ship, not running from riches (aphenos), nor from wealth (plouton) and prosperity (olbon), but from evil poverty, which Zeus dispenses to men (Hes. Op. 631-38, tr. West).

The need for kerdos arises from peniē, a lack of goods outlined with the terms aphenos, ploutos, and olbos, which ultimately suggest agricultural commodities such as cattle, grain, and wool. Hesiod follows this with further reasons for seafaring, which are chrea, need, and limos, hunger:

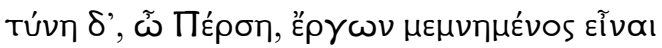

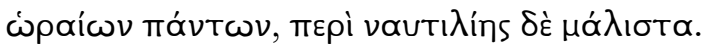

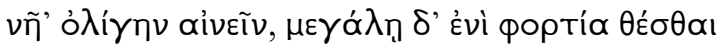

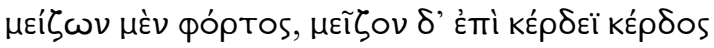

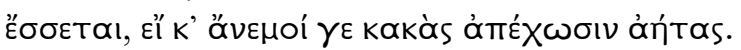

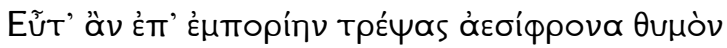

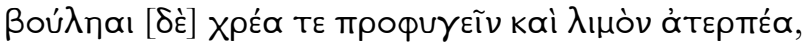

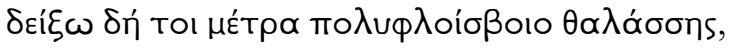

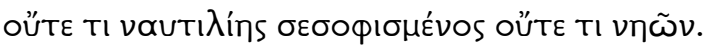

But you, Perses, must attend to all tasks in season, and in the matter of seafaring above all. Compliment a small ship, but put your cargo (phortia) in a big one: bigger will be the cargo (phortos), bigger the extra gain (kerdos), provided that the winds withhold their ill blasts. When you want to escape debt (chrea) and joyless hunger (limon) by turning your blight-witted heart to 
trade (emporiē), I will show you the measure of the resounding sea-quite without instruction as I am either in seafaring or in ships (Hes. Op. 641-69, tr. West).

The cargo of a ship, phortos, and the kerdos to be obtained through the journey are proportional to one another and also interchangeable: the bigger the phortos,$^{51}$ the greater the kerdos that will be obtained. Scholars assume that Hesiod here refers to the sale of agricultural surplus, so that his kerdos includes the profit made on those sales..$^{52}$ Generally, this is thought to apply to grain, ${ }^{53}$ although Hesiod also mentions wool weighing down

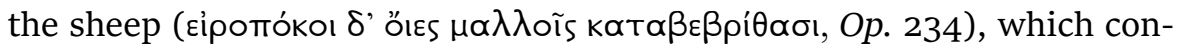
tributes, together with the gifts of Demeter, to save good men from hunger (Op. 230). Wool can only keep hunger away if it is traded for consumable goods. This is not true of the livestock itself which can be slaughtered or kept alive in store for times of hunger. ${ }^{54}$ Thus I suspect that Hesiod's kerdos alludes to animal products such as wool, or the breeding of animals, which are more likely than grain to yield surplus quantities for trade. 55

The only concrete destinations mentioned for the sea journeys in Hesiod are the supraregional festivals; these must therefore be the locations for the exchange of freights (phortia) into gain (kerdea). One such occasion is the poetry festival at Chalkis at which Hesiod claims to have won a tripod (Op. 650-57). In the Homeric Hymn to Hermes, the divine herdsman is also a skilled singer and credited with the invention of the lyre, which he ultimately hands over to Apollo, the owner of the herd, who then, of course, becomes known as the god of the lyre (Hom. Hymn Herm. 47-54, 475-90). ${ }^{56}$ It seems therefore that the singer who travels to a poetry

51. Hesiod does not differentiate between phortos (see Op. 672) and phortia (see Op. 693) and gives no information about the content. Hesiod's advice is to minimize potential losses by not taking the entirety of one's possessions along: 'do not put all your substance (bios) in ships' holds, but leave the greater part and ship the lesser; for it is a fearful thing to meet with disaster' (Hes. Op. 689-90, tr. West).

52. Perysinakis 1986: 116; Reed 1984: 33-43.

53. Bravo supposes the sale of grain (1983: 31). According to him Hesiod was the dependent agent of an aristocratic trader, 'qui envoie des cargoisons de marchandises' (Bravo 1984: 135). Jameson (1983: 8) and Garnsey ([1988]1993: 75) assume the sale of the surplus of the harvest.

54. See Halstead 1980: 307-9.

55. All calculations of surplus (e.g. Garnsey [1988] 1993: 53-58; 89-106) are based on speculation. See the critique by Isager and Skydsgaard 1992: 108-14. On the difficulty of calculating the productivity of ancient agriculture see also Osborne 1987: 44-47.

56. For the meaning of the lyre see now Scheid and Svenbro 2014. 
competition may also be a herdsman or an owner of livestock, out to make some profit or gain, kerdos, from his herds and flocks. This is especially likely given that animals were required for the hecatombs at festivals and that the earliest written evidence for trade in livestock is found in the context of sacrifice. ${ }^{57}$

In summary, kerdos is best defined as a term for concealed interest, aimed at a gain or benefit. Especially in the context of a pastoral economy kerdos may be understood as a benefit earned by moving herds to pastures and market places. This benefit comes closer to being a form of trading profit when it is transported over unspecified distances, primarily by sea, without, however, any evidence for the existence of professional traders. Such benefits, kerdea, can be sought by any agent in epic: warriors and athletes, counsellors and weaving women, herd-owners and farmers. But the term also points to the existence of another field of activity, namely robbery and piracy. As we will see, robbers and warriors are not necessarily different in status.

\subsection{2. Ōnos and apoina}

In the epic poems, the proper term for the benefit earned on a journey, or by transport, is ஸ̃vos (ōnos). The term is frequently rendered as 'price' or 'purchase' but also as 'transaction'. ${ }^{8}$ Such transactions are mainly handled by warriors but also by the Phoenicians, who, in antiquity, were thought of as prototypical traders. ${ }^{59}$ They differ in no way from the Greeks.

In Odyssey 20 the suitors complain to Telemachus about the quality of his guests and tell him it would be more advantageous (poly kerdion) to send the strangers to the Sicilians where they would 'fetch you a fitting

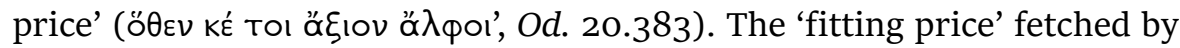

57. For epigraphic and archaeological evidence see Jameson 1988: 87-119 and now Jim 2014.

58. According to Bravo (1977: 7) onos belongs to the commercial terms and means 'achat'. More convincing is Edouard Will (1957: 5) who argues that ōnos never means 'achat' but only 'transaction'. See also Gallagher 1988: 85-106 who discusses the Mycenaean roots of the term. According to him, the term goes back to $o$-no, that means 'ass-load' (91).

59. See von Jhering 1884: 373-82, who also attributes the development of guestfriendship to the Phoenicians. Hasebroek [1928] 1966: 18 has a more negative reading. Reed 1984: 32-35 argues against the notion of the Phoenicians as traders, assuming rather that gift-exchange was a part of Phoenician culture. See also Aubet 1993: 103-11. 
transporting a person abroad is here called axios, a word we have encountered before in the context of weighing up a person's value, their time and which properly means 'that which is weighed up'. What is meant is the quantity of goods that weighs up a person's value, which in this case is determined through the use of force and through transportation. The

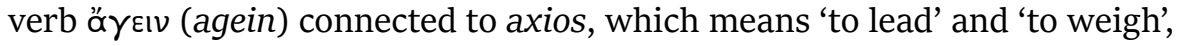
is frequently found linked to the term ōnos. Alongside apoina, ōnos is the proper technical term for the value of a person who has been taken by force. Where apoina are the goods collected by the relatives of a kidnapped or conquered person in return for their recovery, onos is realised only once the person has been transported abroad.

The ransom paid to Achilles for Lycaon, the son of Priam and Laothoë, is an instance of onos. The story of this ōnos is remembered when Lycaon meets Achilles in combat: Achilles had caught Lycaon cutting branches off a fig tree in his father's garden and had taken him off to Lemnos by boat

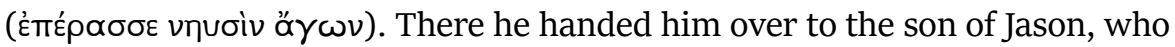

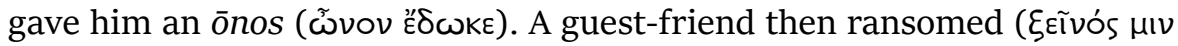
غ̇ $\lambda$ úo๙To) Lycaon for a great price and sent him to Arisbe, presumably selling him on, since Lycaon escapes back to his father's land only to fall back into the hands of Achilles some days later (Il. 21.35-48). ${ }^{60}$ Despite being offered three times the previous ransom, Achilles kills the Trojan (Il. 21.80). The value of the onos Lycaon had fetched before is given as one hundred oxen, as

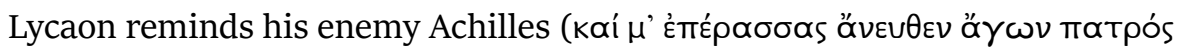

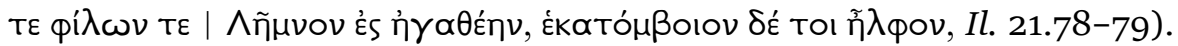
Another part of the same onos reappears during the funeral games: a silver mixing bowl offered as the prize for the winner in the footrace had

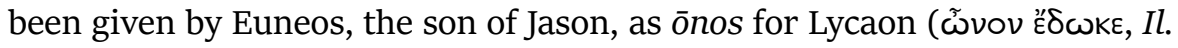
23.740-41). Like other objects circulating as guest-gifts or souvenirs, this silver bowl too has a provenance: it had been handed down by the grandfather, Thoas, who had received it as a gift from the Sidonians (Il. 23.741-47).

The ransom, ámoıva (apoina), Achilles would receive from Priam if his sons Lycaon and Polydorus were still alive also includes bronze and gold items from their mother's property (Il. 22.49-51). Where such ransoms are actually paid by relatives-as for the release of Hector's body-the objects handed over are textiles and gold, as well as tripods and bowls (Il. 24.229-37). Thus, the only difference between onos and apoina is that the former is paid by strangers, the latter by the family.

6o. Garlan (1984: 45) assumes an 'achat'. 
This difference also explains the phrase óvámoıvov ómpıórmv (anapoinon apriatēn) used in the context of the negotiations for the release of Chrysëis. After Agamemnon's refusal to accept apoina for the daughter of Chryses (Il. 1.20), ${ }^{61}$ and following the outbreak of the plague, the seer Calchas determines (Il. 1.99) that Chrysëis must now be returned without

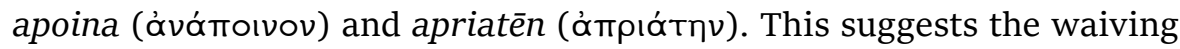
of payments from relatives in the form of apoina and the payment of onos from strangers. The adverb apriatēn is derived from the deponent

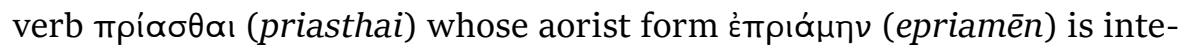

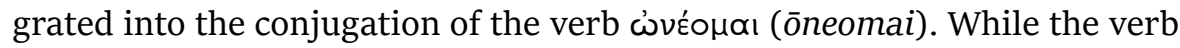
oneomai does not occur in Homer, the aorist epriamēn is used to describe the actions of someone paying an onos for a person who thus gains possession of that person (Od. 1.430; 14.115; 452; 15.483). The action of the person who hands over another person in return for onos is described

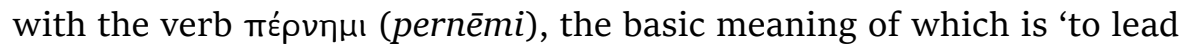
away'. ${ }^{62}$ So Achilles boasts to Lycaon that he has caught many men and

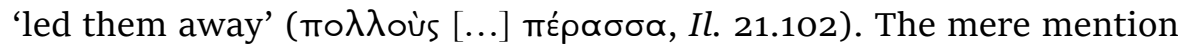
of transportation abroad is enough to express the circumstances of the receipt of onos and thus the 'sale' of the person abroad. Such is the fate envisaged for Apollo and Poseidon when Laomedon threatens to lead them

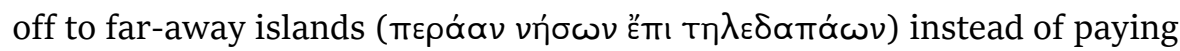
them their wages (Il. 21.454). A similar understanding of transportation as enslavement can still be found in the Hunza valley in Pakistan, where 'to drag over the river' means 'to enslave'. ${ }^{63}$

In the Odyssey those transported over the sea and exchanged for onos are Euameus and his Sidonian nurse, Odysseus's nurse Eurycleia, and allegedly Odysseus himself. The perpetrators are not warriors, however, but Phoenicians of uncertain status.

During his conversation with Eumaeus, Odysseus claims that a Phoenician had pretended to want to transport a cargo to Libya with him, when in

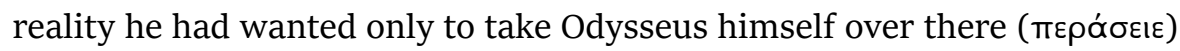

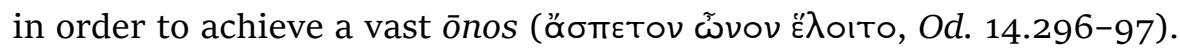
According to Odysseus they are shipwrecked, but he himself is rescued by Pheidon, the king of the Threspotians, who does not make a profit from

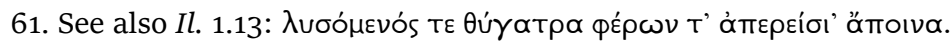

62. Chantraine 1940: 12-15. In post-Homeric sources $\pi \varepsilon \rho \alpha \dot{\omega}$ (perā̄), to cross, occurs more frequently, denoting specifically transportation by sea. The derivative mópvn (pornē, a prostitute) remains.

63. Jettmar 1993: 42. 


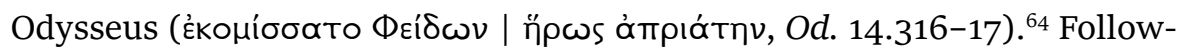
ing from my earlier remarks, the use of the adverb apriatenn suggests that transport abroad and the receipt of onos are here renounced.

When Odysseus goes on to ask after Eumaeus's own fate, we have a clear indication of the kinds of situation in which a person might be carried off to be exchanged for ōnos:

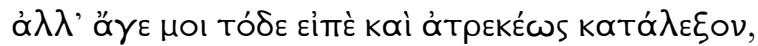

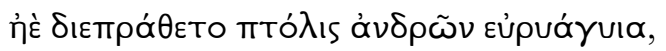

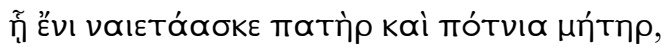

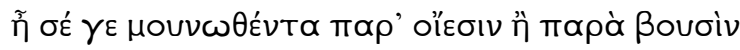

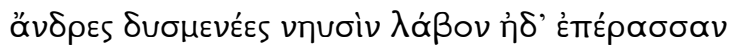

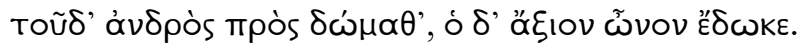

Won't you tell me what happened? Was it sacked, the city of broad streets where your mother and father lived; or did some band of raiders capture you as you tended your sheep and cattle alone and bring you by ship to the palace here and get a good price (axion ōnon) from your master? (Od. 15.383-88, tr. Rieu).

The payment of onnos can hardly be a guarantee of survival, as Garlan believes; ${ }^{65}$ it is clear that the achievement of onos is the purpose of such abductions.

The Sidonian woman, whose story is closely linked to that of Eumaeus, is taken by Taphians on her way from the agros, which may mean either

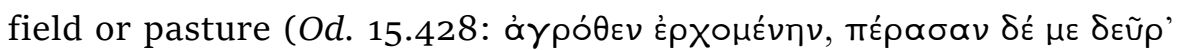

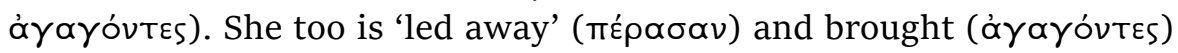
to the house of a man, Eumaeus's father, who had given an appropriate onos, as she explains to Eumaeus's Phoenician kidnappers (ó $\delta$ ' ö $\xi ı v$

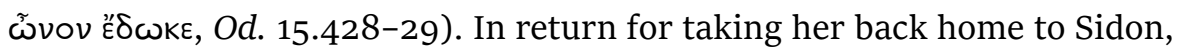
the woman promises to take with her the child of Eumaeus: 'I would lead him (äyoun') on board, and he would fetch you a countless onos when

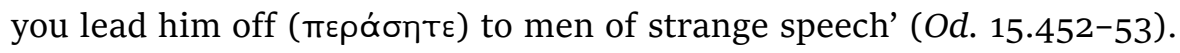
The Sidonian woman dies on the journey, but Eumaeus is 'acquired' by Laërtes (Od. 15.483), just as he had previously 'acquired' Eurycleia

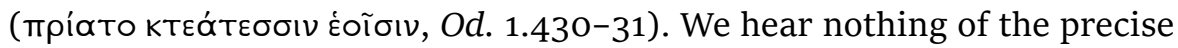

64. According to Heubeck (1989: 215) the term ơmplórтๆv does not make sense here; he therefore assumes a misunderstanding.

65. Garlan 1984: 45 . 
value of the vast onos the child Eumaeus was expected to fetch; of Eurycleia we know that the wealth (ktear) Laërtes gave to acquire her had been the value of twenty oxen. ${ }^{66}$

In these cases, onos is realised only through transport abroad. Thus, onos is a form of ransom, but one paid by strangers rather than relatives. There is one case in which ōnos is proposed to be paid for objects: the Phoenicians offer jewellery to Eumaeus's mother (Od. 15.463), who in

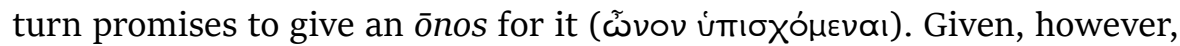
that the real onos the men will take with them is the child Eumaeus, it is not unlikely that the word is used here as a form of foreshadowing of subsequent events. This is also true of the phrase ōnos hodaiōn used by the Sidonian woman as she gives them their instructions after they have sworn an oath to her:

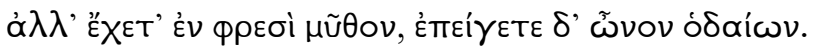

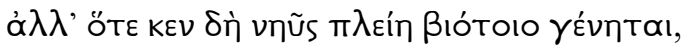

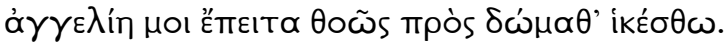

No; keep the idea to yourselves, and collect your homeward cargo (ōnon hodaiōn) as fast as you can. When all the stores (biotos) are on board the ship, quickly send word to me up at the house (Od. 15.445-47, tr. Rieu).

This ōnos hodaiōn, often rendered as 'homeward cargo', will of course turn out to be the child Eumaeus, so that the phrase epeigete d'onnon hodaiōn may also refer to the future profit that Eumaeus will fetch. In other words, and differing from Rieu's translation, what the woman may also be saying to the Phoenicians is: 'Keep my words in mind and seek the proceeds of your cargo!' ${ }^{67}$ Once more we would then have an example of onos realised through transportation.

The term onos alludes to rudimentary origins of the slave-trade, and it is in this context we find the verb oneomai in classical written sources. ${ }^{68}$ This

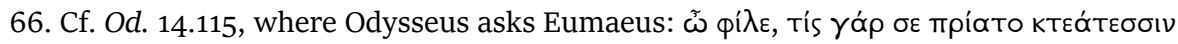
Éoĩoı. This is the case of Mesaulius, whom Eumaeus had acquired with his own revenues (Od. 14.452), which must have been yields of his livestock. The mobile character of possessions named ktear is stressed by Scheid-Tissinier 1994: 46 .

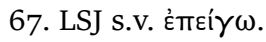

68. See the argumentation of Finley 1955: 173, and Rihll 1993: 77-107, who associates the founding of colonies with slave trade. For the slave trade in archaic and classical Greece see Garlan 1984: 51-54. 
form of trade is structurally connected to kidnap and robbery, since onnos is acquired through the transportation of a kidnapped person. Ōnos may consist of metal objects, such as those circulating as gifts (e.g. the silver mixing bowl offered as ōnos for Lycaon) as well as unspecified kteata; it may also be said to consist of biotos, the means of living, often rendered as 'wealth' or 'substance'. So, the goatherd Melanthius threatens to take Eumaeus away from Ithaca by boat in order that he might fetch him much

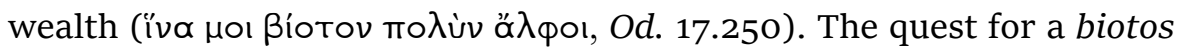
is the catalyst for many journeys in Homer, and it will be the focus of the final section.

\subsection{The quest for the means of living (biotos) and other necessary goods: Alum, purple, linen, and metals}

Within the Homeric poems a series of journeys is undertaken for the purpose of earning both the means of living, Bíotos (biotos) and necessary

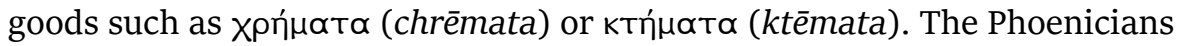
who carry off Eumaeus spend a year on the island of Syria, where Eumaeus's father rules, and fill their ship with biotos ( $\dot{\varepsilon} v$ v

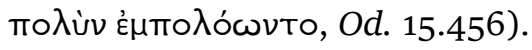

Egypt is frequently named as a place where there is plenty of such 'means of living' to be found. Nestor tells Telemachus of Menelaus's exploits there, where he collected (ageirein) much biotos and gold, taking these goods (also described as ktēmata) back home on ships. ${ }^{69}$ Achilles alludes to the plentiful ktêmata to be found in the houses of Egyptian Thebes when he rejects Agamemnon's gifts of compensation (Il. 9.382). Telemachus learns during his visit at Sparta that Helen and Menelaus had been staying for some time at Thebes, where there were so many ktēmata ( back from Egypt are specified and the names of the donors given: there are two silver baths, a tripod, and ten talents of gold that Menelaus claims to have received from Polybus of Thebes. His wife Alkandre gave Helen the golden spindle and the silver basket she uses during Telemachus's visit (Od. 4.125-35). In addition, there are the фópuaka (pharmaka) Helen uses to induce Telemachus to forget his grief over his father. These pharmaka also come from Egypt where many harmful as well as many beneficial

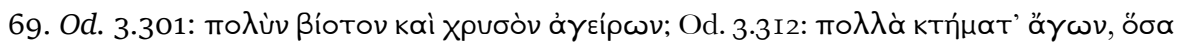

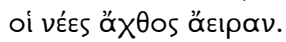


pharmaka are said to grow (Od. 4.228-30). We hear from Mentes that Odysseus had tried to obtain such pharmaka from Ilus, at Ephyra, to use as poison to smear on the tips of his arrows. When Ilus refused to provide the poison, Mentes's father gave it to Odysseus instead (Od. 1.259-64).

In the Cretan tale, Odysseus also alleges a stay in Egypt, where he claims to have collected many goods, described here with the term chrēmata. He emphasises that everyone gave goods, without going into any further de-

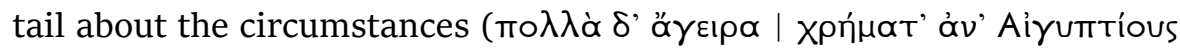

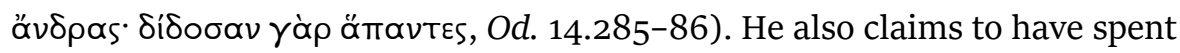
seven years in Egypt, just like Menelaus in the story told by Nestor at Pylos (Od. 3.305-12: Menelaus and Helen; 14.287: Odysseus). In his story Odysseus paints himself as a leader of companions-in-arms who go to Egypt in order to rampage and plunder. This suggests that the chrēmata obtained by Odysseus are most likely booty, sometimes including human booty. He claims that his companions had taken women and children off and killed their men. Whereas his companions are destroyed in battle with Egyptian fighters, he claims that he himself was spared by the king and taken in as a guest-friend (Od. 14.276-84). This may mean that he is taken on as a mercenary, in keeping with a similar tale in Herodotus about some Ionian and Carian pirates who are taken on as mercenaries by Psammetichus I (Hdt. 2.152)..$^{70}$ According to Sarah Humphreys, such exchanges of manpower are more important in archaic times than the exchange of goods. ${ }^{71}$ But equally, this type of traffic in mercenaries cannot be imagined without an attendant exchange of goods.

The list of objects brought back from Egypt to Menelaus's home in Sparta suggests that some of the goods are gifts of remembrance, such as we have already met in the context of our treatment of guest-friendships. But we have also noted that such gifts, brought home from abroad, are always also differentiated according to their material value as metal and textile goods. The terms biotos (means of living, from ßıów-I live), ktēma (acquired good, from kTáoual, I acquire), and chrēma (a thing one needs, from $x$ póoual, I need) do not suggest anything about the materiality of the goods encompassed by the terms. This must mean that there is no fixed material content attached to these terms. What they all have in common is

70. Herodotus also uses the term chrèmata, when he enumerates booty taken from the Persians after the battle of Plataea, including women, horses, camels, talents and other goods (talla chrēmata) which are then specified as silver and gold and patterned garments (Hdt. 9.81-82).

71. Humphreys 1978: 169. 
mobility. Chrēmata, only mentioned in the Odyssey, are collected during a journey, or consumed by the suitors, so that it can be assumed that these tend to be natural goods, mostly the products of livestock farming..$^{72}$ The possibility should not be excluded, however, that they may also include human booty, acquired during a journey and exchanged for other commodities, as we saw in our discussion of kerdos and onos. These other goods are what ktemmata tends to stand for: the treasures found in homes, the keimèlia brought from abroad, and which can also be carried off again; these may be metal or textile goods, depending on the given context. ${ }^{73}$ Biotos appears often to be used as a synonym for agricultural goods or raw materials. The suitors make a distinction between biotos and ktēmata in their plans for dividing among themselves Telemachus's property, which consists of livestock and of material objects. ${ }^{74}$ It seems likely that in this instance biotos refers to the herds and flocks and their products, such as meat and wool. ${ }^{75}$

As for the biotos brought over from Egypt by Menelaus, it can be assumed that the term is meant to point to linen fabrics, or flax. Scholarship tends to assume a Greek interest in Egyptian grain, linen, papyrus, fayence, gold, and medicinal plants. ${ }^{76}$ The Egyptians in turn are thought to have imported oil, wine, woollen fabrics, and silver from Greece. There can be no doubt that gold was a key interest, since Egypt was the main purveyor of gold throughout antiquity, and Homeric epic explicitly

72. The word is also used for the goods consumed by the suitors (Od. 16.389) and the

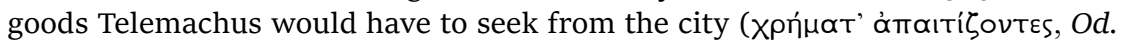

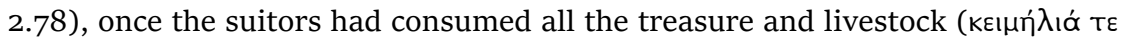
прóßaoív, Od. 2.75). This suggests that chrēmata mostly refers to agricultural but also material goods.

73. Such ktēmata are found in the megaron or the house (oikos) itself (Od. 7.150; 11.341; 17.532; 23.354), like the keimèlia of bronze, gold, and iron that Odysseus claims to have brought and stored in the house of the king of the Thesprotians (Od. 14.3236). They are often enumerated alongside captured women (Od. 9.41). Shepherds are also given ktêmata (Od. $3.154 ; 21.214)$. In the Iliad the fighting is for the sake of Helen and the ktēmata (Il. 3.70; 72; 91; 93; 255; 285; 458; 7.35; 363; 389; 400; 13.626).

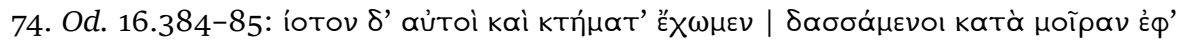
ìuéas.

75. Od. 1.16o: ßíotov vท́ாо

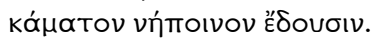

76. Austin 1970: 35-40; Bravo 1983: 18-19; Reed 1984: 36; Boardman 1981: 151-52. Contacts between Egypt and Greece can be traced back to Minoan and (post-) Mycenaean times. See Kelder 2009 and Kramer-Hajos 2016. On the social use of Egyptian exotica in Mycenaean Greece see Burns 2010. 
describes gold as an Egyptian commodity. ${ }^{77}$ Egyptian imports of grain are, however, more doubtful. There is a mention of grain shipments from Egypt in a Bacchylides fragment, ${ }^{78}$ which leads Benedetto Bravo to suspect that the biotos brought from Egypt by Menelaus is grain..$^{79}$ However, there is no evidence in the epics to substantiate this. ${ }^{80}$ Peter Garnsey's research shows that grain imports only became a significant factor during the Peloponnesian war. According to Plutarch, the Egyptian pharaoh sent 40,000 medimnoi of wheat as a gift (dōron) to the Athenians when there was a shortage of grain. ${ }^{81}$ Lin Foxhall has pointed out that in any case it was not barley, which was cultivated in Attica, but finer grain species, such as wheat, that were imported..$^{82}$ It is therefore more likely that Menelaus's Egyptian biotos consists of special commodities which were not available at home but which were not immediate necessities. As well as wheat, these might include fabrics such as linen and raw materials such as flax. There is solid written evidence from early on for the cultivation of flax and the production of linen in Egypt, with only isolated examples for Greece. ${ }^{83}$ Egyptian votive offerings made from linen, such as the decorated linen breastplate offered by Amasis to Athena at Lindos, attracted the attention of ancient authors like Herodotus who gave detailed descriptions (Hdt. 2.182; 3.47). ${ }^{84}$ The assumption that biotos refers to textiles is also in keeping with Homeric usage, since biotos is used to describe wealth possessed by those who are in a position to take in guests. ${ }^{85}$ The word biotos is also used for life at the point when it is about to end in death

77. See Edzard 1960: 18-40; Liverani 1987: 66-73 assumes that the Egyptian monopoly on gold was broken at the end of the second millennium by Syria and Palestine. For gold resources in Egypt see Helck and Otto 1977, s.v. Gold, Goldgewinnung, Goldminen. For further resources of gold in the Aegean (Siphnos, Thasos, Sardis) see Treister 1996: 25-27, 140-41.

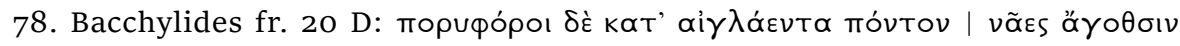

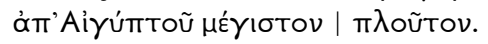

79. Bravo 1983: 17-19.

80. Odysseus's allusion to the Thesprotians' journeys to wheat-rich Dulichium may

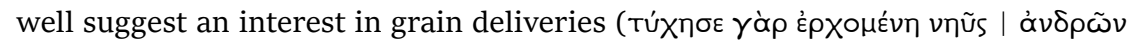

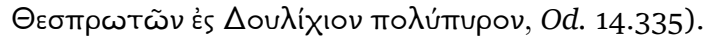

81. Plut. Per. 37; cf. Philochoros FGrHist 328 F 119; Schol. Ar. Vesp. 718 a-b. See Garnsey 1985: 62-75; [1988] 1993: 110-13. Jameson 1983: 6-13 believes that precautions taken against potential famines were generally poor.

82. Foxhall 1998: 300-6.

83. Cf. Robkin 1979: 469-74; Rougement 2007: 46-49.

84. In 2.105 Herodotus compares Egyptian linen with linen from Colchis.

85. Axylos, a philos of men (Il. 6.14), and Diocles (Od. 3.490) are called rich in goods, aphneios biotoio. Both have houses at main routes and are able to host guests. 
(Il. $4.170 ; 7.104 ; 13.563 ; 16.787$ ). Thus, it may also mean the material through which human fate is materialised, and which is necessary for the accommodation of guests: wool and woven cloths. Of course, the gift of the silver wool basket and the golden spindle also indirectly point to this interest in textiles from Egypt.

We have already made the assumption that depictions of the use of oil during weaving suggest knowledge of linen weaving. The dancing girls on

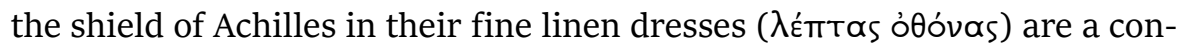
crete example of linen clothing (Il. 18.595). Pliny lists othoninum as one of the most common types of Egyptian linen (Plin. HN 19.2.15). Elsewhere ad-

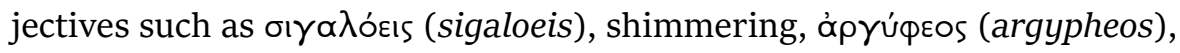

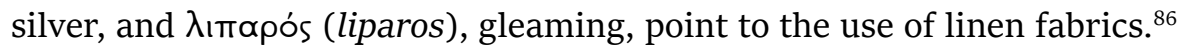
We have seen already that the garments mostly characterised with these adjectives are chitones and pharea, which may therefore be assumed to be made from linen. To these we may add peploi and rhègea. Thus, we find sigaloeis attributed to the chitōnes worn by Odysseus and Telemachus (Od. $19.232 ; 15.60-61$ ), and the garments (heimata) laundered by the Trojan women in basins (Il. 22.154) and by Nausicaa and her friends in the river (Od. 6.26). The latter are specified as peploi and rhègea, which are also described elsewhere as sigaloeis (Od. 6.38; 11.189). Circe and Calypso both wear pharea described with the adjective argypheos (Od. 5.230: Calypso; 10.543: Circe). For the veils worn by Penelope (Od. 1.334; 18.210), Charis (Il. 18.381), and Hecuba (Il. 22.406) the adjective used is liparos. According to Herodotus and Thucydides the long linen chitōn was worn in the cities of Asia Minor up until the fifth century (Thuc. 1.6; Hdt. 5.87-88). In classical times we find linen fabrics listed in the inventories of Hera's sanctuary at Samos but not at any Attic sanctuaries. ${ }^{87}$ The assumption, already made by Ernst Buschor, is that linen clothing was a result of relations with Egypt, relations that were particularly cultivated in the cities of Asia Minor. ${ }^{88} \mathrm{~A}$ memory of the importation of such linen fabrics would not then be unsurprising in an Ionian epic such as the Odyssey.

Helen's Egyptian pharmaka are also connected with a potential interest in textiles. Scholarship in the field of Graeco-Egyptian relations tends to assume that the plants in question are medicinal or poisonous. But Pollux

86. See Blümner 1912: 191-99; Bieber 1967: 25. The word lita for textiles draped over chariots (Il. 8.441) and over chairs in the megaron (Od. 1.130; 10.352) and used as shrouds (Il. 18.352) suggests the use of linen fabrics. See also ch. 2.3, n. 116.

87. Betalli 1982: 266. Cf. now Brøns 2017.

88. Buschor 1912: 44. For confirmation see also Pliny (HN 19.1) and Pollux (6.71). 
and Hesychius show that pharmakon was also used for dyes. ${ }^{89}$ The pharmaka Helen uses to cause Telemachus to forget his grief over his father may well have a double use too. They are described as 'banishing sorrow, lacking gall, and eliminating painful memories':

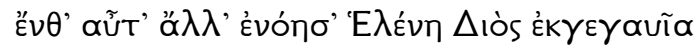

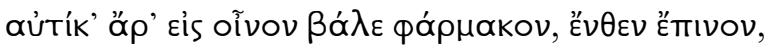

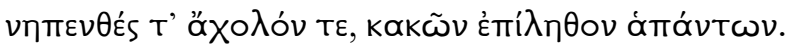

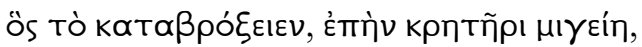

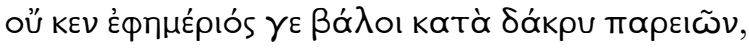

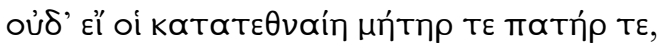

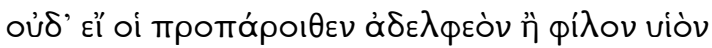

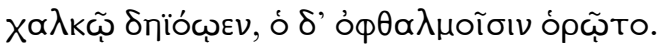

Helen, meanwhile, the child of Zeus, had had an idea. Into the bowl in which their wine was mixed, she slipped a drug (pharmakon) that had the power of robbing grief and anger of their sting and banished all painful memories. No one that swallowed this, dissolved in wine, could shed a single tear that day, even for death of his mother and father, or if they put his brother or his own son to the sword and he were there to see it done (Od. 4.219-26, tr. Rieu).

Pliny the Elder ascribes just such a function of calming the flow of tears to alum, which he otherwise describes in term of its uses for the dying of wool (Plin. HN 35.183-88). Before the invention of synthetic dyes, alum was an important fixing agent, used for dying as well as tanning. ${ }^{90}$ According to Pliny it occurs in different varieties in a number of regions in the Mediterranean and Asia Minor. The most prized variety is from Egypt, followed by that from Melos (laudatissimum in Aegypto, proximum in Melo, Plin. HN 35.184). Herodotus provides evidence that the Greeks obtained alum from Egypt when he has Amasis send a thousand talents of alum to the Delphians to help with rebuilding the temple of Apollo (Hdt. 2.180). It is possible then that Helen's Egyptian pharmaka are an allusion to alum, which has the power to stop tears flowing, and is also used for the dyeing of wool and fabrics. ${ }^{91}$

89. Pollux 7.169; Hesychius s.v. pharmakon. Empedocles (fr. 31 B 23 Diels-Kranz) uses pharmaka for colours used by painters of votive tablets. See Stulz 1990: 30-32. 90. Blümner 1912: 228-32; Faber 1937: 698-711. See now Grand-Clément 2011. 91. The symbolic dimension of Helena's gift as medium of memorializing and forgetting is discussed in ch. 3.2 . 
Dye itself, and purple especially, is among the raw materials that must have been at least partly obtained from abroad. There is evidence for purple sea snails both on the Greek and the Phoenician coasts. According to Pausanias, the best sea snails for the manufacture of purple dye-after those of Phoenicia-were found on the coast of Laconia (Paus. 3.21.6). According to Pliny the best purple in Asia is from Tyre, in Europe from Laconia; he adds to these the North-African coast of Gaetulia, which was a source of purple during the first century CE (Plin. HN 9.127). Meliboean purple from Thessaly was also known in Roman antiquity..$^{92}$ Remains of the purple sea snail or its shell have been found at Cythera on the southern Laconian coast, at a number of locations on Crete, at Akrotiri on Thera, at Troy, and at Rachi by the Isthmus of Corinth. Recent finds at Rachi indicate dying as an activity conducted here on a large scale. ${ }^{93}$ According to Plutarch the five thousand talents of purple Alexander took possession of at Susa came from Hermione, a coastal town in the Argolid not far from Rachi. In his opinion, the addition of honey to the purple dyes resulted in the special brilliance and longevity of the colour (Plut. Alex. 36).

This interest in purple dyeing in the Western Peloponnese may be alluded to in Odysseus's search for pharmaka, as related by Mentes. His search brings him first to Ephyra before he arrives at Taphos. Ephyre is an old name for Corinth, which of course is close to the dyeing-works at Rachi. ${ }^{94}$ The names of the Cypselid family, who ruled at Corinth during the seventh century are revealing in this context: Labda, the mother of the dynasty's founder, is said to have hidden her son in a beehive, a

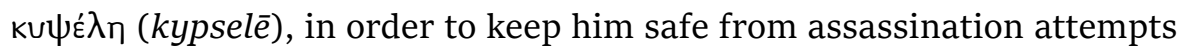
by rivals (Hdt. 5.92). The son of Cypselus, Periandrus, called his wife Melissa, bee (Hdt. 5.92; Diog. Laert. 1.94). According to Pollux the weirs in which murex snails were caught were also called kypselai (Poll. 1.47). Thus, the name of Cypselus himself may allude either to the significance of honey for the preservation of purple dyes, or to the catching of the murex snails. ${ }^{95}$

92. Lucretius 2.499-500; Vergil, Aen. 5.250-51. Cf. also Pind. Pyth. 4.80. For Thessalian purple see Silver 1991: 249.

93. For an overview of purple-dyeing see Alfaro 2004 and Marín-Aquilera, Iacona and Gleba 2018: 132-35, 138. On Rachi see Kardara 1960: 261-66; 1970: 94-97; Anderson-Stojanovic 1988: 268-69; 1991: 303-4.

94. See the scholiast on Il. 6.152. Compare also Pausanias (2.1.1) on the foundation history of Corinth (Ephyra). Thucydides (1.46.4) and Apollodorus (Strab. 7.7.10) think of Ephyra as a place in Thesprotia.

95. This is assumed by Kardara 1960. 
There is some degree of overlap between the regions associated with murex and with purple dyeing and the characters who wear purple in Homer. The adjectives порфúpєos (porphyreos) and фoıvıкóєıs (phoinikoeis) especially point to the use of purple dye, and both are used in connection with the clothing worn by high-status individuals such as Agamemnon, Achilles, Nestor, Thoas, Odysseus, or Telemachus. Achilles, who is said to bring with him purple-coloured textiles referred to as rhègea and tapētes, comes from Thessaly. Helen, weaving a purple diplax, is of course from Laconia. ${ }^{96}$ A purple mantle, pharos, is worn by Agamemnon (Il. 8.221), who is from the Argolid, as well as by Odysseus (Od. 8.84). The cloths and blankets used at Odysseus's house to cover the chairs and to make beds for strangers are also described as porphyreos and phoinokeis. ${ }^{97}$ The Trojans also possess purple-coloured fabrics, as do the inhabitants of mythical locations such as Phaeacia, and mythical figures such as the nymphs at Ithaca. Andromache weaves a purple diplax (Il. 22.441); Arete spins sea-purple

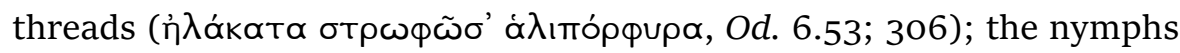

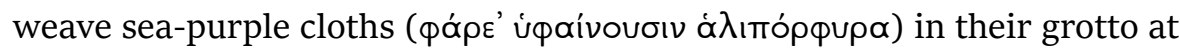
Ithaca. Nearby in the cave there are mixing bowls and jars in which bees store up honey (Il. 4.141-42). Chrysoula Kardara reads the Ithacan cave of the nymphs as a description of a purple dye-works, not least since the location is characterised as rich in water, as well as windy, both necessary conditions for dye-works. ${ }^{98}$ The only explicit instance of purple dyeing in Homer are the Carian and Maeonian women mentioned in the Iliad.99 It has frequently been assumed that the purple called phoinix must stem

96. Il. 24.644-45; 9.200 (Achilles); Od. 4.297-8 (Helen). According to scholia on Il.

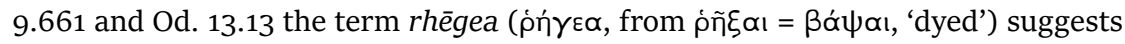
that the fabric is dyed. Stulz 1990: 116, n. 37.

97. Od. $4.115 ; 154$ (woollen chlainai); 20.250-51 (rhēgea, pharea, and tapètes), described with the adjective porphyreos. Those worn by Nestor at Pylos (Il. 10.133), Telemachus (Od. 21.118), and Thoas of Lemnos (Od. 14.500) are described as phoinikoeis. The adjective porphyreos is also used for the peploi used to wrap Hector's remains (Il. 24.796). According to Marinatos (1967: 3) the two terms refer to different shades of red. He also suggests that cherry-red and dark violet tones were achieved through the use of the orchil-producing lichen dyes (made from Roccella tinctoria) rather than murex. Cf. also Barber 1994: 113 and Grand-Clément 2011: 168-69, who assume madder, a plant (Rubia tinctorum, see Baumann 1982: 156, fig. 317 and 320), and kermes, a type of insect living on oaks (see Baumann 1982: 156-58, fig. 38 and 318), as sources of red colours.

98. Kardera 1960: 261-66. See also Silver 1991: 267.

99. Il. 4.141-42. The women in the simile are dyeing ivory ornaments for a horse's bridle. Murex snails have been found also at Troy. Silver 1991: 260. 
from Phoenicia. ${ }^{100}$ There is, however, no clear evidence for this in Homeric epic. When products from Phoenicia appear, these are silver vessels and patterned textiles, which probably included purple colouring-but purple itself is never mentioned. ${ }^{101}$

Given the huge number of murex snails that were required (12,000 creatures to make just two and half kilos of dye), ${ }^{102}$ it is likely that Phoenicians as well as Greeks were interested in exploring new sources. This may account for the foundation of Cyrene by Therans (around 630 BCE) and Carthage by Phoenicians (eighth/seventh century). ${ }^{103}$ We have already seen that Pliny speaks of the Gaetulian coast, which stretches from modern Libya to Morocco, as being rich in murex snails. In Herodotus's account of the foundation of Cyrene, a key role is played by a Cretan murex-fisher who guides the Therans, in search of Libya, to the island of Plataea where they leave him behind. Herodotus gives no explanation for this strange stay on what is described as a deserted island. ${ }^{104}$ The story makes more sense if one assumes that the murex-fisher was exploiting local resources. In Herodotus's account the Therans, in fact, settled in Cyrene, after an interlude at Plataea, because of a famine caused by years of drought. ${ }^{105}$ But the outcome of the move is that the new settlers have access to resources beyond just grain. A Laconian bowl from around 560 BCE shows Arcesilaus, the Cyrenaean ruler, weighing goods usually

100. Blümner 1912: 233; Reinhold 1970: 9-16; Stulz 1990: 97. According to Muhly (1970: 32-34) phoinix is the original Greek word for purple, which was known in Mycenaean times and used by the Sidonians later on.

101. The silver mixing vessel received by Menelaus from the king of the Sidonians and handed on to Telemachus (Od. 4.616-19) provides an example, as does the silver kratēr given as a prize by Achilles from Patroclus's estate and which had been presented to Thoas by Phoenicians (Il. 23.740-47). The decorated peploi dedicated to Hera by Hecuba are said to be the work of Sidonian women (Il. 6.289-91).

102. Blümner 1912: 240; Marín-Aquilera, Iacona and Gleba 2018: 136.

103. For the founding of Cyrene see Boardman 1981: 183-89; Niemeyer 1990: 5758; Aubet 1993: 202-17 underlines the interest of the Phoenicians to gain purple and iron.

104. Hdt. 4.151. Purple-dyeing is attested on Crete since Minoan times. See Reese 1987: 201-6.

105. Hdt. 4.151. On famines and over-population as explanations for the development of colonisation see e.g. Camp 1979: 397-411; Cawkwell 1992: 289-303. For a critique see Osborne 1998: 251-69. Modern research on migration has demonstrated the deficiencies of such models (which can be traced to Thomas Robert Malthus's Essay on the Principle of Population (1798). See for instance Ehmer 1998: 5-29, who shows that modern migration processes are frequently caused by the coalescing of a variety of political, social, and economic factors. 


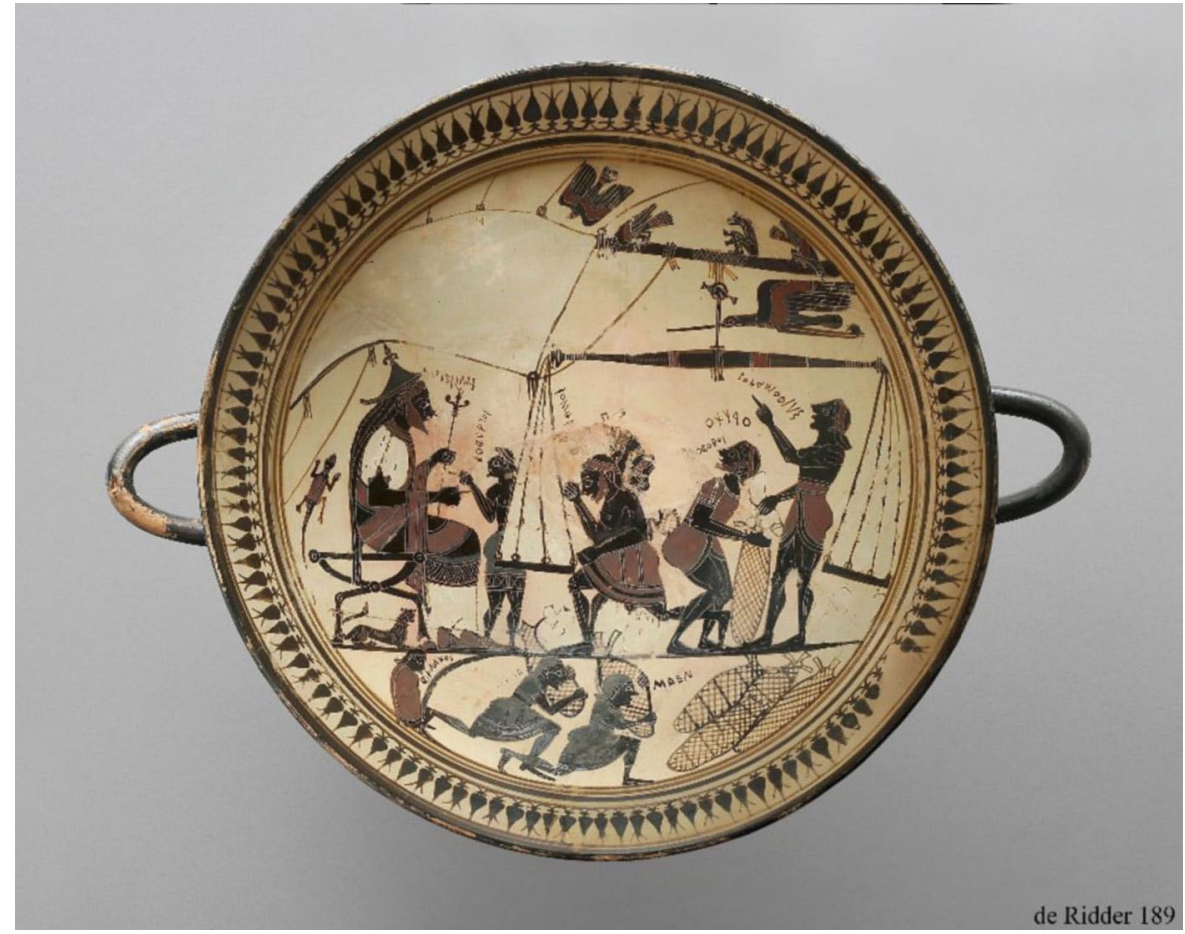

Figure 9: Arcesilaus weighing silphium or wool. Laconian kylix, ca 560 BCE. Bibliothèque Nationale, Cabinet des Médailles 1899. http://medaillesetantiques.bnf.fr/ ark:/12148/c33gbhc8h

assumed to be silphium, a plant attested as native to the region in ancient sources, ${ }^{106}$ or perhaps wool, for which the region is also known. ${ }^{107}$ On the lowest part of the image, however, we observe what appear to be nets, which may be devices used to catch murex snails (Figure 9). ${ }^{108}$ In Pindar's fourth Pythian Ode we find Arcesilaus celebrated because of his victory in a chariot race as a descendant of the Argonauts who flourishes 'as at

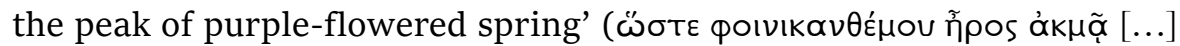
$\theta \alpha \dot{\alpha} \lambda \lambda_{\varepsilon l}$, Pyth. 4.64-65). The phrase phoinikanthemou eros akmai is not just a poetic image-it very specifically evokes the season during which

106. Hdt. 4.169; Theophr. Caus. pl. 6.3; Plin. HN 20.100. Hopper 1982: 46 and Murray 1980: 118 assume silphium. See also Crielaard 2011: 103 who stresses the connection between weighing and authority. The king is considered the guarantee of justice.

107. Hdt. 4.155; 157. Boardman [1964] 1999 assumes wool.

108. Simon 1976, table XV. 
the murex harvest, which runs from the hottest days of summer until spring, reaches its peak. ${ }^{109}$

Certainly, the search for metals, including Egyptian gold but also iron, copper, and silver as well as alloys needed for the production of bronze, was of great significance. Homeric epic clearly indicates this. The ostensible Taphian Mentes claims to be transporting iron on his ship and to be plan-

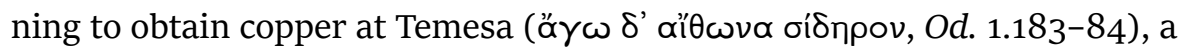
city in Magna Graecia according to the scholia. ${ }^{110}$ The search for metal only comes into focus properly, however, in later historians' accounts. Tartessous, the Spanish silver mine discovered by the Samian Colaeus when he is blown off course on his way to Egypt, is modern Huelva. ${ }^{111}$ Upon his return to Samos, Colaeus dedicates a tenth of his profits to the sanctuary of Hera. He is said to be the first Greek to have taken a ship to Tartessus (Hdt. 4.151-52). ${ }^{12}$ According to the Old Testament, the Phoenicians of Tyre also went to Tartessus for silver, iron, tin, and lead. ${ }^{113}$ In the epics, the search for such resources usually goes hand in hand with the forging of guest-friendships, which are remembered through special objects such as mixing bowls, drinking vessels, or spinning apparatus. This is not only true of the Egyptian contacts made by Menelaus and Helen when they enjoyed the hospitality of Polybus and Alkandre at Thebes. Menelaus also has networks at Sidon in Phoenicia; the mixing bowl received by Telemachus at Sparta was originally given to Menelaus by a guest-friend, the basileus of the Sidonians (Od. 4.615-19). A mixing bowl from Lemnos that fell into the hands of Patroclus as booty was also a Sidonian guest-gift. Based on Herodotus's account, Latacz suspects that Lemnos was an important staging post for Phoenicians on the way to the silver mines of Thasos, and that the Phoenicians therefore cultivated guest-friendships with the local elite at

109. Blümner 1912: 237. On Pindar's metaphorical language see Krummen 1990: 48-50, 58-59. She shows that Pindar's metaphors are not just decorative, they have paradigmatic power to affect the listener or reader since 'he already knows the images'. This becomes especially clear in references to ritual and cult at Cyrene (98-151). Silver 1991: 241-81 connects the myth of the Argonauts to the quest for purple. 110. Schol. Od. 1.184 .

111. Chamorro 1987: 197-232.

112. For dating the journey of Colaeus in the seventh century (638 BCE) see Coldstream 1983: 203.

113. Ezechiel 27.12-13. Cf. Aubet 1993: 98-102; Treister 1996: 30-31; 148-81.

114. Latacz 1990: 11-13. Cf. also Muhly 1970: 42-43 and Stanley 1986: 4-9. Stanley interprets the gift for Thoas as an 'opening gift' to start trading activities. Archaeological evidence is not attested before the second half of the seventh century BCE yet. See Treister 1996: 25-26. Aubet (1993: 117-18) understands the gifts as 'payment in advance'. 
Lemnos. ${ }^{114}$ We must also assume that the guest-friendship between Mentes and Odysseus is based on reciprocal exchange of commodities, even though we only explicitly hear of the pharmaka received by Odysseus.

The combination of two kinds of goods-commemorative and prestige gifts on the one hand, and agricultural and similar resources on the otheris known to us from other cultures. Michael Rowlands has pointed out that wherever 'prestige objects' are in circulation they are seen as rights, and that this circulation is followed by different, subordinate, systems of exchange. ${ }^{115}$ It is not surprising that this leads to the foundation of settlements or colonies only reported by the historians of the fifth century, although the process had already begun by 750-700 BCE. The difficulties surrounding transport and preparation of provisions for journeys made lengthy stays necessary in places where materials needed to be gathered or mined, as is the case with murex and with metals. It makes sense that this then leads to agricultural activity designed to meet the settlers' own needs. ${ }^{116}$

For John Nicholas Coldstream this also provides an explanation for the distribution of Attic geometric pottery around the Mediterranean. Finds of such geometric ware in graves at Salamis on Cyprus, at Knossos, in Israel, at Tyre, and in Huelva in Spain are not, as John Boardman believes, evidence of widespread trade in ceramics but an indication of the existence of guest-friendships forged for the purpose of procuring metals. Coldstream interprets vessels that sometimes serve as grave markers in Athens as guest-gifts for local leaders who had control over metal-routes to Syria, Mesopotamia, or Spain. He does not envisage direct contact between the inhabitants of ninth and eighth century Athens and the population of the sites where the items have been found. Especially in the case of Huelva, Coldstream supposes that ceramics made their way via Tyre to Spain. ${ }^{117}$ Tyre itself lies at the end of a tin-route that led via Syria to Iran during

\section{Rowlands 1987: 8 .}

116. This must have been the case for mining in Etruria. Mining was a seasonal activity until the sixth century BCE. See e.g. the rich metal finds and remains indicating metal smelting processes at the eighth-century Euboean settlement of Pithekussai. See Kopcke 1992: 101-8; Treister 1996: 30-37, 146-81, with warning against overly close connections between colonisation and metal processing. Snodgrass 1980: 335 and Morris 1992: 141 emphasise the link between colonisation and the search for metals. According to Ridgway 2006: 300 the 'Italian connection' goes back to Mycenaean times.

117. Coldstream 1983: 201-7; 1994: 47-59. Ridgway 1992 also argues with the concept of gift-exchange. Osborne 1996: 31-44 assumes a complex network of exchange similar to the modern system of interdependent markets. On earlier Phoenician contacts with the West see Niemeyer 1990: 45-64; Treister 1996: 157-58. 
the second millennium; Michael Heltzer has proposed that this is where the Minoans and Cypriots obtained the tin they required for their bronze production. ${ }^{118}$ Copper and iron can be mined in Greece itself, but tin needed to be imported from Asia Minor, the Taurus mountains, and Afghanistan, or from Spain or England. ${ }^{119}$ The rare find of a seventh-century Greek mixing bowl in the famous Vix-grave in Burgundy is also assumed to be connected to an interest in the western tin-route which led to Cornwall. ${ }^{120}$ While apoikiai with ethnically unified populations grew in the west from the eighth and seventh centuries onwards, the endpoints of the eastern metal-routes became emporia, inhabited by ethnically varied populations. Judging from ceramic finds, one such place, Al Mina, was inhabited by Phoenicians, Cypriots, and Greeks and formed a trading centre for commodities from Asia Minor and the Near East. ${ }^{121}$ Naucratis was another such emporion, founded around 638 BCE by Greeks of Eastern Ionian origin.

Nestor's tale of Odysseus's stay in Egypt fits well into the context of the foundation of Naucratis, according to Michel Austin who also sees in the journey of Helen and Menelaus to Egyptian Thebes a memory of contacts between Egypt and the Minoans. ${ }^{122}$ This distinction may not be particularly important since archaeological finds point to continuity of contacts from the second to the first millennium in almost all locations where archaic and classical written sources attest to exchange between Greeks and other Mediterranean peoples. ${ }^{123}$ This would suggest that there is no reason in the poems to distinguish between tradition and contemporary practice. In Herodotus's account the pharaoh Amasis hands over the city of Naucratis as a privilege, which is presented as a novel act, although the circumstances

118. According to the texts from the archives of Mari examined by Heltzer, this was the form of gift-exchange conducted amongst rulers. The rulers of Mari gave tin from Elam to Ugarit and Crete as gifts, while sending gold and silver back to Elam. In return they received textiles, arms, and ceramics from Crete. Heltzer 1989: 7-27.

119. The origin of tin is highly contested. Muhly 1985: 275-291 argues that tin came from Afghanistan. For discussion see Treister 1996: 28-29, 152-57.

120. Graham 1984: 5-6. The Phocaeans were especially engaged here, through the founding of Massilia and contacts with Tartessos. Cf. Hdt. 1.163. For the Greek engagement in Tartessos see Treister 1996: 148-50.

121. Kearsley 1999; Villing 2005. For oriental influences see Burkert 1984: 1992. On the meaning of the emporion see Demetriou 2011: 272: 'Emporia were nodes along trade networks that connected the Mediterranean on the local level, as redistribution centers that had contacts with their immediate surroundings, the regional level, as stopping points on regional trade networks, and the Mediterranean level, as export and import centers'.

122. Austin 1970: 12-33.

123. See e.g. Smith 1987 for the Italian evidence. Cf. also de Polignac 1994: 11. 
are not clear. Herodotus also says that ships arriving at any other mouth of the Nile had to sail or bring their cargo to Naucratis, in 'such honour

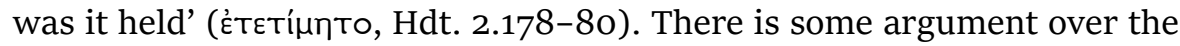
exact nature of this honour, once again featuring the word timan, which we explored earlier in the context of the examination of the privileges of the Homeric basileus. Polanyi considered Naucratis a 'port of trade' supposing that trade there was politically regulated and goods bought and sold at set prices. ${ }^{124}$ Others assume that Egypt feared the free market and reject the idea of trading with set prices. Figueira proposes that the Pharaoh received a 10 per cent tax on all traded goods, as is shown by a Stele of Nektunebo I (380-363 BCE). ${ }^{125}$

There is no contradiction between the two proposals. As we can see, there are very recent examples of privileges granted to individuals and families residing at key points on trade-routes. These would include the right to set the price for certain goods: for example, salt. In return for this right, the individuals would make payments, equivalent to a tax, to an administrative centre. ${ }^{126}$ We might also think of the customs duties that are found in many regions during antiquity, such as the duties levied at the gates of Palmyra for each camel load. ${ }^{127}$ Cypselid Corinth was also a profitable emporion that benefited from toll charges given as the reason for its wealth in chrēmata, by Thucydides (Thuc. 1.13). Hasebroek supposes that the chrēmata are toll charges which Corinth was able to levy because of its strategic location, especially as Thucydides says that the Corinthians fought the pirates and made the roads safe. ${ }^{128}$ According to Heraclides the tyrant Periandrus levied similar charges when he built the port of Lechaion in the Corinthian gulf (Heraclides fr. $5=$ FGH Müller 2.212). Strabo tells us that having control over two harbours, one on each side of the Isthmus, made Corinth wealthy, since one allowed access to Italy and the other to Asia, and this made it easy to exchange cargoes between the two

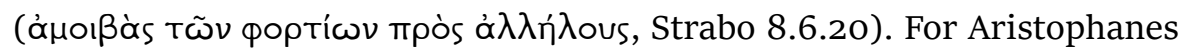
the Isthmus as a point of transfer becomes a source of comedy: 'You have

124. Polanyi [1963] 1968: 238-6o. See now Möller 200o, who works with the concept of Polanyi.

125. Figueira 1984: 25 .

126. Scholars could observe such practices in the Nepalese kingdom during the last century. See Graafen and Seeber 1993: 675; Fürer-Haimendorf 1975: 132-222.

127. See Drexhage 1988: 120-25; Ruffing 2019.

128. Hasebroek 1928: 48; 56. For another view see Hopper (1982: 43), who explains the wealth of Corinth as result of transit trading activities. According to Salmon (1984: 133) the role of trade has been overestimated. 
an Isthmus there man! You glide that cock of yours back and forth faster than the Corinthians' (Ar. Thesm. 647-48). The reference is to the practice of dragging ships travelling in from the Aegean Sea from the Saronic gulf through the Isthmus into the gulf of Corinth to save the journey around the entire Peloponnese. In Aristophanes's Birds we find further reference to such tolls, when Peithetairos schemes to raise a toll, called a phoros, for the passage of the scent from sacrifices from earth to heaven. This is compared to the fee demanded by the Boeotians to let the Athenians travel to Delphi (Ar. Av. 190). Catherine Morgan argues that Corinth was the starting point for two metal-routes, one of which led via Ithaca to Italy, and the other via Delphi to Thessaly and Macedonia. ${ }^{129}$ Although David K. Pettegrew denies the importance of trade in his recent study The Isthmus of Corinth, he underlines the role of the site of Isthmia as the meeting point of maritime and terrestrial roads and stresses its function as 'a gateway for controlling traffic flows.' ${ }^{130}$ In any case, such emporia, which were much frequented by travellers, were clearly a source of wealth for those in charge of them. The importance of clinging on to such advantage is well illustrated in Herodotus's account of the Chians' refusal to sell the Oenussae islands to the Phocaeans: the reason given is that they feared the islands would become an emporion and that this would cut Chios itself off from the market (Hdt. 1.165).

In chapter four I argued that Homeric rulership should be seen as rule over safe conduct. In this chapter so far we have seen the material basis on which such rulership rested. The ability to organise resources, be they pastures and livestock, be they human beings or commodities, must be seen as an essential basis for the power of the basilees. In order to be able to organise such resources, the safe passage of goods, people, and animals through various regions needed to be guaranteed. The raising of road tolls (dōtinai have also been interpreted as such) was a part of this system.

The social status of travellers-whether they were aristocrats themselves, or agents acting on their behalf-is not important here. There is no activity in the Homeric poems that does not involve the recruitment of labour: from the service of soldiers in battle, compensated through gifts

129. Morgan 1988: 330-38.

130. Pettegrew 2016: 45-46 and 47. He claims that the site of Isthmia 'was explicitly valued not for its facility of long-distance trade or trans-shipment but for its particular associations with congregating traffic and contest. Greek writers were concerned especially with the sanctuary of Poseidon, the historic centre of Hellenic assembly, as well as with the strategic value of the region for the defense of Corinth and the broader Peloponnese' (31). 
and portions of booty, to labour needed for weaving or shepherding, which may be obtained by force. The sea-journeys undertaken by basilees or the sons of basilees also require the recruitment of labour. The work of the rowers, such as those recruited by Telemachus, is rewarded in advance by the provision of a banquet. There is no differentiation in status between the different activities; the only difference made is between those who lead and grant safe passage and those who were obligated through gifts or compelled through force to follow.

The acquisition of goods is governed by an ambivalence between giftgiving and plundering. The same ambivalence can be seen in the acquisition of labour forces. The same circle of people who take part in a system of reciprocity and provide each other with war-service in return for gifts, also undertake the kidnapping of other human beings. Instead of gifts of honour (gera) and honour paid at the feast, the return sought for such kidnapping is the ransom (apoina) raised by the victim's relatives, or the price paid by a stranger (ōnos) to acquire the victim for themselves. There are some scholars who think that the colonizing activities of the early Greeks were essentially motivated by such kidnappings. According to Old Testament sources, the Phoenicians at Tyre obtained their human cargo from Greece. ${ }^{131}$ The idea that trade is somehow incompatible with the Greek aristocratic ethos, though it occurs repeatedly in scholarship, is clearly not borne out by evidence. ${ }^{132}$ This is especially true of the one area that our examination has determined is closest to the notion of trade in the sense of the sale of a 'commodity': the trafficking of abducted persons in return for a price, an ōnos.

Apart from this human trafficking, there is no mention of any interest in the export of goods in Homeric epic, although there are plenty of goods that are imported. Mostly, these are acquired while establishing guestfriendships, as we saw in our examination of the term xeinion. This is true of the majority of goods described with the terms chrēmata, ktēmata, and biotos, which, as discussed earlier, are likely to have comprised livestock, wool, linen, alum, purple, and metals. Where there is a relationship described as philotēs this implies, according to the argument of chapter 2, a mutual exchange of resources and goods. The exchange of arms plays a special part and must be understood as forming a bond between warriors, equivalent to the sharing of grazing lands, which forms a similar bond

131. Ezechiel 27.12-13. Cf. Jackson 1993: 64-76; Rihll 1993: 77-107.

132. See Aubet 1993: 103. 
between herd-owners. In both contexts, reciprocity is suggested through the use of the terms of mutual exchange (amoibē, ameibō/ameibomai) and of reciprocity (charis, charizomai). Both genders take part in supraregional exchange, which goes hand in hand with the forging of guest-friendships, and in the giving of memorial gifts. The representation of the supraregional exchange of goods also reflects the structures of Homeric society and its organisation in terms of the bond between a married couple and the bond between warriors.

While warriors, seafarers, shepherds and herd-owners, and robbers tend to have a lot in common, this is true also for seafarers and athletes, although they were contrasted in Euryalus's speech cited at the beginning of this chapter. Classical sources indicate that from the seventh and sixth centuries onwards both successful athletes and successful seafarers dedicated a portion of their profits to the gods. ${ }^{133}$ Archaeological finds and post-Homeric sources suggest that this practice was an innovation following the establishment of central sanctuaries where increasing quantities of dedications were made. There is little evidence of this practice in the Homeric poems, however, where the normal endpoint of the circulation of gifts is the ritual for the dead. Excavations suggest that the sanctuaries of the gods increasingly came to be the final destination of the objects in question, as we shall see. ${ }^{134}$

\subsection{Transhumance, supraregional exchange, and the emergence of extra-urban sanctuaries}

\subsubsection{The golden tripod of the Seven Sages}

I return here to my initial example of the circuit of the golden tripod among the Seven Sages: According to ancient tradition, the golden tripod,

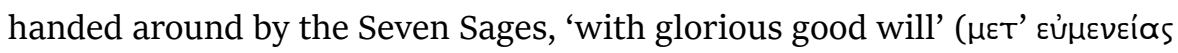

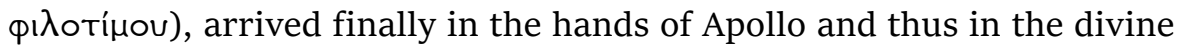
sphere (Plut. Sol. 4). ${ }^{135}$

Antiquity knew a number of variations of this myth, some of which speak of the origin of the tripod, others of the object itself. In a version related by Diogenes Laërtius, Hephaestus gives the tripod as a wedding gift to Pelops, who hands it over to Menelaus, who in turn loses it to Paris

133. See Jim 2014 .

134. See note 142 .

135. See my introductory remarks. 
(Diog. Laert. 1.32 and 82). Elsewhere the tripod's journey is as recounted in Plutarch's Life of Solon, in which Helen, recalling an oracle, is said to have thrown it into the sea on her return from Troy. The tripod is recovered by Coan fishermen, who had sold (priamenon) their catch unseen to strangers (xeinoi) from Miletus prior to their departure. A dispute over the tripod results in military conflict between Coans and Milesians, which is resolved by an oracular decree from Delphi determining that the tripod must be given to the wisest man. Thales of Miletus receives it first but sends it on to Bias at Priene, whom he considers to be wiser. Bias also knows of a wiser man, and thus the circuit of the tripod amongst the wise gets underway, resulting in the eventual return of the tripod to Thales, or, in another version known to Plutarch, to Bias. Finally, the tripod is dedicated to Ismenian Apollo (Plut. Sol. 4). In Diogenes's version the circuit of the tripod ends at the temple of Apollo at Didyma (Diog. Laert. 1.32). ${ }^{136}$ In another version told by Diogenes the tripod is dispatched to Bias, who had restored a group of girls captured in war to their parents in Messenia, having furnished them with dowries himself. In this version, Bias declares that Apollo is wise and refuses to accept the tripod. Diogenes also refers to a variant in which Bias dedicates the tripod to Heracles at Thebes (Diog. Laert. 1.82).

A further two variants occur in Plutarch. According to these, the circulated gift was not a tripod but a phiale, originally a gift from Croesus, or a cup, an heirloom of Bathycles (Plut. Sol. 4). This beaker is mentioned in a Callimachean fragment (191.32-77, Pfeiffer) that gives the most detailed description of its journey: the cup travels from Thales to Bias at Priene, from there to Periandrus at Corinth, and onwards to Solon at Athens. The remaining recipients are Chilon of Sparta, Pittacus of Mytilene, and Cleobulus of Lindos. The cup is then finally displayed in the temple of Apollo at Didyma. ${ }^{137}$

The tripod's circuit touches upon every sphere of exchange we have seen in the epic poems: marriage, trade, war, transregional guestfriendships, and relations with the divine. Only its endpoint is different: dedication in a sanctuary rather than at a funeral ritual. In every variation of the myth, the object (be it the tripod or the phialē), whatever its original function, completes its circuit by being transformed into a votive offering to the gods, most often to Apollo. In a number of cases, conflicts

136. Similar: Sch. Ar. Pl. 9 = Or. 247 Parke-Wormell. The sources are collected by Snell [1938] ${ }^{4} 1971$.

137. Fehling 1985: 23-24 suspects that Callimachus is the original author of the story of the circulating tripod. 
surrounding the ownership of the objects are resolved either by decree from the Delphic oracle or by voting in the assembly. The conduct of the seven wise men also has a regulatory function. Only they are in possession of the quality described by Plutarch as eumeneia philotimon. This can be translated as 'generosity' and stands in contrast to the self-interest of the fishermen and their employers. In this episode the object itself is an emblem of knowledge, ${ }^{138}$ as it is assigned to the wisest. Finally, it must be Apollo, the divinity who is closest to the epic seer and singer, who is distinguished as the wisest.

The dating of the tradition can be traced back to the fourth (or at a push, the late fifth) century, ${ }^{139}$ and in form it probably mirrors the practice of Hellenistic benefactors. ${ }^{140}$ But there is much literary, historical, and epigraphic evidence of tripods given as votive offerings to gods, and material remains dating back to the ninth and eighth centuries that can be found at central sites such as Delphi and Olympia as well as at Ithaca and other locations. ${ }^{141}$ Louis Gernet, who was the first to consider the Seven Sages' tripod with reference to gift-exchange, interpreted the tripod as an object with magical-religious significance and connected it to an originally magical notion of kingship. ${ }^{142}$ Based on the uses of tripods as winners' prizes and as guest-gifts in the Homeric poems, contemporary scholarship tends to view

138. According to Diodorus (9.13.2) the tripod given to Bias because of the testimony of the Messenian maidens was inscribed with the words 'for the wisest'. See also Phanodikos ap. Diog. Laert. 1.82.

139. Plutarch refers to Theophrastus (372-287 BCE). See Fehling 1985: 12-19, who assumes the fifth and fourth centuries BCE as its origin, although Rösler 1991: 35765 argues against this, connecting the emergence of the idea of the sage with the development of the Delphic oracle. Martin 1993: 108-28 takes a similar position to Rösler and emphasises the significance of secularization and internationalizing as distinctive to early Greek notions of wisdom. See now Papalexandrou 2005; Wagner-Hasel 2015.

140. See the philotimoi euergetai and honorific statues which are materialized honour (doxa). Cf. Bolkestein 1939: 154-55. On Plutarch specifically see Frazier 1988: 10927, claiming that for Plutarch generosity is a concrete manifestation of a striving for honour. The characterisation of the Seven Sages as free from self-interest fits better with Solon's interest in the communal good. Cf. Rösler 1991: 36o-61. On the continuity of euergetism from archaic to hellenistic times see now Herman 2006 and Domingo Gygax 2016:58-79.

141. Olympia: Willemsen 1957; Maaß 1978; Delphi: Willemsen 1955; Rolley 1977: 10549; Armandry 1987; Morgan 1990: 138-40; Ithaca: Benton 1934-35: 45-73. For an overview see Reisch 1905: 1669-96; Schwendemann 1921: 155; Coldstream 1977: 332-39; Magou, Philippakis and Rolley 1986: 121-36; Snodgrass 1990: 287-94; de Polignac 1996: 59-66; Papalexandrou 2005.

142. Gernet 1948: 415-62. 
them as evidence of aristocratic exchanges of prestige goods, and thus to connect them to the processes of polis-formation, a consequence of which the possession of land had become the only significant form of wealth. The transfer of objects of aristocratic exchange to the gods forges a reciprocal relationship between gods and humans, as Susan Langdon, for example, argues: 'What these men of wealth received in turn was status, legitimacy, and proof of class and claims to land'. ${ }^{143}$ Removed from circulation among humans, tripods would now be purely symbolic objects, representing the power of those who organised religious cults in their own interests. Langdon also suggests a change from pastoral to agricultural society which took place in post-Homeric times and in which land replaced cattle as the main source of wealth. ${ }^{144}$ Catherine Morgan, whose work focusses specifically on the rise of supraregional sanctuaries such as Olympia and Delphi, views the tripod as a symbol of xenia that comes to be used to forge interstate ties. ${ }^{145}$ François de Polignac takes a similar view in interpreting tripods as prestige goods representing memorials in honour of the sponsor, or of elite interstate alliances, at locations of supra- or intra-regional significance such as Olympia or Ithaca, or the Isthmus and the Heraion at Argos. ${ }^{146} \mathrm{~A}$ more recent study by Nassos Papalexandrou also underlines such territorial symbolism while emphasising the significance (especially for Delphi) of the idea of wisdom in association with the tripod. Papalexandrou views tripods as 'symbols of truthful discourse', and considers the ability to tell stories and remember the heroic past as the essential basis for legitimizing positions of power in early Greece. ${ }^{147}$

However, evidence from Homeric epic does not suggest ways to connect the tripod to magical kingship or to aristocratic land rule. Whether used for bathing guests and washing the dead, or as a tribute or prize, the tripod always invokes a supraregional context of widespread networks of

143. Langdon 1987: 113. Similarly, Linders 1987: 115-22. Cf. also Morris 1986: 12-13, who interprets the tripod as a symbol of an ever-widening circle of aristocratic contest which ends with the display of the tripod in a temple instead of its use as a grave gift. Ulf 1997: 42 thinks that the tripods are dedicated by larger groups, who are able to express their economic power through such dedications.

144. Langdon 1987: 110.

145. Morgan 1990: 218.

146. De Polignac 1996: 63.

147. Papalexandrou 2005: 19: '[...] nothing less than the indispensable tokens of the legitimate right to leadership'. Similar Papadopoulos 2012: 285: 'Such emblems [tripods, animal statuettes, etc.] served as a conscious link between past and present, and in their everyday use they helped define the future'. 
guest-friendships or military alliances. Found as votive offerings in supraregional cult centres tripods remain bound to the realm of supraregional communication. If there is any link between the tripod and claims on land, then this must be land used interregionally, such as pasture, or road networks, passage through which is guaranteed, as demonstrated earlier, by basilēes.

The view that tripods are emblems of wisdom, as underlined by Papalexandrou, does not apply to the epic practice but only to Delphi, and only in connection with the goddess Themis as the embodiment of themistes. The placing of Themis on the tripod at Delphi presents the unification of two types of conflict resolution: one agonistic, within which the tripod functions as a prize at the funeral games, the other verbal, connected to themistes. At Delphi both forms are connected to supraregional communication and to the regulation of transhumance. ${ }^{148}$

\subsubsection{Transhumance and exchange}

Recent years have seen much controversy regarding the spread of transhumance in antiquity. Anthropogeography defines transhumance as the seasonal migration of livestock belonging to fixed agricultural or pastoral settlements between high pastures in summer and lower valley pastures in winter. ${ }^{149}$ The climatic and geographical conditions of Greece (mild, damp winters in the valleys and moderately warm summers in mountainous regions) suggested to older scholarship the widespread existence of a transhumant economy, in the sense of the migration of herds from winter pastures in the valleys to summer pastures in the mountains. ${ }^{150}$ Recent scholarship assumes more regional and historical differentiations and so questions the extent of the spread of transhumance.

The most recent debate originates in prehistorical research, focussed especially on Minoan society, and the assumption here is that transhumance does not begin to develop before the first half of the second millennium. The Minoan peak sanctuaries erected in summer pasture regions are thought of as early evidence of this. ${ }^{151}$ One example is the sanctuary of Kato Symi on the southern slopes of Mount Dicte, excavated in 1972; this

148. Wagner-Hasel 2002b; 2015; 2019.

149. Zöbl 1982: 1.

150. Cf. Semple 1922: 3-38; 1931: 100 and 317-24; Beuermann 1967: 34 and 80-82; Michell 1963: 59; Brendel 1934.

151. Halstead 1980: 331; 1987: 77; Cherry 1988: 6-34. 
was in use from the middle of the second millenium up until the third century CE, with Hellenistic inscriptions suggesting it was dedicated to Hermes and Aphrodite. ${ }^{152}$ Transhumance, for which there are also written sources from the second half of the second millennium, accompanies the development of textile production, which was centrally organised according to evidence from the Linear B tablets. ${ }^{153}$ For Mycenaean Pylos seasonal migration of herds from the valleys into the mountains is assumed, based on evidence from the $\mathrm{Cn}$ Texts in the Linear B archive that list flocks of sheep in connection with place names and personal names. The L-series at Knossos shows a similar picture. ${ }^{154}$

Stella Georgoudi was the first scholar to undertake a systematic investigation of the evidence for transhumance from archaic and classical times, and to consider written evidence for agreements between poleis regarding the use of grazing lands in this capacity. ${ }^{155} \mathrm{~A}$ study by Angelos Chaniotis considers post-Minoan Crete. ${ }^{156}$ Although the written sources presented in these two studies do provide evidence for forms of transhumance in a range of areas, more recent research-based on climatic, political, and economic factors-suggests that the practice played only a small role in archaic and classical times. Stephen Hodkinson points to the Kopais basin in Boeotia and the Mantinean plain in Arcadia as examples where the summer heat does not prevent the year-round use of lowland regions. ${ }^{157}$ Paul Halstead assumes that denser forestation of mountainous regions in antiquity would mean less intensive use of those regions as pasture lands. ${ }^{158}$ Hodkinson uses allusions to the cultivation of feed crops, such as clover in Pliny and Theophrastus, and new evidence regarding settlement structures, to argue that, even in regions where the climate is less amenable, livestock was kept near to farms all year round. ${ }^{159}$ Regional studies in Boeotia, for

152. Lebessi 1976: 2-13.

153. Killen 1964: 1-15; 1985: 241-305; Nosch 2000.

154. Hiller 1976: 126-41 and 190-91; Rougement 2004.

155. For epigraphic evidence see Georgoudi 1974: 155-85 and now Chandezon 2003, who discusses all the epigraphic evidence for stock-rearing in the Mediterranean from the late fifth century BCE to the late first century CE.

156. Chaniotis 1995: 39-89.

157. Hodkinson 1988: 47-48.

158. Halstead 1987: 80 and Garnsey 1988: 206. Geomorphological research casts doubt on the dating of this assumption, however, placing it back during the Weichsel Ice Age. See Hempel 1993a: 161-79.

159. Cf. Plin. HN 13.130 for dried clover used to feed pigs at Athens: Frutux est et cytisus, ab Amphilocho Atheniense miris laudimus praedictus pabulo omnium, aribus vero etiam suum. The cultivation of fodder crops presupposes crop 
instance, show that settlements were not always concentrated around villages or poleis but scattered over the land, and that therefore pasture lands must have been available close to farmsteads. ${ }^{160}$

Jens Erik Skydsgaard, whose research focusses on transhumance in ancient Italy, has argued that feed crops were cultivated only for specific animals such as horses, and that sheep farming was conducted without the cultivation of fodder crops. ${ }^{161} \mathrm{He}$ also points out that animals kept for the purpose of dairy farming would need to be kept close to the farmstead, while the location of animals bred for wool was less important. ${ }^{162}$

A fundamental problem for current scholarship is the lack of clarity when it comes to defining transhumance. Hodkinson, for example, tends to view transhumance as a form of nomadism in contrast to agriculture; he also does not count migration within a radius of $100 \mathrm{~km}$ as transhumance. In his view, the preconditions for the development of transhumance include a lack of strong agriculture, a high market demand for wool, and the existence of a central organisation of the movement of flocks comparable to the Spanish sheep ranchers' association, the 'Mesta.' ${ }^{163}$ Using a modern phenomenon as a criterion for the evaluation of ancient evidence, however, means that forms of transhumance on a smaller scale, or those not geared towards market production, fall out of the picture. Skydsgaard, on the other hand, distinguishes between 'long-distance transhumance', with ranges between 200 and $800 \mathrm{~km}$, and 'short-distance transhumance', with ranges between 20 and $100 \mathrm{~km}$. He regards the latter as typical for ancient Greece, while supposing the development of a system of 'long-distance transhumance' for ancient Italy. ${ }^{164}$ Michael H. Jameson assumes longdistance transhumance for Western Greece, and 'small-scale transhumance' for the regions around the poleis of central and Eastern Greece. ${ }^{165}$

rotation, assumed by Hodkinson against earlier scholarship. Hodkinson 1988: 43. Similarly Halstead 1987: 82; Garnsey 1988: 207. By contrast see Isager and Skydsgaard 1992: 110-14. More generally on cultivation of fodder crops see Khazanov 1984: 72.

16o. Hodkinson 1988: 39-46. For settlement archaeology see for example: Snodgrass 1991: 1-23; Osborne 1985b: 37-42; Bintliff 1994: 212-27; Lohmann 1993; 1997.

161. Skydsgaard 1974: 7-36.

162. Skydsgaard 1988: 78-82.

163. Hodkinson 1988: 50-56. Given the lack of central political authority Hodkinson declines to speak of Homeric evidence for transhumance. Hodkinson 1990: 144. 164. Skydsgaard 1974: 7-36; 1988: 80; Isager and Skydsgaard 1992: 99-104 (with further references). For Italy see now Santillo-Frizell 2004 and 2009.

165. Jameson 1989: 9-11. Similarly, Osborne 1987: 47-52. 
Differentiations in range, such as are made by Skydsgaard and Jameson, seem to me to be crucial when it comes to evaluating the ancient evidence. In Dorothea Zöbl's study of the spread of transhumance in the Mediterranean during the medieval and early modern eras, there are not just two but four different forms of transhumance, each with a different spatial range. On the one hand, she identifies intra- and inter-local transhumance based on the common or reciprocal use of grazing lands by several villages. On the other hand, she identifies intra- and inter-regional transhumance, in which pastures are located in alien territories necessitating arrangements for rights of passage. In the latter cases, transhumance is no longer organised by villages but by larger units such as monasteries or state-like institutions. ${ }^{166}$ The Mesta, which Hodkinson also refers to, is the most well-known example of such inter-regional transhumance. This association enabled the organisation of a frictionless migration of herds across a widespread network of pathways and in close cooperation with the crown. The Spanish crown's fiscal interest in taxing herds and in the use of the network built up through transhumance in turn led to the intensification of transhumance, which then began to come into conflict with agriculture. ${ }^{167}$ Zöbl's study shows that it is not, as Hodkinson suggests, the existence of centralised power that enables the development of transhumance. She shows instead that transhumance brings about spatial integration and thus furthers the development of bigger political units. ${ }^{168}$

In prehistorical scholarship the argument that the practice of transhumance is a 'unifying mechanism' has long been recognised, and it is assumed that networks of communication, which become evident in the spread of pottery styles or funeral practices, are created through transhumant relationships. ${ }^{169}$ For the geometric and archaic periods the location of the early sanctuaries suggests that the supraregional use of pasture lands effected such a density of communication. New insights into the development of the polis also support this by replacing old hypotheses of

166. Zöbl 1982: 56-58. Cleary and Delano Smith 1990: 21-38 and Waldherr 2001 also work with the concept developed by Zöbl.

167. See Klein 1964.

168. Zöbl 1982.

169. Bintliff 1977: 116-17; Cherry 1988: 11-12; Papadopoulos 1987: 137-42 interprets the distribution of grave mounds (tumuli) as evidence of the presence of transhumant shepherds in Ephyra. For the Neolithic era see Jacobsen 1984: 27-43 using ceramic evidence to suggest that the entire northeastern Peloponnese was a unified region of transhumance. For the classical period see Jameson 1989: 13: 'long-distance transhumance acted as intermediaries between mountains and coastal regions'. 
autarchy with a model of much greater mobility. Nicholas Purcell describes this as a 'flexible ecological response' in which resources from different locations are redistributed strategically in order to manage crises. ${ }^{170} \mathrm{Al}-$ though Purcell focusses predominantly on seafaring and on the sea as the space of communication, pointing to the example of Anthedon on the eastern coast of the Aegean, whose inhabitants worked as 'waterborne distributors' of salt and purple dye, and as boat builders and ferrymen, he also mentions the transhumant shepherd 'who engages with a whole range of ecologies and participates in the annual interplay of sedentary and pastoral existence'. He equates this shepherd to the 'coastwise caboteur' who 'exchanges the surpluses of his ports of call. ${ }^{171}$ This suggests that the land routes taken by shepherds must have been no less important than the better-known sea routes. ${ }^{172}$

In Sophocles's Oedipus Tyrannus we have a very good illustration of the encounter between two shepherds on Cithaeron, the mountain range that forms the border between Boeotia, Megara, and Attica. It is in this border region between two poleis that a shepherd employed by Polybus in Corinth received the cursed child from a Theban shepherd, a slave who had grown up in the house of Laius (Soph. OT 1025-29, 1040-44). Polybus's shepherd reports when questioned by Oedipus: 'I am certain he knows well of the time we both stayed in the region of Cithaeron, he with two flocks and I with one. I was close enough to this man for three entire six-month periods from spring to Arcturus. In winter I would drive my flock to my own fold, and he took his to Laius's fold' (1133-39). ${ }^{173}$ According to this statement the two shepherds both stayed in the mountains with their flocks from the rise of the Pleiades (between 22 April and 10 May) up until the rise of Arcturus in October. ${ }^{174}$ The statement about the duration of their stay in the mountains serves to emphasise the shepherd's truthfulness. The shepherds know each other well because of the length of time they have spent together. This

170. Purcell 1990: 42. Cf. also Morgan 1990: 202.

171. Purcell 1990: 52.

172. Jameson 1989: 13 criticises a tendency to underestimate the significance of land routes.

173. This is the main evidence for the practice of transhumance in ancient Greece. Cf. Semple 1922: 28; Beuermann 1967: 80; Georgoudi 1974: 147; Skydsgaard 1988: 75; McInerney 2006: 45.

174. Further sources provide evidence of the use of grazing land in the mountains. See Eur. IT 260-325; Theocr. Id. 13.25-26. The Vlachs begin their herd migrations on St George's day, 23 April, and complete them by St Demetrius's day on 26 October: Ivanka 1950: 352. Cf. also Koster 1976: 19-28, who joined shepherds in such a migration from Epidaurus to Mt. Cyllene in Arcadia in the spring of 1972. 
also emphasises that the mountains are not empty space but are perceived as a meeting place for shepherds from different regions. ${ }^{175}$ Epigraphic and literary evidence of agreements regarding such common use of pasture lands confirms that the case of the Theban and Corinthian shepherds in Sophocles corresponds to actual practices. Thucydides, for instance, mentions the sworn treatises (horkoi) between Boeotians and Athenians which set down that the area of Panakton was to be used only as common grazing land rather than for settlement. ${ }^{176}$ The change to the economy of the polis is not then a change from a pastoral to an agricultural economy but rather a process of spatial integration and concentration which epic poetry alludes to through the use of pasture lands in alien territories.

\subsubsection{Sanctuaries at the periphery}

The very first temples, emerging in the final third of the eighth century $\mathrm{BCE}$, indicate connections to a pastoral economy rather than supraregional trade. These are mostly temples dedicated to Apollo, such as that at Eretria dated to around 725 BCE. Based on the presence of circular houses and apsidal buildings, archaeologists assume that Eretria was originally a seasonally used shepherds' station that gradually developed into a permanent settlement over the course of the eighth century. ${ }^{177}$ Other early sanctuaries were located entirely outside settlements and used by several different communities: the Heraion at the northern edge of the Argive plain, which was used by both Argos and Mycenae (Strabo 8.6.10), ${ }^{178}$ the Heraion of

175. This is confirmed by observations in other mountain regions. In the Himalayas the high summer pastures are meeting places for friends and relatives and the location of numerous festivities: Snoy 1993: 52-53. For the use of border regions in ancient Greece see now Daverio Rocchi 2016: 70-76.

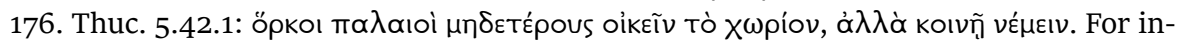
terpretation see Osborne 1987: 37; Skydsgaard 1988: 80. For further evidence see Georgoudi 1974: 178-80; Chaniotis 1995; Waldherr 2001; Howe 2008: 95-106 argues that the outbreak of the Peloponnesian War can be explained with a struggle for pastures between Megara and Athens. See also Daverio Rocchi 2016: 75.

177. Summarising: Snodgrass 1987: 203-4; Coldstream 1977: 317-27; Blome 1991: 51. For the Euboean trading connection with Italy see Crielaard 2006: 291-92. He denotes the basileis as leading figures in all kinds of external affairs. Cf. Crielaard 2012: 147.

178. Morgan 1990: 11 doubts Strabo's notion that both cities used the sanctuary, suspecting instead that Argos used the foundation of the Heraion after the victory over Asine as manifestation of its sole claim over the plain. By contrast de Polignac 1984: 59 assumes that Mycenae and Argos used the sanctuary jointly, at least during the archaic period, since Argos only achieved hegemony over the entire Argolid by $460 \mathrm{BCE}$, at which point it began to make use of the Heraion for political purposes. 
Perachora located in the foothills of the Geraneia mountains, and the Apollo sanctuary located in the Geraneia mountains, the latter two being both under the control of Corinth and Megara (Paus. 1.3.8). ${ }^{179}$ A similar situation obtained at the sanctuary of Poseidon at Onchestos in Boeotia, today the location of the Mazaraki monastery, which was used jointly by Thebes and Orchomenus, two communities located in the same region. ${ }^{180}$ The sanctuary of Artemis Limnatis, located on the border between Laconia and Messenia served as a meeting point for communities from different regions, as did the Heraion of Perachora and the Apollo temple in the Geraneia mountains. The joint use of the Artemis sanctuary by the Spartans and the Messenians is associated with the outbreak of the Messenian War which we have discussed already in connection with the conflict around the use of pasture lands in foreign territories. The Messenian explanation for the outbreak of the war involves provocation caused by the theft of cattle, ${ }^{181}$ while in the Spartan version the conflict involves women. Pausanias reports that the First Messenian War broke out following the rape of Spartan maidens by Messenians. ${ }^{182}$ Such stories suggest that liminal territories can be defined as 'ritual space', as Daverio Rocchi has proposed. ${ }^{183}$

Many of these 'boundary temples' are associated with wars of the archaic period. ${ }^{184}$ The building of the Apollo temple and the Heroon at Eretria are connected to the dispute between Chalkis and Eretria over the Lelantine plain, ${ }^{185}$ reported by Thucydides as the occasion for one of the first pan-Hellenic coalitions (Thuc. 1.15). ${ }^{186}$ De Polignac assumes that the background for the establishment of the Heraion of Perachora must be a dispute between Megara and Corinth over the use of the Isthmian plain, ${ }^{187}$ the gateway to the winter pastures around Epidaurus. The Poseidon sanctuary

179. For discussion see de Polignac 1984: 40-41; Gehrke 1986: 131; Morgan 2003.

180. The Poseidon sanctuary is mentioned at $I l$. 2.506. Pausanias (9.26.5-37.1) describes the remains at the site which was abandoned by his time. On the history of the location see de Polignac 1984: 58.

181. Cf. ch. 5.1.

182. Paus. 4.4.2-3. Cf. also Strab. 6.257 and 8.362. The temple of Artemis at Caryae built by Spartans on the border with Arcadia had a function similar to the Artemis Limnatis sanctuary according to Pausanias (3.10.7). Cf. also Howe 2008: 81-82. 183. Daverio Rocchi 2016: 76.

184. See van Wees 2004: 28-30 who argues that the struggle for land has been underestimated.

185. De Polignac 1984: 61; Sartre 1979: 220; Raaflaub 1988: 520; Parker 1996.

186. Cf. Howe 2008: 83-84.

187. De Polignac 1984: 6o (with further evidence); 1994: 5. Cf. Morgan and Whitelaw 1991: 79-108; Antonaccio 1992: 85-105. 
at Onchestos is linked to the joint use of the Copais basin by Thebes and Orchomenus. ${ }^{188}$ The origin of the temple of Apollo Horaios, or Apollo of the border, at Argos is suggested by Pausanias as a dispute over the borders, won by the Argives (Paus. 2.35.2).

These peripheral sanctuaries, to use my preferred term for the sanctuaries found on the borders of emerging poleis, have been viewed since the 1980 os as serving to define the territorial boundaries of poleis and, together with hero-cult sites, as means of establishing 'a beneficial relationship to a usable ideological past'. ${ }^{189}$ In de Polignac's considerations of this spatial dimension to the emergence of sanctuaries, peripheral temples appear to enact a symbolic separation between wilderness and civilisation, which he claims was necessitated by the shift from pastoral to agricultural society. ${ }^{190}$ He suggests that these contrasts were performed and mediated in initiation rituals and rural festivals, and he finds that this symbolic function of peripheral sanctuaries also explains the concentration on Hera and Apollo. Both are interpreted as protectors of civilisation in the form of marriage and in the form of the social order of the polis. By contrast he suggests that the gods of the wild such as Artemis tended to be worshipped within the city itself. ${ }^{191}$

The discussion above on the character of transhumant economy shows that the fundamental contrast between pastoral and agricultural economy posited by de Polignac's interpretation cannot be assumed. He identifies the life of the polis with a supposed basis in agriculture and associates the world of Homeric epic with a pastoral way of life. In this schema a new definition of space is necessitated by the change from pastoral to

188. De Polignac 1984: 46, 58.

189. Whitley 1988: 181. Cf. also Osborne 1987: 189 and de Polignac 1984: 29, 132-40. Coldstream 1985: 66-97 argues for a multiplicity of explanations. Burkert 1988: 43 argues that sanctuaries were important for the creation of communal identity through the display of votive gifts. Ulf 1997: 48-53 emphasises the political and communicative role played by the temples. More recent research on sanctuaries in southern Italy show that these were also used as locations for the processing of wool. See García Morcillo 2013; Meo 2019.

190. De Polignac 1984: 44 calls such temples 'le sanctuaire extra-urbain' to distinguish them from sanctuaries within the settlement ('sanctuaire urbain') and from those on the margins of the city ('sanctuaire sub-urbain'). He considers them as symbolic protection walls ('rempart symbolique') against the area of disorder and lack of organisation 'et de l'éphémère, où dominent les conjonctions anormales placées sous le signe de la ruse et de la violence non institutionalisée: entre hommes et dieux [...] entre les êtres humains eux-mêmes [...] entre hommes et animaux'.

191. De Polignac 1984: 35-39, 49-84. 
agricultural ways of living: territorial boundaries do not feature in pastoral economies, while agricultural societies depend on the recognition of land ownership and territorial relations. ${ }^{192}$

The supposition that Homeric society was pastoral is as doubtful as the contrast between agricultural and pastoral economies. My analysis of the myth of Polyphemus showed that a key moment of poetic tension is caused precisely by the disruption of a regular exchange of goods between the world of the shepherd and the household of the livestock owner. Epic evidence shows that shepherds and livestock owners act in different production units but within a regulated system of exchange such as is characteristic of transhumant economies. ${ }^{193}$ In addition to this, studies of pastoral societies show that the boundaries of pasture lands are defined with precision and that the concept of boundaries is very much present. ${ }^{194}$ And the mountainous regions in which rural sanctuaries were located were not areas of wilderness but, as Michael Jameson correctly points out, cultural spaces which were used for cattle farming. ${ }^{195}$ Since inhabitants of different regions and poleis were often frequenting mountain areas simultaneously, it makes more sense to view the sanctuaries established in such border territories as meeting places rather than as structures intended as protection from the wild. In a later work, de Polignac admits to this problem and pays more attention to the role of the sanctuaries as places of supraregional exchange. ${ }^{196}$

The sanctuary of Apollo at Delphi, the final recipient of the tripod of the Seven Sages, is surrounded by grazing land, just like Olympia. ${ }^{197}$ Unlike Olympia, which served as a seasonal meeting point for Arcadians, Eleans, and Messenians but remained under the control of Elis, ${ }^{198}$ Delphi came under the control of a supraregional power, the Amphictyonic League. According to the historians the amphictyony included the Thessalians,

192. De Polignac 1984: 19-20, 46-57. Similarly, Qviller 1981: 137. De Polignac leans on the work of Anthony Snodgrass (1987: 199-209), who sees evidence for this transformation in the frequent abandonment of settlements in the geometric era. Snodgrass speaks of transhumance in this context. According to Irad Malkin (1993: 231), the 'only clear evidence both for the institution of heroic cults and their territorial implications is in the world of Greek colonies'.

193. Cf. ch. 2.1.

194. Cf. von Fürer-Haimendorf 1975: 177; Khazanov 1984: 75.

195. Jameson 1989: 7-12. Cf. also Daveri Rocchi 1990: 95-110.

196. De Polignac 1994: 5-11. See now McInerney 2006: 34; García Morcillo 2013.

197. Jameson 1988: 97; Sourvinou-Inwood 1993: 11.

198. Morgan 1990: 192. 
Dolopians, Perrhoebians, Magnesians, Boeotians from the northeast, the Dorians, Ionians from Euboea, Locrians, Oeteans, Phthiotae, Malians, and Phocians until 346 BCE. ${ }^{199}$ The League is linked to the first 'Sacred War', which resulted in the transformation of the Krisean plain into grazing land. What was at issue was not so much the securing of pasture land to cater to the high demand for sacrificial animals, as argued recently by Timothy Howe and Jeremy McInerney, ${ }^{200}$ but more likely the integration of Delphi into a supraregional transhumant network, which necessitated the use of the plain as winter grazing land. ${ }^{201}$ Morgan does not exclude the possibility of a transhumance background for this interregional integration of Delphi, which can be dated to as early as the ninth century, on the basis of ceramic evidence. But in Morgan's view the importance of Delphi is above all as a base along the trading route to Thessaly and as a sea route to Italy. ${ }^{202} \mathrm{De}$ Polignac now attributes a similar gateway function to Olympia and Ithaca, along the lines of the argument made for the southern Italian settlements of the second millennium BCE by Thyrza Smith. ${ }^{203}$ There is no contradiction between these different functions, since the movement of flocks mostly goes hand in hand with trading relations. The wool trade is of course also closely connected with pasture farming. ${ }^{204}$

The dedications at the Heraion at Perachora offer a further point of interest, since a large portion (74 per cent) of the finds there are of Phoenician artefacts. Contrary to earlier assumptions, these cannot be attributed to visits from Phoenician travellers, since a substantial part of the finds are ointment jars, pearls, scarabs, and faience objects that are also found at women's burial sites. On this basis, Imma Kilian-Dirlmeier suspects

199. On the membership of the league cf. Walek 1911: 13-25; Tausend 1992: 35-43; Sanchez 2000.

200. Howe (2003; 2008: 85-93) as well as McInerney (2006: 34) argue that 'largescale animal husbandry designed to serve the needs of sanctuaries and the pilgrims who consulted them'. Emile Bourguet (1905: 26-31 with note 1) argues that the office of the poleteres suggests that pasture lands were leased.

201. See my arguments in Wagner-Hasel 2000a; 2002b and forthcoming.

202. According to Morgan, Delphi was part of a northeastern (Euboean and Thessalian) network of exchange relations during the ninth century. At the end of the eighth century the previously dominant southeastern connection was reoriented towards Thessaly, with the addition of ceramics from Attica, Boeotia, the Argolid, and Corinth. Morgan 1990: 112-37, 199; 1988: 319.

203. Smith 1987; de Polignac 1994: 11. Cf. also Eder 2006.

204. This was my argument in Wagner-Hasel 2000: 295; 2002b; 2016. See now Chandezon 2003, who argues that sanctuaries kept cattle not only for sacrifice but also as a source for revenues when their offspring or wool were sold. 
that the artefacts were gifts or dedications made by local women who had been married abroad. ${ }^{205}$ There is evidence, for instance, that a woman living on Cyprus dedicated a peplos at the sanctuary of Athena Alea at Tegea (Paus. 8.5.3). ${ }^{206}$ Exogamy, which must have also influenced the transfer of techniques and styles, is a feature of the majority of marriages mentioned in Homer, and it was also practised by the tyrants. ${ }^{207}$ The tendency to marry out of the community is contrary to the advice and practice found in Hesiod and in the Attic orators of the fourth century, where it is considered best to marry within the neighbourhood or the extended family (Hes. Op. 695-700). ${ }^{208}$ Although Louis Gernet's initial research into exogamy proposed that such bonds were a way of forging political alliances, it is not the case that politics is the only reason for such marriages. Just like guest-friendships, marriages could also be a way of securing supraregional exchange networks, as the example of the Cypselids shows. Melissa, the wife of the tyrant Periandrus, was a daughter of the tyrant of Epidaurus, who in turn was married to a woman from Arcadia (Hdt. 5.92; Diog. Laert. 1.94; Heraclides fr. 144-151 Wehrli). These marriages establish a link between Corinth and two other regions: Arcadia, known for its wealth in sheep, and the coastal region of Epidaurus, from where even today farmers send their flocks into the mountains of Arcadia for summer pasture. ${ }^{209}$ Contemporary coin imagery depicts beehives, Hermes, and a ram. This suggests the Cypselids' interest in wool products, and later sources attest to the high quality of Corinthian wool products. ${ }^{210}$ The degree to which such marriage practices were peculiar to the tyrants may be indicated by Theognis's scorn for the practice when he accuses the Cypselids of departing from the earlier endogamous marriage conventions of the Bacchiads (Thgn. 183-92; 891-94). ${ }^{211}$ In Homer the abduction of women and female fidelity are key themes, and the stability of marriage bonds plays

205. Kilian-Dirlmeier 1985: 228-32.

206. See Buschor 1912: 45 .

207. Wagner-Hasel 1988; Gernet 1968. Coldstream 1993: 80-107 argues that the practice of mixed marriage in $\mathrm{Al}$ Mina and other emporia was the reason for the adoption of Eastern cultural elements.

208. See Cox 1998: ch. 2.

209. See Koster 1976. Howe 2008: 87.

210. Corinthian strōmata are mentioned by Athenaeus $1.27 \mathrm{~d} ; 12.525 \mathrm{~d} ; 13.582 \mathrm{~d}$. Orth 1924: 609 and Salmon 1984: 136 suggest that the wool products mentioned by Athenaeus stem from Arcadia. Morgan 1988: 338 does not say what Corinth exchanged for metals.

211. On the addressee of Theognis's critique of tyranny, see van der Lahr 1992: 134-51. 
a prominent role at strategic moments in the narrative so that it appears that the poetic world may reflect the interests of the tyrants of the archaic period. The competition for superiority between these tyrants and other aristocrats led to extravagant spending on purple clothing and jewellery as status symbols which can still to be observed in accounts of the fifth and fourth centuries. ${ }^{212}$

It appears that the early tyrants were especially instrumental in furthering supraregional exchange and that their wide-ranging guest-friendships and marriage alliances helped to forge a dense network of communications. ${ }^{213}$ This is not only true of the Cypselids at Corinth or for Samos, where a new type of ship, the Samaina, was developed under the tyrant Polycrates for the transport of large freights. ${ }^{214}$ Herodotus and Aristotle link the Athenian tyrant Peisistratus to the exploitation of Thracian silver mines. ${ }^{215}$ Theognis complains that under the tyrants the phortēgoi, the 'porters' or carriers of freight, are in charge. He accuses the tyrants of giving people hope of kerdoi, the advantages and profits we have seen linked to the undertaking of journeys in the epics. ${ }^{216}$ The administration of this form of trading during the archaic age, best described as exchange of resources, provided individual local leaders with substantial powers. This exchange of resources appears to be much more important than land ownership as the basis for positions of power such as we see crystallised during the age of the tyrants.

Above all, the exchange of resources is a precondition for the processes of networking and centralisation observed in the archaic period. To understand the political aspect of the role of the tyrants and the development of the polis, one should not underestimate the economic factors that played a leading role in the development of an increasingly dense network of communication. Often interpreted as the result of 'peer-polity interaction' and

212. For evidence see Alföldi 1955: 15-55; Geddes 1987: 317-21; Stein-Hölkeskamp 1989: 104-10; Stulz 1990: 121-53. Presumably the critique was a projection of the fifth century, since Theognis 53-68 directs his critique at the nonurban dress of the tyrants. But in any case, it is clear that dress has political significance.

213. Cf. Gernet 1968; Stahl 1987: 93-96; Sancisi-Weerdenburg 2000; Morris 2003: 14.

214. Presumably he had access to the gold and silver of Siphnos. Hdt. 3.57. Treister 1996: 24, 135-36. Cf. also Kurke 1999.

215. Hdt. 1.64; [Arist.] Ath. Pol.15. See Boardman 1981: 271; Treister 1996: 136-38; Lavelle 1995; 2005.

216. Thgn. 667-682 and 823-24. According to Plato (Resp. 579d-e) tyranny is philochrēmatia. See Domingo Gygax 2002 and 2016: 106, who regards the tyrant as a big-man like the Homeric basileus and stresses their generous behaviour. 
rivalry between different political elites, ${ }^{217}$ rivalry and emulation should be considered within a framework of economic relationships. This increase in supraregional exchange forms the economic background that may help us to understand the evolution of extra-urban sanctuaries. ${ }^{218}$

217. Peer-polity-interaction: Renfrew 1986: 1-18; Snodgrass 1986: 47-58. Elite competition: Duplouy 2002; 2006; Ulf 2011; Fisher and van Wees 2011; 2015.

218. This is assumed by Graham (1984: 9) for southern Italy, where Greek objects are found especially in extra-urban sanctuaries. For the economic role of sanctuaries in Italy see now García Morcillo 2013 and Kistler 2015. 


\section{CONCLUSION}

\section{The Sensory World of Gifts: Weaving, Signs, and Communication}

6 Text to agriculture, the arts of making clothing are without dispute 1 the most necessary and useful. There are few inventions which have displayed such sagacity, and done so much honour to the human understanding. ${ }^{1}$ So we are told in The Origin of Laws, Arts, and Sciences and Their Progress among the Most Ancient of Nations, first published in French in 1758. Although he praises the art of textile work itself, the book's author, Antoine-Yves Goguet, shows no appreciation of the products of this 'sagacity', that is, of ancient clothing itself. He is, in fact, harsh in judging the apparel of the ancient Greeks: 'But it must be agreed, that the dress of the Greeks, as well for the men as for the women, was very imperfect. Is it not astonishing, for example, that these people never knew neither breeches, nor stockings, nor drawers, nor pins, nor buckles, nor buttons, nor pockets?'2 Bronze tripods are singled out for praise in Goguet's otherwise negative judgement of Greek artistry: 'Their moveables for luxury at that time consisted in beautiful tripods designed only to ornament the apartment; for they made no other use of them. ${ }^{3}$

Goguet himself wrote during an era in which dress was, alongside homefurnishings, the key means of signalling social rank and distinction. Regulated by numerous rules and laws, dress was a key way of defining and displaying social status, gender, and age during the Middle Ages and especially during the Early Modern Period. ${ }^{4}$ In the upper echelons of society, this way of visibly displaying distinctions in rank and status was sharpened

1. Goguet, vol. 1, 1775: 121.

2. Goguet, vol. 2, 1775: 385 .

3. Goguet, vol. 2, 1775: 386.

4. Bulst 1988; Medick 1996: ch. 6; Slanicka 2002. 
by elite competition and rapidly changing fashions. ${ }^{5}$ It is not surprising then that in a work of this period we find special attention given to the appearance of clothing and that its manufacture is especially praised as a sign of reason-the highest praise during this era. It is equally unsurprising that the author uses dress as a means of distinguishing between cultures as well as between the civilised peoples of his own age and the 'savages', amongst whom Goguet counts the Greeks. ${ }^{6}$

With the arrival of the industrial revolution, and the invention of the Spinning Mule in 1775, the notion that textile work was a product of reason and intellect-found not only in Goguet but in other works of the period too-disappeared. ${ }^{7}$ For a long time, histories of technology and economics tended largely to ignore textile work in favour of metallurgy. ${ }^{8}$ This seems to follow nineteenth-century patterns of thought: the age of industrialisation conceived of progress according to the metals that would come to govern the age of the machine rather than the steps that led to Crompton's Spinning Mule-the spindle, the loom, and the spinning wheel. The three-ages system that orders events and artefacts of prehistory and history into the Stone Age, Bronze Age, and Iron Age-and is still in use today-was developed during this period, in 1819, by the Danish prehistorian Christian Jörgensen Thomsen. ${ }^{9}$ If we were to complement this schema, which accounts only for developments in metallurgy, with a similar one that accounts for developments in textile work, this would take the form (for Europe) of: flax and hemp, wool, cotton, and silk. Taking into account

\section{Dinges 1992.}

6. Goguet, vol. 2, 1775: 387.

7. Lenz [1790] 1976: 38-39: 'So wenig wir auch bestimmen können, wie vollkommen oder unvollkommen die kunst zu sticken damals seyn mußte, die doch einige regeln des zeichnens, genie, gebildeten geschmack u.s.w. voraussetzt, so wenig läßt uns die allgemeine bewunderung dieser weiblichen werke im alterthum zweifeln, daß man es wenigstens für jene Zeiten sehr weit darin gebracht habe'.

8. Cf. e.g. Roebuk 1969; Burford 1972; Landels 1978. A few remarks on textile technology can be found in Hopper 1978 and Schneider 1989. By contrast, Hugo Blümner's four-volume history of the technology and terminology of the arts and crafts in Greece and Rome published in 1912 contains much technical information on ancient textile production. Nineteenth-century histories of ancient private lives ('Privataltertümer') also contain extended reflections on the fabrication of textiles. Publications on ancient economy show a similar picture. See e.g. Finley 1973. The situation has changed during the last decade. See e.g. Bresson 2008, I: 196-99 ('Le cas de l'artinasat textile'); Harris, Lewis and Woolmer 2016. Their book The Ancient Greek Economy contains several articles dealing with textiles. For discussion of the development see Wagner-Hasel and Nosch 2019: 13-15.

9. See Childe 1947. 
tools as well as materials, we would have: spindle and needle, followed by loom and spinning wheel. Neither schema, however, fits well with the traditional three-ages system. Flax processing can be traced back to the Palaeolithic; weaving on looms with wool and flax begins in the Neolithic and is older than the melting of metals; the distaff first occurs in the archaic period, during the Iron Age, while the spinning wheel was invented only in medieval times. ${ }^{10}$

It is not my intention here to redraw current systems of periodisation. The key question is not to reevaluate the sequence of the technological developments of the premodern era. The real problem is the the change from the premodern to the modern age and the way in which this change is determined by the process of industrialisation. This has transformed our perception of the sensory world to a significant degree. For this reason, I think it is worth looking back to the perspective taken by an eighteenthcentury scholar contemplating ancient material culture in order to focus on the ways in which we might profit today from taking a cultural-historical view of ancient gift objects. ${ }^{11}$ Let us start by sketching out the state of contemporary scholarship in cultural history.

During Goguet's time, the definition of culture was firmly anchored in the worlds of farming, forestry, and botany from which the term is derived. Eighteenth-century bureaucratic language defines culture according to the ancient cultura (derived from colere, to inhabit, till, cultivate, worship) as the cultivation of soil, crops, and woodlands. Although the major semantic shift that established culture as a social rather than as an agricultural term did not occur completely until the mid-nineteenth century (sometime between 1830 and 1860), we can already detect a sense of civilisation and refinement in Goguet's cultural-historical observations. ${ }^{12}$ In this sense, culture and civilisation are closely connected concepts, perhaps especially so in the French-speaking world..$^{13}$ Understood as a whole, culture suggests the mores, attitudes and practices of a society or era but also refinement, or a refined way of life, precisely that use of buckles and buttons suggested in the earlier quotation. In this way, culture, in Goguet's work, is inextricably bound to the progress of civilisation.

10. For an overview see Barber 1991: 249-59. For a discussion of the criteria of technical periodisation see Paulinyi 1990. He stresses the factor of 'Mechanisierung der Stofformungstechnik' that means the use of machines.

11. For such an approach see now Schmitt Pantel 2009: 12.

12. Sobrevilla 1971: 2-3.

13. Cf. Bausinger 1980; Rehberg 1986. 
Since then, the concept of culture has undergone a number of shifts in meaning and has changed from a concept defining agricultural practice and a refined way of life to a way of interpreting practice as such. The academic disciplines that shape our understanding of culture include those that specialise in present, past, and alien cultures (sociologists, historians, and ethnologists) along with those whose expertise is the material and literary remains of the past (archaeologists, art historians, and philologists). The concept of culture used in these disciplines can be roughly divided into two areas. Archaeologists and anthropologists tend to make use of an instrumental and substantial concept of culture, in the sense of civilisation, in order to interpret material remains and lived practices. Here, culture is viewed from the perspective of social processes, as by Gordon Childe, and understood as 'the durable material expression of an adaptation to an environment $[. .$.$] that enabled a society to survive and develop. { }^{14}$ Sometimes culture is seen, as by Marvin Harris, from the perspective of the individual adapting to the environment and defined as the entirety of technologies suitable for ensuring survival. ${ }^{15}$ Functionalists such as Malinowski, critical of progress and keen to stress the intrinsic value of culture, also espouse a similar understanding of culture as being linked to civilisation when they observe the functional connections between mores and customs, and technologies and ideas, as well as institutions and practices..$^{16}$ Such an understanding of culture also underlies sociological research into the process and development of patterns and standards of behavioural practices undergone by the individual during the transition from the premodern to the modern age. ${ }^{17}$ With the 'cultural turn' in historical studies, as the discipline shifted from structural and social history to a history of culture and mentalité, we see by contrast the formation of a semiotic concept of culture that builds on a different tradition and emphasises inner values and individual creativity rather than social structures, technological developments, and supra-individual patterns of behaviour. ${ }^{18}$ This semiotic concept of culture looks to research in the field of semantic anthropology to understand culture as the world of symbolic practice. ${ }^{19}$ In this view, culture

\section{Childe 1947: 16.}

15. Harris 1985. Cf. also Hansen 1995: 195, 204.

16. Malinowski 1944.

17. See e.g. Elias ${ }^{8} 1981$.

18. See e.g. Jacob Burckhardt's Griechische Kulturgeschichte. For the background to Burckhardt's approach see Gossman 2000: ch. 12.

19. The key reference must always be Clifford Geertz, The Interpretations of Cultures 1973. On semantic anthropology compare Hastrup 1986: 54-67. 
comprises all the thoughts, actions, and perceptions that together are seen as constituting reality. ${ }^{20}$ The concept transcends its tradition, which also contains an antimodern impetus, directed precisely against the notion of progress in the 'process of civilisation', and at times criticised for elitism. ${ }^{21}$

In anthropology reflecting on culture as a system of meanings, culture must be understood as a way to counteract the objective status of anthropological knowledge and more generally as a part of a process of reflection on the status of ostensibly objective data. In historical studies, the search for a new definition of the concept of culture should be seen in the context of the reevaluation of the role of the subject, as societal structures are seen to dominate. A similar shift of perspective from the study of social structures to the study of the construction of meaning is debated in sociology ${ }^{22}$ and should be understood as a reaction (similar in character to the cultural historical debates that emerged around 1900) to the absence of sense in an increasingly complex and incomprehensible environment. ${ }^{23} \mathrm{My}$ aim in choosing a cultural-historical perspective is to bridge the gap between social structures and the semiotic concept of culture. ${ }^{24}$

Classical studies have for some time been especially dominated by the idea of universal values inherent in humanist cultural history, so that the shift to semiotic readings of culture has been especially important here. ${ }^{25}$ This is true for art-historical and archaeological research ${ }^{26}$ as much as for philological and ancient historical studies of thought, behaviour, and imagination in the ancient world, ${ }^{27}$ and for research into the political and ritual practices of ancient communities. ${ }^{28}$ When forms of cultural expression such as artefacts and literary texts, but also practices and forms of behaviour such as the symposium, are interpreted from a sociopolitical perspective, we find that the subjects of the universal histories of the eighteenth century (e.g. marriage and funeral rituals, dress, and food culture)

20. See the overview of Daniel 1993: 72; 1997: 195-218 and 259-278.

21. Rehberg 1986: 92-95; vom Bruch, Graf and Hübinger 1989; Bausinger 1980: 62.

22. Cf. Neidhardt 1986: 10.

23. Vom Bruch 1989: 9-17.

24. For a critique of the neglect of the social dimension of culture see Kaschuba 1995: 27-46; Canning 2002.

25. 'Third Humanism' is a case in point, see Jaeger 1925; Schadewaldt 1931.

26. Cf. e.g. Hölscher 1989; Zanker 1987; Bérard and Vernant 1984; Giuliani 1986.

27. Cf. e.g. Winkler 1990; Meyer-Zwiffelhoffer 1995; Barghop 1995; Rohweder 1998; Hartmann 2016; Chaniotis 2011; 2017.

28. Cf. e.g. Murray 1990; Schmitt Pantel 1992, reprint 2011; Hunter 1994; Davidson 1997; Dunbabin 2003; Vössing 2004; Stein-Hölkeskamp 2005; Stavrianopoulou 2009; Tietz 2013. 
can be reintegrated into political history. During the course of the increasing professionalisation of historical studies, and their concentration on political events and institutions, those subjects were seen to be relevant only to the lives of individuals and had been marginalised. ${ }^{29}$

The purpose of this study on the materiality of the terms and objects connected to gift-giving was not to determine a new cultural code or symbolic system. My purpose was to find ways to use the material world as we see it in the depiction of exchange in the Homeric epics in order to find new ways to analyse and to read ancient society. In the course of my enquiry it has become clear that the economic value of gifts was far greater than had been recognised in research focussed only on political and social functions. Taking symbolic value into account suggested that gift-exchange had a hitherto little-recognised economic function even in the political sphere, be that Homeric kingship or the formation of the polis. The focus on determining the sensory content of the objects and terms involved, rather than on reconstructing systems for their interpretation, led to this recognition. The exchange relationships and areas of conflict belonging to the world of the eighth to sixth centuries BCE were brought into focus by paying close attention to that sensory, material content. And the very things Goguet singled out particularly in his negative assessment of Greek civilisation-tripods and clothing-prove to be of central significance.

In antiquity, tripods and textiles were never merely utilitarian or decorative objects. Both types of objects represented symbolic action, such as when they were presented as gifts or donations on particular occasions, or when they served to visualize status or service as well as bonds and identity. The three-legged cauldron may be an exceptionally and universally useful object, not least because it has the advantage of being very stable on uneven ground; but the tripod also signifies Greek culture particularly. ${ }^{30}$ Contrary to Goguet's assumption, it did have utilitarian functions both for cooking and for bathing, but it was also and above all a guest-gift, a prize, and a votive offering. At Delphi the tripod came to symbolise Apollo's prophecy and, therefore, to be connected to the transmission of wisdom. ${ }^{31}$

29. Schmitt Pantel [1992] 2011: 493-94; Nippel 1990: 78; Wagner-Hasel 1998: 25-35. See also Schmitt Pantel 2009: 11; 2012.

30. Around 1900 the Vlachs were using tripods to cook their national dish. See Wace and Thompson 1914: 51. Tibetan shepherds were exchanging sheep for iron tripods even at the end of the twentieth century: Goldstein and Beall 1991: 22. In 1970s Euboea, farmers still used iron tripods as du Boulay (1974: 25) could observe.

31. The symbolic meaning of the Delphic tripod is discussed by Papalexandrou 2005. 
We have found that Homeric epic suggests a correspondence on the symbolic level between metal and textile gifts. Even if Greek dress could be criticised for its lack of buttons, buckles, and pockets (the eighteenthcentury critique would eventually be reversed when this lack of elaboration was seen as the virtue of timeless and utilitarian beauty once the dress reforms of the 1920 took hold $^{32}$ ), it was clearly as impressive and distinctive in its use of colour and patterns as any courtly fashion. Recent years have seen a new interest in textile production ${ }^{33}$ and in the symbolic value of clothes. ${ }^{34}$ When we do see studies into the symbolic value of textiles as gifts, structuralist approaches dominate over investigations into historical functional contexts. This is true for instance of the work of Ian D. Jenkins on the destructive effects of textile gifts in tragedy. Without paying any attention to the social and political contexts within which textiles are offered as gifts, Jenkins places textiles within the domain of the basic ambiguity of the feminine that can be both a gift and an evil. ${ }^{35}$ But ignoring contexts means that the messages carried by gifts are concealed. Even in a new study titled Body, Dress, and Identity in Ancient Greece (2015), which deals with the visual, haptic, and olfactory appearance of the clothed body, we find such binary patterns of interpretation with the result that the cultural importance of textiles gets lost. Its author, Mireille M. Lee, assumes an a priori, general idealisation of the naked male body and a contempt in principle for the dressed female body, ${ }^{36}$ an assumption that archaeological research has long since proved wrong. ${ }^{37}$ Deborah Lyons, on the other hand, in her Dangerous Gifts of 2012, emphasises the importance of female gifts in the epics and in tragedy, while ruling out the possibility of genuine reciprocity between husbands and wives. In her view, women were strangers within the household (the oikos), and within the polis they did not have the status of citizens. ${ }^{38}$ Josine Blok and other historians have proved that

32. Bieber [1928] 1977: 1-2.

33. Cf. Pekridou-Gorecki 1989; Barber 1991; Reuthner 2006; Gillis and Nosch 2003, Bundrick 2008; Spantidaki 2016.

34. Bergren 1983; 2008; Jenkins 1985; Koch-Harnack 1989; Scheid and Svenbro 1994; Papadopoulou-Belmehdi 1994; Llewellyn-Jones 2003; Gherchanoc and Huét 2012; Lee 2015; Cifarelli and Gawlinski 2017.

35. Jenkins 1985; cf. also Keuls 1983: 209.

36. Lee 2015; cf. also Lyons 2012.

37. Cf. e.g. research on female nudity (Kreilinger 2007) or on the symbolic meaning of female dress in funeral rites (Sojc 2005).

38. Lyons 2012. Like Jenkins, Lyons also argues that tales of the perils emanating from women's gifts in tragedy reflect fears of female agency, while also suggesting the dependence of men on women with respect to household economy. 
the concept of the citizen, the politēs, existed alongside the politis, i.e. its female form, and that female Athenians were considered as citizens. ${ }^{39}$ The significance of textiles is increasingly recognised in philological research based on discourse-analysis. In such work we find a concentration of interest in the narrative function of objects such as Penelope's shroud or the ritual background of textile metaphors..$^{40}$ In social anthropology, research into technologies of dyeing and into the production of patterns led to extremely illuminating results concerning questions about the messages conveyed by gift-objects. ${ }^{41}$ Research on technologies of patterned weaving yielded insight into poetic techniques ${ }^{42}$ and into the basic structures of communication within which textiles functioned as symbolic capital.

I wish to stress five points to summarise some of the findings of this study. They concern (1) the sensory content of gifts, which can be traced to the terminology used for them and provide insight into (2) the structures of exchange found in the Homeric world, and into (3) the economic dimension of Homeric kingship and centre formation. Two further factors are critical to understanding such gifts: (4) the ritual context of the reception of Homeric epic and (5) the tension between remembrance and forgetting that affects both the epics themselves and the modern processes of the appropriation of the ancient material world.

\section{The sensory content of the gift and its meaning.}

We have pursued gift-objects mentioned in the Homeric epics in their various functions as they circulate as gifts and counter-gifts. In the ritual of guest-friendship tripods are used for bathing, while textiles serve to prepare the stranger's bed and to clothe him. Bathing and clothing effect a change in status, and the establishment of a new identity, as the stranger

39. Blok 2004. The idea of female citizenship through participation in cultic activity is argued for by Waldner $2000 \mathrm{~b}$ in her examination of the Attic Brauronia.

40. Pantelia 1993: 493-501; Papadopoulou-Belmehdi 1994; Felson-Rubin 1994. The ritual practice is considered by Scheid and Svenbro [1994] 2001. See now HarichSchwarzbauer 2016; Harlizius-Klück and Fanfani 2016.

41. Cf. Weiner and Schneider 1989: 1: '[...] cloth has furthered the organization of social and political life [...] cloth helps social groups to reproduce themselves [...] possibilities of color and patterning give cloth an almost limitless potential for communication.'

42. Cf. Nagy 2002 who considers technological aspects of weaving metaphors, and Harlizius-Klück $(2004 ; 2016$; 2019) whose interpretation of weaving metaphors is based on a close knowledge of textile technology. See also Adeline Grand-Clément's (2011) research on colours and Florence Gherchanoc's (2019) research on the symbolic meaning of patterned cloth in rituals of initiation. 
(xeinos) is transformed into a friend (philos). Epic shows how textiles and metal gifts, such as golden beakers and silver mixing bowls given as commemorative gifts to guest-friends, guarantee permanent attachments and two different types of bonds. Textile gifts used as wedding presents integrate the guest into the domestic community and into the host couple's own marriage ties. In addition, the metal gifts, objects associated with the aristocratic symposium, symbolise the guest's ties to a male community of peers.

Both textiles and tripods develop their own symbolism within the context of the funeral ritual. During the washing and clothing of the dead they play a transforming role, as in the guest rituals. They contribute to the body's change in status and serve to grant safe passage (this is especially true of the shroud). They travel with the dead, whose post-mortem appearance they affect, and they are cremated along with the body. The posthumous fame and glory of the dead adhere to the textiles worn by them, as they do to the tripods presented as prizes at funeral games. The prizes remain in circulation among the living, for whom the ritual ensures the renewal of their hierarchies of achievement; the textiles used during the funeral ritual on the other hand are objects of generative power serving to secure the bond between the dead and the living.

Whenever textiles are attributed such important functions, reference is made to their colour and to the effects of their colour and patterning. The assumption that emerged from the debate on gift-exchange had been that objects circulating as gifts bear significant messages inherent in their materiality and that this refers back to their social function. On this, the evidence from the Homeric epics is clearer than that provided by Weiner's classical sites of gift-exchange in the Southern Pacific. In Homer gifts are presented as bearing messages in their decoration, and objects are used purposefully as signs of memory and identity in guest-friendship and in funeral rituals as signs of attachment in social relationships and finally as normative signs in situations requiring decision-making.

In decision-making contexts in the epics two objects are significant: one is the golden sceptre which is connected with guiding both herds and humans and is used to convey the right to speak; the second are the themistes. These themistes have a material and a nonmaterial meaning, as I have argued: they represent customary rules visualized and preserved in woven textures. 
Scholarship has often pointed out the lack of clear rules of heredity in the distribution of positions of power, explaining this either as the result of a transition from monarchy to aristocracy or as part of the relatively low level of institutionalisation in early Greek kingship. Viewed against the background of the textile aspect of kingship, however, and especially through the analysis of the mythical world of the Phaeacians, we see a different explanation for this lack. Power is based on economic and symbolic capital, on access to stores of knowledge and tradition, and on the ability to recruit services and tributes from others. In the world of the Homeric epics we are not dealing with a monolithic system of government in which functions are fixed but with a range of spheres of power which are divided between the male and female members of high-ranking households, and between male representatives of different households. The world of the Phaeacians presents us with an idealised example of this system.

The symbolism of the material worlds as a whole shows a dual structure with respect to both space and time: messages emanating from the prizes and shrouds used during funeral rituals address both, the supraregional community of warriors and the local community. Both types of gifts, metal and textile objects, are able to symbolise time in different ways: as duration and as a process of renewal. The production and presentation of objects requires communal action by different groups, the supraregional warrior community and the domestic or local community. The cohesion of these communities is established by their collaboration and commemorated in the objects themselves.

\section{Terminology and social structure.}

Our enquiry into the symbolic content of gift-objects led us to an analysis of the terminology used in connection with gifts. Among the terms for guest-gifts, honorific offerings, and gifts of thanks investigated here, the word charis stood out as central, as it offered insight into the symbolic as well as the material processes that reproduced the social body. On the one hand, the term charis belongs in the realm of symbolic production, as it is used to describe the effect of images, be they woven, literary, or worked in metal. At the same time, charis also describes the making of such images undertaken as a service or as thanks for services given, and it therefore must be understood as a term of material production and social practice. 
The use of the term affords insight into structures of cooperation we find in the epics. One such structure is the bond between husband and wife, underpinned by the collaborative community of weaving women, which in turn has its divine equivalent in the Graces. Another bond is the supraregional community of warriors, bound into a relationship of reciprocity with the gods through the sacrificial banquet. In the context of the bond between the married couple, charis can be interpreted as the thanks given by the wife in the form of her work on the loom and the products of that work. These are offered in recompense for bridal gifts given by the husband in the form of cattle and jewellery, and which emanate charis in the sense of a visual effect. In a military context, charis is the service given to a leader in battle, and the thanks expected for this. Divine charis often takes the form of the granting of success in battle given by the gods in return for sacrifice made to them.

If there is one term among those here examined that embodies reciprocity, that term is charis because it describes both service given and service returned. If we wanted to determine different types of reciprocity, as Donlan attempts with reference to Sahlin's ethnological studies, it would make sense to determine classifications by differentiating between the different relationships characterised by the term philotēs, which include both collaborative communities and relationships of exchange. The use of the term charis, however, also demonstrates that exchange is not merely a twofold act of giving and returning but that individual acts of exchange form part of a greater circulation. The epics show us that the funeral ritual is at the very heart of that circulation.

Another term with a similar double perspective is amoibe . This word describes the necessary return offered after gifts have been given, be it as sacrificial offerings or guest-gifts. While charis emphasises reciprocity and community, amoibē has a more individualistic character and refers specifically to the reciprocity of exchange between individuals. Unlike previous scholars, I see the function of such reciprocal exchange between guestfriends to be less connected to the formation of political bonds and more to the organisation of an exchange of resources, albeit within the framework of existing guest-friendships. This includes the sharing of pasture lands but above all focusses on moveable goods. Guest-gifts share a material content with these goods and thus form an important reminder of the relationship 
that underpins the exchange of resources such as textiles, especially linen, dyes, and metals.

Materials imported from abroad are only very rarely referred to as guest-gifts or xeinia. When the term is used, it appears to suggest tribute provided by foreign shepherds or foreign masters. This is true of some of the natural xeinia which, as we have established, form part of a relationship of exchange between a shepherd's station and the homestead. When gifts of armour are described as xeinia they are substitutes for personal military service. When textile and metal xeinia are given to strangers, contributions in kind are collected by high-ranking sponsors from the people. Such objects can therefore not properly be counted as tokens of a reciprocal relationship of obligation between strangers but should instead be interpreted as tributes offered to a basileus.

This relationship of exchange, or tribute, between a basileus and his people is best understood through dōtinai and themistes rather than xeinia. These are offerings, probably consisting of textiles, animal products, and metal objects, which are given in return for judgements or perhaps also for the granting of safe passage. It remains the case that there appears to be no system of regular taxation in antiquity, as our investigation shows that the tributes given to kings are always tied to specific benefits or services received. But we have somewhat modified the current image of Homeric kingship. While previous scholarship emphasised the rituals of generosity a basileus needed to perform in order to maintain his power, my examination of the services described by dottinai and themistes has highlighted the functional aspect of the position of the basileus. Apart from their military leadership, Homeric kings owe their privileged position to the granting of spatial passage and the fulfilment of judgement, which can be interpreted as social guidance.

\section{The economics of centre-formation.}

Advancing a functional interpretation of Homeric kingship, which I defined as 'Geleitherrschaft', enabled us to consider the spatial dimension of rulership and thus to review established ideas of pre-state structures based exclusively on personal ties. It is true that personal ties established through guest-friendships and marriages do play a role in the creation of a widespread net of relationships. However, rulership is also connected 
with fixed places or clearly identified settlements where leadership and decision-making are exercised (basileuein) and where tributes and gifts are collected. This means that the Greek tyrants of the sixth century, whose positions of power depended on far-reaching networks based on marriages and guest-friendships, and on the organisation of imported resources, ${ }^{43}$ were able to relate to the Homeric world, notwithstanding the influence of Eastern culture on the design of the works. ${ }^{44}$ Previous research on the spatial aspects of polis formation assumed a transition from a pastoral (Homeric) to an agricultural society, in which land became the only significant form of wealth. However, it is clear that Homeric society in no way corresponds to a pastoral model. Instead, the use of shared pasture lands we find in the epic poems suggests an economy of transhumance which goes hand in hand with agriculture. My observations lead to the conclusion, therefore, that the processes of centralisation and polis formation are a result of this transhumant economy as well as of an intensification of the exchange of resources. Research on Homeric gift-exchange has tended to interpret conflicts in terms of oppression and exploitation and to deduce from this a development of increasing social inequality, which in turn is assumed to have led by necessity to new, institutional ways of regulating conflict. ${ }^{45}$ Our spatial perspective demonstrates the extent to which centre formation, driven by the need for supraregional communication, perpetuated and updated Homeric traditions for regulating conflict and organising spatial movement and social conduct.

\section{Text and ritual, event and discourse.}

The manifold practices and singular objects of giving and exchanging do not display only patterns of behaviour, attitudes, and social values. Investigation of the semantics and the circulation of gifts allows us also to reconstruct a model of social structure whose historical location is a ritual rather than a specific city or region. Epic songs were recited at festival days, such as the Panathenaic Games instituted in 566/5 BCE. ${ }^{46}$ Through

43. Stahl 1987: 201-26.

44. Burkert 1991: 155-81.

45. Qviller 1981; Morris 1986: 4. Cf. also Rose 2012.

46. Peisistratus and his sons were also responsible for the so-called edition of the Homeric epics. This is the argument of Seaford 1994: 144-50 and Stanley 1993: 280-82. For a discussion of the iconographic evidence see Shapiro 1989: 43-48. Cf. also Blok 2000. 
the two key elements of the ritual of the Great Panathenaia represented on the Parthenon frieze, the sacrificial procession and the presentation of the peplos to Athena, the city presents itself as a sacrificial community and, at the same time, places itself under divine protection through the dedication of the peplos. ${ }^{47}$ Thus the Panathenaic ritual suggests two types of bond, both of which we have seen in the epics: ties between warriors and ties between the women of a domestic community. While the sacrifice is supported by a community of young men, the dedication of the peplos (just like the presentation of the shroud at the funeral ritual and the handing over of textile commemorative gifts to guests) is a communal task undertaken by the women weavers. These women are represented in Athenian ritual by the two arrhepphoroi who, on the Acropolis, lead the weaving of the peplos directed by the priestess of Athena. ${ }^{8}$ The two arrhepphoroi suggest the pairs of Homeric amphipoloi, who in turn represent the Charites, the divine weavers, and in classical times were the guardians of festivals. They belong to the group of multiple divinities understood by Nicole Loraux as part of a strategy of deindividualising the feminine. ${ }^{49}$ Loraux's interpretation, however, misreads the social practice embodied by these multiple divinities, which are manifested in the Theogony. They all represent aspects of the symbolic function of woven textiles. ${ }^{50}$ Alongside the Charites, who here grant pleasure at festivities, there are the daughters of Themis, the Horae and the Moirae, who represent law and order in the form of Eunomia (good order) and Dike (righteousness), and the thread of life. While the Graces represent the effects that emanate from woven or poetic images, the Horae embody social values and norms which, in epic poetry, are represented by the (textile) themistes and which we see described in literature and philosophy through the image of the political or communal garment. ${ }^{51}$ Finally, Hesiod also names the Muses, the divine singers who inspire poets, the daughters of Mnemosyne, or memory. Images from the classical period show couples as well as groups of men and groups of women wrapped in a common cloak or mantle, in pairs, or in groups of three or nine (Figure

47. The dedication of the peplos in Iliad 6 is often thought of as a late, Attic addition. See Stanley 1993: 282.

48. See Mansfield 1985; Barber 1992 and now Brøns 2017.

49. Loraux 1991: 45 .

50. Hes. Theog. 901-11; 915-17. On the Charites see Wagner-Hasel 2002.

51. Aristoph. Lys. 568-86; Plato, Politikos 31a-c; Scheid and Svenbro [1994] 2001: 9-34; Wagner-Hasel 2005. 


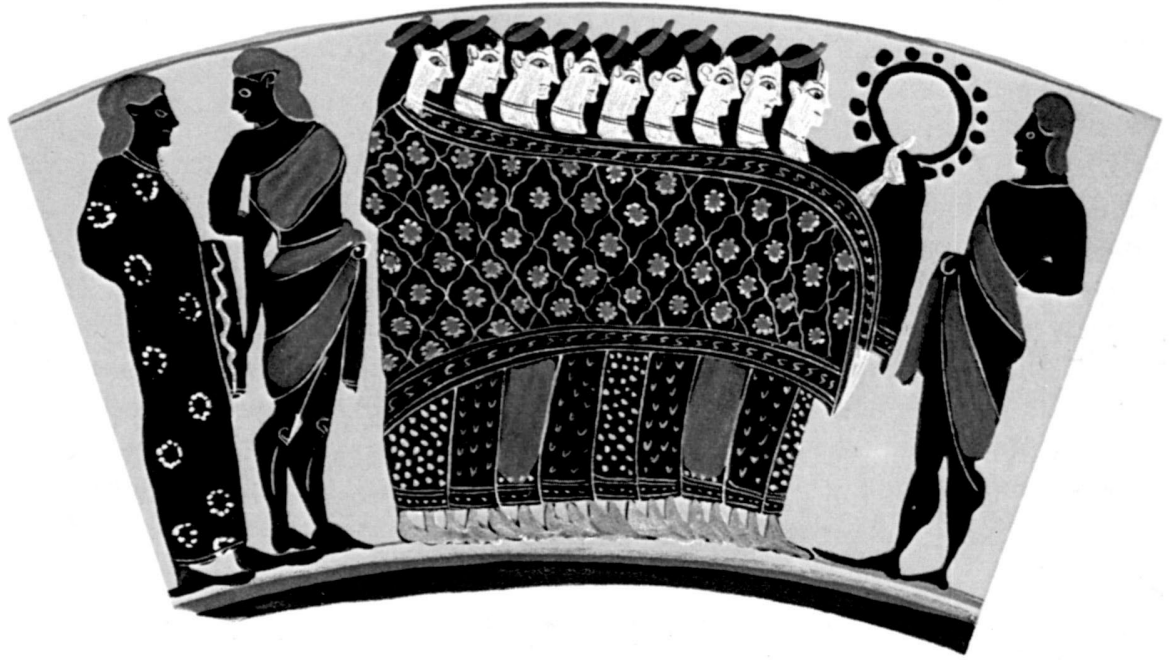

Figure 10: Nine women wrapped in a common cloak. Black-figure kylix, $5^{\text {th }}$ century BCE. Berlin, Antikenmuseum F 3993. After Koch-Harnack 1989: 111, Fig. 1.

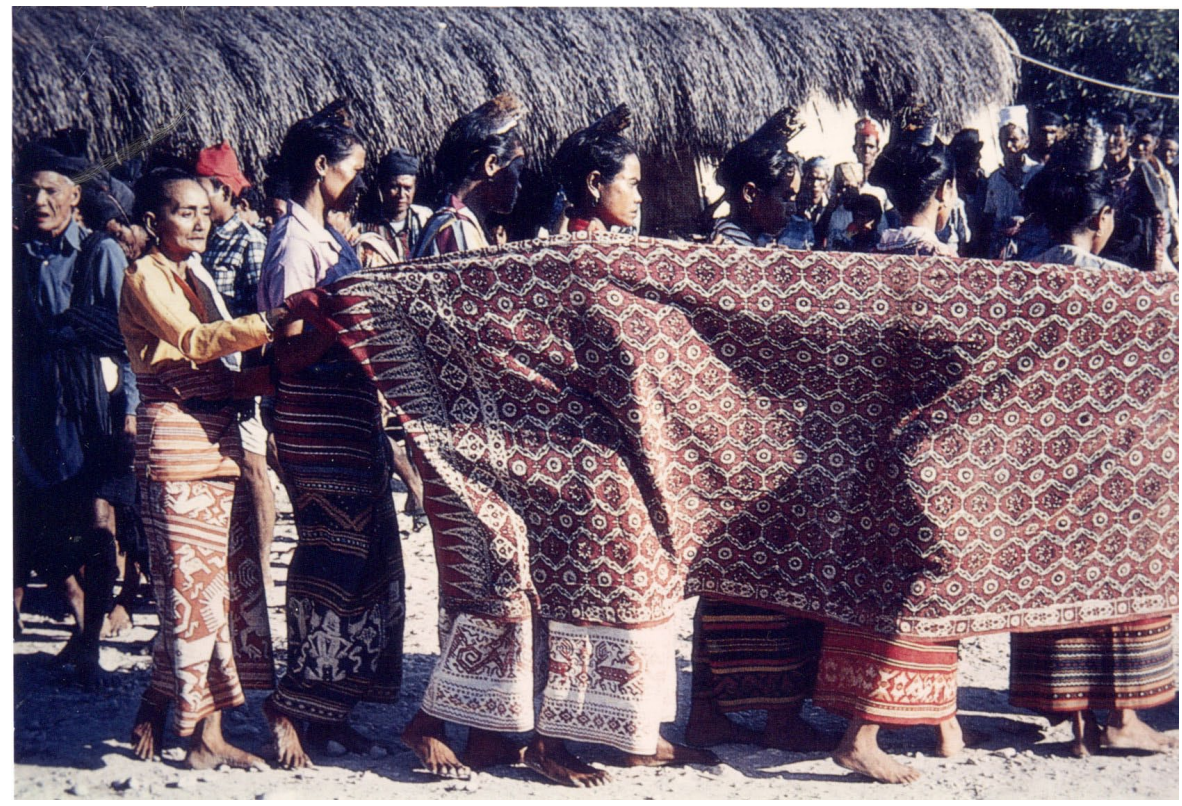

Figure 11: A group of women on Sumba wrapped in an Indian cotton textile performing a dance prior to the burial of King Umbu Nai Wolang of Kapunduk. After KahnMajlis 1991: Fig. 2. 
10). ${ }^{22}$ Gundel Koch-Harnack suggests these images carry erotic symbolism. It is, however, equally possible that the common mantle is a symbol of community resulting from communal action and communal performance in ritual. This is confirmed by a glance at an ethnographic parallel from Indonesia; here a group of women at a funeral ceremony are wrapped in a large mantle in a manner evoking the image on our ancient kylix (Figure 11). ${ }^{53}$ The bonding, or community-building, function of woven garments could suggest that Mauss's supposition that there was a social purpose adhering to the giving, receiving, and returning of gifts might, after all, be true for ancient Greece. However, the integration of objects into concrete rituals of orchestrated communal action makes it quite clear that the social groups behind those objects are tied together through their collaboration rather than by the objects themselves. The objects merely represent this social integration.

While ritual focusses on basic social values and serves to create an idealised or simplified image of reality and to create a sense of social cohesion, ${ }^{54}$ narrative performances can thematise social conflict instead. It has been common in scholarship on the practice of gift-giving to look for depictions of the realities of giving, often without reference to the narrative logic of the epics. But epic narrative depicts ideal practice only selectively, as it is mostly concerned with what occurs when the processes of gift-giving are disturbed. This potential for conflict only becomes comprehensible when we tie it to social structures, not by considering events but by considering the semantics of things and of terms. This means that we have to read on two levels: (1) the narrative level on which events are related and (2) the level of social code or unconscious discourse that underlies the narrative, even when the subject is also the addressee of the narrative and when the narrative revolves around transmitting values and attitudes through poetic images that replicate the world as it is perceived in day-to-day reality, which are always socially determined. Thus, social structures are tacitly inscribed into the text.

52. Koch-Harnack 1989: 111 (fig. 1) and 117 and 143-63.

53. Kahn-Majlis 1991: 16 (fig. 2): 'An Indian cotton textile unites and protects a group of women on Sumba, who are performing a dance prior to the burial of King Umbu Nai Wolang of Kapunduk. They are wearing ceremonial sarongs which indicate that they are members of an aristocratic family'.

54. Bell 1992: 98-99. For ancient evidence see Seaford 1994: XI-XVI; Waldner 2000: 21-28. 
Even when its social structures did not entirely correspond with those represented in epic poetry, Athenian society of the classical period could recognise itself in the rituals and practices depicted in the poems. Once new literary forms such as tragedy came into play, with a public status comparable to that of the epics, it would appear that epic worldviews became increasingly incompatible with contemporary circumstances, so that the role of the Homeric epics in the formation of civic identity also diminished. With Theagenes of Rhegium in the sixth century we see the rise of allegorical interpretations of Homeric epic and the increasing presence of competing versions of poetic 'truths'. ${ }^{55}$ This uncertainty also determines the depiction of epic subject matter, and its continuation, on the tragic stage of the fifth century. So, tragedy treats the contradiction or tension between domestic ties and military alliances between citizens, which were absent from the epics but present in Athenian concerns after the Persian wars. The new dominance of the ties of citizenship over the ties of the couple and the domestic community forms the subject of the fifth-century funeral oration ${ }^{56}$ and of Aeschylean tragedy; ${ }^{57}$ it can also be seen in woven images, such as the pattern on Athena's peplos which depicted the gigantomachy. ${ }^{8}$

\section{Remembering and forgetting.}

Ancient tradition makes the singer Simonides of Ceos (556-468 BCE) the inventor of the art of memory, which consisted of the ability to link images (imagines) with places (loci). The well-known story of the invention of this technique takes place after a banquet hosted by the Thessalian Scopas, who tried to deduct half of the fee promised to the poet for his recital because he had included a lengthy passage in praise of Castor and Pollux in his song for Scopas. The Dioscuri take their revenge on Scopas by causing his house to collapse but save Simonides. The poet is able to identify the victims, crushed beyond recognition by the collapse of the house, according to the places where they had been sitting at the banquet. ${ }^{59}$

In this myth of the origin of memory the banquet is transformed into a funeral feast, a place of memorialising the dead. Pauline Schmitt Pantel's

55. Svenbro 1976: 16-17; Rösler 1980: 301; Feeney 1991: 5-56; Boyd 1995: 2-6.

56. Loraux 1981.

57. Wagner-Hasel 2007 (an English version is in preparation).

58. Wagner-Hasel 2005; Geddes 1987.

59. For evidence and discussion see Blum 1969: 41-46. 
investigation of the history of the banquet highlights the role communal meals play in Greek memorial cult. ${ }^{60}$ In Homeric funerary ritual, the key bearers of the posthumous glory of the dead are the funerary garments and the prizes awarded at funeral games. Mnemonic technique alludes to the manufacture of those objects: the ability of the weaver and the smith to place images in specific places and thus to award a spatial dimension to memory. But in the myth of memory, the singer's art predominates and erases the role of the place and the material media we see so clearly in Homer. And yet, the singer's art itself consisted of the ability to create images that inscribed themselves into the memory of the living.

Instead of Homer's woven garments and tripods, it is the written word of the poet that is anchored in the collective memory of modernity, although a late antique scholiast did suggest that Homer's depiction of the Trojan war was indebted to Helen's tapestry. ${ }^{61}$ It is not necessary to assume an actual priority of the woven image over the poetic one in order to understand Uvo Hölscher's suggestion that Homeric epic 'emerg[ed] at a time that is not illuminated by even a glimmer of history', and is 'as though created from nothing during the first rise of the Hellenic spirit, as a product of a narrative imagination and at the same time of a perfection that must appear as a marvel.' ${ }^{62}$ 'A marvel to behold' (thauma idesthai) is of course how Homer describes the purple threads and garments that are woven and spun by high-ranking women in the epics. In order to trace their role within the circulation of gifts and to inscribe it into our collective memory, it is necessary to define the contexts within which we ask questions about historical circumstances, and to gain some distance from our own cultural values. One way of achieving this is through looking back at the history of scholarship in our field, and through ethnological comparison. Another way was a historical investigation of terminology, which allowed a systematic approach unencumbered by any ready-made conceptual model. To undertake this journey into the past and into alien territories, and reconsider ancient culture based on the new insights gained, is a timeconsuming task. When he came face to face with the Persian king, the aptly named Themistocles ('glory of Themis') asked for 'time' (chronos), to be

6o. Schmitt Pantel 1992: 418-20, 490: Cf. also Scheid-Tissinier 1994: 267-84.

61. Sch. Hom. Il. 3.125. Barber 1991: 373. On the technical similarities see Bergren 1980: 22.

62. Hölscher 1990: 16. 
used to gain a greater understanding of Greece from abroad and to give a good account of it. I will end my own journey into the faraway past with his words and a final invocation of patterned textiles:

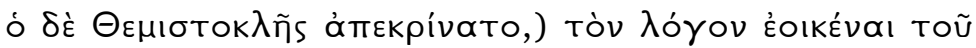

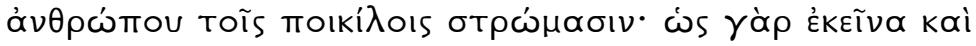

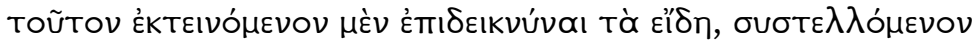

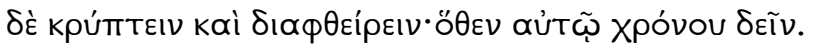

Themistocles answered that the word of man was similar to multicoloured tapestries (poikiloi strōmata). Like them, it needed to be spread out in order to display its figures, but when it was rolled up it concealed and destroyed them. For that reason, he was in need of time. (Plut. Them. 29.4-5). ${ }^{63}$

63. For the meaning of the simile see Gera 2007: 452. The reference point is not the spoken word but the translated speech. According to her, 'Themistocles compares translated speech, words that are conveyed by interpreters, to a rolled-up tapestry. Interpreters compress one's words and consequently the patterns, the subtleties and intricacies of one's thought, are lost'. 


\section{BIBLIOGRAPHY}

Adkins, Arthur W. H. (1960) “'Friendship' and 'Self Sufficiency' in Homer and Aristotle,” Classical Quarterly n.s. 12: 30-45.

— . (1971) "Homeric Values and Homeric Society," The Journal of Hellenic Studies 91: $1-14$.

Adloff, Frank and Steffen Mau (eds.) (2005) Vom Geben und Nehmen: Zur Soziologie der Reziprozität. Francfort.

Adorno, Theodor W. (1985) "Einleitung" to Emile Durkheim, Soziologie und Philosophie, trans. Eva Moldenhauer. 2nd edn. Francfort: 7-44 (orig. 1924).

- . (1971) Minima Moralia. Francfort.

Adshead, K. (1986) Politics and Archaic Peloponnese: The Transition from Archaic to Classical Politics. Amersham.

Agourides, Christos (1997) "Searoutes and Navigation in the Third Millenium Aegean," Oxford Journal of Archaeology 61/1: 1-24.

Alcock, Susan E. (1991) “Tomb Cult and the Post Classical Polis," American Journal of Archaeology 95: 441-67.

Alcock, Susan E. and Robin Osborne (eds.) (1994/1996) Placing the Gods: Sanctuaries and Sacred Space in Ancient Greece. Oxford.

Alexiou, Margaret (1974) The Ritual Lament in Greek Tradition. Cambridge.

Alfaro, Carmen, John Peter Wild, and B. Costa (eds.) (2004) Purpureae Vestes: Textiles $y$ tintes del Mediterráneo en epoca romana. Valencia.

Alföldi, Andreas (1955) "Gewaltherrscher und Theaterkönig," in Late Classical and Medieval Studies in Honor of Albert Mathias Friend Jr. ed. Kurt Weitzmann. Princeton: 15-55.

Algazi, Gadi, Valentin Groebner, and Bernhard Jussen (eds.) (2003) Negotiating the Gift: Pre-Modern Figurations of Exchange. Göttingen.

Allgemeines Landrecht für die Preußischen Staaten von 1794: Textausgabe (1970). With an introduction by Hans Hattenhauer. Francfort and Berlin.

Alram-Stern, Eva and Georg Nightingale (eds.) (2007) Keimelion: Elitenbildung und elitärer Konsum von der mykenischen Palastzeit zur homerischen Epoche; Akten des internationalen Kongresses vom 3. bis zum 5. Februar 2005 in Salzburg. Vienna.

Althoff, Gerd (1990) Freunde und Getreue: Zum politischen Stellenwert von Gruppenbindungen im frühen Mittelalter. Darmstadt.

Amira, Karl von (1882-1885) Nordgermanisches Obligationenrecht. 2 vols. Leipzig.

Ammerman, A. J. (1985) "Anthropology and the Study of Neolithic Exchange Systems in Calabria," Dialoghi di Archeologia 3/1: 11-33.

Ampolo, Carmine (1986) "Storia antica ed antropologia. Un rapporto difficile?"

Dialoghi di Archeologia 4/1: 127-31. 
Anderson, Eva and Marie-Louise Nosch (2003) "With a Little Help from My Friends: Investigating Mycenaean Textiles with Help from Scandinavian Experimental Archaeology," in Metron: Measuring the Aegean Bronze Age; Proceedings of the gth International Aegean Conference, ed. Karen P. Foster and Robert Laffineur. Liège and Austin: 197-203.

Anderson, Øivind (1982) "Litai und Ehre: Zu Ilias 9, 513f." Glotta 6o: 7-13.

Anderson, Øivind and Matthew Dickie (eds.) (1995) Homer's World: Fiction, Tradition, Reality. Bergen.

Anderson-Stojanovic, V. R. (1988) “Cult and Industry of Isthmia," American Journal of Archaeology 92: 268-69.

_ . (1991) "The Rachi Settlement at Isthmia: Report on the 1989 Excavations," American Journal of Archaeology 95: 303-4.

Andreades, Andreas M. (1931 [Greek version 1926/27]) Geschichte der griechischen Staatswirtschaft. I: Von der Heroenzeit bis zur Schlacht bei Chaironeia. Munich.

Andreau, Jean (1995): “Vingt ans après L'économie antique de M. I. Finley. Présentation du dossier 'L'économie antique”, Annales H.S.S. 50: 947-96o = "Twenty years after Moses I. Finley's 'The Ancient Economy'”, in: Walter Scheidel and Sitta von Reden (eds.) The Ancient Economy. Edinbourgh 2002: 33-49.

Andreau, Jean and Etienne, Roland (1984): "Vingt ans de recherches sur l'archaïsme et la modernité des sociétés antiques," Revue des Études Anciennes 86,1-4: 55-83.

Andreev, Juri V. (1979) “Könige und Königsherrschaft in den Epen Homers,” trans. Eberhard Dressler, Klio 61: 361-84.

Andronikos, Manilos (1968) Totenkult. Archaeologia Homerica III/W 1. Göttingen.

- . (1980) The Royal Graves at Vergina. Athen.

— . (1984) Vergina: The Royal Tombs and the Ancient City. Athen.

Antonaccio, Carla M. (1992) “Terraces, Tombs and the Early Argive Heraion,” Hesperia 61: 85-105.

— . (1994) "Placing the Past: The Bronze Age in the Cultic Topography of Early Greece," in Alcock and Osborne 1994: 79-104.

_ . (2001) "Ethnicity and Colonization," in her Ancient Perceptions of Greek Ethnicity, Cambridge, MA: 113-57.

Appadurai, Arjun (ed.) (1986) The Social Life of Things: Commodities in Cultural Perspective. Cambridge.

Armandry, Pierre (1987) “Trépieds de Delphes et du Péleponnèse,” Bulletin de Correspondance Héllenique 91: 79-131.

Arru, Angiolina (1998) "Schenken heißt nicht verlieren. Schenkungen und Vorteile der Gegenseitigkeit in Rom im 18. und 19. Jahrhundert," L'Homme 9/2: 232-251.

Assmann, Jan (1990) Ma'at-Gerechtigkeit und Unsterblichkeit im Alten Ägypten. Munich.

Åström, Paul and Elsa Gullberg (1970) The Thread of Ariadne: A Study in Ancient Greek Dress. Studies in the Mediterranean Archaeology 21. Göteborg.

Athanassakis, Apostolos (1989) "From the Phallic Cairn to Shepherd God and Divine Herald," Eranos 87: 33-63.

Aubet, Maria Eugenia (1993) The Phoenicians and the West: Politics, Colonies and Trade, trans. Mary Turton. Cambridge. 
Audinet, Eugène (1914) "Les traces du droit international dans l'Iliade et dans l'Odyssée," Revue générale du droit international public 21-22: 29-63.

Audring, Gert (1981) "Zur sozialen Stellung der Hirten in archaischer Zeit: Thesen," Antike Abhängigkeitsformen in den griechischen Gebieten ohne Polisstruktur und den römischen Provinzen. Actes du colloque sur l'ésclavage, Jena 29 septembre-2 octobre 1981, ed. Heinz Kreissig and F. Kühnert. Berlin: 12-19.

- . (1989) Zur Struktur des Territoriums griechischer Poleis in archaischer Zeit (nach den schriftlichen Quellen). Berlin.

Austin, Michel M. (1970) Greece and Egypt in the Archaic Age. Cambridge.

Austin, Michel M. and Pierre Vidal-Naquet (1977) Economy and Social History of Ancient Greece. London.

Azoulay, Vincent (2004) Xénophon et les grâces du pouvoir: De la cháris au charisme. Paris.

—_ . (2012) "Du paradigme du don à une anthropologie pragmatique de la valeur," in Anthropologie de l'Antiquité: Anciens objects, nouvelles approches, ed. Pascal Payen and Evelyne Scheid-Tissinier. Turnhout: 17-42.

Bakchylides. Die Lieder des Bakchylides. I: Die Siegeslieder; II: Die Dithyramben und Fragmente; Text, Übersetzung und Kommentar (1997), ed. with an introduction and commentary by Herwig Maehler. Leiden.

Bakker, Egbert J. (2013) The Meaning of Meat and the Structure of the Odyssey. Cambridge.

Bakker, Egbert J. and Ahuvia Kahane (eds.) (1997) Written Voices, Spoken Signs: Tradition, Performance, and the Epic Text. Cambridge.

Baltrusch, Ernst (1994) Symmachie und Spondai: Untersuchungen zum griechischen Völkerrecht der Archaischen und Klassischen Zeit (8.-5. Jh. v. Chr.). Berlin and New York.

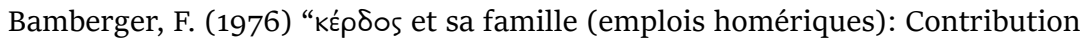
aux recherches sur le vocabulaire de la 'richesse' en grec," Centre de recherches comparatives sur les langues de la Méditerranée ancienne 3: 1-32.

Barber, Elizabeth Wayland J. (1991) Prehistoric Textiles: The Development of Cloth in the Neolithic and Bronze Ages with Special References to the Aegean. Princeton.

— . (1992) "The Peplos of Athena," in Neils 1992: 103-17.

- . (1994) Women's Work: The First 20,00o Years: Women, Cloth, and Society in Early Times. New York and London.

Barceló, Pedro (1993) Basileia, Monarchia, Tyrannis: Untersuchungen zur Entwicklung und Beurteilung der Alleinherrschaft im vorhellenistischen Griechenland. Historia Einzelschriften 79. Stuttgart.

Barghop, Dirk (1994) Forum der Angst: Eine historisch-anthropologische Studie zu Verhaltensmustern von Senatoren im Römischen Kaiserreich. Francfort and New York.

Barkai, Avraham (1988) Das Wirtschaftssystem des Nationalsozialismus: Ideologie, Theorie, Politik 1933-1945. Francfort.

Barnes, Ruth and Joanne Eicher (eds.) (1992) Dress and Gender: Making and Meaning in Cultural Contexts. New York and Oxford. 
Bartoloni, Gilda, Giovanni Colonna, and Christiano Grottanelli (eds.) (1989/90) Anathema: Regime delle offerte e vita dei sanctuari nel mediterraneo antico. Scienze dell' antiquità. Storia archeologia antropologia 3/4. Rome.

Battegazzore, Antonio E. (1987) "La donna e la tessitura nei poemi omerici," Cultura e scuola 26 (104): 30-40.

Bausinger, Hermann (1980) "Zur Problematik des Kulturbegriffs," in Fremdsprache Deutsch I, ed. Alois Wierlacher. Paderborn: 57-69.

Bazant, Jan (1981) Studies in the Use and Decoration of Athenean Vases. Prag.

Bazelmans, J., P. Kehne, and W. Ogris (1998) "Geschenke," in Reallexikon der Germanischen Altertumskunde 11: 466-77.

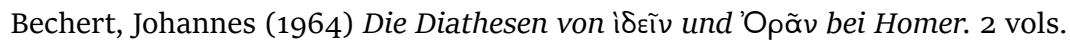
Munich.

Becker, Andrew S. (ed.) (1995) The Shield of Achilles and the Poetics of Ekphrasis. Lanham, MD.

Behrends, Okko (1992) "Rudolf von Jhering, der Rechtsdenker der offenen Gesellschaft: Ein Wort zur Bedeutung seiner Rechtstheorie und zu den geschichtlichen Gründen ihrer Mißdeutung," in his Rudolf von Jhering: Beiträge und Zeugnisse aus Anlaß der einhundertsten Wiederkehr seines Todestages am 17.9.1992. Göttingen: 8-10.

— . (1991) "Rudolf von Jhering und die Evolutionstheorie des Rechts," in Der Evolutionsgedanke in den Wissenschaften: Kolloquium der Akademie der Wissenschaften zu Göttingen am 9. Februar 1990, ed. Günther Patzig. Göttingen: 290-310.

- . (2002) "Der ungleiche Tausch zwischen Glaukos und Diomedes und die KaufTausch-Kontroverse der römischen Rechtsschule," Historische Anthropologie 10/2: 245-66.

Beidelman, Thomas O. (1989) "Agonistic Exchange: Homeric Reciprocity and the Heritage of Simmel and Mauss," Cultural Anthropology 4/3: 227-50.

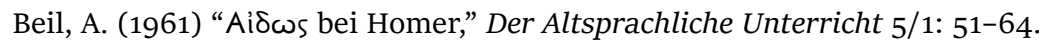

Bell, Catherine (1992) Ritual Theory, Ritual Practice. New York and Oxford.

Bennett, Ian (1977) Rugs and Carpets of the World. London.

Benton, Sylvia (1934/35) “The Evolution of the Tripod-Lebes," The Annual of the British School of Athens 35: 74-130.

Benveniste, Emile ([1951] 1966) "Don et échange dans le vocabulaire indoeuropéenne,” L’année sociologique 3rd sér. 2: 7-20. Rpt. in Problèmes de linguistique génerale I. 1966: 313-26.

—_ (1969) Le vocabulaire des institutions indo-européennes. I: Economie, parenté, société. Paris.

Bérard, Claude (1982) "Récuperer la mort du prince: héroïsation et formation de la cité,” in Gnoli and Vernant 1982: 89-105.

Bérard, Claude and Jean-Pierre Vernant et al. (1984) La cité des images. Lausanne.

Berg, Steffen, Renate Rolle, and Henning Seemann (1981) Der Archäologe und der Tod: Archäologie und Gerichtsmedizin. Munich and Luzern.

Bergier, Jean-François (ed.) (1989) Montagnes, Fleuves, Forêts dans l'Histoire: Barrières ou lignes de convergence? St. Katharinen. 
Bergren, Ann L. (1975) The Etymology and Usage of ПIEIPAP in Early Greek Poetry: The Study in the Interrelationship of Metrics, Lingustics and Poetics. New York.

—_ . (1980) "Helen's Web: Time and Tableau in the Iliad," Helios 7: 19-34.

— . (1983) "Language and the Female in Early Greek Thought," Arethusa 16: 69-95.

- (2008) Weaving the Truth: Essays on Language and the Female in Greek Thought. Cambridge, MA and London.

Beringer, Walter (1985) "Freedom, Family, and Citizenship in Early Greece," in The Craft of the Ancient Historian: Essays in Honor of Chester G. Starr, ed. John W. Eadie and Josiah Ober. London and New York: 41-56.

Berking, Helmuth (1996) Schenken: Zur Anthropologie des Gebens. Francfort and New York.

Bernhardt, Rainer (2003) Luxuskritik und Aufwandsbeschränkungen in der griechischen Welt. Stuttgart.

Berolzheimer, Fritz (1907) System der Rechts- und Wirtschaftsphilosophie. IV: Philosophie des Vermögens einschliesslich des Handelsverkehrs. Munich.

Bertelli, Lucio (2014) “The Ratio of Gift-Giving in Homeric Poems," in Carlà and Gori 2014: 103-34.

Berthoud, Gerald (1991) "Le marché comme simulacre du don," La Revue du Mauss 11: 72-89.

Beßlich, Barbara (2000) Wege in den „Kulturkrieg“: Zivilisationskritik in Deutschland 1890-1914. Darmstadt.

Betalli, Marco (1982) "Note sulla produzione tessile ad Atene in età classica," Opus 1: 261-78.

Bethe, Erich (1931a): “Der homerische Apollonhymnos und das Proiomion," Berichte über die Verhandlungen der Sächsischen Akademie der Wissenschaften zu Leipzig, Philologisch-Historische Klasse 83/2: 1-40.

— . (1931b) "Troia, Mykene, Agamemnon und sein Großkönigtum," Rheinisches Museum 80: 218-36.

Beuermann, Arnold (1967) Fernweidewirtschaft in Südosteuropa: Ein Beitrag zur Kulturgeographie des östlichen Mittelmeergebietes. Braunschweig.

Beyeler, Markus (2011) Geschenke des Kaisers. Studien zur Chroologie, zu den Empfängern und zu den Gegenständen der kaiserlichen Vergabungen im 4. Jahrhundert n. Chr. Berlin.

Bieber, Margarete (1928) Griechische Kleidung. Berlin and Leipzig (rpt. 1977).

- . (1934) Entwicklungsgeschichte der griechischen Tracht von der vorgriechischen Zeit bis zum Ausgang der Antike. Berlin (rpt. 1967).

Bintliff, John L. (1977) Natural Environment and Human Settlement in Prehistoric Greece. British Archaeological Reports 28/1. Oxford.

— . (1994) "Territorial Behaviour and the Natural History of the Polis," in Stuttgarter Kolloquium zur Historischen Geographie des Altertums IV, 199o, ed. Eckart Olshausen and Holger Sonnabend. Amsterdam: 207-49.

Bloch, Françoise and Monique Boisson (1991) "Du don a la dette: La construction du lien social familial," La Revue du Mauss: Mouvement Anti-Utilitariste dans les Sciences Sociales 11: 54-71. 
Bloch, Maurice and Jonathan Parry (eds.) (1989) Money and the Morality of Exchange. Cambridge.

Block, Elizabeth (1985) "Clothing Makes the Man: A Pattern in the Odyssey," Transactions of the American Philological Association 115: 1-11.

Blok, Josine (2000) "Phye's Procession. Culture, Politics and Peistratid Rule", in Sancisi-Weerdenburg 2000: 17-48.

— . (2004), "Recht und Ritus in der Polis. Zu Bürgerstatus und Geschlechterverhältnissen im klassischen Athen," Historische Zeitschrift 278/1: $1-26$.

Blome, Peter (1984) "Lefkandi und Homer," Würzburger Jahrbücher für Altertumswissenschaft 10: 9-21.

Blösel, Wolfgang et al. (2014) Grenzen politischer Partizipation im klassischen Griechenland. Stuttgart.

Blum, Hartmut (1998) Purpur als Statussymbol in der griechischen Welt. Bonn.

Blum, Herwig (1969) Die antike Mnemotechnik. Spudasmata 15. Hildesheim and New York.

Blümner, Hugo (1912) Technologie und Terminologie der Gewerbe und Künste bei Griechen und Römern. 2nd edn. 4 vols. Berlin.

Boardman, John (1955) "Painted Funery Plaques and Some Remarks on Prothesis," Annual of the British School of Athens 50: 55-66.

— . (1974) Athenian Black Figure Vases: The Classical Period. 4th edn. London.

— . (1988) “Trade in Greek Decorated Pottery," Oxford Journal of Archaeology 7: 27-33

_ . (1989) Athenian Red Figure Vases: The Classical Period. London.

— . (1999) The Greeks Overseas: Their Early Colonies and Trade. 4th edn. London (1st edn. 1964).

- (ed.) (2006) The World of Ancient Art. London (1st edn. 1993).

Bodei Giglioni, Gabriella (1989/90) "Economia e religiosità tra Aristotle e Teofrasto. Gratitudine e scambio," Scienze dell' Antichità 3/4: 55-64.

Bohannan, Paul (1955) "Some Principles of Exchange and Investment among the Tiv," American Anthropologist 57: 60-70.

Bohannan, Paul und Laura (1968) Tiv Economy. Evanston.

Bohringer, F. (1979) Cultes et actes des fondateurs de la cité grecque: 8ème-7ème siècles. Paris.

Bol, Peter C. (1985) Antike Bronzetechnik: Kunst und Handwerk antiker Erzbildner. Munich.

Bolchazy, Ladislaus J. (1978) "From Xenophobia to Altruism: Homeric and Roman Hospitality," Ancient World 1: 45-64.

Bolkestein, Hendrik (1939) Wohltätigkeit und Armenpflege im vorchristlichen Altertum. Utrecht.

- . (1958) Economic Life in Greece's Golden Age. Leiden.

Bonnefoy, Yves (ed.) (1992) Greek and Egyptian Mythologies, trans. Gerald Honigsblum. Chicago and London.

Borgeaud, Willy Alfred and Bonnie MacLachlan (1985) "Les Kharites et la lumière," Revue Belge de Philologie d'Histoire 63: 5-14. 
Borlandi, Massimo (1998) "Durkheim, Les Durkheimiens et la sociologie générale: de la première section de L'Année à la reconstruction d'une problématique perdue," L'Année sociologique $48: 27-65$.

Bosacq, Émile (1916) Dictionnaire étymologique de la langue grecque. Heidelberg and Paris.

Bothmer, Dietrich von (1985) The Amasis Painter and His World: Vase-Painting in Sixth-Century B.C. Athens. Malibu, CA: New York and London.

Bourdieu, Pierre (1977) Outline of a Theory of Practice. Cambridge (= Esquisse d'une Théorie de la Pratique. Genf 1972).

Bourguet, Emile (1905) L'administration financière du sanctuaire pythique au IV siècle avant J.C. Paris.

Bourriot, Felix (1976) Recherches sur la nature du génos. Lille and Paris.

Boyd, Timothy W. (1995) "Libri confusi," The Classical Journal 91/1: 35-45.

Bradley, Mark (ed.) (2015) Smell and the Ancient Senses. London and New York.

Bradley, Richard (1982) "The Destruction of Wealth in Later Prehistory," Man n.s. 17: 108-22.

_ . (1985) "Exchange and Social Distance: The Structure of Bronze Artefact Distributions," Man n.s. 20: 692-704.

Bravo, Benedetto (1977) "Remarques sur les assises sociales, les formes d'organisation et la terminologie du commerce maritime grec à l'époque archaïque," Dialogues d'Histoire Ancienne 3: 1-59.

—_ (1983) "Le commerce des céréales chez les Grecs de l'époque archaïque,” in Garnsey and Whittaker 1983: 17-29.

_ . (1984) "Commerce et noblesse en Grèce archaïque: À propos d'un livre d'Alfonso Mele," Dialogues d'Histoire Ancienne 10: 99-16o.

Bréhier, Louis (1904) "La royauté homérique et les origines de l'état en Grèce," Revue historique $84: 1-34$.

Bremmer, Jan (1987a) The Early Greek Concept of the Soul. Princeton.

_ . (1987b) “The So-Called 'Götterapparat' in Iliad XX-XXII," in his Homer: Beyond Oral Poetry: Recent Trends in Homeric Interpretation, ed. Irene J. F. de Jong and J. Kalff. Amsterdam: 31-46.

Brendel, Otto (1934) Die Schafzucht im alten Griechenland. Würzburg.

Brentano, Lujo (1923) "Ethik und Volkswirtschaft in der Geschichte," in his Der wirtschaftende Mensch in der Geschichte: Gesammelte Reden und Aufsätze. Leipzig: 34-76.

Bresson, Alain (2008) L'économie de la Grèce des cites. I: Les structures et la production; II: Les espaces de lèchange. Paris.

Breuer, Stefan (1990) Der archaische Staat. Zur Soziologie charismatischer Herrschaft. Berlin.

Brice, Philip (1989/90) "Archaische Bronzevotive aus dem Heraion von Samos," in Bartoloni 1990: 317-326.

Brice, W. C. (1988) "Notes on Linear A," Kadmos 27: 155-65.

Brommer, Frank (1942) “Gefäßformen bei Homer," Hermes 77: 356-73.

Brøns, Cecilie (2017) Gods and Garments: Textiles in Greek Sanctuaries in the 7th-1st Centuries BC. Oxford and Philadelphia. 
Brown, Norman O. (1947) Hermes, the Thief: The Evolution of a Myth. Madison, WI. Bruch, Rüdiger vom (1988) “Gustav Schmoller," in Hammerstein 1988: 219-38.

Bruch, Rüdiger vom, Friedrich Wilhelm Graf, and Gangolf Hübinger (eds.) (1989) Kultur und Kulturwissenschaft um 1900. Stuttgart.

Bruck, Eberhard Friedrich (1926) Totenteil und Seelgerät im griechischen Recht. Munich.

Brulé, Pierre (1987) La fille d'Athènes: La religion des filles à Athènes à l'époque classique: Mythes, cultes et société. Paris.

Brun, Waclaw von (1912) Die Wirtschaftsorganisation der Maori auf Neuseeland. Leipzig.

Brunner, Otto (1943) Land und Herrschaft: Grundfragen der territorialen Verfassungsgeschichte Südwestdeutschlands im Mittelalter, 3rd rev. edn. Brünn.

Bruns, Gerda (1970) Küchenwesen und Mahlzeiten. Archaeologia Homerica II Q. Göttingen.

Bücher, Karl (1893) Die Entstehung der Volkswirtschaft. Vol I. Tübingen.

— . (1901) Industrial Evolution. Translated from the third German edition by S. Morley Wickett. London.

— . (1918) "Schenkung, Leihe und Bittarbeit," in his Die Entstehung der Volkswirtschaft. Vol II. Tübingen: 3-24.

— . (1922) Beiträge zur Wirtschaftsgeschichte. Tübingen.

Buchholz, Eduard (1871) Homerische Kosmographie und Geographie. Leipzig.

Buchholz, Hans-Georg (1987) “Das Symbol des gemeinsamen Mantels," Jahrbuch des Deutschen Archäologischen Instituts 102: 1-55.

—_ . (1988) "Der Metallhandel des zweiten Jahrtausends im Mittelmeerraum," in Society and Economy in the Eastern Mediterranean c. 1500-10oo B.C.: Proceedings of the International Symposium held at the University of Haifa from the 28th of April to the 2nd of May 1985, ed. Mikha'el Heltzer and Edward Lipiński. Leuven: 187-228.

Büdel, Ernst (1976) "Bevölkerungsabwanderung, demographische Struktur und Landwirtschaftsformen im West-Peloponnes," Gießener Geographische Schriften 37: 18-40.

Bulst, Neithard (1988) "Zum Problem städtischer und territorialer Kleider-, Aufwands- und Luxusgesetzgebung in Deutschland (13.-Mitte 16. Jahrhundert)," in Renaissance du pouvoir legislatif et genèse de l'état, ed. André Gouron and Albert Rigaudière. Montpellier: 29-57.

Bunsdorff, Hans (1992) Zur Rolle des Aussehens des homerischen Menschenbildes. Göttingen and Zürich.

Burckhard, Hugo (1891) Die Stellung der Schenkung im Rechtssystem. Erlangen.

— . (1899) Zum Begriff der Schenkung. Erlangen.

Burford, Alison (1972) Craftsmen in Greek and Roman Society. London.

Bürgin, Alfred (1996) Zur Soziogenese der politischen Ökonomie. 2nd rev. edn. Marburg.

Burke, Brendan (2007) “The Kingdom of Midas and Royal Cloth Production,” in Gillis and Nosch 2007: 64-70. 
- (2010) From Minos to Midas. Ancient Cloth Production in the Aegean and in Anatolia. Oxford.

Burkert, Walter (1976) "Das hunderttorige Theben und die Datierung der Ilias," Wiener Studien 89: 5-21.

- (1977) Griechische Religion der archaischen und klassischen Epoche. Stuttgart.

_ _ (1984a) Anthropologie des religiösen Opfers: Die Sakralisierung der Gewalt. Veröffentlichung der Carl Friedrich von Siemens-Stiftung. Munich.

— . (1984b) Die orientalisierende Epoche in der griechischen Religion und Literatur. Heidelberg = The Orientalizing Revolution: Near Eastern Influence on Greek Culture in the Early Archaic Age. Cambridge, MA 1992.

_ . (1987) "Offerings in Perspective: Surrender, Distribution, Exchange," in Linders and Nordquist 1987: 43-50.

_ . (1988) "The Meaning and Function of the Temple in Classical Greece," in Temple in Society, ed. Michael V. Fox. Winona Lake: 27-47.

_. (1991) "Homerstudien und Orient," in Latacz 1991: 155-81.

Burns, Bryan E. (2010) Mycenaean Greece, Mediterranean Commerce, and the Formation of Identity. New York.

Buschor, Ernst (1912) Beiträge zur Geschichte der griechischen Textilkunst: Die Anfänge und der orientalische Import. Diss. Munich.

Cahill, Nicholas (1985) "The Treasury at Persepolis: Gift-Giving at the City of the Persians," American Journal of Archaeology 89: 373-89.

Caillé, Alain (2008) Anthropologie der Gabe. Francfort and New York.

Caillé, Alain and Jacques T. Godbout (1991) “Le don existe-t-il (encore)?” La Revue du Mauss 11: 11-32.

Cairns, Douglas L. (1993) AI $\Delta \omega \Sigma$ : The Psychology and Ethics of Honour and Shame in Ancient Greek Literature. Oxford.

Calame, Claude (1976) "Mythe grec et structures narratives: Le mythe des Cyclopes dans l'Odyssée,” Ziva Antika 26: 311-28.

Calder, William M. III (1984) “Gold for Bronze: Iliad 6, 232-236," in Studies Presented to Sterling Dow on his Eightieth Birthday. Durham, NC: 31-35.

Campagner, Roberto (1988) "Reciprocità economica in Pindaro," Quaderni Urbinati d Cultura Classica 29: 787-93.

Canciani, Fulvio (1984) Bildkunst. II: Homer und die Denkmäler. Archaeologia Homerica N/2. Göttingen.

Canevaro, Lilah Grace (2018) Women of Substance in Homeric Epic: Objects, Gender, Agency. Oxford.

Canning, Cathleen (2002) "Problematische Dichotomien: Erfahrung zwischen Narrativität und Materialität," Historische Anthropologie 10/2: 163-82.

Carlà, Filippo and Maja Gori (eds.) (2014) Gift Giving and the 'Embedded' Economy in the Ancient World. Heidelberg.

Carlier, Pierre (1984) La Royauté en Grèce avant Aléxandre. Strasbourg.

Cartledge, Paul A. (1983) “Trade and Politics Revisited: Archaic Greece,” in Garnsey, Hopkins and Whittaker 1983: 1-15.

Cartledge, Paul A. and F. David Harvey (eds.) (1985) Crux: Essays in Greek History Presented to G. E. M. de Ste. Croix on his 75th Birthday. London. 
Carroll, Diane Lee (1965) Pattern Textiles in Greek Art. Los Angeles.

— . (1983) "Warping the Greek Loom: A Second Method," American Journal of Archaeology 87: 96-98.

Cathercole, P. (1978) "Hau, mauri and utu: A Reexamination," in Trade and Exchange in Oceania and Australia, ed. Jim Specht and John P. White. Sydney: 324-40.

Cavanagh, William H. (1991) "Surveys, Cities and Synoicism," in Rich and WallaceHadrill 1991: 197-332.

Ceccarelli, Paola (1995) "Le tissage, la mémoire et la nymphe: Une recénte lecture de l'Odyssée," Dialogues d'Histoire Anciennes 21/1: 181-91.

Ceccarelli, Paola, Françoise Létoublon und Martin Steinrück (1998) "L'individu, le territoire, la graisse; du public et du privé chez Homère," Ktema 23: 47-58.

Cefaï, Daniel and Alain Mahé (1998) "Échanges rituels de dons, obligation et contrat : Mauss, Davy, Maunier. Trois perspectives de sociologie juridique," L’Année sociologique 48: 209-28.

Chamorro, J. G. (1987) "Survey of Archaeological Research on Tartessos," American Journal of Archaeology 91: 197-232.

Chandezon, Christophe (2003) L'élevage en Grèce (fin Ve-fin Ier s. a. C.): L'apport des sources epigraphiques. Bordeaux.

Chaniotis, Angelos (1995) "Problems of 'Pastoralism' and 'Transhumance' in Classical and Hellenistic Crete," Orbis Terrarum 1: 39-89.

— . (2011) "Emotional Community through Ritual: Initiates, Citizens, and Pilgrims as Emotional Communities in the Greek World," in his Ritual Dynamics in the Ancient Mediterranean: Agency, Emotion, Gender, Representation. Stuttgart: 263-90.

Chaniotis, Angelos, Nikolaos Kaltsas and Ioannis Mylonopopoulos (2017) (eds.) A World of Emotions: Ancient Greece, 700 BC-200 AD. New York.

Chantraine, Pierre (1940) "Conjugation et histoire des verbes signifiant 'vendre'," Revue philologique 14: 11-24.

_ . (1977) Dictionnaire étymologique de la langue grecque. 3 vols. Paris.

Charle, Christophe and Eva Teklès (1988) Les professeurs du Collège de France: Dictionnaire biographique 1901-1939. Paris.

Chaston, Colleen (2002) "Three Models of Authority in the 'Odyssey', The Classical World 96/1: 3-19.

Cheal, David (1988) The Gift Economy. London and New York.

Cherry, John F. (1984) “The Emergence of the State in the Prehistoric Aegean," Proceedings of the Cambridge Philological Society n.s. 30: 18-48.

_ . (1988) "Pastoralism and the Role of Animals in the Pre- and Protohistoric Economies of the Aegean," in Whittaker 1988: 6-34.

Childe, V. Gordon (1951) Social Evolution. London.

Chiozzi, Paoli (1983) "Marcel Mauss: Eine anthropologische Interpretation des Sozialismus," Kölner Zeitschrift für Soziologie und Sozialpsychologie 35: 655-79.

Christ, Matthew R. (2012) The Limits of Altruism in Democratic Athens. Cambridge.

Christien, Jacqueline (1989) "Les liaisons entre Sparte et son territoire malgré l'encadrement montagneux," in Bergier 1989: 18-44. 
Cifarelli, Megan and Laura Gawlinski (eds.) (2017) What Shall I Say of Clothes? Theoretical and Methodological Approaches to the Study of Dress in Antiquity. Boston.

Clark, Louise (1983) “Notes on Small Textile Frames Pictured on Greek Vases," American Journal of Archaeology 87: 91-96.

Clark, Matthew (2001) "Was Telemachus Rude to His Mother? Odyssey 1.356-59," Classical Philology 96/4: 335-54.

Clavero, Bartolomé (1996) La grâce du don. Anthropologie cathologique de l'économie modern. Paris.

Clay, Jenny Strauss (1989) The Politics of Olympus: Form and Meaning in the Major Homeric Hymns. Princeton.

Clayton, Barbara (2004) A Penelopean Poetics: Reweaving the feminine in Homer's Odyssey. Lanham, MD.

Cleary, Mark C. and Catherine Delano Smith (1990) "Transhumance Reviewed: Past and Present Practices in France and Italy," Rivista di Studi Liguri 56/1-4: 21-38.

Cobet, Justus (1981) “König, Anführer, Herr, Monarch, Tyrann,” in Welskopf 1981: 11-66.

—_ (1983) "Synoikismos als Konzept für die politischen Anfänge Athens und Roms," in Concilium Eirene XVI: Proceedings of the 16. International Eirene Conference, Prague, 31.8.-4.9.1982, ed. Pavel Oliva. Prague: 21-26.

Codere, Helen (1950) Fighting with Property: A Study of Kwakiutl Potlatching and Warefare (1872-1936). New York.

— . (1976) "Exchange and Display," International Encyclopedia of the Social Sciences 5: 239-45.

Coffee, Neil (2017) Gift and Gain: How Money Transformed Ancient Rome. New York.

Cohen, Beth (1995) The Distaff Side: Representing the Female in Homer's Odyssey. New York and Oxford.

Cohen, David (1980) “'Horkia' und 'horkos' in the Iliad," Revue internationale des droits de l'antiquité 27: 49-68.

— . (1991) Law, Sexuality and Society: The Enforcement of Morals in Classical Athens. Cambridge.

Coldstream, John Nicholas (1979) Geometric Greece. 2nd edn. London.

—_ . (1983) "Gift Exchange in the Eighth Century B.C.," in Hägg 1983: 201-7.

_ . (1985) “Greek Temples: Why and Where?” in Greek Religion and Society, ed. Patricia E. Easterling and J. V. Muir. Cambridge: 67-97.

— . (1993) "Mixed Marriages at the Frontiers of the Early Greek World," Oxford Journal of Archaeology 12/1: 80-107.

Cole, Susan Guettel (2004) Landscapes, Gender and Ritual Space: The Ancient Greek Experience. Berkeley, CA.

Constable, Olivia Remie (2003) Housing the Stranger in the Mediterranean World: Lodging, Trade, and Travel in Late Antiquity and the Middle Ages. Cambridge. Conze, Alexander (1870) Zur Geschichte der Anfänge griechischer Kunst. Vienna.

Cox, Cheryl Anne (1998) Household Interests: Property, Marriage Strategies, and Family Dynamics in Ancient Athens. Princeton. 
Cozzo, Andrea (1991) képठos: Le passione economiche nella grecia antica. Palermo. Craig, J. D. (1967) “XPY $\Sigma E A$ XA^KEIWN,” Classical Review n.s. 17: 243-45. Crane, Gregory (1988) Calypso: Backgrounds and Conventions of the Odyssey. Francfort.

_ . (1993) "Politics of Consumption and Generosity in the Carpet Scene of the Agamemnon," Classical Philology 88/2: 117-36.

Crielaard, Jan P. (1992/93) "How the West Was Won, Euboeans vs. Phoenicians," Hamburger Beiträge zur Archäologie 19/20: 234-59.

— . (2002) "Past or Present? Epic Poetry, Aristocratic Self-Reprentation and the Concept of Time in the Eighth and Seventh Centuries BC," in Franco Montanari (ed.), Omero tremille anni dopo. Roma: 239-295.

_ (2006) "Basileis at Sea: Elites and External Contacts in the Euboean Gulf Region from the End of the Bronze Age to the Beginning of the Iron Age," in Ancient Greece: From the Mycenaean Palaces to the Age of Homer, ed. Sigrid Deger-Jalkotzy and Irene S. Lemos. Edinburgh: 271-97.

— - (2011) “The 'Wanax to Basileus Model' Reconsidered: Authority and Ideology after the Collapse of the Mycenaean Palaces," in The 'Dark Ages' Revisited: Acts of an International Symposium in Memory of William D. E. Coulson; University of Thessaly, Volos, 14-17 June 2007, ed. Alexandros Mazarakis-Ainian. Volos: 83-111.

_ _ (2010) "Hygra Keleútha: Maritime Matters and the Ideology of Seafearing in the Greek Epic Tradition," in Alle origini della Magna Grecia mobilità migrazioni fondazioni. Atti del cinquantesimo convegno di studi sulla Magna Grecia, Taranto 1-4 Ottobre 2010. Taranto: 135-157.

Cristofani, Mauro (1975) “Il dono nell' Etruria arcaica," Parola del Passato 161: 132-52.

Culham, Phyllis (1986) “Again, What Meaning Lies in Colour?” Zeitschrift für Papyrologie and Epigraphik 64: 235-45.

Curtius, Ernst (1892) "Die Gastfreundschaft," in his Alterthum und Gegenwart: Gesammelte Reden und Vorträge I. 4th edn. Berlin: 203-18.

Dabney, Mary K. and James C. Wright (1990) "Mortuary Customs, Palatial Society and State Formation in the Aegean Area: A Comparative Study," in Hägg and Nordquist 1990: 45-53.

Dahme, Heinz Jürgen (1988) "Der Verlust des Fortschrittsglaubens und die Verwissenschaftlichung der Soziologie: Ein Vergleich von Georg Simmel, Ferdinand Tönnies und Max Weber,” in Simmel und die frühen Soziologen: Nähe und Distanz zu Durkheim, Tönnies und Max Weber, ed. Otthein Rammstedt. Francfort: 222-74.

Dalby, Andrew (1996) Siren Feast: A History of Food and Gastronomy in Greece. London.

Dalton, George (1961) "Economic Theory and Primitive Society," American Anthropologist New Series 63: 1-25.

_. (1967) Tribal and Peasant Economies: Readings in Economic Anthropology. Austin and London.

Damon, Frederick H. (1980) "The Kula and Generalized Exchange: Considering Some Unconsidered Aspects of the Elementary Structures of Kinship," Man n.s. 15: 267-92. 
Daniel, Ute (1993) “'Kultur' und 'Gesellschaft': Überlegungen zum Gegenstandsbereich der Sozialgeschichte,” Geschichte und Gesellschaft 19: 69-99.

_ . (1997) "Clio unter Kulturschock," Geschichte in Wissenschaft und Unterricht 48: $195-218$ and 259-278.

Darcque, Pascal (1987) "Les Tholoi et l'organisation socio-politique du monde mycénien," in Laffineur 1987: 185-205

Dargun, Lothar von (1885) Soziologische Studien I: Egoismus und Altruismus in der Nationalökonomie. Leipzig.

Daverio Rocchi, Giovanna (1993) "Politische, wirtschaftliche und militärische Grenze im alten Griechenland,” in Eckart Olshausen and Holger Sonnabend (eds.) Gebirgsland als Lebensraum. Stuttgarter Kolloquium zur Historischen Geographie des Altertums 4, 1990, Amsterdam 1993: 95-110.

— . (1996) "Kulturmodelle und Gerichtserfahrungen bei Hirtengemeinschaften der Gebirgsländer Nordgriechenlands," in Eckart Olshausen, Holger Sonnabend (eds.) Gebirgsland als Lebensraum. Stuttgarter Kolloquium zur Historischen Geographie des Altertums 5, 1993. Amsterdam 1996: 335-42.

_ . (2016) "Systems of Borders in Ancient Greece," in Brill's Companion to Ancient Geography: The Inhabited World in Greek and Roman Tradition, ed. Serena Bianchetti et al. Leiden: 58-77.

Davidson, James N. (1997) Courtisans and Fishcakes: The Consuming Passions of Classical Athens. London.

Davis, Natalie Zemon (2000) The Gift in Sixteenth-Century France. Madison.

Davy, Georges (1922) La foi jurée : La formation du lien social. Paris.

Day, Joseph W. (1989) "Rituals in Stone: Early Greek Grave Epigrams and Monuments," The Journal of Hellenistic Studies 109: 16-28.

Deger, Sigrid (1970) Herrschaftsformen bei Homer. Vienna.

Deger-Jalkotzy, Sigrid (1979) "Homer und der Orient: Das Königtum des Priamos," Würzburger Jahrbücher für die Altertumswissenschaft N.F. 5: 25-31.

Deger-Jalkotzy, Sigrid and Irene S. Lemos (eds.) (2006) Ancient Greece from Mycenaean Palaces to the Age of Homer. Edinburgh.

Deichgräber, Karl (1971) Charis und die Chariten, Grazie und Grazien. Munich.

Demand, Nancy (1996) "Poleis on Cyprus and Oriental Despotism," in More Studies in the Ancient Greek Polis, ed. Mogens Herman Hansen and Kurt Raaflaub. Stuttgart: 7-15.

Demetriou, Denise (2011) "What is an Emporion? A Reassessment," Historia 6o/3: 255-72.

Denis, Jacques François (1856) Histoire des théories et des idées morales dans l'antiquité II. Paris and Straßbourg.

Deroy, Louis (1987) "La tablette mycénienne PY FR 1338 et l'hospitalité au 'Palais de Nestor,", Ziva Antica 37: 5-10.

Descat, Raymond (1979) "L’idéologie homérique du pouvoir," Revue des Etudes Anciennes 81: 229-40.

_ - (1986) L'acte et l'effort: Une idéologie du travail en Grèce ancienne (8ème-5ème siècle av. J.-C.). Besançon and Lille.

Detienne, Marcel (1963) Crise agraire et attitude religieuse chez Hésiode. Brussels. 
— - (1967) Les maîtres de la verité dans la Grèce archaïque. Paris.
_ (1998) Apollon le couteau à la main. Paris.

Dietrich, Bernard C. (1957) Death, Fate and the Gods: The Development of a Religious Idea in Greek Popular Belief and in Homer. 2nd edn. London.

Dihle, Albrecht (1985) Die Vorstellung vom Willen in der Antike. Göttingen.

Dinges, Martin (1992) "Der ,feine Unterschied": Die soziale Funktion von Kleidung in der höfischen Gesellschaft," Zeitschrift für Historische Forschung 19/1: 49-76.

Dirlmeier, Franz (1931) ФI^O $\Sigma$ und $\Phi I \wedge I A$ im vorhellenistischen Griechentum. Dissertation. Munich.

Dmitriev, Sviatoslav (2018) The Birth of Athenian Community: From Solon to Cleisthenes. London and New York.

Dodds, Eric R. (1951) The Greeks and the Irrational. Berkeley and Los Angeles.

- . (1973) The Ancient Concept of Progress and other Essays on Greek Literature and Belief. Oxford.

Doherty, Lillian Eileen (1992) "Gender and Internal Audiences in the Odyssey," American Journal of Philology 113: 161-77.

_ - (1993) "Tyro in Odyssey 11: Closed and Open Readings," Helios 20: 3-17.

— . (1995) Siren Songs: Gender, Audiences and Narrators in the Odyssey. Ann Arbor, MI.

Domingo Gygax, Marc (2002) "Peisistratos und Kimon. Anmerkungen zu einem Vergleich bei Athenaios", Hermes 130/2: 245-49.

—_. (2003) “Euergetismus und Gabentausch,” Mètis N.S. 1: 181-200.

- (2016) Benefaction and Rewards in the Ancient Greek City: The Origins of Euergetism. Cambridge.

Domingo Gygax, Marc and Arjan Zuiderhoek (eds.) (forthcoming) Benefactors and the Polis. Cambridge.

Donlan, Walter (1970) "Changes and Shifts in the Meaning of Demos in the Literature of the Archaic Period," Parola del Passato 25: 381-95.

— . (1981) "Scale, Value, and Their Function in the Homeric Economy," American Journal of Ancient History 12: 101-17.

— . (1982a) "Reciprocities in Homer," Classical World 75: 137-75.

_ . (1982b) "The Politics of Generosity in Homer," Helios 9: 1-15.

— . (1989a) "Pre-State-Community in Greece," Symbolae Osloenses 64: 5-29.

_ . (1989b) "The Unequal Exchange between Glaucus and Diomedes in the Light of Homeric Gift-Economy," Phoenix 43: 1-15.

Dougherty, Carol (1993) The Poetics of Colonization: From City to Text in Archaic Greece. New York and Oxford.

Douglas, Mary ( $\left.{ }^{2} 1973\right)$ Natural Symbols. Explorations in Cosmology. London.

Doyle, Richard (1984) 'ATH, Its Use and Meaning: A Study in the Greek Poetic Tradition from Homer to Euripides. New York.

Drews, Robert (1983) Basileus: The Evidence for Kingship in Geometric Greece. New Haven and London.

Drexhage, Hans-Joachim, Heinrich Konen and Kai Ruffing (2002) Die Wirtschaft des Römischen Reiches (1.-3. Jahrhundert). Eine Einführung. Berlin. 
Drexhage, Raphaela (1988) Untersuchungen zum römischen Osthandel. Bonn.

Droß-Krüpe, Kerstin and Marie-Louise Nosch (2016) Textiles, Trade, and Theories: From the Ancient Near East to the Mediterranean. Münster.

Drucker, Peter (1967) “The Potlach,” in Dalton 1967: 481-493.

Dumont, Louis (1972) “Une Science en devenir," L'Arc: Marcel Mauss 48: 8-21.

Dunbabin, Katherine M. D. (2003) The Roman Banquet: Images of Conviviality. Cambridge.

Dunbar, Henry (1962) A Complete Concordance to the Odyssey of Homer. Rev. and enlarged by Benedetto Marzullo. Hildesheim.

Duplouy, Alain (2002) "L'aristocratie et la circulation des richesses, " Revue belge de philologie et d'histoire 80/1: 5-24.

- . (2006) Les prestige des élites: Recherches sur le modes de reconnaissance sociale en Grèce entre les $X^{e}$ et $V^{e}$ sièces avant J.-C. Paris.

— . (2015) "Genealogical and Dynastic Behaviour in Archaic and Classical Greece: Two Gentilician Strategies," in Fisher and van Wees 2015: 59-84.

_ - . (2016) “'Crises' au sein des élites grecques: utilité et ambiguité d'un concept,” in Elite und Krise in antiken Gesellschaften, ed. Lennart Gilhaus et al. Stuttgart: 33-46.

Dürbeck, Helmut (1967) Zur Charakteristik der griechischen Farbenbezeichnungen. Bonn.

Durkheim, Émile (1964) The Division of Labor in Society. Trans. George Simpson. New York.

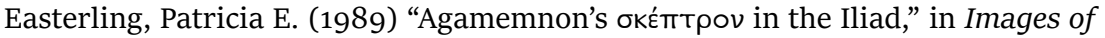
Authority: Papers Presented to Joyce Reynolds on the Occasion of Her Seventieth Birthday, ed. Mary Margaret Mackenzie and Charlotte Roueché. Cambridge: 104-21.

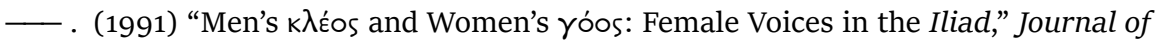
Modern Greek Studies 9/2: 145-51.

Easterling, Patricia E. and E. J. Kenney (eds.) (1985) The Cambridge History of Classical Literature. I: Greek Literature. Cambridge.

Easterling, Patricia E. and J. V. Muir (eds.) (1985) Greek Religion and Society. Cambridge.

Ebert, Joachim (1984) Die Arbeitswelt der Antike. Cologne and Vienna.

Eckstein, Felix (1974) Handwerk. I: Die Aussagen des frühgriechischen Epos. Archaeologia Homerica L/1. Göttingen.

Edelman, Murray J. (1970) The Symbolic Uses of Politics. 4th edn. Urbana.

Eder, Birgitta (2006) "The World of Telemachus: Western Greece 1200-700 BC, in Deger-Jalkotzy and Lemos 2006: 549-80.

Edmonds, J. M. (1931) Theognis, Elegy and Iambus. With an English translation. Cambridge and London.

Edwards, Mark W. (1975) “Type-Scenes and Homeric Hospitality," Transactions of the American Philological Association 105: 51-72.

Edzard, D. O. (1960) "Die Beziehungen Babyloniens und Ägyptens in der mittelbabylonischen Zeit und das Gold," Journal of the Economic and Social History of the Orient 3: 38-55. 
Ehmer, Josef (1998) "Migration und Bevölkerung: Zur Kritik eines Erklärungsmodells," Tel Aviver Jahrbuch für deutsche Geschichte 27: 5-29.

Eich, Armin (2006) Die politische Ökonomie des antiken Griechenland (6.-3. Jahrhundert v. Chr.). Cologne, Weimar and Vienna.

Eichler, F. (1914) " $\Sigma$ HMA and MNHMA in älteren griechischen Grabinschriften," Mitteilungen des Kaiserlich Deutschen Archäologischen Instituts, Athenische Abteilung 39: 138-43.

Eideneier, Hans (ed.) (1991) Ptochoprodromus. Einführung, kritische Ausgabe, deutsche Übersetzung. Cologne.

Eisler, Robert (1910) Weltenmantel und Himmelszelt: Religionsgeschichtliche Untersuchungen zur Urgeschichte des antiken Weltbildes. 2 vols. Munich.

Elias, Norbert (1981) Über den Prozeß der Zivilisation: Soziogenetische und psychogenetische Untersuchungen. 8th edn. 2 vols. Francfort.

Ella, Rev. Samuel (1899) "Polynesian Native Clothing," The Journal of the Polynesian Society 8: 165-70.

Elmer, David (2013) The Poetics of Consent: Collective Decision Making and the Iliad. Baltimore.

Elwert, Georg (1985) “Märkte, Käuflichkeit und Moralökonomie," in Soziologie undgesellschaftliche Entwicklung: Verhandlungen des 22. Soziologentages in Dortmund 1984, ed. Burkart Lutz. Francfort and New York: 509-13.

_ _ . (1991) "Gabe, Reziprozität und Warentausch: Überlegungen zu einigen Ausdrücken und Begriffen," in Ethnologie im Widerstreit: Kontroversen über Macht, Geschäft, Geschlecht in fremden Kulturen; Festschrift Lorenz G. Löffler, ed. Eberhard Berg, Jutta Lauth, and Andreas Wimmer. Munich: 159-77.

Endrödi, Julia (1991) “'Figurative Discourse' and Communication in the Emerging State of Egypt," Göttinger Miszellen 125: 21-36.

Engemann, Josef (2005) “Diplomatische ,Geschenke‘: Objekte aus der Spätantike?“ Mitteilungen zur Spätantiken Archäologie und Byzantinischen Kunstgeschichte 4: 39-64.

Erbse, Hartmut (1986) Untersuchungen zur Funktion der Götter im homerischen Epos. Berlin and New York.

Erffa, Carl E. Freiherr von (1937) AI $\Delta \omega \Sigma$ und verwandte Begriffe in ihrer Entwicklung von Homer bis Demokrit. Philologus Supplement 30/2. Leipzig.

Eustathius, Commentarii ad Homeri Iliadem et Odysseam, ed. G. Stalbaum. 6 vols. Leipzig (1825-1839, rpt. 1960).

Evjen, Harold D. (1986) "Competitive Athletics in Ancient Greece: The Search for Origins and Influences," Opuscula Atheniensia 16: 51-56.

Faber, G. A. (1947) "Färberei und Gerberei im klassischen Altertum,” Ciba-Rundschau 1/20: 698-711.

Fanta, Adolf (1882) Der Staat in Ilias und Odyssee: Ein Beitrag zur Beurtheilung der homerischen Verfassung. Innsbruck.

Fardon, Richard (1990) "Malinowskis Precedent: The Imagination of Equality," Man n.s. 25: 569-87.

Fatheuer, Thomas (1988) Ehre und Gerechtigkeit: Studien zur Entwicklung der gesellschaftlichen Ordnung im frühen Griechenland. Münster. 
Faure, Paul (1987) Parfums et aromates de l'Antiquité. Paris.

Feeney, Denis C. (1993) The Gods in Epic: Poets and Critics of the Classical Tradition. London.

Fehling, Detlev (1985) Die sieben Weisen und die frühgriechische Chronologie: Eine traditionsgeschichtliche Studie. Bern.

Fehr, Burkhard (1979) "Zur religionspolitischen Funktion der Athena Parthenos im Rahmen des Delisch-Attischen Seebundes I," Hephaistos 1: 71-91.

Felson-Rubin, Nancy (1994) Regarding Penelope: From Character to Poetics. Princeton.

Ferguson, Adam (1986) "Essay on the History of Civil Society (1767)," in Versuch über die Geschichte der bürgerlichen Gesellschaft, ed. and introduced by Zwi Batscha and Hans Medick. Francfort.

Ferrari, Gloria (2002) Figures of Speech: Men and Maidens in Ancient Greece. Chicago.

Fidio, Pia di (1979) "La donna e il lavoro nella Grecia arcaica," Nuova DWF, DonnaWomanFemme 12/13: 188-217.

Figueira, Thomas J. (1984) "Karl Polanyi and the Ancient Greek Trade: The Port of Trade," Ancient World 10: 15-30.

Figueira, Thomas J. and Gregory Nagy (eds.) (1985) Theognis of Megara: Poetry and the Polis. Baltimore and London.

Finley, John H. Jr. (1978) Homer's Odyssey. Cambridge.

Finley, Moses I. (1954) The World of Odysseus. New York.

— . (1967) The World of Odysseus. Rev. edn. 1965. New York.

— . (1978) "The World of Odysseus revisited", in his The World of Odysseus. Rev. edn. New York.

- . (2001) The World of Odysseus. New York.

— . (1955) "Marriage, Sale and Gift in the Homeric World," Revue internationale des droits de l'antiquité 3rd sér. 2: 167-94.

_ . (1970) "Aristotle and the Economic Analysis," Past and Present 47: 4-25 = Jahrbuch für Wirtschaftsgeschichte 2 (1971): 87-105.

_ . (1970) "Metals in the Ancient World," Journal of the Royal Society of Arts 118: $597-607$.

- . (1973) The Ancient Economy. Berkeley

- . (1975) The Use and Abuse of History. London.

- . (1981) Economy and Society in Ancient Greece, edn. with an introduction by Brent D. Shaw and Richard Saller. London.

- (1983) Politics in the Ancient World. Cambridge.

_ . (1985) Ancient History: Evidence and Models. London.

Finsler, Georg (1906) "Das Homerische Königtum," Neue Jahrbücher für das Klassische Altertum 17: 313-36 and 395-412.

Firebaugh, W. C. (1928) The Inns of Greece and Rome and a History of Hospitality from Dawn of Time to the Middle Ages. Chicago. 
Firth, Raymond (1963) "The Place of Malinowski in the History of Economic Anthropology," in his Man and Culture: An Evaluation of the World of Bronislaw Malinowski. 4th edn. London: 209-27.

_ . (1972) "Methodological Issues in Economic Anthropology," Man n.s. 7/3: 465-75.

Fisher, Nick (2010) "Kharis, Kharites, Festivals, and Social Peace in the Classical Greek City," in Valuing Others in Classical Antiquity, ed. Ineke Sluiter and Ralph M. Rosen. Leiden: 71-112.

Fisher, Nick and Hans van Wees (eds.) (1998) Archaic Greece: New Approaches and New Evidence. London.

- . (2011) Ancient Competition. Swansea.

- . (2015) 'Aristocracy' in Antiquity: Redefining Greek and Roman Elites. Swansea.

Fittchen, Klaus (1964) Untersuchungen zu den Sagendarstellungen bei den Griechen. Dissertation. Tübingen.

Flaig, Egon (1993) “Loyalität ist keine Gefälligkeit: Zum Majestätsprozeß gegen C. Silius 24 n. Chr.," Klio 75: 289-305.

—_ . (1994) "Das Konsensprinzip im Homerischen Olymp. Überlegungen zum Göttlichen Entscheidungsprozeß Ilias 4, 172,” Hermes 122: 13-31.

— . (1998) Ödipus: Tragischer Vatermord im klassischen Athen. Munich.

— . (2007) “Mit Kapitalismus keine Stadtkultur,” in Reinhard and Stagl 2007: 133-57.

Flinthoff, Everard (1987) “The Treading of the Cloth,” Quaderi Urbinati di Cultura Classica n.s. 25: 119-30.

Flückinger-Guggenheim, Daniela (1984) Göttliche Gäste: Die Einkehr von Göttern und Heroen in der griechischen Mythologie. Bern.

Flügel, Peter (1985) Zum Begriff 'Tausch' in der Ethnologie. Master thesis. Mainz.

Foley, Helen P. (1978) “'Reverse Similes' and Sex Roles in the Odyssey," Arethusa 11: 7-26.

Fornaro, Sotera (1992) Glauco e Diomede: Lettura di Iliade VI 119-236. Venosa.

Forrester, Viviane (1997 [French version 1996]) Der Terror der Ökonomie. Francfort.

Forstenpointner, Gerhard et al. (2007) "Saitenspiel und Purpurschimmer:

archäozoologische Ehrengaben aus dem späthelladischen Ägina Kolonna,” in Alram-Stern and Nightingale 2007: 141-49.

Forster, Ellen D. (1981) “The Flax Impost at Pylos and Mycenaean Landholding," Minos 17: 67-121.

Fortes, Meyer (1975) "Strangers," in Meyer Fortes and Sheila Patterson (eds.) Studies in African Social Anthropology. London et al.: 229-53.

Fournier, Marcel (2006) Marcel Mauss. A Biography. Trans. Jane Marie Todd. Princeton and Oxford (= Paris 1994).

Fowler, Robert (ed.) (2004) The Cambridge Companion to Homer. Cambridge.

Foxhall, Lin (1998) "Cargoes of the Heart's Desire: The Character of Trade in the Archaic Mediterranean World," in Fisher and van Wees 1998: 295-309.

_ . (2007) Olive Cultivation in Ancient Greece: Seeking the Ancient Economy. Oxford. 
Foxhall, Lin and Karen Stears (2000) "Redressing the Balance: Dedications of Clothing to Artemis and the Order of Life Stages," in Moira Donald and Linda Hurcombe (eds.) Gender and Material Culture in Historical Perspective. New York and London: 3-16.

Fränkel, Hermann (1955) "Die Zeitauffassung in der frühgriechischen Literatur," in his Wege und Formen des frühgriechischen Denkens. Munich: 1-22.

—_ (1977) Die Homerischen Gleichnisse. 2nd edn. Göttingen (orig. 1921).

Frankenstein, Susan (1979) "The Phoinicians in the Far West: A Function of NeoAssyrian Imperialism," in Power and Propaganda: A Symposium on Ancient Empires, ed. Mogens Trolle Larsen. Copenhagen: 263-94.

Fraß, Stefan (2014) Egalität, Gemeinsinn und Staatlichkeit im archaischen Griechenland. Munich.

Frayn, Joan M. (1984) Sheep-Rearing and the Wool-Trade in Italy during the Roman Period. Liverpool.

Frazier, Françoise (1988) “À propos de la 'philotimia' dans les 'Vies', Revue de Philologie de littérature et d'histoire anciennes 62: 109-27.

Frei, Norbert (1993) “Wie modern war der Nationalsozialismus?” Geschichte und Gesellschaft 19/3: 363-87.

Frevert, Ute (2019) Kapitalismus, Märkte und Moral. Salzburg.

Fried, Morton H. (1967) The Evolution of Political Society: An Essay in Political Anthropology. New York.

Friedman, Jonathan (1975) “Tribes, States and Transformation," in Marxist Analyses and Social Anthropology, ed. Maurice Bloch. London: 161-202.

Frisk, Hjalmar (196o/1972) Griechisches etymologisches Wörterbuch. 3 vols. Heidelberg.

Frontisi-Ducroux, Françoise (1975) Dédale: Mythologie de l'artisan en Grèce ancienne. Paris.

Fürer-Haimendorf, Christoph von (1975) Himalayan Traders: Life in Highland Nepal. London.

Gage, John (1993) Colour and Culture: Practice and Meaning from Antiquity to Abstraction. London.

Gale, Noel H. and Zofia Stos-Gale (1981) "Blei und Silber in der ägäischen Kultur," Spektrum der Wissenschaft 8: 92-105.

Gallagher, William R. (1988) "A Reconsideration of o-no in Mycenaean Greek," Minos 23: 85-106.

Gallant, Tom W. (1988) "Agricultural Systems, Land Tenure, and the Reforms of Solon," Annual of the British School of Athens 77: 111-24.

Gane, Mike (ed.) (1992) The Radical Sociology of Durkheim and Mauss. London and New York.

Ganzer, Burkhard (1981) "Altruismus, Egoismus, Interaktion: Bemerkungen zu M. D. Sahlins Reziprozitätskontinuum," Zeitschrift für Ethnologie 106: 23-41.

Garcia, Lorenzo F., Jr. (2013) Homeric Durability: Telling Time in the Iliad. Cambridge, MA and London. 
García Morcillo, Marta (2013) "Trade and Sacred Places: Fairs, Markets and Exchange in Ancient Italy Sanctuaries," in Religiöse Vielfalt und Soziale Integration, eds. Martin Jehne, Bernhard Linke and Jörg Rüpke. Heidelberg: 236-274.

— . (2014): "Limiting Generosity: Conditions and Restrictions on Roman Donations,” in Carlà and Gori 2014: 241-266.

Garlan, Yvon (1984) Les esclaves en Grèce ancienne. Paris.

- . (1989) Guerre et économie en Grèce ancienne. Paris.

Garland, Robert (1985) The Greek Way of Death. London.

- (2014) Wandering Greeks: The Ancient Greek Diaspora from the Age of Homer to the Death of Alexander the Great. Princeton.

Garnsey, Peter (1985) “Grain for Athens," in Cartledge and Harvey 1985: 62-65.

— . (1986) "Mountain Economies in Southern Europe or: Thoughts on the Early History; Continuity and Individuality of the Mediterranean Upland Pastoralism," in Wirtschaft und Gesellschaft in Berggebieten, ed. Markus Mattmüller. Basel: 7-29 = Whittaker 1988: 196-209.

- . (1988) Famine and Food Supply in the Graeco-Roman World: Responses to Risk and Crisis. Cambridge (rpt. 1993).

Garnsey, Peter and C. R. Whittaker (eds.) (1983) Trade and Famine in the Classical Antiquity. Cambridge.

Garnsey, Peter, Keith Hopkins, and C. R. Whittaker (eds.) (1983) Trade in the Ancient Economy. London.

Gauer, Werner (1984) "Was geschieht mit dem Peplos?" in Parthenon-Kongress: Referate und Berichte 4.-8. April 1982 I, ed. Ernst Berger. 2 vols. Mainz: 220-29.

Gaul, Wilhelm (1914) "Das Geschenk nach Form und Inhalt im Besonderen untersucht an afrikanischen Völkern," Archiv für Anthropologie 13/3: 223-79.

Gauthier, Philippe (1972) "Notes sur l'étranger et hospitalité en Grèce et à Rome," Ancient Society 3: 1-21.

- (1992) Symbola : Les étrangers at la justice dans les cités grecques. Nancy.

Geary, Patrick (2003) "Gift Exchange and Social Science Modelling: The Limitations of a Construct," in Algazi, Groebner and Jussen 2003: 129-40.

Geddes, Ann G. (1984) “Who’s Who in Homeric Society,” Classical Quarterly 34: 17-36.

_ . (1989) "Rags and Riches: The Costume of Athenian Men in the Fifth Century," Classical Quarterly 37: 307-31.

Geertz, Clifford (1973) “Thick Description: Towards an Interpretative Theory of Culture", in his The Interpretations of Cultures. Selected Essays. New York: 3-30.

Gehrig, Ulrich (1990) "Die Phönizier in Griechenland,” in his Die Phönizier im Zeitalter Homers, ed. Hans-Georg Niemeyer. Mainz: 23-31.

Gehrke, Hans-Joachim (1986) Jenseits von Athen und Sparta: Das dritte Griechenland und seine Staatenwelt. Munich.

_ . (1987) "Die Griechen und die Rache: Ein Versuch in historischer Psychologie," Saeculum 38: 121-49.

Gellner, Ernest (1985) "Malinowski Go Home. Reflections on the Malinowski Centenary Conference," Anthropology Today 1/5: 5-7. 
Georgoudi, Stella (1974) "Quelques Problèmes de la transhumance dans la Grèce ancienne," Revue des Études Grecques 87: 155-85.

Gernet, Louis (1948) “La notion mythique de la valeur en Grèce," Journal de Psychologie normale et pathologique 41: 415-462.

— - (1951) “Droit et prédroit en Grèce ancienne," L’Année sociologique 3rd sér. 2: 21-119 = Droit et institutions en Grèce antique. 2nd edn. Paris 1982: 7-119.

Gernet, Louis (1968) "Mariages de tyrans" (1954) in Anthropologie de la Grèce antique, Paris: 344-359.

Gherchanoc, Florence (2009) "Des cadeaux pour nymphai: dôra, anakalyptêria et epaula," in La religion des femmes en Grèce ancienne: Mythes, cultes et société, ed. Lydie Bodiou and Véronique Mehl. Rennes: 207-23.

— _ (2019) "Poikilia: Zur Symbolik gemusterter Stoffgeschenke in Übergangsriten im antiken Griechenland," in Wagner-Hasel and Nosch 2019: 375-94.

Gherchanoc, Florence and Huét, Valerie (eds.) (2012) Vêtements antiques: s‘h́abiller, se déshabiller dans les mondes anciens. Paris.

Giddens, Anthony (1976) "Classical Social Theory and the Origin of Modern Sociology," American Journal of Sociology 81(4): 703-729.

Gierke, Otto F. von (1917) Deutsches Privatrecht. II: Schuldrecht. Munich and Leipzig.

— . ([1902] 1962) Vom Wesen der menschlichen Verbände. Darmstadt.

Gilbert, Felix (1990) History: Politics or culture? Reflections on Ranke and Burckhardt. Princeton.

Gill, Christopher, Norman Postlethwaite, and Richard Seaford (eds.) (1998) Reciprocity in Ancient Greece. Oxford.

Gill, David W. J. (1991) "Pots and Trade: Space-fillers or Objects d'Art," Journal of Hellenic Studies 111: 29-47.

Gillis, Carole and Marie-Louise Nosch (eds.) (2007) Ancient Textiles: Production, Craft and Society. Oxford.

Giuffrida, Margherita (1985) "Cipro nei poemi omerici," Seia 2: 15-39.

Giuliani, Luca (1986) Bildnis und Botschaft. Francfort.

Gleba, Margarita (2018) "Textile Culture in Europe 1200-50o BC: A View from Greece," in Arachne 5: 14-23.

Gleba, Margarita, Beatrix Marín-Aquilera and Francesco Iacona (2018) "Couloring the Mediterranean: Production and Consumption of Purple-dyed Textiles in PreRoman Times," Journal of Mediterranean Archaeology 31(2): 127-154.

Gnoli, Gherardo and Jean-Pierre Vernant (eds.) (1982) La mort, les morts dans les sociétés anciennes. Cambridge.

Godart, M. Louis (1970) "The Grouping of Place-Names in the Cn Tablets," Bulletin of the Institute of Classical Studies of the University of London 17: 159-61.

Godbout, Jacques T. and Alain Caillé (1991) “Le don existe-t-il (encore)?” Revue du Mauss 11: 11-32.

Godbout, Jacques T. and Alain Caillé (1992) L'esprit du don. Paris.

Gödde, Susanne (2011) Euphêmia: Die gute rede in Kult und Literatur in der griechischen Antike. Heidelberg.

Godelier, Maurice (1966) Rationalité et irrationalité en économie. Paris. 
. (1969) "La monnaie de sel des Barayu de Nouvelle Guinée," L’Homme 9/2: 5-37.

—_ (1980) "L'État: les processus de sa formation, la diversité de ses forms et de ses bases," Revue internationale des sciences sociales 37/4: 18-35.

— . (1984) L'Idéel et le Matériel. Paris.

- . (1996) L'énigme du don. Paris.

Godley, A. D. (2004) Herodotus. With an English translation. Cambridge and London.

Goguet, Antoine Yves (1775 [French version 1758]) The Origin of laws, arts, and sciences: and their progress amongst the most ancient of nations $I$, trans. Robert Henry; II, trans. D. Dunn. Edinburgh.

Golden, Mark (1992) "The Uses of Cross-Cultural Comparison in Ancient Social History," Echos du monde classique 36: 309-31.

Goldstein, Melwyn C. and Cynthia M. Beall (1991) Die Nomaden Westtibets. Nürnberg.

Gossman, Lionel (2000) Basel in the Age of Burckhardt. A Sudy in Unseasonable Ideas. Chicago, Illinois.

Gottesman, Alex (2010) "The Beggar and the Clod: The Mythic Notion of Property in Ancient Greece," Transactions of the American Philological Association 140/2: 287-322.

— . (2014) “The Authority of Telemachus," Classical Antiquity 33/1: 31-6o.

Gould, John P. (1991) Give and Take in Herodotus: Myres Memorial Lecture. Oxford: 5-19.

Graafen, Rainer and Christian Seeber (1993) "Alte Handelsrouten im Himalaya," Geographische Rundschau 45/11: 674-79.

Graf, Fritz (1991) "Religion und Mythologie im Zusammenhang mit Homer: Forschung und Ausblick," in Latacz 1991: 331-64.

Graham, A. J. (1984) “Commercial Interchanges Between Greeks and Natives,” Ancient World 10: 3-10.

— . (2001) Collected Papers on Greek Colonization. Leiden.

Grand-Clément, Adeline (2011) La fabrique des couleurs: Histoire du paysage sensible des Grecs anciens (VIIIe s.-début du Ve s. av. N. è.). Paris.

Grand-Clément, Adeline et al. (eds.) (2017) Les traces du sensible: pour une histoire des sens dans les sociétés anciennes. Trivium: revue franco-allemande de sciences humaines et sociales 27. Paris.

Grant, Adam (2014) Give and Take. A Revolutionary Approach to Success. London.

Gras, Michel (1986) "La coupe et l'échange dans la Méditerranée archaïque," in Hommages à F. Daumas. Montpellier: 351-59.

Grassl, Herbert (1985) "Hirtenkultur in Griechenland," in Bericht über den 16. österreichischen Historikertag in Krems/Donau in der Zeit vom 3. bis 7. September 1984, ed. vom Verband österreichischer Historiker und Geschichtsvereine. Vienna: 77-85.

— . (1990) "Zur Rolle der Frau in antiken Hirtenkulturen," Laverna 1: 13-17.

Gregory, Chris A. (1980) "Gifts to Men and Gifts to God: Gift Exchange and Capital Accumulation in Contemporary Papua," Man n.s. 15: 626-52.

_ . (1982) Gifts and Commodities. London. 
Greenewalt, Crawford H. and Lawrence J. Majewski (1980) “Lydian Textiles,” in de Vries 1980: 133-47.

Greindl, Max (1938) K^EO $\Sigma$, KY $\triangle \mathrm{O} \Sigma$, EYXO $\Sigma$, TIMH, ФATI $\Sigma, \triangle O X A$ : Eine bedeutungsgeschichtliche Untersuchung des epischen und lyrischen Sprachgebrauchs. Diss. Munich.

Grethlein, Jonas (2008) "Memory and Material Objects in the Iliad and the Odyssey," The Journal of Hellenic Studies 128: 27-51.

— . (2017) Homer und die Kunst des Erzählens. Munich.

Griffin, Jesper (1984) Homer on Life and Death. Oxford.

_ . (1995) "Homer, Pastoral, and the Near East," Studi italiani di filologia classica 85, 3rd sér 10: $552-76$.

Griffin, Miriam (2003) "De Beneficiis and Roman Society," The Journal of Roman Studies 93: 92-113.

Grimm, Jacob (1865) “Ueber Schenken und Geben (1848)," in his Kleinere Schriften. II: Abhandlungen zur Mythologie und Sittenkunde. Berlin: 173-210.

Groebner, Valentin (2000) Gefährliche Geschenke. Korruption und politische Sprache am Beginn der Neuzeit. Konstanz (Postdoctoral thesis. Basel 1998).

Groh, Dieter (1988) "Strategien, Zeit und Ressourcen," in Ökonomie und Zeit, ed. Eberhard K. Seifert. Francfort: 131-88.

Grothe, Hermann (1866) "Die Geschichte der Wolle und Wollmanufaktur im Alterthum," Deutsche Vierteljahrs-Schrift 29: 259-304.

Grottanelli, Cristiano (1976/77) "Notes on Mediterranean Hospitality," Dialoghi di Archeologia 9-10: 186-94.

_. (1989/90) "Do ut des?" in Bartoloni 1990: 45-54.

Gruber, Joachim (1963) Über einige abstrakte Begriffe des frühen Griechischen. Beiträge zur klassischen Philologie 9. Meisenheim am Glan.

Grünbart, Michael (ed.) (2011) Geschenke erhalten die Freundschaft: Gabentausch und Netzwerkpflege im europäischen Mittelalter I. Berlin.

Grüner, Andreas (2007) "Gabe und Geschenk in der römischen Staatskunst," in Geschenke und Steuern, Zölle und Tribute: Antike Abgabenformen in Anspruch und Wirklichkeit, ed. Hilmar Klinkott, Sabine Kubisch, and Renate Müller-Wollermann. Leiden and Boston: 431-84.

Guery, Alain (1976) Studien zur Terminologie der Sklaverei. II: Untersuchungen zur älteren insbesondere homerischen Sklaventerminologie. Wiesbaden.

_ _ (1984) "Le roi dépensier: Le don, la contrainte, et l'origine du système financier de la monarchie française d'Ancien Régime,” Annales E. S. C. 6: 1241-69.

—_ . (1991) "Zur homerischen Staats- und Gesellschaftsordnung: Grundcharakter und geschichtliche Stellung," in Latacz 1991: 182-204.

_ . (1992) "Volk, Nation: Altertum," in Geschichtliche Grundbegriffe VII, ed. Otto Brunner, Werner Conze, and Reinhart Koselleck. Stuttgart: 151-71.

— . (1997) Gschnitzer, Fritz (1965) "BA $\Sigma \mid \wedge E Y \Sigma$ : Ein terminologischer Beitrag zur Frühgeschichte des Königtums bei den Griechen,” Innsbrucker Beiträge zur Kulturwissenschaft 11: 99-112.

Hägg, Robin (ed.) (1983) The Greek Renaissance of the Eighth Century B.C.: Tradition and Innovation; Proceedings of the Second International Symposium at the Swedish Institute in Athens, 1-5 June, 1981. Stockholm. 
. (1987a) "Gifts to the Heroes in Geometric and Archaic Greece," in Linders and Nordquist 1987: 93-99.

— . (1987b) "Submycenaean Cremation Burials in the Argolid," in Laffineur 1987: 207-11.

— . (ed.) (2002) Peloponnesian Sanctuaries and Cults: 11-13 June 1994.

Proceedings of the International Symposium at the Swedish Institute in Athens 48. Stockholm.

Hägg, Robin and Gullög C. Nordquist (eds.) (1990) Celebrations of Death and Divinity in the Bronze Age Argolid: Proceedings of the Sixth International Symposium at the Swedish Institute at Athens, 11.-13. June 1988. Stockholm.

Hagner, Michael (1987) Zur Geschichte vom Licht im Auge und der Physiologie des Druckphosphens im Verhältnis zu den jeweils zeitgenössischen Sehtheorien. Diss. Berlin.

Hall, Jonathan (2004) "How Greek Were the Early Western Greeks," in Greek Identity in the Western Mediterranean: Papers in honour of Brian Shefton, ed. Kathryn Lomas. Leiden: 35-54.

Halstead, Paul (1981) “Counting Sheep in Neolithic and Bronze Age Greece," in Hodder, Isaac and Hammond 1981: 307-39.

_ . (1987a) "Man and Other Animals in Later Greek Prehistory," Annual of the British School at Athens 82: 71-83.

— . (1987b) "Traditional and Ancient Rural Economy in Mediterranean Europe: Plus ça Change," The Journal of Hellenic Studies 107: 77-87.

Halverson, John (1985) "Social Order in the 'Odyssey'," Hermes 113: 129-45.

— . (1986) "The Succession Issue in the 'Odyssey', Greece \& Rome 33/2: 119-28.

Hamilakis, Yannis (ed.) (2014) Archaeology of the Senses: Human Experience, Memory, and Affect. New York.

Hammerstein, Notker (ed.) (1988) Deutsche Geschichtswissenschaft um 1900. Stuttgart.

Hammond, Nicholas (1983) "Migration and Assimilation in Greece," in Greece Old and New, ed. Tom Winnifrith and Penelope Murray. London and Basingstoke: 39-64.

Hamp, Eric P. (1982) “ФI^O乏,” Bulletin de la Société de Linguistique 77/1: 251-62.

Hampe, Roland and Erika Simon (1985) Griechisches Leben im Spiegel der Kunst. Mainz.

Hands, Arthur R. (1968) Charities and Social Aid in Greece and Rome. London.

Handschur, Erna (1970) Die Farb- und Glanzwörter bei Homer und Hesiod. Diss. Vienna.

Hannig, Jürgen (1988) "Ars donandi: Zur Ökonomie des Schenkens im frühen Mittelalter," in Armut, Liebe, Ehre: Studien zur historischen Kulturforschung, ed. Richard van Dülmen. Francfort: 11-37.

Hansen, Klaus P. (1995) Kultur und Kulturwissenschaft. Tübingen and Basel.

Hansen, Mogens Herman (1976) Agagoge, Endeixis und Ephegesis against Kakourgoi, Atimoi, and Pheugontes. A Study in the Athenian Administration of Justice in 4 th Century B.C. Odense. 
— - (1982) "Atimia in Consequence of Private Debts," in Symposion 1977. Vorträge zur griechischen und hellenistischen Rechtsgeschichte, ed. Joseph Modrzejewski and Detlef Liebs. Cologne: 113-20.

_ . (1998) Polis and City-State: An Ancient Concept and Its Modern Equivalent; Acts of the Copenhagen Polis Centre. Copenhagen.

Hanson, Victor D. (1983) Warfare and Agriculture in Classical Greece. Cambridge.

Harbsmeier, Michael (1994) Wilde Völkerkunde. Francfort and New York.

Harding, Anthony F. (1987) "Fernhandel in der Bronzezeit: Analyse und Interpretation," Saeculum 38/4: 297-311.

Harich-Schwarzbauer, Henriette (2011) "Gewebte Bilder. Textilekphrasis in Claudians Raub der Proserpina (rapt. I, 246-275)," Bild und Text im Mittelalter, ed. Karin Krause and Barbara Schellewald. Cologne, Weimar and Vienna: 29-39.

— . (ed.) (2016) Weben und Gewebe in der Antike: Materialität-RepräsentationEpisteme-Metapoetik. Oxford and Philadelphia.

Harlizius-Klück, Ellen (2004) Weberei als episteme und die Genese der deduktiven Mathematik. Berlin.

—_ (2006) "Nur nicht von einer Frau geboren werden ...؛ Genealogisches zu Mathematik und Weberei in der Antike," in Ingeborg Kader (ed.) Penelope rekonstruiert: Geschichte und Deutung einer Frauenfigur. Munich: 121-133.

_ _ (2016) "Denkmuster in der antiken Weberei: Eine Spurensuche," in HarichSchwarzbauer 2016: 87-107.

— - (2019) "Der Stoff und die Ordnung des Kosmos: Zur Bedeutsamkeit des textilen Mustertransfers im frühen Griechenland," in Wagner-Hasel and Nosch 2019: 397-430.

Harlizius-Klück, Ellen and Giovanni Fanfani (2016) "(B)orders in Ancient Weaving and Archaic Greek Poetry," in Spinning Fates and Song of the Loom: The Use of Textiles, Clothing and Cloth Production as Metaphor, Symbol and Narrative Device in Greek and Latin Literature, ed. Giovanni Fanfani, Mary Harlow, and MarieLouise Nosch. Oxford: 61-99.

Harris, Edward M., David M. Lewis and Mark Woolmer (eds.) (2016) The Ancient Greek Economy: Markets, Households and City-States. Cambridge.

Harris, Marvin (1968) The Rise of Anthropological Theory. New York.

Hartmann, Elke (2016) Ordnung in Unordnung. Kommunikation, Konsum und Konkurrenz in der frühen Kaiserzeit. Stuttgart.

Harvey, F. David (1985) “Dona Ferentes: Some Aspects of Bribery in Greek Politics," in Cartledge and Harvey 1985: 76-117.

Hasebroek, Johannes (1928) Staat und Handel im Alten Griechenland: Untersuchungen zur antiken Wirtschaftsgeschichte. Tübingen (rpt. 1966).

Hastrup, Kirsten (1986) "Ethnologie und Kultur: Ein Überblick über neuere Forschungen,” in Vom Umschreiben der Geschichte, ed. Ulrich Raulff. Berlin: 54-67.

Hattenauer, Hans (1992) Europäische Rechtsgeschichte. Heidelberg.

Hauck, Gerhard (1984) Geschichte der soziologischen Theorie: Eine ideologiekritische Einführung. Reinbek bei Hamburg. 
Havelock, Christine Mitchell (1981) “Mourners on Greek Vases,” in Hyatt 1981: 103-18.

Havelock, Eric A. (1963) Preface to Plato. Oxford.

- . (1978) The Greek Concept of Justice: From Its Shadow in Homer to Its Substance in Plato. Cambridge, MA and London.

_ . (1986) The Muse Learns to Write: Reflections on Orality and Literacy from Antiquity to the Present. New Haven, MA.

Haverkamp, Anselm (ed.) (1996) Theorie der Metapher. 2nd edn. Darmstadt.

Hawke, Jason (2011) Writing Authority. Elite Competition and Written Law in Early Greece. Illinois.

Hecht, Ann (1989) The Art of the Loom: Weaving, Spinning \& Dyeing Across the World. London.

Heiden, Bruce (1991) “Shifting Contexts in the Iliad," Eranos 89: 1-12.

Heitsch, Ernst (1992) “Die epische Schicksalswaage," Philologus 136/2: 143-57.

Helbig, Wolfgang (1901) "Zu den homerischen Bestattungsgebräuchen," in Sitzungsberichte der philosophisch-philologischen Classe der königlich bayrischen Akademie der Wissenschaften Jahrgang 1900. Munich: 199-279.

Helck, Wolfgang and E. Otto (eds.) (1977) Lexikon der Ägyptologie II. Wiesbaden: s.v. "Gold, Goldgewinnung, Goldminen."

Helfer, Christian (1970) "Jherings Gesellschaftsanalyse im Urteil der heutigen Sozialwissenschaft," in Wieacker and Wollschläger 1970: 79-88.

Heltzer, Michael (1989) "The Trade of Crete and Cyprus with Syria and Mesopotamia and Their Eastern Tin-Sources in the XVIII-XVII Centuries B.C.," Minos 24: 7-27.

Hempel, Ludwig (1993a) "Jungquartäre Klimaveränderungen im ostmediterranen Raum. Auswirkungen auf Reliefgestalt und Pflanzendecke," in Rundgespräche der Kommission für Ökologie: Probleme der Umweltforschung in historischer Sicht. Munich: 161-79.

— _ (1993b) "Natürliche Höhenstufen und Siedelplätze in griechischen Hochgebirgen," Hellenika: 77-91.

Hénaff, Marcel (2002) Le prix de la verité: Le don, l'argent, la philosophie. Paris. Herman, Gabriel (1987) Ritualised Friendship in the Greek City. Cambridge.

_ . (1998) "Reciprocity, Altruism and the Prisoner's Dilemma: The Special Case of Classical Athens," in Gill 1998: 199-226.

— . (2006) Morality and Behaviour in Democratic Athens: A Social History. Cambridge.

Hesiod (1984) Theogonia, Opera et dies, Scutum, ed. Friedrich Solmsen. Oxford Classical Texts. Oxford.

Hettne, Björn (1990) The Contemporary Crisis: The Rise of Reciprocity, in PolanyiLevitt 1990: 208-20.

Heubeck, Alfred (1974) Die homerische Frage: Ein Bericht über die Forschung der letzten Jahrzehnte. Darmstadt.

Heubeck, Alfred et al. (eds.) (1988-1992) A Commentary on Homer's Odyssey. 3 vols. Oxford.

Hicks, R. D. (1950) Diogenes Laertius. Lives of Eminent Philosophers. With an English translation. Vol I. London and Cambridge. 


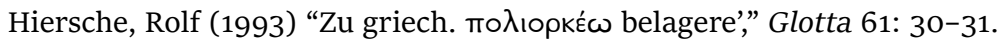

Hildebrandt, Berit (2007) Damos und Basileus. Überlegungen zu Sozialstrukturen in den Dunklen Jahrhunderten Griechenlands. Munich.

_ . (2019) "Von der Gabe zur Entlohnung: Kleidung als kaiserliches Geschenk in Rom," in Wagner-Hasel and Nosch 2019: 117-36.

Hildebrandt, Berit and Caroline Veit (eds.) (2009) Der Wert der Dinge: Güter im Prestigediskurs. Munich.

Hilger, Dietrich (1982) "Der Herrschaftsbegriff im Zeitalter der Revolutionen: Grundzüge seiner Geschichte," in Geschichtliche Grundbegriffe III, ed. Otto Brunner, Werner Conze and Reinhart Koselleck. Stuttgart: 64-102.

Hiller, Stefan (1972) Studien zur Geographie des Reiches um Pylos nach den Mykenischen und Homerischen Texten. Vienna.

_ . (1987) “A-PI-QO-RO Amphipoloi," Minos 2: 239-55.

Hiller, Stefan and Oswald Panagl (1976) Die frühgriechischen Texte aus mykenischer Zeit. Darmstadt.

Hiltbrunner, Otto (1972) "Gastfreundschaft," in Reallexikon für Antike und Christentum 8: 1061-123.

- . (1983) "Gastfreundschaft und Gasthaus in der Antike," in Gastfreundschaft, Taverne und Gasthaus im Mittelalter, ed. Hans Conrad Peyer in collaboration with Elisabeth Müller-Luckner. Munich and Vienna: 1-20.

- . (2005) Gastfreundschaft in der Antike und im frühen Christentum. Darmstadt. Hilzheimer, Max (1936) “Sheep," Antiquity 10: 195-206.

Hirzel, Rudolf (1902) Der Eid: Ein Beitrag zu seiner Geschichte. Leipzig.

_ . (1907) Themis, Dike und Verwandtes: Ein Beitrag zur Geschichte der Rechtsidee bei den Griechen. Leipzig.

Hitch, Sarah (2009) King of Sacrifice: Ritual and Royal Authority in the Iliad. Cambridge, MA and London.

Hodder, Ian (1989) The Meaning of Things: Material Culture and Symbolic Expression. London.

Hodder, Ian, Glynn Isaac, and Norman Hammond (eds.) (1981) Patterns of the Past: Studies in Honour of David Clarke. Cambridge.

Hodkinson, Stephen (1988) "Animal Husbandry in the Greek Polis," in Whittaker 1988: 35-74.

_ . (1990) "Politics as a Determinant of Pastoralism: The Case of Southern Greece, ca. 800-300 B.C.," Rivista di studi Liguri 56: 139-63.

Hoëg, Carsten (1925) Les Saracatsans, un tribu nomade grecque. Paris and Copenhagen.

Hoffmann, Marta (1964) The Warp-Weighted Loom: Studies in the History of Technology in an Ancient Implement. Oslo.

Hofmann, Inge (1973) Bürgerliches Denken: Zur Soziologie Emile Durkheims. Francfort.

Hofmann, J. B. (1950) Etymologisches Wörterbuch des Griechischen. Munich, s.v.

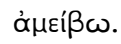

Holenstein, Andre (1991) Die Huldigung der Untertanen: Rechtskultur und Herrschaftsordnung 800-1800. Stuttgart. 
Hölkeskamp, Karl-Joachim (1992) “Written Law in Archaic Greece," Proceedings of the Cambridge Philological Society 38: 87-117.

— . (1999) Schiedsrichter, Gesetzgeber und Gesetzgebung im archaischen Griechenland. Stuttgart.

- . (2002) "Ptolis and Agore. Homer and the Archaeology of the City-State," in Omero tremila anni dopo, ed. Franco Montanari. Storia e letteratura 210. Roma: 297-342.

- (2004) "The Polis and its Spaces-The Politics of Spatiality. Tendencies in Recent Research," Ordia Prima 3: 25-40.

Hollander, Anne (1980) Seeing through Clothes. New York.

Hollier, Denis (1972) “Malaise dans la Sociologie," L'Arc. Marcel Mauss 48: 55-61.

Hölscher, Lucian (1979) Öffentlichkeit und Geheimnis: Eine begriffsgeschichtliche Untersuchung zur Entstehung von Öffentlichkeit in der frühen Neuzeit. Stuttgart.

Hölscher, Tonio (1989) Die unheimliche Klassik der Griechen. Bamberg.

Hölscher, Uvo (1983) “Die Odyssee-Epos zwischen Märchen und Literatur," in Schrift und Gedächtnis Beiträge zur Archäologie der literarischen Kommunikation, ed. Aleida and Jan Assman, and Christof Hardmeier. Munich: 94-108.

— . (1990) Die Odyssee zwischen Märchen und Roman. Munich.

Holst-Warhaft, Gail (1992) Dangerous Voices: Women's Laments and Greek Literature. London.

Homeri Opera, 4 vols. (1979) Ed. Thomas W. Allen. Oxford Classical Texts. Oxford.

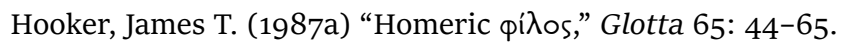

_ . (1987b) "Homeric Society. A Shame-Culture?” Greece \& Rome 34: 121-25.

_ . (1989) "Gifts in Homer," Bulletin of the Institute of Classical Studies 36: 79-90.

— . (1995) "Linear B as a Source for Social History," in The Greek World, ed. Anton Powell. London: 7-26.

Hopper, Robert J. (1979) Trade and Industry in Classical Greece. London.

Howe, Timothy (2003) "Pastoralism, the Delphic Amphictiony and the First Sacred War: The Creation of Apollo's Sacred Pastures," Historia 52/2: 129-46.

_ . (2008) Pastoral Politics, Animals, Agriculture and Society in Ancient Greece. Claremont.

Huber, Ingeborg (2001) Die Ikonographie der Trauer in der griechischen Kunst. Peleus: Studien zur Geschichte Griechenlands und Zyperns 10. Mannheim and Möhnesee.

Humphreys, Sarah C. (1981) “Death and Time," in Humphreys and King 1981: 261-83 = Humphreys 1983a: 144-64.

- (1983a) The Family, Women and Death: Comparative Studies. London.

— . (1983b) "Family Tombs and Tomb-Cult in Classical Athens: Tradition or Traditionalism?” in Humphreys 1983a: 79-129.

- . (1983c) Anthropology and the Greeks. 2nd edn. London.

— . (1983d) "History, Economics and Anthropology: The Work of Karl Polanyi," in Humphreys 1983c: 31-75.

— . (1983e) "Homo politicus and homo oeconomicus: War and Trade in the Economy of Archaic and Classical Greece," in Humphreys 1983c: 159-74. 
— - (1983f) “The Work of Louis Gernet,” Humphreys 1983c: 283-88.

- . (2018) Kinship in Ancient Athens. Oxford.

Humphreys, Sarah C. and Helen King (eds.) (1981) Mortality and Immortality. The Anthropology and Archaeology of Death. London.

Hunter, Virginia J. (1981) “Classics and Anthropology," Phoenix 35: 144-55.

— . (1994) Policing Athens: Social Control in the Attic Lawsuits, 420-320 B.C. Princeton.

Hyatt, Stephen L. (ed.) (1981) The Greek Vase. Latham, N.Y.

Hyde, Lewis (1983) The Gift: Imagination and Erotic Life of Property. 3rd edn. New York.

Isler, Hans Peter (1994) “ГЕРPAІ: Ein neuer inschriftlicher Beleg aus Sizilien," Zeitschrift für Papyrologie und Epigraphik 101: 104-6.

Issing, Otmar (ed.) (1988) Geschichte der Nationalökonomie. 2nd rev. edn. Munich.

Ivánka, Endre von (1950) "Berghirtentum und Staatenbildung im antiken und mittelalterlichen Balkan,” Saeculum 1: 349-61.

Jachmann, Günther (1953) “Das homerische Königtum,” Maia 6: 241-56.

Jackson, Alastar (1993) "War and Raids for Booty in the World of Odysseus," in Rich and Shipley 1993: 64-76.

Jacobsen, Thomas W. (1984) "Seasonal Pastoralism in Southern Greece: A Consideration of the Ecology of Neolithic Urfirnis Pottery," in Pots and Potters: Current Approaches in Ceramic Archaeology, ed. Prudence M. Rice. Los Angeles: 27-43.

Jacoby, Felix (1933) "Der homerische Apollonhymnos," in Sitzungsberichte der Preußischen Akademie der Wissenschaften, Philosophisch-Historische Klasse. Berlin: 682-751.

Jaeger, Friedrich (1994) Bürgerliche Modernisierungskrise und historische Sinnbildung: Kulturgeschichte bei Droysen, Burckhardt und Max Weber. Göttingen.

Jameson, Michael (1983) "Famine in the Greek World," in Garnsey and Whittaker 1983: 6-16.

— . (1988) "Sacrifice and Animal Husbandry," in Whittaker 1988: 87-119.

— . (1989) "Mountains and the Greek City States," in Bergier 1989: 7-17.

Janko, Richard (1982) Homer, Hesiod and the Homeric Hymns. Cambridge.

Janssen, Jac J. (1982) “Gift-Giving in Ancient Egypt as an Economic Feature," Journal of the Egyptian Archaeology 68: 253-58.

Jeffrey, Lilian H. (1961) The Local Scripts of Archaic Greece. Oxford.

Jenkins, Ian D. (1985) “The Ambiguity of Greek Textiles," Arethusa 18: 109-32.

Jensen, Minna Skafte (1980) The Homeric Question and the Oral-Formulaic Theory. Copenhagen.

Jettmar, Karl (1993) "Voraussetzungen, Verlauf und Erfolg menschlicher Anpassung im nordwestlichen Himalaya mit Karakorum," in Schweinfuhrt 1993: 31-47.

Jhering, Rudolf von (1887) "Die Gastfreundschaft im Alterthum," Deutsche Rundschau 51: 357-97.

— . (1970) Der Zweck im Recht I (1877) and II (1883), ed. with a foreword by Christian Helfer and two yet unpublished additions of Jhering's inheritance. Hildesheim and New York (rpt. of the 4th edn. 1904/05). 
Jim, Theodora Suk Fong (2014) Sharing with the Gods, Aparchai and Dekatai in Ancient Greece. Oxford.

Johnson, Marie (ed.) (1964) Ancient Greek Dress: A New Illustrated Edition Combining Greek Dress by Ethel Beatrice Abrahams; Chapters of Greek Dress by Lady Maria Midington Evans. Chicago.

Jones, W. H. S. and Litt, D. (1964) Pausanias' Description of Greece. Vol. I. Cambridge and London.

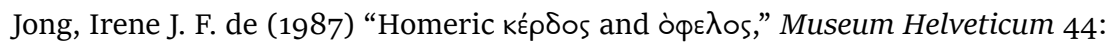
79-81.

— . (1991) "Gynaikeion ethos: Misogyny in the Homeric Scholia," Eranos 89: 13-24.

Kabadias, G. B. (1965) Pasteurs-Nomads Méditerrannées: Les Saracatsans de Grèce. Paris.

Kahn, Maurice (1979) "La frontière et l'identité ambigue," Ktema 4: 201-11.

Kahn-Majlis, Brigitte (1984) Indonesische Textilien: Wege zu Göttern und Ahnen. Cologne.

- . (1991) Woven Messages. Indonesian Textile Tradition in Course of Time. Gewebte Botschaften: Indonesische Traditionen im Wandel. Hildesheim.

Kahrstedt, Ulrich (1953) "Delphoi und das Heilige Land des Apollon," in Mylonas and Raymond 1953: 749-57.

Kakridis, Hélène J. (1963) La notion de l'amitié et de l'hospitalité chez Homère. Thessaloniki.

Kan, Sergei (1986) “The XIXth Century Tlingit Potlatch: A New Perspective," American Anthropologist 13/2: 191-212.

Karali, Llilian and F. Megaloudi (2008) "Purple Dyes in the Environment and History of the Aegean: A Short Review," in Vestidos, Textiles Y Tintes. Estudios sobre la producción de bienes de consumo en la Antigüedad, ed. Carmen Alfaro and Llilian Karali, Valencia: 181-84.

Karanastassi, Pavlina (1997) “Themis," in Lexicon Iconographicum Mythologiae Classicae 8/1: 1199-205.

Karanika, Andromache (2014) Voices at Work: Women, Performance, and Labor in Ancient Greece. Baltimore.

Karavites, Peter Panayiotis (1986) "Philotes, Homer and the Near East," Athenaeum 3/4: 474-81.

Karavites, Peter Panayiotis in collaboration with Thomas Wren (1992) PromiseGiving and Treaty-Making: Homer and the Near East. Leiden.

Kardera, Chrysoula (1960) "Dyeing and Weaving Works at Isthmia," American Journal of Archaeology 65: 261-66.

_ . (1970) "Athena Phoinika," Athens Annals of Archaeology 3: 94-97.

Kaschuba, Wolfgang (1995) "Kulturalismus: Vom Verschwinden des Sozialen im gesellschaftlichen Diskurs,” Zeitschrift für Volkskunde 91: 27-46.

Kaser, Max (1971) Das römische Privatrecht. 2nd edn. Munich.

Katluhn, Carl (1914) ГEPA $\Sigma$. Diss. Königsberg.

Katz, Marylin A. (1991) Penelope's Renown: Meaning and Indeterminacy in the Odyssey. Princeton. 
Kearsley, R. (1999) "Greeks Overseas in the 8th Century B.C. Euboeans, Al Mina and Assyrian Imperialism," in Ancient Greeks West and East, ed. Gocha R. Tsetskhladze. Leiden: 109-34.

Kehl, Alois (1978) "Gewand (der Seele)," in Reallexikon für Antike und Christentum 10: 945-1025.

Kelder, Jorrit M. (2009) "Royal Gift Exchange between Mycenae and Egypt: Olives as 'Greeting Gifts' in the Late Bronze Age Eastern Mediterranean,” American Journal of Archaeology 113/3: 339-52.

Kelsen, Hans (1982) Vergeltung und Kausalität: Mit einer Einleitung von Ernst Topitsch. Vienna (rpt. of 1941 edn.).

Kemper, Peter (1988) "Postmoderne” oder der Kampf um die Zukunft. Francfort. Kerenyi, Karl (1942) Die antike Religion. Amsterdam.

Keuls, Eva C. (1983) "Attic Vase-Painting and Home Textile Industry," in Ancient Greek Art and Iconography, ed. Warren G. Moon. Madison, WI: 209-29.

Khazanov, Anatoly M. (1984 [Russian version 1983]) Nomads of the Outside World. Cambridge.

Kiekebusch, Joachim (1928) "Schenkung," in Handwörterbuch der Rechtswissenschaft V, ed. Fritz Stier-Somlo and Alexander Elster. Berlin and Leipzig: 282-88.

Kiesel, Helmuth (1989) "Aufklärung und neuer Irrationalismus in der Weimarer Republik," in Aufklärung und Gegenaufklärung in der europäischen Literatur, Philosophie und Politik von der Antike bis zur Gegenwart, ed. Jochen Schmidt. Darmstadt: 497-521.

Kilian-Dirlmeier, Imma (1985) "Fremde Weihungen in griechischen Heiligtümern vom 8. bis zum Beginn des 7. Jahrhunderts v. Chr.," Jahrbücher des RömischGermanischen Zentralmuseums 32: 215-54.

Killen, John T. (1964) “The Wool Industry of Crete in Late Bronze Age," Annual of the British School at Athens 59: 1-15.

— . (1966) “The Knossos Lc(Cloth)Tablets," Bulletin of the Institute of Classical Studies 13: 105-9.

_ . (1985) "The Linear B Tablets and the Mycenaean Economy," in Linear B: A 1984 Survey, ed. Anna M. Davies and Y. Duhoux. Louvain-la-Neuve: 241-305.

— . (2007) "Cloth Production in Late Bronze Age Greece: The Documentary Evidence," in Gillis and Nosch 2007: 50-58.

King, Helen (1983) "Bound to Bleed: Artemis and the Greek Women," in Images of Women in Antiquity, ed. Averil Cameron and Amélie Kuhrt. London: 109-27.

Kippenberg, Hans Gerhard (1971) "Wege zu einer historischen Religionssoziologie," Verkündigung und Forschung: Beiheft zur Evangelischen Theologie 16: 54-82.

_ _ (1997) Die Entdeckung der Religionsgeschichte: Religionswissenschaft und Moderne. Munich.

Kirk, Geoffrey S. (1971) Myth: Ist Meaning and Function. Cambridge.

— . (1985) “The Homeric Hymns," in Easterling and Kenney 1985: 114-15.

Kirk, Geoffrey S. et al. (eds.) (1985-1993) The Iliad: A Commentary. 6 vols. Cambridge.

Kirsten, Ernst (1956) Die griechische Polis als historisch-geographisches Problem des Mittelmeerraumes. Colloquium Geographicum 5. Bonn. 
Kistler, Erich et al. (eds.) (2015) Sanctuaries and the Power of Consumption. Networking and the Formation of Elites in the Archaic Western Mediterranean World. Proceedings of the International Conference in Innsbruck, 2oth to 23rd March 2012 (= Philippika 92). Wiesbaden.

Kitts, Margo (2005) Sanctified Violence in Homeric Society: Oath-Making Rituals and Narratives in the Iliad. Cambridge.

Klein, Julius (1964) The Mesta: A Study in Spanish Economic History 1273-1836. Port Washington, NY.

Klinkott, Hilmar, S. Kubisch, and Renate Müller-Wollermann (eds.) (2007) Geschenke und Steuern, Zölle und Tribute: Antike Abgabenformen in Anspruch und Wirklichkeit. Leiden and Boston.

Knigge, Ursula (1988) Der Kerameikos von Athen. Athen.

Knox, Mary O. (1970) “'House' and 'Palace' in Homer,” The Journal of Hellenic Studies 90: 117-20.

Koch-Harnack, Gundel (1983) Knabenliebe und Tiergeschenke: Ihre Bedeutung im päderastischen Erziehungssystem Athens. Berlin.

— . (1989) Erotische Symbole: Lotosblüte und gemeinsamer Mantel auf antiken Vasen. Berlin.

Köcke, Jasper (1979) "Some Early German Contributions to Economic Anthropology," Research in Economic Anthropology 2: 119-67.

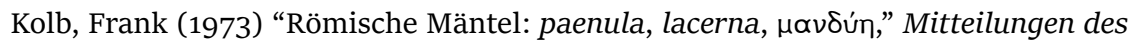
Deutschen Archäologischen Instituts, Römische Abteilung 80: 69-165.

Komornicka, A. M. (1984) "Poésie et poète: Termes et notions dans la littérature grecque," Giornale filologica ferrarese 7: 3-17.

König, René (1972) “Marcel Mauss (1872-1950),” Kölner Zeitschrift für Soziologie und Sozialpsychologie 24: 633-57.

Konstan, David (1997) Friendship in the Classical World. Cambridge.

Kopcke, Günter (1990) Handel. Archaeologia Homerica M. Göttingen.

Koppers, Wilhelm (1915/16) “Die ethnologische Wirtschaftsforschung," Anthropos 10-11: 611-51, 971-1097.

Korfmann, Manfred (1986) "Troy: Topography and Navigation," in Troy and the Troyan War: A Symposium held at Bryn Mawr College October 1984, ed. Machteld J. Mellink. Bryn Mawr: 1-16.

Koster, Harold A. (1976) “The Thousand Year Road," Expedition 19/1: 19-28.

Koster, Harold A. and Joan Bouza (1976) "From Spindle to Loom: Weaving in the Southern Argolid," Expedition 19/1: 20-39.

Köstler, Rudolf (1950) Homerisches Recht. Vienna.

Krämer, Augustin (1902) Die Samoa-Inseln: Entwurf einer Monographie mit besonderer Berücksichtigung Deutsch-Samoas. 2 vols. Stuttgart.

Kramer, Fritz (1979) "Nachwort," in Bronislaw Malinowski, Argonauten des Westlichen Pazifik. Translation Heinrich Ludwig Herdt, ed. Fritz Kramer. Francfort 1979: 548-70.

- (1981) Verkehrte Welten: Zur imaginären Ethnographie des 19. Jahrhunderts. 2nd edn. Francfort. 
Kramer-Hajos, Margaretha (2016) Mycenaean Greece and the Aegean World: Palace and Provinces in the Late Bronze Age. Cambridge.

Kreilinger, Ulla (2007) Anständige Nacktheit. Körperpflege, Reinigungsriten und das Phänomen weiblicher Nacktheit im archaisch-klassischen Athen. Rahden.

Kretschmer, Paul (1945) "Penelope," in Anzeiger der Akademie der Wissenschaften, Philosophisch-Historische Klasse. Vienna: 80-93.

Krischer, Tilman (1989) "Aretes Frage: Zur Phäakenepisode der Odyssee," Mnemosyne 42: 12-23.

Kromer, Karl (1982) "Gift Exchange and the Hallstatt Courts," Bulletin of the Institut of Archaeology 19: 21-30.

Krug, Antje (1968) Binden in der griechischen Kunst: Untersuchungen zur Typologie, 6.-1. Jh. v. Chr. (Diss. Mainz 1967) Hösel.

Krummen, Eveline (1990) Pyrsos Hymnon: Festliche Gegenwart und mythisch-rituelle Tradition als Voraussetzung einer Pindartradition (Isthmie 4, Pythie 5, Olympie 1 und 3). Berlin and New York.

Kullmann, Wolfgang (1956) Das Wirken der Götter in der Ilias: Untersuchungen zur Frage der Entstehung des Homerischen „Götterapparats“. Berlin.

—_ . (1988) “'Oral Tradition/Oral History’ und die frühgriechische Epik,” in Ungern-Sternberg and Reinau 1988: 184-96.

Kullmann, Wolfgang and Michael Reichel (eds.) (1990) Der Übergang von der Mündlichkeit zur Literatur bei den Griechen. Tübingen.

Kurke, Leslie (1999) Coins, Bodies, Games, and Gold. The Politics of Meaning in Archaic Greece. Princeton.

Kurtz, Donna Carol and John Boardman (1971) Greek Burial Customs. Aspects of Greek and Roman Life. London.

Laffineur, Robert (ed.) (1987) Thanatos: Les coutumes funéraires en Égée à l'âge du bronze. Actes du colloque de Liège (21-23 avril 1986). Liège.

Lahr, Stefan van der (1992) Dichter und Tyrannen im archaischen Griechenland: Das Corpus Theognideum als zeitgenössische Quelle politischer Wertvorstellungen archaisch-griechischer Aristokraten. Munich.

Lamberterie, Charles de (1992) "Le problème de l'homonymie: Les trois verbes ophello en grec ancien," in La langue et les textes en grec ancien. Actes du colloque Pierre Chantraine, Grenoble 5-8 Septembre 1989, ed. Françoise Létoublen. Amsterdam: 201-17.

Landels, John Gray (1978) Engineering in the Ancient World. London.

Landercy, Mathilde (1933) "La destination de la кєркís dans le tissage en Grèce au IVe siècle,” L'Antiquité Classique 2: 357-362.

Landfester, Manfred (1966) Das griechische Nomen qí̉os und seine Ableitungen. Spudasmata 11. Hildesheim.

Langdon, Susan (1987) "Gift Exchange in the Geometric Sanctuaries," in Linders and Nordquist 1987: 107-13.

Laroche, Emmanuel (1949) Histoire de la racine nem- en grec ancienne. Paris.

Latacz, Joachim (1966) Zum Wortfeld 'Freude' in der Sprache Homers. Heidelberg.

_. (ed.) (1979) Homer: Tradition und Neuerung. Darmstadt. 
. (1988) "Zu Umfang und Art der Vergangenheitsbewahrung in der mündlichen Überlieferungsphase des griechischen Heldenepos," in Ungern-Sternberg and Reinau 1988: 153-83.

_ . (1989) Homer: Der erste Dichter des Abendlandes. 2nd edn. Munich and Zurich.

_ . (ed.) (1991) Zweihundert Jahre Homer-Forschung: Rückblick und Ausblick. Colloquium Rauricum 2. Leipzig and Stuttgart.

- . (2001) Homer: His Art and His World, trans. James P. Holoka. Ann Arbor (1st edn. 1996).

- . (2004) Troy and Homer: Towards a Solution of an Old Mystery, trans. Kevin Windle and Rosh Ireland. Oxford.

Laughlin, C. D. Jr. (1986) “On the Spirit of the Gift,” Journal of the Indian Anthropological Society 21/2: 156-76.

Laum, Bernhard (1924) Heiliges Geld: Eine historische Untersuchung über den sakralen Ursprung des Geldes. Tübingen.

— . (1933) Die geschlossene Wirtschaft: Soziologische Grundlegung des Autarkieproblems. Tübingen.

— - (1960) Schenkende Wirtschaft: Nicht marktmäßiger Güterverkehr und seine soziale Funktion. Francfort.

Lavelle, Brian M. (1980/81) “Archilochos Fr. 6 West and XEINIA,” Classical Journal 76: 197-99.

— . (1995) "The Pisistratids and the Mines of Thrace", Athenaeum 83: 45-66.

— . (2005) Fame, Money, and Power: The Rise of Peisistratos and 'Democratic' Tyranny at Athens. Ann Arbor.

Lavizzari-Raeuber, Alexandra (1989) Thangkas: Rollbilder aus dem Himalaya; Kunst und mythische Bedeutung. 3rd edn. Cologne.

Lay, Rupert (1990) Die Macht der Moral: Unternehmenserfolg durch ethisches Managment. Düsseldorf.

— . (1991) Ethik für Wirtschaft und Politik. Francfort.

Leacock, Eleanor (1978) "Women's Status in Egalitarian Society: Implications for Social Evolution," Current Anthropology 19/2: 247-75.

— . (1981) Myths of Male Dominance: Collected Articles on Women Crossculturally. New York.

Leacock, Seth (1954) “The Ethnological Theory of Marcel Mauss," American Anthropologist 56: 58-73.

Lebessi, Angeliki (1976) "A Sanctuary of Hermes and Aphrodite on Crete," Expedition 18/3: 2-13.

Leduc, Claudine (1991) "Comment la donner en mariage? La mariée en pays grec (Ixe-IVe siècle av. J.-C.),” in Schmitt-Pantel 1990 : 259-316.

Lee, Mireille M. (2015) Body, Dress, and Identity in Ancient Greece. New York. Leeuw, Gerardus van der (1920/21) "Die do-ut-des Formel in der Opfertheorie," Archiv für Religionswissenschaft 20: 241-53.

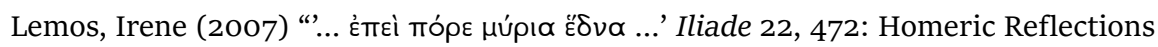
in Early Iron Age Elite Burials,” in Alram-Stern and Nightingale 2007: 275-83. 
Lenz, Carl Gotthold (1790) Geschichte der Weiber im heroischen Zeitalter. Hannover (rpt. 1976).

Lenz, Ilse and Ute Luig (eds.) (1990) Frauenmacht ohne Herrschaft:

Geschlechterverhältnisse in nichtpatriarchalen Gesellschaften. Berlin.

Lepenies, Wolf (ed.) (1981) Geschichte der Soziologie: Studien zur kognitiven, sozialen und historischen Identität einer Disziplin. 4 vols. Francfort.

Lesky, Albin (1971) Geschichte der griechischen Literatur. 3rd edn. Bern and Munich.

Letourneau, Charles (1897) L'évolution du commerce. Paris.

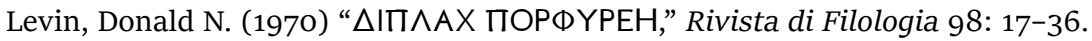

Lévi-Strauss, Claude (1967) The Elementary Structures of Kinship, tr. Harle Bell, v. Sturmer, Needham. Boston.

Lévy, Edmond (1985) "Lien personel et titre royal: anax et basileus dans l'Iliade," in his Le système palatial en Orient, en Grèce et à Rome: Actes du Colloque de Strasbourg, 19-22 juin 1985. Leiden: 291-314.

Lévy, Harry L. (1963) “The Odyssean Suitors and the Host-Guest Relationship," Transactions of the American Philosophical Society 94: 145-53.

Lévy-Bruhl, Henri (1948/49) “In memoriam Marcel Mauss," L’Année Sociologique, 3rd sér. 2: 1-4.

Lewis, Thomas S. W. (1981) “Homeric Epic and the Greek Vase," in Hyatt 1981: 81-102.

Lexicon Iconographicum Mythologiae Classicae 2/1. (1984) Ed. Fondation pour LIMC. Zürich.

Liddel, Peter (2007) Civic Obligation and Individual Liberty in Ancient Athens. Oxford.

Liddell, Henry George and Robert Scott (1968) A Greek-English Lexicon: With a Supplement 1968, rev. and augmented by Sir Henry Stuart James and Roderick McKenzie. Oxford (orig. 1940).

Lienau, Cay (1989) Griechenland: Geographie eines Staates der europäischen Südperipherie. Darmstadt.

Ligt, Luuk de and Pieter W. de Neeve (1988) "Ancient Periodic Markets: Festivals and Fairs," Athenaeum n.s. 66: 391-416.

Linden, David (1992) "Ehre und Ehe: Handlung und Gerechtigkeit in Ilias und Odyssee," Hermes 120: 110-14.

Linders, Tullia (1987) “Gods, Gifts, Society,” in Linders and Nordquist 1987: 115-22.

— . (1989/90) "The Melting Down of Discarded Metal Offerings in Greek Sanctuaries," in Bartoloni 1990: 281-85.

Linders, Tullia and Brita Alroth (eds.) (1992) Economics of Cult in the Ancient World: Proceedings of the Uppsala Symposium 1990. Uppsala.

Link, Stefan (1994) “Temenos und ager publicus bei Homer?” Historia 43/2: 241-45. Lissarrague, François (1987) Un flot d'images : Une esthétique du banquet grec. Paris.

— . (1991) "Femmes au figuré," in Schmitt-Pantel 1991: 159-251.

Liverani, Mario (1987) "The Collapse of the Near Eastern Regional System at the End of the Bronze Age: The Case of Syria," in Rowlands, Larsen and Kristiansen 1987: 66-73.

Llewellyn-Jones, Lloyd (2003) Aphrodite's Tortoise. The Veiled Woman of Ancient Greece, Swansea. 
Loew, Otto (1908) XAPI $\Sigma$. Marburg.

Lohmann, Hans (1985) "Landleben im klassischen Attika: Ergebnisse und Probleme einer archäologischen Landesaufnahme des Demos Atene,” in Jahrbuch der Ruhruniversität Bochum. Bochum: 71-96.

— . (1992) "Agriculture and Country Life in Classical Attica," in Agriculture in Ancient Greece. Proceedings of the Seventh International Symposium at the Swedish Institute at Athens, 16-17 May 1990, ed. B. Wells. Stockholm: 29-6o.

— . (1993) Atene: Forschungen zur Siedlungs- und Wirtschaftsstruktur des klassischen Attika. Cologne.

— . (1997) "Antike Hirten in Westkleinasien und der Megaris: Zur Archäologie der mediterranen Weidewirtschaft," in Volk und Verfassung im vorhellenistischen Griechenland: Beiträge auf dem Symposium zu Ehren von Karl-Wilhelm Welwei in Bochum, 1.-2. März 1996, ed. Walter Eder and Karl-Joachim Hölkeskamp. Stuttgart: $63-89$.

Lonsdale, H. Steven (1990) Creatures of Speech: Lion, Herding, and Hunting Similes in the Iliad. Stuttgart.

Loraux, Nicole (1981) L'invention d'Athènes: Histoire de l'oraison funèbre dans la cité classique. Paris.

_ . (1991) "Qu'est-ce qu'une déesse," in Pauline Schmitt-Pantel 1991: 31-62 = (1992) 'What is a goddess?' in History of Women in the West. I: From Ancient Goddesses to Christian Saints, ed. Georges Duby and Michelle Perrot. Cambridge, MA: 11-44.

Lordkipanidze, Otar (ed.) (1985) Das alte Kolchis und seine Beziehungen zur griechischen Welt vom 6. bis zum 4. Jahrhundert v. Chr. Konstanz.

Low, Poly (2007) Interstate Relations in Classical Greece: Morality and Power. Cambridge.

Loycke, Almut (ed.) (1992) Der Gast, der bleibt: Dimensionen von Georg Simmels Analyse des Fremdseins. Francfort and New York.

Luhmann, Niklas (1988) Die Wirtschaft der Gesellschaft. Francfort.

Luke, Joanna (1994) “The Krater, Kratos, and the Polis,” Greece \& Rome 41: 23-32.

Lullies, Reinhard and Wolfgang Schiering (ed.) (1988) Archäologenbildnisse. Mainz.

Lundgreen, Christoph (ed.) (2014) Staatlichkeit in Rom? Diskurse und Praxis (in) der römischen Republik. Stuttgart.

—_ . "Schlüsselmonopole oder Governance-Funktionen? Alternative Annäherungen an Staatlichkeit in der griechischen Archaik," in Meister 2020: 157-92.

Lupi, Elisabetta (2016) "Milesische Wolle in Sybaris: Neuentdeckung eines Fragments von Timaios (FGrH 566 F 50) und die Frage nach dem Textilhandel," in Droß-Krüpe and Nosch 2016: 169-91.

Lyons, Deborah (2003) "Dangerous Gifts. Ideologies of Marriage and Exchange in Ancient Greece," Classical Antiquity 22/1: 93-134.

- . (2012) Dangerous Gifts: Gender and Exchange in Ancient Greece. Austin.

Maaß, Michael (1978) Die geometrischen Dreifüße von Olympia. Olympische Forschungen X. Berlin.

MacCamp, J. II (1979) “A Draught in the Late Eighth Century B.C.," Hesperia 48: 397-411. 
Macfie, Lawrence (1985) "Adam Smith's Theorie der Ethischen Gefühle als Grundlage für seinen ,Wohlstand der Nationen' (1957)," in Ethik, Wirtschaft und Staat: Adam Smiths Politische Ökonomie heute, ed. Horst Claus Recktenwald. Darmstadt: 131-57.

Maehle, Ingvar B. (2018) "The Economy of Gratitude in Democratic Athens," The Journal of the American School of Classical Studies at Athens 87/1: 55-90.

Maffi, Alberto (1979) "Rilevanza delle 'regole di scambio' omeriche per la storia e la metodologia del diritto," in Symposion 1974: Vorträge zur griechischen und hellenistischen Rechtsgeschichte, ed. Arnaldo Biscardi. Cologne and Vienna: 33-62.

Maftei, Marta (1976) Antike Diskussionen über die Episode von Glaukos und Diomedes im VI. Buch der Ilias. Meisenheim am Glan.

Magou, E., S. Philippakis, and Cl. Rolley (1986) “Trépieds géometriques de bronze," Bulletin de correspondance hellénique 110: 121-36.

Maine, Henry S. (1894) Ancient Law. 15th edn. London.

Malinowski, Bronislaw ([1922] 1999) Argonauts of the Western Pacific: An Account of Native Enterprise and Adventure in the Archipelagoes of Melanesian New Guinea. Preface by Sir James G Frazer. London.

- - ([1926] 1952) Crime and Custom in Savage Society. New York.

— . (1944) A Scientific Theory of Culture. Chapel Hill.

Malkin, Irad (1989) "Delphoi and the Founding of Social Order in Archaic Greece," Métis 4/1: 129-53.

— . (1993) "Land Ownership, Territorial Possesion, Hero Cults and Scholarly Theory," in Nomodeiktes: Greek Studies in Honor of Martin Ostwald, ed. Ralph M. Rosen and Joseph Farrell. Ann Arbor: 225-34.

- . (2011) A Small Greek World: Networks in the Ancient Mediterranean. Oxford.

Mann, Christian (2007) Die Demagogen und das Volk. Zur politischen Kommunikation im Athen des 5. Jahrhunderts v. Chr. Berlin.

Mann, Michael (1986) The Sources of Social Power. I: A History of Power from the Beginning to A.D. 1760 . Cambridge.

Mannsprenger, Dietrich (1992) "Das Gold Troias und die griechische Goldprägung im Bereich der Meerengen," in Troia: Brücke zwischen Orient und Okzident, ed. Ingrid Gamer-Wallert. Tübingen: 124-51.

Mansfield, John (1985) The Robe of Athena and the Panathenaic 'Peplos'. Dissertation. Berkeley, CA.

Manville, Philip Brook (1980) "Solon's Law of Statis and ATIMIA in Archaic Athens," Transactions of the American Philological Association 10: 213-21.

- . (1990) The Origins of Citizenship in Ancient Athens. Princeton.

Maran, Joseph and Eftychia Stavrianopoulou (2007) "Пótvıos Avńp-Reflections on the Ideology of Mycenaean Kingship," in Alram-Stern and Nightingale 2007: 285-98.

Marek, Christian (1984) Die Proxenie. Francfort.

Marg, Walter (1970) Hesiod, Sämtliche Gedichte: Theogonie, Erga, Frauenkataloge. Zürich and Munich.

Marinatos, Spyridon N. (1967) Kleidung, Haar- und Barttracht. Archaeologia Homerica A. Göttingen. 
Marinatos, Nanno and Robin Hägg (eds.) (1993) Greek Sanctuaries: New Approaches. London and New York.

Marquardt, Penelope A. (1993) "Penelope as Weaver of Words," in Woman's Power, Man's Game: Essays on Classical Antiquity in Honor of Joy K. King, ed. Mary De Forest. Illinois: $149-58$.

Martin, Jochen (1990) "Aspekte antiker Staatlichkeit," in Staat und Staatlichkeit in der frühen Römischen Republik: Akten eines Symposiums 12.-15. Juli 1988, ed. Walter Eder. Stuttgart: 220-32.

— . (1994) "Der Verlust der Stadt," in Meier 1994: 95-114.

Martin, Richard P. (1993) “The Seven Sages as Performers of Wisdom," in Cultural Poetics in Archaic Greece: Cult, Performance, Politics, ed. Carol Dougherty and Leslie Kurke. Cambridge: 108-28.

Marwitz, Herbert (1961) “Das Bahrtuch," Antike und Abendland 10: 7-18.

Mattingly, David J. and Salmon, John (ed.) (2001): Economies Beyond Agriculture in the Classical World. London and New York.

Maucourant, Jérôme (2008) "Figures du néomodernisme: le 'marché' est-il un 'signifiant vide'?” in L'économie antique, une économie de marché?, ed. Yves Roman and Julie Dalaison. Paris: 17-47.

Mauss, Marcel (1921) "Une forme ancienne de contract chez les Thraces," Revue des Etudes Grecques 34: 388-97.

— _ (1923/24) "Essai sur le don: Forme et raison de l'échange dans les sociétés archaiques,” L’Année sociologique n.s. 1: 30-196 (rpt. 1950/1975).

- . (1990) The Gift: The Form and Reason for Exchange in Archaic Societies, trans. W. D Halls, with a foreword by Mary Douglas. London and New York = (1923/42) "Essai sur le don: Forme et raison de l'échange dans les sociétés archaïques." L’Année sociologique n.s. 1: 30-196.

- . (2011) The Gift: Forms and Functions of Exchange in Archaic Societies, trans. Ian Cunnison. Mansfield Centre, CT.

- . (2016) The Gift. Expanded edn. Selected, annotated, and translated by Jane I. Guyer. Foreword by Bill Maurer. Chicago.

Mauzé, Marie (1986) "Boas, les kwagul et le potlatch : Eléments pour une réévaluation," L'Homme 26/4: 21-63.

Maxwell-Stuart, P. G. (1981) Studies in Greek Colour Terminology. 2 vols. Mnemosyne Supplement 65. Leiden.

McCall, Grant (1982) "Association and Power in Reciprocity and Requital: More on Mauss and the Maori," Oceania 52/4: 303-19.

McCartney, Eugene S. (1953) "Undoing by Night Work Done by Day: A Folklore Motif," in Mylonas and Raymond 1953: 1249-53.

McCormack, Geoffrey (1976) "Reciprocity," Man n.s. 11: 89-103.

— . (1982) "Mauss and the 'Spirit' of the Gift," Oceania 52/4: 286-93.

McInerney, Jeremy (2006) "On the Border: Sacred Land and the Margins of the Community," in City, Countryside, and the Spatial Organization of Value in Classical Antiquity, ed. Ralph M. Rosen and Ineke Sluiter. Leiden and Boston: 33-59.

- (2010) The Cattle of the Sun: Cows and Culture in the World of the Ancient Greeks. Princeton, NJ. 
McLachlan, Bonnie (1993) The Age of Grace: Charis in Early Greek Poetry. Princeton.

McNeil, Linda (2005) "Bridal Cloths, Cover-Ups, and kharis: The 'Carpet Scene' in Aeschylus' Agamemnon,” Greece \& Rome 52/1: 1-17.

Medick, Hans (1973) Naturzustand und Naturgeschichte der bürgerlichen Gesellschaft: Die Ursprünge der bürgerlichen Sozialtheorie als Geschichtsphilosophie und Sozialwissenschaften bei Samuel Pufendorf, John Locke und Adam Smith. Göttingen.

— . (1984) "'Missionare im Ruderboot'? Ethnologische Erkenntnisweise als Herausforderung an die Sozialgeschichte," Geschichte und Gesellschaft 10: 295-319.

— . (1996) Weben und Überleben in Laichingen 1650-1900: Lokalgeschichte als allgemeine Geschichte. Göttingen.

Meier, Christian (1985) Politik und Anmut. Berlin.

—_ . (1989) Die Welt der Geschichte und die Provinz des Historikers: Drei Überlegungen. Berlin.

_ . (ed.) (1994) Die okzidentale Stadt nach Max Weber: Zum Problem der Zugehörigkeit in Antike und Mittelalter. Historische Zeitschrift Beiheft 17. Munich 1994 .

Meister, Jan (forthcoming) "Adel” und gesellschaftliche Differenzierung im archaischen und frühklassischen Griechenland. Stuttgart.

Meister, Jan and Gunnar Seelentag (eds.) (2020) Konkurrenz und Institutionalisierung in der griechischen Archaik. Stuttgart.

Mele, Alfonso (1979) Il commercio greco arcaico. Naples.

Melena, José L. (1975) Studies on Some Mycenaean Inscriptions from Knossos Dealing with Textiles. Minos Supplement 5. Salamanca.

Merkelbach, Reinhold (1952) "Die pisistratische Redaktion der homerischen Gedichte," Rheinisches Museum N. F. 95: 23-47.

Meyer, Eduard (1910) Geschichte des Altertums. I: Elemente der Anthropologie. 3rd edn. Stuttgart and Berlin.

Meyer, Richard (1898) "Zur Geschichte des Schenkens," Zeitschrift für Kulturgeschichte 5: 18-29.

Meyerfeld, Franz Wilhelm Ludwig von (1835) Die Lehre von den Schenkungen nach Römischem Recht I. Marburg.

Meyers, Gretchen E. (2013) "Women and the Production of Ceremonial Textiles: A Reevaluation of Ceramic Textile Tools in Etrusco-Italic Sanctuaries," American Journal of Archaeology 117/2: 247-74.

Meyer-Zwiffelhoffer, Eckhard (1995) Im Zeichen des Phallus: Die Ordnung des Geschlechtslebens im antiken Rom. Francfort and New York.

Michel, Cécile and Marie-Louise Nosch (eds.) (2010) Textile Terminologies in the Ancient Near East and Mediterranean from the Third to the First Millenia BC, Oxford and Oakville.

Michel, Jacques (1962) Gratuité en droit Romain : Etudes d'histoire et d'ethnologie juridique. Bruxelles.

Michell, Humfrey (1963) The Economics of Ancient Greece. 2nd edn. Cambridge.

Militello, Pietro (2007) “Textile Industry and Minoan Palaces,” in Gillis and Nosch 2007: 36-45. 
Millett, Paul (1984) "Hesiod and his World," Proceedings of the Cambridge Philological Society 30: 84-115.

- (1991) Lending and Borrowing in Classical Athens. Cambridge.

Mills, Harriane (1984) “Greek Clothing Regulations: Sacred or Profane?” Zeitschrift für Papyrologie und Epigraphik 55: 255-65.

Missfelder, Jan-Friedrich (2014) “Ganzkörpergeschichte: Sinne, Sinn und Sinnlichkeit für eine Historische Anthropologie,” Internationales Archiv für Sozialgeschichte der deutschen Literatur 39/2: 457-75.

Mitchell, Lynette G. (1997) Greeks Bearing Gifts: The Public Use of Private Relationship in the Greek World 435-323 B.C. Cambridge.

Möller, Astrid (2000) Naukratis: Trade in Archaic Greece. Cambridge.

Mommsen, Theodor (1864) "Römisches Gastrecht," in his Römische Forschungen I. Berlin (rpt. 1962).

Mondi, Robert (1980) " $\Sigma$ KHПTOYXOI BA $\Sigma I \wedge E I \Sigma$ : An Argument for Divine Kingship," Arethusa 13/2: 203-16.

Monsacré, Hélène (1984) Les larmes d'Achille : Le héros, la femme et la souffrance dans la poésie d'Homère. Paris.

— . (1984) "Weeping Heroes in the Iliad," History and Anthropology 1: 57-75.

Moonwoman, Birch (1994) “Color Categorization in Early Greek," Early Journal of Indo-European Studies 22/1-2: 37-65.

Moravia, Sergio (1989) Beobachtende Vernunft. Philosophie und Vernunft in der Aufklärung. Trans. Elisabeth Piras. Francfort (= La scienza dell' uomo nel settecento. Bari 1970).

Morgan, Catherine (1988) "Corinth, the Corinthian Gulf and Western Greece During the Eighth Century B.C.," Annual of the British School at Athens 88: 313-38.

- (1990) Athletes and Oracles: The Transformation of Olympia und Delphi in the Eighth Century B.C. Cambridge.

— . (1993) “The Origins of Pan-Hellenism," in Marinatos and Hägg 1993: 18-44.

—_ . (2003) Early Greek States Beyond the Polis. London and New York.

Morgan, Catherine and Todd Whitelaw (1991) "Pots and Politics: Ceramic Evidence for the Rise of the Argive State," American Journal of Archaeology 95: 79-108.

Morgan, Kathleen (1991) "Odyssey 23, 218-24: Adultery, Shame, and Marriage," American Journal of Philology 112: 1-3.

Morley, Neville (2007) Trade in Classical Antiquity. Cambridge.

Morris, Ian (1986a) "Gift and Commodity in Archaic Greece," Man n.s. 21: 1-17.

__ (1986b) "Use and Abuse of Homer," Classical Antiquity 5: 81-129.

— . (1987) Burial and Ancient Society: The Rise of the Greek City State. Cambridge.

_ . (1988) "Tomb Cult and the 'Greek Renaissance': The Past and the Present in the 8th Century B.C.," Antiquity 62: 750-61.

— . (1989) "Attitudes Toward Death in Archaic Greece," Classical Antiquity 8/2: 268-320.

— . (1991) "The Early Polis as City and State," in Rich and Wallace-Hadrill 1991: 25-57. 
_ - (1996) Death-Ritual and Social Structure in Classical Antiquity. Cambridge.

Morris, Sarah (2003) "Imaginary Kings: Alternatives to Monarchy in Early Greece," in Popular Tyranny: Sovereignty and Its Discontents in Ancient Greece, ed.

Kathryn A. Morgan. Austin: 1-24.

Morris, Sarah P. (1992) Daidalos and the Origins of Greek Art. Princeton.

Mosley, D. J. (1971) “Greeks, Barbarians, Language and Contact,” Ancient Society 2: $1-6$.

Moszkowski, Max (1911) Vom Wirtschaftsleben der primitiven Völker. Jena.

Mueller, Melissa (2001) "The Language of Reciprocity in Euripides 'Medea,", American Journal of Philology 122/4: 471-504.

— - (2007) "Penelope and the Poetics of Remembering," Arethusa 40: 337-62.

— . (2010) "Helen's Hands: Weaving for Kleos in the Odyssey," Helios 37: 1-21.

Muhly, James D. (1970) "Homer and the Phoinicians," Berytus 19: 19-64.

— . (1985) "Sources of Tin and the Beginnings of Bronze Metallurgy," American Journal of Archaeology 89: 272-91.

Müller, Dietram (1974) Handwerk und Sprache: Die sprachlichen Bilder aus dem Bereich des Handwerks in der griechischen Literatur bis $400 \mathrm{v}$. Chr. Meisenheim am Glan.

Müller, Ernst W. (1981) Der Begriff „Verwandtschaft“ in der modernen Ethnosoziologie. Mainzer Ethnologica 2. Berlin.

Müller, Rudolf Wolfgang (21981) Geld und Geist. Francfort and New York.

Münch, Richard (1984) Die Struktur der Moderne: Grundmuster und differenzielle Gestaltung des institutionellen Aufbaus der modernen Gesellschaften. Francfort.

Münkler, Marina, Antje Sablotny, and Matthias Standke (eds.) (2015)

Freundschaftszeichen: Gesten, Gaben und Symbole von Freundschaft im Mittelalter. Heidelberg.

Murnaghan, Sheila (1987) "Penelope's Agnoia: Knowledge and Gender in the Odyssey," in Rescuing Creusa: New Methodological Approaches to Women in Antiquity, ed. Marylin Skinner. Lubbock, Tex.: 103-15.

— . (1992) "Maternity and Mortality in Homeric Poetry," Classical Antiquity 11/2: 242-64.

Murra, John V. (1962) "Cloth and Its Function in the Inca State," American Anthropologist 65: 710-25.

Murray, A. T. and G. E. Dimock (1998) Homer, Odyssey. With an English translation. Cambridge and London.

Murray, A. T. and W. F. Wyatt (1999) Homer, Iliad. With an English translation. Cambridge and London.

Murray, Caroline and Peter Warren (1976) "Po-ni-ki-jo Among the Dye Plants of Minoan Crete," Kadmos 15: 40-6o.

Murray, Oswyn (1980) Early Greece. Brighton (2nd edn., London 1993).

— . (ed.) (1990) Sympotica: A Symposium on the Symposium. Oxford.

— . (1991) "The Social Function of Art in Early Greece," in New Perspectives in Early Greek Art, ed. Diana Buitron-Oliver. Hanover and London: 23-30. 
Murray, Oswyn and Simon Price (eds.) (1990) The Greek City from Homer to Alexander. Oxford.

Mylonas, George E. and Doris Raymond (eds.) (1953) Studies Presented to David Moore Robinson on his Seventieth Birthday II. St. Louis, MO.

Nafissi, Mohamed (2005) Ancient Athens and Modern Ideology. Value, Theory and Evidence in Historical Sciences: Max Weber, Karl Polanyi \& Moses I. Finley. London.

Nagy, Gregory (2002) Plato's Rhapsody and Homer's Music. Cambridge, MA and London.

- . (2003) Homeric Responses. Austin.

Nagy, Joseph F. (1981) “The Deceptive Gift in Greek Mythology,” Arethusa 14: 191-204.

Nash, Manning (1968) "Economic Anthropology," International Encyclopedia of the Social Sciences 4: 359-65.

Neils, Jenifer (ed.) (1992) Goddess and Polis: The Panathenaic Festival in Ancient Athens. Princeton.

Nestle, Wilhelm (1942) “Odysseus: Interpretationen I," Hermes 77: 46-139.

Neumann, Manu (1950) Homerische Wörter. Basel.

Neumer-Pfau, Wiltrud (1987) "Töten, Trauern, Sterben: Weiblichkeitsbilder in der antiken griechischen Kultur," in Weiblichkeit und Tod in der Literatur, ed. Renate Berger and Inge Stephan. Cologne and Vienna: 12-34.

Newton, Rick M. (2015) “Eumaeus Rustles up Dinner," Classical Journal 110/3: 257-78.

Niemeyer, Hans Georg (ed.) (1982) Phönizier im Westen. Mainz.

— . (1990) "Die phönizischen Niederlassungen im Mittelmeerraum," in his Die Phönizier im Zeitalter Homers, ed. Ulrich Gehrig. Mainz: 45-64.

_ . (1996) Semata: Über den Sinn griechischer Standbilder. Hamburg.

Niethammer, Lutz in collaboration with Dirk van Laak (1989) Posthistoire: Ist die Geschichte zu Ende? Reinbek bei Hamburg.

Nilsson, Martin P. (1927) "Das homerische Königtum," in Sitzungsberichte der preußischen Akademie der Wissenschaften, Philosophisch-Historische Klasse 7: 25-40.

- . (1967) Geschichte der griechischen Religion. 3rd edn. 2 vols. Munich.

Nippel, Wilfried (1982) "Die Heimkehr der Argonauten aus der Südsee: Ökonomische Anthropologie und die Theorie der griechischen Gesellschaft in klassischer Zeit," Chiron 12: 1-39.

_ (1988) "Sozialanthropologie und Alte Geschichte," in Historische Methode, ed. Christian Meier and Jörn Rüsen. Munich: 300-18.

_ . (1990a) Griechen, Barbaren und ,Wilde’: Alte Geschichte und Sozialanthropologie. Francfort.

_ . (1990b) "Prolegomena zu Eduard Meyers Anthropologie," in Leben und Leistung eines Universalhistorikers, ed. William M. Calder III and Alexander Demandt. Leiden: 311-28.

_ _ (1991) "Finley und Weber: some Comments and Theses," Opus VI-VII: 43-50. 
_ _ (1993) Max Weber und die Althistorie seiner Zeit: Antrittsvorlesung 3o. Juni 1992. Berlin.

Noonan, John T. Jr. (1984) Bribes. New York.

Nosch, Marie-Louise (2000) "Schafherden unter dem Namenspatronat von Potnia und Hermes in Knossos," in Österreichische Forschungen zur ägäischen Bronzezeit 1998: Akten der Tagung am Institut für Klassische Archäologie der Universität Vienna 2.-3. Mai 1998, ed. Fritz Blakolmer. Wiener Forschungen zur Archäologie 3. Vienna: 211-15.

_ . (2003) "The Women at Work in the Linear B tablets," in Gender, Cult, and Culture in the Ancient World from Mycenae to Byzantium, eds. Lena LarssonLovèn and Agneta Strömberg. Sävedalen: 12-26.

— . (2006) "More Thoughts on the Mycenaean ta-ra-si-ja System," in Fiscality in Mycenaean and Near Eastern Archives, ed. Massimo Perna. Naples: 161-82.

— . (2007) The Knossos Od Series: An Epigraphical Study. Vienna.

Nosch, Marie-Louise et al. (2008) "New Research on Bronze Age Textile Production," Bulletin of the Institute of Classical Studies 51: 171-74.

Nosch, Marie-Louise, Henriette Koefoed and Eva Andersson Strand (eds.) (2013) Textile Production and Consumption in the Ancient Near East: Archaeology, Epigraphy, Iconography. Oxford.

Nybakken, Oscar E. (1945/46) “The Moral Basis of Hospitium Privatum," Classical Journal 41: 248-53.

Oakley, John H. and Rebecca Sinos (1993) The Wedding in Ancient Greece. Madison.

Oates, Joan (ed.) (1993) Ancient Trade: New Perspectives. London.

Oexle, Otto Gerhard (1984) "Memoria und Memorialbild," in Memoria: Der geschichtliche Zeugniswert des liturgischen Gedenkens im Mittelalter, ed. Karl Schmid and Joachim Wollasch. Munich: 384-440.

_ . (1988) “Otto Gierkes 'Rechtsgeschichte der Deutschen Genossenschaft': Ein Versuch wissenschaftsgeschichtlicher Rekapitulation,” in Hammerstein 1988: 193-217.

— . (1994) "Kulturwissenschaftliche Reflexionen über soziale Gruppen in der mittelalterlichen Gesellschaft: Tönnies, Simmel, Durkheim und Max Weber," in Meier 1994: 115-59.

— - (ed.) (1995) Memoria als Kultur. Göttingen.

Ogris, W. (1990) "Schenkung," in Handwörterbuch zur Deutschen Rechtsgeschichte IV, ed. Adalbert Erler and Ekkehard Kaufmann in collaboration with Ruth SchmidtWiegand. Berlin: 1382-84.

Olson, S. D. (2010) Athenaeus, the Learned Banqueters. Cambridge and London. Onians, Richard B. (1989) The Origins of European Thought about the Body, the Mind, the Soul, the World, Time and Fate. 3rd edn. Cambridge (1st edn. 1951).

Osborne, Robin (1985a) "The Erection and Mutilation of the hermai," Proceedings of the Cambridge Philological Society n.s. 31: 47-73.

_ (1985b) Demos: The Discovery of Classical Attica. Cambridge.

- . (1987) Classical Landscape with Figures: The Ancient Greek City and Its Countryside. London. 
. (1988) "Social and Economic Implications of Leasing of Land and Property in Classical and Hellenistic Greece," Chiron 18: 279-323.

_ - (1991) "Pride and Prejudice, Sense and Subsistence: Exchange and Society in the Greek City," in Rich and Wallace-Hadrill 1991: 7-17.

— - (1994) "Archaeology, the Salaminioi, and the Politics of Sacred Space in Archaic Attica," in Alcock and Osborne 1994: 143-6o.

_ . (1998) "Early Greek Colonization? The Nature of Greek Settlement in the West," in Fisher and van Wees 1998: 251-269.

—_. (2004) "Homer's Society," in Fowler 2004: 206-19.

O’Sullivan, James N. (1990) “Nature and Culture in Odyssey 9?" Symbolae Osloenses 65: 7-17.

Page, Denys L. (1955) The Homeric Odyssey. Oxford.

Pallas, Peter S. (1776) Sammlungen historischer Nachrichten über die Mongolischen Völkerschaften. St. Petersburg (rpt. 1980).

Panagl, Otto (1970) "Apollons Pythonkampf und die delphische Orakelgründung im Spiegel antiker Mythenkritik," Kairos 12: 31-41.

Pantelia, Maria C. (1993) "Spinning and Weaving: Ideas of Domestic Order in Homer," American Journal of Philology 114: 493-501.

Papadopoulos, John K. and Gary Urton (eds.) (2012) The Construction of Value in the Ancient World. Los Angeles.

Papadopoulos, Thanasis J. (1987) “Tombs and Burial Customs in Late Age Epirus," in Laffineur 1987: 137-42.

Papadopoulou-Belmehdi, Ioanna (1994) Le chant de Pénélope: Poétique du tissage féminin dans l'Odyssée. Paris.

Papalexandrou, Nassos (2005) The Visual Poetics of Power: Warriors, Youth, and Tripods in Early Greece. Lanham.

Pappenheim, Max (1933) "Über die Rechtsnatur der altgermanischen Schenkung," Zeitschrift der Savigny-Stiftung für Rechtsgeschichte, Germanistische Abteilung 53: 35-88.

Parke, Herbert W. and Donald E. W. Wormell (1956) The Delphic Oracle. I: The History. Oxford.

Parker, Victor (1996) Untersuchungen zum Lelantischen Krieg und verwandten Problemen der frühgriechischen Geschichte. Stuttgart.

Patzek, Barbara (1990) "Mündliche Dichtung als historisches Zeugnis: Die 'homerische Frage' in heutiger Sicht," Historische Zeitschrift 250: 529-48.

_ _ (1992) Homer und Mykene: Mündliche Dichtung und Geschichtsschreibung. Munich.

Paulinyi, Akos (1990) "Die Entwicklung der Stofformungstechnik als Periodisierungskriterium der Technikgeschichte," Technikgeschichte 57: 299-314.

Payen, Pascal and Évelyne Scheid-Tissinier (eds.) (2012) Anthropologie de l'Antiquité: Anciens objects, nouvelles approaches. Turnhout.

Pedrick, Victoria (1988) “The Hospitality of Noble Women in the Odyssey," Helios n.s. 15: 85-101.

Peifer, Egon (1987) Eidola und andere mit dem Sterben verbundene Flügelwesen in der attischen Vasenmalerei in spätarchaischer und klassischer Zeit. Bern. 
Pekridou-Gorecki, Anastasia (1989) Mode im antiken Griechenland: Textile Fertigung und Kleidung. Munich.

Pernice, Herbert (1882) Zur Lehre von der Insinuation der Schenkungen. Diss. Greifswald.

Perysinakis, Ioannis (1986) "Hesiod's Treatment of Wealth," Métis 1/1: 97-119.

Petropoulou, Angeliki (1985) Beiträge zur Wirtschafts- und Gesellschaftsgeschichte Kretas in hellenistischer Zeit. Francfort.

Petruso, Karl M. (1986) "Wool-Evaluation at Knossos and Nuzi," Kadmos 25: 26-37.

Pettegrew, David K. (2016) The Isthmus of Corinth: Crossroads of the Mediterranean World. Ann Arbor.

Peukert, Detlev J. K. (1989) Max Webers Diagnose der Moderne. Göttingen.

Pflüger, H. H. (1942) “Die Gerichtsszene auf dem Schilde des Achilleus," Hermes 77: 140-48.

Philippson, Alfred (1951) Die griechischen Landschaften: Eine Landeskunde 1/2, edn. in collaboration with Herbert Lehmann, with an appendix by Ernst Kirsten: "Beiträge zur historischen Landeskunde des östlichen Mittelgriechenlands und Euboeas," Francfort.

Phillipson, Coleman (1911) International Law and Customs of Ancient Greece and Rome $I$ and II. London.

Pielhoff, Stephen (2007) "Stifter und Anstifter: Vermittler zwischen ,Zivilgesellschaft' Kommune und Staat im Kaiserreich," Geschichte und Gesellschaft 33/1: 20-45.

Pindar 1992 (Greek and German) Siegeslieder, ed. and trans. with an introduction by Dieter Bremer. Munich.

Pirenne-Delforge, Vinciane (1996) "Les Charites à Athènes et dans l'île de Cos," Kernos 9: 195-214.

Pitt-Rivers, Julian A. (1977) The Fate of Shechem or the Politics of Sex: Essays in the Anthropology of the Mediterranean. Cambridge.

Plumpe, Werner (2007) “Die Geburt des 'Homo oeconomicus': Historische Überlegungen zur Entstehung und Bedeutung des Handlungsmodells der modernen Wirtschaft," in Reinhard and Stagl 2007: 319-52.

— . (2009) "Ökonomisches Denken und wirtschaftliche Entwicklung: Zum Zusammenhang von Wirtschaftsgeschichte und historischer Semantik der Ökonomie," Jahrbuch für Wirtschaftsgeschichte/Economic History Yearbook 1: 27-52.

Plutarchus 1959. Lives. I: Theseus and Romulus; Lycurgus and Numa; Solon and Publicola, trans. Bernadotte Perrin. London.

Podlecki, A. J. (1961) "Guest-Gifts and Nobodies in the Odyssey 9," Phoenix 15: 125-33.

Pöhlmann, Egbert (1990) "Zur Überlieferung griechischer Literatur vom 8. zum 4. Jh.," in Kullmann and Reichel 1990: 11-30.

Polanyi, Karl (1935) "The Essence of Fascism," Christianity and the Social Revolution, eds. John D. Lewis, Karl Polanyi and Donald Kitchin. London 1935.

— . ([1944] 2001) The Great Transformation: The Political and Economic Origins of Our Time. Foreword by Joseph E. Stiglitz. With a new introduction by Fred Block. Boston. 
. ([1947] 1968), “Our Obsolete Market Mentality,” in Polanyi and Dalton 1968: $59-77$.

— . (1957a) "The Economy as Instituted Process," in Polanyi et al. 1957: 243-70 = Polanyi and Dalton 1968: 139-74.

— . (1957b) "Aristotle Discovers the Economy," in Polanyi et al. 1957: 64-94.

— _ ([1963] 1968), "Ports of Trade in Early Societies," in Polanyi and Dalton 1968: 238-6o.

- . (1968) Primitive, Archaic and Modern Economies: Essays of Karl Polanyi, ed. George Dalton. Garden City, NY. 1968.

Polanyi, Karl, Conrad M. Arensberg and Harry W. Pearson (eds.) (1957) Trade and Market in the Early Empires: Economies in History and Theory. Glencoe/Illinois.

Polanyi-Levitt, Kari (ed.) (1990) The Life and Work of Karl Polanyi: A Celebration. Montréal and New York.

Polignac, François de (1984) La naissance de la cité grecque: Cultes, espace et sociétés VIIIe-VIIe siècles avant J.-C. Paris = de Polignac 1995.

_ . (1994) "Mediation, Competition, and Sovereignty: The Evolution of Rural Sanctuaries in Geometric Greece," in Alcock and Osborne 1994: 3-18.

- (1995) Cults, Territory, and the Origins of the Greek City-State, trans. Janet Lloyd. Chicago.

—_ (1996) "Offrandes, mémoire et compétition ritualisée dans les sanctuaires grecs à l'époque géometrique," in Religion and Power in the Ancient Greek World, ed. Pontus Hellström. Boreas 24. Uppsala: 59-66.

Post, Albert Hermann (1895) Grundriss der ethnologischen Jurisprudenz II. Oldenburg and Leipzig.

Pötscher, Walter (1960) “Moira, Themis und time im homerischen Denken,” Wiener Studien 73: 5-39.

Prellwitz, Walther (1905) Etymologisches Wörterbuch der griechischen Sprache. 2nd edn. Göttingen.

Prendergast, Guy L. (1962) A Complete Concordance to the Iliad of Homer. Rev. and enlarged by Benedetto Marzullo. Hildesheim.

Price, Simon (1986) "Delphi and Divination," in Easterling and Muir 1986: 128-54.

Pritchett, William K. (1985) Studies in Greek Topography V. Berkeley.

Prodi, Paolo (1997) Das Sakrament der Herrschaft: Der politische Eid in der Verfassungsgeschichte des Okzidents. Schriften des Italienisch-Deutschen Historischen Instituts in Trient 11. Berlin.

Puhvel, Jan (1958) "Helladic Kingship and the Gods," in Minoica: Festschrift für Johannes Sundvall, ed. Ernst Grumach. Berlin: 327-33.

Pullen, Daniel J. (2013) “Crafts, Specialists, and Markets in Mycenaean Greece: Exchanging the Myenaean Economy," American Journal of Archaeology 117/3: 437-45.

Purcell, Nicholas (1990) "Mobility and the Polis," in Murray and Price 1990: 29-58.

Purves, Alex (ed.) (2018) Touch and the Ancient Senses. London and New York.

Quijano, Anibal (1993) “Modernity, Identity and Utopia in Latin America," Boundary 2. Vol 20/3: 140-55. 
Qviller, Bjørn (1981) “The Dynamics of the Homeric Society," Symbolae Osloenses 56: 109-55.

Raaflaub, Kurt (1991) "Homer und die Geschichte des 8. Jhs. v. Chr." in Latacz 1991: 205-56.

— . (ed.) (1993) Die Anfänge des politischen Denkens in der Antike: Die nahöstlichen Kulturen und die Griechen. Munich.

— . (1997) "Politics and Interstate Relations in the World of Early Greek Poleis: Homer and Beyond," Antichthon 31: 1-27.

_ . (1998) "A Historian's Headache: How to Read 'Homeric Society'?" in Fisher and van Wees 1998: 169-93.

Raaflaub, Kurt and Hans van Wees (eds.) (2009) A Companion to Archaic Greece. Malden, MA and Oxford.

Racine, Luc (1987) “Les formes élémentaires de la reciprocité,” L’Homme 99: 97-118.

Rackham, H. (1952) Aristotle, The Athenean Constitution. With an English translation. London and Cambridge, MA.

- . ([1934] 1990) Aristotle, The Nicomachean Ethics. With an English translation. London and Cambridge, MA.

Rackham, Oliver (1990) "Ancient Landscapes," in Murray and Price 1990: 85-111.

Ready, Jonathan L. (2011) Character, Narrator, and Simile in the Iliad. Cambridge.

Rebenich, Stefan (2012) "Monarchie," Reallexikon für Antike und Christentum 24: 1112-1196.

Recktenwald, Horst C. (1985) Ethik, Wirtschaft und Staat: Adam Smiths Politische Ökonomie heute. Darmstadt.

Reden, Sitta von (1995) Exchange in Ancient Greece. London.

Redfield, James E. (1983) “The Economic Man,” in Approaches to Homer, ed. Cynthia W. Shelmerdine. Austin: 218-47.

Reece, Steve (1993) The Stranger's Welcome: Oral Theory and the Aesthetics of the Homeric Hospitality Scenes. Ann Arbor.

Reed, C. M. (1984) "Maritime Traders in the Archaic Greek World," Ancient World 10: 31-44.

- (2003) Maritime Traders in the Ancient Greek World. Cambridge.

Reese, David S. (1987) "Palaikastro Shells and Bronze Age Purple-Dye Production in the Mediterranean Basin," The Annual of the British School at Athens 82: 201-6.

Rehak, Paul (ed.) (1995) The Role of the Ruler in the Prehistoric Aegean, Aegaeum II, Lüttich.

Rehberg, Karl-Siegbert (1986) "Kultur versus Gesellschaft: Anmerkungen zu einer Streitfrage in der deutschen Soziologie," in Kultur und Gesellschaft: René König, dem Begründer der Sonderhefte, zum 8o. Geburtstag gewidmet, ed. Friedhelm Neidhardt, Mario Rainer Lepsius, and Johannes Weiss. Opladen: 92-117.

Rehbinder, Manfred (ed.) (2012) Vom homo oeconomicus zum homo reciprocans? Auf der Suche nach einem neuen Menschenbild als Erklärungsmuster für Recht, Wirtschaft und Kultur. Bern.

Reiner, Eugen (1938) Die rituelle Totenklage der Griechen. Tübinger Beiträge zur Altertumswissenschaft 30. Stuttgart and Berlin. 
Reinhard, Wolfgang (1999) Geschichte der Staatsgewalt. Eine vergleichende Verfassungsgeschichte Europas von den Anfängen bis zur Gegenwart. Munich.

Reinhard, Wolfgang and Justin Stagl (eds.) (2007) Menschen und Märkte: Studien zur historischen Wirtschaftsanthropologie. Vienna.

Reinhold, Meyer (1970) History of Purple as a Status Symbol in Antiquity. Collection Latomus 116. Brüssel.

Reisch, R. (1905) "Dreifuß," in Realencyclopädie der classischen Altertumswissenschaften 5/2: 1669-96.

Renfrew, Colin (1975) "Trade as Action at a Distance: Questions of Integration and Communication," in Ancient Civilization and Trade, ed. Jeremy A. Sabloff and C.C. Lamberg-Karlovsky. Albuquerque: 3-59.

_ . (1986) "Introduction: Peer-Polity Interaction and Socio-Political Change," Renfrew and Cherry 1986: 1-18.

Renfrew, Colin and Stephen Shennan (eds.) (1982) Ranking, Resource and Exchange: Aspects of the Archaeology of Early European Society. Cambridge.

Renfrew, Colin and John F. Cherry (eds.) (1986) Peer Polity Interaction and SocioPolitical Change. Cambridge.

Rengakos, Antonios and Bernhard Zimmermann (eds.) (2011) Homer Handbuch: Leben-Werk-Wirkung. Stuttgart and Weimar: 257-78.

Reuthner, Rosa (2006) Wer webte Athenes Gewänder? Die Arbeit von Frauen im antiken Griechenland. Francfort and New York.

Rhodes, Peter J. (1984) Aristotle, the Athenean Constitution. Translated with introduction and notes. Harmondsworth.

Rich, John and Andrew Wallace-Hadrill (eds.) (1991) The City and the Country in the Ancient World. London.

Rich, John and Graham Shipley (eds.) (1993) War and Society in the Greek World. London and New York.

Richter, Gisela M. A. (1966) The Furniture of the Greeks, Etruscans, and Romans. London.

Richter, Will (1968) Die Landwirtschaft im Homerischen Zeitalter. Archaeologia Homerica II/H. Göttingen.

Ridgway, David (1990) “The First Western Greeks and Their Neighbours, 1935-1985," in Greek Colonists and Native Populations: Proceedings of the First Australian Congress of Classical Archaeology held in honour of Emeritus Professor A. D. Trendall, ed. Jean-Paul Descoeudres. Canberra: 61-72.

_ . (1992) The First Western Greeks. Cambridge.

_ . (2000) "The First Western Greeks Revisited," in his Ancient Italy in Its Mediterranean Setting: Studies in Honour of Ellen MacNamara. London: 179-91.

_ . (2006) "Aspects of the Italian Connection," Deger-Jalkotzy and Lemos 2006: 299-313.

Riedinger, Jean-Claude (1976) "Remarques sur la TIMH chez Homère," Revue des études grecques 89: 244-64.

_. (1980) "Les deux đíós chez Homère," Revue de Philologie 54: 62-79.

Riegl, Alois (1893) Stilfragen: Grundlagen zu einer Geschichte der Ornamentik. Berlin. 
Rieu, E. V. (ed.) (2003) Homerus, The Iliad, trans. E. V. Rieu. With an introduction and notes by Peter Jones. London.

Rieu, E. V. (ed.) (2003) Homerus, The Odyssey, trans. E. V. Rieu, rev. trans. D. C. H. Rieu with an introduction by Peter Jones. London.

Rihll, Tracey (1993) "War, Slavery, and Settlement in Early Greece," in Rich and Shipley 1993: 77-107.

Rihll, Tracey H. and Andrew G. Wilson (1991) "Modelling Settlement Structures in Ancient Greece: New Approaches to the Polis," in Rich and Wallace-Hadrill 1991: 59-95.

Robkin, Ann L. H. (1979) "The Agricultural Year, the Commodity SA and the Linen Industry of Mycenaean Pylos," American Journal of Archaeology 85: 469-74.

Roebuk, Carl (ed.) (1969) The Muses at Work: Art, Crafts and Professions in Ancient Greece and Rome. Cambridge and London.

Rohweder, Christine (1998) Macht und Gedeihen: Eine politische Interpretation der Hiketiden des Aischylos. Francfort.

Rolley, Claude (1977) Les trépieds à cuve clouée. Fouilles de Delphes V/3. Paris.

Römisches Recht (1987). On basis of the work of Paul Jörs, Wolfgang Kunkel, and Leopold Wenger. 4 th edn. rev. Heinrich Hionsell, Theo Meyer-Maly, and Walter Selb. Berlin.

Röpke, Jochen (1969) "Nationalökonomie und Ethnologie: Die ökonomische Theorie primitiver Gesellschaften in kritischer Betrachtung," Sociologus N.F. 19: 101-34.

Rose, A. (1985) “Clothing Imagery in Apollonius' Argonautica," Quaderni Urbinati di Cultura Classica 50: 29-44.

Rose, Peter (2012) Class in Archaic Greece. Cambridge.

Rosen, Ralph M. (1989) "Poetry and Sailing in Hesiod's Works and Days," Classical Antiquity 8: 99-113.

Rösler, Wolfgang (1980) "Die Entdeckung der Fiktionalität in der Antike," Poetica 12: 293-319.

— . (1991) "Die Sieben Weisen," in Weisheit: Archäologie der literarischen Kommunikation III, ed. Aleida Assmann. Munich: 357-65.

Rougement, Françoise (2004) "The administration of Mycenaean sheep-rearing (flocks, shepherds, "collectors")," in Santillo-Frizell 2004: 24-34.

_ . (2007) "Flax and Linen Textiles in the Mycenaean Palatial Economy," in Gillis and Nosch 2007: 46-63.

- . (2009) Contrôle économique et administration à l'époque des palais mycéniens (fin du IIe milléniaire av. J.-C.). Bibliothèque des Écoles françaises d'Athènes et de Rome 332. Athènes.

Rouillard, Pierre (ed.) (2005) Autour de Polanyi. Vocabulaires, théories et modalités des échanges. Nanterre, 12-14 juin 2004. Colloques de la Maison René-Ginouvès. Paris.

Rowlands, Michael (1987) “Centre and Periphery: A Review of a Concept," in Rowlands, Larsen, and Kristiansen 1987: 1-11.

Rowlands, Michael, Mogens Larsen and Kristian Kristiansen (eds.) (1987) Centre and Periphery in the Ancient World. Cambridge.

Rudolph, Kelli C. (ed.) (2018) Taste and the Ancient Senses. London and New York. 
Ruffing, Kai (2019) “Nach Westen und dann immer geradeaus ... Zum Seidenhandel üer Palmyra in das Imperium Romanum,” in Wagner-Hasel and Nosch 2019: 317-30.

Runciman, W. G. (1982) "Origins of the States: The Case of Archaic Greece," Comparative Studies in Society and History 24: 351-77.

Runnels, Curtis and Tjeerd van Andel (1988) "Trade and the Origins of Agriculture in the Eastern Mediterranean," Journal of the Mediterranean Archaeology 1/1: 83-109.

Rüstow, Alexander (1952) Ortsbestimmung und Gegenwart: Eine universalhistorische Kulturkritik. II: Weg der Freiheit. Zürich.

Ruzé, Françoise (1989) “Basileis, Tyrans et Magistrats," Métis 4/2: 211-23.

Ryder, Michael L. (1982) "Sheep: Hilzheimer 45 Years On," Antiquity 56: 15-23.

- . (1983) Sheep and Men. London.

— . (1991) "The Last Word on the Golden Fleece Legend," Oxford Journal of Archaeology 10/1: 57-60.

Sahlins, Marshall (1974) "On the Sociology of Primitive Exchange," in his Stone Age Economics. London: 185-275.

— . (1984) "The Spirit of the Gift," in his Stone Age Economics. 3rd edn. London: 149-83.

Sakellariou, Michael B. (1989) The Polis-State: Definition and Origin. Athen.

Sakowski, Anja (1997) Darstellungen von Dreifußkesseln in der griechischen Kunst bis zum Beginn der Klassischen Zeit. Francfort.

Sallares, Robert (1998) “Getreide”, in Der Neue Pauly 4: column 1029-38.

Salmen, Walter (1980) “Musizierende Sirenen,” in Krinzinger et al. 1980: 293-400.

Salmon, J. B. (1984) Wealthy Corinth: A History of the City to 338 B.C. Oxford.

Salomon, Max (1937) Der Begriff der Gerechtigkeit bei Aristoteles: Nebst einem Anhang über den Begriff des Tauschgeschäftes. Leiden.

Samter, Ernst (1911) Geburt, Hochzeit und Tod: Beiträge zur vergleichenden Volkskunde. Leipzig and Berlin.

Sanchez, Pierre (2001) L'Amphictionie des Pyles et de Delphes: recherches sur son rôle historique, des origines au IIe siècle de notre ère. Historia Einzelschriften 148. Stuttgart.

Sancisi-Weerdenburg, Helen (ed.) (200o) Peisistratos and the Tyranny: A Reappraisal of Evidence. Amsterdam.

— . (2000) "The Tyranny of Peisistratos," in Sancisi-Weerdenburg 2000: 1-15.

Sandel, Michael (2012) What Money Can't Buy: The Moral Limits of Markets. London.

Santillo-Frizell, Barbro (ed.) (2004) Pecus: Man and Animal in Antiquity. Proceedings of a Conference at the Swedish Institute in Rome, September 9-12. Rome.

- (2009) Arkadien: Mythos und Wirklichkeit, trans. Ylva Eriksson-Kuchenbuch. Cologne.

Sarasin, Philipp (1990) Die Stadt der Bürger: Struktureller Wandel und bürgerliche Lebenswelt, Basel 1870-189o. Basel and Francfort.

Sartre, Maurice (1979) "Aspects économique et aspects religieux de la frontière dans les cités grecques," Ktema 4: 313-24. 
Satlow, Michael L. (ed.) (2013) The Gift in Antiquity. Oxford.

Schadewaldt, Wolfgang (1931) "Begriff und Wesen der antiken Klassik," in Das Problem des Klassischen und die Antike: Acht Vorträge gehalten auf der Fachtagung der Klassischen Altertumswissenschaft zu Naumburg 1930, ed. Werner Jaeger. Leipzig and Berlin: 15-32.

__ . (1959) "Kleiderdinge: Zur Analyse der Odyssee," Hermes 87: 13-26. Rpt. in his Hellas und Hesperien: Gesammelte Schriften zur Antike und zur Neueren Literatur. 1970: 79-93.

Schäfer, G. (1944) “Zur Geschichte des Flachsanbaues," Ciba-Rundschau 62: 2262-64. Schefold, Bertram (1988) "Karl Bücher und der Historismus in der Deutschen Nationalökonomie,” Hammerstein 1988: 239-68.

Scheid, Evelyne (1979) "Il matrimonio omerico," Dialoghi di Archeologia n.s. 1: 6o-73.

Scheid, John and Jesper Svenbro (1994 [English version 2001]) Le métier de Zeus: Mythe du tissage et du tissu dans le monde gréco-romain. Paris.

_ _ (2014) La tortue de la lyre. Dans l'átelier du mythe antique. Paris.

Scheid-Tissinier, Evelyne (1994) Les usages du don chez Homère: Vocabulaire et pratiques. Nancy.

_ . (2005) “'Le monde d'Ulysse' de M. I. Finley. Le vocabulaire et les pratiques," in Rouillard 2005: 217-28.

— . (2015) "Eurykléia, une vie, un nom," Pallas 99: 21-29.

Schein, Seth L. (1970) "Odysseus and Polyphemus in the Odyssey," Greek, Roman and Byzantine Studies 11: 73-83.

Schlesier, Renate (1994) Kulte, Mythen und Gelehrte: Anthropologie der Antike seit 180o. Francfort.

Schlicht, Ekkehart (1976) Einführung in die Verteilungstheorie. Hamburg.

Schmidt, Leopold (1882) Ethik der Alten Griechen II. Berlin.

Schmidt, Manfred (1979) "Hom. $\mu \tilde{\eta} \lambda \propto$ und die antiken Erklärungen," Glotta 57: 174-82.

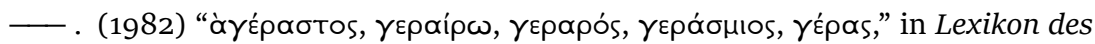
Frühgriechischen Epos 10: 133-36.

Schmidt-Colinet, Andreas (ed.) (1995) Palmyra: Kulturbegegnung im Grenzbereich. Mainz.

— . (2019) "Bauornamentik und Textilmuster in Palmyra," in Wagner-Hasel and Nosch 2019: 477-85.

Schmitt, Tassilo (2009) "Kein König im Palast: Heterodoxe Überlegungen zur politischen und sozialen Ordnung in der mykenischen Zeit," Historische Zeitschrift 288: 281-346.

Schmitt-Pantel, Pauline (1990) Marcel Mauss et les historiens de l'antiquité: Beitrag zur Konferenz 'The Gift and Its Transformations'; National Humanities Center, Research Triangle Park, North Carolina, November 1-3. Unpublished manuscript.

— - (ed.) (1991) Histoire des femmes en occident. I: L'Antiquité. Rome.

_. (1992) La cité au banquet: Histoire des repas publics dans les cités grecques. Paris and Rome (rpt. 2011). 
—_ . (2019) "Der Gürtel. Körperschmuck, Statussymbol und Geschlechtsmerkmal," in Wagner-Hasel and Nosch 2019: 333-55.

Schmölders, Günter (1988) "Historische Schule," in Geschichte der Nationalökonomie, ed. Otmar Issing. 2nd edn. Munich: 109-21.

Schmoller, Gustav von (1900) Grundriss der Allgemeinen Theorie der Volkswirtschaftslehre I. Leipzig.

Schneider, Helmuth (1989) Das griechische Technikverständnis: Von den Epen Homers bis zu den Anfängen der technologischen Fachliteratur. Darmstadt.

— . (1990) “Die Bücher-Meyer Kontroverse,” in Calder III and Demandt 1990: 417-45.

- (1992) Einführung in die antike Technikgeschichte. Darmstadt.

Schortman, E. M. (1989) "Interregional Interaction in Prehistory: The Need of a New Perspective," American Antiquity 54/1: 52-65.

Schulz, Fabian (2011) Die homerischen Räte und die spartanische Gerusie. Düsseldorf. Schurtz, Heinrich (1898) Grundriss der Entstehungsgeschichte des Geldes. Weimar.

Schwabl, Hans (1982) "Traditionelle Gestaltung, Motivwiederholung und Mimesis im homerischen Epos," Wiener Studien 16: 13-33.

Schwarzenberg, Erkinger (1966) Die Grazien. Bonn.

Schwendemann, K. (1921) "Der Dreifuß,” Jahrbuch des Archäologischen Instituts 36: 98-185.

Scott, John A. (1938/39) "Odysseus and the Gifts from the Phaeacians," Classical Journal 34: 102-93.

Scott, Mary (1981) "Some Greek Terms in Homer Suggesting Non-Competitive Attitudes," Acta Classica 24: 1-15.

_ . (1982) "Philos, Philotes and Xenia," Acta Classica 25: 1-19.

_ . (1983) "Charis in Homer and the Homeric Hymns," Acta Classica 26: 1-13.

- . (2014) Delphi and Olympia: The Spatial Politic of Panhellenism in Archaic and Classical Greece. 2nd edn. Cambridge.

Scully, Stephen (1990/1994) Homer and the Sacred City. Ithaca and London.

Seaford, Richard A. S. (1994) Reciprocity and Ritual: Homer and Tragedy in the Developing City State. London and Oxford.

_ . (2004) Money and the Early Greek Mind: Homer, Philosophy, Tragedy. Cambridge.

Sealey, Raphael (1983) "How Citizenship and the City Began in Athens," American Journal of Ancient History 8: 97-129.

Seelentag, Gunnar (2015) Das archaische Kreta. Institutionalisierung im frühen Griechenland. Berlin.

Semper, Gottfried (1878) Die Textilkunst. 2nd edn. Munich.

Semple, Ellen C. (1922) "The Influence of Geographic Conditions upon Ancient Mediterranean Stock-Raising," Annuals of the Association of American Geographers 12: 3-38.

— . (1931) The Geography of the Mediterranean Region: Its Relation to Ancient History. New York.

Sergent, B. (1978) “Sur les frontières de l'Élide aux hautes époques," Revue des Etudes Anciennes 80: 16-36. 
Service, Elman R. (1975) Origins of the State and Civilization: The Process of Cultural Evolution. New York.

Settis, Salvatore (2005) Die Zukunft des Klassischen. Eine Idee im Wandel der Zeiten. Trans. Friederike Hausmann. Berlin.

Seybold, Klaus and Jürgen von Ungern-Sternberg (1993) "Amos und Hesiod: Aspekte eines Vergleichs,” in Raaflaub 1993: 215-39.

Shapiro, H. Alan (1980) “Jason's Cloak," Transactions of the American Philological Association 110: 263-86.

- (1989) Art and Cult under the Tyrants in Athens. London.

Shaw, Brent D. and Richard Saller (1981) 'Editor's introduction', in Finley 1981: ix-xxvi.

Shaw, Maria C. and Anne P. Chapin (eds.) (2016) Woven Threads: Patterned Textiles of the Aegean Bronze Age. Oxford and Philadelphia.

Shipp, George P. (1979) Modern Greek Evidence for the Ancient Greek Vocabulary. Sydney.

Siebert, Wolfgang (1938) "Schenkung," in Rechtsvergleichendes Handwörterbuch für das Zivil- und Handelsrecht des In- und Auslandes VI, ed. Franz Schlegelberger. Berlin: 144-59.

Siemons, Mark (1993) Schöne Neue Gegenwelt: Über Kultur, Moral und andere Marketingstrategien. Francfort and New York.

Siewert, Peter (1982) Die Trittyen Attikas und die Heeresreform des Kleisthenes. Munich.

Silber, Ilana F. (2002) "Echoes of sacrifice? Repertoires of Giving in the Great Religions," in Sacrifice in Religious Experience, ed. Albert I. Baumgarten. Leiden, Boston and Cologne: 291-312.

Silver, Morris (1991) "The Commodity Composition of Trade in the Argonautic Myth," in his Ancient Economy in Mythology: East and West. Savage, MD: 241-81.

Simmel, Georg (1897) “Comment les formes sociales se maintiennent," L’Année sociologique 1: 71-109.

__ . (1898) "Die Selbsterhaltung der socialen Gruppe. Sociologische Studie," Schmollers Jahrbuch für Gesetzgebung, Verwaltung und Volkswirtschaft im Deutschen Reich 22/1: 235-86.

_ . (1911) "Soziologie der Geselligkeit," in his Verhandlungen des Ersten Deutschen Soziologentages vom 19.-22. Oktober 1910 in Frankfurt a. M.: Reden und Vorträge. Tübingen.

— . (1989) Philosophie des Geldes. Francfort (rpt. 1901).

Simon, Erika (1985) Die Götter der Griechen. Darmstadt.

Simon, Erika and Max Hirmer (1976, $\left.{ }^{2} 1981\right)$ Die griechischen Vasen. Munich.

Singer, Peter (2015) The Most Good You Can Do: How Effective Altruismus Is Changing Ideas about Living Ethically. New Haven et al.

Siurla-Theodoridou, Vasiliki (1989) Die Familie in der griechischen Kunst und Literatur des 8. bis 6. Jahrhunderts v. Chr. Munich.

Skydsgaard, Jens Erik (1974) “Transhumance in Ancient Italy," Analecta Romana Instituti Danici 7: 7-36.

—_ (1988) “Transhumance in Ancient Greece,” in Whittaker 1988: 75-86. 
Skydsgaard, Jens Erik and Signe Isager (1992) Ancient Greek Agriculture. London and New York.

Slanicka, Simona (2002) Krieg der Zeichen: Die visuelle Politik Johanns ohne Furcht und der armagnakisch-burgundische Bürgerkrieg. Göttingen.

Slawisch, Anja (ed.) (2013) Handels- und Finanzgebaren in der Ägäis im 5. Jh. v. Chr. Istanbul.

Smith, C. F. (1977) Thucydides, History of the Peloponnesian War. With an English translation. Vol. III. London and Cambridge.

Smith, Jonathan (1982) Imagining Religion. Chicago.

Smith, Thyrza (1987) Mycenaean Trade and Interaction in the West Central Mediterranean 1600-100o B.C. Oxford.

Snell, Bruno ([1938] 41971) Leben und Meinungen der Sieben Weisen. Munich.

Snodgrass, Anthony M. (1974) “An Historical Homeric Society?” Journal of Hellenic Society 94: 114-25.

— . (1982) "Les origines du culte des Heros dans la Grèce antique," in Gnoli and Vernant 1982: 107-19.

— . (1983) "Heavy Freight in Archaic Greece," in Garnsey, Hopkins and Whittaker 1983: 16-26.

— . (1986) "Interaction by Design: The Greek City State," in Renfrew and Cherry 1986: 47-58.

— . (1987) An Archaeology of Greece: The Present State and Future Scope of a Discipline. Berkeley.

— . (1989/90) “The Economics of Dedication," in Bartoloni 1990: 287-94.

_ . (1991) "Archaeology and the Greek City," in Rich and Wallace-Hadrill 1991: $1-23$.

Snoy, Peter (1993) "Alpwirtschaft im Hindukusch und Karakorum," in Neue Forschungen im Himalaya, ed. Ulrich Schweinfuhrt. Stuttgart: 49-73.

Snyder, Jane M. (1980/81) "The Web of Song: Weaving Imagery in Homer and the Lyrik Poets," Classical Journal 76: 193-96.

— . (1989) Women and the Lyre: Women Writers in Classical Greece and Rome. Illinois.

Sobrevilla, David (1971) Der Ursprung des Kulturbegriffs, der Kulturphilosophie und der Kulturkritik: Eine Studie über deren Entstehung und deren Voraussetzung. Dissertation. Tübingen.

Solmsen, Friedrich (1954) "The 'Gift' of Speech in Homer and Hesiod," Transactions of the American Philological Association 85: 1-15.

Sojc, Natascha (2005) Trauer auf attischen Grabreliefs: Frauendarstellungen zwischen Ideal und Wirklichkeit. Berlin.

Somló, Felix (1909) Der Güterverkehr in der Urgesellschaft. Brüssel and Leipzig.

Sommer, Michael (2004) "Die Peripherie als Zentrum: Die Phöniker und der interkontinentale Fernhandel," in Commerce and Monetary Systems in the Ancient World: Means of Transmission and Cultural Interaction; Proceedings of the Fifth Annual Symposium of the Assyrian and Babylonian Intellectual Heritage Project Held in Innsbruck, Austria, October 3rd-8th 2002, ed. Robert Rollinger and Christoph Ulf. Melammu Symposia V. Stuttgart: 233-41. 
Sommerstein, Alan H. and Isabelle C. Torrance (2014) Oaths and Swearing in Ancient Greece. Berlin et al.

Sontheimer, Kurt (1978) Antidemokratisches Denken in der Weimarer Republik. Munich.

Sorge, Christoph (2012) "Die Schenkung im Bürgerlichen Recht: Gabe oder Vergeltung? Eine rechtshistorische Untersuchung über den Einfluss von Reziprozitätsbeziehungen auf das Schenkungsrecht des BGB," in Vom homo oeconomicus zum homo reciprocans: Auf der Suche nach einem neuen Menschenbild als Erklärungsmuster für Recht, Wirtschaft und Kultur, ed. Manfred Rehbinder. Bern: 145-82.

. (2016) "Die rechtshistorischen Wurzeln des Wirtschaftsmenschen: Grabungen in der Ideengeschichte von Descartes bis Bentham," in Der homo oeconomcus in der Rechtsanwendung, ed. Andreas Dieckmann and Christoph Sorge. Tübingen: 39-122.

Sourvinou-Inwood, Christiane (1983) "A Trauma in Flux: Death in the 8th Century and After," in Hägg 1983: 33-48.

- . (1991) 'Reading' Greek Culture: Texts and Images, Rituals and Myths. London.

— _ . (1993) "Early Sanctuaries: The Eighth Century and Rituals Space: Fragments of a Discourse," in Marinatos and Hägg 1993: 1-17.

— . (1995) Reading Greek Death: To the End of the Classical Period. Oxford.

Spahn, Peter (1998) 'Die Steuer der Peisistratiden-idion, koinon oder hieron?' in François de Polignac and Pauline Schmitt Pantel (eds.) Public et privé en Grèce ancienne: lieux, conduites, pratiques. Ktèma 23: 197-206.

Spantidaki, Stella (2016), Textile Production in Classical Athens. Oxford and Philadelphia.

Späth, Späth and Beate Wagner-Hasel (eds.) (2000) Frauenwelten in der Antike. Stuttgart and Weimar.

Speyer, W. (1983) “Gürtel," in Reallexikon für Antike und Christentum 12/96: column 1232-66.

Spisak, Arthur L. (1998) "Gift-giving in Martial," in Toto Notus in Orbe: Perspektiven der Martial-Interpretation, ed. Farouk Grewing. Stuttgart: 243-55.

Spittler, Gerd (2008) Founders of the Anthropology of Work. German Social Scientists of the 19th and Early 2oth Centuries and the First Ethnographers. Münster.

Squire, Michael (ed.) (2016) Sight and the Ancient Senses. London and New York.

Stagl, Justin (1974) Die Morphologie segmentärer Gesellschaften: Dargestellt am Beispiel des Hochlandes von Neuguinea. Meisenheim am Glan.

— . (1991) "Malinowskis Paradigma," Geschichte und Gegenwart 2: 91-105.

—_ . (1998) "Geschenk und Gabe," Ethik und Sozialwissenschften 9/3: 414-16.

Stahl, Michael (1987) Aristokraten und Tyrannen im archaischen Athen: Untersuchungen zur Überlieferung, zur Sozialstruktur und zur Entstehung des Staates. Stuttgart.

— . (2003) Gesellschaft und Staat bei den Griechen: Archaische Zeit; Klassische Zeit. 2 vols. Paderborn et al.

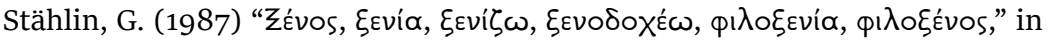
Theologisches Wörterbuch zum Neuen Testament V, ed. Gerhard Friedrich. Stuttgart. 
Stahlmann, Ines (1998) "Scham. Zu einem Verhaltensregulativ der homerischen Gesellschaft," in Psychologie und Geschichte 8/1: 85-111.

Stanfield, J. Ron (1990) "Karl Polanyi and the Contemporary Economic Thought," in Polanyi-Levitt 1990: 195-207.

Stanley, Keith (1993) The Shield of Homer: Narrative Structure in the Iliad. Princeton. Stanley, Philip V. (1986) “The Function of Trade in Homeric Society," Münstersche Beiträge zur antiken Handelsgeschichte 5/2: 5-15.

Starbatty, Joachim (ed.) (1989) Klassiker des ökonomischen Denkens II. Munich. Starr, Chester G. (1961) “The Decline of the Early Greek Kings," Historia 10: 129-38.

_ . (1986) Individual and Community: The Rise of the Polis. 80o-50o B.C. New York and Oxford.

Stavrianopoulou, Eftychia (2009) "Die Bewirtung des Volkes: Öffentiche Speisungen in der römischen Kaiserzeit," in Ritual Dynamics and Religious Change in Roman Empire, ed. Oliver Hekster, Sebastian Schmidt-Hofner, and Christian Witschel. Leiden and Boston: 159-80.

Stein-Hölkeskamp, Elke (1989) Adelskultur und Polisgesellschaft: Studien zum griechischen Adel in archaischer und klassischer Zeit. Stuttgart.

— . (2005) Das römische Gastmahl: Eine Kulturgeschichte. Munich.

Steinkopf, Gerhard (1937) Untersuchungen zur Geschichte des Ruhms bei den Griechen. Diss. Halle.

Stengel, Paul (1910) Opferbräuche der Griechen. Leipzig and Berlin.

Stocking, G. W. (1978) "Die Geschichtlichkeit der Wilden und die Geschichte der Ethnologie," Geschichte und Gesellschaft 4: 520-35.

Straten, Folkert T. van (1981) "Gifts for the Gods," in Faith, Hope and Worship: Aspects of Religious Mentality in the Ancient World, ed. Hendrik S. Versnel. Leiden: 65-151.

Streissler, Erich (1989) “Carl Menger (1840-1921)," in Klassiker des ökonomischen Denkens II, ed. Joachim Starbatty. Munich: 119-34.

Stulz, Heinke (1990) Die Farbe Purpur im frühen Griechentum: Beobachtet in der Literatur und in der bildenden Kunst. Beiträge zur Altertumskunde 6. Stuttgart.

Stupperich, Reinhard (1977) Staatsbegräbnis und Privatgrabmal im klassischen Athen. Diss. Münster.

Sussman, Linda S. (1978) "Workers and Drones: Labor, Idleness and Gender Definition in Hesiod's Beehive," Arethusa 11: 27-41.

Svenbro, Jesper (1976) La parole et le marbre: Aux origines de la poétique grecque. Lund and Paris.

- . (1984) "Vengeance et société en Grèce archaïque: A propos de la fin de l'Odyssée," in Vengeance: pouvoirs et idéologies dans quelques civilisations de l'Antiquité, ed. Raymond Verdier and Jean-Pierre Poly. Paris: 49-63.

Swoboda, Heinrich (1905) "Beiträge zur griechischen Rechtsgeschichte," Zeitschrift der Savigny-Stiftung für Rechtsgeschichte, Romanistische Abteilung 26: 149-284.

Taillardat, Jean (1982) “ФI $\mathrm{OTE} \Sigma$, $\Pi I \Sigma T \mathrm{TI}$ et FOEDUS," in Revue des Etudes Grecques 95: 1-14. 
Takabatake, Sumio (1988) "The Idea of xenos in Classical Athens: Its Structure and Peculiarities," in Forms of Control and Subordination in Antiquity, ed. Toru Yuge and Masaoki Doi. Leiden and New York: 449-55.

Tausend, Klaus (1992) Amphiktyonie und Symmachie: Formen zwischenstaatlicher Beziehungen im archaischen Griechenland. Stuttgart.

Theognis, Mimnermos, Phokylides (2005). Frühe griechische Elegien. Greek and German. Introduction and translation by Dirk Uwe Hansen. Darmstadt.

Theokrit 1999. Gedichte. Greek and German. Ed. and trans. by Bernd Effe. Darmstadt

Thesaurus Linguae Graecae (ed.) (1982-1991) Lexikon des Frühgriechischen Epos, founded by Bruno Snell, im Auftrag der Akademie der Wissenschaften in Göttingen. 2 vols. Göttingen.

Thomas, Carol C. (1966) "The Roots of Homeric Kingship," Historia 15: 387-407.

—_. (1978) "From Wanax to Basileus," Hispania Antiqua 6: 187-204.

Thomas, Rosalind (1992) Literacy and Orality in Ancient Greece. Cambridge.

Thommen, Lukas (1996) "Nacktheit und Zivilisationsprozeß in Griechenland," Historische Anthropologie 4: 435-50.

Thompson, Edward P. (1977) "Folklore, Anthropology and Social History,“ The Indian Historical Review 3: 247-366.

Thompson, Wesley (1982) "Weaving: A Man's Work," Classical World 75: 217-22.

Thomson, George D. (1941) Aischylus and Athens: A Study in the Social Origin of the

Drama. London.

— . (1978) Prehistoric Aegean. 4th edn. London.

Thornton, Robert J. (1985) “'Imagine yourself set down ...': Mach, Frazer, Conrad, Malinowski and the Role of Imagination in Ethnography," Anthropology Today 1/5: 7-14.

Thurnwald, Richard (1911) "Stufen der Staatsbildung bei den Urvölkern," Zeitschrift für vergleichende Rechtswissenschaft 25: 417-32.

- . (1912) Forschungen auf den Salomon-Inseln und dem Bismarck-Archipel. Berlin.

—_ . (1921) Die Gemeinde der Bánaro. Stuttgart.

- . (1932) Werden, Wandel und Gestaltung der Wirtschaft im Lichte der Völkerforschung. Berlin.

_ _ (1936) "Gegenseitigkeit im Aufbau und Funktionieren der Gesellungen und deren Institutionen," in Reine und angewandte Soziologie: Eine Festgabe für Ferdinand Tönnies zu seinem achtzigsten Geburtstag am 26. Juli 1935. Leipzig: 275-97.

Tietz, Werner (2013) Dilectus ciborum: Essen im Diskurs der römischen Antike. Göttingen.

— _ (2015) Hirten-Bauern-Götter: eine Geschichte der römischen Landwirtschaft. Munich.

Tölle-Kastenbein, Renate (1994) Wasserleitungsnetz für Athen. Mainz.

Tomasello, Michel (2010) Warum wir kooperieren. Berlin.

Tönnies, Ferdinand (1991) Gemeinschaft und Gesellschaft: Grundbegriffe der reinen Soziologie. Darmstadt (orig. 1887; rpt. of 8th edn. 1935). 
Tracy, Catherine (2014) "The Host's Dilemma: Game Theory and Homeric Hospitality," Classical Studies 39: 1-16.

Treister, Michail Y. (1976) The Role of Metals in Ancient Greek History. Leiden.

Tsetskhladze, Gocha R. (ed.) (2006/2008) Greek Colonsation: An Account of Greek Colonies and Other Settlements Overseas. 2 vols. Leiden.

Tuck, Anthony (2006), "Singing the Rug: Patterned Textiles and the Origins of IndoEuropean Metrical Poetry," American Journal of Archaeology 110: 539-50.

Uchitel, Alexander (1984) "Women at Work: Pylos and Knossos, Lagash and Ur," Historia 33/3: 257-82.

Uhlig, Harald (1973) "Wanderhirten im westlichen Himalaya," in Vergleichende Kulturgeographie der Hochgebirge des südlichen Asiens, ed. Carl Rathjens, Carl Troll, and Harald Uhlig. Erdkundliche Forschungen 5. Wiesbaden.

Ulf, Christoph (1990) Die homerische Gesellschaft: Materialien zur analytischen Beschreibung und historischen Lokalisierung. Vestigia 43. Munich.

_ _ (1997) "Überlegungen zur Funktion überregionaler Feste im archaischen Griechenland," in Volk und Verfassung im vorhellenistischen Griechenland. Beiträge auf dem Symposium zu Ehren von Karl-Wilhelm Welwei in Bochum, 1.-2. März 1996, ed. Walter Eder and Karl-Joachim Hölkeskamp. Stuttgart: 37-61.

— . (2001): "Gemeinschaftsbezug, soziale Stratifizierung, polis-drei Bedingungen für das Entstehen aristokratischer und demokratischer Mentalität im archaischen Griechenland," in Gab es das griechische Wunder? Griechenland zwischen dem Ende des 6. Und der Mitte des 5. Jahrhunderts v. Chr., eds. Dietrich Papenfuß and Volker Michael Strocka. Mainz: 153-86.

— . (2002): "Herkunft und Charakter der grundlegenden Prämissen für die Debatte über die historische Auswertung der homerischen Epen," Klio 84/2: 319-54.

— . (2011) "Zur ,Vorgeschichte der Polis': Die Wettbewerbskultur als Indikator für die Art des griechischen Bewusstseins," Hermes 139/3: 291-315.

Ungern-Sternberg, Jürgen von (1998) "Innovation in Early Greece: The Political Sphere," in Political Competition, Innovation and Growth: A Historical Analysis, ed. Peter Bernholz, Manfred E. Streit, and Roland Vaubel. Berlin and Heidelberg: 85-107.

Ungern-Sternberg, Jürgen von and Hansjörg Reinau (eds.) (1988) Vergangenheit in mündlicher Überlieferung. Colloquium Rauricum 1. Stuttgart.

Urry, James (1992) "Would the Real Malinowski Please Stand up?" Man 27/1: 181-82. Vasilescu, Michael (1989) "Hellènes et barbares dans l'épopées homeriques," Klio 71: 70-77.

Vatin, Claude (1982) "Poinè, Timè, Thoiè dans le droit homérique," Ktema 7: 275-80. Varto, Emily (2017): “The Idea of Descent in Early Greek Kinship," in Mediterranean Families in Antiquity: Households, Extended Families, and Domestic Space, eds.

Sabine R. Huebner and Geoffrey Nathan. Malden, Oxford and Chichester: 44-64.

Venturi, Franco (1963) “Despotism,” Journal of the History of Ideas 24: 133-42.

Verboven, Koenraad (2002) The Economy of Friends: Economic Aspects of amicitia and Patronage in the Late Republic. Bruxelles.

Verdenius, W. J. (1944) “AIDOS bei Homer," Mnemosyne 3rd sér. 12: 47-6o. 
Vermeule, Emily (1979) Aspects of Death in Early Greek Art and Poetry. Berkeley. Vernant, Jean-Pierre (1962) Les origines de la pensée grécque. Paris.

—_ . (1975) "Hestia-Hermès: Sur l'expression religieuse de l'espace et du mouvement chez les Grecs," in his Mythe et pensée chez les Grecs Paris. Paris: 97-143.

— . (1986) "Corps obscur, corps éclant," in his Corps des dieux, ed. Charle Malmoud. Paris : 19-46.

_ - (1989) "Figures féminines et la mort en Grèce," in his L'individue, la mort, l'amour. Paris : 131-52 = (1985) "La douceur amère de la condition humaine" Lettre international 6: 45-48.

Veyne, Paul (1976) Le pain et le cirque: Sociologie historique d'un pluralisme politique. Paris (= Bread and Circuses: Historical Sociology and Political Pluralism. Trans. B. Pearce. London 1990).

Vidal-Naquet, Pierre (1968) "Fonction de la monnaie dans la Grèce archaïque," Annales 23: 206-8.

- (1983) The chasseur noir. Formes de pensées et formes de société dans le monde grec. Ed rev. et corr. Paris (= The Black Hunter: Forms of Thought and Forms of Society in the Greek World. Trans. Andrew Szegedy-Maszak. Baltimore 1986).

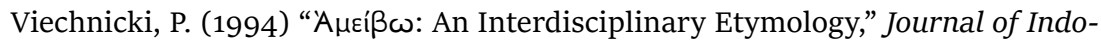
European Studies 22/1-2: 113-32.

Viehweg, Theodor (1970) "Rechtsdogmatik und Rechtszetetik bei Jhering," in Wieacker and Wollschläger 1970: 211-16.

Villing, Alexandra (ed.) (2005) The Greeks in the East: British Museum Research Publication 157. London.

Vlachos, Georges C. (1974) Les sociétés politiques homériques. Paris.

Vlemick, Serge (1982) "L’aspect institutionel de la тınń homérique à la lumière de l'étymologie," Ziva antiqua 32/2: 151-64.

Vogt, Wolfgang P. (1981) "Über den Nutzen des Studiums primitiver Gesellschaften: Eine Anmerkung zur Durkheim-Schule 1890-1940," in Geschichte und Soziologie III, ed. Wolf Lepenies. Francfort: 276-97.

Vössing, Konrad (2004) Mensa Regia: Das Bankett beim hellenistischen König und römischen Kaiser. Munich.

Vries, Keith de (1980) "Greeks and Phrygians in the Early Iron Age," in his From Athens to Gordion: Papers of a Memorial Symposium for Rodneys S. Young, Philadelphia, PA: 41-42.

Wace, Alan J. B. (1934) “The Veil of Despoina," American Journal of Archaeology 38: 107-11.

_ . (1948) "Weaving or Embroidery," American Journal of Archaeology 52: 51-55.

Wace, Alan J. B. and Maurice S. Thompson (1914) The Nomads of the Balkans. London (rpt. 1972).

Wagner, Adolph (1876) Allgemeine und theoretische Volkswirthschaftslehre:

Mit Benutzung von Rau's Grundsätzen der Volkswirthschaftslehre. Rau'schen Volkswirthschaftslehre. 9th edn. Leipzig and Heidelberg. 
Wagner, Günther A., Gerd Weisgärber, and Werner Kroker (eds.) (1985) Silber, Blei und Gold auf Sifnos: Prähistorische und antike Metallproduktion.

Veröffentlichungen aus dem Deutschen Bergbau-Museum Bochum 31. Bochum.

Wagner-Hasel, Beate (1988) "Geschlecht und Gabe: Zum Brautgütersystem bei Homer," Zeitschrift der Savigny Stiftung für Rechtsgeschichte, Romanistische Abteilung 105: 32-73.

_ . (ed.) (1992) Matriarchatstheorien der Altertumswissenschaft. Darmstadt.

_ _ (1997) "Die Macht der Penelope: Zur Politik des Gewebes im homerischen Epos." in Kybele-Prophetin-Hexe: Religiöse Frauenbilder und Weiblichkeitskonzeptionen, ed. Richard Faber and Susanne Lanwerd. Würzburg: $127-46$.

— . (1998a) "Wissenschaftsmythen und Antike: Zur Funktion von Gegenbildern der Moderne am Beispiel der Gabentauschdebatte," in MythenMächte-Mythen als Argument, ed. Wolfgang Schmale and Annette Völker-Rasor. Berlin: 33-63.

— . (1998b) "Le privé n'éxiste pas: Quelques remarques sur la construction du privé par l'Altertumswissenschaft au 19ième siècle," Ktema 23: 25-35.

— _ (1998c) "Herakles und Omphale im Rollentausch: Mythologie und Politik in der Antike," in Geschlechterperspektiven: Forschungen zur Frühen Neuzeit, ed. Gisela Engel and Heide Wunder. Königstein: 205-28.

—_ . (1998d) "Gastfreundschaft," in Der Neue Pauly 4: column 794-97.

— . (1998e) "Geschenke, Griechenland," in Der Neue Pauly 4: column 984-88.

_ . (2000a) "Zentrumsbildung und überregionale Kommunikation: Delphi und der Dreifuß des Apollon," in Beate Wagner-Hasel, Der Stoff der Gaben: Kultur und Politik des Schenkens und Tauschens im archaischen Griechenland. Francfort and New York 2000: 261-305 and 422-38.

_ . (2000b) "Die Reglementierung von Traueraufwand und der Nachruhm der Toten," in Späth and Wagner-Hasel 2000: 81-102.

_ . (2002a) “The Graces and Colour-Weaving," in Women's Dress in the Ancient Greek World, ed. Lloyd Llewellyn-Jones. London: 17-32.

_ . (2002b) "Kommunikationswege und die Entstehung überregionaler Heiligtümer: Das Fallbeispiel Delphi,"in Eckart Olshausen and Holger Sonnabend (eds.) $\mathrm{Zu}$ Wasser und zu Land: Verkehrswege in der antiken Welt. 7. Kolloquium zur Historischen Geographie des Altertums. Stuttgart: 16o-8o.

— . (2003a) "Egoistical Exchange and Altruistic Gift," in Algazi, Groebner, and Jussen 2003: 141-71.

— . (2003b) "Streit um Troia. Eine wirtschaftsanthropologische Sicht," Historische Anthropologie 11/2: 263-77.

- . (2006a) "Gift-Exchange: Ancient Attitudes and Modern Theories," in DegerJalkotzy and Lemos 2006: 257-69.

_ . (2006b [French version 2017]) "Duftende Kleider-Gesalbte Körper," in Duftnoten: was Griechen und Römern in die Nase stieg; Ausstellungskatalog Kestner-Museum Hannover, ed. Angelika Dierichs and Anne Viola Siebert. Hannover: 20-25.

— . (2007) "Der Stoff der Macht-Kleideraufwand, elitärer Konsum und homerisches Königtum," in Alram-Stern and Nightingale 2007: 325-37. 
_ . (2009a) "Brautgut oder Mitgift? Das textile Heiratsgut in den Solonischen Aufwandbestimmungen," in Hildebrandt and Veit 2009: 143-81.

_ _ (2009b) "Hundert Jahre Gelehrtenstreit über den Charakter der antiken

Wirtschaft: Zur Aktualität von Karl Büchers Wirtschaftsanthropologie,”

Historische Anthropologie I 7/2: 178-201.

—_. (2011) Die Arbeit des Gelehrten: Der Nationalökonom Karl Bücher (1847-1930), Francfort and New York.

_ . (2012a) "Tria himátia: Vêtement et mariage en Grèce ancienne," in Gherchanoc and Huét 2012: 39-46.

_ _ (2012b) "L'étoffe du pouvoir: La royauté homérique et le genre," in Le banquet de Pauline Schmitt Pantel: Genre, mœurs et politique dans l'antiquité grecque et romaine. Paris: 207-23.

— . (2013) "Marriage Gifts in Ancient Greece," in Satlow 2013: 158-72.

_ . (2014) "Karl Bücher and the Birth of the Theory of Gift-Giving," in Carlà and Gori 2014: 51-69.

— _ (2015) "Dreifußkessel und der Stoff der Gaben: Plädoyer für einen materiellen Kulturbegriff," Historische Anthropologie 23/3: 326-52.

_ . (2018a) "Hektemoroi-Kontraktbauern, Schuldknechte oder abgabenpflichtige Bauern?" in Emas non quod opus est, sed quos necesse est: Beiträge zur Wirtschafts-, Sozial-, Rezeptions- und Wissenschaftsgeschichte der Antike; Festschrift für Hans-Joachim Drexhage zum 7o. Geburtstag, ed. Kai Ruffing and Kerstin Droß-Krüpe. Philippika 125. Wiesbaden: 295-308.

— - (2018b) "Penelopes Wohnzimmer: Polemische Anmerkungen zu Mary Beards Streitschrift ,Frauen \& Macht"," Historische Anthropologie 26/3: 414-21.

_ . (forthcoming) "The Garden of Pisistratus: Benefactions and Dues in Archaic Athens," Benefactors and the Polis, ed. Marc Domingo Gygax and Arjan Zuiderhoek. Cambridge.

Wagner-Hasel, Beate and Marie-Louise Nosch (eds.) (2019) Gaben, Waren und Tribute: Stoffkreisläufe und antike Textilökonomie. Stuttgart.

__ . (forthcoming) "Herakles und Dreifußraub von Delphi. Überlegungen zu den Hintergründen eines Mythos," in Balbina Bäbler and Günther Nesselrath (forthcoming) Delphi: Apollons Orakel in der Welt. Stuttgart.

Waibl, Elmar (1992) Ökonomie und Ethik. I: Die Kapitalismusdebatte in der Philosophie der Neuzeit. 3rd edn. Stuttgart.

Walcot, Peter (1970) Greek Peasants, Ancient and Modern: A Comparison of Social and Moral Values. Manchester.

Waldherr, Gerhard (2001) "Antike Transhumanz im Mediterran: Ein Überblick,” in his Landwirtschaft im Imperium Romanum, ed. Peter Herz. St. Katharinen: 331-57.

Waldner, Katharina (2000a) Geburt und Hochzeit des Kriegers: Geschlechterdifferenz und Initiation in Mythos und Ritual der griechischen Polis. Religionsgeschichtliche Versuche und Vorarbeiten 46. Berlin and New York.

— . (200ob) "Kulträume von Frauen in Athen: Das Beispiel der Artemis Brauronia,” in Späth and Wagner-Hasel 2000: 53-81.

Walek, Tadeusz B. (1911) Die delphische Amphiktyonie in der Zeit der aitolischen Herrschaft. Dissertation. Berlin. 
Walter, Uwe (1993) An der Polis teilhaben: Bürgerstaat und Zugehörigkeit im archaischen Griechenland. Stuttgart.

— . (2004) "Paradigmen für fast alle Typen: Migration in der Antike," Geschichte, Politik und ihre Didaktik 32: 62-73.

Weber, Leo (1935) Solon und die Schöpfung der Attischen Grabrede. Francfort.

Weber, Martha (1971) "Die geometrischen Dreifußkessel: Fragen zur Chronologie der Gattungen und deren Herstellungszentren," Mitteilungen des Deutschen Archäologischen Instituts 86: 15-30.

Weber, Max (1980) Wirtschaft und Gesellschaft: Grundriss der verstehenden Soziologie, edn. with a foreword by Johannes Winckelmann. 5th edn. Tübingen.

Wees, Hans van (1992) Status Warriors, War, Violence and Society in Homer and History. Amsterdam.

— . (1998) "The Law of Gratitude: Reciprocity in Archaeological Theory," in Gill et al. 1998: 13-49.

— . (2002) "Greed, Generosity and Gift-Exchange in Early Greece and the Western Pacific," in After the Past: Essays in Ancient History in Honour of H. W. Pleket, ed. Willem Jongman and Marc Kleijwegt. Leiden: 341-378.

_ . (2004) Greek Warfare: Myths and Realities. London.

- . (2005) "Trailing Tunics and Sheepskin Coats: Dress and Status in Early Greece," in The Clothed Body in the Ancient World, ed. Liza Cleland, Mary Harlow, and Lloyd Llewellyn-Jones. Oxford: 44-51.

— . (2013) "Farmers and Hoplites: Models of Historical Development," in Men of Bronze: Hoplite Warfare in Ancient Greece, ed. Donald Kagan and Gregory F. Viggiano. Princeton and Oxford: 222-55.

Wehler, Hans-Ulrich (1987) Deutsche Gesellschaftsgeschichte. II: Von der Reformära bis zur industriellen und politischen 'Deutschen Doppelrevolution' 1815-1845/9. Munich.

Weigand, Gustav (1894/95) Die Aromunen. 2 vols. Leipzig.

Weiher, Anton (ed.) (51986) Homerische Hymnen. Greek and German. Darmstadt.

Weiner, Annette B. (1976) Women of Value, Men of Renown: New Perspectives in Trobriand Exchange. Austin.

— . (1980) “'Reproduction': A Replacement for Reciprocity,” American Ethnologist 7/1: 71-85.

— . (1983) “'A World of Men is not a World of Born': Doing Kula in Kiriwana,” in The Kula: New Perspectives on Massim Exchange, ed. Jerry W. and Edmund Leach. Cambridge: 147-70.

- . (1989) "Why Cloth? Wealth, Gender, and Power on Oceania," in her Cloth and Human Experience, ed. Jane Schneider. Washington: 33-72.

Welskopf, Charlotte (ed.) (1981) Soziale Typenbegriffe im alten Griechenland und ihr Fortleben in den Sprachen der Welt. III: Untersuchungen ausgewählter altgriechischer sozialer Typenbegriffe. Berlin.

Welwei, Karl-Wilhelm (1992) Athen: Vom neolithischen Siedlungsplatz zur archaischen Großsiedlung. Darmstadt.

Wenzel, Horst (1988) "Partizipation und Mimesis: Die Lesbarkeit der Körper am Hof und in der höfischen Literatur," in Materialität und Kommunikation, ed. Hans Ulrich Gumbrecht and K. Ludwig Pfeiffer. Francfort: 178-202. 
— _ (1991) "Imaginatio und Memoria: Medien der Erinnerung im höfischen Mittelalter," in Mnemosyne: Formen und Funktionen der kulturellen Erinnerung, ed. Aleida Assmann and Dietrich Hardt. Francfort: 57-82.

— . (1995) Hören und Sehen, Schrift und Bild: Kultur und Gedächtnis im Mittelalter. Munich.

Wesel, Uwe (1988) Juristische Weltkunde. 4th edn. Francfort.

West, Martin L. (1990) "Archaische Heldendichtung: Singen und Schreiben," in Kullmann and Reichel 1990: 33-50.

West, M. L. (2008) Hesiod, Theogony and Works and Days. A new translation. Oxford and New York.

Wéry, Louise-Marie (1967) "Le fonctionnement de la diplomatie à l'époque homérique," Revue Internationale des droits de l'antiquité 3rd sér. 14: 169-205.

White, Kenneth D. (1977) Country Life in Classical Times. London.

Whitley, James (1988) "Early States and Hero-Cults: A Re-appraisal," The Journal of Hellenic Studies 108: 173-82.

— . (1991) Style and Society in Dark Age Greece: The Changing Face of a Preliterate Society 110o-70o B.C. Cambridge.

Whittaker, C. R. (ed.) (1988) Pastoral Economies in Classical Antiquity. Cambridge. Wickert-Micknat, Gisela (1982) Die Frau. Archaeologia Homerica Q. Göttingen. Widzisz, Marcel (2012) “Timing Reciprocity in the Iliad,” Arethusa 45/2: 153-76. Wieacker, Franz (1942) Rudolf von Jhering: Eine Erinnerung zu seinem 50. Todestag. Leipzig.

—_. (1973) "Jhering und der ,Darwinismus‘," in Festschrift für Karl Larenz zum 70. Geburtstag, ed. Gotthard Paulus, Uwe Diederichsen, and Claus-Wilhelm Canaris. Munich: 63-92.

Wieacker, Franz and Christian Wollschläger (eds.) (1970) Jherings Erbe: Göttinger Symposium zur 150. Wiederkehr des Geburtstages von Rudolf von Jhering. Abhandlungen der Akademie der Wissenschaften zu Göttingen, PhilologischHistorische Klasse 3/75. Göttingen.

Wild, John Peter (2008) “Textile Production," in The Oxford Handbook of Engineering and Technology in the Classical World, ed. John P. Oleson. Oxford: 465-82.

Will, Eduard (1954a) Korinthiaka. Paris.

— . (1954b) "Trois quarts de siècle de recherches sur l'économie grecque antique," Annales 9: 7-22.

_ - (1954c) "De l'aspect éthique des origines grecques de la monnaie," Revue historique 212/2: 209-31.

_ _ (1955) "Reflections et hypothèses sur l'origine du moyannage," Revue numismatique 5th sér. 17: 5-23.

_ _ (1957) "Aux origines du régime foncier grec: Homère, Hésiode et l'arrière-plan mycénien," Revue des Etudes Anciennes 59: 5-50.

Willemsen, Franz (1955) “Der delphische Dreifuß," Jahrbuch des Deutschen Archäologischen Instituts 70: 85-104.

— . (1957) Dreifußkessel von Olympia. Berlin.

Willenbrock, Harro (1944) Die poetische Bedeutung der Gegenstände in Homers Ilias. Diss. Marburg (rpt. 1969). 
Wilson, J.-P. (1997) “The Nature of Greek Overseas Settlements in the Archaic Period: Emporion or apoikia?" in The Development of the "Polis" in Archaic Greece, ed. Lynette G. Mitchell and P. J. Rhodes. London: 199-207.

Winkel, Harald (1977) Die deutsche Nationalökonomie im 19. Jahrhundert. Darmstadt. — . (1989) “Gustav von Schmoller (1838-1917)," in Klassiker des ökonomischen Denkens II, ed. Joachim Starbatty. Munich: 97-118.

Winkler, John J. (1990) The Constraints of Desire: The Anthropology of Sex and Gender in Ancient Greece. New York and London.

Winterling, Aloys (1999) Aula Caesaris. Munich.

Wittenburg, Andreas (1995) "Bernhard Laum und der sakrale Ursprung des Geldes," in Altertumswissenschaft in den 2oer Jahren: Neue Fragen und Impulse, ed. Helmut Flashar. Stuttgart: 259-74.

— . (2012) "Antiquité et anthropologie en Allemagne: Eduard Meyer et après," in Payen and Scheid-Tissinier 2012: 323-42.

Wöhrle, Georg (1999) Telemachs Reise: Väter und Söhne in Ilias und Odyssee oder ein Beitrag zur Erforschung der Männlichkeitsideologie in der homerischen Welt. Göttingen.

Wolf, Eric R. (1982) Europa and the People Without History. Berkeley, Los Angeles and London.

Wood, Ellen Meiksins (1989) Peasant-Citizen and Slave: The Foundations of Athenian Democracy. London and New York.

Wright, James C. (1987) "Death and Power at Mycenae: Changing Symbols in Mortuary Practice," in Laffineur 1987: 171-84.

Wunder, Heide (1994) “'Gewirkte Geschichte’: Gedenken und ,Handarbeit': Überlegungen zum Tradieren von Geschichte am Beginn der Neuzeit," in Modernes Mittelalter: Neue Bilder einer populären Epoche, ed. Joachim Heinzle. Francfort and Leipzig: 324-54.

Yamagata, Naoko (1993) Homeric Morality. Leiden, New York and Cologne.

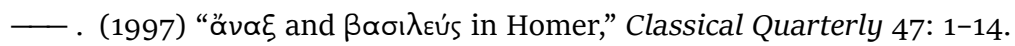

- . (2005) "Clothing and Identity in Homer: The Case of Penelope's Web," Mnemosyne 58: 539-546.

Young, Michael (1984) “The Intensive Study of a Restricted Area, Or, Why Did Malinowski Go to the Trobriand Island?” Oceania 55/1: 1-26.

Zaccagnini, C. (1987) "Aspects of Ceremonial Exchange in the Near East During the Late Second Millenium B.C.," in Rowlands, Larsen, and Kristiansen 1987: 57-65.

— - (1989/90) "Dono e tributo come modelli instituzionali di scambio: Echi e persistenze nella documentazione administrativa vicino-orientale del Tardo bronze," in Bartoloni 1989/90: 105-10.

Zanker, Paul (1965) Wandel der Hermesgestalt in der attischen Vasenmalerei. Bonn.

Zeisel, Hans (1968) "Karl Polanyi," International Encyclopedia of the Social Sciences 12: $172-74$.

Zengel, Eva (1991) “Troia,” in Troia: Katalog, ed. Ruhrland Museum der Stadt Essen. Essen: $30-67$.

Zielinski, Tadeusz (1924) "Charis und die Chariten," Classical Quarterly 18: 158-63. 
Zöbl, Dorothea (1982) Die Transhumanz (Wanderschafhaltung) der europäischen Mittelmeerländer im Mittelalter in historischer, geographischer und volkskundlicher Sicht. Berliner Geographische Studien 10. Berlin.

Zschietzmann, Willy (1928) "Die Darstellungen der Prothesis in der griechischen Kunst," Mitteilungen des Deutschen Archäologischen Instituts, Athenische Abteilung 53: 17-47.

Zuiderhoek, Arjan (2009) The Politics of Munificence in the Roman Empire: Citizens, Elites and Benefactors in Asia Minor. Cambridge.

. (forthcoming) "Benefactors and the Poleis in the Roman Empire: Civic Munificence in the Roman East in the Context of the longue durée," in Domingo Gygax and Zuiderhoek (forthcoming).

Zweigert, Konrad (1970) "Jherings Bedeutung für die Entwicklung der rechtsvergleichenden Methode," in Wieacker and Wollschläger 1970: 240-51. 


\section{INDEX}

\section{INCLUDING GLOSSARY OF GREEK TERMS}

Achaeans, 96, 100-101, 107-108, 110, 134, 154, $163,199,210,212-213,254,283$

Achilles, 15, 78, 84, 92-93, 98, 101-102, 106, 109-110, 126, 131, 133-134, 141-143, 147148, 150, 153-154, 162, 167-168, 174, 177178, 185, 189, 191-199, 201, 203-213, 216217, 220-225, 229, 232, 235-238, 241-243, 245-248, 251, 254-259, 269, 277, 283-284, 286, 291-292, 295, 299, 302-303

Adrastus, 150, 225

advantage s. képठos (kerdos)

Aegisthus (Aigisthos), 94, 143, 207, 234

Aegyptius, 242

Aeneas (Aineias), 102-103, 153, 156, 161, 203, 215, 236, 283

Aeolus (Aiolos), 103, 131, 136

Aepeia, 201

Aeschylus (Aischylos), 10, 89, 278, 344

Aëthe, 147

aethla ( $\alpha \theta \lambda \alpha \alpha)$ : prizes of contest, $61,100,119$, 153, 182, 191, 199, 207, 216, 232, 256-257, 262, 264, 266, 282, 291, 303, 313-315, 333 , 336-337, 345

Aëthon, 119, 128, 147, 205, 277, 284

Aetolians, 203, 206, 275

Afghanistan, 307

Agamemnon, 16, 69, 91-92, 94, 98, 101, 105106, 108, 133-135, 138, 147-150, 153, 176, 179, 185, 189, 191-196, 198, 200-219, 221230, 234-235, 242-246, 255-256, 267, 282284, 292, 295, 302

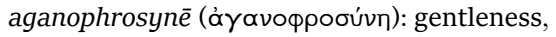
kindliness, 251-252

aganos (áyavós): mild, gentle, 251-252

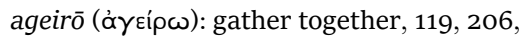
295-296

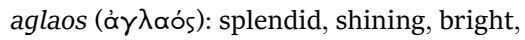
115, 150, 175-176, 178, 234, 247

agnythes (áyvũ $\theta \varepsilon s):$ loom weights, 164

(Figure)

Agesilaus (Agesilaos), 111-112

Agis, 105

Aglaia, 157 agora, 199, 208, 220

aidōs ( ๔ỉ $\omega_{\text {s) }}$ : awe, shame, respect, 175, 188, 209-211, 216, 229, 404

aidoios ( $\alpha i$ íoĩos): having a claim to regard, shamefaced 212, 224, 227

aideomai ( $\alpha i \delta$ Éouณı): to be ashamed, stand in awe of 210-212, 272

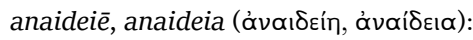
shamelessness 210-212

Aigae, 152

Aisa, 237, 238-239, 240

Ajax, 103, 107, 16o, 162, 193, 278, 281

Akrotiri, 301

Alcaeus (Alkaios), 287

Alcinous (Alkinoos), 93, 105, 109, 113, 115117, 120-121, 126, 128, 132, 141, 149, 154, 179, 203-206, 209, 225-227, 238, 244-245, 278, 286

Alcmaeonids (Alkmeonidai), 112

Alkandre, 119, 295, 305

Alkiphron, 105

alliance, 20, 45, 54, 56, 60-62, 67-70, 73-74, 79, 81-83, 93, 96, 105, 107, 110-112, 149, 314-315, 325-326, 344

Al Mina, 307, 325

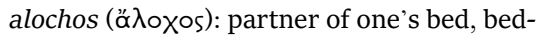
fellow, wife, 103, 141, 245, 248

Alpheus (Alpheios), 274, 279

Althaea (Althaia), 224

altruism, 21, 24, 30-35, 50, 64, 80, 84, 132

alum, 269, 295, 300, 310

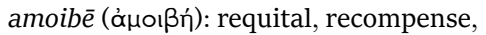
counter-gift, 15, 79, 120, 267, 269, 270, 276-277, 311, 338

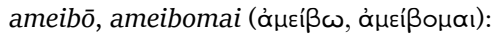
requite, answer, give in exchange, cross, 97, 101, 276-278, 280, 311; epamoibima

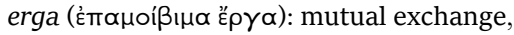
barter, 278, 280

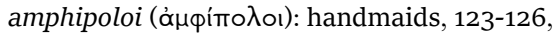
145, 155, 157-161, 169, 171, 341

Amasis, 158, 298, 300, 307

ambrosia, 84-85, 159, 171, 258 
Amira, Karl von, 29

Amphictyonic League, 323

Amphidamas, 106

Amphimedon, 234-235

Amphion, 207

Amyntor, 106

Amythaon, 181

anassō (óvóoow): to be master, 190, 205, 207,

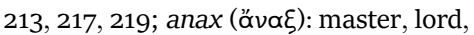
85-86, 116, 151, 186, 189-191, 205-207, 219,

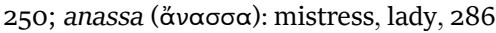

Anchialus, 277

Anchises, 102, 156, 173, 205

Andromache, 16o-161, 163, 165, 176-177, 206, 224, 248-249, 252, 257-258, 283, 302

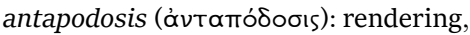
requiting, 144

Antenor, 105, 129, 283

Anthedon, 319

Antheia, 201

anthropology, 9-11, 13, 18, 21, 35-36, 53-54, 331-332, 335

anti-individualism, 43-44

Antinous, 218, 233, 285

Antilochus, 281

antion (ơvtíov): cloth beam, 164 (Figure)

aphenos (ฉ̋qєvos): revenue, wealth, riches, abundance, 194-195, 288

Aphrodite, 102-103, 134-135, 137-139, 145, 156-157, 159-161, 169, 171, 173-174, 183, 241, 316

apoina (ớтоı) ): ransom, compensation, 55,

91, 143, 150, 193, 201, 268, 290-293, 310

anapoinos (ávórtoıvos): without compensation, 292

Apollo, 91, 94, 103, 151-153, 177, 180, 193, 241, 251, 254, 276, 278-279, 285, 289, 292, 300, 311-313, 320-323, 333

Apollodorus, 301

Apollonius Rhodius, 139, 163, 166, 221

Apollophanes, 111

Arcadia, Arcadians, 207, 279, 316, 319, 321, 323,325

archē, 191

Arcesilaus, 304

Ares, 103, 138-139, 142, 151, 202

Arete, 63, 114-116, 121, 124, 126, 141, 159-161, $173,216,224-227,230,235-236,244-246$, 261, 302

Argolid, Argolis, 75, 207, 264, 301-302, 320, 324

Argonauts, 9, 12, 19, 26, 40, 55, 304-305, 325
Argos, 97, 104-105, 118, 131, 207, 209, 219, 314, 320, 322

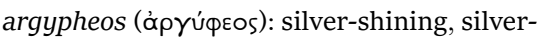
white, 114, 282, 299

Ariadne, 139

Arisbe, 131, 291

Aristophanes, 173, 308-309

aristeia, 98, 101, 104

aristocracy, 7, 190, 268, 337

Aristotle, 39, 51, 99, 144, 174, 212, 326

arms-exchange, 98-99, 100-101, 104-105, 107 , 109,128

Arneus, 224

Artemis, Artemis Limnatis, 103, 138, 321-322

Asia Minor, 299-300, 307

Asine, 320

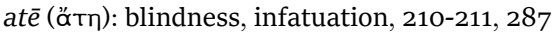

Athenaeus, 101, 279, 325

Athena, 103, 109, 120, 133, 137, 141, 145, 148, 151-152, 154, 158-162, 169-175, 177-178, 197, 199, 206, 216-217, 222, 224, 242, 276, $283,285-286,298,325,341,344$

Athens, 8, 10, 71-72, 111-112, 144, 152, 158, 181, 222, 306, 312, 316, 320

atimia, 199

Atreus, 147, 194, 219

Atropos, 240

Attica, 75, 105, 165, 259, 263-264, 274, 298, 319, 324

Augias, 205, 273

autarchy, 319

authority, 37-38, 58, 6o, 188, 190, 201, 205, 207, 208, 220, 227-228, 246, 253, 264), 304,317

Autolycus (Autolykos), 106, 153

Automedon, 101

Axius (Axios), 102

Axylos, 89, 298

Bacchiads (Bakchiadai), 325

Bacchylides, 113, 146, 181, 256, 298

banquet, 117, 122, 128, 133, 151, 179, 192, 310, $338,344-345$

barley, 217, 298

barter, bartering, 26, 28, 278, 280

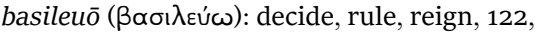
137, 190, 218, 224-225, 340

basileus, basilēes, basileis ( $\beta \propto \sigma \mathrm{\lambda} \lambda \varepsilon \cup$ 's,

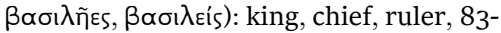
$84,88,116,121-122,137,152,186,188-192$, 198, 202, 206, 215-218, 222, 226, 229, 232, 244-245, 252, 305, 308, 326, 339 
basileia ( $\beta \alpha \sigma i ́ \lambda \varepsilon ı \alpha)$ : mistress, queen, female ruler, 186, 189-190, 224-226, 229-230

basileuteros ( $\beta \alpha \sigma \iota \lambda \varepsilon \cup ́ t \varepsilon \rho \circ \varsigma)$ : more royal, more able to decide, 223

Bathycles, 312

Bellerophon, 97, 99-100, 103, 128, 202-203, 223, 228, 242

benefactor, 313

Bias, 100, 312-313

big-man system, big-men system, 189-190 biotos (ßíotos): livelihood, means of living, 92, 269, 294-298, 310

Bloch, Maurice, 11, 45, 51, 54, 56

Boeotians, 309, 320, 324

Bohannan, Paul, 11, 53, 55

boon, 287

boon-work, 23-24, 36, 40

booty, 100, 119, 149-150, 169, 192, 197, 209, 213 , 235, 241, 252, 257, 273, 296-297, 305, 310

bridewealth, 148, 155, 168, 199 s. also hedna

Brisëis, 16, 148, 150, 185, 195-196, 199, 209210, 212, 222, 247-249, 252

bronze, 69, 97, 102, 104, 116, 118-119, 150, 162, 197, 199, 237, 276, 279, 291, 297, 305, 307,328

Bücher, Karl, 23-26, 30, 36, 40, 42, 48-49, 61$62,71,74,176,267$

Burckhard, Hugo, 27, 30-31, 37

Burgundy, 307

Cadmeans, 207

Calchas (Kalchas), 193, 242, 292

Caligula, 221

Callimachus (Kallimachos), 312

Calypso (Kalypso), 85, 87-88, 91-92, 109, 121, 125, 130, 138, 157, 176, 224, 260, 282, 299

Cardamyle (Kardamyle), 201

Carthage, 303

Cassandra (Kassandra), 248

Castor, 215, 262, 344

cattle, 89, 91, 94, 119, 133, 155, 195, 197, 199, 201, 205, 233, 257, 270-276, 279, 285, 287288, 293, 314, 321, 323-324, 338

Cauconians, 271, 276

cauldron, 68, 115-116, 118-119, 122, 154, 200, 206, 229, 257, 333

centralisation, 191, 326, 340

Cephallenians, 206

Chalkis, 289, 321

Charis, wife of Hephaestus, 84, 109, 157, 174, 208, 299 charis (xópıs): service, grace, favour, thankfulness, gratitude, gratification, beauty, 15, 16, 79, 106, 111, 144-146, 149-

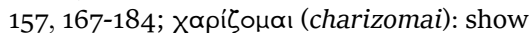
a favour or kindness, gratify, oblige, 144146, 148, 150-154, 159, 167-168, 172; x х 야15 (charieis): graceful, beautiful, 152-154, 177179, 182; वैx $x \propto \rho ı$ (acharis): without grace, ungracious, thankless, 151

Charites, 8, 144-146, 155-157, 159, 161, 169, 170-177, 179-181, 341

Charon, 179

cheese, 86, 91, 93, 205, 207

chiefdom, chieftain, 46, 65-67, 113, 116, 189

Chios, 309

chitōn ( $\chi เ T \omega \dot{v})$ : garment worn next to the skin, tunic, 89, 114, 116, 119-120, 122-127, 130-131, 174, 183, 208, 212, 228, 229, 258, 299

chlaina ( $\chi \lambda \alpha$ ĩv $\alpha)$ : upper-garment, cloak, blanket, 89, 119-120, 122-127, 130-131, 133 , 136, 138-139, 212, 228-229, 302

Chloris, 224

chreios (Хрєі̃os): need, want, use, debt, 15, 55, 79, 267-273, 276

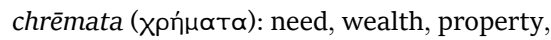
206, 269, 284, 295-297, 308, 310

Chrysëis, 153, 171, 193, 195, 209, 213, 242, 292 Chryses, 91, 152-153, 193, 209, 219, 292

Cilicians, 205

Circe (Kirke), 109, 124-126, 138, 176, 224, 277, 299

Cithaeron (Kithairon), 319

citizenship, 199, 335, 344

class-struggle, 6o, 64-65

Cleisthenes (Kleisthenes), 199

Cleitus, 147

Cleobulos, 312

cloth beam s. antion, 164 (Figure)

Clotho (Klotho), 238-240

Clytemnestra (Klytaimestra), 171, 209, 234, 245

Coans, 312

coinage, 42, 51

Colaeus (Kolaios) 305

Colchis (Kolchis), 298

colonisation, 263, 303, 306

commodity-exchange, 54

competition, 7, 22-23, 46, 66, 100, 105, 133, 189, 220, 280-282, 290, 326-327, 329

concubine, 216, 245

consensus, 52, 6o, 63, 111, 190-191, 230 
copper, 266, 305, 307

Corinth, 147, 207, 228, 279, 301, 308-309, $312,319-321,324-326$

Cornwall, 307

cosmos, 78, 211, 221, 231

council, councillor, 66, 69, 186, 190, 213, 222, 230, 243, 254-255, 264, 277, 283

counsellor, 213, 217-218, 290

counter-gift, 15, 23, 28, 29-30, 48-49, 55, 63, 120, 156, 276, 335

couple, married, 8, 27, 121, 139, 140 (Figure), $168,187,224,227,245,258,311,336,338$, 344

coverlet, 114, 119, 122-124, 126, 138-140

(Figure)

Cranaë, 137

cremation, 258-259

Croesus (Kroisos), 62, 112, 312

Cronos (Kronos), 86, 97, 218-219, 230

Ctesippus, 87

Curetes, 153

cultura, 330

cultural relativism, cultural relativists, 14, 40

cultural turn, 331

currency, 56-57

Cyclops, Cyclopes, 61, 86-92, 94-96, 241

Cyme (Kyme), 288

Cyprus (Kypros), 106, 119, 147, 207, 259, 306, 325

Cypselids (Kyselidai), 325-326

Cypselus (Kypselos), 301

Cyrene (Kyrene), 119, 303, 305

Cythera (Kythera), 106, 301

daidaleos ( $\delta \propto \triangleleft \delta \alpha \dot{ } \lambda \varepsilon \circ \varsigma)$ : cunningly or curiously wrought, 161-162, 172-173

Dardanelles, 207

Dargun, Lothar von, 31, 40, 44

debt, 51, 55, 69, 267-268, 270, 272-273, 276, 288

debt-economy, 54

decision-making, 67, 110, 190, 218, 226, 228, $244,336,340$

Deïkoon, 215

Deinias, 181

Deiphobus, 216, 224, 283

Delphi, Delphians, 8, 17, 105, 112, 180, 277, 279, 300, 309, 312-315, 323-324, 333

Demeter, 175, 289

Democritus (Demokritos), 178

Demodocus (Demodokos), 132, 138, 149, 179, 186,246

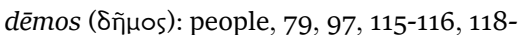
$119,121-122,152,154,180,186-188,193$, 202-203, 205-206, 212-213, 215, 217, 225228, 233-236, 248, 252-253, 264, 270, 272, 275,284

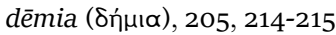

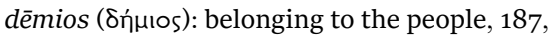
270-271

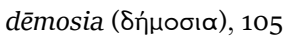

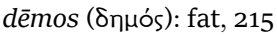

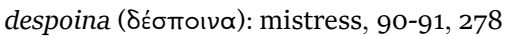

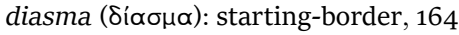

(Figure), s. also exastis

Didyma, 312

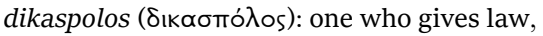
judge, arbiter, 217, 203

$\operatorname{dike}(\delta i ́ k \eta):$ custom, usage, order, righteousness, 211

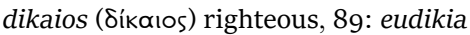

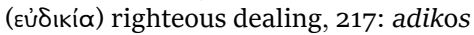

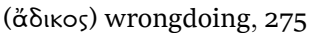

Dike: Goddess of righteousness, justice, 221, 341

Diocles (Diokles), 85, 89, 298

Diodorus (Diodoros), 313

Diogenes Laërtius, 311

Diomedes, 16, 62, 96-99, 101-105, 107-109, $112,128,133,148,162,206,212,215,223$, 242, 282

Dionysos, 139

Dioscuri (Dioskouroi), 113, 344

diplax ( $(i \operatorname{\pi } \lambda \alpha \xi)$ : double-folded mantle, 120, 163, 302

dishonour(ed), 16, 16o, 185-187, 199, 202, $224,228,245,275,284$

distaff, 119, 330

distribution, $11,17,32,44,50,57-59,66,68-$ 69, 74, 100, 190, 201, 213, 215, 222, 225 , 227, 230-232, 244, 257, 306, 318, 337, s. also redistribution

Dmetor, 204

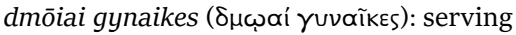
women, 123, 159, 169, 206, 224

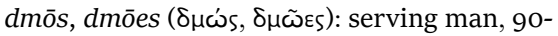
91, 16o, 206, 224

Dolius, 243

Dolon, 94, 150, 282

Dolopians, 131, 205-206, 324

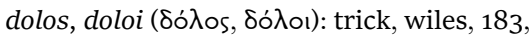
233, 235, 242-243, 245, 285-286

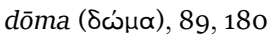

Donlan, Walter, 10-11, 16, 55, 63, 65-67, 74, 81, 96, 99-101, 107, 110, 189), 205 


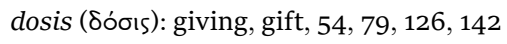
dōron, dōra ( $\delta \tilde{\omega} \rho o v, \delta \tilde{\omega} \rho \alpha)$ : gift, present, offering, 42, 55, 79, 82, 106-107, 113-120, 132-133, 135-136, 142, 150, 152-157, 225 , 227-228, 277, 298

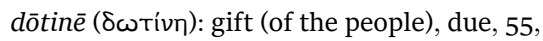
$79,83,86,92-93,115-16,121,200,204-$ 205,220

dowry, 8, 201-202

dues s. dōtinē

Dulichium, 298

Durkheim, Émile, 20-21, 36, 41-42, 50, 63, 230

dye-work, 301-302

Dymas, 158

Echeneus (Echeneos), 226

Echepolus (Echepolos), 147

Eëtion, 207, 257

egoism, 21, 31-32, 34, 49, 53, 80

Egypt, 152, 157, 255, 266, 295-300, 305, 307308

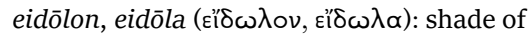
the dead, 256, 259-261

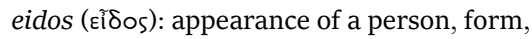
shape, 183, 225, 227, 260

Eirene, 221, 341

Elam, 307

Electra (Elektra), 166

Elis, 206, 272-275, 323

elite, 7, 55, 72, 264, 268, 305, 314, 327, 329

Elpenor, 254, 258

Empedocles (Empedokles), 300

emporion, 307-308

Enope, 201

Ephyra, 301, 318

Epidaurus (Epidauros), 319, 321, 325

epikouroi, 102, 105-106

epinētron (غ́тívптроv): a ceramic covering to protect the knee and thigh and to protect a hard surface for working wool, 240

episkopos, 250, 252

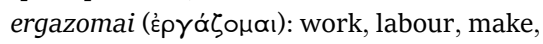
earn by working, 159-161, 206, 249

Eretria, 263-265, 320-321

Erinys, 210

Eriphyle, 197

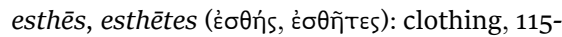
$116,126,118,156,258$

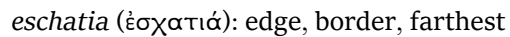
part, 94, 205, 235

Eteoneus, 85, 131
Etruria, 306

Euaephnus (Euaiphnos), 275-276

Euëlthon, 119

Eumaeus (Eumaios), 83, 85-86, 88-92, 94-95, 109, 120, 123, 130-133, 136, 138, 142, 152, 16o, 168, 206, 216, 220, 224, 275, 277, 279, 292-295

Eumelus (Eumelos), 205

Euneos, 266, 291

eunomia, 221, 341

Euphetus (Euphetos), 205

Euphorbus (Euphorbos), 177, 208

Euphrosyne, 180

Euripides, 10

Euryalus (Euryalos), 179, 267, 269, 281, 311

Eurycleia (Eurykleia), 159, 210, 216, 224, 228, 245, 292-294

Eurymedon, 225

Eurymedusa, 209

Eurynome, 170

Eurystheus, 206

Eurytos, 107

evolutionism, evolutionary theory, 14, 34, 40, 64,65

exogamy, 325

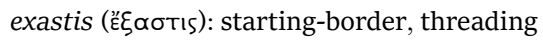
band, 164 (Figure)

Ezechiel, 305, 310

fame, 9, 217, 244-245, 252, 255-257, 282, 285, 336

fate, $147,159,169,217,236-240,244,252$, 254, 26o, 286, 292-293, 299

favour, 15, 29, 33, 35, 42, 45, 65, 87, 106, 109, $111,133,136,142-148,150-154,167,181-$ 182, 232, 252, 329

Finley, Moses I., 10-12, 14, 16, 49, 61-68, 70, 72, 74, 80, 96, 98-99, 101, 104, 149, 161, 189, 203-204, 236, 294, 329

flax, 208, 266, 297-298, 329-330

footbath, 126

friendship, 25, 35, 68, 105, 107, 109-113, 119, 127, 133-134, 139, 144, 149, 228

funeral, 56-58, 154, 168, 182, 191, 229, 247 , 253-256, 259, 265, 312, 318, 332, 334, 336338f, 341, 343-345

funeral games, 100, 153, 156, 191, 199, 256257, 262, 280-281, 291, 315, 336, 345

Gaetulia, 301, 303

Gaia, Ge, 108, 231

Gaul, Wilhelm, 34-35, 37 
Geleitherrschaft, 232, 339

generosity, 8, 10, 28, 31, 33-35, 55, 66, 67, 201, 226, 228, 313, 339

genos, 230

Geraneia mountains, 321

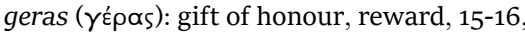
$79,142,150,168,185-189,191-195,198-$ 199, 203, 209-210, 212-13, 215, 217, 223 , 229, 232-236, 243-247, 254, 263, 266, 279,

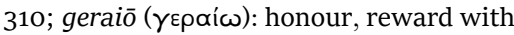

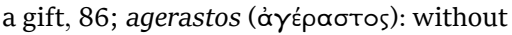
a gift of honour, unrecompensed, 192, 209 gēras ( $\left.\gamma \tilde{n} \rho \alpha_{5}\right)$ : old age, 208, 244

Gernet, Louis, 10, 62-63, 65, 213, 313, 325-326 Gierke, Otto, 27-30

gift-exchange, 9-25, 27-30, 32-43, 45-55, 6o-63, 65, 67-70, 72, 74, 76, 98-100, 109, 201, 269, 280, 290, 306, 307, 313, 333, 336,340

gift-giving, 9-11, 13-14, 23-25, 27-31, 35, 3839, 46-47, 49-52, 61-65, 67-68, 71, 76, 83, 98-99, 115, 118, 144, 227, 310, 333, 343

gigantomachy, 344

girdle, 138-139, 156, 239

goblets, 112-113, 257

godlike, 116, 121, 153-154, 202, 216, 236, 251

Glaucus (Glaukos), 16, 62, 96-103, 105, 107109, 111-112, 128, 150, 202, 216

gold, 94, 97, 99-104, 106, 112, 114-121, 150, 170, 172, 175, 177, 197-198, 200, 207-208, 229, 257, 291, 295-298, 305, 307, 326

golden, 9, 97, 112-114, 118-122, 124-125, 135 , 139, 154, 156-157, 172, 175, 237, 258, 295 , 299, 311, 336

goods-exchange, 9, 11

goos (Yóos): lament, complaint, 246-254, 269 s. also lament

Gorgon, 166

Graces s. Charites

grain, 9o, 93-94, 119, 153, 266-267, 269, 288289, 297-298, 303

gratitude, 29, 34, 182

graves, 114, 119, 165, 254, 306

Grimm, Jacob, 28, 76

guest-friendship, 11, 42, 54, 62, 67, 69-70, 80-83, 86, 88, 91-92, 96, 98-99, 101, 104105, 107, 109-113, 117, 121-122, 135, 139, 156, 245, 257-259, 276-277, 290, 296, 305-306, 310-312, 315, 325-326, 335-336, 338-340

guest-gift, 15, 29, 35, 42, 54-55, 68, 72, 73, 79, 8o, 96-97, 107, 113-114, 119-120, 182, 191, 257, 291, 305-306, 313, 333, 337-339
Hades, 92, 179, 192, 231, 234, 237, 246, 247 , 256, 258-259, 278

hair, 109, 130, 169, 177, 183, 208, 214, 220

hairband, 172

Halbwachs, Maurice, 41, 141

Halitherses, 148

Harpalion, 106

Hasebroek, Johannes, 267, 290, 308

heanos (غ̇avós): fine robe, 162, 258

Hebe, 176

Hector (Hektor), 94, 101-104, 106-108, 134 , 141-143, 147, 149, 154, 16o-163, 169, 174, 177-178, 183, 191, 196, 212, 214-216, 229, 236-238, 240, 246-252, 254-258, 263, 283, 286, 291, 302

Hecuba (Hekabe), 88, 174, 208, 224, 238, 248-250, 252, 254, 299, 303

Heddle, s. mitos

heddle bar, heddle rod s. kanōn, 164 (Figure) hedna (" $\delta \vee \alpha)$ : bridewealth, wedding-gifts, 55 , 155,199

hēgemonia, 191

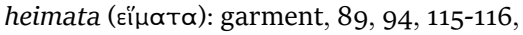
$123,126,130-133,170,173,176-179,195$, 228, 245, 258, 299

heirloom, 58, 107, 312

Hekamede, 209

Helen, Helena, 85, 113, 117-120, 128-129, 131, $134,137,139,141,159-163,166,173-174$, 176, 192, 196-197, 211, 227-228, 234, 248, 251-252, 262, 283, 286, 295-297, 299-300, 302, 305, 307, 312, 345

Helice (Helike), 152

Helios, 152, 91, 108, 135, 138, 231, 235, 276

Hellespont, 112, 255

Hephaestus (Hephaistos), 84, 103, 114, 157, 16o-162, 167, 170, 174, 197, 219, 311

Hera 103, 109, 133, 138, 142, 152, 156, 162, 172, 206, 224, 229, 238, 254, 299, 303, 305,322

Heracles (Herakles), 272-273, 312

Heraclides, 308, 325

Heraion, 263, 314, 320-321, 324

herdsmen, 83-84, 86, 88-95, 120, 206-207, 269, 275-276, 279, 289, 290

herkos (घ̈ркољ): fence, enclosure, 277

hermai, 278

Hermes, 85, 87-88, 91, 103, 133, 143, 152-153, 176, 179, 180, 219-220, 261 (Figure), 278280, 285, 289, 316, 325

Hermione, 301

Herod, 222 
Herodotus, 10, 84-85, 93, 111-112, 119, 296, 298-300, 303, 305, 307-309, 326

hero-cult, 17, 74-75, 192, 263-264, 322

hero-worship, 14

Hesiod (Hesiodos), 23, 139, 172, 180-183, 221, 266, 281, 287-289, 325, 341

Hestia, 180

Hesychius, 300

hetairoi, 159, 187, 216

Himalaya, 320

Hippolochus, 150

Hippomachus, 147

Hire, 201

histopodes (ібто́тобєs): loom upright, 164 (Figure)

histos (iđTós): loom, beam of the loom, 162, 169, 173, 176, 178, 209, 233-235

Historical School of national economy, 13-14, 20-26, 42

Historical Legal School, 30-32, 34

homo oeconomicus, 21, 24, 37, 71

honey, 258, 301-302

honour s. time

Horae (Horai), 241, 341

horkia (öркıа) oaths, swearing solemnly at a sacrifice, 70, 108-110, 134, 137, 383

horkos (ӧрко ): oath, 109, 277, 320

hospitality, 32-34, 37, 39, 61, 69-71, 80-87, 89, 92-93, 95-96, 106-107, 109, 112-113, $118,120-121,123-123,126-131,133-136,139$, 144, 151, 213, 226-228, 261, 272, 277, 305

household-economy, 40

Huelva, 305

hyphainō (úqaívw): weave, 116, 162, 169, 181, 233, 242-243, 302

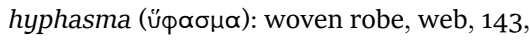
166

Hypnos, 156

Hypsenor, 215

Idaeus, 135, 196

idion ('́̊ıov): one's own, 144, 187, 270-271

Idomeneus, 129, 16o, 205-206, 214

Ilus, 255, 296

Imbros, 251

immortality, 177, 179, 232, 259, 262

individualism, 20, 30-31, 37, 40, 43, 48

Indonesia, 164, 343

Ino Leucothea s. Leucothea

international law, 32, 110

Ion, 166
Iphidamas, 155

Iphigenia, 166

Iphitos, 107, 111-112, 272, 276

Iran, 306

iron, 150, 257, 297, 303, 305, 307, 330, 333

Iron Age, 74, 329-330

Isthmia, 309, 321

Isthmus, 301, 308-309, 314

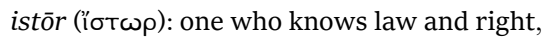
judge, 221

Italy, 317, 320, 322, 324, 327

Ithaca, 87, 90, 94-95, 109, 116-122, 131, 135, 16o, 170-171, 173-174, 189, 196, 218-219, 227, 233, 235, 271-272, 275, 277, 295, 302, 309, 313-314, 324

Jason, 166, 221, 291

Jhering, Rudolf von, 31-34, 36-37, 39, 72, 73, $80-82,88,290$

judge, 225, 227, s. also dikaspolos

kairos (kaĩpos): shed bar, 164 (Figure)

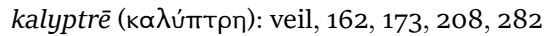

kamnō (ка́ $\mu \nu \omega)$ : toil, labour for someone, 161-162, 166-168, 195, 241, 254; kamatos

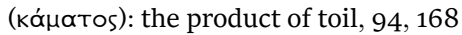

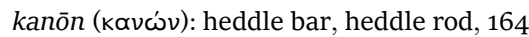
(Figure), 239

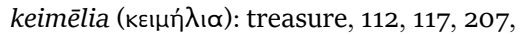
297

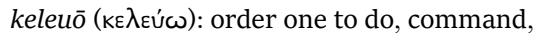
16o-161, 243

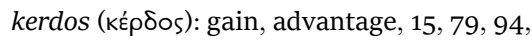
267-269, 275-276, 280-290, 297, 326;

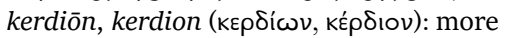
profitable, more advantageously, 280-

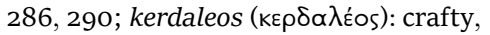
cunning, 280-282, 285-286; kerdaleophrōn

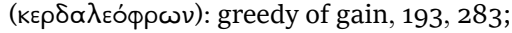

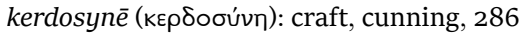
kerkis (кєркís): weavers's shuttle, 164 (Figure) $k \bar{e} r, k \bar{e} r e s$ (кńр, кñрєs): doom, weights in scales of Zeus, 240-241, 260

kerostasia, 260

kidnapping, 280, 310

kinship, 64-66, 68, 104, 107, 149

Kinyras, 106, 147

kleos ( $\mathrm{\lambda} \lambda$ Éos): rumour, good report, fame, 101, 177-118, 212, 217, 246, 255-258, 262, 265256, 282-283

klēroi ( $\mathrm{\lambda} \lambda \dot{\rho} \rho \mathrm{s})$ : lots of land, 203

klōthō ( $\mathrm{\lambda} \lambda \omega \theta \omega)$ : spin, twist by spinning, 240 
kindness s. aganophrosynē

kingship s. basileus

Knossos, 218, 306, 316

Koatoporeia, 207

koiranos (кoípavos): military leader, 218

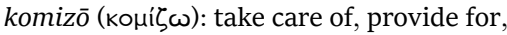

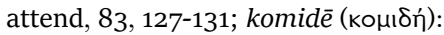
attendance, care, 130

Köstler, Rudolf, 48, 61-62, 69, 88, 110, 155, 220-221

kratēr (крати́р): mixing bowl, 117, 122, 135, 228, 263

kratos (кра́то५): strength, might, power, 115 , 191-192, 226

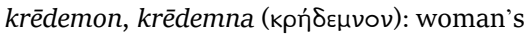
head-dress, veil, 141, 171, 197, 208, 232, 241, 260-261, 299

Krethon, 194, 240

Krisean plain, 324

krokē (кро́кп): weft thread, 164 (Figure), 239

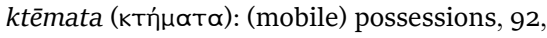
115, 134, 196, 207, 225, 235, 295-297, 310

kudos (kũठos): glory resulting from victory in the battle, renown, 101, 104, 152, 192, 198199, 214, 222-223, 238, 283

Kula, Kula ring, Kula traders, 9, 12, 37, 57

Labda, 301

labour, 23, 40, 65, 74, 94, 145, 16o-161, 167$168,183,204,206,250,263,279,309-310$ labour force, 74

Lacedaemonians, 111, 275-276

Lachesis, 240

Laconia, 301-304, 321

Laërtes, 89, 120, 122, 127-129, 157, 16o, 178, 206, 233, 235, 243, 245-246, 263, 277, 293-294

Laestrygonians, 87, 94, 96

laiai = agnythes: loom weights, 164 (Figure)

Laius (Laios), 319

lament, 192, 246-249, 252-254, 258, 263-265, 269 s. also goos, thrēnos

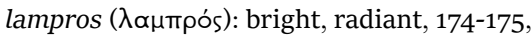
178

lanolin, 174

Laogonos, 215

Laomedon, 94, 138, 151, 242, 292

Laothoë, 102

Laum, Bernhard, 18, 42-43, 48, 50, 61, 120, 276

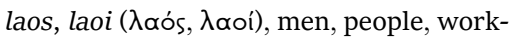
people, 106, 151, 171, 186, 206, 214, 216$217,219,227,244,249,271-272$ lead, 305

Lechaion, 308

Lefkandi, 114, 259

Leiodes, 150

Lelegans, 206

Lemnos, 213, 251, 291, 302, 305

Leto, 103

Leucothea (Leukothea), 232, 241, 260, 262

Levi-Strauss, Claude, 45-46, 54, 68

leukos ( $\lambda$ Eukós): light, bright, clear, white, 175 , 178,258

liberal theory, 13, 39

Libya, 207, 292, 303

lifespan, 58, 259, 262

Lindos, 298, 312

Linear B, 124, 157, 189, 205, 277, 316

linen, 114, 122, 125, 126, 174, 208, 258, 266, 269, 295, 297-299, 310

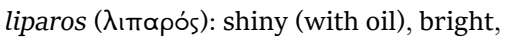
brilliant, radiant, splendid, 171, 174, 200201, 208, 221, 243-244, 299

Litae (Litai), 211

liturgies (leitourgiai), 29, 50, 152

livestock, 28, 76, 84, 87, 93, 95, 266, 271-28o, 284-287, 289-289, 294, 297, 309-310, 315316,323

loan, 22

Lobates, 207

loom, 91-92, 114, 157, 161-165, 168, 176, 182, 184-185, 209, 233, 239-243, 266, 329-330, 338

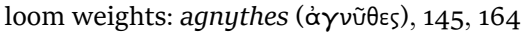
(Figure)

Lucretius, 301

Lycaon (Lykaon), 257, 291-292, 295, 297

Lycia, 97, 104, 147, 189, 202, 207

Macedonia, 152, 309

Magna Graecia, 305

Maleia, 278

Malinowski, Bronislaw, 9-12, 14, 19, 25-26, 33, $41,44-45,50,53-57,62-63,331$

Manticlus, 276

market-exchange, market-economy, 19, 48, 52

Mari, 307

marriage, 54, 58, 61-64, 67, 102, 117, 138-139, $141,144-145,148,155-156,171-172,200$, 202, 223-224, 232-234, 238, 241, 312, 322, 325-326, 332, 336 
Martial, 10

Massilia, 307

materialism, 40

matriarchy, 14, 64, 236

Mauss, Marcel, 9-11, 13-14, 19-20, 27-28, 3239, 41-45, 47-50, 53-57, 6o, 62-63, 65, 67, $70,76,98$

meat, 5o, 86, 91, 95, 124f., 128, 180, 197, 202, 205, 215, 235, 297

Medon, 224

Megara, 319-21

megaron ( $\mu \varepsilon ́ \gamma \propto \rho \circ \nu), 115,128-129,162,233$, 235, 251, 297, 299

mēla $(\mu \tilde{n} \lambda \alpha)$ : sheeps or goats, small cattle, 95 , 197, 202, 217, 279

Melanthius, 295

Melantho, 160

Meleager, 153, 203

Melissa, 301, 325

Melos, 106, 300

mementoes, 113, 117-118, 122

memorialisation, 262

memory, 16, 59, 63, 77, 79, 98, 118, 121, 136, $146,176,181-182,232,243-245,252,255$, 262, 299, 307, 336, 341, 344-345

Menelaus, 85, 101, 103, 105-108, 117-119, 122, 129, 131, 134-136, 139, 150, 16o, 181, 183, 187, 194-199, 205-207, 214, 223, 230, 238, 242, 255, 270-271, 281-282, 295-298, 303, 305, 307, 311

Menidi, 263

Mentes, 62, 120, 126, 197, 206, 233, 277, 296, 301, 305-306

Mentor, 109, 207, 271, 276

mercenary, 296

Meriones, 106

Mesopotamia, 306

Messene, 272, 274, 276

Messenia, 208, 263, 312, 321

Messenian War, 275-276, 321

Mesta, 317-318

metal-routes, 306-307, 309

metalwork, 161-162, 221

Metaneira, 175

mētis ( $\mu$ ñTıs): cunning, wisdom, skill, craft, counsel, plan, 100, 218, 232, 242-43, 282, 285

Meyer, Richard M., 29-30, 35-36, 51, 70

migration, 205, 276, 278, 303, 315-319

Miletus, 312

Minos, 218, 225 misogyny, 245

misthos ( $\mu$ ıөós): hire, wage, recompense, reward, 94, 144, 152, 237, 241-242

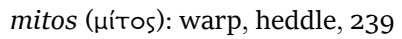

mixing bowl, 113, 117, 119, 122, 125, 135, 166 (Figure), 257, 391, 295, 302, 305, 307, 336

mnēma ( $\mu \nu \tilde{\eta} \mu \alpha)$ : memorial, memento, remembrance, grave mound, 107, 254-255

Mnemosyne, 341

moira ( $\mu$ ĩpa): one's portion of life, lot, fate, destiny, 237, 240, 275-276, 297

Moirae, Moirai, 210, 221, 238, 240, 341

Mommsen, Theodor, 37, 81

monarchy, 64, 189-190, 201, 203, 229, 337

money, 18, 25, 33, 42-43, 51, 54, 195

moral economy, 46, 47, 53

Morocco, 303

mother-right, 63

murex, 269, 301-306

Muse, Muses, 113, 144, 180, 253-254, 279, 341

mutualism, mutuality, 21, 30-31, 53

Mycenae, Mycenaean, 16, 63-64, 74, 98, 100, 105-106, 124, 139, 157, 159, 165, 188-190, 201, 203, 205-208, 224, 240, 259, 263, 274, 290, 297, 303, 306, 316, 320

Myrmidons, 206-207, 216, 248

mythos, 242, 186

Mytilene, 312

Naucratis, 307-308

Nausicaa, 117, 121, 126, 138, 142, 158-159, 169171, 176, 224, 226, 261, 278, 286, 299

nectar, $84-85,258$

neighbourhood, 325

Nektunebo I., 308

Neleus, 124, 224, 273-274

Neoptolemus, 209

Nereid, 258

Nestor, 84-85, 101, 106, 109, 122, 124, 128129, 135, 141, 153, 176, 186-187, 206-209, 211-213, 216, 218, 222-224, 238, 242-243, 270, 272-274, 281, 295-296, 302

Niobe, 168, 254

Noëmon, 275

noos (vóos): mind, sense, wit, 138, 281-282

nymph, 85, 88, 91, 232

oath, 62, 69-70, 98, 107-110, 121, 134-135, 137, $141,144,178,180,230,277,294$

Oceanus (Okeanos), 138, 239 
Odysseus, 16, 67, 81, 84-95, 101, 105-107, $109,111-113,115-123,125-133,136-138,141-$ $142,147-154,160,162,168-171,173-176$, 178-179, 185, 193-194, 197-198, 203-206, 210, 212, 216-218, 224-228, 230, 232-237, 241-244, 246, 254, 258-261, 267, 269-270, 272, 275-279, 281-286, 292-294, 296-299, 301-302, 306-307

Oedipus (Oidipous), 207, 319

Oenussae (Oinoussai), 309

Oineus, 97, 99-100, 103, 128

oikos, 72, 123, 128, 141, 189, 228, 233, 245, 271, 297, 334

olbos (ö $\lambda \beta \circ$ ): happiness, bliss, wealth, 238 , 244, 279, 288

Olympia, 108, 274, 285, 313-314, 323-324

offering, 11, 84, 89, 108, 143, 147-148, 150, 152-154, 159, 162, 177, 204, 222, 262, 265 , 298, 312-313, 315, 333, 337-339

office holding, 67

Onchestos, 279, 321-322

ōnos (ฝَvos): ransom for a person brought to foreign people, purchase-money, price, 15, 55, 79, 89, 257, 267-269, 280, 290-295, 297,310

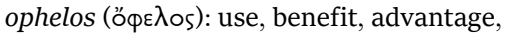
150, 178, 281

oral poetry, 16, 77, 100, 161, 181

Orchomenos, 174-175, 205, 207, 321-322

Orestes, 166, 245

Orsilochus, 194, 240

Ortilochus, 205, 272

othoninum, 299

Ouranos, 231

Palmyra, 164, 308

Panakton, 320

Panathenaia, 146, 158, 341

Pandora, 162, 172f., $183 f$.

Pandareus, 16o, 241

Pandarus, 147, 150, 283

Paris, 103, 106-107, 129, 134-135, 137, 141, 173, 183-184, 196, 211, 251, 283, 311

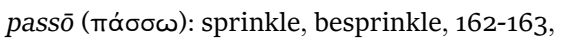
166

pasture, 93, 95, 266, 270, 274-276, 278-280, 284-285, 290, 293, 309, 315-318, 320-325, 338,340

patricide, 245

Patroclus, 84, 101-102, 134, 141, 148-150, 153, 168, 177-178, 194-195, 198-199, 216, 240, 246248, 251-255, 257-259, 280, 283, 303, 305 patronage, 68, 72, 205

pattern-weaving s. weaving

Pausanias, 104, 274-276, 279, 301, 321-322

Pedasus, 201

peirar (пєір $\propto$ ): rope, weft, end, completion, 239-240

Peisistratus, 16, 85, 89, 118, 124, 131, 135, 230, $235,238,326,340$

Peithetairos, 309

Peitho, 172

Peleus, 84, 88, 102,131, 200, 205-206, 223, 238, 257

Pelops, 219, 311

pēnē $(\pi \eta n v \eta)=k r o k \bar{e}:$ weft thread, 164

(Figure), 243

Penelope, 16, 63, 78, 89, 91-92, 115, 118-122, 126-131, 136, 138, 141, 148, 150, 159-162, 170-173, 178-179, 185, 189, 196-198, 208, 210, 212, 217, 224, 227-228, 232-237, 240, 242-244, 246, 26o, 263, 281, 284-286, 299, 335

pēnion $(\pi \eta v i ́ o v)=$ kerkis: $($ weft $)$ spool, 164 (Figure), 239

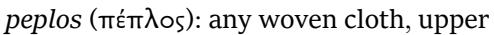
garment worn by women, robe, 117-120, $122,126,139,141-143,156,158,161-162$, 174, 177-178, 181, 229, 258, 299, 302-303, $325,341,344$

Perachora, 321, 324

Peraeus, 129, 228

Periandrus, 301, 308, 312, 325

Pericles, 105

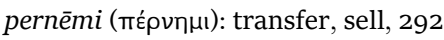

Persephone, 92

Perses, 288

Persia, Persian, 10, 85, 111, 152, 190, 265, 296, 344-345

Phaeacia, Phaeacians, 90, 92-93, 113-116, 118, 120-123, 125-128, 130, 141-142, 154, 159, 161, 170-173, 179, 197-198, 204-206, 208, 216-217, 225-227, 230, 232, 238, 241, 244245, 267-270, 284, 302, 337

Phaidimus, 122

Phainos, 106

Phanodikos, 313

pharmakon (фápuaкov): drug, medicine, chemical reagent, poison, 176, 277, 295296, 299-301, 306

Pharnabazus, 111-112

pharos (фа̃рos): cloak, mantle, 114, 116, 119, 122, 124, 126-127, 176, 178, 208, 229, 233235, 237, 258, 282, 299, 302 
Pherae, Pherai, 89, 201

Pheretime, 119

phiale, 257-258, 312

Phigalia, 275

philia ( 119

Philochoros, 298

Philoctetes, 206

Philoetius, 94-95, 206, 275

philotēs ( affection, intercourse, 83, 107-108, 110, 118, 127-129, 133-139, 141, 143-144, 149, 155-156, 171, 212, 227-229, 245, 310, 338; phileō ( affection, 83, 89, 105, 127-133, 137, 159, 186, 218, 227, 277; philos, philē (qí̀os, фí $\lambda \eta)$ : beloved, dear, one's own, 141-142, 144, 159, 170-171, 250-252, 259, 294, 298, 336

phoinikoeis (фоเvıкóєı): purple-red, crimson, red, 302

phortos, phortia (фо́ртоs, форті́): load, freight, cargo, 268, 288-289, 308

phrēn (фрі́v): mind, thought, 97, 99, 137, 169, 171, 173, 179, 181, 210, 225, 235, 242-243, 286

Phocaeans, 307, 309

Phoenix, 126, 131-133, 147, 205-206, 211, 223 , 245,269

Phoenicians, 82, 290, 292, 294-295, 303, 305, 307, 310

phoros, phoroi (фópos, фópol): that which is brought in, tribute, 207, 309

Phthia, 106, 131, 194, 206, 248

Pieria, 279

pirates, piracy, 269-270, 275, 296, 308

Pithekussai, 306

Plakos, 218, 224

Plataea, 262, 296, 303

Plato, 84, 99, 211, 240, 254, 276, 326, 341

Pliny (Plinius), 299-301, 303, 316

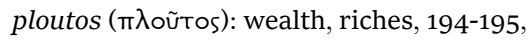
238, 279, 288, 298

Plutarch (Plutarchos), 9, 298, 301, 312-313

Pindar (Pindaros), 10, 146, 174-175, 177, 180182, 304-305

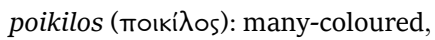
patterned, 117, 138, 161-163, 181, 346 poinē (пoเví): blood-money, were-gild, fine, penalty, 55, 195-196; nēpoinos (vímoıvos): without fine, without compensation, 92, 168, 196, 285, 297
Polanyi, Karl, 10-11, 39, 43-44, 52-53, 144, 267, 308

polis, 10, 15, 17, 51, 59, 64-68, 71-74, 79, 100111, 152, 192, 199, 207, 211, 252-253, 263264, 271, 277, 284, 295, 297, 314, 318, 320, $322,326,333-334,340$

Pollux, 208, 299-301, 344

Polybius, 275

Polybus, 119, 295, 305, 319

Polycaste, 124, 126

Polychares, 275-276

Polycrates, 326

Polydeuces, 262

Polydorus, 102, 291

Polygnotus, 105

Polyneices, 105, 206

Polyphemus, 83, 86-89, 91-96, 116, 121, 204, 207, 242, 270, 323

pompē (понти́): conduct, escort, procession, 93, 115-16, 122, 132, 226-228, 238-239

porphyreos (порфúрєоร): purple, 112, 120, 124-126, 175-176, 258, 302

Poseidon, 94, 103, 151-152, 198-199, 227, 230232, 239, 241, 276, 282, 292, 309, 321

potlatch, 20, 35, 37, 46, 50, 62-63, 67, 98-100

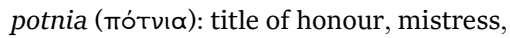
female ruler, 141, 157, 224, 229, 232, 247248, 250, 293

power, 17-18, 22, 37-40, 45, 57-6o, 63, 67-68, 70, 72-73, 79, 99, 115, 146, 156, 16o, 169, 175, 181-182, 185, 189-192, 196, 200-201, 207, 211, 218-219, 220-223, 226-228, 230, 232, 234, 236, 240, 243-245, 252, 264, 281-283, 300, 305, 309, 314, 318, 323, 326, 336-340

prēktēr (прпкти́р): accomplisher, one who does or executes, 268-270

pre-state(hood), 16, 61-62, 65, 68-70, 72-73, 339

prestige goods, 9, 11, 53, 67, 69, 73, 314

prēxis ( $\pi \rho \tilde{\eta} \xi 15)$ : doing, transaction, business, 15, 79, 187, 267-271

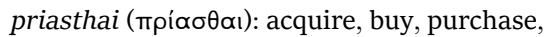
292-294; apriatēn (ámpıórт̄)): without purchase-money (ōnos), 292-293

Priam (Priamos), 93, 102, 105, 129, 141-143, 168, 196, 206-207, 215, 220, 228, 236, 238, 249, 253, 257-258, 269, 291

price, 15, 44, 108, 154, 267, 276, 290-293, 308, 310

Priene, 312

private, $19,48,64,68,96,187-188,201,203-$ 204, 212, 271, 329 
prize s. aethla

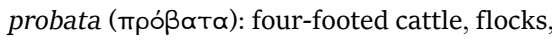
herds, sheep and goats, 278-279

profit, 15, 19, 25-26, 41-42, 44, 46, 49-52, 54, 66, 94, 98, 233, 267-268, 275, 279-282, 284285, 287-290, 292, 294, 305, 311, 326, 330

Proserpina, 166

Prosymna, 263

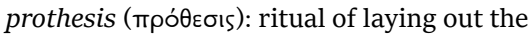
dead corpse and lament, 166, 246, 253, 258, 263

Psammetichus I., 296

psychē, psychai, 259-26o

public, 22, 29, 69, 80, 86, 101, 105, 179, 187188, 197, 210-211, 214-215, 220, 233, 253, 271,344

purchase, 26, 28, 42, 266, 268, 290

purple, 99-101, 107, 113, 120, 122, 124-126, $139,163,173,175-176,178,208,245,258$, 263, 266, 295, 301-305, 310, 319, 326, 345 purple-dyeing, 301, 303

Pylos, Pylians, 85, 109, 118, 122, 134-135, 152, 171, 201, 206-207, 218, 224, 235, 270-275, 279, 296, 302, 316

quit-money, 195

Rachi, 301

rag, 126

ramson s. apoina

rationalism, 19, 40, 42, 48, 51

reciprocity, 9-12, 21-26, 29-30, 36-37, 43-44, 47-48, 50, 52-59, 62, 67-68, 71, 76, 81, 96, 98, 110, 120, 133, 143-144, 146, 149-151, 153-154, 156, 159, 167-168, 182, 184, 186, 188, 190, 202, 204, 277, 287, 310-311, 334, 338

redistribution, 44, 57, 65, 307

replacement, 52, 57, 59, 66

revenge, 88, 129, 135, 198, 247, 249, 254, 277, 344 s. also tisis

Rhadamanthys, 241

rhakos (ṕókos): ragged, tattered garment, 126

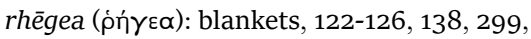
302

Rhexenor, 236

robbery, 36, 39, 280, 290, 295

rod s. kanōn, 164, 239

rosette-motif, 163, 166

rulership, 10-11, 54, 63, 67, 70-71, 73, 79, 188190, 192, 200-201, 205-207, 209, 217, 219, 225, 231-232, 309, 339 sacrifice, 11, 29, 50-51, 88, 108-110, 128, 133 , 134, 137, 141-142, 152, 154, 231, 276, 290, 309, 324, 338, 341

Sahlins, Marshall, 11, 38, 50, 53-55, 60

Salamis, 119, 306

salt-money, 54

Samaina, 326

Samoa, 55, 57-59

Samos, 267, 275, 299, 305, 326

Samothrace, 251

sanctuary, 299, 305, 309, 312, 315, 320-321, 323, 325

Sappho, 175, 177, 180

Sarakatsani, 275

Sardis, 298

Sarpedon, 101, 103, 150, 178, 202, 204, 206, 216, 233, 225, 240, 254, 257

sceptre s. skêptron

Schedius, 206

Schmoller, Gustav von, 21-22, 44

Schurtz, Heinrich, 35, 54, 56

Scopas, 344

sea-trade, 269

Selene, 231, 235

self-interest, 21, 25, 31, 51, 53, 6o, 71, 81-82, 313

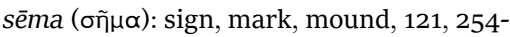
257, 262

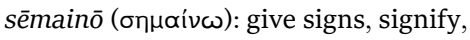
indicate, point out, 214, 223 ,

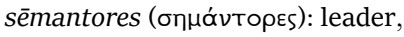
commander, informer, guide, 227-228

Seneca, 10, 240

Service, Elman, 6o, 65

Seven Sages, 9, 17, 311, 313, 323

shame s. aidōs

sheep, 88, 93-95, 155, 197, 202, 205, 207, 217, 233, 272-273, 275, 279, 289, 293, 316-317, 325,333

shepherd, 92, 94, 97, 102, 116, 120, 123-123, $136,151,216,219-220,227,237,243,268-$ 269, 272-273, 275-276, 279, 281, 284-285, 297, 318-320, 323, 333, 339

shroud, 78, 114, 164, 178, 182, 191, 232-236, 240, 259-26o, 262-264, 299, 335-337, 341

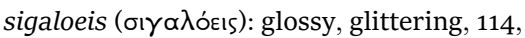
229

Sicily, 145

Sikyon, 147, 218, 225

Sidon, Sidonian, 109, 117, 141, 163, 257, 291294, 303, 305 sight, 24, 54, 138, 154, 226-227 
silphium, 304

silver, 101, 107, 114, 117, 119, 124-125, 172, 175, 177, 197, 208, 251, 256-257, 291, 295-297, 299, 301-303, 305, 307, 326, 336

Simiand, François, 36

Simmel, Georg, 36

Simonides, 253, 344

Siphnos, 298, 326

slave-labour, 268

slave-trade, 294

skēptron (бкñாтроv): staff, stick, sceptre, 175, 208, 217, 218-223, 225-227, 229-230, 236

Smith, Adam, 21, 39-40

Socus, 224, 241

Solon, 8-9, 65, 199, 287, 312-313

Somló, Felix, 24, 36, 74

Sophocles, 320

Spain, 306-307

Sparta, Spartans, 62, 85, 105, 111-112, 118, 124-125, 128, 159, 161, 171, 187, 201, 204, 227, 235, 275-276, 286, 295-296, 305, 312, 321

Sphinges (sg. Sphinx), 259-260

spindle, 119, 161, 168, 173, 240, 266, 295, 299, 329-330

Spinning Mule, 329

spinning wheel, 329

spoils, 116, 185, 194, 199

spool, 239, s. also pēnion

starting-border, 239, s. also exastis, diasma state, statehood, 10, 16-17, 32, 38, 42-43, 48, 52, 6o-61, 64-73, 91, 99, 107, 133, 136, 144, 187-188, 201, 207, 210-211, 220, 245, 262, $273,318,330$

stēmōn, s. warp thread

Stesichorus, 177

Sthenelus, 148, 223

Strabo, 274, 308, 320

structuralism, structuralist, 14, 51, 88, 91, 334

Styx, 231

subsistence, 11,53

Sumatra, 167, 262

symmachia, 110

symposium, 99, 121, 332, 336

Syria, 295, 298, 306

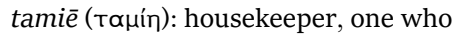
distributes, dispenser 85, 124-125, 209, 237

tapestry, tapestries, 221-222, 345-346 tapētes (тóntттєs): carpets, rugs spread on seats and beds, 112, 119, 122, 124, 126, 131, 229, 302

Taphians, 62, 206, 293

Taphos, 301

Tartaros, 231

Tartessos, 305, 307

Taurus, 307

tax, taxes, taxation, 23, 31, 35, 61, 66, 70, 204, 308, 318, 339

tears, 132, 168, 209, 220, 248, 250-251, 253254,300

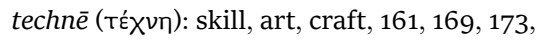
181

Tegea, 325

Teiresias, 219

Telemachus, 62, 85, 89, 92, 95, 109, 117-118, 120, 122-126, 129-131, 134-136, 139, 141, 148, 154, 161-161, 170-171, 174, 176, 187, 197-198, 203, 206, 216-219, 224, 227-228, 233-235, 242, 270-271, 275, 277, 284, 286, 290, 295, 297, 299-300, 302-303, 305, 310

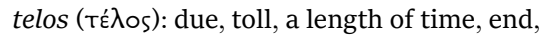
state of completion, something ordered to be done, 180, 196, 240-242, 244

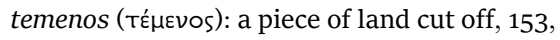
200-204, 213

Temesa, 305

Teucer (Teukros), 101

textiles, 7, 18, 56-58, 70, 78, 82-83, 88-92, 112-114, 116-119, 122-124, 127-128, 133, 138$139,143,145,157-158,161-166,173,176$, 181-182, 195, 197, 221, 229, 239, 241, 245, 257-258, 262-263, 265, 269, 291, 296-299, 302-303, 307, 328-329, 333-337, 339, 341343,346

thalamos ( $\theta \dot{\alpha} \lambda \alpha \mu \circ \varsigma)$ : chamber, store-room, bedroom, 114, 117, 270

thalassa ( $\theta \dot{\alpha} \lambda \alpha \sigma \sigma \alpha)$ : sea, 172, 193, 217, 231

Thales, 312

Thangka, 222

thankfulness, 145

Thasos, 298, 305

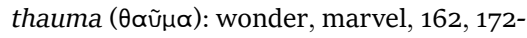
173, 194, 345

Theagenes, 78, 344

Theano, 130, 142, 156, 228

Thebes (Boiotian), 105, 157, 206-207, 312, 321-322

Thebes (Egyptian), 119, 205, 295, 305, 307

Themis (personification of good counsel), 69, 220-221, 315, 341, 345 


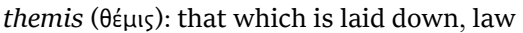
as established by custom, 84, 87, 96, 175,

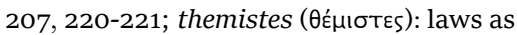
established by custom, phoroi, 93, 200-201, 204, 207-208, 218-222, 225, 230, 243-244,

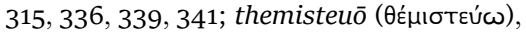
ministering law 90; themistopolos

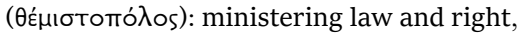
175

Themistocles, 346-347

Theoclymenus, 129, 136, 206, 228, 230, 234

Theognis, 268, 325-326

Theocritus, 119, 240, 274

theomachy, 103-104

Theophrastus, 51, 313, 316

Thera, 301

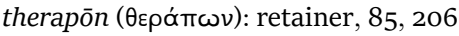

Thersites, 138

Theseus, 174

Thesprotia, Thesprotians, 130, 297-298, 301

Thessaly, 301-302, 309, 324

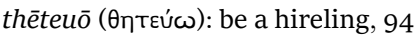

Thetis, 84, 102-103, 109, 143, 167, 174, 198, 200, 224, 229, 241, 256

Thetys, 138

Thoas, 16o, 206, 215, 257, 291, 302-303, 305

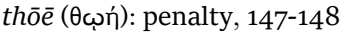

thōrax $(\theta \omega \rho \propto \xi)$ : corslet, armour, 106, 147, 162, 202

Thrace, 62, 213

Thrasyllus, 105

Thrasymelos, 206

thrēnos ( $\theta \rho \tilde{\nu}$ os): lament, complaint, 246, 249, 253-254

Thucydides, 105, 252, 262, 299, 301, 308, 320-321

Thurnwald, Richard C., 9, 24-25, 36-37, 39, 44

Thyestes, 219

timē (тıй): honour, esteem, worth, dignity, authority, present of honour, 15, 185-189, 191-200, 203-204, 208, 210-212, 214, 218 , 222-223, 225-236, 244, 252, 262, 276,

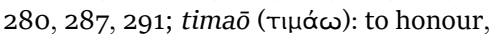
to revere, 92, 116, 186, 192, 200, 202, 213216, 228-230, 308; tiō (тí⿴): to honour, to esteem, 83, 186, 192, 213-216, 224, 228,

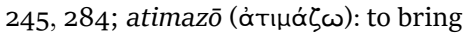
dishonour upon, suffer dishonour, treat as unworthy of, 186, 213, 215-216, 224, 228, 245, 284; timēeis, timēessa (тıни́єાs,

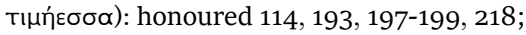

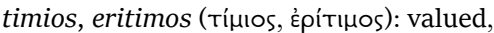

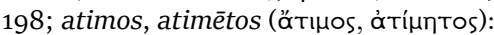
dishonoured, without present of honour, 185, 192-199, 209, 233, 285

tin-route, 306-307

tisis (tíoıs): vengeance, 195, 200, 277

Tönnies, Ferdinand, 25

toll, 207, 308-309

tomb-markers, $264 \mathrm{~s}$. also sēma, mnēma

trade, 9, 11, 15, 26, 29, 32-33, 35, 37, 39, 42, $46,49,53,63,68,73,80,96,100,207$, 266-268, 271, 278, 281, 287, 289-290, 295, 306-310, 312, 320, 324

transhumance, 8, 279, 280, 311, 315-319, 323324, 340

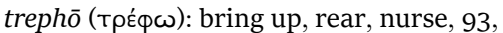
130, 172

tribute, $7,34,84,142,147,154,194,196,314$, 339

Triphylia, 274

tripous (трі́точs) s. tripod

tripod, 9, 17, 68, 79, 113, 115-116, 118-119, 122 , 125-126, 154, 199-200, 205-206, 229, 257, 273, 289, 291, 295, 311-315, 323, 328, 333, 335-346, 345

Trobriand Islands, 9, 37, 40, 50, 55-56

Troy (Troia), Trojans, 42, 69, 84, 96, 100-102, 105-108, 110, 116, 129, 131, 134-135, 141$142,147-152,155-156,162-163,178,183$, 188-189, 192, 194, 196, 200, 2003, 206207, 212-213, 215, 228, 230, 237, 239, 242, 247, 249, 251, 253-254, 257, 282-283, 286, 301-302, 312

Tychios, 161, 162

Tydeus, 97, 103, 105, 206, 215

tyranny, 67, 188-189, 201, 230, 325-326

tyrants, 10, 16, 229, 308, 325-326, 340

Tyro, 224

Tyre (Tyros), 301, 305-306, 310

Ugarit, 307

utilitarianism, 32, 40-42, 50-51

veil, 141, 162, 171, 173-174, 208, 232, 241, 26o261, 299 s. also krēdemnon, kalyprē

vengeance, 247, 249, 252, 254, s. also tisis

Vergil, 301

Vergina, 164

Vix-grave, 307

Vlachs, 319, 333 
Wagner, Adolph, 22

warp (in the upright loom): stēmōn ( $\sigma \tau n ́ \mu \omega v)$, 163, 239, 241

warp-weighted loom, 163-165 (Figures)

weaving: technique, 16, 92, 95, 114, 120, $145-145,155-157,159-162,167,169,176$, 185, 233, 236, 246, 281, 285, 290, 299, 302, 310, 328, 330, 338, 341; metaphoric weaving, 78, 118, 176, 181, 232, 239-245, 335; pattern weaving, 146, 162-164,173, 179, 181, 263, 335

Weber, Max, 39, 70, 73, 188, 190, 230

wedding, 27, 29, 33, 58, 138-39, 162, 166, 169, 174, 197, 237, 244, 248, 311, 336

wedding bed, 139

wedding cloth, 174, 237

wedding gifts, 29, 33, 311, 336

weft thread, 239-240, s. also pēnē, krokē weft spool, 239

Weiner, Annette B., 45, 55-59, 78, 335-336

wheat, 202, 217, 298

wine, 42, 84, 86, 90-93, 95, 108, 113, 116, 119, 122, 124-126, 153, 168, 180, 197, 202, 205, 213-215, 233, 267, 270, 297, 300

wisdom, 171, 223, 232, 236, 243-244, 281, $285,313-315,333 \mathrm{~s}$. also mētis

woof thread = weft thread, 239

wool, woollen, 93, 95, 106, 114, 122, 124-126, $157,159,174,197,205,221,237,238,240$, 243, 260, 288-289, 297, 299-300, 302, $304,310,317,322,324-325,329-330$ wrath, 147, 156, 218, 245

\section{Xanthus, 202}

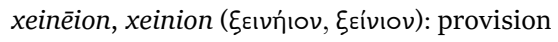
made to a guest, 15, 55, 79, 8o-89, 92-93, 106-107, 112-122, 220, 310, 339; xeinizō ( $\left.\xi \varepsilon ı v^{\prime} \zeta \omega, \xi \varepsilon v i \zeta \omega\right):$ receive or entertain a guest, 83, 123, 127-130; xeinos, xenos

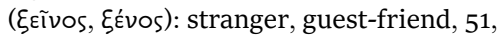
82, 85-86, 93, 96-97, 105-106, 114-118, 132, 135, 213, 225, 228, 238, 259, 268, 272, 291, 336

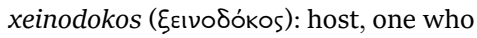
receives strangers, 82, 107, 118, 129, 132

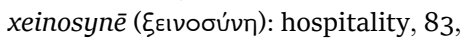

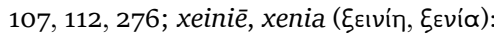
friendly gifts, guest-friendship, 83, 112 xenophobia, 8o, 82, 88, 95

Xenophon, 111, 119

Xenophon of Ephesus, 139

Xenophanes, 175

Zakynthos, 275

Zeus, 83, 86, 96-97, 102-103, 106, 108, 116, $121,123,129,135,137-138,142-144,151-$ 152, 156, 162, 172, 188, 198-200, 210-211, 214-215, 218-219, 221-223, 229, 231-232, 237-239, 241-242, 244, 254, 262, 276, 280, 282-283, 288, 300 


\section{Summary}

When Agamemnon, the leader of the Greeks in the war against Troy, takes for himself the beautiful woman awarded to Achilles as his spoils of battle, the anger of Achilles is boundless. In his critique of modern capitalism, the former Greek finance minister Yanis Varoufakis chooses this Homeric example to explain the difference between market value and experiential value. Varoufakis of course prizes experiential values, among which he counts the spoils of Achilles - a matter of esteem rather than material value - above those of the market. In this, the economist is part of a long scholarly tradition that regards the practices of gift giving as counter models to market relations.

The present study sets out to re-examine the history of the debate on gift-exchange, beginning with the critique of exchange practices found in 19th century economics, long before the emergence of Marcel Mauss's famous Essai sur le don (1923-4). Wagner-Hasel's vision of early Greece contradicts the Maussian assumption that gifts had exclusively social functions and were never linked to profitmaking. She analyses the sensory content of a wide range of gifts, including those given to guests, at sacrificial rituals and at funerals, to brides and to heroes. Through close analysis of the very fabric of these gifts WagnerHasel's study unfolds a panorama of social networks and models of rulership embedded in a world of pastoral and textile economy. She shows that there are two types of objects that represent this world: tripods, and textile gifts. It is in the textile gifts that she finds the clearest representation of social cohesion - the key value ascribed to the gift by the earliest theorists of gift-giving.

Beate Wagner-Hasel, Professor of Ancient History at the Leibniz University of Hannover from 2001 until 2018, specialises in Ancient Economic History and Gender Studies. She published a biography of Karl Bücher, the founder of the debate on the character of ancient economy, in 2011 (Die Arbeit des Gelehrten. Der Nationalökonom Karl Bücher 1847-1930). Her study on Old Age in Antiquity (2012) is focussed on women as well as on men. Her last book, published together with Marie-Louise Nosch, deals with textile economics in antiquity (Gaben, Waren und Tribute 2019). The Fabrics of Gifts is a revised edition of her study of gifts in Early Greece (Der Stoff der Gaben, 2000). 
